\title{
CENOZOIC DEEP-WATER AGGLUTINATED FORAMINIFERA \\ IN THE NORTH ATLANTIC
}

by

MICHAEL ANTHONY KAMINSKI

B.A. (1979) Rutgers University

M.Sc. (1982) Jagiellonian University

\author{
SUBMITTED IN PARTIAL FULFILLMENT \\ OF THE REQUIREMENTS FOR THE DEGREE OF \\ DOCTOR OF PHILOSOPHY
}

\author{
at the \\ MASSACHUSETTS INSTITUTE OF TECHNOLOGY \\ and the \\ WOODS HOLE OCEANOGRAPHIC INSTITUTION
}

DECEMBER 4, 1987

(C) Michael A. Kaminski, 1987

The author hereby grants to MIT and WHOI permission to reproduce and distribute copies of this thesis in whole or in part.

Signature of the author

Woods Hole Oceanographic Institution/Massachusetts Institute of Technology Joint Program in Oceanography, Woods Hole Oceanographic Institution, Woods Hole, MA 02543.

Certified by

William A. Berggren

Thesis Supervisor

Accepted by

Marcia McNutt

Chairman, Joint Committee for Marine Geology and Geophysics

Massachusetts Institute of Technology/Woods Hole Oceanographic Institution 
"I am rather inclined to think that in Paleozoic times... the ocean then had a nearly uniform high temperature and that life was then either absent or represented by bacteria and other low forms at great depths. From many considerations, one is led to suggest that cooling at the poles commenced in early Mesozoic times, that cold water, decending then in polar areas, slowly filled the greater depths, and by carrying down a more abundant supply of oxygen, life in water deeper than the mudline became possible; subsequently migrations [of deep taxa] gradually took place from the mudline into deep regions of the ocean basins."

- Sir John Murray, 1895 

CENOZOIC DEEP-WATER AGGLUTTNATED FORAMINIFERA IN THE NORTH ATLANTIC.

by

Michael A. Kaminski

Submitted to the Joint Committee for Marine Geology and Geophysics at the Woods Hole 0ceanographic Institution and the Massachusetts Institute of Technology on November 12,1987 in partial fulfillment of the requirements for the degree of Doctor of Philosophy in Oceanography.

\section{ABSTRACT}

Cenozoic (predominantly Paleogene) "flysch-type" agglutinated foraminiferal assemblages and their modern analogs in the North Atlantic and adjacent areas have been studied to provide an overview of their spatial and temporal distribution and utility for paleoenvironmental analysis. Over 200 species of agglutinated foraminifera have been recognized in Paleogene sediments from North Atlantic and Tethyan basins. This unified taxonomic data base enables the first general synthesis of biostratigraphic, paleobiogeographic and paleobathymetric patterns in flysch-type agglutinated assemblages from upper Cretaceous to Neogene sediments in the North Atlantic. The majority of taxa are cosmopolitan, but latitudinal, temporal and depth-related trends in diversity and species composition are observed among flysch-type assemblages.

Modern deep-sea agglutinated foraminiferal faunas provide an analog to fossil flysch-type assemblages and serve as models for paleoecologic studies. Core-top samples from the Panama Basin, Gulf of Mexico and Nova Scotian continental rise were examined in order to determine the habitats of modern species of agglutinated foraminifera. The ecology of modern taxa provides constraints on the paleoenvironmental significance of fossil agglutinated assemblages in the North Atlantic, and their utility for paleoceanography.

Towards this end, spade core samples from a $3912 \mathrm{~m}$ deep station in the Panama Basin were studied to determine abundance and microhabitat partitioning among living agglutinated foraminiferal populations and the preservation of dead assemblages. The genera Dendrophrya, Cribrostomoides and Ammodiscus have epifaunal habitats and the genus Reophax is predominantly infaunal. Species of Reophax are probably responsible for fine reticulate burrows observed in $x-$ radiographs. An experiment using recolonization trays in the Panama Basin was designed to identify opportunistic species of benthic foraminifera, and to assess the rate at which a population can colonize an abiotic substrate. The most successful colonizer at this site is Reophax, while Dendrophrya displays the lowest capability for dispersal. After nine months the abundance of living individuals in sediment trays was one-tenth to one-third that of background abundance, but the faunal diversity did not differ greatly from control samples. Recolonization by benthic foraminifera is more rapid than among macrofaunal invertebrates.

Modern agglutinated assemblages from the Louisiana continental slope were examined to determine changes in species composition associated with hydrocarbon seeps. Organic-rich substrates are characterized by a decrease in astror- 
hizids and an increase in trochamminids and textulariids. Highly organicenriched substrates with chemosynthetic macrofauna are dominated by Trochammina glabra and Glomospira charoides.

The biostratigraphy of fossil agglutinated foraminifera in the North Atlantic is based on detailed analysis of 670 samples from 14 wells and one outcrop section, and examination of additional picked faunal slides from industry wells. Local biostratigraphic schemes are established for Trinidad, Northern Spain, the Labrador Sea, Baffin Bay, and the Norwegian-Greenland Sea. These schemes are compared with existing biostratigraphic frameworks from the Labrador Margin, the North Sea, and the Polish Carpathians. A number of species show utility for biostratigraphy in the North Atlantic. Lineages which contain stratigraphically useful species include the Haplophragmoides cf. glabra - Reticulophragmium group, Hormosina, and Karreriella.

Significant faunal turnovers are observed at the Paleocene/Eocene, Ypresian/Lutetian and Eocene/0ligocene boundaries. A reduction in diversity occurs at the Paleocene/Eocene boundary in all bathyal sections studied, and agglutinated forminifera disappear entirely from abyssal low-latitude DSDP sites. In the Gibraltar Arch, the Labrador Sea and the Norwegian-Greenland Sea, the Ypresian/Lutetian boundary is characterized by a Glomospira-facies. This is attributed to a rise in the lysocline associated with increased paleoproductivity and the NP14 sealevel lowstand. The Eocene/0ligocene boundary is delimited by another major turnover and the last occurrence of a number of important taxa. At Site 647, where recovery across the Eocene/0ligocene boundary was continuous, the change from an Eocene agglutinated assemblage to a predominantly calcareous assemblage in the early oligocene took place gradually, over a period of about $4 \mathrm{~m} . \mathrm{y}$. The rate of change of the faunal turnover accelerated near the boundary. This faunal turnover is attributed to changes in the preservation of agglutinated foraminifera, since delicate species disappeared first. Increasingly poorer preservation of agglutinated foraminifera in the late Eocene to earliest oligocene reflected the first appearance of cool, nutrient-poor deep water in the southern Labrador Sea. The approximately coeval disappearance of agglutinated assemblages along the Labrador Margin was caused by a regional trend from slope to shelf environments, accentuated by the "mid"-0ligocene sealevel lowstand.

Paleobiogeographic patterns in flysch-type foraminifera were examined in the Paleogene of the North Atlantic. In the early Paleogene, general decrease in diversity is observed from low to high latitudes and from the continental slope to the deep ocean basins. The diversity of these microfossils declines in most studied sections throughout the Paleogene. The last common occurrence (LCO) of flysch-type foraminifera in the North Atlantic exhibits a pattern of diachrony with latitude and depth. Extinctions occurred first at abyssal depths and at low latitudes. Agglutinated assemblages disappeared from the northern Atlantic region in the early oligocene. However, the deep NorwegianGreenland Sea served as a refuge for many species, and agglutinated assemblages persisted there until the early Pliocene. The LCO of flysch-type foraminifera may have been related to the transition from a warm, sluggish deep sea environment to a cooler, more oxygenated, thermohaline-driven deep circulation pattern caused by bipolar cooling. 
The paleobathymetry of Paleogene agglutinated assemblages in the North Atlantic differs from Cretaceous patterns. Shallow-water assemblages of Paleogene age contain robust astrorhizids, loftusiids and coarse lituolids, whereas deep assemblages possess delicate tubular forms, ammodiscids, and smooth lituolids. At low latitudes, upper bathyal assemblages contain abundant calcareous ataxophragmiids. Paleocene paleobathymetric patterns in the North Atlantic compare well with patterns observed in the Carpathian troughs.

The utility of agglutinated foraminifera in paleoceanography is illustrated by a study of the paleocommunity structure of fossil assemblages in ODP Hole $646 \mathrm{~B}$ on the Eirik Ridge (Labrador Sea). The synecology of benthic foraminifera in Hole 646B places constraints on the history of Denmark Straits overflow Water over that site. Below seismic horizon "R3", a Miocene assemblage contains smooth agglutinated species with abundant Nuttalides umbonifera, indicating corrosive bottom water and tranquil conditions. $\bar{A}$ coarse agglutinated assemblage with "NADW-type" calcareous benthics is observed above the seismic horizon. This faunal turnover at horizon "R3" reflects the onset (or renewal) of significant Denmark Straits overflow at $\sim 7.5 \mathrm{Ma}$. Agglutinated species disappear between reflector "R2", and the base of the sediment drift, indicating a change in deep-water properties associated with the re-opening of the Mediterranean. The onset of drift sedimentation at the Eirik Ridge is dated at $\sim 4.5 \mathrm{Ma}$. Drift formation ceased at $\sim 2.5 \mathrm{Ma}$, concomitant with the appearance of ice-rafted sediments.

Thesis Supervisor: Dr. William A. Berggren

Senior Scientist,

Department of Geology \& Geophysics, Woods Hole Oceanographic Institution. 
TABLE OF CONTENTS :

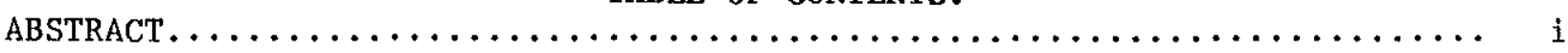

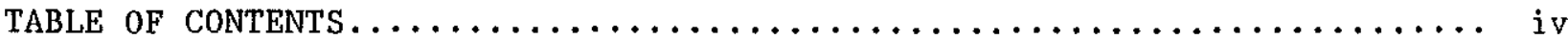

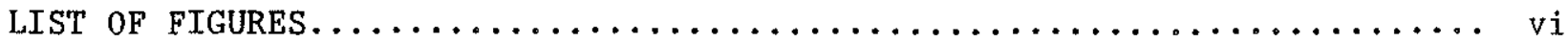

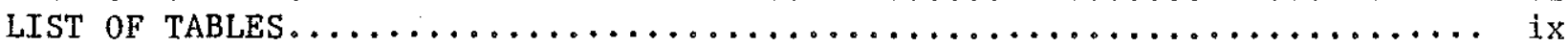

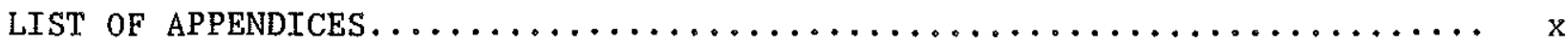

PREFACE. .....................................

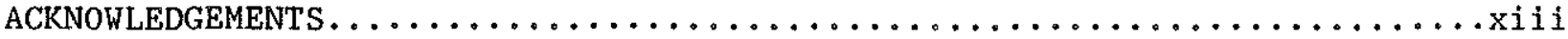

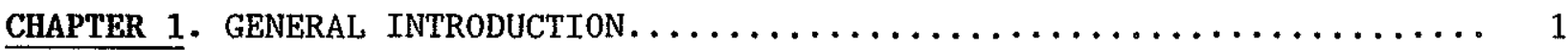

REFERENCES TO GENERAL INTRODUCTION................. 7

CHAPTER 2. OBSERVATIONS ON THE ECOLOGY OF MODERN AGGLUTINATED FORAMINIFERA AND A CASE HISTORY OF PALEOENVIRONMENTAL ANALYSIS USING NEOGENE AGGLUTINATED ASSEMBLAGES AT ODP SITE 646 , LABRADOR SEA........ 9

A. Life history and recolonization by Agglutinated Foraminifera

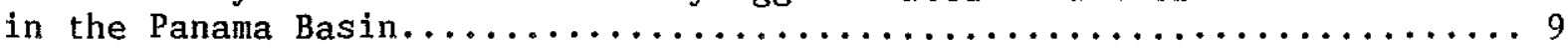

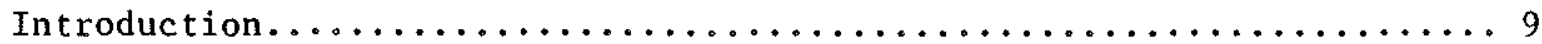

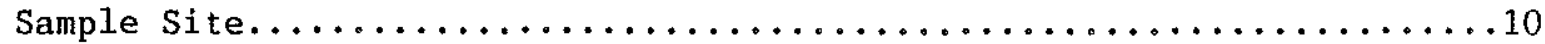

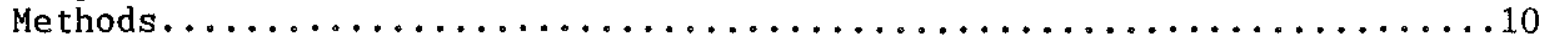

Results - Foraminiferal abundance and diversity ...............

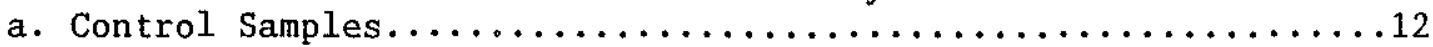

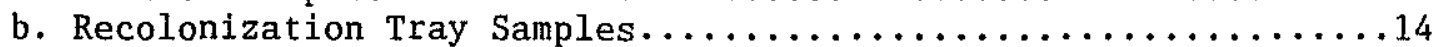

Discussion - Tranquil vs Disturbed environments..................

a. Habitat Partitioning (Infaunal vs. epifaunal forms) .........22

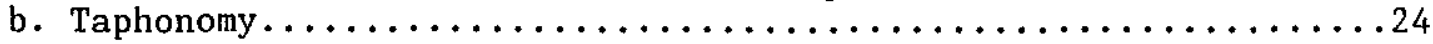

c. Recolonization by agglutinated foraminifera..............

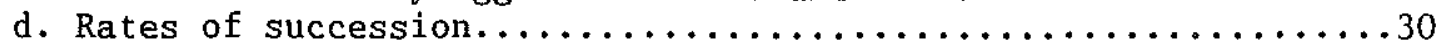

e. A generalized model relating community structure

to substrate disturbance............................ 30

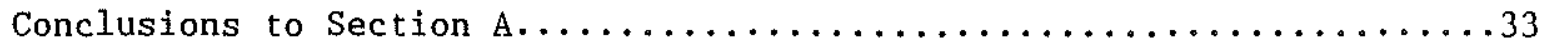

B. Agglutinated foraminifera from a hydrocarbon seep region on the

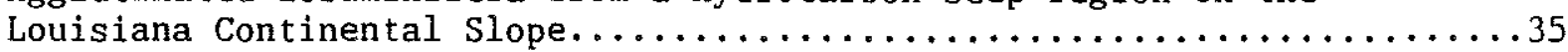

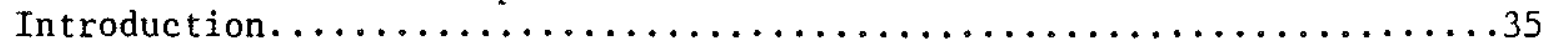

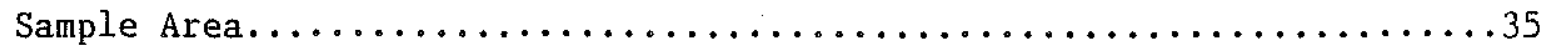

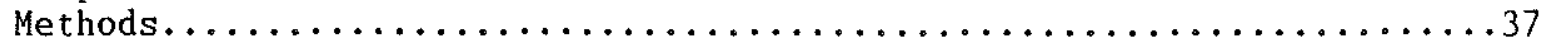

Results - Hydrocarbon-rich vs. control stations...................

Discussion - application of modern patterns to the fossil record.....43

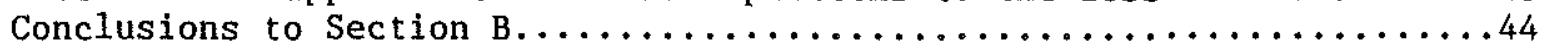

C. Paleoenvironmental analysis using agglutinated assemblages:

the Neogene record of ODP Site 646 , Eirik Ridge................45

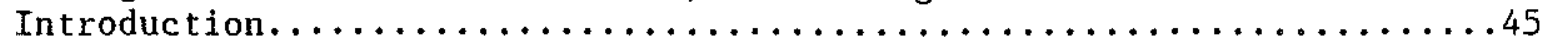

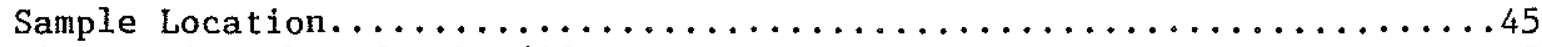

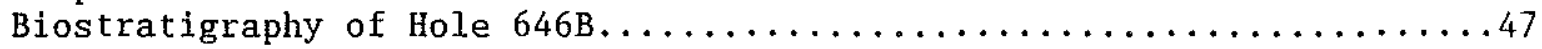

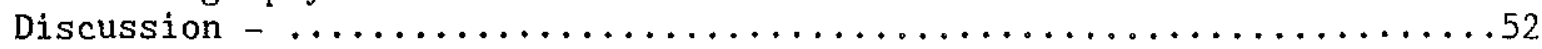

a. Paleoecology of Benthic Foraminifera in Hole $646 \mathrm{~B} \ldots \ldots \ldots \ldots . . . .52$

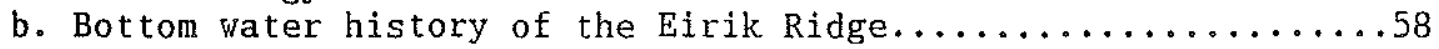

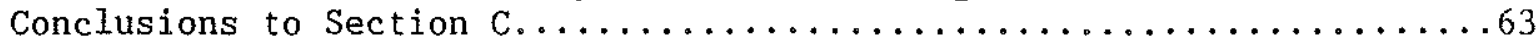

APPENDIX 2-1. Abundance data of taxa in samples from ODP Hole 646B.......64

CHAPTER 3. BIOSTRATIGRAPHY OF FLYSCH - TYPE AGGLUTINATED FORAMINIFERA

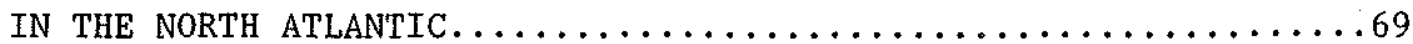




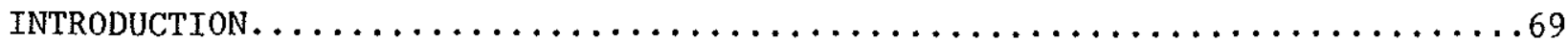

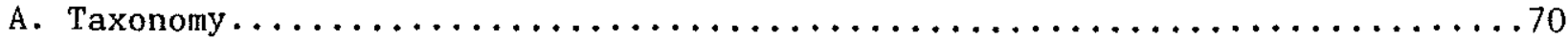

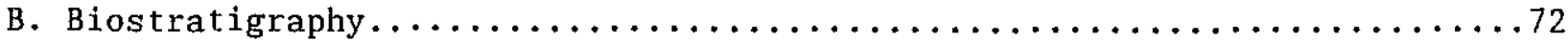

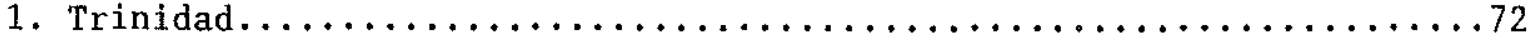

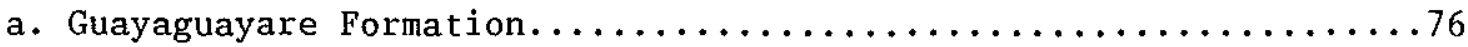

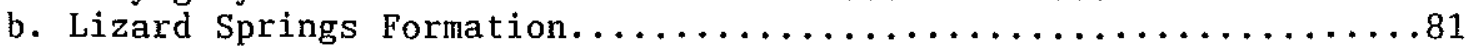

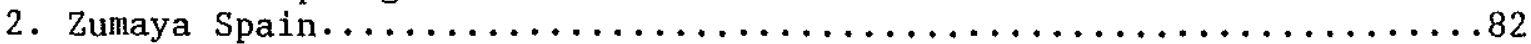

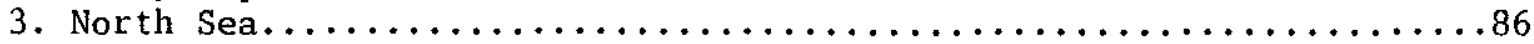

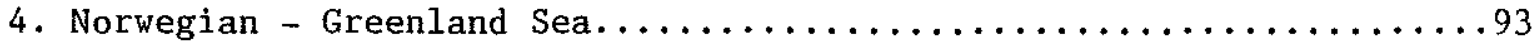

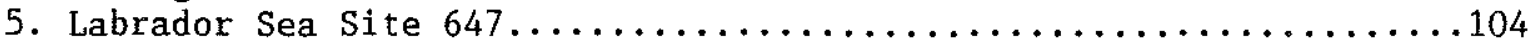

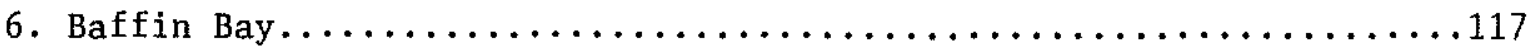

7. Texaco Blue $\mathrm{H}-28$ well, Labrador Margin....................... . . . . . .

C. Comparison of Regional Zonations based on Agglutinated Foraminifera....123

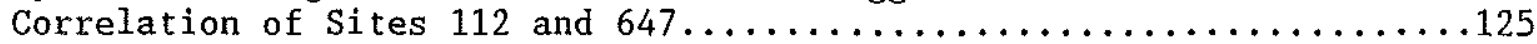

Comparison of Site 647 with Labrador Margin Biostratigraphy... . . . . 128

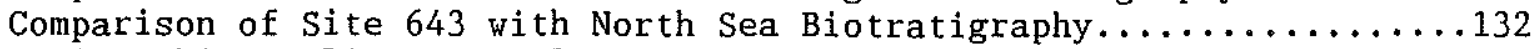

D. Stratigraphic Utility of Agglutinated Foraminifera in the North Atlantic

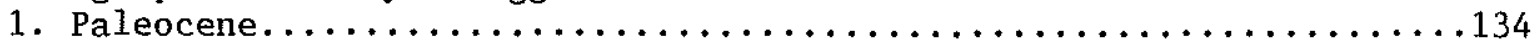

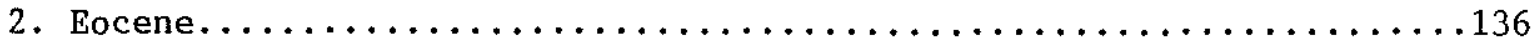

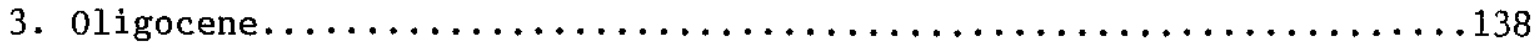

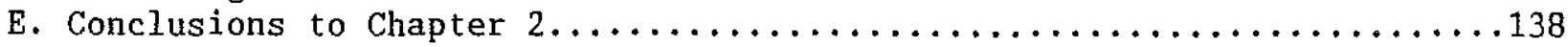

APPENDIX 3-1 Relative abundance of taxa in samples from Zumaya.........142 APPENDIX 3-2 Relative abundance of taxa in samples from ODP Hole 643A...144 APPENDIX 3-3 Abundance data of taxa in samples from oDP Hole 647A......146

\section{CHAPTER 4. PALEOBIOGEOGRAPHY OF AGGLUTINATED FORAMINTFERA}

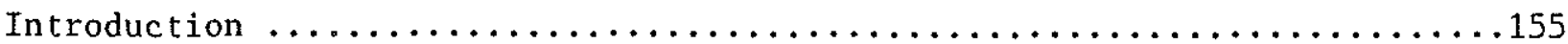

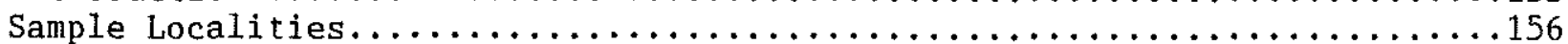

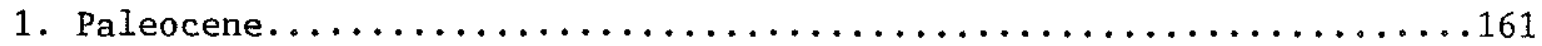

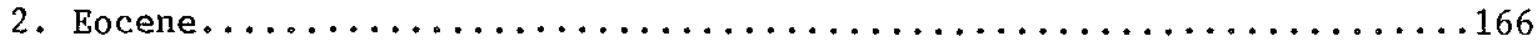

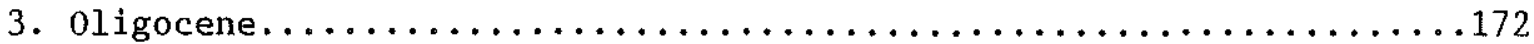

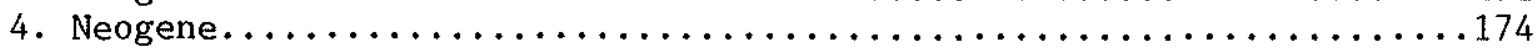

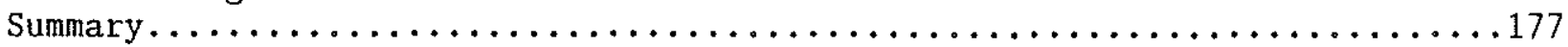

\section{CHAPTER 5. PALEOECOLOGY AND PALEOCEANOGRAPHY}

A. Paleobathymetry of Agglutinated Foraminifera.................

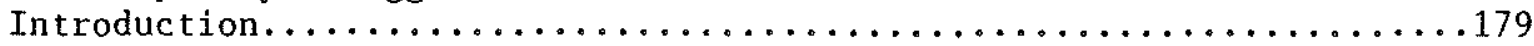

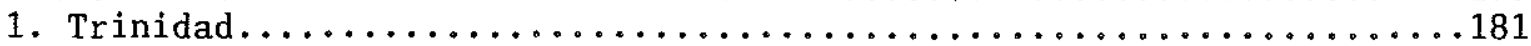

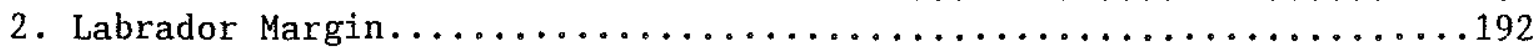

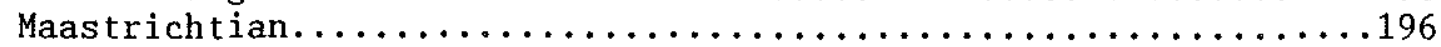

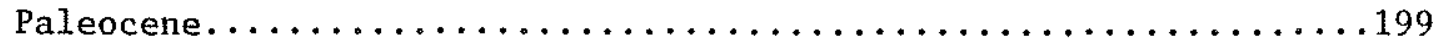

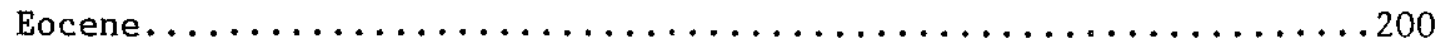

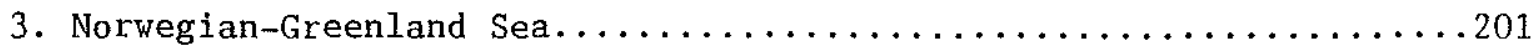

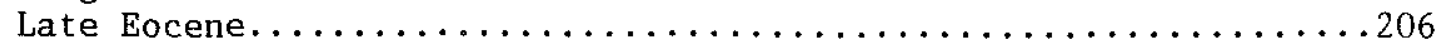

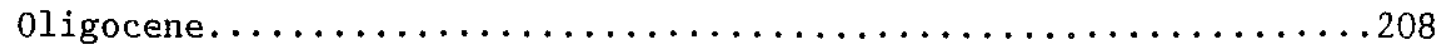

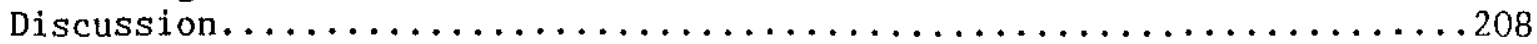

North Atlantic vs. Carpathian Paleobathymetry..............208

Cretaceous vs Paleogene paleobathymetric models.............212

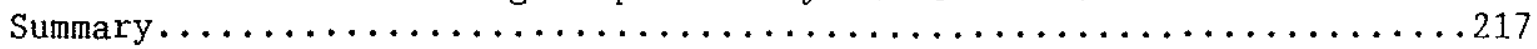

B. Paleoceanography

1. The Glomospira Facies and the NP14 Sea Level event...........219

2. Agglutinated Foraminifera and the Eocene/0ligocene Boundary......223 
3. Paleoceanographic significance of Flysch-type assemblages.......225

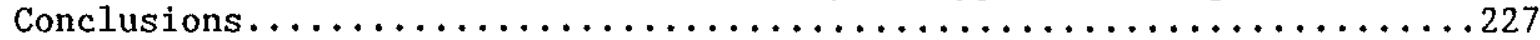

APPENDIX 5-1. Foraminiferal data from the North Leif well.............229

APPENDIX 5-2 Foraminiferal data from the Roberval well..............231

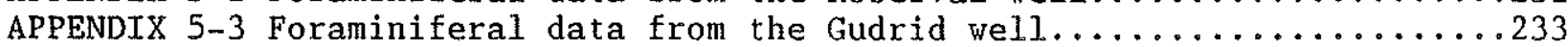

APPENDIX 5-4 Foraminiferal data from the Indian Harbour well..........235

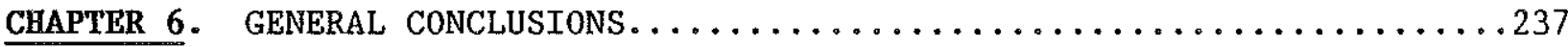

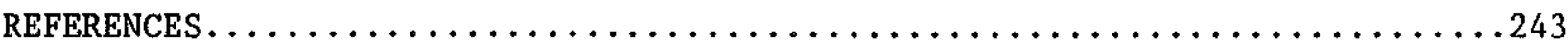

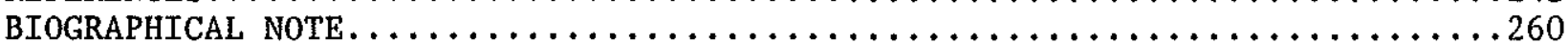

\section{LIST OF FIGURES:}

Figure 2-1. Map of Panama Basin study area....................11

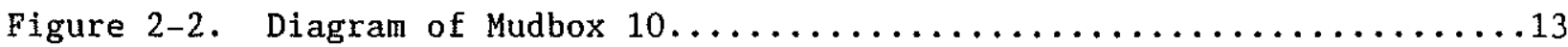

Figure 2-3. Rarefaction curve showing diversity of control and

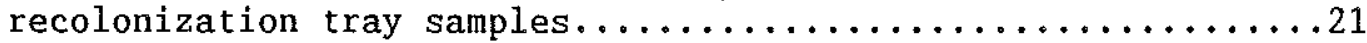

Figure 2-4. X-radiograph of sediment surface layer from a spade core.....23

Figure 2-5. Agglutinated foraminiferal populations and dead assemblages

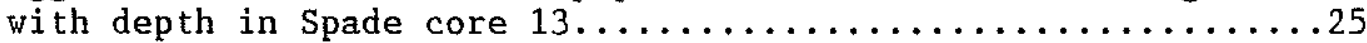

Figure 2-6. Generalized model showing the effect of substrate disturbance on the structure of agglutinated foraminiferal communities....31

Figure 2-7. Location of OCS Blocks 184 and 272 in the Green Canyon area of the Louisiana continental slope.................... 36

Figure 2-8. Relative proportions of superfamily groups in control sample and at hydrocarbon seep stations in Block $184 \ldots \ldots \ldots \ldots \ldots \ldots 1$

Figure 2-9. Relative proportions of superfamily groups in control sample and at hydrocarbon seep stations in Block $272 \ldots \ldots \ldots \ldots \ldots \ldots 42$

Figure 2-10. Location of ODP and DSDP Sites and exploration wells in the Labrador Sea and Baffin Bay ...................... 46

Figure 2-11. Lithostratigraphic and Seismic Units of Site 646 , correlated to regional seismic reflectors on a a single-channel seismic line crossing the Eirik Ridge...................... 48

Figure 2-12. Accumulation rates of benthic foraminifera, $\mathrm{CaCO} 3$ content and percent Nuttallides umbonifera in Site $646 \ldots \ldots \ldots \ldots . . .49$

Figure 2-13. First and last occurrences of benthic foraminifera in Hole 646 , plotted against shipboard nannofossil stratigraphy.......50

Figure 2-14. Benthic foraminiferal assemblages and the deep-water history of the Eirik Ridge........................61 
Figure 3-1. Stratigraphic distribution of agglutinated assemblages in the Atlantic...................................

Figure 3-2. Location of samples from the Lizard Springs Formation of Trinidad and surrounding areas.................... 75

Figure 3-3a. Campanian to lower Eocene stratigraphic distribution of agglutinated foraminifera in Trinidad................. 77

Figure 3-3b. Campanian to lower Eocene stratigraphic distribution of agglutinated foraminifera in Trinidad................ 78

Figure 3-4. Map of Zumaya, Spain showing location of outcrop samples

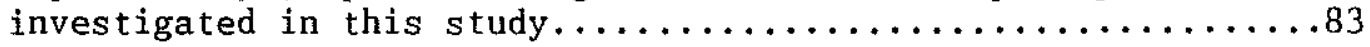

Figure 3-5. Range chart of agglutinated species in the Zumaya section.....85

Figure 3-6. Location of 29 exploration wells in the Central North Sea....87

Figure 3-7. Average stratigraphic distribution of 29 agglutinated species

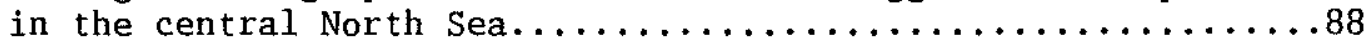

Figure 3-8. Correlation of the foraminiferal zonation of Gradstein et al. with the planktonic foraminiferal biostratigraphy and the neritic zonation of King (1983) ......................

Figure 3-9. Age of Paleogene sediments in Leg 38 and Leg 104 Sites......94 Figure 3-10. Map of the Voring Plateau showing location of Site $643 \ldots \ldots \ldots 96$

Figure 3-11. Range chart of agglutinated foraminifera in Hole 643A......100

Figure 3-12. Age, diversity of benthic foraminifera and characteristic

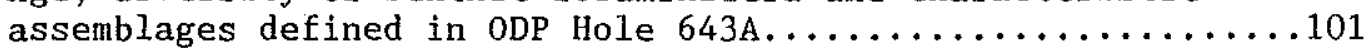

Figure 3-13. Location of DSDP and ODP Sites in the Labrador Sea and exploration wells on the Labrador Margin................ 105

Figure 3-14. Comparison of lithostratigraphy, seismic reflectors, \% $\mathrm{CaC0} 3$ and TOC with benthic foraminiferal assemblages in Hole 647A...108

Figure 3-15. Relative abundance of common benthic foraminiferal species

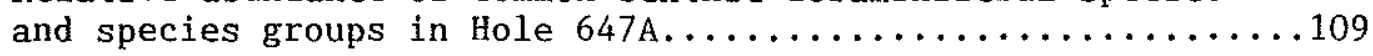

Figure 3-16. Relative abundance of stratigraphically important benthic

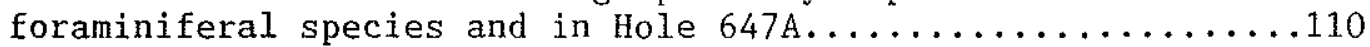

Figure 3-17. Biostratigraphy of common agglutinated species in Hole 647A...111

Figure 3-18. Lithostratigraphy and summary of the benthic foraminiferal assemblages and associated microfossils at site $645 \ldots \ldots \ldots 119$

Figure 3-19. Biostratigraphy of the TEXACO Blue H-28 well............ 
Figure 3-20. Comparison of Paleogene zonal classifications in areas containing flysch-type assemblages................... 120

Figure 3-21. Important benthic foraminiferal extinction levels in 7 exploration wells on the Labrador Margin.................. 129

Figure 3-22. Comparison of microfossil extinction levels in common between the Labrador Margin optinum sequence and Site $647 \ldots \ldots \ldots \ldots 131$

Figure 3-23. Comparison of microfossil extinction events in common between the North Sea optimum sequence of Gradstein et al. (in press)

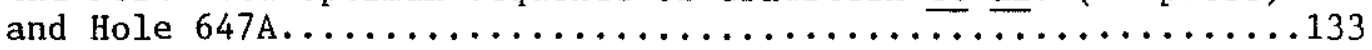

Figure 4-1. Paleobiogeography of Paleocene benthic foraminiferal facies...163

Figure 4-2. Paleobiogeography of Eocene benthic foraminiferal facies.....168

Figure 5-1. Diversity, faunal composition, sedimentology, and composition

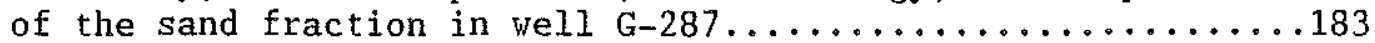

Figure 5-2a. Relative abundance of agglutinated genera in well G-287.....185

Figure 5-2b. Relative abundance of agglutinated genera in well G-287.....186

Figure 5-3. Distribution of benthic foraminiferal species on first three

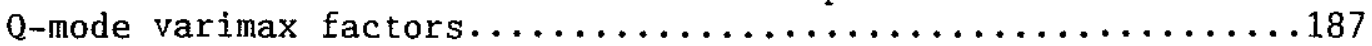

Figure 5-4. Relative abundance of important calcareous benthic taxa compared with faunal factor 3 in well G-287.............. 188

Figure 5-5. Paleobathymetry of agglutinated taxa in equatorial Atlantic...190

Figure $5-6$. Location of Labrador sea wells...................... 194

Figure 5-7. Cenozoic stratigraphy of four Labrador Margin wells studied...195

Figure 5-8. Paleobathymetry of agglutinated taxa in the northern Atlantic.197

Figure 5-9. Paleodepth curve and the lysocline history at site $647 \ldots \ldots 201$

Figure 5-10. DSDP and ODP Sites in the Norwegian-Greenland Sea containing

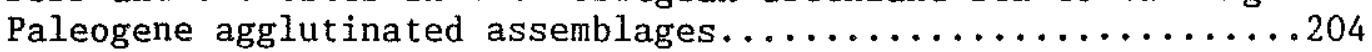

Figure 5-11. Paleobathymetry of agglutinated taxa in the Norwegian-Greenland

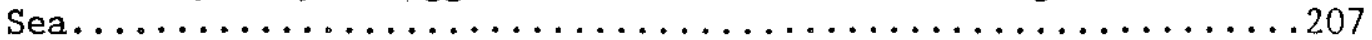

Figure 5-12. Comparison of upper Cretaceous and Paleocene paleobathymetric models for agglutinated foraminiferal assemblages..........214

Figure 5-13. North Atlantic Paleogene paleoceanography and biofacies......221 
LIST OF TABLES:

Table 2-1. Faunal data from Spade Core 9, Panama Basin..................

Table 2-2. Faunal data from Spade Core 13, Panama Basin...............

Table 2-3. Faunal data from Mudbox 7 , Panama Basin................ 17

Table 2-4. Faunal data from Mudbox 10, Panama Basin.................

Table 2-5. Faunal data from Mudbox 11, Panama Basin.................. 19

Table 2-6. Agglutinated foraminifera from the Panama Basin ranked in terms of increasing fossilization potential..............27

Table 2-7. Abundance of live individuals in control samples and colonization trays in the Panama Basin....................... 29

Table 2-8. Faunal data from OCS Block 184, Louisiana continental slope.....39

Table 2-9. Faunal data from OCS Block 272, Louisiana continental slope....40

Table 2-10. Sediment parameters from North Atlantic DSDP and ODP sites with occurrence of agglutinated assemblages noted...........55

Table 2-11. Summary of important benthic foraminiferal species and

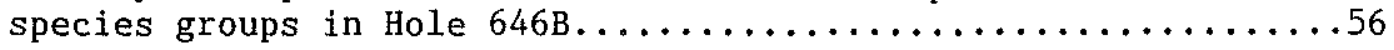

Table 3-1. Samples from the Lizard Springs and Guayaguayare Formations of Trinidad examined in this study....................

Table 3-2. A checklist of species from Trinidad with a key to modifications of the taxonomy of Cushman and Renz (1946)......79

Table 3-3. Agglutinated taxa from Hole 643A, with nomenclatoral changes to the taxonomy of Verdenius and Van Hinte (1983) ...........98

Table 3-4. Microfossil datums used to construct the age - depth model

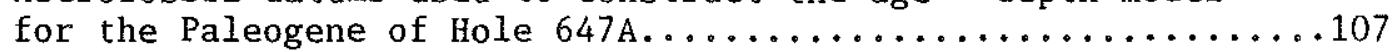

Table 3-5. Chronology of benthic foraminiferal first and last occurrence

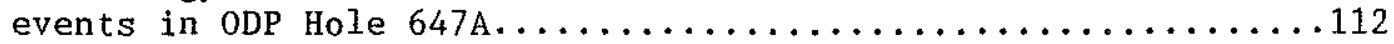

Table 3-6. Age assignments of cores in Hole $112 \ldots \ldots \ldots \ldots \ldots \ldots \ldots \ldots$

Table 4-1. A checklist of species from Atlantic and Tethyan localities....157

Table 4-2. Main features of Paleocene and lower Eocene assemblages.......164

Table 4-3. Main features of Middle Eocene and 0ligocene assemblages.......169

Table 4-4. Main features of Miocene assemblages................... 175

Table 5-1. Labrador Margin wells and DSDP/ODP Sites studied............194 
Table 5-2. Paleodepth of Norwegian-Greenland Sea sites..............205

Table 5-3. Agglutinated taxa found in greater abundance in deep facies in the Polish Carpathians and Trinidad.......................

\section{LIST OF APPENDICES:}

APPENDIX 2-1. Abundance data of taxa in samples from ODP Hole 646B.......64 APPENDIX 3-1. Relative abundance of taxa in samples from Zumaya.........142 APPENDIX 3-2. Relative abundance of taxa in samples from ODP Hole 643A....144 APPENDIX 3-3. Abundance data of taxa in samples from oDP Hole 647A.......146 APPENDIX 5-1. Foraminiferal data from the North Leif well...............229 APPENDIX 5-2. Foraminiferal data from the Roberval well............231

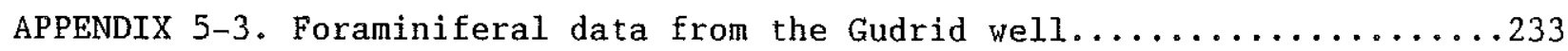
APPENDIX 5-4. Foraminiferal data from the Indian Harbour well.........235 
PREFACE:

In September of 1981 , a small group of specialists gathered together in Amsterdam at what became known as the First International Workshop on Agglutinated Foraminifera (IWAF). The purpose of the meeting was to attempt to synthesize the current state of research on the subject of fossil and living agglutinated foraminifera from shallow- and deep-water environments. In the decade preceding this workshop, deep-water agglutinated foraminiferal faunas had been discovered in economically important areas of the North Atlantic, as well as at a number of DSDP sites. These developments sparked renewed interest in these microfossils for biostratigraphic and paleoenvironmental analyses. Unfortunately, knowledge of the taxonomy, stratigraphy, and paleoecology of deep-water agglutinated foraminifera was still at a rudimentary stage. Many of the classic type specimen collections were virtually inaccessible, and the classic localities in alpine regions had little to offer in the way of continuous, well-dated sections. The paleoecologic implications of these agglutinated assemblages were not well understood, owing to a lack of basic information on the distribution and ecology of their modern analogs. At the very least, the first IWAF meeting in Amsterdam shed light on where the gaps in our understanding lay, and where future research efforts needed to be focused in order to improve our knowledge of agglutinated foraminifera.

In the five intervening years between the Amsterdam meeting and the 2nd IWAF in Vienna, a number of pioneering studies were published by some of the original participants which quickly became classic references. Biostratigraphic and taxonomic information on deep-water agglutinated foraminifera became available from high-latitude sedimentary basins such as the North Sea, Norwegian-Greenland Sea, Labrador Sea, Beaufort Sea, as well as from the classic localities in the Carpathians and Alps. Now there exists a need to expand the available data base to include additional basins and to develop a general synopsis of the taxonomy and distribution of these microfossils on an ocean-wide scale.

This thesis is a direct outgrowth of that first meeting in Amsterdam. As part of a long-term project to improve our understanding of the taxonony, stratigraphy and paleoecology of Cenozoic deep-water foraminifera carried out by W.A. Berggren and colleagues at the Woods Hole 0ceanographic Institution, I have undertaken a number of related studies on agglutinated foraminifera to help fill some of the gaps in our knowledge of this group of organisms. My earlier studies (M.Sc.) with Prof. Stan Geroch at the Jagiellonian University on the classic Grzybowski Collection of agglutinated foraminifera from the Carpathians provided valuable experience and training. The close and continuing cooperation with Dr. Felix Gradstein, who had obtained material from the classic type localities and was instrumental in planning deep drilling in the Labrador Sea, has resulted in a plethora of new and exciting data on the stratigraphy and paleoecology of agglutinated foraminifera. Cooperative studies at the HEBBLE Site, and continuing cooperation with Drs. Fred Grassle and $\mathrm{C}$. Wiley Poag have provided me with unique opportunities to examine unexplored aspects of the ecology of modern agglutinated faunas, and to use these findings to help interpret the fossil record.

This study synthesizes the results of my research on living and fossil deep-water agglutinated foraminifera, mostly in the North Atlantic and in the Panama Basin. Chapter 2 discusses the major results of experiments and observations carried out on living agglutinated foraminifera, and an application of 
the ecologic information gained in this study to the fossil record. Section A of Chapter 2 has been accepted for publication in the Proceedings of the Second International Workshop on Agglutinated Foraminifera and is referenced throughout this volume as Kaminski et al. (in press, a). Section $C$ of Chapter 2 is extracted from a study accepted for publication in the Proc. Init. Repts. ODP, Leg 105, and is referenced as Kaminski et al., (in press, c). The reader should refer to the pre-print for additional information about Site 646. The third, fourth and fifth chapters, respectively present the taxonomic, stratigraphic, and paleoecologic results of studies on fossil assemblages from Atlantic margin basins and Deep Sea Drilling Project/0cean Drilling Program sites carried out under the auspices of the Deep-Water Benthic Foram Project. Stratigraphic and paleoecologic results from Trinidad are synthesized from a study that has been accepted for publication in the Proceedings of the Second International Workshop on Agglutinated Foraminifera which is referenced as Kaminski et al. (in press, b). Sections dealing with the biostratigraphy of the Labrador Sea have been extracted from a study which has been submitted for publication in the Proc. Init. Repts. ODP, Leg 105, referenced as Kaminski et al., (in press, d). The reader should refer to the respective pre-prints for additional information about these localities. This synthesis is dedicated to all the "sand boys" from Amsterdam and Vienna whose diverse scientific efforts have stimulated my interest in this group of organisms. 


\section{ACKNOWLEDGEMENTS :}

Many of topics elaborated upon in this thesis have grown out of my contacts and discussions over the past five years with many individuals who have left indelible marks on the development of this work. I am especially grateful for the support and guidance given me by my thesis advisors Bill Berggren and Felix Gradstein, and the advice and encouragement provided by my thesis committee: Bill Berggren, Ed Boyle, Felix Gradstein, Fred Grassle, Ken Miller and Brian Tucholke, and everyone in the WHOI Education office. Special thanks go to Bill Berggren, Anne S. Edwards, Lloyd Keigwin, Ken Miller, Bruce Corliss, A. Lawrence "Jake" Peirson, Dave Johnson and Charlie Hollister for all the practical advice given me during my first years in the Joint Program.

I an grateful to Bill Berggren, James M. Brooks, Stan Geroch, Felix Gradstein, Fred Grassle, Axel von Hillebrandt, Garry Jones, Robert D. Liska, Wolfgang Kuhnt, Ken Miller, Enrica Morlotti, C. Wiley Poag, John Van Couvering, and the Ocean Drilling Program for providing me with sample material from different parts of the world. I would also like to express my gratitude to the Captain and crew of the JOIDES Resolution, the R/V Knorr, the $\mathrm{R} / \mathrm{V}$ Atlantis II and the submersible "Alvin", and the Johnson Sea Link. I also wish to thank Bob Commeau, Kathy Mackinnon, Amy Pallant, Frank Thomas, and UNOCAL Science \& Technology Division for assistance with the sample preparation. Kozo Takahashi, Dave Lazarus, and my wife Danuta helped me with technical aspects of the study. Martin Buzas and Suzan Richardson provided much appreciated assistance during my work with the Cushman Collection. John Van Couvering provided access to collections at the American Museum of Natural History.

Various aspects of this study have benefited greatly from valuable discussions with Mike Arthur, Jack Baldauf, Jean-Pierre Beckmann, Martin Buzas, Brad Clement, Tony Charletta, Bob Commeau, Bruce Corliss, Leonard Ford, Stan Geroch, Bob Goll, Al Grant, Martin J. Head, Heinrich Hiltermann, Dave Johnson, Garry D. Jones, Bob W. Jones, John Firth, Charlie Hollister, Lloyd Keigwin, Wolfgang Kuhnt, Dave Lazarus, Robert D. Liska, Mark Leckie, Nick McCave, Dave McNeil, Linda Morse-Porteus, Jeno Nagy, Barbara 0lszewska, Lisa 0stermann, C. Wiley Poag, Suzan Richardson, Fred Rogl, Howard Sanders, Charlie Schafer, Detmar Schnitker, Claudia Schroder, Dave Scott, Craig Smith, Ruetiger Stein, Shiri Srivastava, Leonard Tjalsma, Jim Weinberg, Eileen Williams, Jim Zachos and Herman Zimmerman. I am especially grateful to all of my co-authors for tolerating my writing style and self-imposed deadlines. I owe a special debt of gratitude to Garry Jones for his meticulous review of this thesis and all of the associated pre-prints.

Last but not least, I would like to thank my wife Danuta, my parents Michael and Vernita, and Helen and Michael Peters for their moral and logistic support throughout the course of my graduate studies.

Financial support for this study was provided through grants from the 0cean Drilling Program, the Texas A\&M Research Foundation/US Scientific Program (1892-B05), the National Science Foundation through grants OCE-8217586 to J.F. Grassle and OCE 82-17413 to R.B. Whitlatch, the Geological Society of America (86-3599), the WHOI Education Office, and the Margaret $M$. Patterson Memorial Scholarship Fund. The Dean's Office of the Jagiellonian University provided support during my work with the Grzybowski Collection.

This is a contribution of the Deep-Water Benthic Foram Project, which is conducted by W.A. Berggren and colleagues at the Woods Hole Oceanographic Institution and is sponsored by a consortium of oil companies (ARCO, B.P., Chevron-Gulf, Elf-Aquitane, Exxon, Mobil, Phillips, Shell International, Shell USA, SOHIO, Texaco, and UNOCAL). 



\section{CHAPTER 1}

GENERAL INTRODUCTION:

Most studies of Cenozoic biostratigraphy and paleoceanography to date have primarily utilized calcareous planktonic and benthic microfossil groups. Unfortunately, in high-latitude basins in the North Atlantic and on the abyssal plains where pelitic sedimentation dominates, the stratigraphic record of calcareous microfossils is often poor and incomplete. In intervals where these microfossils are present, low species diversity usually renders this group useless for detailed study. Therefore the conventional tools of stratigraphy and paleoceanography - stable isotopes and studies of calcareous plankton assemblages - are inadequate in these areas. Instead, the micropaleontologist must use noncalcareous plankton (palynomorphs, diatoms, radiolarians, silicoflagellates) and benthos as stratigraphic and paleoceanographic tools. This thesis focuses attention on a ubiquitous, yet poorly documented group of noncalcareous benthic foraminifera which has demonstrated utility in petroleum-bearing basins such as the North Sea and southern Labrador Sea.

The only group of foraminifera with a relatively complete stratigraphic record in these basins are the Textulariida, or agglutinated foraminifera. This group possesses a long stratigraphic record and is among the most diverse groups of microfossils in high latitudes. Agglutinated foraminifera are also common components of lower Cenozoic benthic foraminiferal assemblages in areas where the rapid deposition of fine-grained clastic sediments result in a benthic environment unfavorable to the preservation of calcareous foraminifera. These microfossils have been used for stratigraphic purposes in economically important sedimentary basins since the late 19 th Century (Grzybowski, 1898). In the 1970's, the discovery of diverse flysch-type assemblages in offshore wells on continental margins and DSDP Sites in North Atlantic basins led to special taxonomic and paleoecological studies of these organisms.

Some of the early studies of flysch-type agglutinated foraminiferal assemblages from pelitic intervals of flysch sediments (Brouwer, 1965, Gradstein and Berggren, 1981) and from DSDP Sites throughout the world (Miller et al. 1982) have revealed the cosmopolitan nature of many deep-water agglutinated species. At present count, over 200 species of agglutinated foraminifera have been recorded from Paleogene sediments in North Atlantic and 
Tethyan basins, but the stratigraphic and paleobiogeographic distribution of these organisms is still poorly documented in the available literature. The utility of agglutinated foraminifera for interregional studies is limited at present by the lack of a standardized taxonomic nomenclature and a standard biochronology. No single study has attempted to synthesize the distribution of these organisms in the North Atlantic. A major goal of this thesis is to examine Paleogene flysch-type assemblages to determine their biostratigraphy in a number of well-dated reference sections, and to recognize first-order patterns in diversity and the distribution of important genera along latitudinal and paleodepth gradients. By documenting major distributional patterns of these organisms in the North Atlantic, I seek to improve the utility of this group for biostratigraphy, paleoecology and deep-water paleoceanography.

In general, two main types of flysch-type assemblages can be distinguished which probably reflect faunistic trends (Gradstein and Berggren, 1981). The "type-A" assemblage is comprised of large, coarsely agglutinated simple forms, and corresponds to the Rhabdammina-fauna of Brouwer (1965). This assemblage is found in slope basins and in rapidly subsiding troughs where restricted bottom water circulation leads to oxygen-deficient substrates that may limit the occurrence of normal marine taxa and favor the development and preservation of agglutinated forms. Cretaceous and lower Paleogene type-A assemblages have also been recovered from DSDP Sites with paleodepths between 2.5 and $4.5 \mathrm{~km}$ (Miller et al. 1982). The "type-B" agglutinated assemblage is comprised of minute, smooth-walled varieties and was apparently restricted to deep Cretaceous paleodepths $(>4 \mathrm{~km})$, such as at DSDP Sites 196, 198A, 260, 261, 263 (Krasheninnikov, 1973, 1974) and at selected sites in the North Atlantic, most notably at Sites 137 and 138 (Beckmann, 1972), 543A (Hemleben and Troester, 1985), and 641A. This fauna is generally restricted to zeolitic clays, and probably lived in ridge-flank environments and on the abyssal plains beneath the oceanic lysocline.

The distribution of benthic foraminiferal species on the sea floor is influenced by depth-related water mass and sedimentological properties. Because benthic foraminiferal biofacies change with increasing depth and distance from shore, these organisms are used as tools to reconstruct the paleobathymetric and subsidence/burial history of sedimentary basins. The use of benthic foraminifera as paleobathymetric indicators in sedimentary basins 
is influenced by our knowledge of their distribution in modern sediments. Interpretations of paleobathymetry of fossil assemblages are usually based on the principle of taxonomic uniformitarianism, whereby the distribution of modern benthic species along bathymetric gradients serves as a key that allows us to assign paleodepths to fossil assemblages. This approach has been used with great success in reconstructing sea level curves for the Pleistocene. But in contrast with earlier epochs, the Pleistocene is a time of strong climatic gradients and increased contrasts between associated biotic provinces. In the early Paleogene, latitudinal climatic zonation was weaker (Wolf, 1987), there is no evidence for polar ice, and deep-water temperatures were about 10 degrees warmer than today (Miller et al., 1987). In the late Cretaceous and early Paleogene, analogies between modern and fossil distribution patterns are more tenuous due to evolutionary turnovers and changes in habitat preference of benthic taxa. As a result, some ancient sedimentary environments and their associated faunas have no modern analogs. This breakdown in the uniformitarian approach to paleoecology makes it increasingly difficult to calibrate the distribution of benthic microfossils in ancient sediments to paleobathymetry.

Nevertheless, the uniformitarian approach has been used by some authors to construct "paleobathymetric models" of benthic foraminiferal distribution patterns for sediments as old as mid-Cretaceous. For example, Sliter and Baker (1972) compiled a model of the bathymetric distribution of species on the Pacific Margin, and used this information to interpret the depositional environment of upper Cretaceous deposits in Southern California. A more generalized model was compiled by Haig (1979), who used both modern and fossil data to interpret global distribution patterns for mid-Cretaceous foraminiferids. Haig divided benthic assemblages into three general paleobathymetric associations. His classification of benthic assemblages into a neritic "Ammobaculites association", a bathyal "Marssonella association" and an abyssal "Recurvoides association" was well-received by paleontologists familiar with benthic foraminiferal assemblages in the alpine basins and these terms have become widely used in the literature. But what exactly are these associations and can they be applied to Paleogene flysch-type assemblages? One of the goals of this thesis is to examine the paleobathymetric distribution of Paleogene agglutinated species in different areas of the North Atlantic to 
determine whether consistent paleobathymetric patterns can be recognized and to test Haig's tripartate classification of assemblages.

A rigid paleobathymetric differentiation between the type-A and type- $B$ faunas may be an oversimplification and other paleoecological factors must be taken into account. The faunas were no doubt influenced by factors such as physiographic province (slope, rise, abyssal plain or ridge crest), the type of substrate, and the availability of nutrients. For example, the modern analog of Type-A agglutinated assemblages can be found living in continental slope and rise environments along the northwest Atlantic Margin. Several recent studies have documented the distribution of agglutinated species off Newfoundland (Schafer et al., 1983), and off Nova Scotia (Williamson, 1983; Thomas, 1985; Schroder, 1986a). In both areas, large coarsely agglutinated forms are associated with coarse substrates that reflect winnowing by bottom currents. The modern equivalent of a Type-B assemblage has been studied by Schroder (1986a). Although these faunas can occur at similar depths as the faunas from the continental rise, the type $B$ faunas are found on the abyssal plains below the oligotrophic North Atlantic central gyres. In this setting, the depositional environment is tranquil, the substrate typically finegrained, and the availability of nutrients low.

An extreme example of an area with increased food availability is the benthic community associated with hydrocarbon seeps on the Louisiana continental slope. In these areas, abundant bacteria which metabolize hydrocarbons and hydrogen sulfide support dense colonies of "vent-type" macrobenthos (Kennicutt et al. 1985). The study of agglutinated foraminifera from these areas provides a modern analog for some fossil assemblages in organic-rich sediments, and may furnish a biological tracer of such environments.

Our knowledge of the ecology of modern deep-sea agglutinated foraminiferal communities is still at an early stage. Studies of the distribution of modern deep-sea species of agglutinated foraminifera in the North Atlantic from the slope to the abyssal plain have demonstrated that many species have wide geographic and bathymetric ranges (Schroder, 1986a). This suggests that agglutinated foraminifera may be less affected by water mass properties than calcareous foraminifera. The community structure of agglutinated faunas is certainly influenced by environmental factors which may be independent of depth or watermass. If our goal is to interpret the fossil 
record, it is essential to extend our investigations of modern species beyond the biogeographic stage. First, it is necessary to better quantify the assemblage composition for well-defined ecologic niches (Schafer et al., 1983), and second, it is neccessary to gather data on the life history of agglutinated foraminifera and examine the response of these organisms to changes in their environment on a time-frame comparable to the lifespan of individuals. Only then shall we understand the niche of agglutinated foraminifera in the benthic community and be able to apply this knowledge to interpret the paleoenvironmental significance of fossil assemblages.

By applying uniformitarian principles, it ought to be possible to use the modern agglutinated faunas as a model to help interpret the paleoecological significance of fossil agglutinated assemblages. This approach has been successfully used with calcareous benthic foraminifera, which have a demonstrated utility in reconstructing the subsidence and water mass history of sedimentary basins. Many of the Tertiary basins in the North Atlantic, however, contain predominantly or exclusively agglutinated assemblages. The amount of paleoenvironmental information that can be extracted from these assemblages is a function of how well we understand the ecology of modern deep-sea agglutinated faunas. Therefore, synecological studies of modern agglutinated foraminifera play an essential role in establishing a baseline for paleoenvironmental analyses using Elysch-type assemblages.

In the North Atlantic, it has been suggested that the composition of modern foraminiferal assemblages may be influenced by water mass properties, and variations in the distribution of calcareous benthic assemblages in space and time have been interpreted as reflecting changing water masses (Streeter, 1973; Schnitker, 1974). Furthermore, turnovers in benthic foraminiferal assemblages at major stratigraphic boundaries have been attributed to the establishment of deep-water connections between basins (Berggren and Hollister, 1974). Our knowledge of the possible water mass dependence of agglutinated foraminifera is still in an early stage, but by examining assemblages in key areas it may be possible to identify species associations which can help us interpret the the chronology of deep-water connections between high-latitude ocean basins. Until now, studies of the history of deepwater connections between the Arctic and North Atlantic have been based primarily on geophysical evidence. Because the record of calcareous benthic foraminifera is poor or missing in the Norwegian-Greenland and Labrador Seas, 
no benthic foraminiferal studies have been performed to test the geophysical models of early Cenozoic paleoceanography in these areas.

The primary objectives of this study are to:

1. document the life history and ecology of benthic foraminifera in welldocumented ecologic settings, in order to better constrain the paleoenvironmental significance of "flysch-type" assemblages and identify potential tools for petroleum exploration and paleoceanography. To attain this objective, two separate studies were carried out with the goals of: a assessing the response of agglutinated foraminifera to community disequilibrium in the Panama Basin by examining biocoenoses and taphocoenoses in spade cores and recolonization trays placed on the sea floor, and b. assessing how benthic foraminiferal biofacies are affected by organicrich substrates at hydrocarbon seeps.

2. summarize the stratigraphic distribution of flysch-type agglutinated foraminifera from North Atlantic and Tethyan localities and present new data from the Zumaya Flysch in Northern Spain, and ODP Site 643A in the NorwegianGreenland Sea. Another goal in this respect is to document the nature of benthic foraminiferal assemblages in the high-latitude basins to help constrain the timing of deep-water connections between basins.

3. conduct a survey of agglutinated taxa from the Labrador Sea, North Sea, Norwegian-Greenland Sea, West Greenland, Trinidad, Jamaica, Poland, Spain, and Morocco based on standardized taxonomy, and identify paleobiogeogeographic patterns in their distribution.

4. develop a generalized paleoslope model for the North Atlantic which relates the composition and relative abundance of agglutinated foraminiferal taxa to paleobathymetry. Another goal is to compare the paleobathymetric distribution of assemblages from the North Atlantic with contemporaneous flysch-type agglutinated faunas from the Carpathian basins to determine whether consistent paleobathymetric patterns exist in these regions. Finally, it is necessary to compare the paleobathymetry of Paleogene agglutinated foraminifera in the North Atlantic with Cretaceous paleobathymetric models. 
REFERENCES :

Beckmann, J.P., 1972. The foraminifera and some associated microfossils of Sties 135 to 144. in: Haynes, D.E., and Pimm, A.C., et al., 1972. Init. Repts. DSDP 14, Washington (U.S. Govt. Printing Office), 389-420.

Berggren, W.A., and Hollister, C.D., 1974. Paleogeography, Paleobiogeography and the history of circulation in the Atlantic Ocean. in: Hay, W.W. (ed), Studies in Paleo-oceanography. SEPM Spec. Publ. 20. pp. 126-186.

Brouwer, J., 1965. Agglutinated foraminiferal faunas from some turbiditic sequences I, II. Proceedings of the Koninklijke Nederlandse Akademie van Wetenschappen series $\mathrm{B}, 68: 309-334$.

Gradstein, F.M., and Berggren, W.A., 1981. Flysch-type agglutinated foraminiferal stratigraphy and the Maestrichtian to Paleogene history of the Labrador and North Seas. Marine Micropaleontology 6:212-268.

Grzybowski, J., 1898. Otwornice pokladow naftonosnych okolicy Krosna. Rozprawy Akademii Umiejetnosci w Krakowie, Wydzial mat-przyr., serya 2, $33: 257-305$

Haig, D.W., 1979. Global distribution patterns for mid-Cretaceous foraminiferids. Jour. Foram. Res. 9:29-40.

Hemleben, C., and Troester, J., 1984. Campanian-Maestrichtian deep-water foraminifers from Hole 543A, Deep Sea Drilling Project. in: Biju-Duval, B., Moore, J.C., et al. Init. Repts. DSDP, 78A: Washington, D.C., (U.S. Government Printing office), 509-532.

Kennicutt, M.C., Brooks, J.M., Bidigare, R.B., Fay, R.R., Wade, T.L., and McDonald, T.J., 1985. Vent-type taxa in a hydrocarbon seep region on the Lousiana slope. Nature 317:352-352.

Krasheninnikov, V.A., 1973. Cretaceous benthic foraminifera, Leg 20, Deep Sea Drilling Project. in: Heezen, B.C., MacGregor, I.D., et al., Init. Repts. DSDP 20, Washington (U.S. Govt. Printing Office), 205-2 $2 \overline{1}$.

Krasheninnikov, V.A., 1974, Upper Cretaceous benthonic foraminifera, Leg 27, Deep Sea Drilling Project. in: Veevers, J.J., Hertzler, J.R., et al., Init. Repts. DSDP 27, Washington (U.S. Govt. Printing Office), $632-6 \overline{61}$.

Miller, K.G., Gradstein, F.M., and Berggren, W.A., 1982. Late Cretaceous to early Tertiary agglutinated benthic foraminifera in the Labrador Sea. Micropaleontology 28:2-30.

Miller, K.G., Fairbanks, R.G., and Mountain, G.S., 1987. Tertiary oxygen isotope synthesis, sea level history, and continental margin erosion. Paleoceanography $2: 1-19$.

Schnitker, D., 1974. West Atlantic abyssal circulation during the pas 120,000 years. Nature 248:385-387.

Schroder, C.J., 1986a. Deep-water arenaceous foraminifera in the Northwest 
Atlantic 0cean. Canadian Tech. Rept. of Hydrography and 0cean Sciences no. 71. $191 \mathrm{pp}$.

Schafer, C.T., Cole, F.E., and Carter, L., 1983. Paraecology of bathyal zone arenaceous foraminifera genera and species associations off northeast Newfoundland. Proc. First Workshop on Arenaceous Foraminifera, 7-9 Sept., 1981. IKU Publication 108:133-146.

Sliter, W.V., and Baker, R.A., 1972. Cretaceous bathymetric distribution of benthic foraminifers. Jour. Foram. Res. 2:167-183.

Streeter, S.S., 1973. Bottom water and benthonic foraminifera in the North Atlantic--glacial-interglacial contrasts. Quaternary Res. 3:132-141.

Thomas, F.C., 1985. Lower Scotian Slope benthic foraminiferal faunas past and present, with taxonomic outline [M.Sc. Thesis]. Dalhousie University, Halifax. 159pp.

Williamson, M.A., 1983. Benthic foraminiferal assemblages on the continental margin off Nova Scotia: A multivariate approach. Dalhousie University Ph.D. thesis, $347 \mathrm{pp}$.

Wolfe, J.A., 1987. Late Cretaceous-Cenozoic history of desiduousness and the terminal Cretaceous event. Paleobiology 13:215-226. 
CHAPTER 2.

OBSERVATIONS ON THE ECOLOGY OF MODERN AGGLUTINATED FORAMINIFERA AND A CASE HISTORY OF PALEOENVIRONMENTAL ANALYSIS USING NEOGENE AGGLUTINATED ASSEMBLAGES AT ODP SITE 646, LABRADOR SEA.

\section{SECTION A:}

LIFE HISTORY AND RECOLONIZATION BY AGGLUTINATED FORAMINIFERA IN THE PANAMA BASIN :

\section{INTRODUCTION}

The life history and community structure of deep-sea benthic foraminifera is a subject which has received little attention over the years, yet this information is essential to help assess the rates of disequilibrium processes such as disturbance and succession in abyssal assemblages. Recolonization of substrates by benthic foraminifera has been empirically observed in modern shallow water environments (Schafer, 1983) and in the deep sea (Kaminski, 1985). Successive recolonization of the sea floor has also been postulated as the cause of small-scale vertical changes in fossil foraminiferal assemblages in hemipelagic sediments above turbidites in alpine flysch deposits (Grun et al., 1964; Butt, 1981). In shallow water environments, benthic macrofaunal communities have been shown to recover from physical disturbance in a few months (Levin, 1984), but in the deep sea, rates of recolonization are typically one or two orders of magnitude slower (Grassle, 1977; 1978). No experimental study, however, has focused attention on the patterns of benthic foraminiferal response to conditions of community disequilibrium in an abyssal habitat, yet these organisms serve an important role in the trophic structure of deep-sea benthic communities. By studying the life history of benthic foraminifera and estimating the rate at which biological succession takes place, one can better interpret patterns observed in fossil assemblages. The deep Panama Basin is an excellent environment in which one can test the response of benthic foraminifera to substrate disturbance. The area has no observable nepheloid layer or current-derived bedforms, and x-radiographs have demonstrated that bottom sediment at the station is dominated by biogenic rather than physically formed structures (Aller and DeMaster, 1984). Therefore, one can be reasonably certain that the benthic community is not 
disturbed by bottom currents and that any artificial disturbance introduced in the area will not be augmented by natural causes.

In this study, I document the life history and ecology of benthic foraminifera in the Panama Basin by examining biocoenoses and taphocoenoses in spade cores and recolonization trays placed on the sea floor and assessing their response to community disequilibrium.

\section{STATION LOCATION}

The Panama Basin station is located at $5^{\circ} 20.65^{\prime} \mathrm{N}, 81^{\circ} 56.19^{\prime} \mathrm{W}$ at a depth of 3912 m (Fig. 2-1). Bottom water potential temperature and salinity in this area are $1.8^{\circ} \mathrm{C}$ and $34.67 \%$, respectively, and dissolved oxygen concentration is 2.4-2.6 $\mathrm{ml} / 1$ (Laird, 1971; Lonsdale, 1976). Bottom current velocities in the area are slow, $2-5 \mathrm{~cm} / \mathrm{s}$, and generally east to west in direction (Laird, 1971; Lonsdale, 1976; Honjo et al. 1982). No nepheloid layer is detected, so there is little chance that benthic fauna might be resuspended and advected into sediment trays by bottom currents.

Panama Basin sediments are typically hemipelagic mud, containing about $30 \%$ biogenic components $\left(\mathrm{CaCO}_{3}, \mathrm{SiO}_{2}\right)$. The organic carbon content is around $2.5 \%$, and the clay fraction is composed of $50-70 \%$ smectite, $15-20 \%$ chlorite, $5-10 \%$ illite and $10-15 \%$ kaolinite (Heath et al. 1974). Studies of $\mathrm{Pb}-210$ distribution in surface sediments at the site indicate rapid biogenic reworking in the upper few centimenters (Aller and DeMasters, 1984). The surface mixed layer is approximately $6 \mathrm{~cm}$ thick. Beneath this zone, mixing is about $10 \mathrm{X}$ slower but is present to at least $20 \mathrm{~cm}$ depth. Primary productivity in Panama Basin surface waters displays an east-west spatial gradient between 500 and $1000 \mathrm{mg} \mathrm{C} / \mathrm{m}^{2}$ day, with highest seasonal production in February-March and June-July (Moore et al. 1973: Honjo et al. 1982). The long term sediment accumulation rate is about $6-10 \mathrm{mg} / \mathrm{cm} \mathrm{yr}^{2}$ based on $\mathrm{C}-14$ measurements at the seafloor (Swift, 1977).

\section{SAMPLING}

The samples examined in this study were collected by the R/V Atlantis II and the submersible "Alvin" in summer of 1982. These consist of surface sediment from two spade cores and three sediment trays, or "mudboxes" which were collected within $100 \mathrm{~m}$ of one another. The spade cores were gathered to 


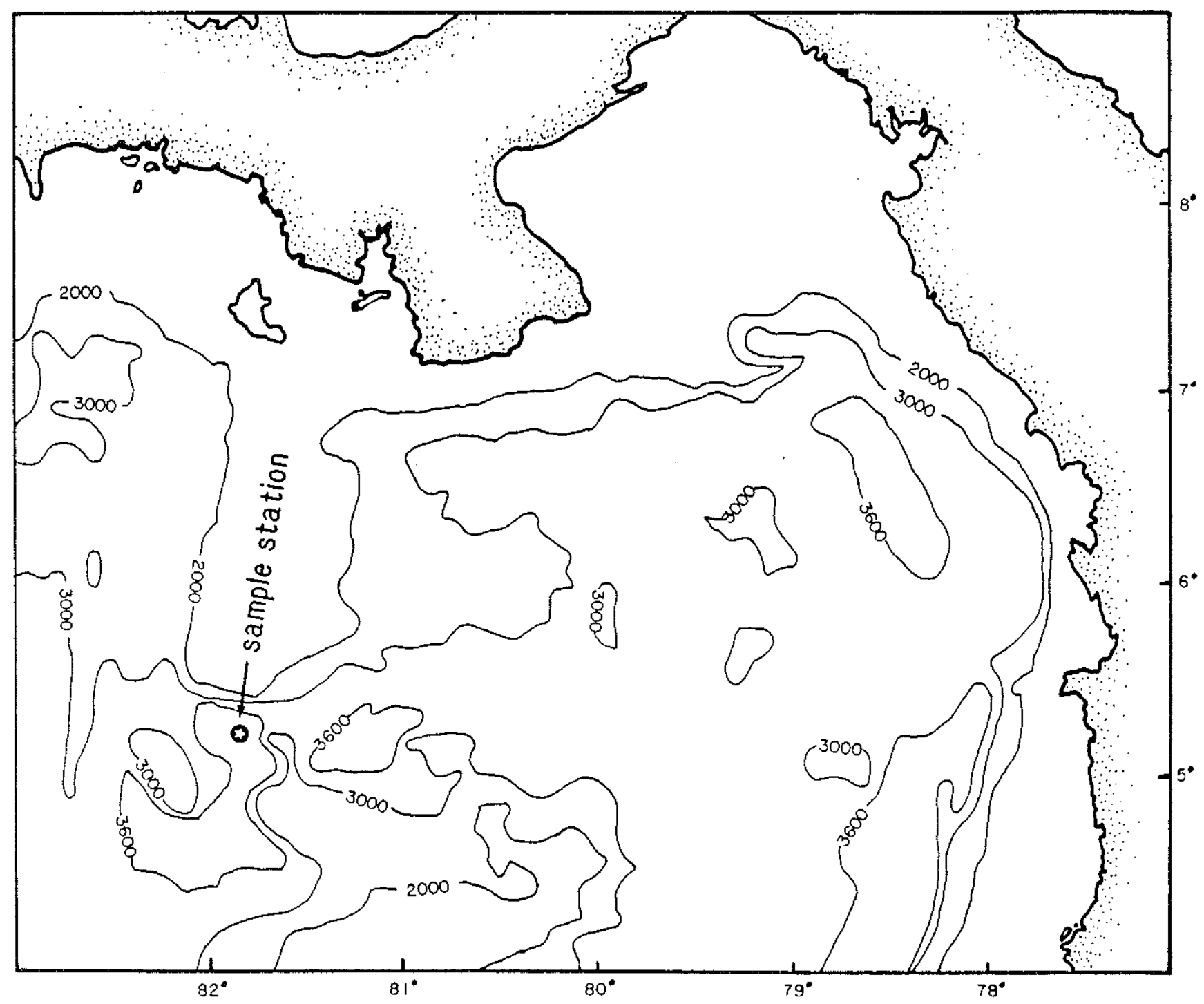

Figure 2-1. Map of study area showing location of sample station. Base map from Van Andel et al. (1971), depth in meters. 
provide control samples to determine faunal composition and abundance of taxa at this site.

A portion of the sediment collected in spade cores was subdivided into 9 sections $10 \times 10 \mathrm{~cm}$ in area, and each section was sampled at depth intervals of $0-2,2-5,5-10$, and $10-15 \mathrm{~cm}$. Another portion of the sediment was allowed to equilibrate to ambient room temperature, then frozen in the ship's refrigerator at $-15^{\circ} \mathrm{C}$, to eliminate any biota present. This mud was allowed to thaw and transferred to $30 \mathrm{~cm} \times 30 \mathrm{~cm} \mathrm{X} 5 \mathrm{~cm}$ fiberglass trays for emplacement on the sea floor. In each recolonization tray, the sediment was approximately $5 \mathrm{~cm}$ thick. Sediment from different depth sections of the spade core was handled separately and placed in different sectors of each tray (Fig. 2-2). The trays were fitted with a hinged PVC lid to prevent loss of mud during emplacement and recovery. The submersible "Alvin" deployed the trays on September 11, 1981, close to the site where spade cores were taken, and once in place on the sea floor, the lids were opened to expose the abiotic mud. After nine months (June 10-12, 1982), the trays were recovered. The Alvin closed the lids on the trays and carried them to the surface for sampling.

Each tray was subsampled in 16 sections $7.5 \times 7.5 \mathrm{~cm}$ in area, and these were not further subdivided with depth. Mud samples from spade cores and trays were fixed overnight in a buffered formalin solution, sieved through a 297 micron sieve, transfered to storage jars and preserved in ethyl alcohol. In the labratory, preserved samples were stained overnight with Rose Bengal, and prior to picking, samples were again gently sieved and washed into a petri dish with ethyl alcohol. Foraminifera were picked using an eyedropper to transfer specimens to glass vials for storage. All specimens of foraminifera were picked from each subsample and the numbers of live and dead individuals were recorded. With some species it was necessary to crush specimens or make a small hole in the last chamber with a dissecting needle to determine whether red protoplasm was present.

\section{RESULTS :}

FORAMINIFERAL ABUNDANCE AND DIVERSITY

A. Control Samples --

The numbers of living and dead individuals were tallied separately for 4 subsamples (totalling $400 \mathrm{~cm}^{2}$ ) from each of two spade cores taken in close 


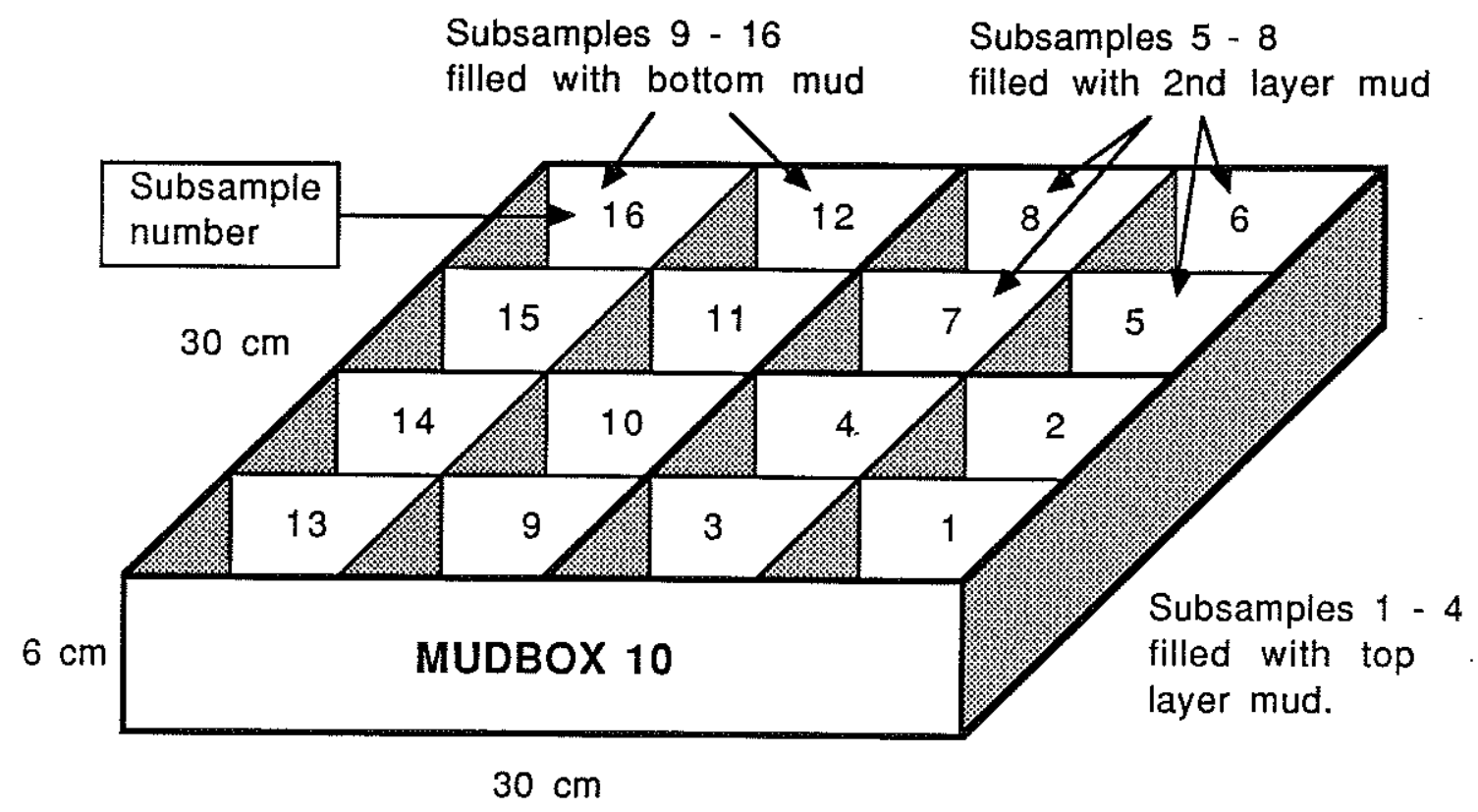

2-2. Diagram of Mudbox 10 showing configuration of subsamples and the type of sediment used. 
proximity to each other (Table 2-1). Spade core 13 was sampled at four depth intervals $(0-2,2-5,5-10$, and $10-15 \mathrm{~cm})$ and therefore provides a more complete data set than Spade core 9, which was only sampled at $0-2,2-5$, and $5-10 \mathrm{~cm}$. No living calcareous benthics were observed in any of the samples, but occasionally, dead specimens of Pyrgo murrhina, Planulina wuellerstorfi and entosolenians were found. These were rare and were not included in the counts. The living fauna consisted entirely of agglutinated foraminifera. The $400 \mathrm{~cm}^{2}$ area from Spade core 13 contained a total of 497 live individuals of agglutinated foraminifera belonging to 16 species, while 3,058 dead specimens belonging to 29 species were found. The same area from Spade core 9 contained 475 live individuals belonging to 18 species, and 3,593 dead specimens belonging to 26 species. Only $12.75 \%$ of the total agglutinated foraminiferal assemblage was living at the time of collection, as determined by Rose Bengal. This number contrasts with values of $30-40 \%$ in abyssal areas in the western North Atlantic determined by Schroder (1986a), with the difference probably a result of faster degradation of dead tests in the organic carbon-poor North Atlantic.

The data presented in Tables 2-1 and 2-2 show that the major difference in populations between the two spade cores lies in the numbers of Dendrophrya, which is more abundant in Spade core 9 by a factor of two, and Reophax dentaliniformis, which is three times more abundant in spade core 13 . These differences may be due in part to differential handling and sample quality (the problems of counting fragments of tubular species are legendary and need not be repeated here). Assuming equal fragmentation, the discrepancy in counts may be partly due to loss of some of the flocculent surface layer in Spade core 13, which would introduce a bias towards infaunal species. However, the cores did not appear to be disturbed, and an equally likely explanation is that the difference in abundance of the two taxa is real, and simply reflects the patchy distribution of species on the sea floor.

\section{B. Recolonization Tray Samples --}

The numbers of living and dead specimens in replicate subsamples from the three recolonization trays are tabulated in Tables 2-3 to 2-5. Because the size of the subsamples from the trays differed in area from those taken from 
Table 2-1. Faunal data from Spade Core 9, Panama Basin.

PANAMA BASIN, AII 112, SPADE CORE 9, LIVE/DEAD INDIVIDUALS

\begin{tabular}{lcccccccccccc} 
DEPTH INTERVAL: & \multicolumn{3}{c}{$0-2 \mathrm{~cm}$} & \multicolumn{1}{c}{$2-5 \mathrm{~cm}$} & \multicolumn{3}{c}{$5-10 \mathrm{~cm}$} \\
SUBCORE: & $\mathbf{2}$ & $\mathbf{4}$ & $\mathbf{7}$ & $\mathbf{8}$ & $\mathbf{2}$ & $\mathbf{4}$ & $\mathbf{7}$ & $\mathbf{8}$ & $\mathbf{2}$ & $\mathbf{4}$ & $\mathbf{7}$ & $\mathbf{8}$ \\
\hline Dendrophrya arborescens & $37 / 396$ & $61 / 362$ & $26 / 663$ & $8 / 125$ & $5 / 32$ & $18 / 56$ & $3 / 61$ & $18 / 36$ & $0 / 1$ & $0 / 0$ & $0 / 2$ & $0 / 0$ \\
Reophax dentiliniformis & $2 / 14$ & $0 / 6$ & $1 / 7$ & $3 / 6$ & $0 / 22$ & $3 / 21$ & $10 / 25$ & $5 / 17$ & $4 / 12$ & $1 / 22$ & $6 / 23$ & $2 / 20$ \\
Hormosina ovicula & $0 / 6$ & $1 / 4$ & $0 / 6$ & $1 / 5$ & $1 / 21$ & $1 / 19$ & $1 / 15$ & $3 / 16$ & $0 / 34$ & $1 / 30$ & $0 / 25$ & $2 / 49$ \\
Hormosina distans & $0 / 2$ & $0 / 0$ & $2 / 1$ & $0 / 0$ & $0 / 0$ & $0 / 0$ & $0 / 0$ & $0 / 0$ & $0 / 1$ & $0 / 0$ & $0 / 0$ & $0 / 1$ \\
Reophax excentricus & $0 / 8$ & $0 / 6$ & $2 / 20$ & $1 / 3$ & $2 / 13$ & $5 / 41$ & $10 / 25$ & $3 / 11$ & $5 / 28$ & $4 / 31$ & $9 / 20$ & $14 / 41$ \\
Saccammina sp. & $0 / 3$ & $0 / 3$ & $2 / 5$ & $2 / 4$ & $1 / 12$ & $0 / 20$ & $0 / 12$ & $0 / 19$ & $0 / 31$ & $0 / 25$ & $0 / 30$ & $0 / 34$ \\
Trochammina globigeriniformis & $0 / 7$ & $0 / 8$ & $1 / 2$ & $0 / 4$ & $0 / 9$ & $1 / 17$ & $0 / 16$ & $0 / 2$ & $0 / 21$ & $0 / 15$ & $1 / 26$ & $1 / 23$ \\
Rhizammina sp. (large) & $0 / 15$ & $2 / 3$ & $0 / 3$ & $1 / 2$ & $0 / 4$ & $0 / 6$ & $0 / 3$ & $0 / 1$ & $0 / 1$ & $0 / 4$ & $0 / 1$ & $0 / 3$ \\
Lana sp. & 5 & 4 & 3 & 2 & 4 & 4 & 2 & 3 & 0 & 1 & 0 & 2 \\
Cribrostomoides subglobosus & $0 / 2$ & $2 / 1$ & $1 / 2$ & $1 / 3$ & $0 / 0$ & $0 / 1$ & $0 / 6$ & $0 / 3$ & $0 / 8$ & $0 / 6$ & $0 / 10$ & $1 / 9$ \\
Recurvoides spp. & $2 / 5$ & $0 / 3$ & $1 / 4$ & $0 / 6$ & $0 / 6$ & $0 / 3$ & $4 / 5$ & $0 / 3$ & $0 / 7$ & $0 / 7$ & $0 / 7$ & $1 / 11$ \\
Buzasina ringens & $0 / 1$ & $0 / 0$ & $1 / 1$ & $0 / 2$ & $0 / 1$ & $0 / 3$ & $0 / 4$ & $0 / 0$ & $0 / 1$ & $0 / 6$ & $0 / 1$ & $0 / 2$ \\
Ammodiscus incertus & $0 / 2$ & $0 / 0$ & $1 / 2$ & $2 / 5$ & $1 / 4$ & $0 / 2$ & $0 / 1$ & $0 / 4$ & $0 / 8$ & $0 / 10$ & $0 / 11$ & $0 / 12$ \\
Ammobaculites sp. & $0 / 1$ & $0 / 0$ & $0 / 0$ & $0 / 0$ & $0 / 2$ & $0 / 2$ & $0 / 2$ & $0 / 2$ & $0 / 8$ & $0 / 1$ & $0 / 7$ & $0 / 4$ \\
Hormosina globulifera & $0 / 2$ & $0 / 1$ & $0 / 1$ & $0 / 1$ & $0 / 1$ & $0 / 1$ & $1 / 2$ & $0 / 1$ & $0 / 2$ & $0 / 2$ & $0 / 5$ & $0 / 3$ \\
Eggerella propinqua & $0 / 0$ & $0 / 0$ & $1 / 0$ & $0 / 0$ & $0 / 2$ & $0 / 0$ & $1 / 1$ & $0 / 1$ & $0 / 0$ & $0 / 2$ & $0 / 1$ & $0 / 1$ \\
Eggerella bradyi & $0 / 0$ & $0 / 0$ & $0 / 0$ & $0 / 0$ & $0 / 0$ & $0 / 1$ & $0 / 0$ & $0 / 0$ & $0 / 1$ & $0 / 0$ & $0 / 0$ & $0 / 0$ \\
Pelosina sp. & $1 / 3$ & $1 / 1$ & $0 / 0$ & $3 / 3$ & $0 / 1$ & $0 / 1$ & $1 / 1$ & $0 / 0$ & $1 / 1$ & $0 / 0$ & $0 / 0$ & $0 / 0$ \\
& & & & & & & & & & \\
\hline
\end{tabular}


Table 2-2. Faunal data from Spade Core 13, Panama Basin.

PANAMA BASIN, AII 112, SPADE CORE 13, LIVE/DEAD INDIVIDUALS DEPTH INTERVAL: $\quad 0-2 \mathrm{~cm} \quad 2-5 \mathrm{~cm} \quad 5-10 \mathrm{~cm} \quad 10-15 \mathrm{~cm}$ \begin{tabular}{lllllllllllllllll} 
SUBCORE & 1 & 3 & 9 & 6 & 1 & 3 & 9 & 6 & 1 & 3 & 9 & 6 & 1 & 3 & 9 & 6 \\
\hline
\end{tabular}

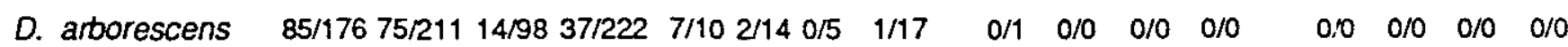
$\begin{array}{lllllllllllllllll}\text { R. dentaliniformis } \quad 1 / 11 & 4 / 17 & 2 / 9 & 3 / 10 & 15 / 45 & 19 / 36 & 15 / 30 & 23 / 54 & 5 / 35 & 12 / 52 & 22 / 50 & 11 / 46 & 5 / 27 & 8 / 33 & 6 / 38 & 5 / 50\end{array}$ $\begin{array}{lllllllllllllllll}H . \text { ovicula } & 3 / 3 & 3 / 6 & 3 / 40 & 0 / 6 & 1 / 21 & 0 / 19 & 1 / 12 & 0 / 20 & 0 / 21 & 0 / 26 & 0 / 36 & 0 / 26 & 0 / 1 & 1 / 12 & 0 / 20 & 0 / 7\end{array}$ $\begin{array}{llllllllllllllllll}\text { R. excentricus } & 2 / 9 & 1 / 3 & 1 / 2 & 0 / 4 & 3 / 15 & 1 / 15 & 2 / 7 & 3 / 11 & 7 / 17 & 6 / 47 & 3 / 32 & 2 / 38 & 7 / 92 & 2 / 65 & 2 / 54 & 6 / 66\end{array}$ $\begin{array}{lllllllllllllllllllll}\text { Saccammina sp. } & 2 / 5 & 1 / 1 & 0 / 5 & 0 / 4 & 2 / 8 & 0 / 6 & 0 / 4 & 0 / 11 & 1 / 16 & 0 / 21 & 0 / 27 & 0 / 31 & 0 / 27 & 0 / 19 & 1 / 18 & 0 / 18\end{array}$ $\begin{array}{llllllllllllllllll}\text { T. globigeriniformis } & 3 / 5 & 1 / 5 & 1 / 8 & 2 / 4 & 0 / 10 & 0 / 14 & 0 / 9 & 0 / 18 & 3 / 28 & 0 / 16 & 0 / 19 & 0 / 18 & 0 / 41 & 0 / 31 & 0 / 21 & 0 / 28\end{array}$

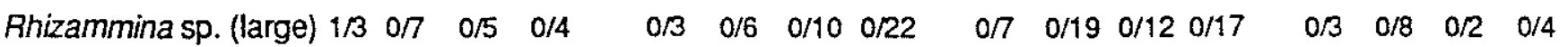
$\begin{array}{llllllllllllllllll}\text { Lana } s p . & 3 & 5 & 5 & 3 & 0 & 1 & 2 & 1 & 0 & 1 & 1 & 0 & & 1 & 0 & 0 & 0\end{array}$

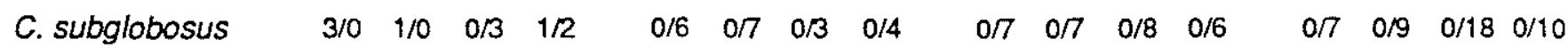
$\begin{array}{lllllllllllllllll}\text { Recurvoides sp. } & 0 / 0 & 4 / 1 & 0 / 8 & 0 / 2 & 3 / 9 & 0 / 1 & 0 / 6 & 0 / 3 & 0 / 5 & 0 / 7 & 0 / 9 & 0 / 9 & 0 / 10 & 0 / 5 & 0 / 3 & 0 / 7\end{array}$ $\begin{array}{llllllllllllllllll}\text { B. ringens } & 0 / 0 & 1 / 1 & 1 / 2 & 1 / 0 & 0 / 3 & 0 / 1 & 0 / 0 & 1 / 2 & 0 / 6 & 0 / 5 & 0 / 5 & 0 / 1 & 0 / 4 & 0 / 5 & 0 / 6 & 0 / 3\end{array}$ $\begin{array}{lllllllllllllllll}\text { A. incertus } & 1 / 1 & 0 / 1 & 0 / 0 & 0 / 1 & 0 / 0 & 0 / 0 & 0 / 0 & 0 / 0 & 0 / 3 & 0 / 0 & 0 / 0 & 0 / 0 & 0 / 0 & 0 / 1 & 0 / 3 & 0 / 1\end{array}$ $\begin{array}{lllllllllllllllll}\text { Ammobaculites sp. } & 0 / 0 & 0 / 0 & 0 / 0 & 0 / 0 & 0 / 1 & 0 / 1 & 0 / 2 & 0 / 4 & 0 / 3 & 0 / 0 & 0 / 0 & 0 / 0 & 0 / 5 & 0 / 6 & 0 / 2 & 0 / 6\end{array}$ $\begin{array}{lllllllllllllllll}H . \text { globulifera } & 0 / 0 & 2 / 0 & 0 / 0 & 0 / 1 & 0 / 0 & 0 / 0 & 0 / 2 & 0 / 1 & 0 / 1 & 0 / 2 & 0 / 2 & 0 / 2 & 0 / 2 & 1 / 2 & 0 / 2 & 0 / 0\end{array}$ $\begin{array}{lllllllllllllllll}\text { E. propinqua } & 0 / 1 & 0 / 2 & 0 / 0 & 0 / 0 & 0 / 2 & 0 / 0 & 0 / 0 & 0 / 0 & 0 / 0 & 0 / 1 & 0 / 0 & 0 / 1 & 0 / 2 & 0 / 2 & 0 / 4 & 0 / 1\end{array}$ $\begin{array}{lllllllllllllllll}\text { E. bradyi } & 0 / 0 & 0 / 0 & 0 / 1 & 0 / 0 & 0 / 0 & 0 / 0 & 0 / 0 & 0 / 0 & 0 / 0 & 0 / 2 & 0 / 0 & 0 / 0 & 0 / 1 & 0 / 0 & 0 / 2 & 0 / 0\end{array}$ $\begin{array}{lllllllllllllllll}\text { Pelosina sp. } & 0 / 0 & 0 / 0 & 3 / 0 & 0 / 0 & 0 / 0 & 0 / 0 & 5 / 0 & 2 / 0 & 0 / 0 & 0 / 0 & 0 / 0 & 0 / 0 & 0 / 0 & 0 / 2 & 1 / 0 & 0 / 0\end{array}$ 
Table 2-3. Faunal data from Mudbox 7, Panama Basin.

\section{PANAMA BASIN, AII-112, MUDBOX 7, LIVE/DEAD INDIVIDUALS}

SUBCORE : $\begin{array}{lllllllll}1 & 6 & 7 & 8 & 9 & 11 & 12 & 13 & 14\end{array}$

$\begin{array}{llllllllll}\text { Dendrophrya arborescens } & 0 / 0 & 0 / 0 & 0 / 0 & 0 / 0 & 0 / 0 & 0 / 0 & 0 / 0 & 0 / 0 & 0 / 0\end{array}$ $\begin{array}{llllllllll}\text { Reophax dentaliniformis } & 1 / 7 & 0 / 6 & 2 / 12 & 3 / 11 & 0 / 16 & 2 / 18 & 0 / 7 & 2 / 18 & 5 / 25\end{array}$ $\begin{array}{llllllllll}\text { Hormosina ovicula } & 0 / 3 & 1 / 1 & 0 / 1 & 1 / 3 & 0 / 13 & 1 / 11 & 0 / 9 & 1 / 18 & 1 / 9\end{array}$ $\begin{array}{llllllllll}\text { Hormosina distans } & 0 / 0 & 0 / 0 & 0 / 0 & 0 / 1 & 0 / 1 & 0 / 0 & 0 / 0 & 1 / 0 & 0 / 1\end{array}$ $\begin{array}{llllllllll}\text { Reophax excentricus } & 4 / 34 & 5 / 44 & 4 / 18 & 2 / 44 & 0 / 48 & 0 / 23 & 0 / 11 & 4 / 32 & 5 / 40\end{array}$ $\begin{array}{llllllllll}\text { Saccammina Sp. } & 0 / 2 & 0 / 1 & 0 / 5 & 0 / 6 & 0 / 8 & 0 / 6 & 0 / 1 & 0 / 24 & 0 / 16\end{array}$

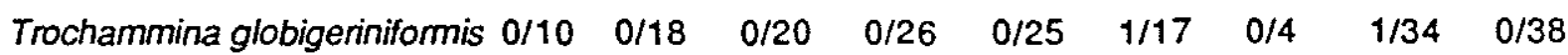
$\begin{array}{llllllllll}\text { Rhizammina } \$ \text { Sp. (large) } & 0 / 3 & 0 / 1 & 0 / 1 & 0 / 3 & 0 / 13 & 1 / 3 & 0 / 5 & 0 / 12 & 0 / 7\end{array}$ Lana sp. $\begin{array}{lllllllll}0 & 0 & 0 & 0 & 0 & 2 & 2 & 0 & 0\end{array}$ $\begin{array}{lllllllll}\text { Cribrostomoides subglobosus } 0 / 5 & 0 / 2 & 0 / 3 & 0 / 3 & 0 / 5 & 0 / 2 & 0 / 2 & 0 / 12 & 1 / 7\end{array}$ $\begin{array}{llllllllll}\text { Recurvoides spp. } & 0 / 3 & 0 / 1 & 0 / 2 & 0 / 2 & 0 / 7 & 0 / 2 & 0 / 0 & 0 / 9 & 0 / 7\end{array}$ $\begin{array}{llllllllll}\text { Buzasina ringens } & 0 / 3 & 0 / 3 & 0 / 4 & 0 / 0 & 0 / 5 & 1 / 3 & 0 / 1 & 1 / 3 & 0 / 3\end{array}$ $\begin{array}{llllllllll}\text { Ammodiscus incertus } & 0 / 0 & 1 / 4 & 0 / 0 & 1 / 2 & 0 / 2 & 0 / 4 & 0 / 1 & 0 / 14 & 0 / 1\end{array}$ $\begin{array}{llllllllll}\text { Ammobaculites sp. } & 0 / 2 & 0 / 3 & 0 / 3 & 0 / 3 & 0 / 5 & 0 / 0 & 0 / 0 & 0 / 8 & 0 / 8\end{array}$ $\begin{array}{llllllllll}\text { Hormosina globulifera } & 0 / 0 & 0 / 0 & 0 / 0 & 0 / 0 & 0 / 0 & 0 / 0 & 0 / 0 & 0 / 0 & 1 / 1\end{array}$ $\begin{array}{llllllllll}\text { Eggerella propinqua } & 0 / 0 & 0 / 0 & 0 / 0 & 0 / 0 & 0 / 0 & 0 / 1 & 0 / 0 & 0 / 0 & 0 / 0\end{array}$ $\begin{array}{llllllllll}\text { Eggerella bradyi } & 0 / 0 & 0 / 0 & 0 / 0 & 0 / 3 & 0 / 0 & 0 / 0 & 0 / 0 & 0 / 3 & 0 / 0\end{array}$ $\begin{array}{llllllllll}\text { Pelosina sp. } & 0 / 0 & 0 / 0 & 0 / 0 & 0 / 1 & 0 / 0 & 0 / 0 & 0 / 0 & 0 / 0 & 1 / 0\end{array}$ 
Table 2-4. Faunal data from Mudbox 10, Panama Basin.

\begin{tabular}{|c|c|c|c|c|c|c|c|c|c|}
\hline $\begin{array}{l}\text { PANAMA BASIN, A] } \\
\text { SUBCORE: }\end{array}$ & $\begin{array}{c}11-112 \\
3 \\
\end{array}$ & 6 & $\begin{array}{l}\text { UDBO } \\
8 \\
\end{array}$ & $\begin{array}{l}X 1 \\
9 \\
\end{array}$ & $\begin{array}{l}1 \mathrm{LI} \\
11 \\
\end{array}$ & 12 & 13 & 14 & 16 \\
\hline Dendrophrya arborescens & $0 / 0$ & $0 / 0$ & $0 / 0$ & $0 / 0$ & $0 / 0$ & $0 / 0$ & $0 / 0$ & $0 / 0$ & $0 / 0$ \\
\hline Reophax dentaliniformis & $4 / 14$ & $1 / 9$ & $11 / 21$ & $2 / 15$ & $3 / 9$ & $0 / 17$ & $7 / 11$ & $12 / 23$ & $8 / 23$ \\
\hline Hormosina ovicula & $0 / 1$ & $1 / 4$ & $1 / 2$ & $0 / 6$ & $0 / 0$ & $0 / 0$ & $0 / 13$ & $1 / 10$ & $1 / 17$ \\
\hline Hormosina distans & $0 / 0$ & $0 / 0$ & $0 / 1$ & $1 / 0$ & $0 / 0$ & $0 / 0$ & $0 / 0$ & $2 / 3$ & $0 / 0$ \\
\hline Reophax excentricus & $2 / 78$ & $7 / 73$ & $12 / 140$ & $5 / 69$ & $5 / 63$ & $2 / 71$ & $5 / 41$ & $9 / 63$ & $6 / 50$ \\
\hline Saccammina sp. & $2 / 8$ & $0 / 8$ & $2 / 10$ & $0 / 8$ & $0 / 11$ & $0 / 7$ & $0 / 6$ & $0 / 18$ & $0 / 7$ \\
\hline Trochammina globigeriniformis & is $0 / 28$ & $0 / 33$ & $3 / 31$ & $0 / 25$ & $1 / 23$ & $0 / 19$ & $0 / 16$ & $1 / 27$ & $0 / 19$ \\
\hline Rhizammina sp. (large) & $0 / 8$ & $0 / 4$ & $1 / 12$ & $0 / 5$ & $0 / 2$ & $0 / 3$ & $0 / 5$ & $0 / 13$ & $2 / 13$ \\
\hline Lana sp. & 1 & 0 & 0 & 0 & 4 & 2 & 0 & 1 & 0 \\
\hline Cribrostomoides subglobosus & $s 1 / 4$ & $4 / 1$ & $0 / 0$ & $4 / 2$ & $2 / 1$ & $1 / 4$ & $0 / 3$ & $1 / 6$ & $2 / 8$ \\
\hline Recurvoides spp. & $1 / 3$ & $0 / 1$ & $1 / 2$ & $0 / 1$ & $0 / 3$ & $0 / 0$ & $1 / 3$ & $1 / 6$ & $0 / 2$ \\
\hline Buzasina ringens & $0 / 0$ & $0 / 0$ & $0 / 0$ & $0 / 2$ & $1 / 0$ & $0 / 1$ & $0 / 1$ & $0 / 3$ & $0 / 2$ \\
\hline Ammodiscus incertus & $0 / 0$ & $0 / 0$ & $0 / 0$ & $0 / 2$ & $0 / 0$ & $0 / 1$ & $0 / 1$ & $0 / 4$ & $2 / 6$ \\
\hline Ammobaculites sp. & $0 / 5$ & $0 / 6$ & $1 / 13$ & $1 / 11$ & $0 / 7$ & $0 / 8$ & $0 / 5$ & $1 / 6$ & $1 / 9$ \\
\hline Hormosina globulifera & $0 / 1$ & $0 / 3$ & $0 / 0$ & $0 / 2$ & $0 / 2$ & $0 / 0$ & $0 / 0$ & $0 / 0$ & $0 / 2$ \\
\hline Eggerella propinqua & $0 / 0$ & $0 / 1$ & $0 / 0$ & $0 / 0$ & $0 / 0$ & $0 / 0$ & $0 / 0$ & $0 / 2$ & $0 / 1$ \\
\hline Eggerella bracyi & $0 / 0$ & $0 / 0$ & $0 / 1$ & $0 / 1$ & $0 / 0$ & $0 / 0$ & $0 / 0$ & $0 / 0$ & $0 / 1$ \\
\hline Pelosina sp. & $0 / 0$ & $0 / 0$ & $0 / 0$ & $1 / 0$ & $0 / 0$ & $0 / 0$ & $0 / 0$ & $0 / 1$ & $0 / 0$ \\
\hline
\end{tabular}


Table 2-5. Faunal data from Mudbox 11, Panama Basin.

\section{PANAMA BASIN, AII-112, MUDBOX 11, LIVE/DEAD INDIVIDUALS} SUBCORE: 4

$\begin{array}{llllllllll}\text { Dendrophrya amorescens } & 0 / 0 & 0 / 0 & 0 / 0 & 0 / 0 & 0 / 0 & 0 / 0 & 0 / 0 & 0 / 0 & 0 / 0\end{array}$ $\begin{array}{llllllllll}\text { Reophax dentaliniformis } & 3 / 23 & 3 / 17 & 0 / 12 & 1 / 3 & 1 / 11 & 0 / 5 & 0 / 8 & 2 / 6 & 0 / 7\end{array}$ $\begin{array}{llllllllll}\text { Hormosina ovicula } & 1 / 13 & 0 / 3 & 0 / 1 & 0 / 0 & 0 / 2 & 0 / 1 & 0 / 1 & 0 / 2 & 0 / 0\end{array}$ $\begin{array}{llllllllll}\text { Hormosina distans } & 0 / 2 & 0 / 0 & 0 / 0 & 0 / 0 & 0 / 0 & 0 / 0 & 0 / 0 & 0 / 0 & 0 / 0\end{array}$ $\begin{array}{llllllllll}\text { Reophax excentricus } & 4 / 72 & 5 / 49 & 4 / 53 & 2 / 27 & 2 / 42 & 4 / 35 & 5 / 48 & 2 / 40 & 3 / 39\end{array}$ $\begin{array}{llllllllll}\text { Saccammina sp. } & 0 / 17 & 0 / 13 & 0 / 11 & 0 / 3 & 0 / 5 & 0 / 11 & 0 / 9 & 0 / 3 & 0 / 5\end{array}$

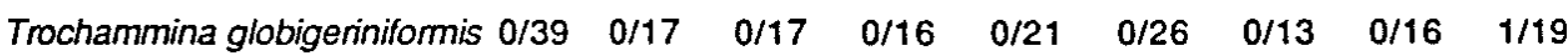
$\begin{array}{llllllllll}\text { Rhizammina sp. (large) } & 0 / 11 & 0 / 7 & 0 / 5 & 0 / 3 & 0 / 1 & 0 / 1 & 0 / 2 & 0 / 4 & 0 / 4\end{array}$ $\begin{array}{llllllllll}\text { Lana sp. } & 1 & 0 & 1 & 0 & 0 & 0 & 0 & 0 & 1\end{array}$

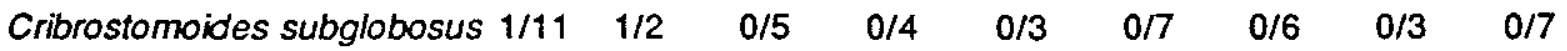
$\begin{array}{llllllllll}\text { Recurvoides spp. } & 0 / 5 & 0 / 4 & 0 / 3 & 0 / 0 & 0 / 2 & 0 / 2 & 0 / 2 & 0 / 1 & 0 / 1\end{array}$ $\begin{array}{llllllllll}\text { Buzasina ringens } & 0 / 4 & 0 / 1 & 0 / 2 & 0 / 0 & 0 / 3 & 0 / 5 & 0 / 0 & 0 / 0 & 0 / 0\end{array}$ $\begin{array}{llllllllll}\text { Ammodiscus incertus } & 0 / 4 & 0 / 2 & 0 / 0 & 0 / 0 & 0 / 0 & 0 / 0 & 0 / 1 & 0 / 1 & 0 / 0\end{array}$ $\begin{array}{llllllllll}\text { Ammodiscus sp. } & 0 / 15 & 0 / 3 & 0 / 6 & 0 / 3 & 0 / 11 & 0 / 6 & 0 / 3 & 0 / 3 & 0 / 3\end{array}$ $\begin{array}{llllllllll}\text { Hormosina globulifera } & 0 / 0 & 0 / 1 & 0 / 1 & 0 / 0 & 1 / 2 & 0 / 2 & 0 / 1 & 0 / 1 & 0 / 0\end{array}$ $\begin{array}{llllllllll}\text { Eggerella propinqua } & 0 / 0 & 0 / 0 & 0 / 3 & 0 / 1 & 0 / 3 & 0 / 0 & 0 / 1 & 0 / 1 & 0 / 1\end{array}$ $\begin{array}{llllllllll}\text { Eggerella bradyi } & 0 / 2 & 0 / 1 & 0 / 3 & 0 / 1 & 0 / 0 & 0 / 0 & 0 / 1 & 0 / 0 & 0 / 0\end{array}$ $\begin{array}{llllllllll}\text { Pelosina sp. } & 0 / 1 & 0 / 0 & 0 / 1 & 0 / 1 & 0 / 0 & 0 / 0 & 0 / 0 & 0 / 0 & 0 / 0\end{array}$ 
spade cores ( $7.5 \times 7.5 \mathrm{~cm}$ for the trays versus $10 \times 10 \mathrm{~cm}$ for spade cores), more subsamples from the trays were counted to obtain comparable data ( 9 subsamples from a tray corresponds to an area of $506.25 \mathrm{~cm}^{2}$ ). The abundance of dead specimens did not differ greatly from tray to tray, and totaled 999 specimens in Mudbox 7, 1029 specimens in Mudbox 11, and 1,432 specimens in Mudbox 10.

The numbers of live individuals were small in comparison with control samples, with 48 live individuals in Mudbox 11, 56 individuals in Mudbox 7 , and 156 in Mudbox 10. Collectively, only $6.9 \%$ of the individuals in trays were alive at the time of retrieval. This compares with $15.6 \%$ living individuals in the upper $5 \mathrm{~cm}$ of the control samples. In each tray, sediment from different layers of the spade core was handled separately and placed in different areas of the tray (Fig. 2-2). This differential treatment is not reflected in the numbers of dead individuals present in different subsamples. The Shannon-Wiener diversity of live populations from recolonization trays does not differ greatly from that of the control samples, at 2.48 for Mudbox 7, 1.61 for Mudbox 11, and 2.79 for Mudbox 10, versus values of 1.55 and 2.09 for control samples. When Hulburt's Rarefaction Method (Hulburt, 1971) is used to calculate $\mathrm{E}(\mathrm{Sn})$ the expected number of species at a given sample size (Fig. 2-3), the differences in diversity between trays becomes apparent. At a sample size of 40, the calculated species richness in Mudbox 10 is 10.19 , but in Mudbox 11 is only 6.44. The value of $E$ (S40) of control samples falls between those of the trays, at 6.86 and 7.73 .

The abundance of macrofaunal invertebrates in the trays reflects the same pattern as that of the foraminifera, with 7 living individuals in Mudbox 11, eleven individuals in Mudbox 7, and 19 individuals in Mudbox 10. About 70\% of the individuals are polychaetes, $22 \%$ are crustacea, and $8 \%$ molluscs. Two new species of spionid polychaete in the genus Prionospio are the only species represented by more than two individual.s. The mean abundance of macrofaunal invertebrates in the recolonization trays is 1.4 live individuals $/ 100 \mathrm{~cm}^{2}$. This compares with a mean abundance of 15.6 live individuals $/ 100 \mathrm{~cm}^{2}$ in control samples from nine Alvin boxcores gathered at the same site. 


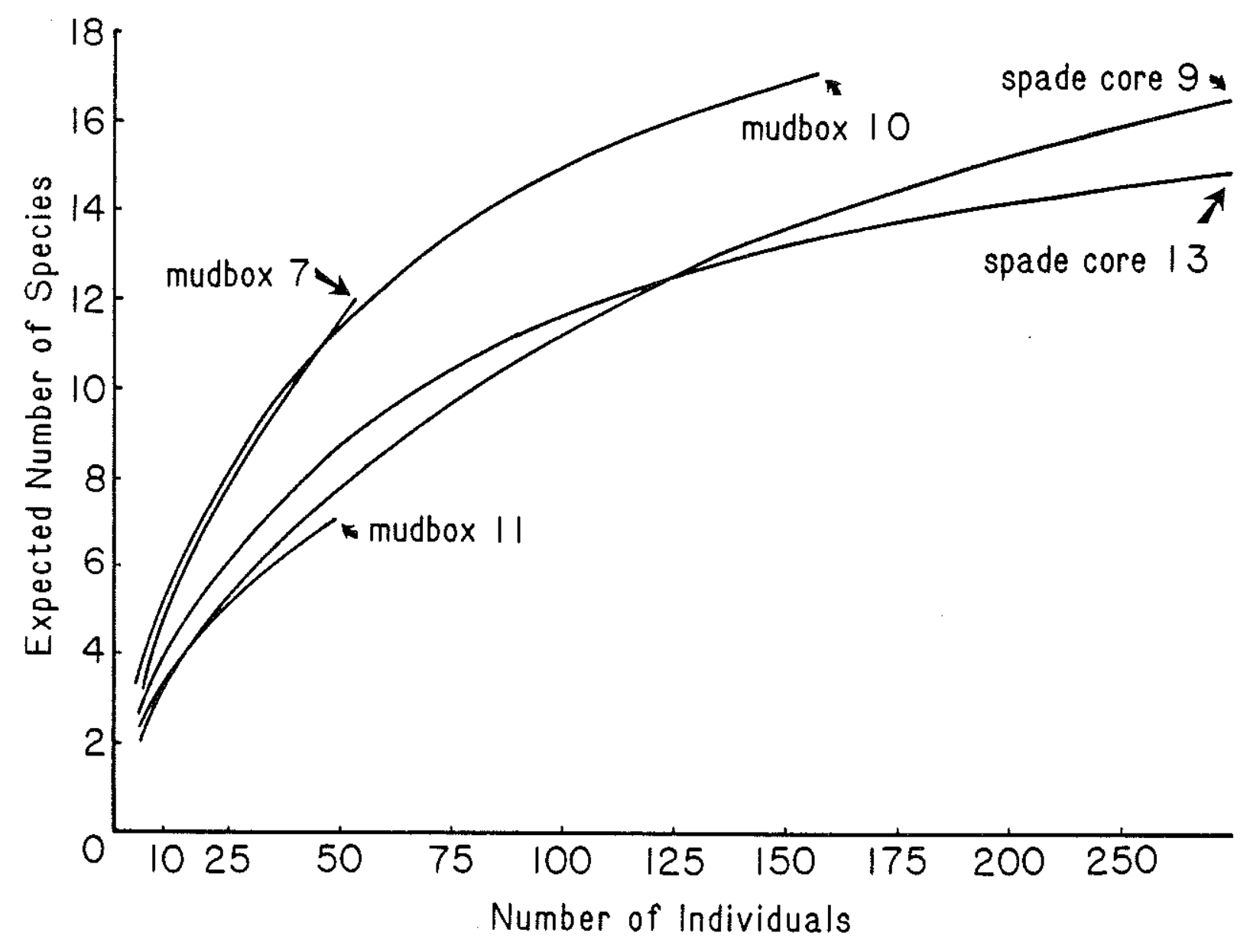

2-3. Rarefaction curve showing diversity of spade core and recolonization tray samples examined in this study. 
DISCUSSION:

A. Habitat partitioning --

A number oi studies have suggested microhabitat partitioning as an important factor for the maintenance of diversity in deep sea benthic communities (Jumars, 1975; 1976; Bernstein et al., 1978). Under equilibrium conditions, species which do not share the same microhabitat do not compete with one another, and the diversity of the community can be maintained at high levels.

Among foraminifera, Corliss (1985) has reported vertical stratification of living calcareous benthic taxa in boxcores from the western North Atlantic. Flat, planoconvex genera such as Planulina and Cibicidoides were found to prefer an epifaunal habitat, while smooth planispiral forms and globularelongate forms such as Melonis and Chilostomella prefer an infaunal habitat. A similar relationship between microhabitat and shape is apparent in the observations of Kitazato (1984). In the shallow-water environment of 0 tsuchi Bay, Japan, the pyriform species Sigmoidella pacifica and Guttalina cf. yabei occupy an infaunal habitat and are reported to move through the sediment. Burrowing behavior has also been observed in the miliolid genus Quinqueloculina in shallow-water sediments (Severin et al., 1982).

Analogies can be drawn between the test shape of agglutinated foraminifera from the Panama Basin and patterns observed by Corliss (1985). In our material, the elongate uniserial species Reophax dentaliniformis and Reophax excentricus clearly prefer, but are not confined to, an infaunal habitat. The elongate shape of the test may be an adaptation for mobility in the mixed layer of the sediment. Agglutinated foraminifera have been suspected of being responsible for causing the fine, apparently randomly oriented burrows which is laconically known as "vermicelli bioturbation" (C.D. Hollister, personal communication) observed in $\mathrm{x}$-radiographs from the High Energy Benthic Boundary Layer Experiment (HEBBLE) Site on the lower continental rise off Nova Scotia.

A similar type of "vermicelli bioturbation" is ubiquitous in $\mathrm{x}-$ radiographs from the site in the Panama Basin, as example of which is shown in figure 2-4. I attribute the small burrows to Reophax, since it is the most abundant macrofaunal-size ( 2 mm or more) infaunal taxon present at this site. Several species of agglutinated foraminifera were found living mainly in 


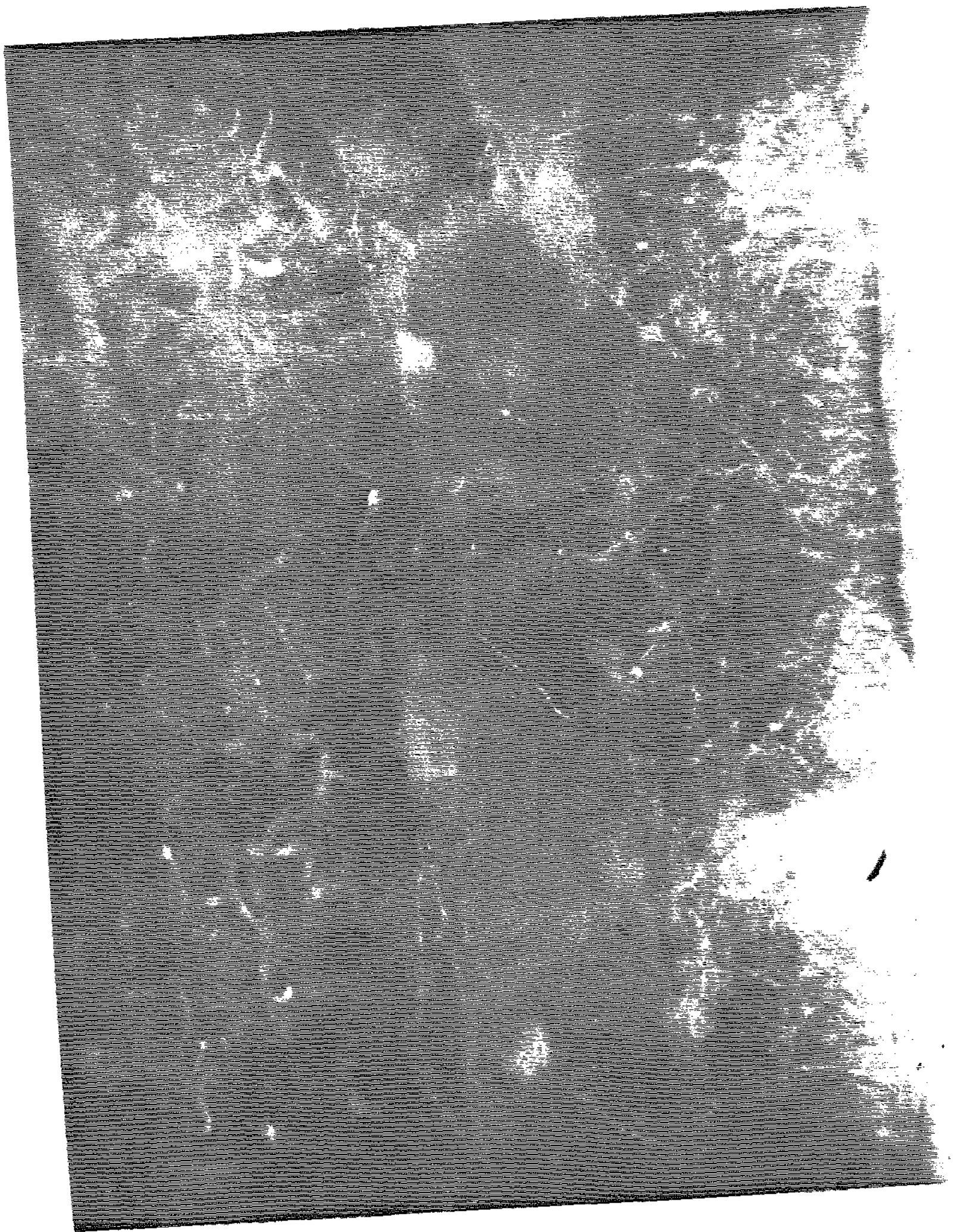

2-4. X-radiograph of sediment surface layer from a spade core collected at our station (courtesy of Robert $C$. Aller). The fine reticulate burrows ("vermicelli bioturbation") are attributed to agglutinated foraminifera. Scale approximately $1: 1$. 
the flocculent surface layer, which at the site has a thickness of approximately $2 \mathrm{~cm}$. These are the Komokiaceans, Dendrophrya arborescens, Cribrostomoides subglobosus, and Ammodiscus incertus. The branching species are assumed to be immobile suspension feeders (Jones and Charnock, 1985), and planispiral and disc-shaped forms have been interpreted as being adapted to an epifaunal mode of life (Corliss, 1985).

\section{B. Taphonomy --}

Agglutinated foraminifera construct their tests with an organic cement which in some species contains oxidized iron compounds (Hedley, 1963; Schroder, 1986a), which probably serve as an electron acceptor during the bacterial degradation of organic matter. Some species of agglutinated foraminifera are more susceptible to degradation than others, therefore the compostion of the death-assemblage will change with time after the death of the organism. The differential preservation of agglutinated species has a profound effect on the composition of faunal assemblages.

In the Panama Basin, I observed a change from a Dendrophrya-dominated assemblage in the surface layer of the sediment to an assemblage dominated by Reophax at depth. This is expressed in figure 2-5. The abundance of Dendrophrya drops dramatically beneath the flocculent surface layer, being entirely absent below $5 \mathrm{~cm}$. The absence of dead specimens of Dendrophrya in the recolonization trays indicates that degradation of this species is very rapid, taking place in less than nine months. The disappearance of Dendrophrya in the trays may have been assisted by the feeding activities of Reophax, which is included by Jones and Charnock (1985) in the group of detrital feeding scavengers.

The transition from brownish to greyish-brown sediments at the site is located about $6-7 \mathrm{~cm}$ below the surface, indicating reducing conditions, and foraminiferal tests from deeper subsamples are sometimes coated with manganese. In this zone, most empty tests which contain iron compounds in their cement, such as $\mathrm{C}$. subglobosa, $\underline{\mathrm{H} \text {. ovicula, Recurvoides, Buzasina }}$ ringens, Saccammina, Trochammina globigeriniformis, Hormosina globulifera, and Eggerella propinqua are bleached white in color. A good measure of the fossilization potential of agglutinated species is the ratio of living to dead 
FORAMINIFERAL POPULATIONS
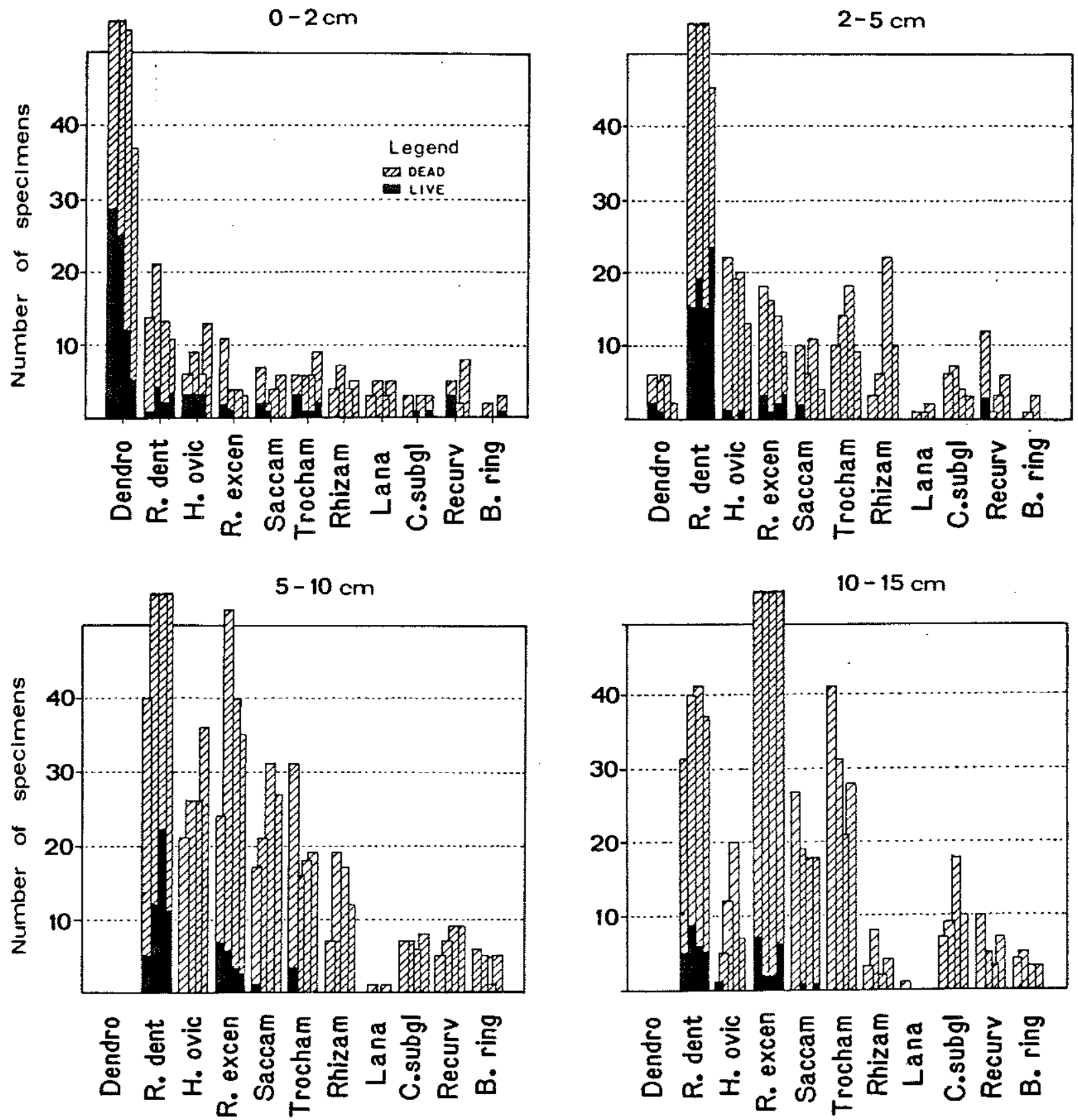

2-5. Composite diagram showing changing agglutinated foraminiferal populations and dead assemblages with depth in spade core 13. The four bars per species indicate values for each subcore. The abundance of Dendrophrya was arbitrarily divided by three. 
tests in the assemblage. In spade core 13, the least preservable form is Pelosina sp., since 11 live individuals but only 2 dead specimens were found. The most resistant species is Rhizammina sp. (large), which constructs its test from diatom frustules and other siliceous debris and makes an audible high-pitched crunching sound when pierced with a dissecting needle.

Table 2-6 ranks the common species recovered from Spade cores 9 and 13 according to their fossilization potential. The Komokiaceans are not included because of the difficulty in distinguishing living from dead tests, but are no doubt the least preservable group of benthic foraminifera. From this ranking, it would appear that the presence of iron compounds in the cement increases the preservability of specimens, since the four least preservable species in our samples are not brown in color. This data are in general agreement with the observations of Schroder, (1986a) who ranked agglutinated foraminifera from the western North Atlantic in terms of test stability.

\section{Recolonization by Agglutinated Foraminifera --}

In studies of fossil assemblages from alpine flysch regions (Grun et al. 1964; Butt, 1981) and the Norwegian-Greenland Sea (Verdenius and Van Hinte, 1983), the simple tubular species were assumed to represent opportunistic species. Small-scale vertical changes in assemblage composition from an astrorhizid-dominated assemblage directly above the coarse layer of a turbidite to a more diverse assemblage higher in the hemipelagite was interpreted as evidence of recolonization of the sea floor after a catastrophic event. Verdenius and Van Hinte further elaborated on this subject, describing a "frontier-area subfauna" of primitive forms and a species-rich "mature subfauna" which was interpreted as a later stage of faunal succession. A change from a frontier fauna to a mature fauna at younger levels at Site 345 was attributed to a reduction in turbidite intensity with time.

More recent studies, however, have interpreted concentrations of tubular species as a result of hydrodynamic sorting. Schroder (1986a) reported "countless" tubular fragments in a turbidite layer from the Nares Abyssal Plain. By comparing sedimentological evidence with benthic faunal data, Kaminski et al. (in press, a) distinguished a redeposited "Dendrophrya Assemblage" in turbidite clays of the lower Lizard Springs Formation of Trinidad. Considering the epifaunal habitat of Dendrophrya in the Panama 
Table 2-6. Agglutinated foraminifera from the Panama Basin ranked in terms of increasing fossilization potential, defined as the ratio of living to dead tests observed in spade core samples. At the top of the list are species least likely to be preserved.

1. Pelosina sp.

2. Reophax dentaliniformis

3. Dendrophrya arborescens

4. Reophax excentricus

5. Hormosina globulifera

6. Eggerella propinqua

7. Recurvoides spp.

8. Buzasina ringens

9. Cribrostomoides subglobosus

10. Ammodiscus incertus

11. Hormosina ovicula

12. Trochammina globigeriniformis

13. Saccammina sp.

14. Rhizammina sp. (large) 
Basin, this taxon would no doubt be entrained and redeposited by downslope currents. If erosion by a turbidity current occurs mainly in the flocculent surface sediment, one would expect to see concentrations of Dendrophrya in the turbidite "d" layer of the Bouma Sequence.

Although it is not possible to recreate the large-scale devastation of benthic biota caused by a turbidity current, I believe that the recolonization trays provide a good approximation as to which organisms are likely to recolonize a naturally disturbed patch of the sea floor. This experiment is not free of bias, however, because the type of disturbance introduced in mudboxes is unlike anything known in nature. A discussion of the type of experimental bias introduced by the sampling design is given by Smith (1985) .

The abundance of living individuals in the mudboxes, summarized in Table 2-7, identifies the opportunistic species. The control sample is the pooled data from the $0-2$ and $2-5 \mathrm{~cm}$ subsections of both spade cores. Contrary to a priori expectations, the tubular species Dendrophrya arborescens was found to be a poor colonizer, since no living individuals were found in any of the trays. The best colonizers in the samples were Reophax excentricus and Reophax dentaliniformis. The species $\mathrm{R}$. excentricus was present in greater abundance in the mudbox samples than in control samples, which suggests it is a particularly good colonizer. Other species which display good dispersial capabilities are Hormosina ovicula, Cribrostomoides subglobosus, Psammosphaera sp., and Trochamminina globigeriniformis.

The mode of colonization of the substrate by Reophax cannot be confirmed without in-situ observation of the living animal. An interesting point is that the spade-core data indicate that this genus is predomiantly infaunal, and one would expect infaunal taxa to be less likely to colonize a sediment tray (Smith, 1985). Whether this genus has free-swimming zygotes as in other benthic foraminifera is not known, and I cannot discount the possibility that some or all individuals did not colonize the samples by crawling up the sides of the trays. Crawling behavior in the shallow water species Reophax moniliformis has recently been described by Knight (1986). Knight reports that when a specimen of R. moniliformis is placed in an observation cell with its aperture close to a vertical surface, the animal will attach its pseudopodia and climb the wall of the container while holding its test horizontally. Presumably, mobile taxa are better adapted to recolonize disturbed patches of sea floor. 
Table 2-7. Abundance of live individuals/100 $\mathrm{cm}^{2}$ in control samples and colonization trays in the Panama Basin. Control samples are the combined abundance from $0-5 \mathrm{~cm}$ layers of both spade cores.

Species

Dendrophrya arborescens

Reophax dentaliniformis

R. excentricus

Hormosina ovicula

Pelosina sp.

Recurvoides spp.

Saccammina sp.

Cribrostomoides subglobosus

Trochammina globigeriniformis

Buzasina ringens

Ammodiscus incertus

Bathysiphon sp.

Rhizammina sp. (large)

Hormosina globulifera

Hormosina distans

Ammobaculites sp.

Psammosphaera sp.

\section{$\underline{\text { Control }} \underline{\text { MB 10 }}$ MB 11 $\quad \underline{\text { MB 7 }}$}

68.3

0.0

0.0

0.0

13.1

9.5

2.0

3.0

4.6

10.5

6.1

4.8

2.4

0.8

0.2

1.0

1.6

0.2

0.0

0.2

1.6

0.6

0.0

0.0

1.3

0.8

0.0

0.0

1.1

3.0

0.4

0.2

1.1

0.8

0.4

0.4

0.8

0.2

0.0

0.4

0.6

0.4

0.0

0.4

0.6

0.0

0.0

0.0

0.5

0.6

0.0

0.2

0.4

0.0

0.2

0.2

0.3

0.8

0.0

0.2

0.0

0.8

0.0

0.0

0.0

1.8

0.4

0.2

TOTAL:

97.8

30.2

9.5

11.1 
D. Rates of Succession --

The total abundance of live individuals in control samples is 97.8 individuals $/ 100 \mathrm{~cm}^{2}$. However, if one ignores Dendrophrya, the abundance of remaining species is 29.4 individuals $/ 100 \mathrm{~cm}^{2}$. This figure compares well with the abundance in Mudbox 10 (30.2 live individuals $/ 100 \mathrm{~cm}^{2}$ ), which suggests that except for tubular forms, nine months may be sufficient time for an agglutinated foraminiferal fauna to recover to background levels of abundance after a disturbance. This finding is in contrast with the density of macrofaunal invertebrates, which did not recover to background levels in any of the trays over the nine month period.

There is evidence in the data that faunal recolonization occurs at different rates. This increases the likelihood that localized disturbance of benthic communities may result in patches of organisms in different stages of succession, or contemporaneous disequilibrium (Grassle and Sanders, 1973). The expected number of species in a given sample size differs by nearly a factor of two, and abundance differs by a factor of three between MB 10 and MB 11 . These differences are greater than those observed in control samples. The observation of patches of agglutinated foraminifera with diversity differing significantly from other patches within a $4 \mathrm{~km}^{2}$ area was reported by Kaminski (1985) from the HEBBLE Site. The results from both the Panama Basin and the HEBBLE Site indicate that physical disturbance resulting in severe population reduction, and different rates of recovery to background faunal abundance is an important source of spatial heterogeneity in the distribution of deep-sea benthic organisms.

\section{E. A General Model Relating Community Structure to Disturbance --}

To study the effect of the sedimentary environment on the community structure of agglutinated foraminiferal faunas, I examined whether particular "morphogroups" (in the sense of Jones and Charnock, 1985) exhibit preference for tranquil or disturbed environments. By synthesizing data from the recolonization experiment and from studies of the distribution of modern agglutinated foraminifera in the western North Atlantic (Kaminski 1985, Schroder, 1986a; Kaminski and Schroder, 1987; Kaminski et al., in press, b), it is now possible to develop a generalized model of the effect of substrate disturbance on the structure of agglutinated foraminiferal communities (Fig. $2-6)$. 


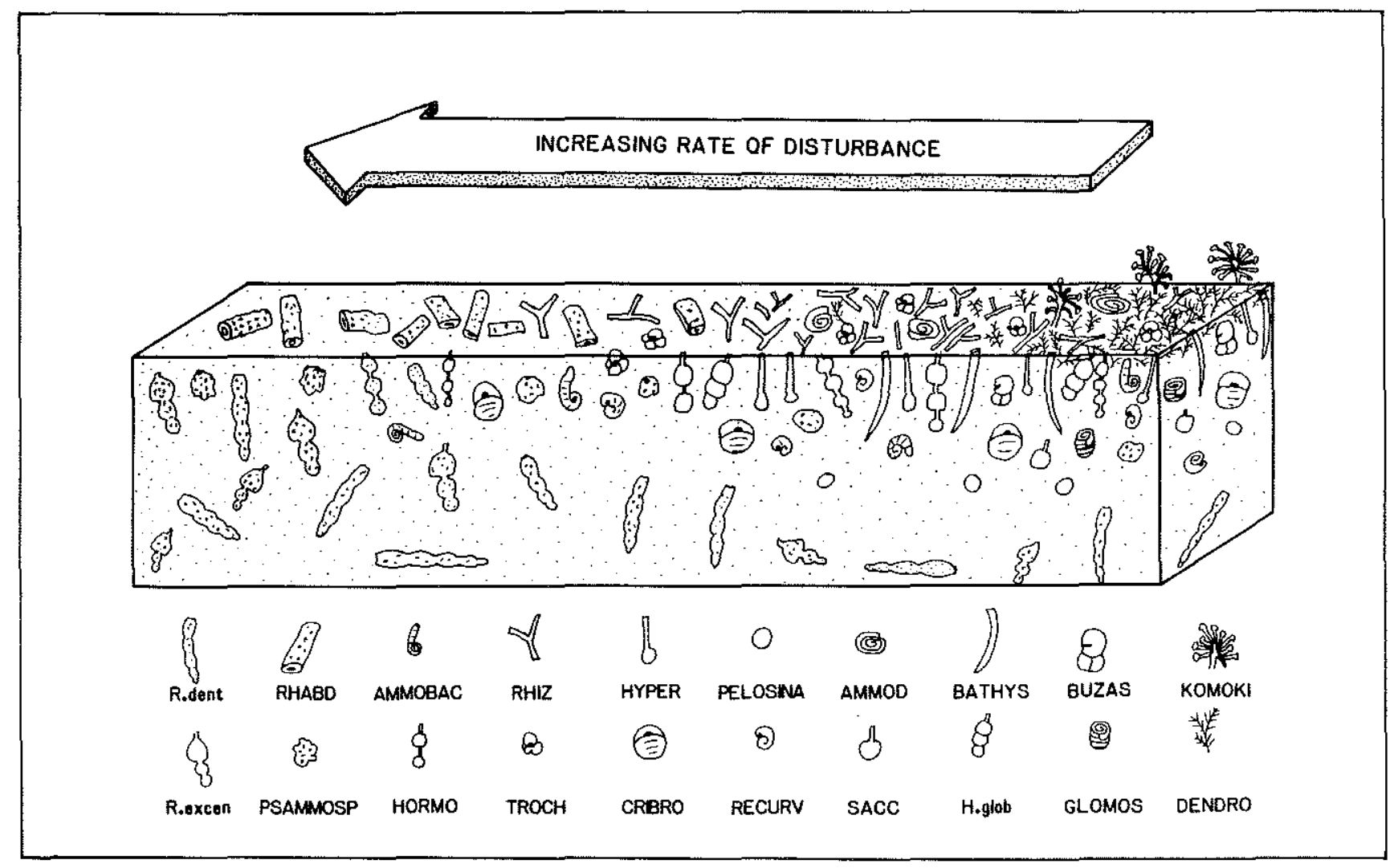

$2-6$. Generalized model showing the effect of substrate disturbance on the structure of agglutinated foraminiferal communities, synthesized from Kaminski, 1985; Schroder, 1986a,; Kaminski and Schroder, 1987; Kaminski et al., in press, b. 
Tranquil areas such as the Panama Basin site and the Nares Abyssal Plain (Schroder 1986a) are covered by fine-grained pelagic sediment, and provide stable environments for benthic organisms. No evidence of turbidites or winnowing was observed in boxcores collected at either site. The agglutinated fauna in such an environment is dominated by species of Komokiacea and Astrorhizidae, which have branching tubular tests and live in the flocculent surface layer. Some of these taxa have an erect epifaunal life position and comprise the trophic morphogroup of primary suspension feeders according to Jones and Chernock (1985). Other common genera on the Nares Abyssal Plain are Adercotrema, Reophax, and Nodellum (Schroder 1986a). These genera possess a coiled or elongate chamber arrangement and prefer an infaunal mode of life. They belong to the morphogroup of sediment-dwelling herbivores and detritivores and are most common 2-2 $\mathrm{cm}$ below the sediment surface (Schroder 1986a; in press). At the Panama Basin Site, branching tubular species comprise up to $90 \%$ of the fauna. Nearly all living tubular specimens were found in the upper $2 \mathrm{~cm}$. Lituolids and ammodiscids also live mainly in the surface layer. Below $5 \mathrm{~cm}$ the live fauna consists mainly of Reophax. Another example of a relatively tranquil environment is the upper continental rise off Nova Scotia. The region between $2200 \mathrm{~m}$ and $2500 \mathrm{~m}$ lies above the influence of the Western Boundary Undercurrent (WBUC). The sediment contains abundant light particles such as diatom shells, fragments of planktonic foraminifera and organic debris. These components suggest a lack of strong bottom currents, although some downslope transport is indicated by the occurrence of calcareous slope foraminifera (Schroder 1986a). At this site, the assemblage is dominated by the suspension-feeding species Rhizammina algaeformis. At a relatively tranquil location at $4185 \mathrm{~m}$ on the continental rise (the HEBBLE Shallow Site of Kaminski, 1985), the agglutinated assemblage contains a large proportion of species which utilize fine-grained material in the construction of their test.

Disturbed environments are found along the western margin of the North American Basin, which is characterized by two zones of increased current velocity (Tucholke et al., 1985). The WBUC flows in a southwesterly direction along the middle continental rise between 2500 and $4000 \mathrm{~m}$. Abundant intact planktonic foraminiferal tests, coarse detrital sand and reduced numbers of diatom tests form a relatively coarse grained substrate that has been winnowed by currents. The agglutinated component is diverse and includes reworked 
specimens. The assemblage contains a large proportion of species which utilize coarse-grained material in the construction of their tests, reflecting the coarse nature of the substrate. The fauna is dominated by robust, nonbranching species of Astrorhizidae and a number of lituolids and trochamminids. These groups are epifaunal, and constitute the morphogroup of surface-dwelling herbivores, detritivores and omnivores (Jones and Chernock, 1985).

The second zone of high currents is the lower continental rise (below $4200 \mathrm{~m})$ south of Nova Scotia which was studied in detail at the HEBBLE Area (Kaminski, 1985; Schroder, 1986a). This region is subjected to brief periods of disturbance by "benthic storms" which are caused by the interaction between a southwesterly mean flow and eddies and rings of the Gulf stream. The sediment is relatively coarse grained, with increasing sand content $(>50 \%)$ towards the base of the continental rise (Driscoll et al., 1985). The agglutinated assemblage on the lower rise displays reduced diversity in comparison with the HEBBLE Shallow Site, and consists of branching specimens of Rhizammina and abundant specimens of the infaunal genus Reophax. Detailed examination of assemblages at the HEBBLE Area by means of factor analysis (Kaminski, 1985) revealed an end-member assemblage characterized by Reophax. At the HEBBLE Site two benthic storms were recorded in early spring of 1983 which disturbed the sediment surface layer to a depth of up to $6 \mathrm{~cm}$. Boxcore samples recovered in June of that year revealed an agglutinated foraminiferal assemblage dominated by species of Reophax, including Reophax dentaliniformis, which was interpreted by Kaminski (1985) as an opportunistic form. The Reophax assemblage was dominant in box-core samples with a thick, finely laminated surface layer visible in X-radiographs, which was apparently deposited after a benthic storm. In the deep Panama Basin, the most effective colonizers were also species of Reophax. Unexpectedly, the branching tubular forms were found to have limited dispersial capability in the Panama Basin. The common occurrence of Reophax in recolonization trays in the Panama Basin and at the HEBBLE site support the idea of this genus being opportunistic and capable of invading newly deposited sediment after a benthic storm.

\section{CONCLUSIONS}

The study of living and dead assemblages in recolonization trays and with depth in spade cores allows us to reconstruct the life history of agglutinated 
benthic foraminifera in the deep Panama Basin. Tubular and planispiral forms such as Dendrophrya, Cribrostomoides and Ammodiscus, have an epibenthic habitat, whereas the elongate uniserial genus Reophax prefers an infaunal mode of existance and is credited with causing the fine network of burrows observed in $x$-radiographs. A smaller proportion of the total assemblage was living at the time of collection when compared with data from the North Atlantic (12.75\% vs $30-40 \%$ ).

The tubular species Dendrophrya arborescens is a delicate form which disintegrates within nine months after the death of the animal and possesses poor dispersal capabilities, since it was not found in recolonization trays. This finding contradicts the idea of "primitive" tubular forms being more opportunistic than "advanced" species. The most effective colonizers were two species of Reophax, a finding which is corroborated by observations on the lower continental rise off Nova Scotia. The density of taxa in recolonization trays differed from one another by a factor of three, which may suggest recolonization taking place at different rates among different patches of fauna. Recolonization by benthic foraminifera in the deep Panama Basin is more rapid than among macrofaunal invertebrates in the same samples.

A comparison of tranquil and disturbed habitats indicates that the composition and trophic structure of agglutinated foraminiferal communities are influenced by the deposional environment. There appears to be a predictable response of agglutinated foraminifera to substrate disturbance. Tranquil environments are dominated by suspension feeders with branching, fragile tests, and contain a large proportion of finely agglutinated forms. Disturbed environments with strong bottom currents are characterized by robust, coarse-grained epifaunal and infaunal species. Elongate species of Reophax are well suited for colonizing substrates after physical disturbance of their habitat. Therefore, modern faunas with large proportions of this genus can be interpreted as indicating a disturbed environment or a fauna in an early stage of faunal succession. 


\section{SECTION B:}

AGGLUTINATED FORAMINIFERA FROM A HYDROCARBON SEEP REGION ON THE LOUISIANA CONTINENTAL SLOPE

\section{INTRODUCTION:}

Recent discoveries of a biological community of hydrothermal vent-type organisms in areas of active hydrocarbon seepage (Brooks et al., 1985; 1987; Kennicutt et al., 1985) have provided new insight into the effect of high organic-carbon substrates on benthic marine communities. Carbon isotope studies of organisms collected from hydrocarbon seeps indicate that animals utilize hydrogen sulfide and methane as their primary energy source (Kennicutt et al., 1985). Chemosynthetic communities containing bivalves and tube worms have now been indentified at 17 locations in the Green Canyon, Garden Banks, Ewing Bank and East Breaks lease areas on the Louisiana continental slope (Brooks et al., 1987), which is evidence that these faunas may be locally abundant in regions of submarine hydrocarbon seeps. Because of the utility of benthic foraminifera in petroleum exploration, it is important that we assess how this component of the benthic community is affected by organic-rich substrates at hydrocarbon seeps. By studying benthic foraminiferal faunas that are associated with chemosynthetic communities, it is possible to better constrain the paleoenvironmental significance of fossil assemblages and identify a potential tool for petroleum exploration and paleoceanography.

\section{SAMPLE LOCALITIES:}

Areas of hydrocarbon seepage are known from seismic lines recorded from at least 34 locations on the Louisiana continental slope (Brooks et al., 1987). Foraminiferal assemblages examined in this study were collected from Green Canyon OCS Lease Blocks 184 and 272 (figure 2-7). The environment and macrofauna from Lease Block 184 has been studied by Brooks et al. 1987. In an area of Block 184 known as "Bush Hill", a photographic survey undertaken using the submersible Johnson Sea-Link documented large clusters of vestamentiferian tube worms up to $2 \mathrm{~m}$ in length, mussel beds associated with active methane seepage, and bacterial mats associated with oil. Sediment cores recovered from the vicinity of the chemosynthetic community contain extractible hydrocarbon contents of between 0.02 and $12 \%$ (Brooks et al., 1987). 


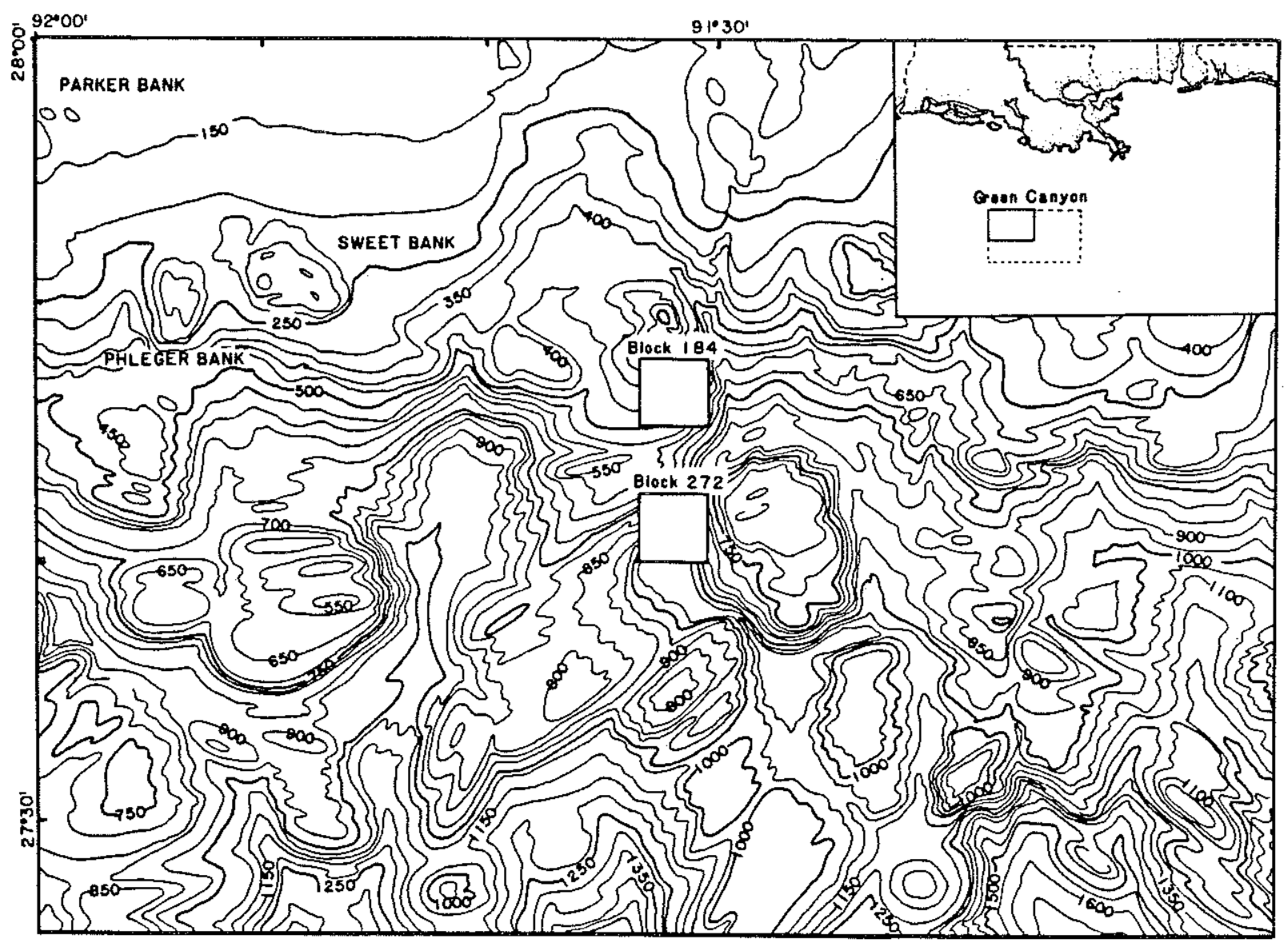

2-7. Location of OCS Blocks 184 and 272 in the Green Canyon area of the Louisiana continental slope. Bathymetry in meters. Base map redrawn from NoS Map 15-3. 
Two box cores from oCS Block 184 were examined for benthic foraminifera. Box core 34 was collected at $27^{\circ} 47.05^{\prime} \mathrm{N} ; 91^{\circ} 30.5^{\prime} \mathrm{W}$ from a depth of $542 \mathrm{~m}$ (uncorrected wire length). This sampling site is situated in a seismic "wipeout zone" (Kennicutt et al., 1985), an area in which the stratification of sediments in seismic records is masked by the presence of gas or gas hydrates. This box core recovered an entanglement of tube worms and bivalves which were associated with visibly oil-stained sediment. A piston core taken at the same location as Box core 34 recovered authigenic carbonate rubble and gas hydrates in sediments that were oil-stained, gassy and emitted a strong $\mathrm{H}_{2} \mathrm{~S}$ odor (R.F. Commeau, personnal communication 1987). A second nearby box core (BC-32) collected in a non-wipe-out zone $\left(27^{\circ} 48.1^{\prime} \mathrm{N} ; 91^{\circ} 30.7^{\prime} \mathrm{W}, 532 \mathrm{~m}\right.$ uncorrected water depth) did not contain chemosynthetic macrofauna and serves as a control station for Block 184. Sediments in a piston core taken in the non-wipe-out zone were not visibly oil-stained and did not emit a noticeable $\mathrm{H}_{2} \mathrm{~S}$ odor (R.F. Commeau, personnal communication 1987).

A second set of box cores was gathered in OCS Block 272, which is situated downslope from Block 184. Box core 10 was collected in a wipe-out zone at $27^{\circ} 40.39^{\prime} \mathrm{N}, 91^{\circ} 31.80^{\prime} \mathrm{W}$ from a depth of $685 \mathrm{~m}$. This box core contained visibly oil-stained sediment, but did not recover any macrofauna typical of the oil seep community. The control station in this area (non-wipe-out zone, box core 11 ) was recovered at $27^{\circ} 40.34^{\prime} \mathrm{N}, 91^{\circ} 29.93^{\prime} \mathrm{W}$ from a depth of $696 \mathrm{~m}$. This station is outside the area of hydrocarbon seepage identified on seismic records. Sediments in a piston core taken at the control station were not visibly oil-stained or gassy and did not have a $\mathrm{H}_{2} \mathrm{~S}$ odor.

\section{METHODS:}

Samples from all of the box cores were collected from the surface layer $(0-1.5 \mathrm{~cm})$ and sieved through a 63 micron screen. Agglutinated foraminifera were picked from the $>63$ micron fraction from each sample and mounted on cardboard slides. The taxonomic classification used here is adopted from Schroder $(1986 a, b)$. Although these samples were not stained, one can assume that a large portion of the agglutinated assemblage was alive at the time of collection, because dead tests readily disintegrate. In the modern North Atlantic, Schroder (1986a) reported that $\sim 40 \%$ of the total agglutinated assemblage in the surface layer of sediment was alive at the time of collection. In Leg 96 Holes in the Gulf of Mexico, agglutinated foraminifera 
which utilize organic cement are absent below the oxidized surface layer (Schroder 1986b).

RESULTS :

Tables 2-6 and 2-7 present a faunal census of agglutinated taxa from the two Block 184 and Block 272 samples, respectively. Calcareous benthic taxa from these samples are currently being studied by other workers and will be reported elsewhere. The control sample from Block 184 contains 33 species of agglutinated foraminifera represented by 254 individuals. The agglutinated fauna in this core is numerically dominated by hormosinids and astrorhizids (Fig. 2-8). Both infaunal varieties (hormosinids) and epifaunal components (astrorhizids, ammodiscids, trochamminids) are well represented in the total assemblage.

In contrast to the control sample, the agglutinated fauna from the Block 184 hydrocarbon seep area $(\mathrm{BC}-34)$ is depauperate, consisting of only 16 species which are numerically dominated by the trochamminids, ammodiscids and textulariids (Fig. 2-8). Relative to the control sample, this assemblage displays an increased dominance of Trochammina glabra, Glomospira charoides, and Textularia wiesneri. The infaunal genus Reophax is noticeably lacking. One species (Ammobaculites agglutinans) was present in the hydrocarbon seep area, but not in the control sample.

Block 272 is located farther offshore and downslope from Block 184, and the microfauna from this area differs in the relative proportions of faunal groups (Fig. 2-9). The control sample (BC-11) contains 36 species of agglutinated foraminifera, and astrorhizids comprise of over $50 \%$ of the assemblage. The assemblage in $\mathrm{BC}-11$ is dominated by Rhizammina indivisa, with subdominant Saccorhiza ramosa, Glomospira spp., Karreriella sp. (minute), and H. bradyi.

The sample from the hydrocarbon seep area (BC-10) in Block 272 is less diverse (with 25 species) and is co dominated by Saccammina spherica, Trochammina glabra, Reophax dentaliniformis, H. bradyi and R. indivisa. Most noteable in this sample are the presence of Textularia wiesneri and Ammobaculites agglutinans, which were not found at the control station. In contrast with the samples from Block 184, the seep assemblage in Block 272 contains an increased proportion of hormosinids. 
Table 2-8. Faunal data from OCS Block 184, Louisiana continental slope.

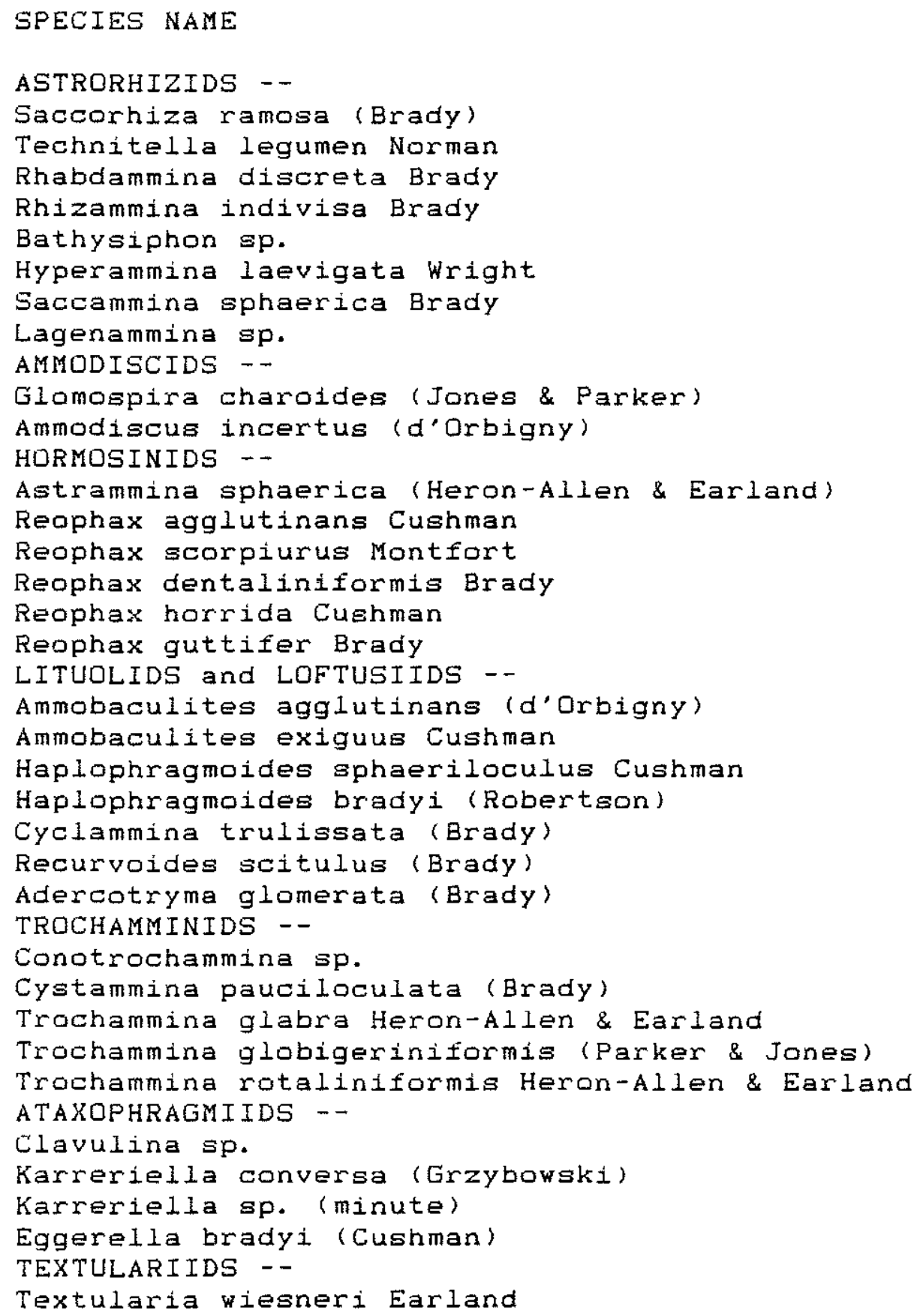


Table 2-9. Faunal data from OCS Block 272, Louisiana continental slope.

\begin{tabular}{|c|c|c|}
\hline SPECIES MAME & $\begin{array}{l}\text { Contral } \\
8 C-11\end{array}$ & $\begin{array}{r}\text { Seep } \\
B C-10\end{array}$ \\
\hline \multicolumn{3}{|l|}{ ASTRORHIZIDS -- } \\
\hline Saccorhiza ramosa (Brady) & 26 & 3 \\
\hline Technitella legumen Norman & 1 & 2 \\
\hline Rhabdammina discreta Brady & 11 & 8 \\
\hline Rhizammina indivisa Brady & 62 & 16 \\
\hline Rhizammina (with planktonic tests) & 3 & 2 \\
\hline Hyperammina cylindrica Parr & 2 & 0 \\
\hline Rhabdammina (large, coarse) & 13 & 13 \\
\hline Hyperammina laevigata Wright & 15 & 2 \\
\hline Dendrophrya arborescens Brady & 1 & 4 \\
\hline Saccammina sphaerica Brady & 14 & 22 \\
\hline Lagenammina sp. & 3 & ๑ \\
\hline \multicolumn{3}{|l|}{ AMMODISCIDS -- } \\
\hline Glomospira charoides (Jones \& Parker) & 23 & 8 \\
\hline Ammodiscus incertus (d'Orbigny) & 3 & 7 \\
\hline Tolypamina sp. & 3 & \\
\hline \multicolumn{3}{|l|}{ HORMOSINIDS -- } \\
\hline Hormosina carpenteri Brady & 4 & 0 \\
\hline Reophax agglutinans Cushman & 4 & $\oslash$ \\
\hline Reophax scorpiurus Montfort & 4 & 0 \\
\hline Reophax dentaliniformis Brady & 3 & 18 \\
\hline Reophax horrida Cushman & 3 & 8 \\
\hline Reophax guttifer Brady & 1 & $\emptyset$ \\
\hline Reophax pilulifer Brady & $\emptyset$ & 1 \\
\hline Hormosina ovicula Brady & 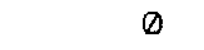 & 3 \\
\hline Subreophax aduncus (Brady) & 2 & $\emptyset$ \\
\hline \multicolumn{3}{|l|}{ LITUOLIDS and LOFTUSIIDS -- } \\
\hline Ammobaculites agglutinans (d'Orbigny) & 0 & 3 \\
\hline Ammobaculites exiguus Cushman & 1 & 0 \\
\hline Haplophragmoides sphaeriloculus Cushman & 4 & 4 \\
\hline Haplophragmoides bradyi (Robertson) & 19 & 17 \\
\hline Cyclammina trulissata (Brady) & 2 & $\oslash$ \\
\hline Recurvoides scitulus (Brady) & 3 & 4 \\
\hline Recurvoides (large) & 3 & $\oslash$ \\
\hline Adercotryma glomerata (Brady) & 6 & $\theta$ \\
\hline Discammina compressa (Goes) & 1 & $\oslash$ \\
\hline $\begin{array}{l}\text { Cribrostomoides wiesneri (Parr) } \\
\text { TROCHAMMINIDS -- }\end{array}$ & TROCHAMMINIDS -- & 2 \\
\hline Cystammina pauciloculata (Brady) & 1 & 1 \\
\hline Trochammina glabra Heron-Allen \& Earland & 13 & 20 \\
\hline Trochammina globigeriniformis (Parker \& Jones) & 10 & b \\
\hline Trochammina (with planktonic tests) & 1 & 0 \\
\hline \multicolumn{3}{|l|}{ ATAXOPHRAGMIIDS -- } \\
\hline \multicolumn{3}{|l|}{ Clavulina sp. } \\
\hline Karreriella conversa (Grzybowski) & 5 & 0 \\
\hline Karreriella sp. (minute) & 20 & 0 \\
\hline $\begin{array}{l}\text { Eggerella propinqua (Brady) } \\
\text { TEXTULARIIDS -- }\end{array}$ & 2 & 1 \\
\hline Textularia wieeneri Earland & 0 & 12 \\
\hline 501 & 292 & $1 \Xi$ \\
\hline
\end{tabular}




\section{AGGLUTINATED FORAMINIFERAL ASSEMBLAGES FROM BLOCK 184}

\section{BC-32 CONTBOL}

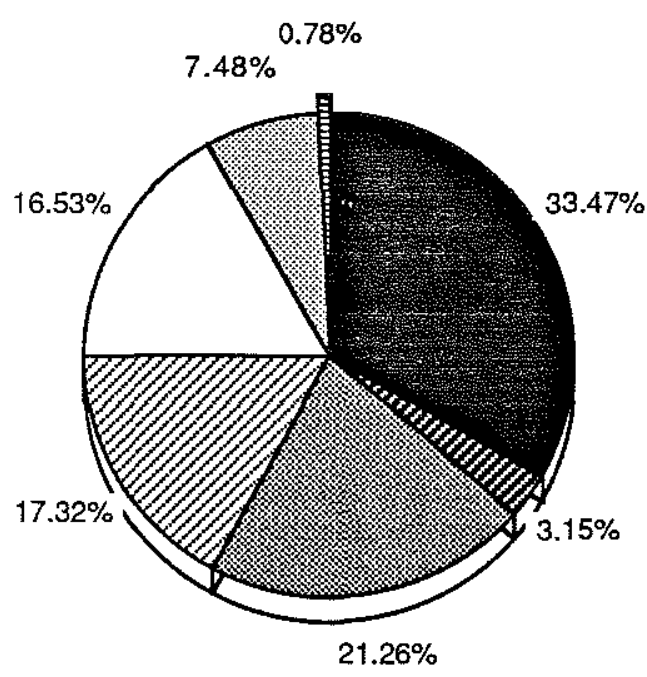

ASTRORHIZIDS

AMMODISCIDS

HORMOSINIDS

$\square$ LITUOLIDS

TROCHAMMINIDS

굼 ATAXOPHRAGMIIDS

目 TEXTULARIIDS

\section{BC-34 SEEP AREA}

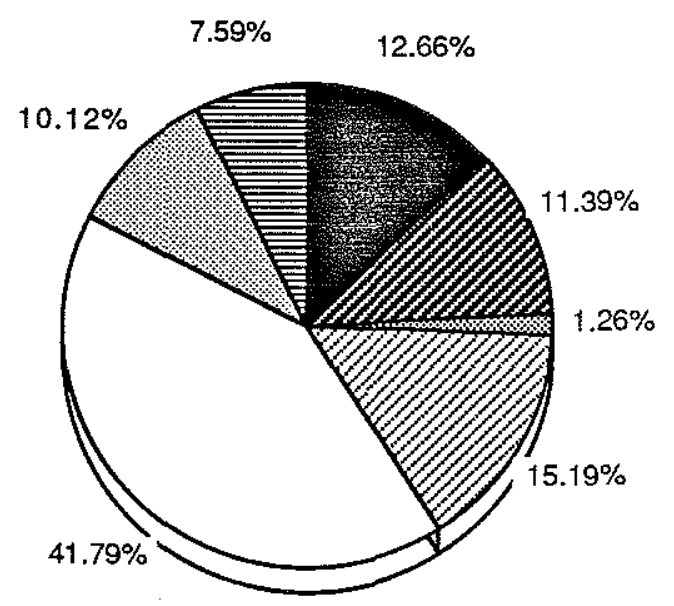

ASTRORHIZIDS

Z AMMODISCIDS

HORMOSINIDS

EA LITUOLIDS

$\square$ TROCHAMMINIDS

ATAXOPHRAGMIIDS

TEXTULARIIDS

2-8. Relative proportions of superfamily groups in control sample and at hydrocarbon seep stations in Block 184. 


\section{GGGLUTINATED FORAMINIFERAL ASSEMBLAGES FROM BLOCK 272}

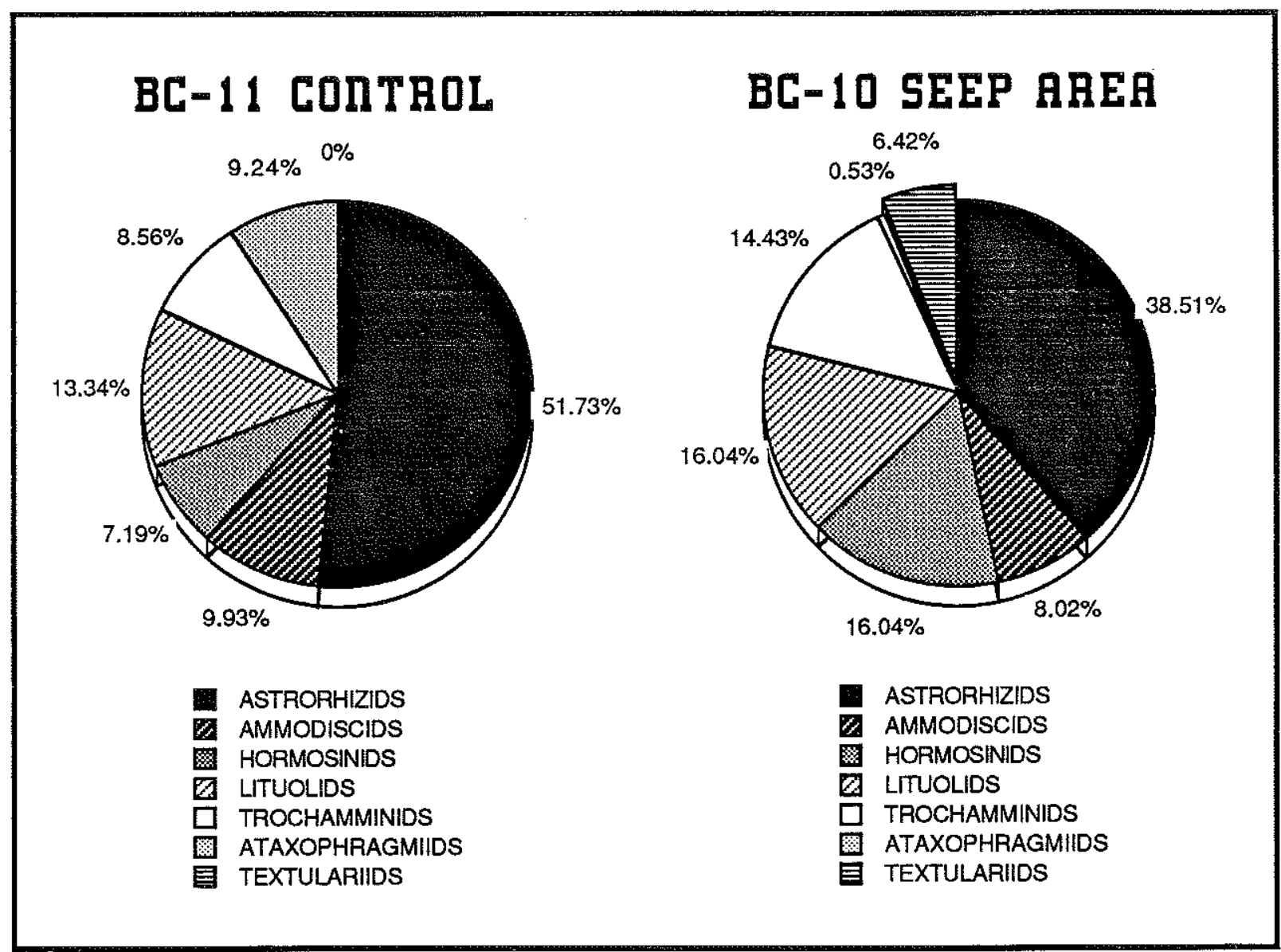

2-9. Relative proportions of superfamily groups in control sample and at hydrocarbon seep stations in Block 272 . 


\section{DISCUSSION:}

The identification of bathyal agglutinated foraminiferal assemblages associated with organic-rich substrates and chemosynthetic macrofauna places ecological constraints on some common modern agglutinated species. In both study areas, the hydrocarbon seep assemblage is characterized by a decrease in the proportion of astrorhizids and a corresponding increase in the relative abundance of trochamminids and textulariids. The most pronounced differences beween control and hydrocarbon seep assemblages are observed in Block 184, which was not unexpected because the hydrocarbon seep site sampled in this area harbors a chemosynthetic community. Although chemosynthetic communities do exist in Block 272, the samples did not recover chemosynthetic macrofauna at this site.

The genera Technitella and Trochammina are considered to be epifaunal, some species of which live as epiphytes attached to algae or other objects above the sediment/water interface (Haynes, 1981; Jones and Charnock, 1985). Since Box core 34 contained a chemosynthetic community including vestamentiferian tube worms, the abundance of Trochammina is not suprising. Although the seep sample from Block 272 did not contain tube worms, the assemblage from Box core 10 possesses an increased percentage of $\mathrm{T}$. glabra. However, whether the trochamminids and technitellids are more closely associated with the substrate or the tube worms awaits further study. Fossil associations with abundant Trochammina have also been found in organic carbonrich sediments from the Jurassic Agardhfjellet member in Spitsbergen (Nagy et al., in press). These authors also found an inverse relationship between TOC values and the diversity of benthic foraminifera, a pattern also evident in the Green Canyon area box cores.

A species which is clearly associated with the hydrocarbon seep community in Block 184 is Glomospira charoides. This is a stratigraphically longranging species that is known to occur in presumed carbon-rich, oxygendeficient paleoenvironments such as those represented by the Mediterranean Pleistocene sapropels (Cita and Grignani, 1982) and by the Cenomanian/Turonian "Black Band" of northwest Europe (Hart and Bigg, 1983). The finding of G. charoides in Box core 34 confirms the observation that this species tolerates or favors organic-rich substrates. The paleoceanographic significance of Eocene Glomospira assemblages is discussed in Chapter 5. 
The lack of infaunal forms at the hydrocarbon seep site in Block 184 may indicate anoxic or otherwise toxic conditions at shallow depth in the sediment. However, the epifaunal tubular varieties also occur in much reduced numbers compared with the control site. According to Jones and Charnock, tubular forms such as Rhizammina and Rhabdammina are regarded as suspension feeders. By analogy with hydrothermal vent communitiies (Lonsdale, 1976), submarine hydrocarbon seep communities ought to be enriched in the suspensionfeeding organisms owing to the abundance of chemosynthetic bacteria. If tubular varieties are indeed suspension feeders, their near absence in $\mathrm{BC}-34$ is enigmatic and warrents further study.

CONCLUSIONS :

Agglutinated foraminiferal assemblages on the Louisiana continental slope display distinct changes in connection with organic-rich substrates and hydrocarbon seep communities. At both locations studied, the hydrocarbon seep samples contain Textularia wiesneri and Ammobaculites agglutinans, species which are absent or rare in control samples. Both sites also display changes in the relative abundance of superfamily groups. Trochamminids and textulariids display increased relative abundance at the hydrocarbon seeps, but contrary to expectations the astrorhizids are less common in hydrocarbon seep samples than in control samples. At the highly organic-rich substrate in Block 184, infaunal morphotypes are absent and the predominant species are Trochammina glabra and Glomospira charoides. Similar types of assemblages have been reported from organic-rich sediments as old as Jurassic in age. 


\section{SECTION C:}

PALEOENVIRONMENTAL ANALYSIS USING AGGLUTINATED ASSEMBLAGES: THE NEOGENE RECORD OF ODP SITE 646, EIRIK RIDGE

\section{INTRODUCTION}

In areas where disturbance by bottom currents results in population reduction, epifaunal species may be at risk and the rigorous environment may favor infaunal or opportunistic species. This information, if preserved in the fossil record, may be useful for determining whether vigorous deep currents were present in a given area. In this study, I test this assumption by examining the agglutinated component in modern deep-sea settings and using the resultant ecologic information to interpret the paleoenvironment of Neogene agglutinated assemblages recovered on ODP Leg 105.

Another aspect of the ecology of agglutinated foraminifera that has been studied is their agglutinating behavior (Schroder 1986a). Since this group incorporates particles of the local sediment into their tests with a varying degree of selectivity, agglutinated species respond to changes in the substrate (Schroder 1986a). Both substrate and stability of the benthic environment are influenced by the local hydrographic regime, such as the presence of a nepheloid layer or strong bottom currents which scour or otherwise disturb the sea floor. Therefore, one might ask whether agglutinated assemblages reflect the dynamic properties of their environment.

\section{SAMPLE LOCATION:}

Site 646 was drilled in 3450 meters of water on the northwest flank of the Eirik Ridge, a prominent sediment drift located off the southern tip of Greenland (Fig 2-10). The Eirik Ridge is a current-generated feature which is situated close to the present pathway of Denmark Straits Overflow water. Drilling in Hole 646B recovered $766.7 \mathrm{~m}$ of terrigenous silty clays and silts with varying amounts of biogenic components. Dropstones are present to a depth of 236.4 mbsf and define the base of Lithologic Unit 1. Biogenic silica is present to a depth of $330 \mathrm{mbsf}$. Lithologic Unit 2 extends from $236.4 \mathrm{mbsf}$ to the base of Hole $646 \mathrm{~B}$, and consists of silty claystones and clayey siltstones with layers containing up to 50-60\% nannofossils. 


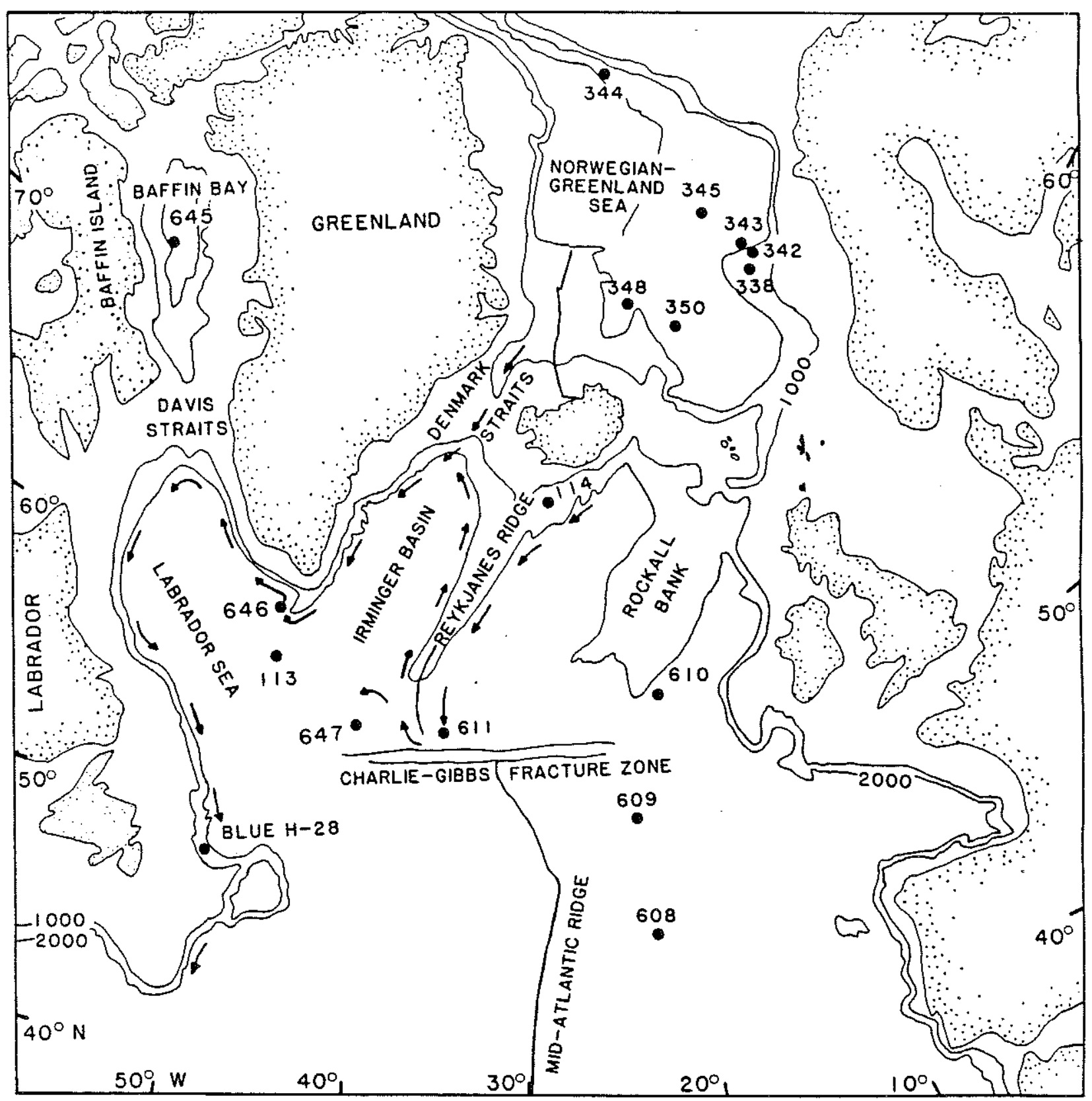

2-10. Location of ODP and DSDP Sites and exploration wells in the Labrador Sea and Baffin Bay. Arrows indicate inferred pathways of deep circulation in the western North Atlantic. Base map is from Srivastava and Tapscott (1986). 
Prominent seismic reflectors subdivide the sedimentary record of Hole 646B into four major seismic units (Fig 2-11). Seismic reflector "R1" defines the base of Seismic Unit 1 , and corresponds to a lithologic break between icerafted sediments and pre-glacial Pliocene sediments at 236.4 mbsf. Seismic Unit 1 therefore coincides with Lithologic Unit 1 . Seismic Unit 2 encompasses the drift sequence between 236.4 and 377 mbsf. The base of Seismic Unit 2 in Hole 646B lies conformably on Seismic Unit 3 and delineates the base of the sediment drift sequence visible in seismic profiles across the Eirik Ridge. Locally, the base of Unit 2 is expressed as an erosional unconformity, but there is no evidence of a hiatus in Hole 646B. Reflector "R2" corresponds to a change in carbonate content at $\sim 500$ mbsf, about 0.05 seconds below the top of Seismic Unit 3. Seismic Unit 3 extends from 377 to $680 \mathrm{mbsf}$, and its base is delineated by seismic reflector "R3". Reflector "R3" is actually a couplet of closely-spaced reflectors corresponding to changes in the carbonate content of the sediment at 680 and 710 mbsf. Below 710 mbsf, the sediments of Seismic Unit 4 are comprised of dark gray silty claystones with carbonate contents below $10 \%$.

\section{RESULTS}

A. Site 646 Biostratigraphy --

A total of 140 samples from Holes $646 \mathrm{~A}$ and $646 \mathrm{~B}$ were examined for benthic foraminifera; faunal abundance data was given in Kaminski et al. (in press, c). The planktonic foraminiferal biochronology of this site is discussed by Aksu and Kaminski (in press). For this study, foraminiferal accumulation rates were calculated and plotted with respect to the carbonate record and the regional seismic reflectors (figure 2-12). The record of important first and last benthic foraminiferal occurrences is presented in figure 2-13. In Hole $646 \mathrm{~B}$, major changes in the benthic foraminiferal assemblages occur in close proximity to several of the seismic reflectors identified from shipboard seismic and downhole logging studies. The composition of each assemblage is discussed below.

The upper interval of Seismic Unit 1 between 0 and 45.0 mbsf (Samples $105-646 \mathrm{~B}-1 \mathrm{H}-2,33-35 \mathrm{~cm}$ to $-6 \mathrm{H}-2,13-15 \mathrm{~cm}$ ) contains an abundant fauna dominated by Stetsonia horvathi, with common occurrences of $\mathrm{F}$. fusiformis and Pullenia subcarinata. The species Epistominella exigua, Melonis barleeanum, 


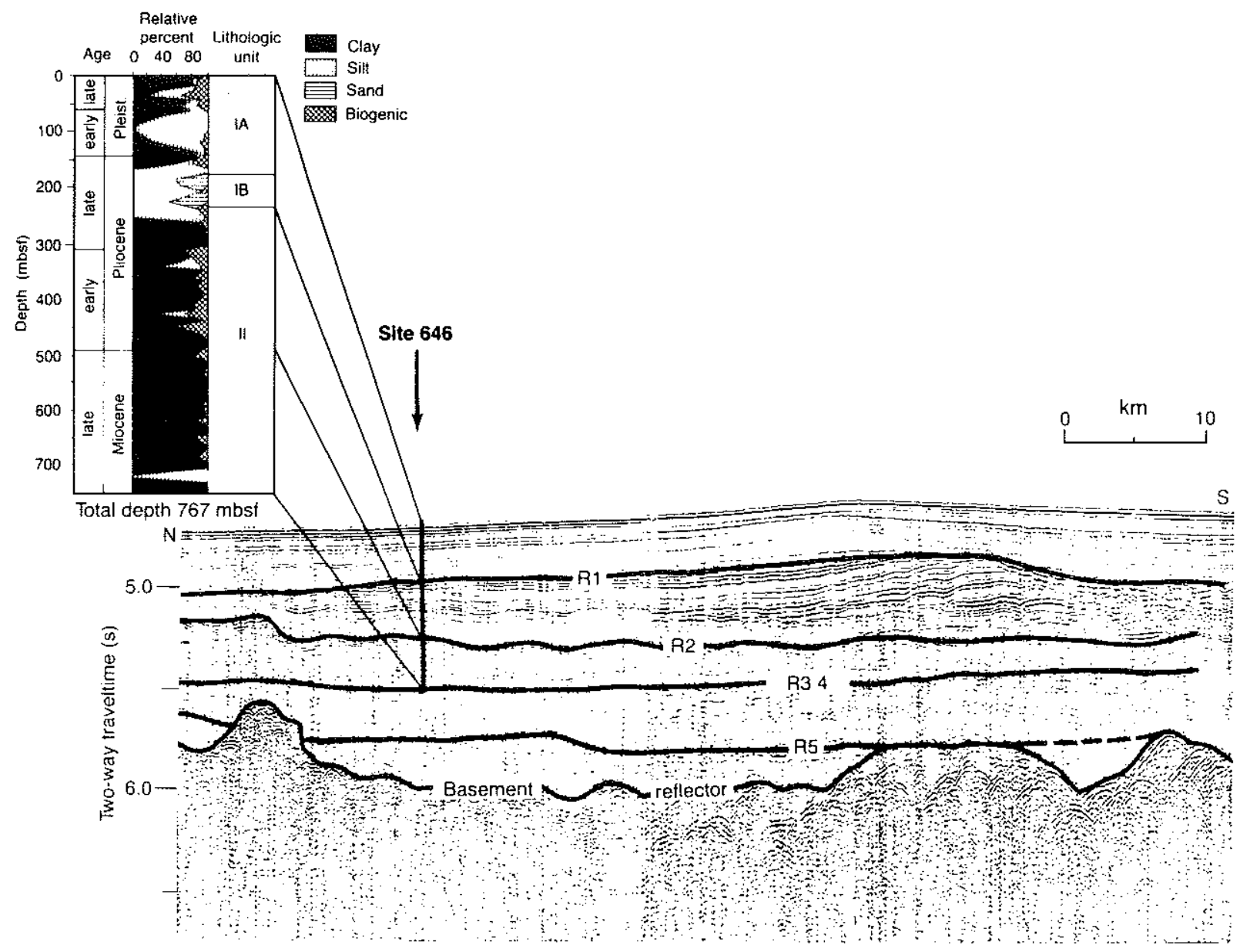

2-11. Lithostratigraphic and Seismic Units of Site 646, correlated to regional seismic reflectors on a single-channel seismic line crossing the Eirik Ridge. 


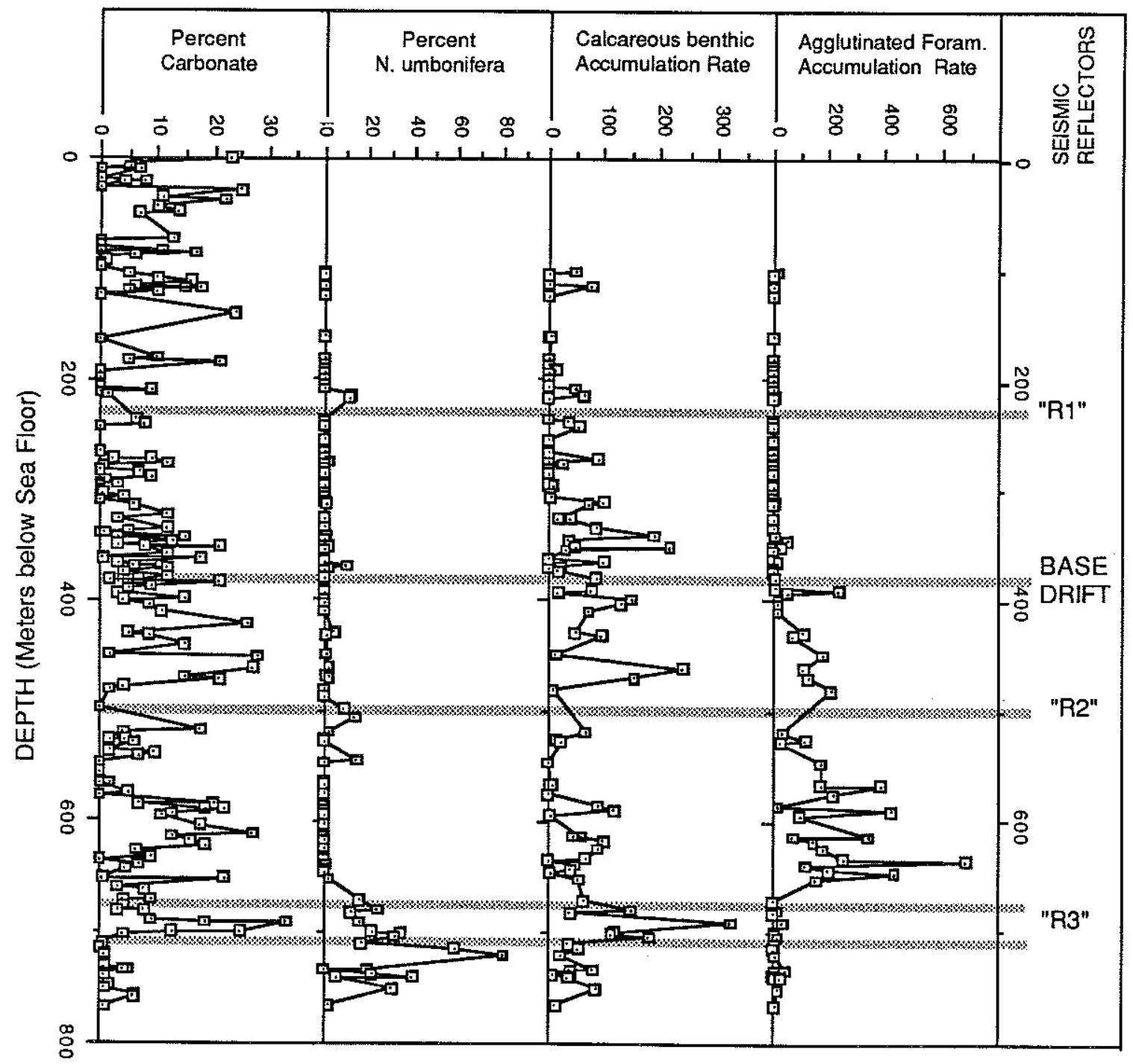

2-12. Accumulation rates of benthic foraminifera (\# specimens $/ \mathrm{cm}^{2} / \mathrm{k} . \mathrm{y} \cdot$ ), calcium carbonate content and percent Nuttallides umbonifera in Hole $646 \mathrm{~B}$. Also shown are the depths of important regional seismic reflectors. 


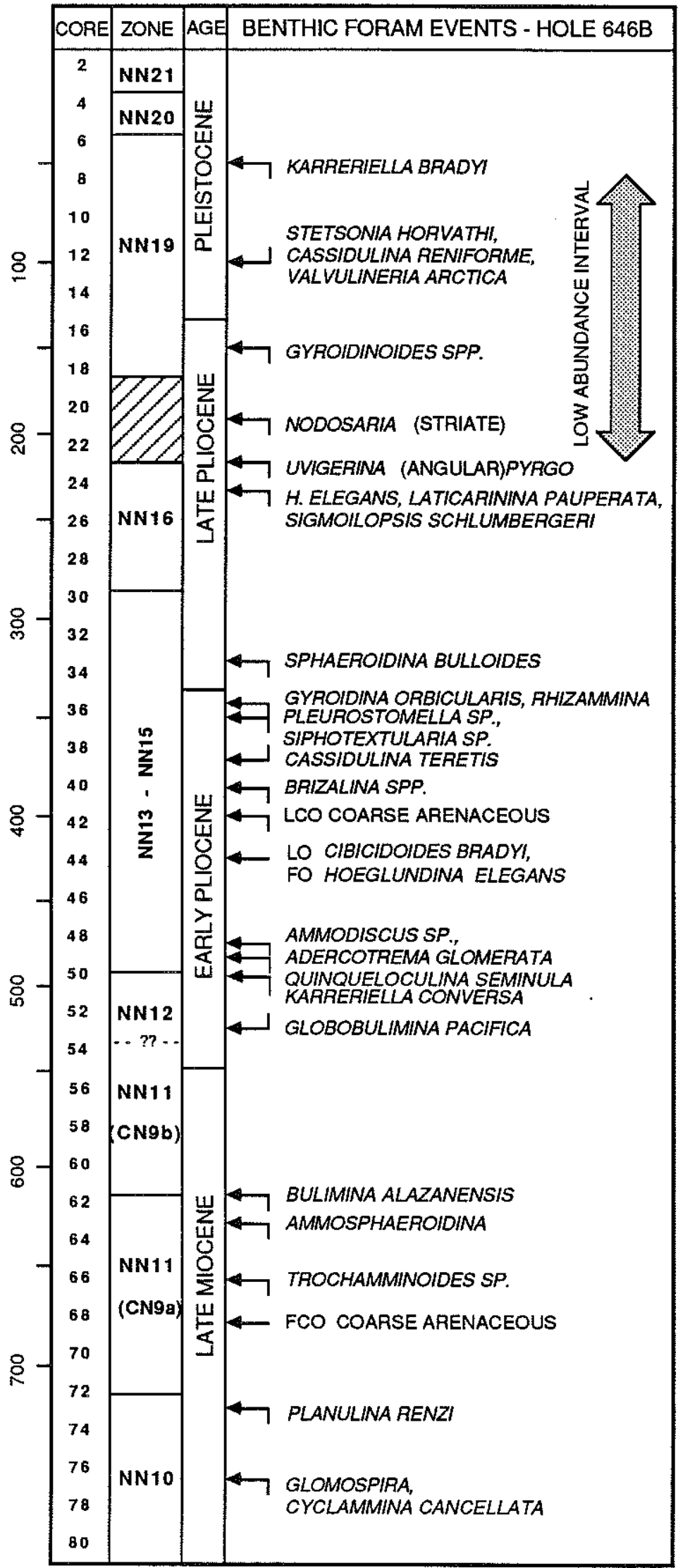

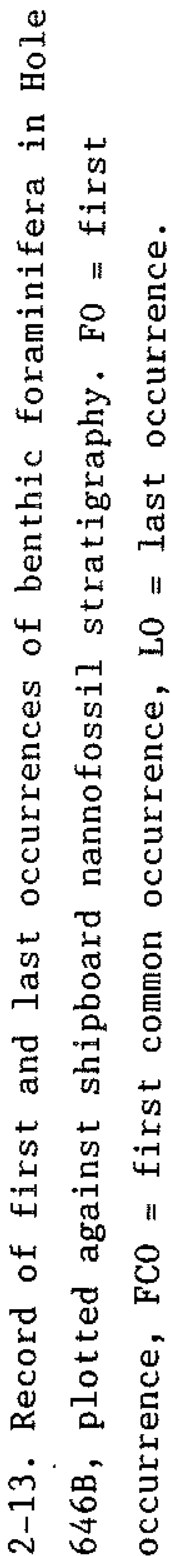


Planulina wuellerstorfi, Cassidulina spp. and Pullenia bulloides are present throughout this interval in lower but significant percentages. The uppermost sample $(105-646 \mathrm{~B}-1 \mathrm{H}-2,33-35 \mathrm{~cm})$ is co-dominated by Pullenia subcarinata, $\mathrm{M}$. barleeanum, F. Eusiformis and Uvigerina $\mathrm{sp}$. The assemblages in the upper part of Unit 1 generally display good preservation.

Between 53.1 and $101.4 \mathrm{mbsf}$ (Cores 105-646B-6H and $-11 \mathrm{H}$ ) the sediments are essentially barren of foraminifera, except for Sample 105-646B-9H-5, 138$140 \mathrm{~cm}$ which contains abundant Fursenkoina fusiformis and Bolivina arctica, and Sample $-8 \mathrm{H}-3,108-110 \mathrm{~cm}$ which contains a few specimens of 0ridorsalis. A major turnover in the benthic assemblage occurs near the base of Seismic Unit 1, which overlies the sediment drift. Between 206 and 236 mbsf (Samples 105$646 \mathrm{~B}-23 \mathrm{X}-5,122-124 \mathrm{~cm}$ to $-25 \mathrm{X}, \mathrm{CC})$, the last occurrence of Laticarinina pauperata, Hoeglundina elegans, and Sigmoilopsis schlumbergeri is encountered. In the Norwegian-Greenland Sea, Laticarinina and Hoeglundina also disappear before the onset of glacial conditions (Talwani, Udintsev, et al., 1976). At Rockall Margin Site 552A, the L0 of Laticarinina was recorded in the late Pliocene by Murray (1984). The lower part of Seismic Unit 1 contains a low abundance Melonis barleeanum assemblage. Assemblages with common $M$. barleeanum are typical of glacial sediments in lower bathyal DSDP Sites in the Northern North Atlantic (Murray, 1984) and in the Norwegian-Greenland Sea (Talwani, Udintsev, et al., 1976).

Within the sediment drift (Seismic Unit 2), the abundance of benthic foraminifers is still low, and the assemblage is numerically dominated by Melonis barleanum, Pullenia bulloides, Cibicidoides spp, and unilocular forms (Lagena, Oolina and Fissurina) and entosolenians. This assemblage also contains a greater proportion of species which are typical of modern North Atlantic Deep Water (Oridorsalis spp., Planulina wuellerstorfi, Globocassidulina subglobosa) than assemblages in other seismic units. The first occurrence of Islandiella teretis was found in Sample 105-646B-39X-2, 15-17 cm. This species first appears in the upper Pliocene of Rockall Margin sites (Murray, 1984).

The base of the drift sequence was placed at 377 mbsf from the seismic record. A major benthic faunal break occurs between 387.4 and 391.0 mbsf (between Samples 105-646B-41X-5, 10-12 cm and $-41 \mathrm{X}, \mathrm{CC}$ ). Below the seismic reflector delineating the base of the drift, the upper Miocene to basal Pliocene benthic foraminiferal assemblages of Seismic Unit 3 are numerically 
dominated by coarse Rhizammina and associated agglutinated taxa (Cyclammina pusilla, Haplophragmoides, Psammosphaera, Recurvoides, Reophax, Trochammina, Lagenammina, and Ammobaculites). Calcareous benthic foraminifera are numerically subordinate, and are represented by oridorsalis, Melonis barleeanum, M. pompilioides, Pullenia bulloides, and Cibicidoides spp. Near the middle of Seismic Unit 3, (between Samples 646B-47X, CC and -53, CC) Nuttallides umbonifera occurs sporadically and in low numbers. There is a smaller percentage of unilocular species in Seismic Unit 3 than in the overlying unit.

The upper reflector of the "R3" couplet was originally placed at $680 \mathrm{mbsf}$ (Shipboard Scientific Party, 1987a). Between 671 and 651 mbsf another distinct change in the benthic foraminiferal assemblage occurs: coarse agglutinated taxa become sporadic and rare downhole. The calcareous assemblages within the seismic couplet (Cores $646 \mathrm{~B}-72 \mathrm{X}$ and $-73 \mathrm{X}$ ) are transitional between assemblages from Seismic Units 3 and 4 . In the six samples examined from Cores $646 \mathrm{~B}-72 \mathrm{X}$ and $-73 \mathrm{X}$, the proportion of $\mathrm{N}$. umbonifera is approximately equal to the proportion of "NADW species". The calcareous species Planulina renzi was found in samples $646 \mathrm{~B}-73 \mathrm{X}-2,58-60 \mathrm{~cm}$ and $-73 \mathrm{X}$, CC. In the Gulf of Mexico, the last occurrence of this species is reported in Zone N17 (Van Morkhoven et al., 1986).

In Seismic Unit 4 ( 710 - 766 mbsf), the benthic foraminiferal assemblage is dominated by Nuttallides umbonifera (Fig. 2-12). The abundance of this species is positively correlated with the degree of undersaturation of bottom waters with respect to calcium carbonate (Bremer and Lohmann, 1982). Characteristic accessory species in this assemblage are agglutinated foraminifera with smooth, finely finished tests, such as Bathysiphon, Ammodiscus and Glomospira. Isolated specimens of Cyclammina cancellata also occur near the base of Hole 646B.

\section{PALEOECOLOGY OF NEOGENE AGGLUTINATED FORAMINIFERA:}

Neogene agglutinated foraminiferal assemblages are known from silled high-latitude basins such as the Norwegian-Greenland Sea and Baffin Bay, but until now, Neogene agglutinated assemblages have not been reported from any DSDP site in the deep North Atlantic. Agglutinated assemblages are present in Paleogene sediments of the Labrador Sea (Gradstein and Berggren, 1981) as well as in the modern North Atlantic (Schroder 1986a), but are usually not 
preserved in Neogene sediments. Until now the only link in time between these occurrences has been the Pliocene agglutinated assemblages in cutting samples from the Texaco Blue H-28 well on the northern Grand Banks. Therefore, the microfossil record from Hole $646 \mathrm{~B}$ is unique in containing cores with well preserved agglutinated foraminifera.

The presence of agglutinated foraminifera in Cenozoic sediments is usually associated with sediment parameters allowing the preservation of organic matter. The ecology of early Cenozoic "flysch-type" agglutinated assemblages was discussed by Gradstein and Berggren (1981) and Miller et al. (1982). These authors noted the occurrence of these assemblages in areas of rapid sedimentation and in sedimentary basins containing corrosive bottom water. The set of environmental conditions associated with flysch-type assemblages has become known as the "old bottom water model". The disappearance of these assemblages from the deep Labrador Sea near the Eocene/0ligocene boundary was correlated with the onset of vigorous deep circulation and more oxygenated conditions (Miller et al. 1982, Miller and Tucholke, 1983). After this event in the North Atlantic, agglutinated assemblages persisted only in the high-latitude basins. In accordance with the old bottom water model, in order for agglutinated assemblages to be preserved in the upper Miocene to lower Pliocene of the Labrador Sea, sediment parameters or bottom water properties must have surpassed a certain threshhold. But which parameter or combination of parameters is unique to Site $646 ?$

A compilation of sediment properties (Table 2-10) reveals that Site 646 has little in common with most Atlantic sites. With the exception of Site 114 on the east flank of the Reykjanes Ridge, lower Pliocene sediments in the Eastern Altlantic are nannofossil oozes with high calcium carbonate contents. Hole 114 penetrated drift sediments with a carbonate content of about $26 \%$ and a higher sedimentation rate than in Hole $646 \mathrm{~B}$, but no agglutinated assemblages were recovered.

The Miocene to early Pliocene deep water in the Norwegian-Greeland Sea and Arctic was apparently corrosive, since carbonate contents at deep sites are less than 1 percent (Talwani, Udintsev, et al., 1976). Agglutinated foraminiferal assemblages are present in pre-glacial Pliocene sediments of Hole 344 on the Knipovich Ridge and Hole 345 in the Lofoten Basin. In Cores 26-33 of Hole 344, the generic composition of the foraminiferal assemblage is 
remarkably similar to the assemblages in the Eirik Ridge. The assemblage consists mainly of Bathysiphon, Haplophragmoides, Reophax, Hormosina and Saccammina, but at some levels Melonis barleeanum and I. teretis occur with the planktonic species Neogloboquadrina atlantica. The last occurrence of coarse agglutinated species is associated with the appearance of ice-rafted sediments in Hole 345. The pre-glacial assemblage at this site is more diverse than the underlying Miocene assemblage and contains Cyclammina, Haplophragmoides and Martinotiella (Talwani, Udintsev, et al., 1976).

I speculate that the coarse agglutinated assemblages at Site 646 indicate the presence of old, corrosive bottom water derived from the NorwegianGreenland Sea. Labrador Sea Hole 113 recovered a thick sequence of turbidite sediments in a local topographic depression. Calcium carbonate content is low, and sedimentation rate is higher than in Hole 646B. However, Hole 113 is not in the pathway of Denmark Straits Overflow water.

The trophic structure of the agglutinated foraminiferal assemblage is another clue to the nature of the depositional environment at site 646 . The assemblage in Seismic Unit 3 is strongly dominated by coarsely agglutinated specimens of Rhizammina, which is reported to be an epibenthic suspensionfeeder (Jones and Charnock, 1985). Benthic communities dominated by suspension-feeders are rare in the deep sea (Jumars and Gallagher, 1982), since the proportion of suspension-feeders to deposit-feeders normally declines with depth and distance from shore (Levinton, 1982). Suspensionfeeding communities in the deep sea have only been found near hydrothermal vents (Lonsdale, 1977) or in areas where there is a lateral advection of food particles (L. Mullineaux, personal communication, 1987). In Alvin dives, H. Sanders (personal communication, 1987) has observed concentrations of suspension-feeding animals atop local topographic elevations, while local depressions are occupied by deposit-feeders. In the modern North Atlantic, there is an increased proportion of the coarse tubular agglutinated species beneath the Western Boundary Undercurrent (Schroder 1986a). A Rhizammina community, therefore, presumably requires moving bottom currents to supply it with food. However, the genus is sessile and probably cannot escape the effects of strong bottom currents. The change from agglutinated asssemblages below the sediment drift to calcareous assemblages in the drift may reflect higher bottom current intensities, which would have inhibited Rhizammina and resulted in increased ventilation of the deep environment. 
Table 2-10. A compilation of sediment parameters from DSDP and ODP sites in the North Atlantic with the occurrence of agglutinated assemblages noted.

\begin{tabular}{|c|c|c|c|c|c|c|c|c|c|c|c|c|}
\hline - scaticn & Ji: & 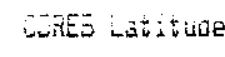 & th & ivio & & & & & & & JEG : & $\underline{4}+\therefore$ \\
\hline$\angle A B S E A$ & 646 & $26-5359 \times 134$ & 3455 & 2 & 30.4 & $3-a$ & 90 & 5 & 70 & yes & 90 initay & yes \\
\hline & 113 & 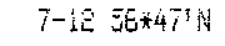 & ZEIE & 2 & 8.4 & -12 & $5 \%$ & 37 & 70 & 6 & i 50 : $3 /$ aly & $n 0$ \\
\hline & $112 A$ & $554 * 47^{1} \mathrm{~N}$ & 3615 & 1.7 & VA & $\mathrm{NA}$ & $N A$ & 模 & not & 100 & 20 ininy & $\mathrm{ma}$ \\
\hline & $\mathscr{1 A}$ & $5-650 * 251$ N & 1797 & 1.7 & 0.1 & 72 & 31 & 54 & no & $\mathrm{mo}$ & 0.4 fa/ hly & $n$ \\
\hline E.N.AL & 114 & $4-559 * 56 !$ & 1927 & 1.5 & $a_{1} i$ & 26 & 23 & 20 & yes & yes & SOL & 10 \\
\hline & $\$ 16$ & $257 \times 329$ & $: 151$ & 1.7 & 20.1 & 30 & $i 4$ & $\Xi$ & yes & 30 & 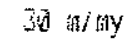 & $n$ \\
\hline & Eil & $2-33 \quad 2 * 0^{3} h$ & 3200 & 1.8 & 湖 & 70 & NA & $\mathrm{NA}$ & no & yes & 50 : a/rily & rio \\
\hline & $E 10$ & $8-1053 * 131 \mathrm{~N}$ & 5417 & 1.8 & $\mathrm{NA}$ & 95 & 河 & $M A$ & 10 & yes & EI niny & 30 \\
\hline & 609 & $26-3149 * 3 \mathrm{c}^{5} \mathrm{~N}$ & 3883 & 1.8 & NA & 98 & $\mathrm{NA}$ & $\mathrm{NA}$ & 30 & no & 99 in/tay & 60 \\
\hline & 508 & $15-1542 * 501$ N & 3541 & 1.7 & NA & 95 & NA & $\mathrm{NR}$ & no & no & $19 \mathrm{~m} / \mathrm{t}$ y & 30 \\
\hline & $5 S A$ & $14-2356 * 639 N$ & 2311 & 1.7 & $\bar{b} .1$ & 93 & 83 & 5 & yes & yes & 25 in/谓y & no \\
\hline & $55 \mathrm{~A}$ & $356 * 66^{\prime} \mathrm{N}$ & 2339 & 1.7 & 0.1 & 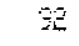 & 30 & 5 & yes & yes & 30 61 / $19 y$ & no \\
\hline & 34 & $5-656 * 18^{5}$ & 5584 & 1.7 & 0.1 & 37 & 35 & 10 & yes & $n$ & $7 \mathrm{in} / \mathrm{my}$ & mo \\
\hline & 555 & $56 * 34^{1} \mathrm{~N}$ & 1669 & 1.8 & 0.1 & 94 & 70 & 15 & yes & no & 16 in/ $/$ ay & 60 \\
\hline 6-5 Higne & 407 & $8-1463 \times 56$ ' & 2498 & 1.5 & 湖 & 85 & $\mathrm{Sh}$ & HA & no & Yoo & $45: \mathrm{a} / \mathrm{tay}$ & 60 \\
\hline & $4 \overrightarrow{06}$ & $11-1263 * 23 \mathrm{~N}$ & 1634 & $1, \dot{\varepsilon}$ & HA & 35 & $\mathrm{NA}$ & $\mathrm{NR}$ & yes & no & 35 miny & 60 \\
\hline 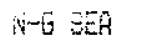 & 337 & $4-554 * 53$ & 2657 & $1 . \overline{5}$ & D.E & $\mathrm{AH}$ & 40 & 8 & no & 30 & 2 nisy & $n 0$ \\
\hline & 344 & $25-3376 \times 699$ & 2001 & 31 & $\overline{0.8}$ & $\dot{1}$ & 45 & $\bar{J}$ & $\mathrm{mat}$ & no & 76 miay & $y=5$ \\
\hline & 345 & $5, \mathrm{cc}-6 \quad 69 * 50$ & 3216 & 1.7 & 0.4 & 1 & $\mathrm{NA}$ & $\mathrm{NR}$ & no & ro & VA & yes \\
\hline & 348 & $5-758 * 30 ! N$ & 1777 & 1.4 & $0 . \overline{3}$ & 1 & 50 & $\xi_{j}$ & yes & no & 3 解证y & 10 \\
\hline
\end{tabular}

WED = Wet Fuik Dereity, TOC = Totai Ornanic Caroon

Gilica? = Fresence of biogenic sijica, Drift? = Sibe iocated un sedinert drift Fggl? = Fresence of aggiutinated foraninifers 
Table 2-11. Summary of important benthic foraminiferal species and species groups in Hole 646B. Numbers represent the mean values of census data from each seismic unit. Seismic Unit $3 / 4$ samples are from the calcareous interval within the reflector "R3" couplet. "NADW species" include the combined relative abundance of P. wuellerstorfi, 0ridorsalis, G. subglobosa and E. exigua.

\begin{tabular}{|c|c|c|c|c|}
\hline TAXA & $\begin{array}{l}\text { Seismic } \\
\text { Unit } 2\end{array}$ & $\begin{array}{l}\text { Seismic } \\
\text { Unit } 3\end{array}$ & $\begin{array}{l}\text { Seismic } \\
\text { Unit } 3 / 4\end{array}$ & $\begin{array}{l}\text { Seismic } \\
\text { Unit } 4\end{array}$ \\
\hline Melonis spp & $18.1 \%$ & $5.2 \%$ & $12.1 \%$ & $3.2 \%$ \\
\hline Smooth Agglutinated spp. & 0.0 & 0.0 & 0.7 & 7.0 \\
\hline Coarse Agglutinated spp. & 7.0 & 65.6 & 8.0 & 13.9 \\
\hline Nuttallides umbonifera & 0.9 & 0.9 & 18.4 & 25.0 \\
\hline NADW species & 10.3 & 4.9 & 19.4 & 11.5 \\
\hline 0 ther & 63.7 & 23.3 & 41.3 & 39.4 \\
\hline $\mathrm{n}$ & 32 & 40 & 6 & 12 \\
\hline
\end{tabular}


In contrast, the assemblage in Seismic Unit 4 of Site 646 contains a greater proportion of species with finely agglutinated tests (Table 2-11). Species restricted to this assemblage, Ammodiscus and Glomospira, have been identified as epifaunal detrital feeders (Jones and Charnock, 1985) and presumably have a low tolerance for disturbed environments. In the modern North Atlantic, these organisms are present in greater proportion in environments that are relatively undisturbed by bottom currents (Kaminski, 1985).

The agglutinated assemblages from the Texaco Blue $\mathrm{H}-28$ well are remarkably similar to those from Seismic Unit 3 in Hole 646B. Each species found by us in the Pliocene of the Blue H-28 well also occurs in Hole 646B, and specimens of Rhizammina are about the same size. This well site is located under the current axis of the Western Boundary Undercurrent. The predominant lithology is hemipelagic clay, and sedimentation rates increase dramatically from $100 \mathrm{~m} / \mathrm{my}$ in the late Miocene to $300 \mathrm{~m} / \mathrm{my}$ in the Pliocene and Pleistocene. In the Miocene interval of the well, the occurrence of agglutinated taxa is fairly continuous, but in the Pliocene, agglutinated taxa cluster at discrete levels. I tentatively interpret the preservation of this fauna as an indication of periods of slower deposition. The highest level with agglutinated taxa at 2610 mbsf may coincide with an increase in local WBUC circulation near the onset of ice rafting at $2.5 \mathrm{Ma}$. However, the exact chronology cannot be resolved.

One of the key environmental factors controlling the presence of Neogene flysch-type faunas in the high-latitude North Atlantic basins appears to be the local formation of bottom waters. The change from a predominantly agglutinated assemblage to a calcareous assemblage in the Pliocene is associated with the onset of drift sedimentation at Site 646. This change may reflect a change in deep-water properties and current intensities which may be ultimately linked to the initiation of convective overturn of deep waters and the onset of vigorous circulation in the Norwegian-Greenland Sea. Agglutinated assemblages are present in the Miocene to lower Pliocene of Norwegian-Greenland Sea sites, but the present microfossil chronology of the area does not provide the resolution to determine if the last occurrence of flysch-type taxa is isochronous in both regions. However, I speculate that the events are closely linked. Agglutinated assemblages persisted to younger stratigraphic levels in the deep Arctic 0cean. In some of the longer cores 
obtained by the Arctic Ocean CESAR Expedition, the Pliocene/Pleistocene boundary is marked by the LCO of agglutinated foraminifera. This event appears to be correlated with the onset of perennial sea ice formation in the Arctic Ocean (Scott et al., 1987). The formation of dense waters through brine release from sea ice formation apparently ventilates the deep basins. Therefore, the observed pattern of LCO of flysch-type assemblages in the highlatitude North Atlantic basins appears to be consistent with the old bottom water model of Gradstein and Berggren. I believe that the increase in bottom water formation by thermohaline processes resulted in the loss of agglutinated foraminifera from the high-latitude fossil record.

\section{B. BOTTOM WATER HISTORY OF THE EIRIK RIDGE -}

1. Modern Hydrographic Setting --

At present, the deep-water masses in the northern Atlantic are derived from both northern and southern sources. Dilute Antarctic Bottom Water (AABW) is present below $2500 \mathrm{~m}$ in the Rockall Trough and Iceland basins and is presumed to flow along the eastern Atlantic margin in a weak cyclonic gyre (McCave and Tucholke, 1986). In the Rockall region, this water is joined by Norwegian Sea Deep Water (NSDW) which flows southward through the FaeroeShetland Channel and across the Wyville-Thompson Ridge and then turns northwestwards following bathymetric contours around Rockall Bank. Additional amounts of NSDW flow across the Iceland-Scotland Ridge south of Iceland (Worthington and Volkmann, 1965). This flow travels along the eastern flank of the Reykjanes Ridge at a depth of $1300-2200 \mathrm{~m}$ and passes over the Garder Drift. The flow then descends and passes through the Charlie-Gibbs Fracture Zone into the Labrador Sea.

In the present-day Labrador Sea and Irminger Basin, the deep-water mass consists entirely of northern-source water. The Iceland-Scotland overflow water flows in a cyclonic loop along the western flank of the Reykjanes Ridge at a depth of around 3200m (Worthington, 1976). Southwest of Iceland, ISOW is joined by cooler, denser Denmark straits overflow Water (DSOW) which descends beneath it. The DSOW is derived mainly from Arctic Intermediate water which forms by winter convection north of Iceland and overlies NSDW (Swift, 1986). This combined flow of ISOW and DSOW forms the Western Boundary Undercurrent which flows southwestward along the eastern margin of Greenland and around the Eirik Ridge (McCave and Tucholke, 1986). 


\section{History of Deep Circulation --}

The dating of regional seismic reflectors at site 646 reveals a much younger age for the Eirik Ridge than previously predicted. The Eirik Ridge was originally thought to be coeval with the Gloria Drift in the southern Labrador Sea, which is of oligocene age (Tucholke and Mountain, 1986). Instead, the major period of drift sedimentation at Site 646 occurred in the Pliocene, although there is evidence of weaker currents occurring earlier. The seismic horizon marking the onset of drift deposition at this site is dated at approximately $4.5 \mathrm{Ma}$, based on the age-depth model for Hole 646B. Although there is no obvious hiatus in Hole 646B, a prominent seismic horizon observed within the drift sequence to the east of Site 646 is interpreted as indicating erosion. This horizon occurs between Reflecctor "R1" and the base of the drift, and by correlation with the reflectors in Hole 646B I interpret the age of this erosional pulse as occurring between 4.5 and $2.5 \mathrm{Ma}$. This compares well with an age of $3-2$ Ma for the "Blue" erosional event in the western North Atlantic reported by Tucholke and Mountain (1986).

The history of the deep circulation over the Eirik Ridge can be reconstructed by comparing benthic foraminiferal assemblages at site 646 with those recovered on Leg 38 (Norwegian-Greenland Sea) and Leg 94 (Eastern Atlantic). Benthic assemblages in Hole 646B display turnovers which may be interpreted as reflecting changes in water mass properties. The occurrence of N. umbonifera with smooth agglutinated taxa in Hole $646 \mathrm{~B}$ and N. umbonifera assemblages in nannofossil Zones NN10 to NN11 and in Holes 608, 609 and 611C in the eastern Atlantic (Murray, 1987; Thomas, 1987) point to the presence of a sluggish, corrosive deep-water mass in the northern Atlantic basins in the Tortonian. This finding is supported by benthic carbon isotope studies of Miller et al. (1987), which indicate that at $\sim 8$ Ma deep water in the North Atlantic did not differ greatly isotopically from deep water in the Pacific. Murray (1987) interpreted the presence of N. umbonifera assemblages in Leg 94 DSDP holes as an indicator of "AABW-type" water in the North Atlantic in the late Miocene. The influence of corrosive deep water persisted into the early Pliocene at Site 611 on the Gardar Drift where assemblages containing both N. umbonifera and modern NADW species were recovered. If ISOW were the predominant water mass over the Eirik Ridge in the early Pliocene, one might expect to find evidence of this entrained corrosive water reflected by assemblages in Hole 646B. However the lack of any assemblages with abundant 
N. umbonifera above Seismic Unit 4 (Fig. 2-12, Table 2-11) argues against the influence of this water mass. The assemblages of Seismic Unit 3 are comprised of mainly coarse agglutinated species and Melonis, and are unlike Miocene assemblages at other North Atlantic sites. Instead, the assemblages from unit 3 bear closest resemblance to pre-glacial assemblages from intermediate and deep depths in the Norwegian-Greenland Sea. A likely cause of this pattern is that Denmark Straits Overflow Water was the dominant deep-water mass over the Eirik Ridge since the late Miocene, displacing the corrosive bottom water in the Irminger Basin at approximately $7.5 \mathrm{Ma}$ (Fig. 2-14). This interpretation is supported by both carbon isotopic evidence and the presence of displaced microfossils. Miller et al. (1987) noted that the benthic carbon isotope record at Site 608 diverged from the Pacific record between 8 and $6 \mathrm{Ma}$. At $\sim 6$ $\mathrm{Ma}$, deep water in the North Atlantic was isotopically enriched with respect to Pacific water, indicating the production of "younger" deep waters analogous to modern NADW. Also, the reworked palynomorph Aquilapollenites was found above reflector "R3" in Hole 646B, but not below (Martin Head, personal communication to MAK, 1987). Aquilapollenites is a high-latitude form known from the Cretaceous sediments of the northern North Sea, Greenland and Svalbard (Batten, 1984). Sedimentologic evidence at Site 646 indicate increased bottom currents and increased sediment accumulation rate above the "R3" seismic reflector (Shipboard Scientific Party, 1987a).

The benthic foraminiferal and seismic data indicate the period of maximum DSOW current velocities occurred between $\sim 4.5$ and $2.5 \mathrm{Ma}$. The disappearance of Rhizammina and coarse grain size of sediments within the drift sequence is evidence of deposition of drift sediments under conditions of increased current velocities. This is in contrast with the model of Miller and Tucholke (1983) who interpret the onset of drift sedimentation to reflect a decrease and stabilization of abyssal circulation. The approximately coeval occurrence of hiatuses in the western North Atlantic and Norwegian-Greenland Sea also suggests increased current velocities at this time. At Sites $338,342,348$, 350, and 647 glacial Plio-Pleistocene sediments rest on the Miocene, indicating a period of strong current activity possibly associated with the breakdown of a stable, stratified water column. The change from a coarse agglutinated assemblage in Seismic Unit 3 of Hole $646 \mathrm{~B}$ to a calcareous 
SITE 646 EIRIK RIDGE

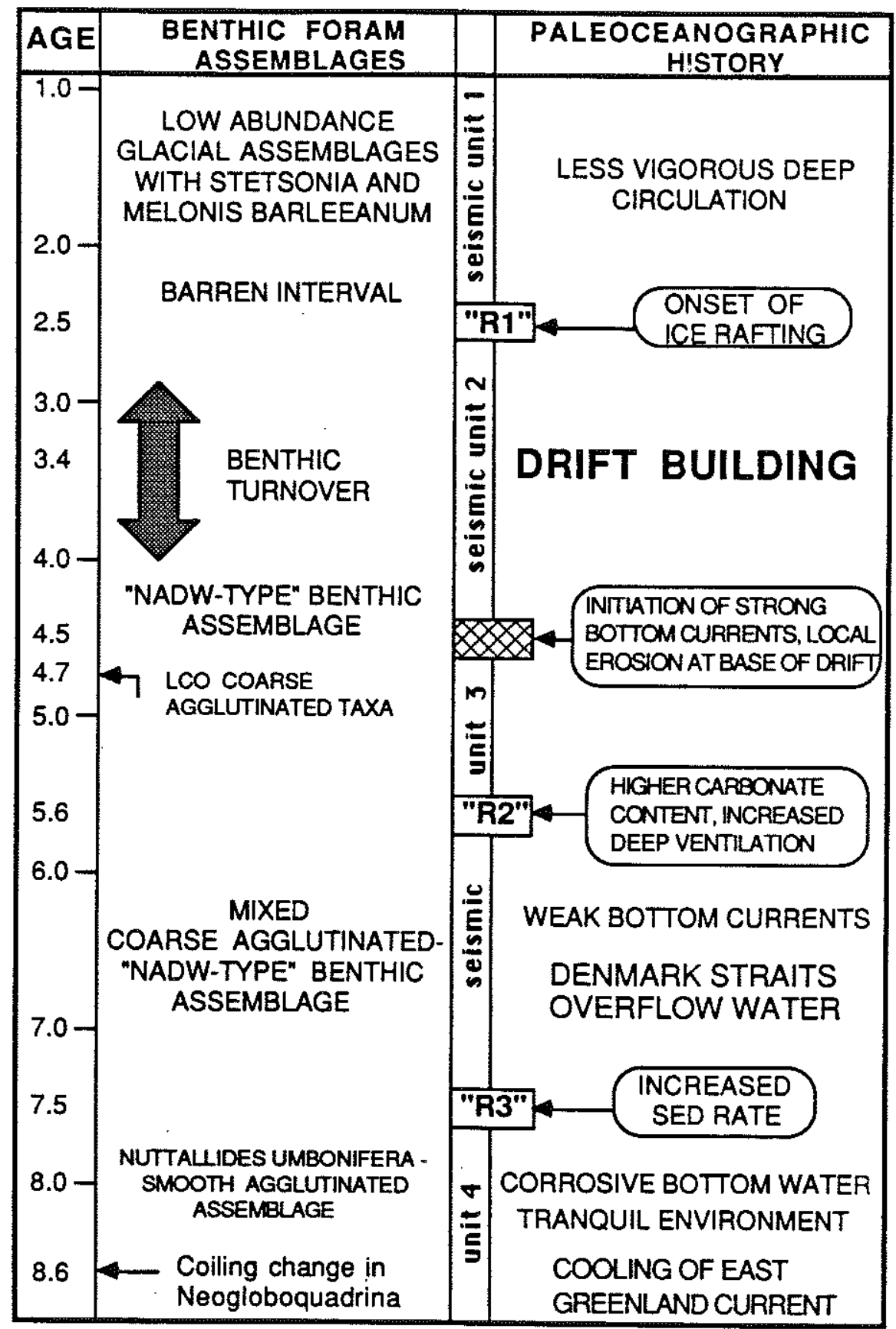

2-14. Summary of benthic foraminiferal assemblages and the deep-water history of the Eirik Ridge. 
assemblage in Seismic Unit 2 probably reflects the increased ventilation of deep water associated with this current activity.

My observation of DSOW at Site 646 since 7.5 Ma agrees with findings of Keigwin et al. (1987), who presented isotopic evidence for the continued production of NADW during the Messinian Salinity Crisis. Their results contradict earlier suggestions that the cutoff of Mediterranean outflow Water during the Messinian would result in a cessation of NADW production in the Norwegian-Greenland Sea (Blanc and Duplessy, 1982). In the basal Pliocene to Messinian sediments beneath the sediment drift, Nuttallides umbonifera is present, but in lower proportions than before $7.5 \mathrm{Ma}$. The assemblage is still dominated by agglutinated taxa and species typical of modern NADW. The "R2" reflector reflects a change from carbonate-poor sediments (below) to more carbonate-rich sediments (above). This change is interpreted as reflecting increased ventilation of the deep water at $\sim 5.6 \mathrm{Ma}$. At Site 609 in the eastern Atlantic, an analogous change from poor carbonate preservation (below) to increased carbonate preservation (above) began at $\sim 5.8 \mathrm{Ma}$ and reached a maximum at $\sim 5.3 \mathrm{Ma}$ (Hooper and Weaver, 1987), which suggests that this may be a basin-wide event. Hooper and Weaver interpreted the latest Miocene peak in carbonate preservation as indicating increased contribution of northern-source deep water to the basin at this time.

An increase in the production of NADW may have been caused by a number of oceanographic and climatic factors. Cooler late Miocene sea surface temperatures at high latitudes, culminating in the proposed 5.2 to $4.8 \mathrm{Ma}$ glacial events reported by Keigwin et al. (1987) and Keigwin (in press), may have contributed to greater NADW production. Indeed, the appearance of DSOW at Site 646 is preceeded by a coiling change in Neogloboquadrina atlantica (at 8.6 Ma) which indicates cooling of the surface waters in the East Greenland Current (Aksu and Kaminski, this volume). With the reopening of the Mediterranean at $4.83 \mathrm{Ma}$ (Zijderveld et al., 1986), the northward advection of saline water to the Norwegian-Greenland Sea combined with cool sea surface temperatures, may have resulted in the production of denser, more oxygenated intermediate and deep waters. This raises the possibility that Mediterranean water may have been a contributing factor to the presence of hiatuses, the onset of drift sedimentation at Site 646 and the LCO of agglutinated taxa. The period of drift formation also correlates with the maximum northward penetration of "AABW" observed in the eastern Atlantic in the early Pliocene 
by Murray (1987). This correlation suggests that a feedback mechanism or "teleconnection" between NADW and AABW may have been operative in the early Pliocene analogous to the present day (see Johnson, 1982).

CONCLUSIONS :

Information on the trophic structure and life position of agglutinated benthic foraminiferal assemblages can be used to help interpret the depositional environment and water mass history of the Eirik Ridge (Fig. 214). Before $7.5 \mathrm{Ma}$, an assemblage dominated by Nuttallides umbonifera and smooth agglutinated species point to a tranquil environment with southernsource deep water. After 7.5 Ma northern-source deep water is present over the Eirik Ridge. Above the "R3" seismic reflector, the benthic assemblage consists mainly of coarse agglutinated taxa with affinities to the NorwegianGreenland Sea. The predominance of Rhizammina in this assemblage is interpreted as indicating weak bottom currents. The onset of drift sedimentation at the Eirik Ridge at $\sim 4.5 \mathrm{Ma}$ is accompanied by a change to a predominantly calcareous assemblage. This faunal turnover is interpreted as indicating increased ventilation of the deep Labrador Sea owing to a more vigorous flow of Denmark Straits 0verflow Water. Drift sedimentation at the Eirik Ridge ceased at $\sim 2.5 \mathrm{Ma}$, concomitant with the onset of ice-rafting in the North Atlantic. 
APPENDIX 2-1. Benthic foraminifera from ODP Hole 646B.

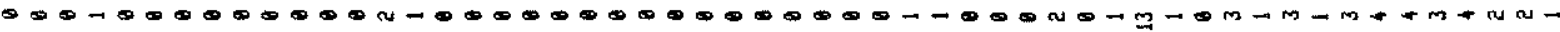

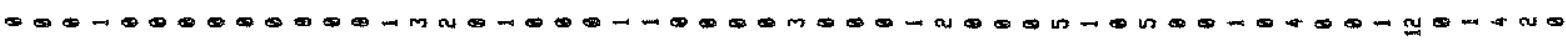

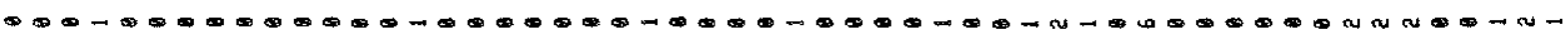
- 000000000000000000000000000000000000000000

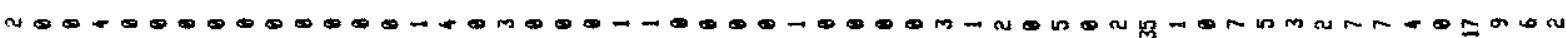
- $+\infty 0000000$ u

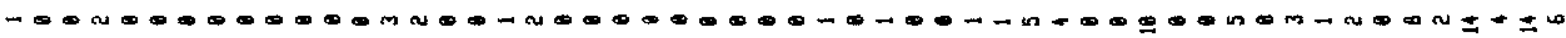

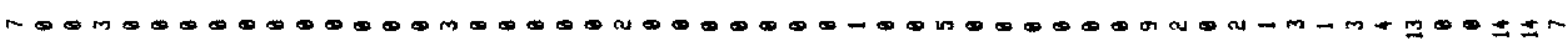

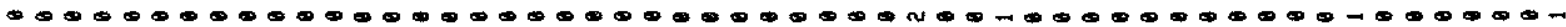

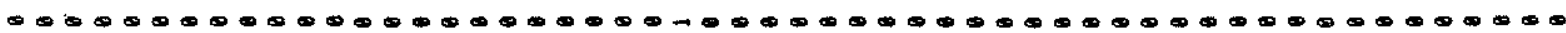
0000000000000000000000000000000000000000000000000

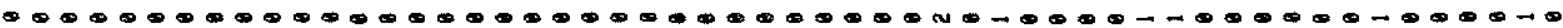

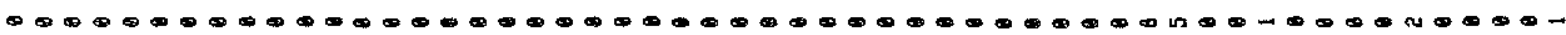
00000000000000000000000000000000000000000000000 $0000000000-000000000000000-000-\pi 00000000$ in

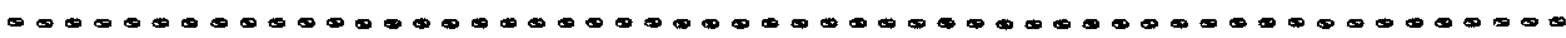
- 00000000000000000000000000000000000000000000000

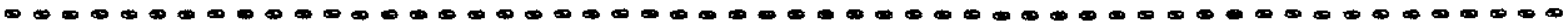
- 00000000000000000000000000000000000000000000000 00000000000000000000000000000000000000000000000 000000000000000000000000000000000000000000000000000

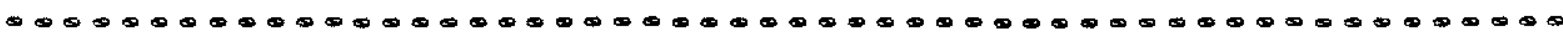
000000000000000000000000000000000000000000000000 0000000000000000000000000000000000000000000000000000

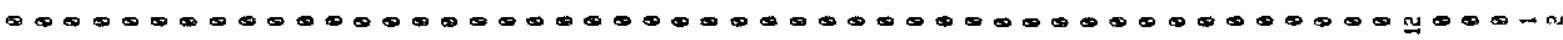

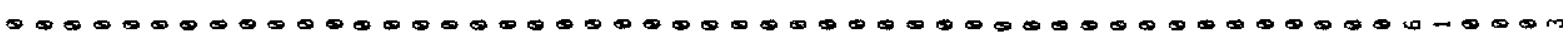
000000000000000000000000000000000000000000000001000000

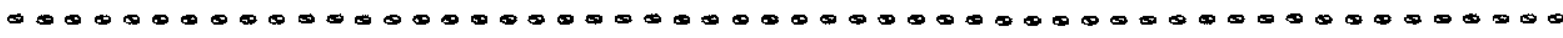
- 000000000000000000000000000000000000000000000

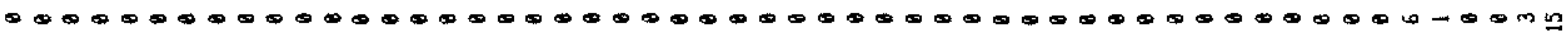

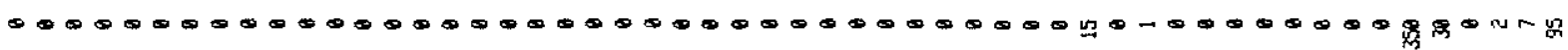

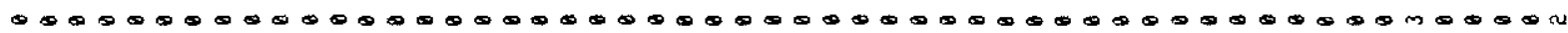

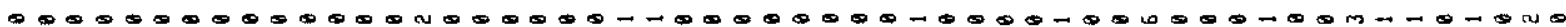

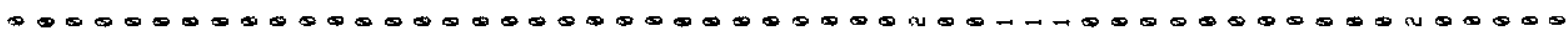
$+000000000000000000000000000000000000000-00000010$ $000000000000000000000000000000000000000000000400-\infty$

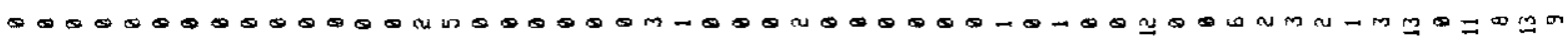

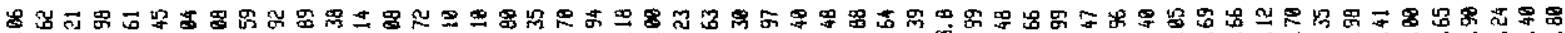

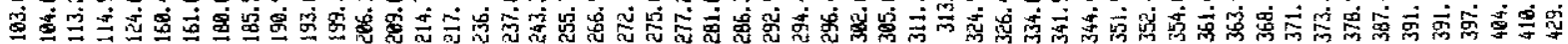

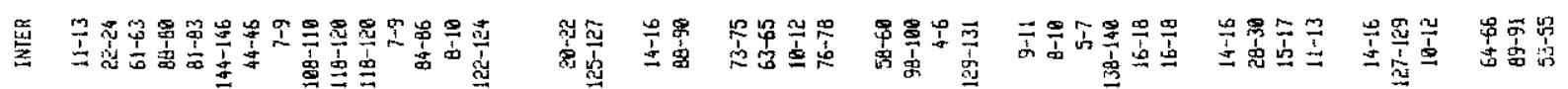

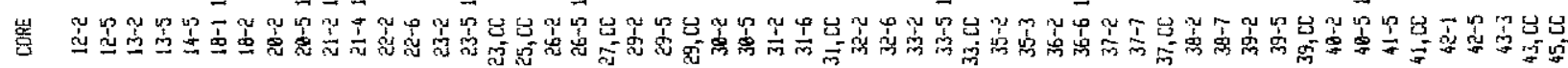


APPENDIX 2-1 (Continued).

n m

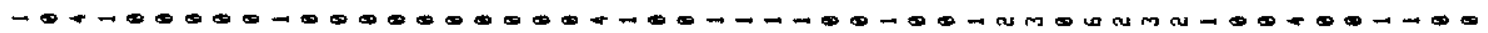

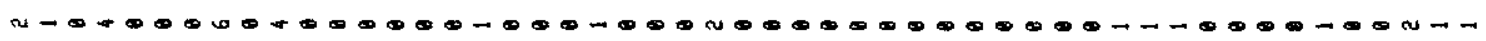

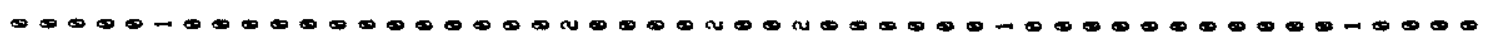
0 -

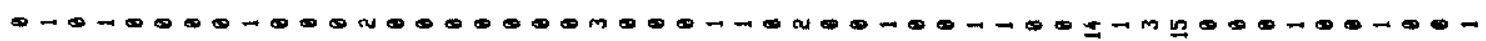
- + u 요유

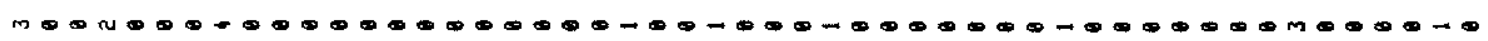

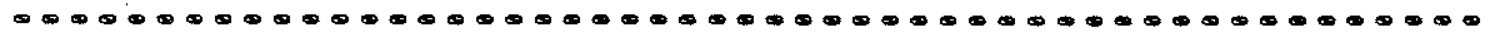

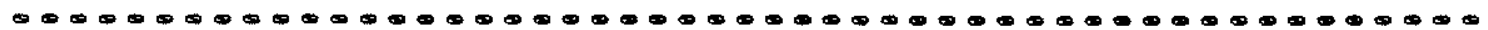
n-

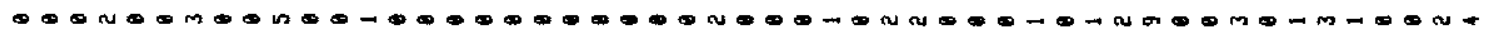
0. ल $00000000000000000000000000000000000000000000,000 \mathrm{000}$

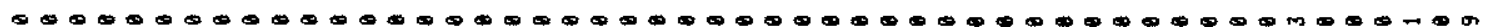

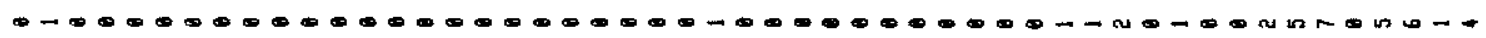
$0+0000000000000000000000000-000-000000000000000000$

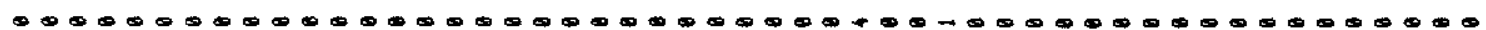
$0000000000000000000000000000-00000000000000000000000$ $000000000000000000000000000+-00-00000000000000000$

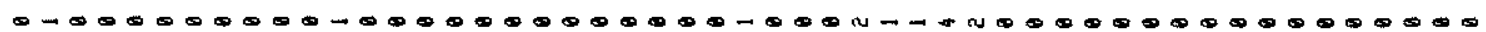

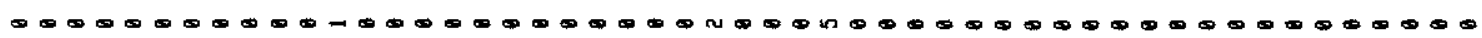

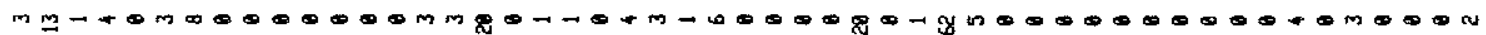

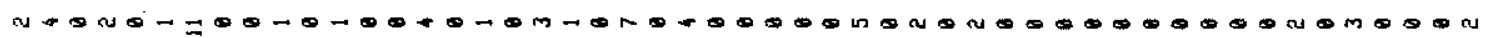
"

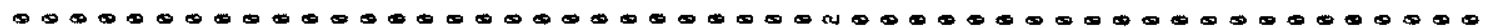

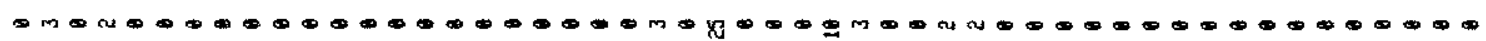
M

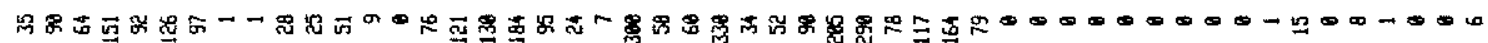

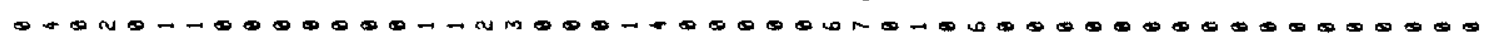
o$0000000000000000000000000-0000000000000000000000000$

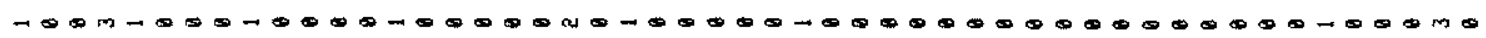

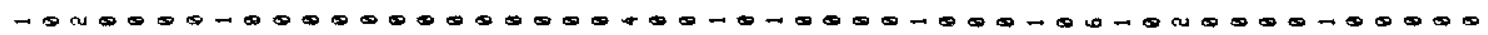
monmosond

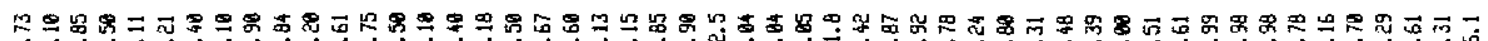

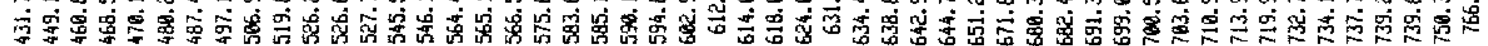

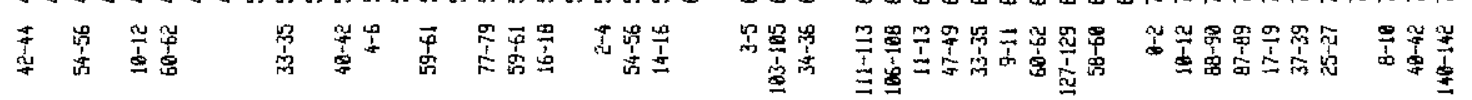

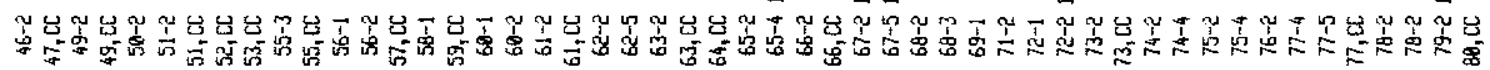
$--\ldots--\ldots-\ldots-\ldots-\ldots-\ldots-\ldots-\ldots-\ldots-\ldots$ 
APPENDIX 2-1 (Continued).

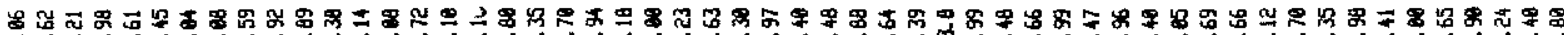

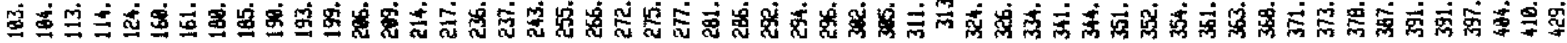
争 에에

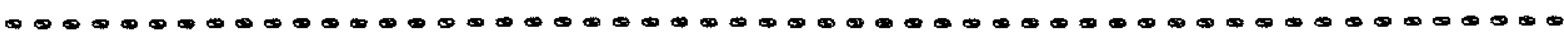
000000000000000000000000000000000000000000000000000 000000000000000000000000000000000000000000000000000 00000000000000000000000000000000000000000000000

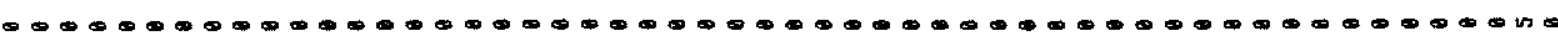

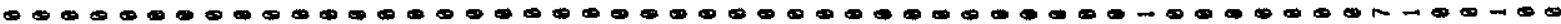

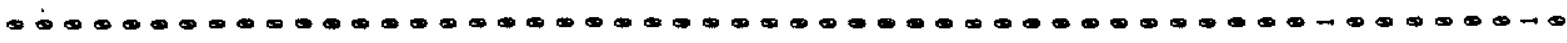

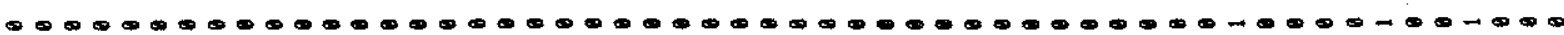

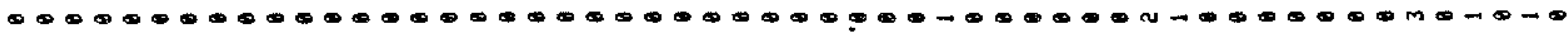

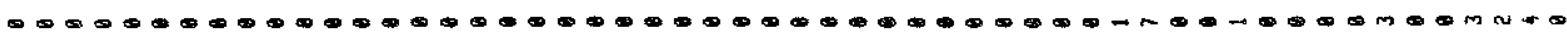

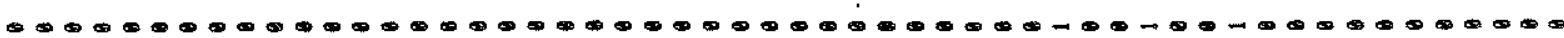
$000000000+000000000000000000000-0000000000000000$

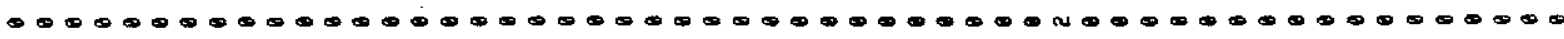

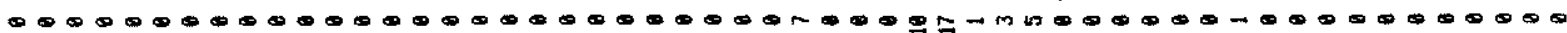
$000000000000000000-0000000000-\infty 00000000000000000$ - $0000000000000000-0000000000-\infty-\infty 00000000000000$

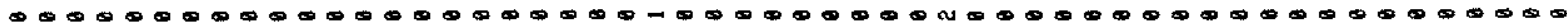

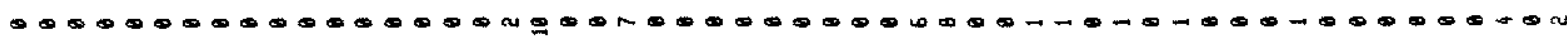

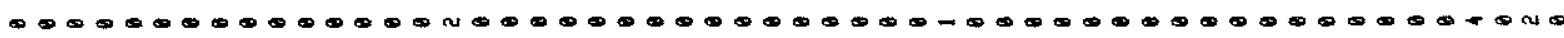

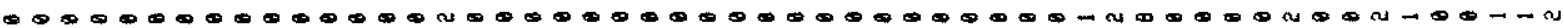

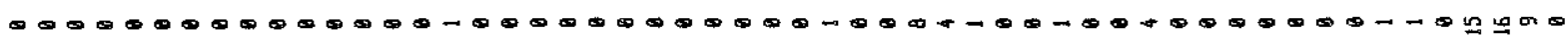

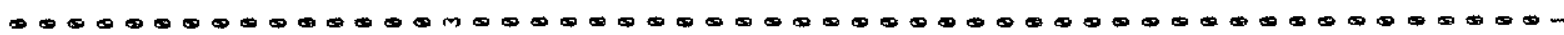

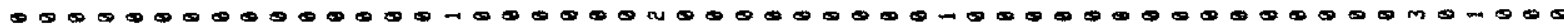

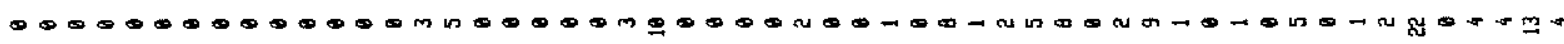

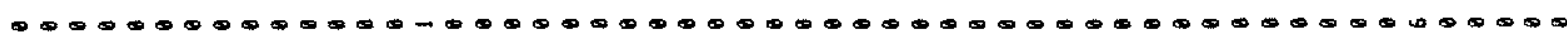
$000000000000 \mathrm{~m} n-00000000000000-000-\infty 00000000000000$

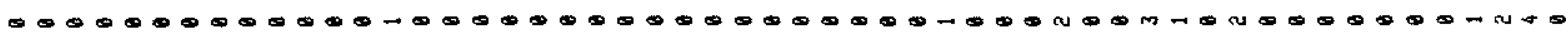

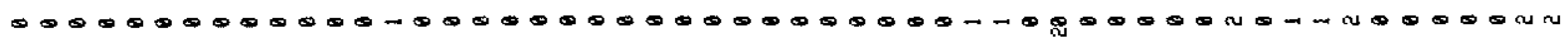
$00000000-0000000000000000000000000000000000000000000$

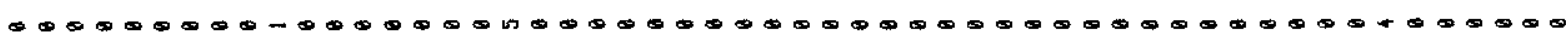

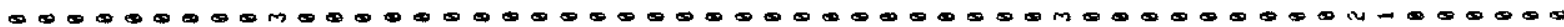

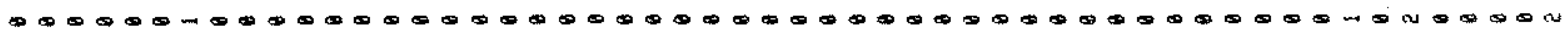

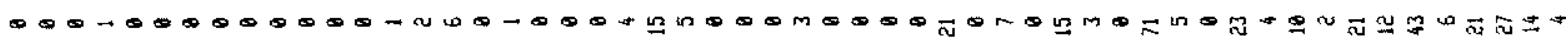

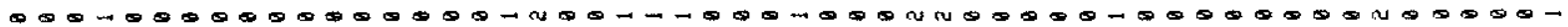

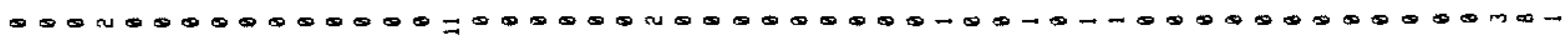

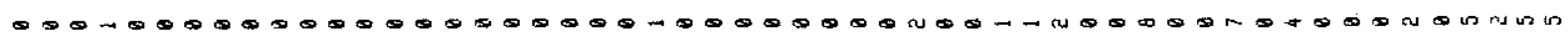
$00-000000000000000 \mathrm{~N}-00000000000000000000000000000$

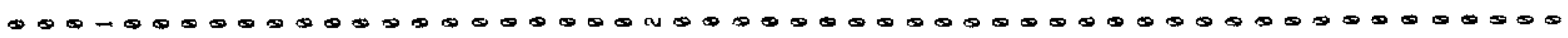

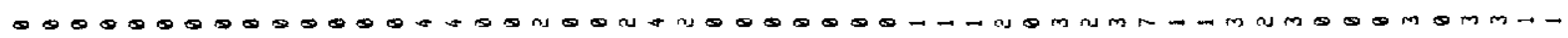


APPENDIX 2-1 (Continued).

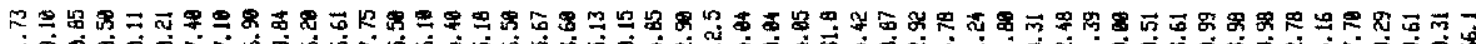

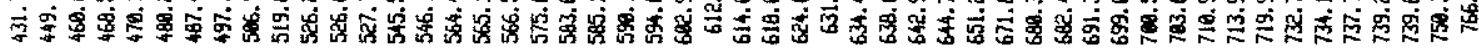

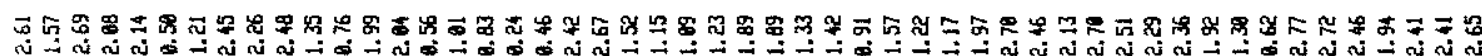

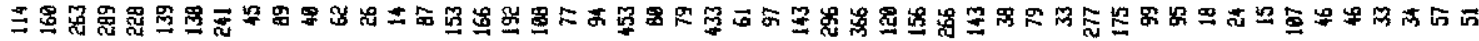
000000000000000000000000000000000000000000000

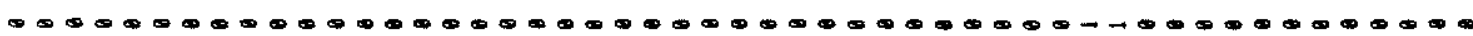

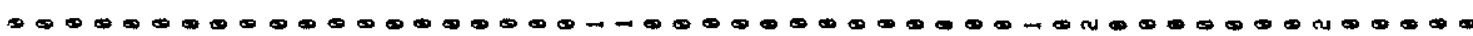

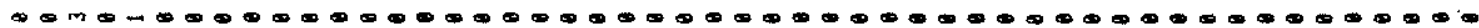
$\rightarrow \infty$ 几 и य

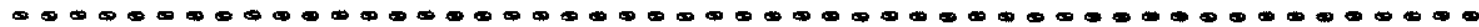

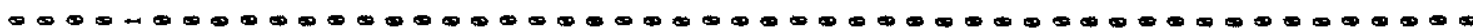

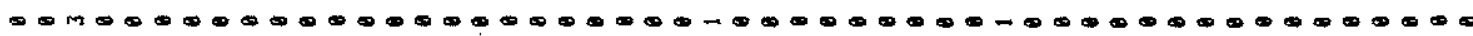

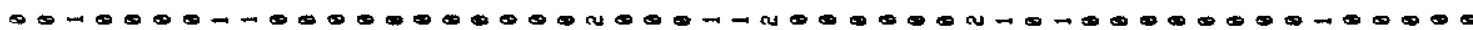
$000000000-000000000000000000000000000,00-0000000000$ nomomolom-

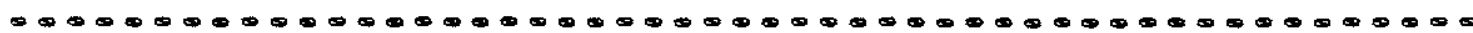
$\approx 00000000000000000000000000000000000000000000000000$

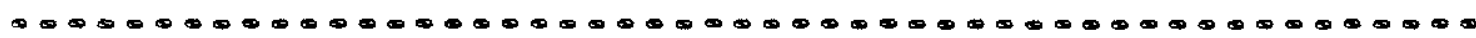

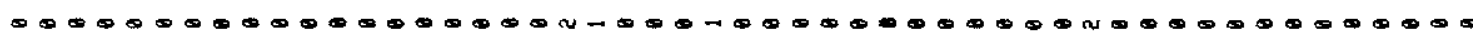
$=0000000000000000000000010000000000000-000000000000$

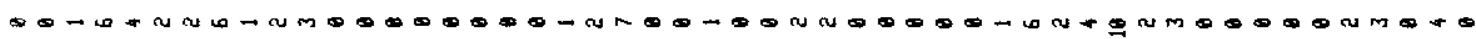

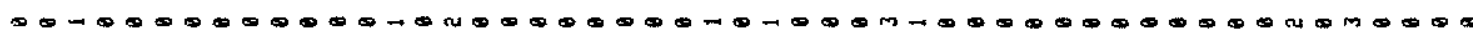
$0000000000000000000000000+0000000000000000000000000$

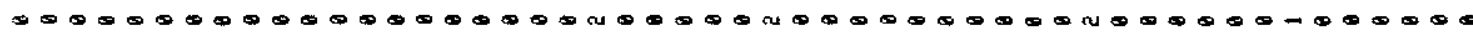
त

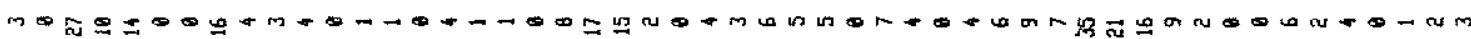
$00000000000000000000000000000000000-0000000000000000$

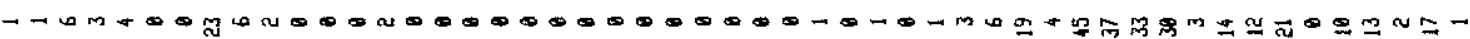

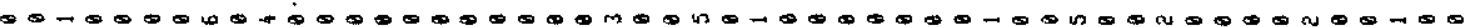
m

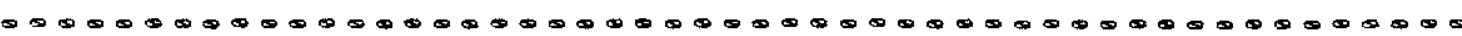
$000000000000000000000000000-0000000000000000000000$

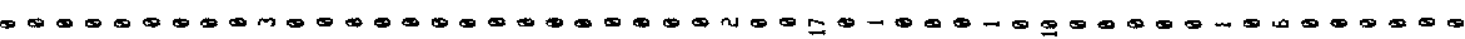
-

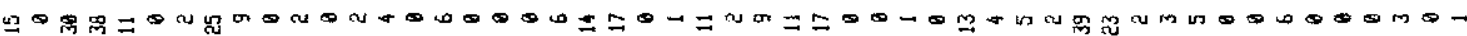

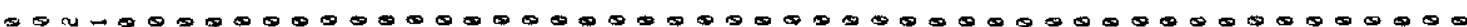

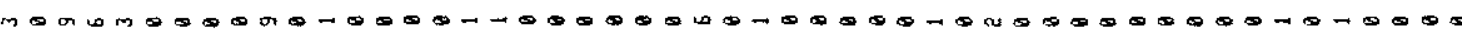
- 0 m

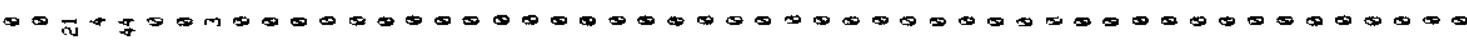

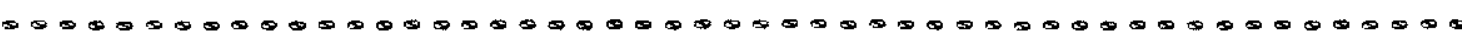

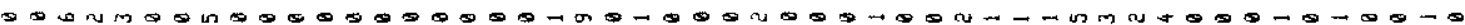




\title{
APPENDIX 2-1 (Continued).
}

\author{
ARBREVIATIONS OF SPECIES NAES: \\ Ebro = Eggerella bradyi (Cushman) \\ I SIPH = Siphotextularia Spp. \\ 1 MART = Martinotiella spp. \\ K Krd = Karreriella bradyi CCushman \\ I Ssch = Sigaiolapsis schluabergeri (Silvestri) \\ I LAGM = Lagenamisina $5 \mathrm{p}$. \\ I RHIZ = Rhizantuina Spp. \\ I PSAl = Psamasphaera fusca Schultze \\ A AivB $=$ Amobaculites 5pp. \\ 1 ASCH = Aschenonella spp. \\ 1 IROC = Trochammina spp. \\ I RECV = Recurvoides spg. \\ 1 Cpus = Cyclasuina pusilla (Brady) \\ 1 HAPL = Haplophragwoides sp. \\ I REID = Reophax pilulifer Brady \\ 1 Khor a Karreriella korrida Mjatliuk \\ I AWES = Amosphaeroidina sp. \\ I $\quad$ TROI $=$ Trochanainoides $5 p$. \\ I ADER = Adercotrewa glowerata (Brady) \\ I Anto = Antodiscus spp. \\ I GLOF = Glowospira nordialis (Jones and Parker) \\ I Ccan = Cyclamaina cancellata Brady \\ 1 PYR6 = Pyrgo murrhina (Schwager) \\ 1 Qsed = Quimuiloculina seminula (Linnet \\ Q Qang = Quinqueloculina sp (angular) \\ 1 Qrnd = Quinqueloculina sp (rounded) \\ 1 Tarc $=$ Triloculina arctica (Cushean) \\ I Tri = Triloculina trihedra Loeblich and Tappan \\ 1 CPTH = Opthainidie 5 p. \\ 1 ORID = Oridorsal is unbonatus (Reuss) \\ Mpen = Melonis pompilioides (Fichtel and Moll) \\ 1 Psub = Pullenia sutcarinata (d'Drtigny) \\ CIB = Cibicidoides $5 p$. (transitional between \\ C. bradyi and $P$, muellerstorfi) \\ STIL = Stilostowel!a spp. \\ DENT = Dentalina spo \\ FISS = Fissurina spp. \\ I 0 O:N = Oolina spp. \\ I LAG = Lapena spp. \\ Gaur = Globobulimina auriculata (Bailey) \\ 1 6 a ac = Globobulinina pacifica Cushman \\ Pwye $=$ Planul ina wuel lerstorfi (5chwager) \\ ELPH = Elphidits spp. \\ I ?ENT = entosolenian, possibly Glandulina sp. \\ 1 Mbar = Melonis barleeanum (Hillianson) \\ I GOID = Gyroidinoides $5 p p$. \\ 1 $\mathrm{NJDO}=$ Nodesaria spg. \\ i Nstr = Nodosaria so. (striate) \\ I SARA = Saracenaria spp. \\ I UVIG = Uvigerina peregrina Cushaan \\ I Uswa = Uvigerına sp. (swall) \\ 1 Numb = Nuttallides umbonifera (Cushran) \\ 1 PSPL = Fseudopolymorphina sp. \\ ( Pbul = Pullenia bulloides (d'Crbigny)
}

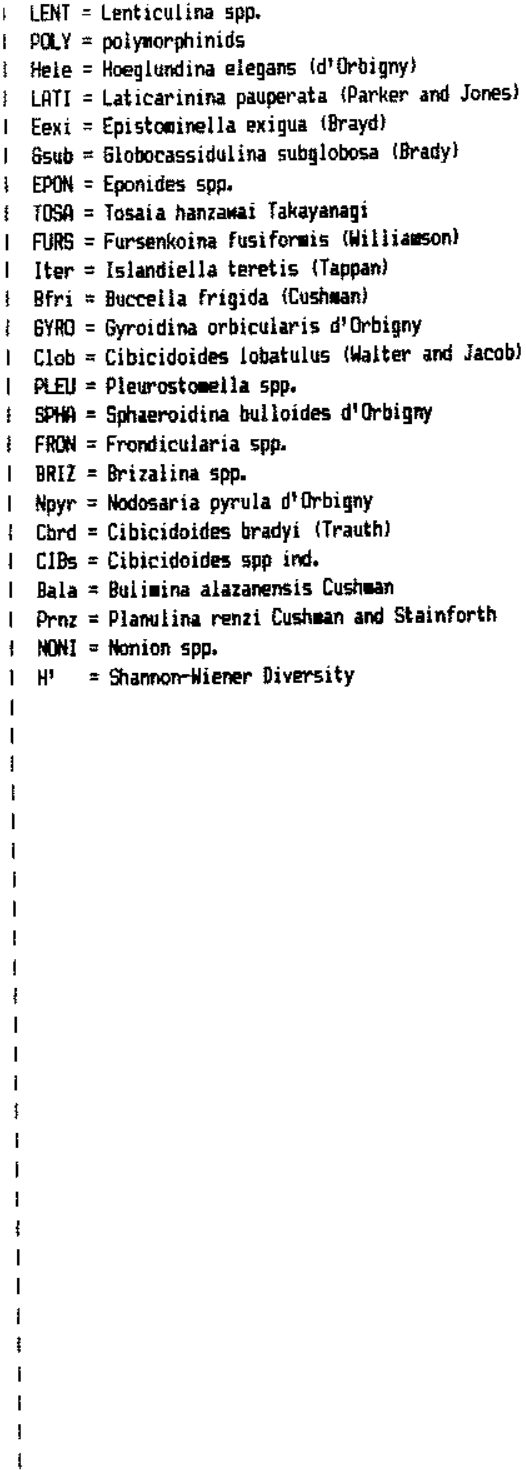


CHAPTER 3.

BIOSTRATIGRAPHY OF CENOZOIC FLYSCH-TYPE AGGLUTINATED FORAMINIFERA IN THE NORTH ATLANTIC.

\section{INTRODUCTION:}

Stratigraphic information on upper Cretaceous to Paleogene flysch-type foraminiferal assemblages have now been collected from a number of sedimentary basins and ODP Sites in the North Atlantic. Initial studies by Gradstein and Berggren (1981) in the North Sea and Labrador Margin and by Kaminski et al. (in press, a) in Trinidad have demonstrated that a unified approach to taxonomy and stratigraphy yields excellent stratigraphic and paleoecologic information. In this study, I use this approach to compare microfossil assemblages from Trinidad, Zumaya Spain, the Labrador and northern Newfoundland margins, Baffin Bay, West Greenland, the Labrador and North Seas and the Norwegian-Greenland Sea to establish a standard taxonomic and biostratigraphic framework for Cenozoic flysch-type assemblages.

The North Sea and the Labrador Margin are the classic areas for flysch-type assemblages in the North Atlantic region (Gradstein and Berggren, 1981). The initial work on agglutinated assemblages from the North Sea was expanded upon by King (1983), and Gradstein et al. (in press). Subsequent studies on the Labrador Margin were carried out by Gradstein and Agterberg (1982), Gradstein et al., 1985, D'Iorio (1986), and Kaminski et al. (in press, d). Deep-water equivalents of the flysch-type assemblages have been studied at ODP Sites 112 and 647 in the Labrador Sea (Miller et al., 1982; Kaminski et al., in press, d). The stratigraphy of Paleogene flysch-type foraminifera has also been described from other localities, including the Norwegian-Greenland Sea (Verdenius and Van Hinte, 1983), the Beaufort Sea (Young and McNeil, 1984), the Swiss Alps (Winkler, 1984), Polish Carpathians (Morgiel and 0lszewska, 1981; Geroch and Nowak, 1984), the Rif Flysch of Morocco (Morgiel et al., 1980, Morgiel and 0lszewska, 1982; Kuhnt, 1987), Trinidad (Kaminski and Geroch, 1987; Kaminski et al., in press, a).

Neogene agglutinated assemblages have only been reported from high-latitude DSDP sites in the North Atlantic, and thus far have found limited usefulness for biostratigraphy. Berggren and Schnitker (1983) reported a relatively diverse Miocene assemblage from Site 348 in the Norwegian-Greenland Sea, and Kaminski et al. (in press, c) reported Miocene assemblages from Baffin Bay Site 645 and Labrador Sea Site 646. 
The purpose of this chapter is to summarize recent work on the stratigraphic distribution of flysch-type agglutinated foraminifera from North Atlantic and Tethyan localities and present new data from the Zumaya Flysch in Northern Spain, and ODP Site 643A in the Norwegian-Greenland Sea. I have used the geomagnetic polarity time scale (GPTS) of Berggren et al. (1985a,b) for the age of stage boundaries and planktonic foraminiferal and nannofossil zones. Whenever possible, the stratigraphic ranges of agglutinated formainifera were calibrated to the GPTS via second-order correlations using planktonic microfossil zonations. In one case (ODP Site 647), the biostratigraphy was calibrated to the GPTS by means of magnetic reversal stratigraphy. An overview of the stratigraphic distribution of flysch-type agglutinated foraminiferal assemblages from these localities is shown in figure 3-1. A detailed discussion of each locality follows below.

\section{TAXONOMY:}

The taxonomic framework for Paleogene bathyal agglutinated assemblages in the North Atlantic follows the systematics established for Trinidad. In Trinidad, 105 species of agglutinated foraminifera were reported from the Maastrichtian to lower Eocene Guayaguayare and Lizard Springs Formations. Specimens from the Trinidad formations were compared with type specimens of species described by Cushman and co-workers housed at the Natural History Museum, Washington D.C. Material from Trinidad was also compared with specimens in the White Collection (American Museum of Natural History, New York), and the Grzybowski Collection (Jagiellonian University, Krakow Poland). The results of these comparisons can be found in Kaminski et al. (in press, a) and need not be repeated here.

Eocene to 0ligocene agglutinated species were illustrated from ODP Site 647 in the southern Labrador Sea by Kaminski et al. (in press, d). The taxonomic scheme for ODP Site 643A (Norwegian-Greenland Sea) used in this study is based on that established by Verdenius and Van Hinte (1983) with modifications based on work by Gradstein et al. (in press) and Kaminski et al. (in press, d). Checklists of the species found in each section are given in the tables and in the faunal appendixes. A full list of agglutinated taxa found at each locality studied is given in Chapter 4 . 
STRATIGRAPHIC DISTRIBUTION OF NORTH ATLANTIC FLYSCH-TYPE ASSEMBLAGES

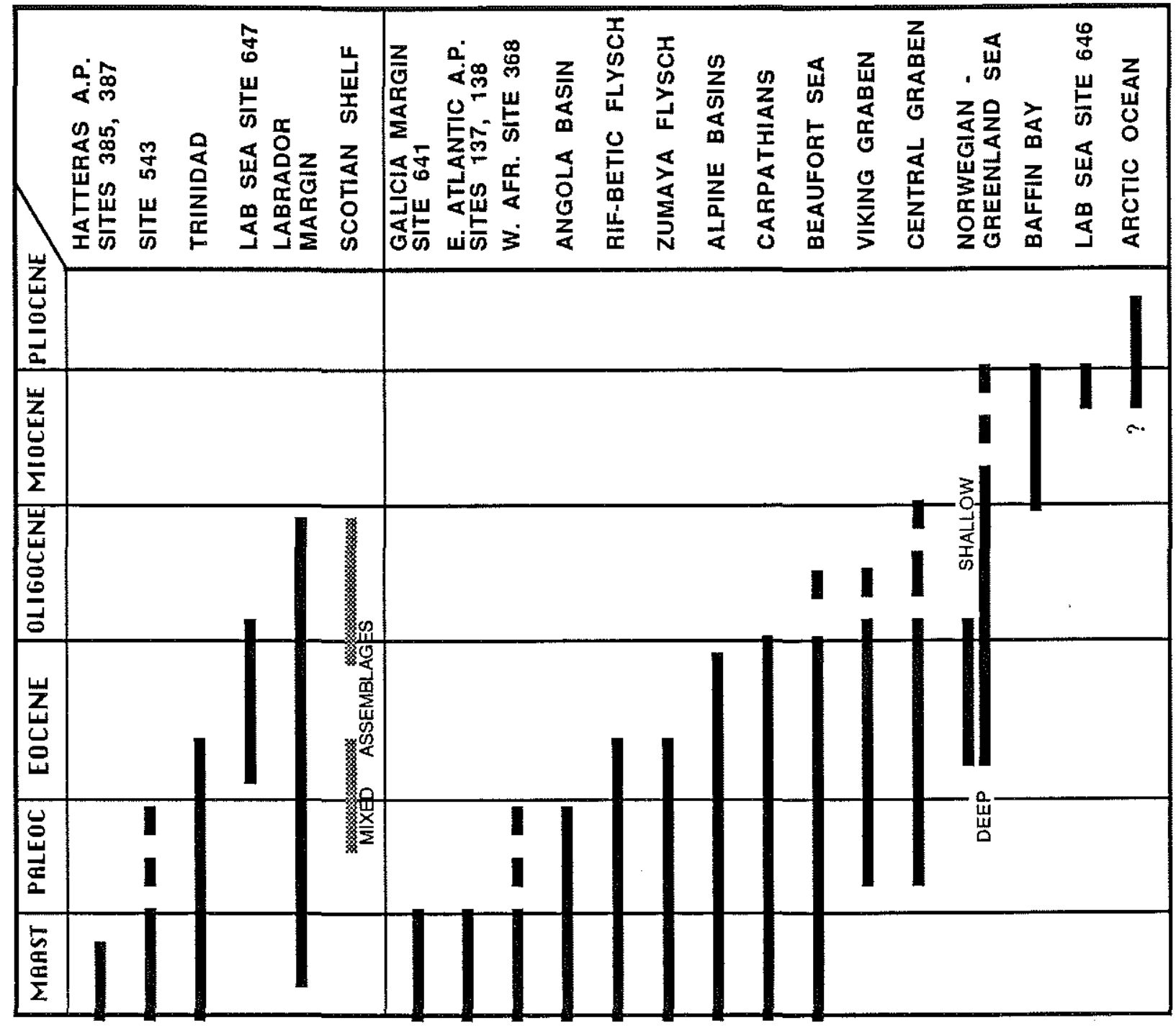

3-1. Stratigraphic distribution of agglutinated assemblages in the western (left) and eastern (right) Atlantic. The last common occurrence of flyschtype taxa occurs first in the deep western basin, and later in the eastern Atlantic and at bathyal localities. 


\section{PALEOGENE BIOSTRATIGRAPHY:}

1. TRINIDAD -

Foraminifera from the Lizard Springs Formation o $\overrightarrow{\mathbf{r}}$ Trinidad were initially studied by Cushman and Jarvis (1928, 1932) and Cushman and Renz (1946, 1947), who subdivided the formation into a lower and upper unit based on benthic foraminifera. These authors regarded the assemblages from Lizard Springs as representing open-marine, deep-water conditions. Samples with Rzehakina epigona were designated as lower Lizard Springs. Both zones were originally regarded as Cretaceous (upper Maastrichtian to Danian) in age, but were later assigned a Paleocene age by Bolli (1952) and Bronnimann (1952) based on studies of planktonic foraminifera. Beckmann (1960) tabulated the ranges of benthic foraminifera from the Guayaguayare and Lizard Springs Formations and was able to show that at least some of Cushman's samples from the upper Lizard Springs contain a mixture of Paleocene species and reworked elements from the Cretaceous. Ranges of some additional species of benthic foraminifera from the Guayaguayare and Naparima Hill Formations were given by Beckmann (in Kugler and Bolli, 1967).

The planktonic foraminiferal zonation of southeast Trinidad was developed by Bolli (1957a,b, 1959, 1966) and Kugler and Bolli (1967), who divided the Guayaguayare Formation into 3 zones, and the Lizard Springs Formation into 9 zones. Bolli (1957b) assigned a Paleocene to early Eocene age to the Lizard Springs Formation. The wholly agglutinated Rzehakina epigona facies of the basal Lizard Springs was given zonule rank, although this facies may also occur higher in the formation if only agglutinated foraminifera constitute the assemblage (Bolli, 1957b). The "Rzehakina epigona zonule" is approximately equivalent to the Subbotina pseudobulloides zone.

\section{STRATIGRAPHY :}

The Guayaguayare Formation has been described from exploration wells in . southern Trinidad and from isolated slump blocks in Tertiary strata in the Central Range (Bolli, 1950; 1957a; Kugler and Bolli, 1967). It overlies the Turonian-Campanian Naparima Formation, and consists of mottled grey calcareous shale. The type locality of the Guayaguayare Formation is in the Texaco Trinidad G-163 well (Guayaguayare field) between 5588 and $6000 \mathrm{ft}$. This well is the type locality for the Maastrichtian Abathomphalus mayaroensis, Globotruncana gansseri, and G. lapparenti tricarinata zones of Bolli (1957a). 
The Paleocene to lower Eocene Lizard Springs Formation is best developed in the subsurface of the Guayaguayare field where it lies unconformably on the Guayaguayare Formation and attains a thickness of $400 \mathrm{~m}$ (Kugler, 1956; Bolli, 1957b). It consists of dark grey calcareous or noncalcareous foraminiferal shales. Gamma ray and Sp logs from wells G-163 and G-287 suggest a predominantly argillaceous facies. In surface outcrops, the Lizard Springs Formation is strongly disturbed and incomplete. Very dark grey claystones of the Morozovella uncinata to Planorotalites pseudomenardii zones crop out in the Lizard Springs area. The type locality described by Cushman and Renz (1946), which is the type locality of the Morozovella velascoensis zone, consists of a slip mass within a clay boulder bed of Miocene age (Bolli, 1957a). The lowermost Eocene Morozovella edgari zone has not been recognized in Trinidad (Stainforth et al., 1975), indicating a possible hiatus of at least $1 \mathrm{~m} \cdot \mathrm{y}$. duration. The upper Lizard Springs Formation differs lithologically from underlying sediments and consists of light tan to creamcolored slightly siliceous marly clay (R.D. Liska, personal communication, 1986). Bolli (1959) placed the contact of the Lizard Springs Formation with the overlying Navet Formation at the top of the Morozovella aragonensis zone.

MATERIALS and METHODS:

The biostratigraphy of flysch-type agglutinated foraminifera from Trinidad is based on examination of 63 samples from the Lizard Springs and Guayaguarare Formations that were gathered by a variety of sources (Table 3-1). The majority of the samples were provided by R.D. Liska, Texaco Trinidad, and consist of 34 washed residues and petrographic slides from three-inch diameter conventional core samples from Guayaguare wells 163 and 287 (Fig. 3-2), and washed residue from two outcrop samples collected by James Terry Christian from the "Tank Site 0listostrome" at Pointe-a-Pierre (Christian, 1979). An outcrop sample from the type locality of the Lizard Springs Formation in Ravine Ampelu, and three samples from the Guayaguayare Formation in the G-163 well were provided by $\mathrm{Dr}$. J. Van Couvering from archived material deposited in the American Museum of Natural History by H.M. Bolli, H.H. Renz, and B. Stone. I also examined the original samples from the Lizard Springs Formation collected by P.W. Jarvis and H.H. Renz. These samples consist of picked assemblage slides sent to Joseph A. Cushman for taxonomic purposes and are 
Table 3-1. Samples from the Lizard Springs and Guayaguayare Formations of Trinidad examined in this study

\begin{tabular}{|c|c|c|c|}
\hline SAMPLE NUMBER & TYPE & AGE & COMMENTS \\
\hline \multicolumn{4}{|c|}{ SAMPLES COLLECTED BY P.W. JARVIS: } \\
\hline $\begin{array}{l}\text { BON ACCORD } 2 \\
\text { LS CALEX } 116^{\prime} \\
\text { LS PIT } 70 \\
\text { LS PIT } 82 \\
\text { LS PIT } 96 \\
\text { LS PIT } 102 \\
\text { TCO WELL \#1, 720' } \\
\text { RAVINE AMPELU }\end{array}$ & $\begin{array}{l}1 \text { SLIDE } \\
2 \text { SLIDES } \\
1 \text { SLIDE } \\
1 \text { SLIDE } \\
1 \text { SLIDE } \\
\text { MISC. SLIDES } \\
1 \text { SLIDE } \\
\text { MISC. SLIDES }\end{array}$ & $\begin{array}{l}? \\
? \\
? \\
? \\
? \\
? \\
? \\
?\end{array}$ & $\begin{array}{l}\leftarrow \text { "MARL LENS IN VELASCO BEDS" } \\
\leftarrow \text { "NEAR TRINIDAD CENTRAL } \\
\text { OILFIELDS WELL \# } 1 .\end{array}$ \\
\hline \multicolumn{4}{|c|}{ SAMPLES COLLECTED BY H.H. RENZ: } \\
\hline $\begin{array}{l}\text { RENZ } 378 \\
\text { RENZ 283; 286-291 } \\
\text { HGK } 3463 \\
\text { HGK } 3465 \\
\text { MAERKY 102A } \\
\text { HGK } 4006 \\
\text { HGK } 3460 B \\
\text { MAERKY 102B, I } \\
\text { MAERKY 102B, II } \\
\text { MAERKY 102B, III } \\
\text { MAERKY 102B, IV }\end{array}$ & $\begin{array}{l}\text { SEDIMENT } \\
5 \text { SLIDES } \\
2 \text { SLIDES } \\
2 \text { SLIDES } \\
3 \text { SLIDES } \\
1 \text { SLIDE } \\
1 \text { SLIDE } \\
2 \text { SLIDES } \\
2 \text { SLIDES } \\
2 \text { SLIDES } \\
2 \text { SLIDES }\end{array}$ & $\begin{array}{l}\text { P8 } \\
? \\
? \\
\text { P3b } \\
\text { M. velas } \\
\text { P7 or F } \\
\text { M. subb } \\
\text { P8 } \\
\text { P8 } \\
\text { M. subb } \\
\text { P6 }\end{array}$ & $\begin{array}{l}\text { TYPE LOCALITY OF LIZARD SPRINGS FM. } \\
\text { MIXED PLANKTON ASSEMBLAGES } \\
\text { NOPLANKTON } \\
\text { scoensis Zone } \\
\text { } 8 \text { otinae Zone } \\
\text { sotinae Zone }\end{array}$ \\
\hline
\end{tabular}

SAMPLES SUPPLIED BY R.D. LISKA:

GUAYAGUAYAREWEL 30 WASHED RESIDUES $P 1 b$.

G-287, 3205' TO 3364' \& PETROGRAPHIC SLIDES P1C CORE SAMPLES

GUAYAGUAYARE WEL

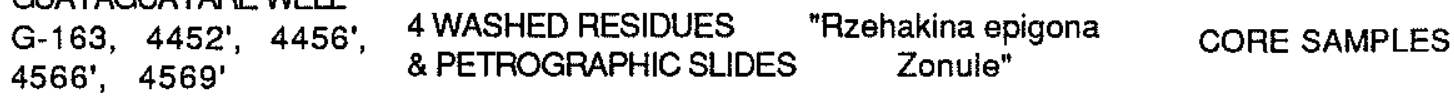

SAMPLES COLLECTED BY J.T. CHRISTIAN:

TC-145

$\mathrm{TC}-174$
WASHED RESIDUE WASHED RESIDUE
P4

Upper P2
Tank Site at

Point-a-Pierre

\section{SAMPLES COLLECTED BY H.M. BOLLI:}

\begin{tabular}{|c|c|c|c|}
\hline Sample 1006 & WASHED RESIDUE & P. pseudomenardii Zone & Well G-163 \\
\hline Sample 1007 & WASHED RESIDUE & $\mathrm{P} 2$ & $\begin{array}{l}\text { "South of Point-a-Pierre } \\
\text { Railroad Station" }\end{array}$ \\
\hline Sample 1008 & WASHED RESIDUE & A. mayaroensis Zone & Well G-163, 5588-5598' \\
\hline Sample 1110 & WASHED RESIDUE & G. tricarinata Zone & Well G-163, 5882-5902' \\
\hline
\end{tabular}




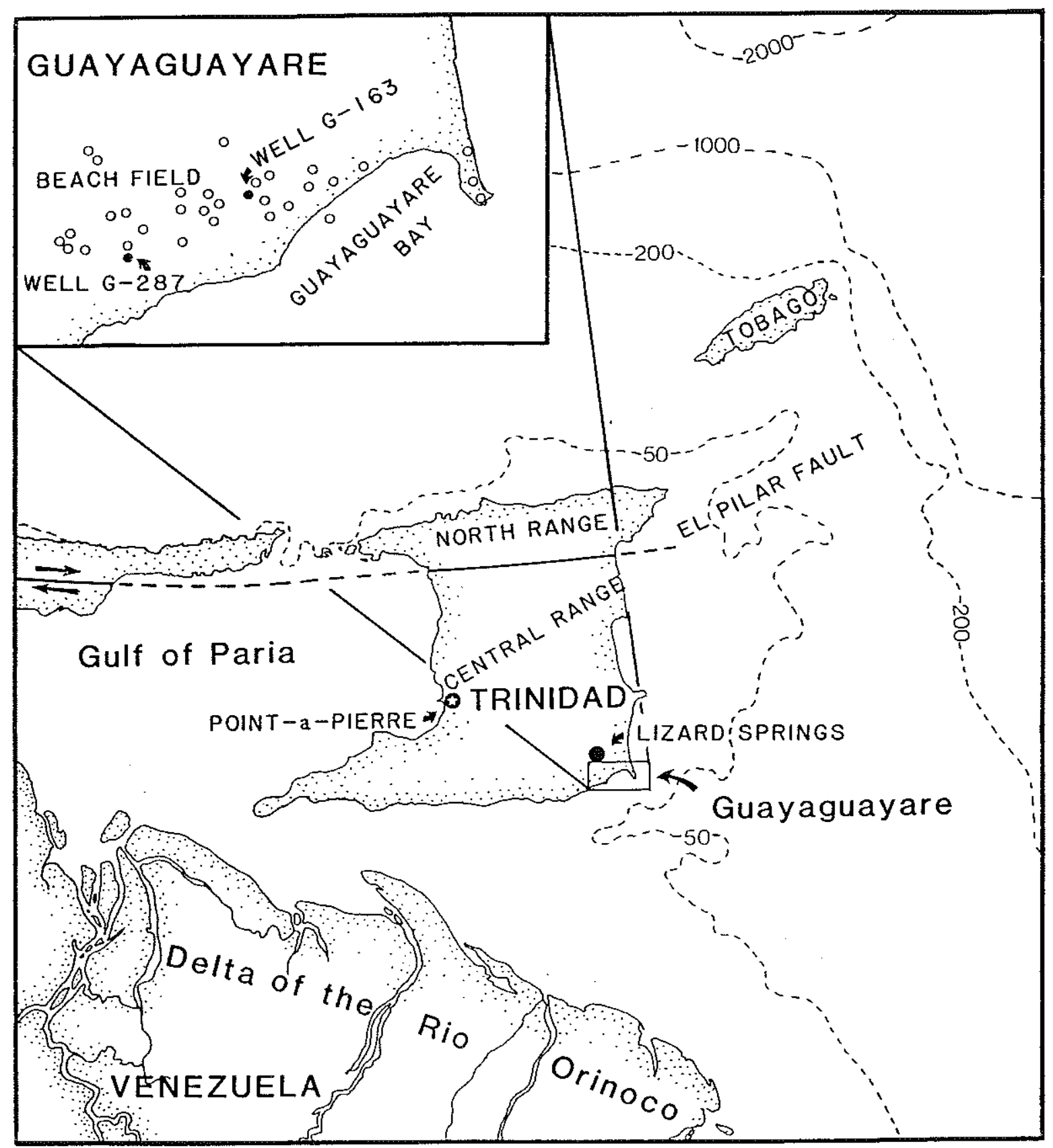

3-2. Location of samples from the Lizard Springs Formation of Trinidad and surrounding areas. Base map adopted from DMA Chart 2408, bathymetry in fathoms. Insert map courtesy of R.D. Liska. 
housed at the U.S. Natural History Museum in Washington, D.C.. Renz's samples from the upper Lizard Springs Formation contain planktonic foraminifera which allow zonal age assignments (Table 3-1), but none of Jarvis' eight samples in the Cushman collection contain enough planktonic foraminifera to make precise age determinations. The stratigraphic range chart (Fig. 3-3a,b) is based on the material mentioned above and is supplemented by information contained in unpublished reports on Trinidad type localities (see Bolli 1957a,b).

Faunal Composition -

Benthic foraminiferal assemblages of the Lizard Springs Formation are more diverse than in the underlying Guayaguayare Formation, display generally poorer preservation of calcareous forms, and are not as diluted by nonbiogenic sand particles. Table 3-2 presents a taxonomic checklist of species found in this study with a key to our modifications of the taxonomy of Cushman and Renz (1946). The stratigraphic ranges of agglutinated species from the Lizard Springs and Guayaguayare Formations are presented in figure 3-3a,b.

\section{A. Guayaguayare Formation -}

In the lower part of the Guayaguayare Formation (the Globotruncana tricarinata Zone of Bolli, 1957a), the agglutinated assemblage is dominated by simple, coarse grained species of astrorhizids, saccamminids and hormosinids. The most common species are Dendrophrya ex gr. excelsa, Rzehakina epigona, Saccammina complanata, Hormosina trinitatensis, Karreriella conversa, Ammobaculites sp. 2, and Spiroplectammina spectabilis. Species unique to this zone are Rhizammina grzybowskii and Gaudryina ex gr. cretacea.

Higher in the Guayaguayare Formation the agglutinated assemblage is more similar in composition to assemblages from the overlying Lizard Springs Formation. Sample G-163-1108, which is the type sample of the Abathomphalus mayaroensis zone of Bolli (1957a) contains diverse agglutinated and calcareous foraminifera. The agglutinated assemblage is dominated by astrorhizids. D.

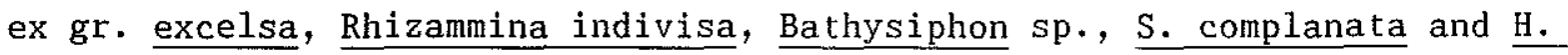

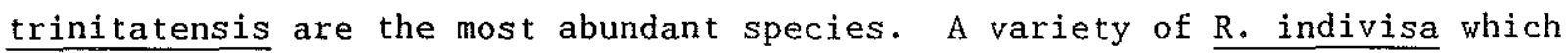
agglutinates small planktonic foraminifera is common in this sample, and there are numerous ataxophragmiids which are usually associated with calcareous facies, such as Gaudryina pyramidata and Matanzia varians. Compared with the 


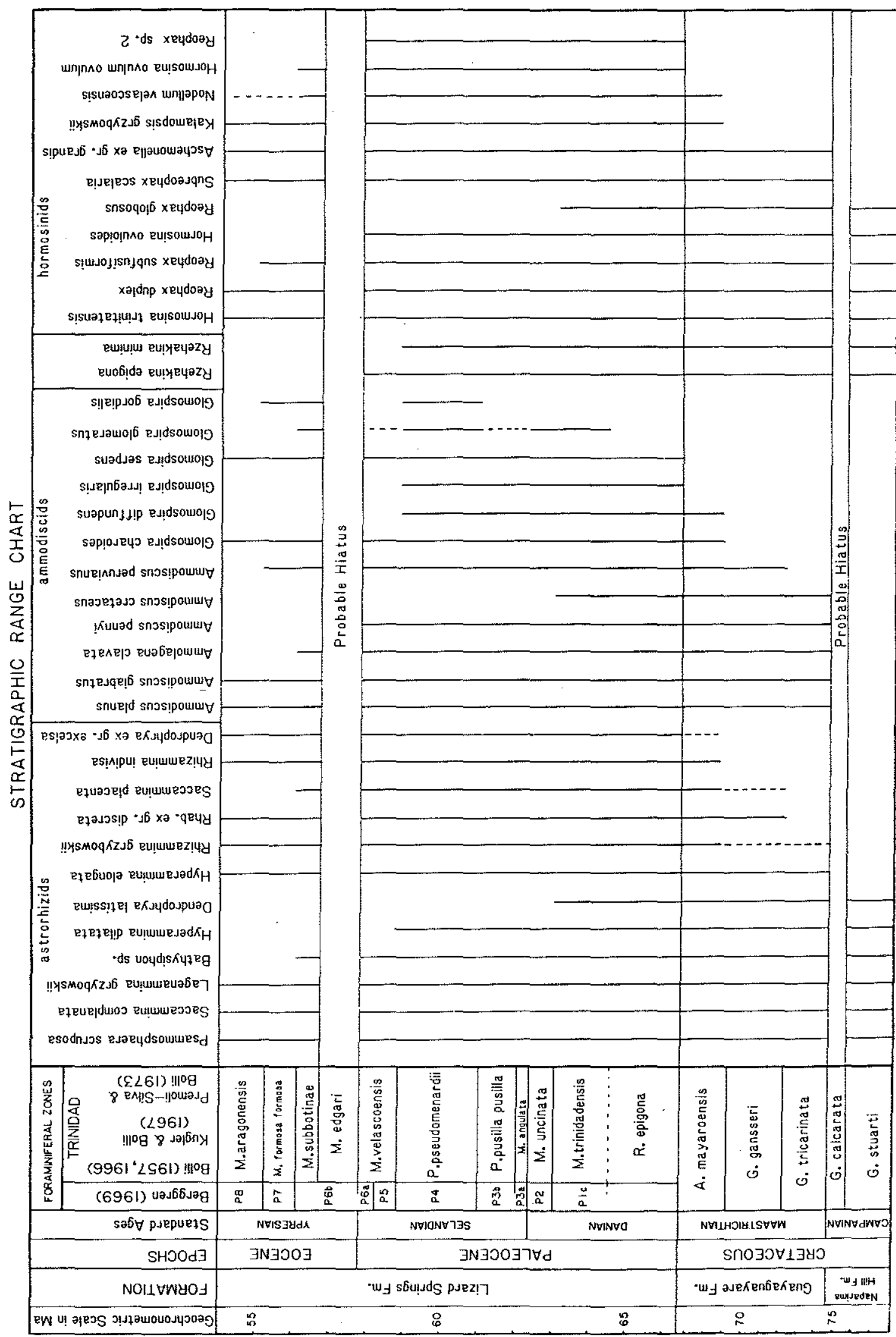




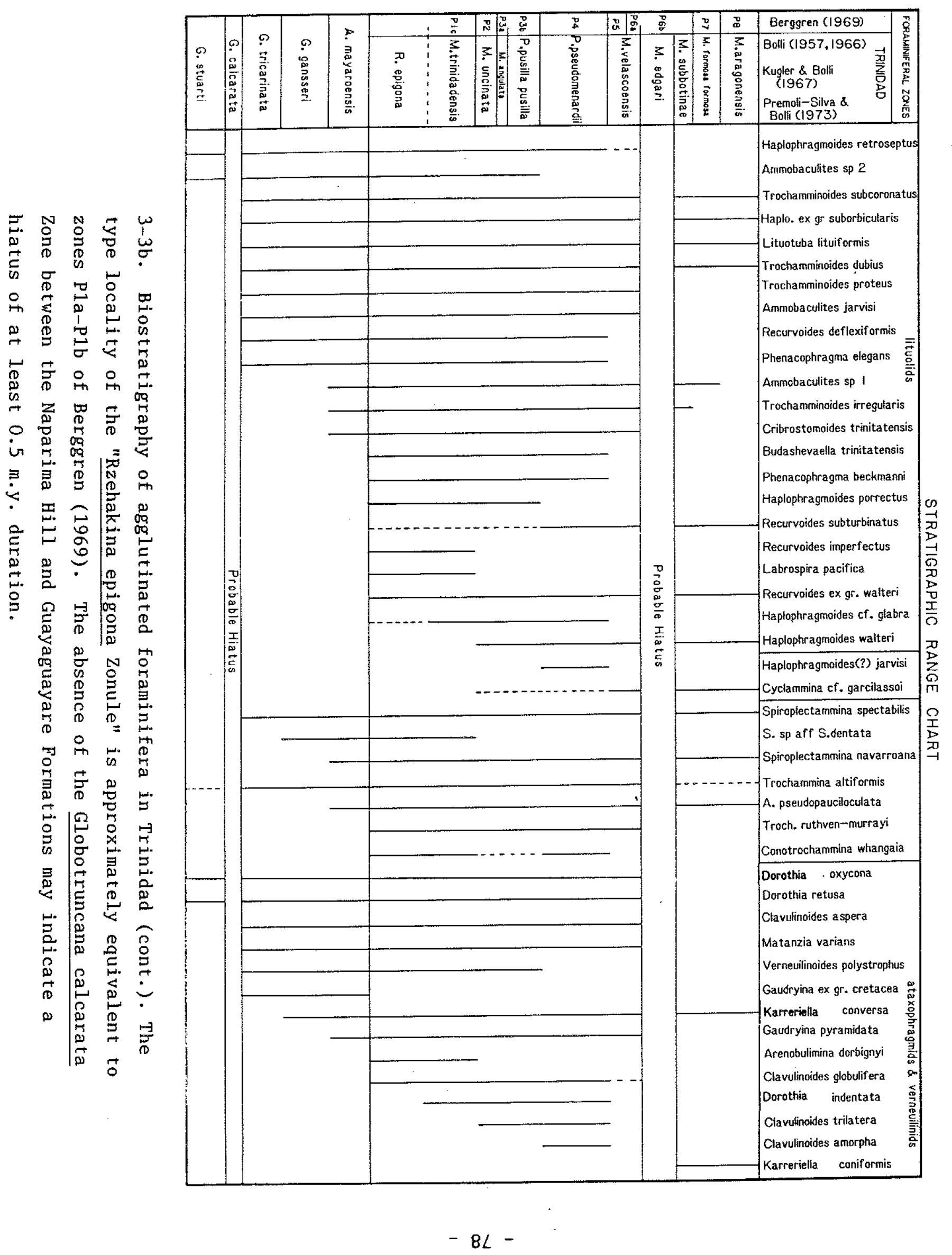


Table 3-2. Agglutinated species from the Guayaguayare and Lizard Springs

Formations with modifications of the taxonomy of Cushman and Renz (1946).

\section{THIS STUDY}

ASTRORHIZACEA BRADY, 1881

Bathysiphon microrhaphidus Samuel Bathysiphon sp.

Dendrophrya ex gr. excelsa Grzybowski

Dendrophrya latissima Grzybowski

Lagenammina grzybowskii (Schubert)

Rhabdammina ex gr. discreta Brady

Rhizammina indivisa Brady

Rhizammina grzybowskii Liszka \& Liszkowa

Psammosphaera scruposa (Berthelin)

Psammosphaera testacea Flint

Saccammina complanata (Franke)

Saccammina placenta (Grzybowski)

Thurammina sp.

HYPERAMMINACEA Eimer \& Fickert, 1899

Hyperammina dilatata Grzybowski

Hyperammina elongata Brady

Hyperammina ex gr. subnodosiformis Grzybowski

AMMODISCACEA Reuss, 1862

Ammodiscus cretacous (Reuss)

Ammodiscus glabratus Cushman \& Jarvis

Ammodiscus pennyi Cushman \& Jarvis

Ammodiscus peruvianus Berry

Ammodiscus planus Loeblich

Ammolagena clavata (Jones \& Parker)

Glomospira charoides (Jones \& Parker)

Glomospira diffundens (Cushman \& Renz)

Glomospira glomerata (Grzybowski)

Glomospira gordialis (Jones \& Parker)

Glomospira irregularis (Grzybowski)

Glomospira serpens (Grzybowski)

RZEHAKINACEA Cushman, 1933

Rzehakina epigona (Rzehak)

Rzehakina minima Cushman \& Renz

HORMOSINACEA Haeckel, 1894

Aschemonella ex gr. grandis (Grzybowski)

Hormosina ovuloides (Grzybowski)

Hormosina ovulum ovulum (Grzybowski)

Hormosina trinitatensis Cushman \& Renz

Kalamopsis grzybowskii (Dylazanka)

Nodellum velascoensis (Cushman)

Reophax duplex Grzybowski

Reophax globosus Sliter

Reophax subfusiformis Earland emend. Höglund

Reophax sp. 2

Subreophax pseudoscalaria (Samuel)

Subreophax scalaria (Grzybowski)

LITUOLACEA de Blainville, 1827

Ammobaculites jarvisi Cushman \& Renz

Ammobaculites sp. 1

Ammobaculites sp. 2

Ammobaculites sp. 3

Budashevaella of. multicameratus (Voloshinova \& Budasheva)

Budashevaella trinitatensis (Cushman \& Renz)

Cribrostomoides trinitatensis Cushman \& Jarvis

Haphragmoides cf. glabra Cushman \& Waters

Haplophragmoides horridus (Grzybowski)

Haplophragmoides lamella (Grzybowski)

Haplophragmoides porrectus Maslakova

Haplophragmoides retroseptus (Grzybowski)

\section{CUSHMAN \& RENZ (1946)}

\author{
Bathysiphon? dubia (White) pars \\ $-$ \\ Rhabdammina discrota Brady \\ Rhabdammina discreta Brady, var. \\ $-$ \\ $-$ \\ Pelosina complanata Franke \\ Saccammina thumbleri (Franke) \\ Hyperammina elongata Brady \\ Hyperammina? sp.
}

Ammodiscus glabratus Cushman \& Jarvis Ammodiscus pennyi Cushman \& Jarvis

Ammolagena clavata (Jones \& Parker) G. charoides var. corona Cushman \& Jarvis

G. gordialis var. diffundens Cushman \& Renz

Glomospira gordialis (Jones \& Parker) ${ }^{\prime}$

Glomospira sp. $\mathrm{A}^{2}$

R. epigona var. lata Cushman \& Jarvis $R$. epigona var. minima Cushman \& Renz

$-$

-

H. globulifera var. trinitatensis Cushman \& Renz. Bathysiphon dubia White (pars)

Nodellum velascoense (Cushman)

$$
\text { - }
$$

$-$

$\rightarrow$

$-$

Reophax? sp

Ammobaculites jarvisi Cushman \& Renz

Ammobaculites coprolithiformis (Schwager) a) Haplophragmoides flagleri var. trinitatensis Cribrostomoides trinitatensis Cushman \& Jarvis (pars) Haplophragmoides glabra Cushman \& Waters ${ }^{1}$

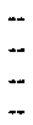


Table 3-2 (continued).

\section{THIS STUDY}

Haplophragmoides ex gr. suborbicularis (Grzybowski) Haplophragmoides walteri (Grzybowski) Haplophragmoides(?) jarvisi (Thalmann)

Labrospira pacifica Krashenninikov Lituotuba lituiformis (Brady)

Phenacophragma beckmanni Kaminski \& Geroch Phenacophragma elegans Kaminski Recurvoides deflexiformis (Noth) Recurvoides gerochi Pflaumann Recurvoides imperfectus Hanzliková

Recurvoides ct. subturbinatus (Grzybowski)

Recurvoides sp. 1

Recunoides sp. 2

Sphaerammina gerochi Hanzliková Trochamminoides dubius (Grzybowski)

Trochamminoides irregularis White Trochamminoides proteus (Karrer)

Trochamminoides subcoronatus (Grzybowski)

LOFTUSIACEA Brady, 1884

Reticulophragmium ct. garcilassoi (Frizzel)

SPIROPLECTAMMINACEA CUshman, 1927

Spiroplectammina aff. S. dentata (Alth)

Spiroplectammina excolata (Cushman) Spiroploctammina navarroana Cushman Spiroplectammina spectabilis (Grzybowski)

TROCHAMMINACEA Schwager, 1877 Ammosphaeroidina pseudopauciloculata (Mjatliuk) Conotrochammina whangaia Finley Trochammina atitormis Cushman \& Renz Trochammina ruthven-murrayi Cushman \& Renz

VERNEUILINACEA Cushman, 1911

Gaudryina ex gr. cretacea (Karrer)

Gaudryina pyramidata Cushman

Vemeuilinoides polystrophus (Reuss)

ATAXOPHRAGMIACEA Schwager, 1877

Arenobulimina dorbignyi (Reuss)

Arenobulimina truncata (Reuss)

Clavulinoides amorpha (Cushman)

Clavulinoides aspera (Cushman)

Clavulinoides globulifera (ten Dam \& Sigal)

Clavulinoides paleocenica (Tjalsma \& Lohmann)

Clavulinoides trilatera (Cushman)

Dorothia beloides Hillebrandt

Dorothia indentata (Cushman \& Jarvis)

Dorothia oxycona (Reuss)

Dorothia retusa (Cushman)

Dorothia cf. trochoides (Reuss)

Eggerella trochoides (Reuss)

Karreriella coniformis (Grzybowski)

Karreriella conversa

Karreriella horrida Mjatliuk

Karreriella tenuis (Grzybowski)

Karreriella sp. 2

Matanzia varians (Glaessner)

TEXTULARACEA Eherenberg, 1839

Textukriaso.

- not reported 1 from Cushman \& Jarvis (1932)

\section{CUSHMAN \& RENZ (1946)}

Cribrostomoides trinitatensis Cushman \& Jarvis (pars) Haplophragmoides excavata Cushman Nonion jarvisi Thalmann

Lituotuba lituiformis (Brady)
Ammomarginulina sp. A
--
--
--
--
--
Cribrostomoides trinitatensis (pars)
--
Haplophragmoides coronata (Brady)
--
-

Gyclammina of. garcilassoi Frizzel

S. dentata (Alth), S. anceps (Reuss) var., $S$. jarvisi Cushman.

Spiroplectammina excolata (Cushman)

Gaudryina fooda (Reuss)

Spiroplectammina grzybowskii Frizzel

Trochammina globigeriniformis var. altiformis (pars) --

T. globigeniniformis var. altiformis Cushman \& Renz Trochammina ruthven-murrayi Cushman \& Renz

Gaudryina (Pseudogaudryina) pyramidata Cushman Vemevilina polystropha (Reuss)

$-$

Pseudoclavulina amomha (Cushman)

Clavulinoides aspera (Cushman)

Clavulinoides aspera var. whitei (Cushman \& Jarvis)

Clavulinoides trilatera (Cushman)

Marssonella indentata Cushman \& Jarvis

M. oxycona var. trinitatensis Cushman \& Renz

Gaudryina retusa Cushman ${ }^{1}$

Eggerella trochoides (Reuss)

--

Gaudryina filiformis Berthelin; G. bentonensis (Carmen)

-

$-$

Textulariella trinitatensis Cushman \& Renz

T. trinitatensis var. subcylindrica Cushman \& Renz

Textuariase

2 from Beckmann (1960) 
underlying assemblage, there is a greater abundance of species with finely agglutinated tests, such as Ammodiscus spp., Trochamminoides spp., Bathysiphon sp. and Ammosphaeroidina.

\section{B. Lizard Springs Formation -}

Agglutinated assemblages in Danian Zones P1c and P1d are more diverse than Maastrichtian assemblages, and are characterized by the appearance of a number of species typical of deeper paleodepths, such as Glomospira serpens, Glomospira irregularis, Hormosina ovulum, Haplophragmoides porrectus,

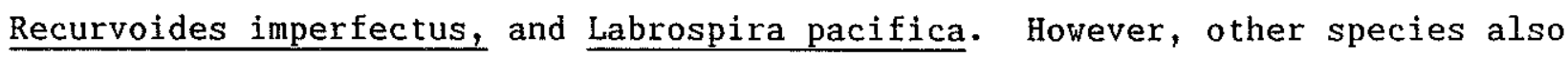
have their Fo's in the Danian that are not necessarily indicative of deeper water. These include Arenobulimina d'orbignyi, Trochammina ruthven-murrayi, Conotrochammina whangaia and Clavulinoides globulifera. The Danian assemblages in samples from Well G-287 are numerically dominated by astrorhizids. Ataxophragmiids are common in the basal interval of the well, whereas spiroplectamminids, rzehakinids, ammodiscids and hormosinids increase in abundance in the upper section. One interval between $3309^{\prime}$ and $3320^{\prime}$ contains assemblages wholly comprised of agglutinated foraminifera.

Benthic foraminiferal assemblages from Zone P2 and younger contain a mixture of calcareous and agglutinated species. Samples from the Morozovella uncinata zone contain markedly fewer astrorhizids than lower Danian assemblages, and many specimens are green in color. The assemblage is dominated by Saccammina placenta, Rzehakina epigona, Haplophragmoides spp., Clavulinoides aspera, Dorothia retusa, Trochammina altiformis, and Conotrochammina whangaia (with closed umbilicus). The first probable occurrence of Reticulophragmium has been found in the upper part of Zone P2.

Samples from the Selandian similarly contain few astrorhizids, and are dominated by Saccammina placenta, Dendrophrya ex gr. excelsa, Karreriella conversa, Trochammina altiformis, and Glomospira spp. (G. charoides, G. diffundens, G. glomeratus, G. gordialis, G. irregularis). The ataxophragmiids are well represented, and include Dorothia beloides, Karreriella horrida, and five species of Clavulinoides (C. amorpha, C. aspera, C. globulifera, C. paleocenica, and C. trilatera). Stratigraphically restricted forms include Haplophragmoides(?) jarvisi, large typical specimens of $\underline{\mathrm{H} \text {. walteri }}$ and

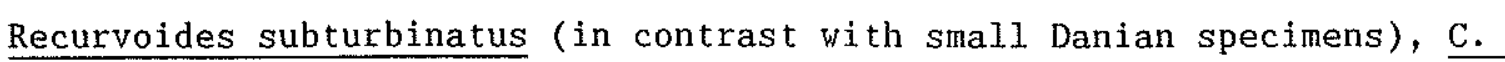


whangaia with an open umbilicus, and the first primitive variety of Reticulophragmium (R. cf garcilassoi s.1.).

The interval from Zones P5 to P6b encompassing the Paleocene/Eocene Boundary contains the LO's of at least 40 species of agglutinated foraminifera (Fig. 3a,b). The agglutinated assemblage from the type locality of the Lizard Springs Formation in Ravine Ampelu is less diverse, as noted by Cushman and Renz (1946), and is dominated by astrorhizids and lituolids. The most abundant genera in lower Eocene assemblages are Dendrophrya, Rhizammina, Rhabdammina, Saccammina, Hormosina, Trochamminoides, Haplophragmoides and Spiroplectammina. The dominent lituolids are Haplophragmiodes ex gr. suborbicularis, Trochamminoides dubius, T. irregularis, and T. subcoronatus. The most distinctive forms in this assemblage are Hyperammina ex gr. subnodosiformis, Ammodiscus planus, Ammobaculites sp. 1, and two species which utilize small planktonic foraminifera in the construction of the test wall: Rhizammina indivisa (identical to specimens from the Guayaguayare Formation), and Psammosphaera testacea, a species described from the recent Gulf of Mexico (Flint, 1899), but hitherto unreported from fossil material. Two species which have Fo's in the upper Lizard Springs Formation are Karreriella coniformis and the more inflated morphotype of Reticulophragmium cf. garcilassoi with 12 or more chambers in the last whorl which displays affinity to Reticulophragmium amplectens.

2. ZUMAYA, SPAIN -

The samples analyzed in this study were collected from coastal exposures at Playa de San Telmo, near the town of Zumaya in northern Spain collected by $A$. von Hillebrandt in 1962 (Fig. 3-4). The section consists of interbedded marls, claystones, and sandy claystones that are part of a thick upper Cretaceous to Paleogene section that was deposited in a flysch trough of the Basque-Cantabric Basin (Lamolda et al. 1981). Paleocene sediments are mostly marls and claystones, whereas lower Eocene sediments contain more sandy layers. The sediments at Zumaya are a result of hemipelagic and turbidite sedimentation in a deep shelf or slope basinal setting below the photic zone and wave base, but above the local lysocline (Mount et al., 1986). Planktonic foraminiferal stratigraphy (Hillebrandt, 1965) indicates continuous sedimentation in this section from the Maastrichtian to the middle Eocene. 


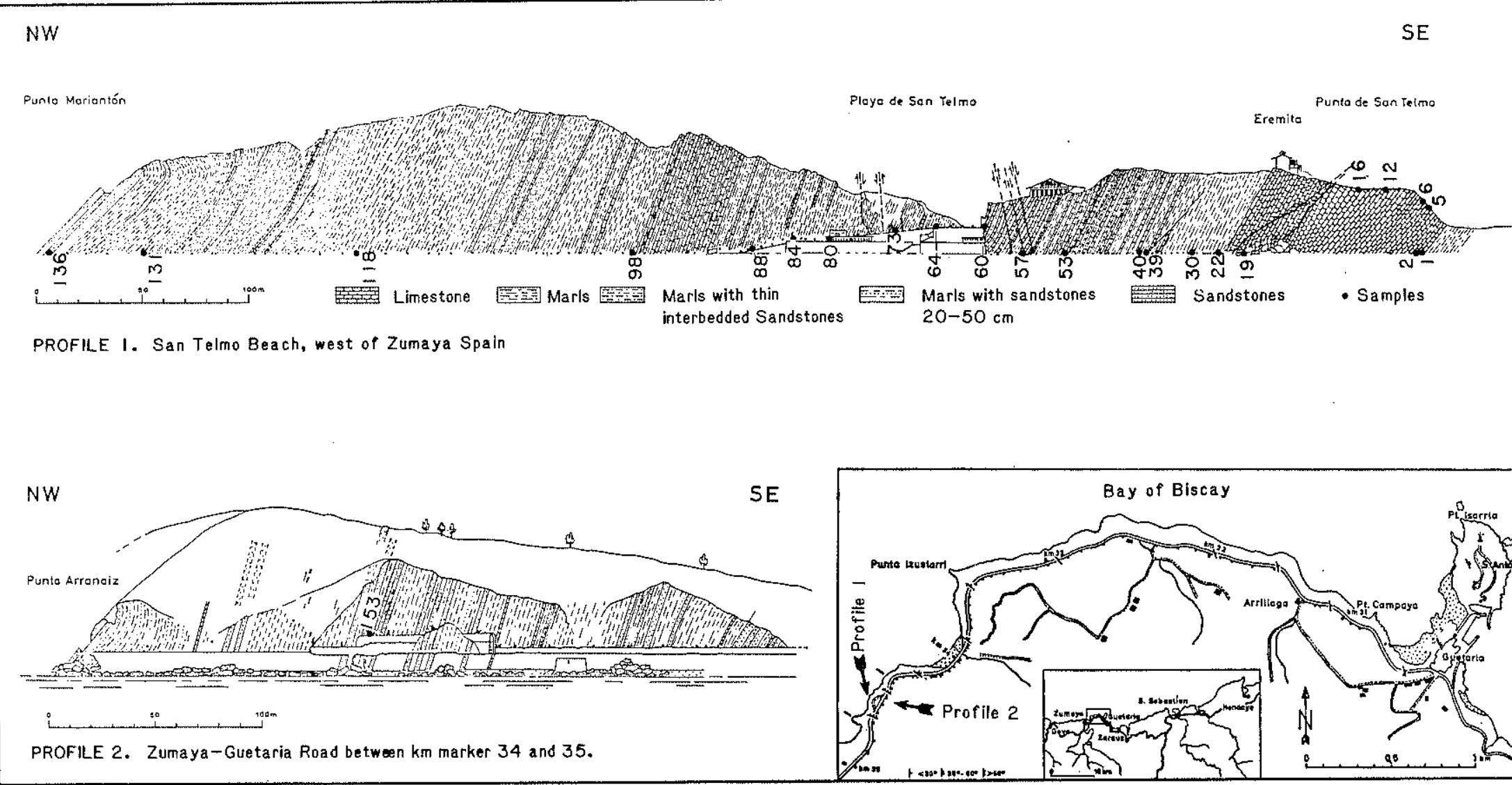

3-4. Map of Zumaya, Spain showing location of outcrop samples investigated in this study (redrawn after Von Hillebrandt, 1965). 
Agglutinated foraminifera have been reported by Hillebrandt to occur throughout the Paleocene in this section, but no special study of this group was made at the time. Because each planktonic foraminiferal zone is present, this section provides a unique opportunity to calibrate the stratigraphic ranges of agglutinated taxa to the standard time scale in a mid-latitude paleogeographic setting. This section is also important because it is the geographically closest section to the North Sea that contains both agglutinated and planktonic foraminifera.

The stratigraphy of agglutinated taxa (Fig. 3-5) is based on examination of 23 samples ranging from Danian Zone P1b to lower Eocene Zone P8. One to three samples were examined from each zone, and the relative abundance data is given in Appendix 3-1. Although there is noticeable reworking of Cretaceous plankton in the Paleogene strata, color changes between the Cretaceous and Danian, and between the Danian and Selandian allow us to determine whether benthic foraminifera are reworked from older strata.

Faunal composition -

Assemblages from the Playa de San Telmo section can be sudivided into Danian, Selandian and Ypresian assemblages, based on the ranges and relative abundance of distinctive taxa. Danian samples contain large numbers of calcareous taxa and agglutinated foraminifera which utilize calcareous material in the construction of their tests. The genera Arenobulimina, Dorothia and Clavulinoides are more abundant in Danian samples than in overlying assemblages. The species Trochammina altiformis, Recurvoides gerochi, Recurvoides deflexiformis, Spiroplectammina israelskyi and Hormosina ovulum are also common in the Danian. One species, Spiroplectammina dentata, is restricted to Zone $\mathrm{P} 1 \mathrm{~b}$.

Selandian assemblages are more diverse than the underlying Danian assemblages and contain more taxa that are typical of greater water depths, such as Bathysiphon, Sphaerammina, Glomospira and Trochamminoides. The Selandian assemblages are numerically dominated by tubular forms such as Dendrophrya ex gr. excelsa, Rhizammina grzybowskif, and Rhabdammina. 0ther common forms include Saccammina placenta, Recurvoides ex gr. walteri, Clavulinoides globulifera, Dorothia beloides, Karreriella horrida, and Spiroplectammina navarroana. 


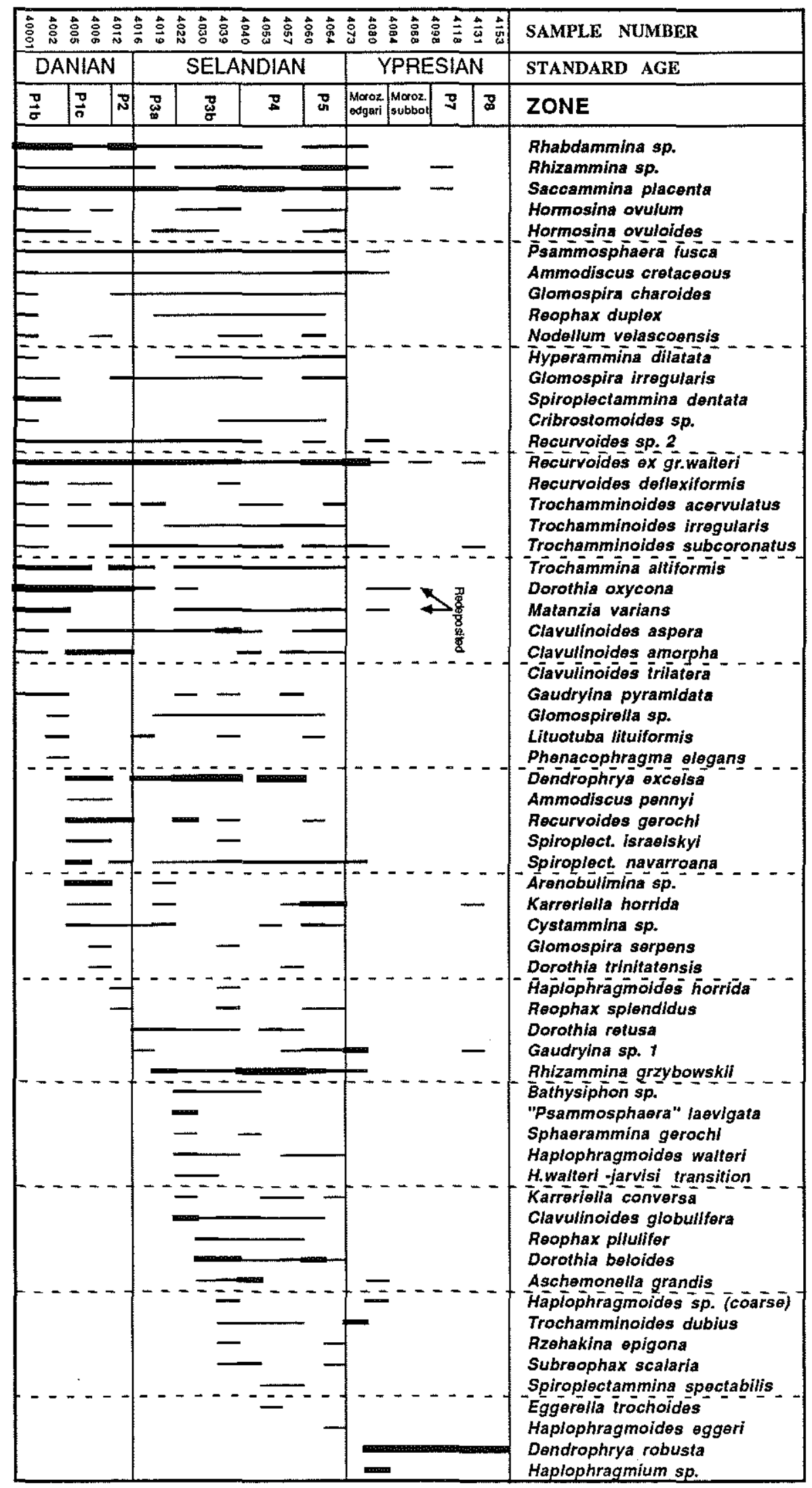


There are two notable occurrences in the Selandian which may have timestratigraphic significance in the Atlantic. A morphotype of Haplophragmoides

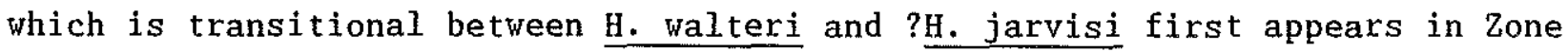
$\mathrm{P} 3 \mathrm{~b}$. This $\mathrm{H}$. walteri/jarvisi transitional form was also observed in Zone $\mathrm{P} 4$ of the Lizard Springs Formation. Another microfossil, "Cenosphaera" lenticularis (=Psammosphaera laevigata White) occurs in Zone P3b. This species, which is actually a spongodiscid radiolarian infilling, was described by White (1928) from the Velasco Shale. White's type sample, which was made available to me for comparison, is also from Zone P3b.

The Paleocene/Eocene boundary in the Playa de San Telmo section is marked by the local disappearance of the majority of the agglutinated taxa. Lower Eocene sediments are markedly more terrigenous and contain mostly Dendrophrya robusta. About 14 species range up into the lower Eocene section, including Rhabdammina, Rhizammina, Saccammina placenta, Ammodiscus cretaceus, Recurvoides ex gr. walteri, Trochamminoides subcoronatus, T. dubius, Spiroplectammina navarroana, but the majority of these are not found above the M. subbotinae Zone.

\section{NORTH SEA -}

Agglutinated assemblages are well-developed in the central part of the North Sea where they appear abruptly in shaly intervals of a thick Selandian to Eocene deltaic clastic complex immediately overlying Maastrichtian to Danian carbonates (Gradstein and Berggren, 1981). The stratigraphy of these assemblages is based on upper range limits of microfossils in exploration wells, and has been discussed by Gradstein and Berggren (1981), Miller et al. (1982), King (1983) and Gradstein et al. (in press). The paleoecology and paleobathymetry of Paleocene assemblages is discussed by Jones (in press). For this study, 9 wells were examined for foraminifera (Total 3/9A-1, Total 3/25-1, Total 9/10B-1, Total 14/30-1, Mobil 9/13-3a, Mobil 9/13-5a, Mobil 21/28-1, Phillips 16/29-2x, Phillips 16/17-1). These data were incorporated in the Central North Sea data base of Gradstein et al. (in press) consisting of 29 wells (Fig. 3-6).

The stratigraphic ranges of selected taxa in the 29 well data base are shown in figure 3-7. These stratigraphic ranges are plotted against the RASC optimum microfossil sequence determined in these wells, which in turn, has been scaled in linear time by means of chronostratigraphically important 


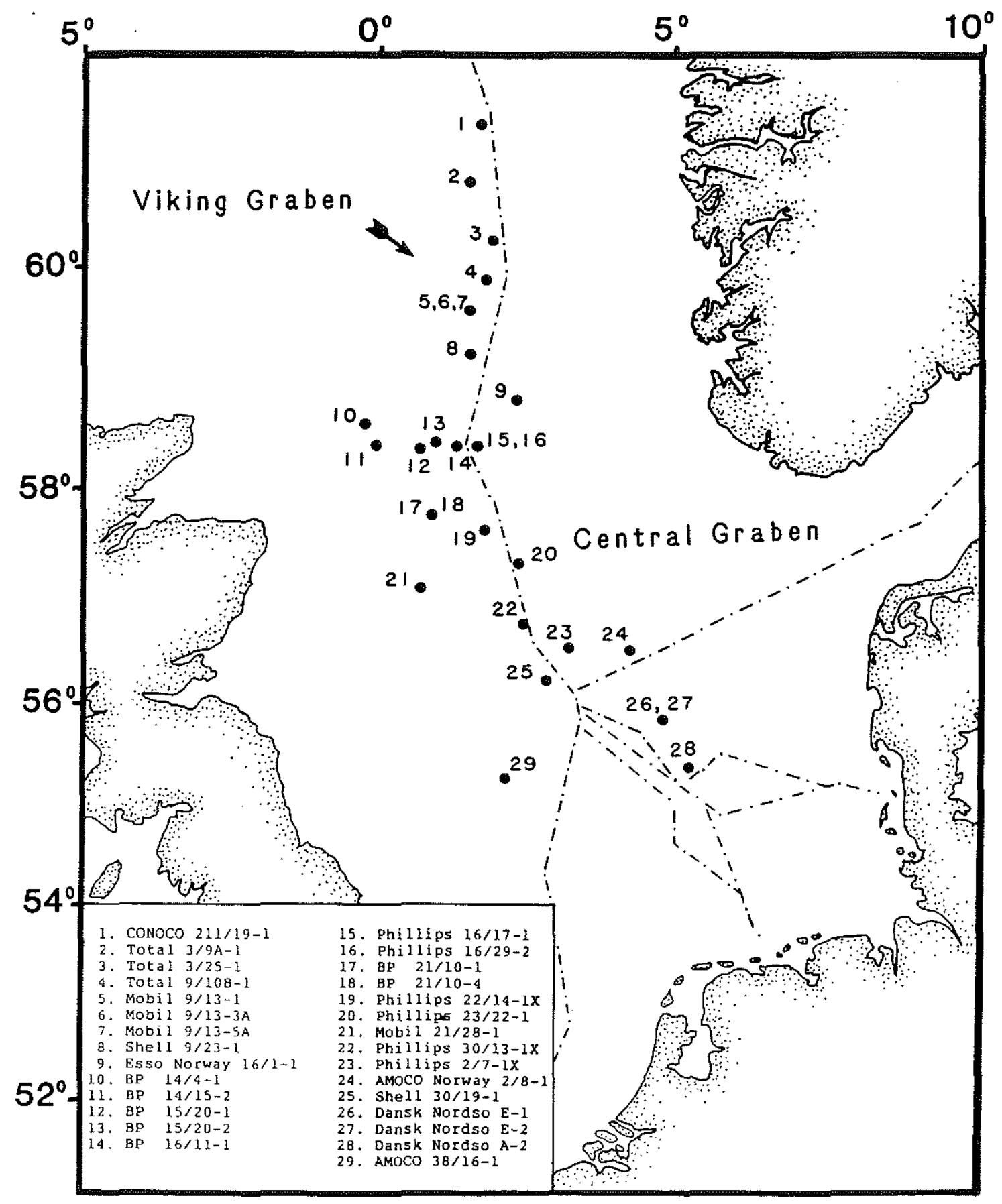

3-6. Location of 29 exploration wells in the Central North Sea (after Gradstein, et al., in press). 


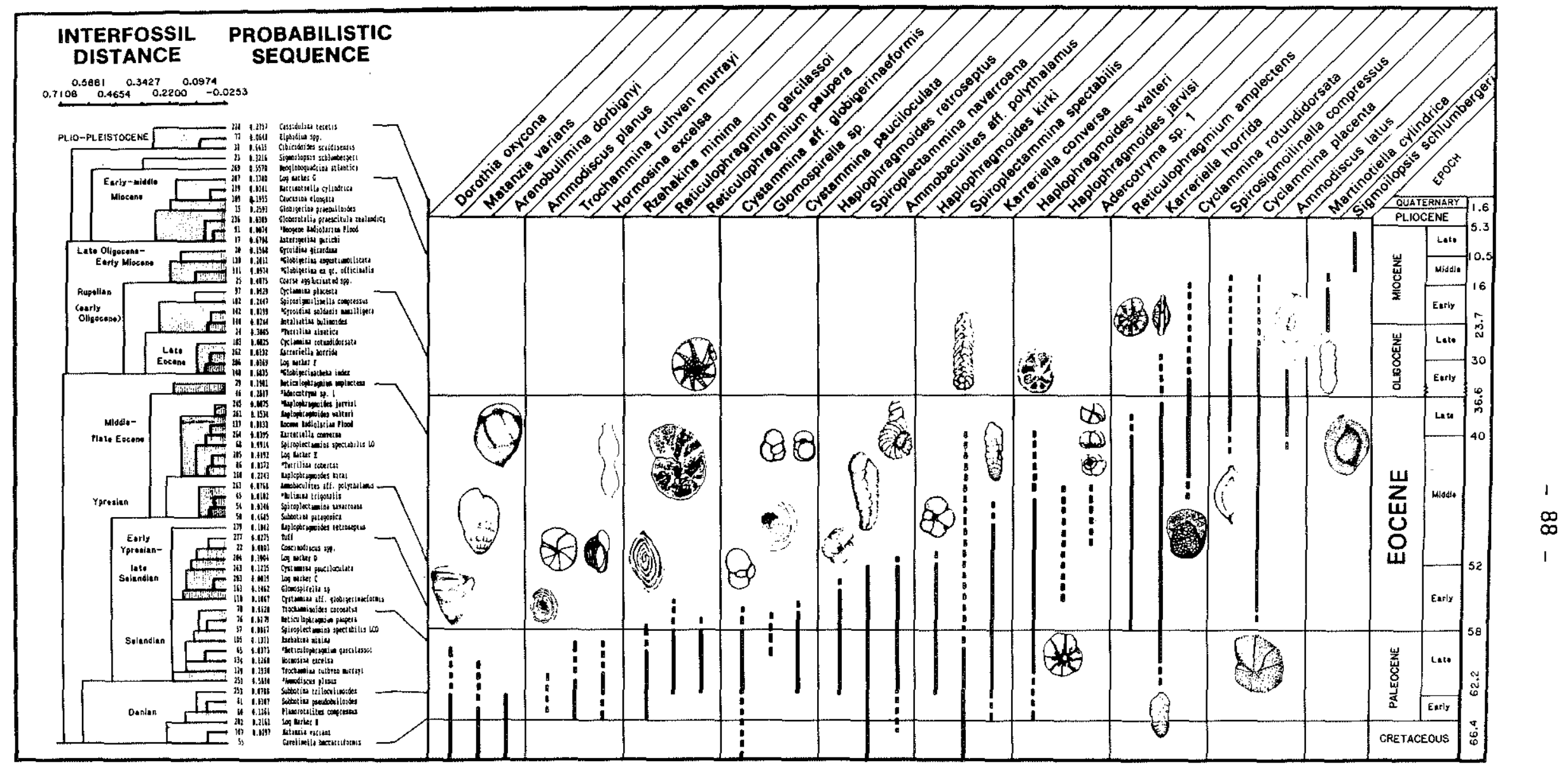

3-7. Average stratigraphic distribution of 29 agglutinated species in the central North Sea. Isolated first or last occurrences are shown with dashed lines. The zonation to the left is the scaled optimum sequence of microfossil events and $\log$ markers in 29 wells. Unique events (those occurring in fewer than 8 wells) are marked with an asterisk (after Gradstein, et al., in press). 
paleontologic and lithologic "tie-points" (Gradstein et al., in press). This probabilistic zonation divides the Paleogene sequence of the central North Sea into 7 microfossil interval zones (figure $3-8$ ) and is discussed in the next section.

Faunal Composition -

The Paleocene assemblages of the central North Sea beneath the Paleocene/Eocene ash sequence can be divided into two assemblages that reflect regional differences in lithofacies.

Carbonate-rich Danian sediments were placed in the Subbotina pseudobulloides zone by Gradstein et al. (in press). The agglutinated assemblage of this zone displays low diversity, and contains two species that utilize calcareous material in the construction of their tests and may be restricted to carbonate facies, Arenobulimina dorbignyi and Matanzia varians. The upper range limits of Hormosina ovulum ovulum and Reophax duplex are also associated with this zone.

The overlying carbonate-poor clastic section contains an assemblage of Selandian age dominated by morphologically simple astrorhizids, ammodiscids and coarsely agglutinated lituolids. This assemblage was designated the Trochammina ruthven-murrayi - Reticulophragmium paupera zone by Gradstein et al., based on the characteristic occurrence of the nominate taxa. other immortant upper range limits in the Selandian of the North Sea are those of Trochamminoides coronatus, Rzehakina minima and Hormosina excelsa. Less commonly, the LO's of Hyperammina sp. "supercoarse", Nodellum velascoensis, Labrospira pacifica, Ammodiscus planus, Sphaerammina gerochi, Trochammina subvesicularis and Reticulophragmium garcilassoi are observed in the $T$. ruthven-murrayi - R. paupera zone. An acme of spongodiscid radiolarians ("Cenosphaera" lenticularis) was observed in the middle Selandian of well $16 / 29-2 x$. This occurrence is isochronous with the spongodiscid radiolarian event in Zumaya, which suggests that this event may become a useful chronostratigraphic tie-point.

Ataxophragmiids and rzehakinids are rare in the Selandian of the North Sea in comparison to Lizard Springs, and are largely represented by Karreriella, Matanzia and less frequently Gaudryina. It is interesting that the Selandian of the North Sea also contains primitive Reticulophragmium, a genus known from Trinidad and coeval strata in Spitsbergen ( $\mathrm{J}$. Nagy, personal communication 


\begin{tabular}{|c|c|c|c|c|}
\hline \multicolumn{2}{|c|}{$\mathrm{EPOCH}$} & $\begin{array}{l}\text { BLOW } \\
1979\end{array}$ & GRADSTEIN ET AL. (IN PRESS) & $\begin{array}{l}\text { KING } \\
1983\end{array}$ \\
\hline \multicolumn{2}{|c|}{$\begin{array}{l}\text { PLEISTOC. } \\
\text { PLIOCENE }\end{array}$} & \multirow[t]{2}{*}{$\begin{array}{l}\text { N21- } \\
\text { N19 }\end{array}$} & Cassidulina teretis & \multirow{4}{*}{ NSP11 } \\
\hline & L & & & \\
\hline Шூய & $M$ & \multirow[t]{2}{*}{$\begin{array}{l}\text { ?N11- } \\
\text { N6 }\end{array}$} & $\begin{array}{c}\text { Globorotalia praescitula } \\
-\overline{-} \\
\text { G. zealandica }\end{array}$ & \\
\hline$\geq$ & E & & & \\
\hline \multirow{2}{*}{$\begin{array}{l}\frac{U}{2} \\
\text { 岁 } \\
\text { d } \\
\frac{1}{0}\end{array}$} & L & \multirow[t]{2}{*}{$\begin{array}{l}\text { ?N5- } \\
\text { P21 }\end{array}$} & $\begin{array}{l}\text { Globigerina } \\
\text { ex gr. officinalis }\end{array}$ & \multirow[b]{2}{*}{ NSB7 } \\
\hline & $E$ & & $\begin{array}{l}\text { Rotaliatina } \\
\text { buliminoides }\end{array}$ & \\
\hline \multirow{4}{*}{$\begin{array}{l}\text { W } \\
\text { யூ } \\
\text { யூ }\end{array}$} & $\mathrm{L}$ & \multirow{2}{*}{$\begin{array}{l}\text { P17- } \\
\text { P15 }\end{array}$} & Globigerinatheka index & NSP8 \\
\hline & $M$ & & $\begin{array}{l}\text { Reticulophragmium } \\
\text { amplectens }\end{array}$ & \multirow[b]{2}{*}{ NSP5-NSB3 } \\
\hline & \multirow[t]{2}{*}{$\mathrm{E}$} & \multirow{2}{*}{$\begin{array}{l}\text { P6b-P8 } \\
\text { P5-P6b }\end{array}$} & $\begin{array}{l}\text { Subbotina } \\
\text { patagonica }\end{array}$ & \\
\hline & & & Coscinodiscus spp. & NSP4 \\
\hline \multirow{2}{*}{ 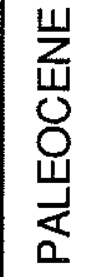 } & $\mathrm{L}$ & \multirow[t]{2}{*}{ P3-P4 } & $\begin{array}{l}\text { Trochammina ruthven murrayi } \\
\text { Reticulophragmium paupera }\end{array}$ & \multirow[t]{2}{*}{ NSP1-NSB2 } \\
\hline & $E$ & & Subbotina pseudobulloides & \\
\hline
\end{tabular}

3-8. Correlation of the foraminiferal zonation of Gradstein, et al. with the standard planktonic biostratigraphy and the neritic zonation of King (1983). 
1986), but absent in the Paleocene of the Labrador Sea and Polish Carpathians. The North Sea Selandian fauna differs from contemporaneous assemblages in Trinidad and Labrador by its high diversity of tubular forms. Al though all tubular varieties were initially placed in only three taxonomic designations (Gradstein and Berggren, 1981), morphotypes can be found corresponding to species described from the Carpathians and Greenland-Norwegian Sea. The coarse, agglutinated astrorhizids common in the North Sea, such as Hyperammina rugosa, Rhizammina grzybowskii, and Psammosphaera fusca, may be faciesdependent. Their absence at Lizard Springs may be due to the paucity of large sand grains. A number of important species in the Paleocene of the North Sea, such as Hormosina excelsa and Ammobaculites aff. polythalamus are not present in Trinidad or Zumaya.

The microfossil assemblage associated with the North Sea tuffs contain abundant pyritized Coscinodiscus infillings, and was named the Coscinodiscus spp. zone by Gradstein et al. (in press). This zone straddles the Paleocene/Eocene boundary and is characterized by the transition from the Selandian "greenbug" fauna to a less diverse Ypresian assemblage above.

Foraminifera in the Coscinodiscus spp. zone are often stained a brownish color. Near the base of the zone many of the typical Paleocene forms such as Saccammina placenta, Glomospira diffundens, Glomospirella spp., Trochammina subvesicularis, and Kalamopsis grzybowskii have their last occurrences. Last occurrences associated with this zone include Glomospirella spp., Cystammina pauciloculata and Coscinodiscus spp. Benthic foraminifera which seem to be associated with this interval are Trochamminoides spp., and Reticulophragmium garcilassoi.

The upper Ypresian of the North Sea was placed in the Subbotina patagonica zone, and often contains sediments stained a reddish color. In the RASC scaled optimum sequence of Gradstein et al. (Fig. 3-7) the species $\underline{\mathrm{s}}$. navarroana occurs directly above $S$. patagonica but the interfossil distance between the two events is small, which indicates that the highest occurrences of these species cross over from well to well.

The benthic foraminiferal assemblages of the Subbotina patagonica zone are characterized by Ammobaculites aff. polythalamus, Spiroplectammina navarroana, Haplophragmoides "kirki", Haplophragmoides retroseptus, and Haplophragmoides(?) jarvisi, a species displaying morphological affinity to Reticulophragmium that was first found in the Paleocene of Trinidad. 
Middle Eocene assemblages were placed in the Reticulophragmium amplectens zone and display a continued trend towards decreased diversity with time. In the optimum sequence the average Lo of $\mathrm{S}$. spectabilis occurrs below that of the Eocene Radiolarian Flood. This may be due to the diachronous Lo of this species in different sectors of the North Sea. Important last occurrences in the $\underline{R}$. amplectens zone include Karreriella conversa, S. spectabilis, Haplophragmoides walteri and R. amplectens. An event in this zone which may have wider chronostratigraphic value is the Eocene radiolarian flood.

Upper Eocene to lower 0ligocene assemblages mostly contain robust, coarsely agglutinated taxa such as Dendrophrya robusta, Rhabdammina discreta, Cyclammina placenta/cancellata, Cyclammina rotundidorsata, and Ammodiscus latus. However, smaller and more finely agglutinated species such as Karreriella horrida, Spirosigmoilinella, Dorothia sp. 6, and Ammodiscus cretaceus also occur. These assemblages comprise the Globigerinatheka index and Rotaliatina bulimoides zones, named after these calcareous species particularly found in several of the more southern wells in the central North Sea. In several of the wells studied, the robust tubular forms are among the last agglutinated forms to disappear in the lower 0ligocene. This pattern has also been observed in the Playa de San Telmo section and in the Labrador Sea site discussed below. 


\section{NORWEGIAN-GREENLAND SEA:}

Sixteen sites were cored in the Norwegian-Greenland Sea during DSDP Leg 38 and three sites were drilled during ODP Leg 104. In total, 10 sites recovered sediments of Paleogene age, resulting in a relatively complete composite Eocene to Oligocene section (Fig. 3-9). The Leg 38 sites unfortunately contain $9.5 \mathrm{~m}$ to $28.5 \mathrm{~m}$ coring gaps in some of the intervals of interest, therefore the biostratigraphic resolution is limited. Gaps exist in the record of planktonic microfossils, which likewise limited the ability of Leg 38 scientists to correlate these sites to the standard geochronology. Nevertheless, these sites are important for constraining the paleobiogeographic and paleobathymetric distribution of microfossil groups in the Norwegian-Greenland Sea. The record of benthic foraminifera is more complete than that of planktonic microfossil groups, and the chronostratigraphy of this region can be constrained by comparison with our benthic foraminiferal zonation in the North Sea.

The most complete continuously cored section available for benthic foraminiferal analysis is ODP Site 643 on the Vøring slope (Fig. 3-10). This site is located at $67^{\circ} 42.9^{\prime} \mathrm{N} ; 01^{\circ} 02.0^{\prime} \mathrm{E}$ at a present water depth of 2768 $\mathrm{m}$, on anomaly $23 / 24$, which is the oldest oceanic crust in the region. This site constitutes the deep end of a transect of ODP Leg 104 sites drilled on the Voring Plateau. Drilling in Hole 643A penetrated 565.2 m of sediment, including approximately $165 \mathrm{~m}$ of Eocene sediments and $125 \mathrm{~m}$ of oligocene to lower Miocene sediments. These sediments provide a record of depositional environments in a deep basinal setting under the western boundary of the Norwegian Current.

The sediments in Hole $643 \mathrm{~A}$ were subdivided into 5 lithologic units by the shipboard scientific party. For this study, I sampled Lithologic Unit 5, which occurs between 400.7 and $565.2 \mathrm{mbsf}$, and the lowermost part of Lithologic Unit 4, occurring between 274.05 and 400.7 mbsf. The sediments of Unit 5 consist of predominantly dark greenish gray to dark reddish brown zeolitic mudstones, most of which are compacted and laminated. The base of the unit contains pebble sized basaltic fragments, indicating a close proximity to oceanic basement. Significant quantities of volcanic ash are found in the lower $100 \mathrm{~m}$ of this unit. Unit 4 is comprised of monotonous, compaction-laminated mudstones and minor amounts of chalk and siliceous 
3-9. Stratigraphic summary of Paleogene sediments in Leg 38 and Leg 104 Holes. The presence of microfossils in each site is indicated by the following letters: $\mathrm{N}=$ nannofossils and/or planktonic foraminifera; $\mathrm{S}=$ siliceous microfossils; $\mathrm{CB}=$ calcareous benthic foraminifera, $\mathrm{AF}=$ agglutinated foraminifera. Large numbers refer to footnotes:

1 - After Muller (1976). 2 - Following Fenner's (1985) correlation of the Norwegian-Greenland Sea C. oblongus and T. inconspicuum triloba zones of Schrader and Fenner (1976) to the low latitude Brightwellia imperfecta zone and lower part of the Asterolampa marylandica zone; which according to Bolli et al. (1985) correlates to P14. This contrasts with the late Eocene age assigned by Manum (1976) for his Dinoflagellate Zones IV and V described from the same interval. M.J. Head interprets this dinocyst assemblage as middle-upper Eocene, rather than strictly upper Eocene (written communication, 1986).

3 - After Muller (1976). 4 - Cores 5-6 were reported to be lower middle Eocene (Naviculopsis minor Zone) by Martini and Muller (1976), but may be as young as the D. hexacantha Zone of Bukry (1977) based on the occurrence of Dictyocha frenquelli, which is reported to be restricted to that zone in tropical and subtropical regions by Bukry (1981). This zone was correlated to NP16-NP17 by Bolli et al. (1985). Manum (1976) reports Cores 5-6 to correlate best with dinocyst Zone $V$ of Site 338, which supports our reassignment of that zone to P14 via the diatom zonation (see footnote 2). 5-Muller (1976) assigned this interval to NP12 and Berggren and Schnitker (1983) assigned this to P7, based on the occurrence of Subbotina patagonica (=G. linaperta reported by Van Hinte in the Site reports). 6 - Dinocysts are present. Manum (1976) places Cores 8-9 in dinocyst Zone IV, but I tentatively assign a younger age based on the occurrence of an agglutinated foraminiferal assemblage wi thout Spiroplectammina spectabilis (see Verdenius and Van Hinte, 1983). 7 - An Eocene age is based on the presence of $\mathrm{S}$. spectabilis in Core 10 (Verdenius and Van Hinte, 1983). 8 - NP19 or younger based on the presence of Isthmolithus recurvus in Core 19. 9 - An oligocene age is suggested by Manum (1976). 10-AggIutinated foraminifera are the only indigenous fossils present. A rich assemblage implys an Eocene age. Basement was not reached, and the magnetic anomaly is not known. Rare calcareous benthics are redeposited. 11 - Sample 349-5-6, $148 \mathrm{~cm}$ contains nannofossils suggesting a late Eocene age. Core 12 contains I. recurvus (=NP19 or younger). Cores 4-6 contain only tubular agglutinated foraminifera, so may be 0ligocene in age. 12 - Cores 10-15 were assigned a late 0ligocene age based on agglutinated foraminifera (Verdenius and Van Hinte, 1983) and were assigned to dinocyst Zone III (Oligocene) by Manum (1976). 13 - Cores 15-21 were assigned to dinocyst Zone IV or lower by Manum (1976), but agglutinated foraminifera suggest an 01igocene age. 14 - Verdenius and Van Hinte (1983) assigned an Eocene age to Cores 30-32 based on R. amplectens; S. spectabilis was not found. 15 - Age of crust was reported by Talwani and Udentsev (1976) to be between anomalies 13 and 20 , but the site is probably closer to Anomaly 20 based on the Leg 104 map. 16 - Silicoflagellates give conflicting ages, e.g. cooccurrence of Corbisema apiculata (Eocene - lower 0ligocene) and Naviculopsis ponticula (Miocene). The top of the C. apiculata Zone of Bukry (1978) is correlated to CP17 by Bukry (1981), which suggests that Core 9 is no younger that $34 \mathrm{Ma}$. 17 - Age of crust at this site is anomaly 12 , according to Nunns et al. (1983). The site was drilled $20 \mathrm{~km} \mathrm{E}$ of the extinct axis on the steep slope $\overrightarrow{\text { of }}$ the magnetic anomaly $(?=$ base $12 \mathrm{~N})$. 18 - Silicoflagellates give conflicting ages (Naviculopsis lata Zone $=$ lower Miocene). 19 - Sedimentation in this interval was assumed continuous by Leg 38 scientists (Site 338 Report). Fossils were undiagnostic. 20 - Our best estimate from the magnetic anomaly map of Nunns et al. (1983). 21 - Basement was not reached. My estimate of the magnetic anomaly is from the map of Nunns et al. (1983). 


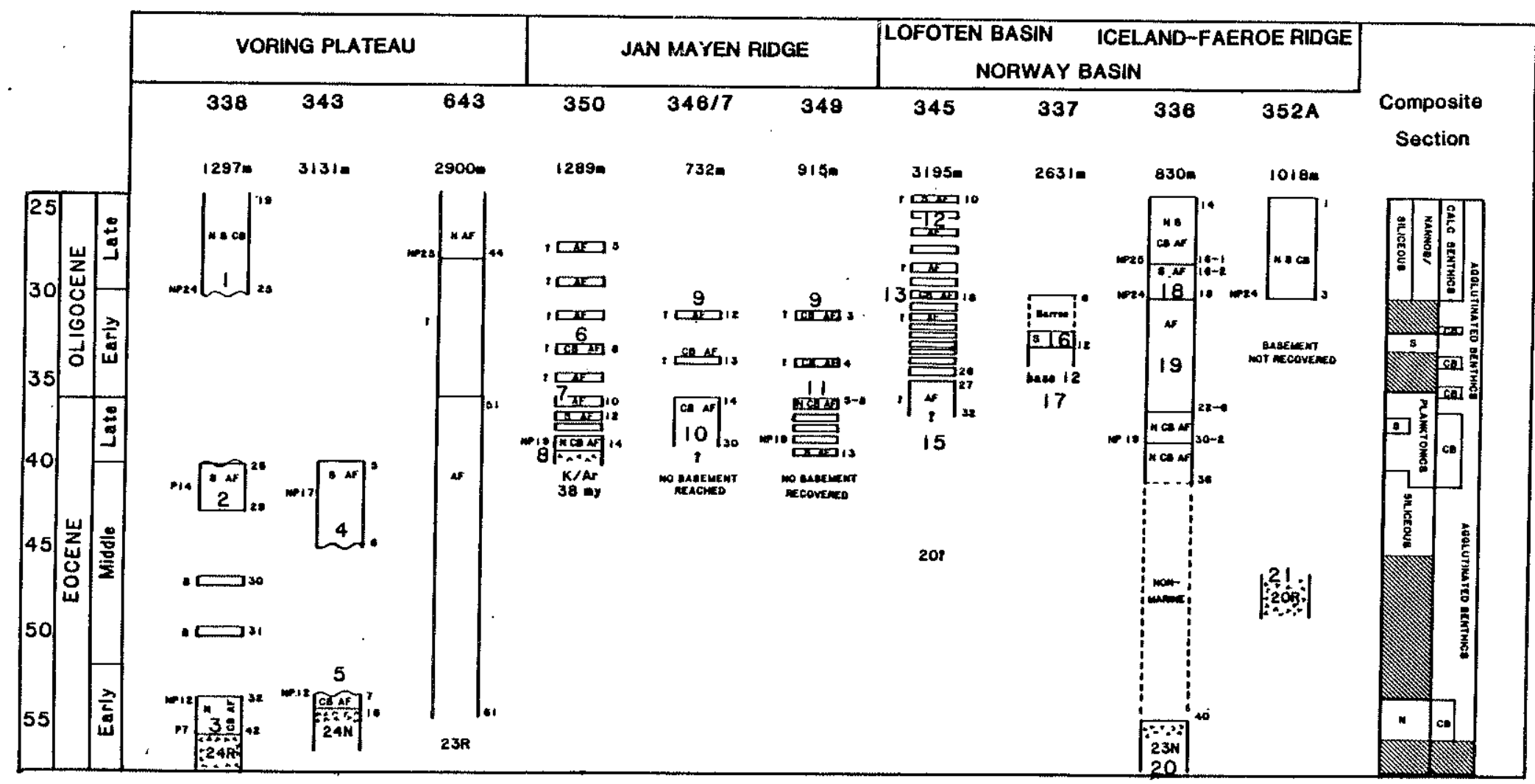




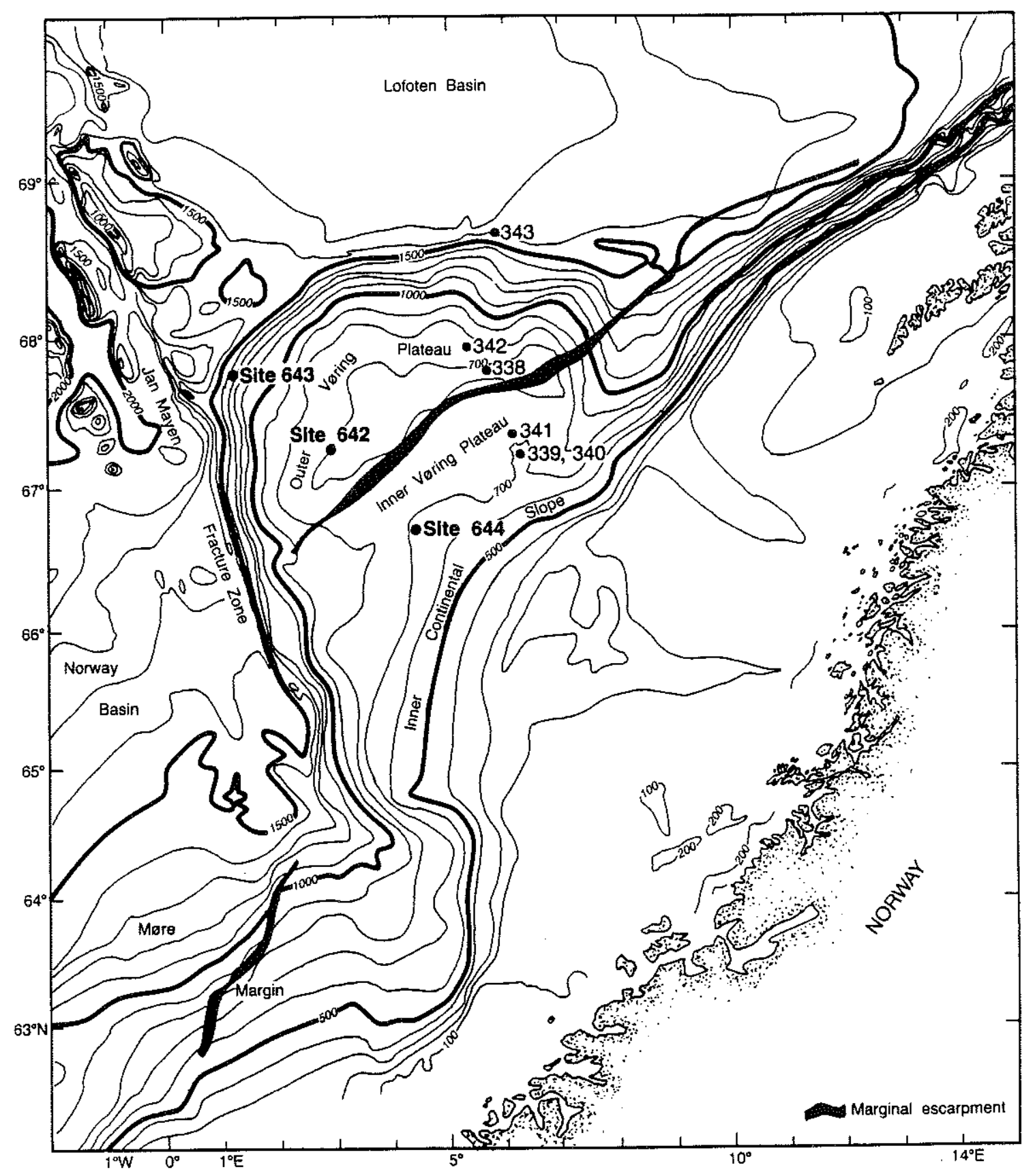

3-10. Map of the Voring Plateau showing the location of ODP Site 643 and other DSDP and ODP sites (after Shipboard Scientific Party, 1987b). 
mudstone. The amount of biogenic silica increases upcore from the upper Eocene to the lower Miocene.

The age assignments of Paleogene sediments from Hole $643 \mathrm{~A}$ is based primarily on shipboard analyses of nannofossils, dinoflagellates, and foraminifera (Shipboard Scientific Party, 1987b), which at times yielded conflicting ages. Samples from Core $43 \mathrm{X}$ yielded Discolithina enormis, and were assigned to Zone NP25. The boundary between the upper Eocene and 0ligocene was placed within Core $50 \mathrm{X}$, based on palynomorph assemblages. The lower Eocene was recognized by the occurrence of Subbotina patagonica in Cores 53X-56X (reported as G. linaperta in the Site 643 Chapter) and upper-lower Eocene palynomorph assemblages in Cores $57 \mathrm{X}$ and $59 \mathrm{X}$.

For this study, a total of 55 samples from Cores $41 \mathrm{X}$ to $63 \mathrm{X}$ were processed for benthic foraminifera, dinocysts and radiolarians following the methodology outlined in Kaminski et al. (in press, d). The taxonomy of benthic foraminifera from the Leg 38 sites in the Norwegian-Greenland Sea was originally developed by Verdenius and Van Hinte (1983). For this study, I have followed their taxonomic scheme with some modifications. The nomenclatorial changes and the complete list of species found in Hole $643 \mathrm{~A}$ is given in Table 3-3. The relative abundance of benthic foraminiferal taxa was estimated for each sample (Appendix 3-3), and the stratigraphic ranges of common species were compiled into a range chart (Fig. 3-11). Examination of the biostratigraphic data yields 5 major assemblages of benthic foraminifera, based on the ranges of characteristic taxa (Fig. 3-12). These assemblages are discussed below in order of their stratigraphic occurrence.

Foraminiferal Assemblages:

1. Rhabdammina-Cyclammina Assemblage (Sample $643 \mathrm{~A}-62 \mathrm{X}-1,77-81 \mathrm{~cm}$ to $-56 \mathrm{X}-1$, $77-82 \mathrm{~cm})$. Lower Eocene.

The lowermost $70 \mathrm{~m}$ of Hole $643 \mathrm{~A}$ beneath the barren interval in Core $55 \mathrm{X}$ contains a benthic assemblage dominated by tubular agglutinated forms. The diversity of the assemblage is low (typically 5 or 6 species per sample) reflecting deposition at relatively shallow paleodepth. The most abundant nontubular species is Cyclammina placenta, which is accompanied by Haplophragmoides "kirki", and H. excavata. The latter species may be an

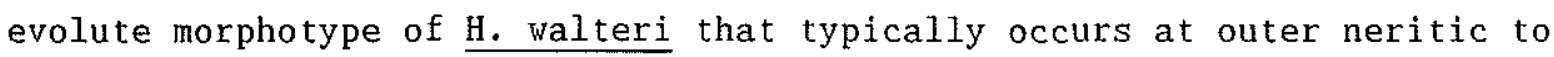


Table 3-3. Agglutinated taxa recovered in ODP Hole 643A, with nomenclatoral changes to the taxonomy of Verdenius and Van Hinte (1983).

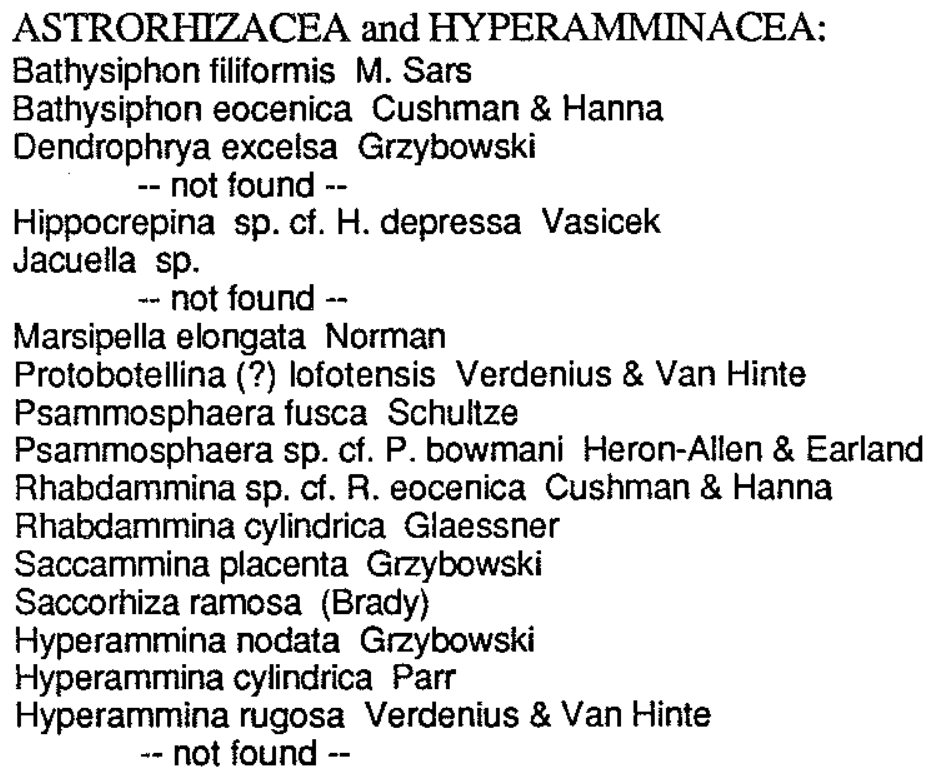

Lituotuba sp.

Ammolagena clavata (Jones \& Parker)

\section{RZEHAKINACEA}

Miliammina earlandi Loeblich \& Tappan

Silicosigmoilina californica Cushman \& Church

Spirolocammina lamposa (Hussey)

Spirolocammina sp.

Spirosigmoilinella sp.

HORMOSINACEA

Hormosina excelsa (Dylazanka)

Reophax trinitatensis (Cushman \& Renz)

Reophax subfusiformis Earland

-- not found --

$$
\text { -- not found -- }
$$

\section{LITUOLACEA}

$$
\text { -- not found -- }
$$

Ammobaculites strathaernensis Cushman \& LeRoy

-- not found --

-- not found --
Bathysiphon sp.

Dendrophrya robusta Grzybowski

Dendrophrya excelsa

Dendrophrya latissima Grzybowski

Hippocrepina sp.

-- not found --

Lagenammina $\mathrm{sp}$.

Aschemonella crassatina

Rhizammina indivisa Brady

Psammosphaera fusca

Psammosphaera sp. A.

Rhabdammina discreta Brady

Rhabdammina discreta Brady

Saccammina complanata (Franke)

Saccorhiza ramosa

Hyperammina ex gr. subnodosiformis Grzyb.

Rhabdammina cylindrica Glaessner

Hyperammina rugosa

Aschemonella spp. ind.

Ammodiscus cretaceus (Reuss)

Ammodiscus infimus

Ammodiscus tenuissimus Grzybowski

Glomospira gordialis (Jones \& Parker)

Glomospira charoides (Jones \& Parker)

Glomospira irregularis (Grzybowski)

Ammolagena clavata

Sigmoilopsis schlumbergeri (Silvestri)

Spirosigmoilinella compressa

Spirosigmoilinella sp.

Reophax guttifer Brady

Reophax pilulifer Brady

Reophax subfusiformis

Subreophax scalaria (Grzybowski)

Reophax subnodosiformis Grzybowski

Adercotrema sp 1. Gradstein et al. (in press)

Ammobaculites aff. polythalamus Loeblich

Cribrostomoides spp. ind. 
Table 3-3 (continued).

VERDENIUS AND VAN HINTE (1983)

Haplophragmoides compressa LeRoy -- not found --

Haplophragmoides excavata Cushman

Haplophragmoides walteri Grzybowski

Haplophragmoides kirki Wickenden

Recurvoides contortus Earland

Recurvoides deflexiformis (Noth)

Recurvoides sp. sff. R. deflexiformis (Noth)

LOFTUSIACEA

Cyclammina placenta (Reuss)

Cyclammina acutidorsata (Hantken)

Cyclammina rotundidorsata (Hantken)

Cyclammina amplectens Grzybowski

Reticulophragmium sp.

SPIROPLECTAMMINACEA

Spiroplectammina spectabilis (Grzybowski)

Spiroplectammina navarroana Cushman

\section{TROCHAMMINACEA}

-- not found --

-- not found --

Trochammina globigeriniformis (Parker \& Jones)

-- not found --

-- not found --

-- not found --

Budashevaella sp. aff. B. multicamerata (Budasheva)

ATAXOPHRAGMIACEA

Dorothia principiensis Cushman \& Bermudez

Karreriella conversa (Grzybowski)

Karreriella siphonella (Reuss)

$$
\text { -- not found -- }
$$

Martinotiella communis (d"Orbigny)
THIS STUDY

Haplophragmoides compressa

Haplophragmoides eggeri Cushman

Haplophragmoides excavata

Haplophragmoides walteri

Haplophragmoides "kirki"

Recurvoides spp. ind.

Recurvoides spp. ind.

Recurvoides spp. ind.

Cyclammina placenta

Cyclammina acutidorsata

Cyclammina rotundidorsata

Reticulophragmium amplectens

Reticulophragmium sp.

Spiroplectammina spectabilis

Spiroplectammina navarroana

Ammosphaeroidina sp.

Cystammina aff. pauciloculata (Brady)

Trochammina aff. globigeriniformis

Trochammina altiformis Cushman and Jarvis

Trochammina deformis Grzybowski

Trochammina sp. (6-chambered)

Budashevaella cf. multicamerata

Dorothia principiensis

Karreriella conversa

Karreriella siphonella

Karreriella horrida Mjatliuk

Martinotiella communis 


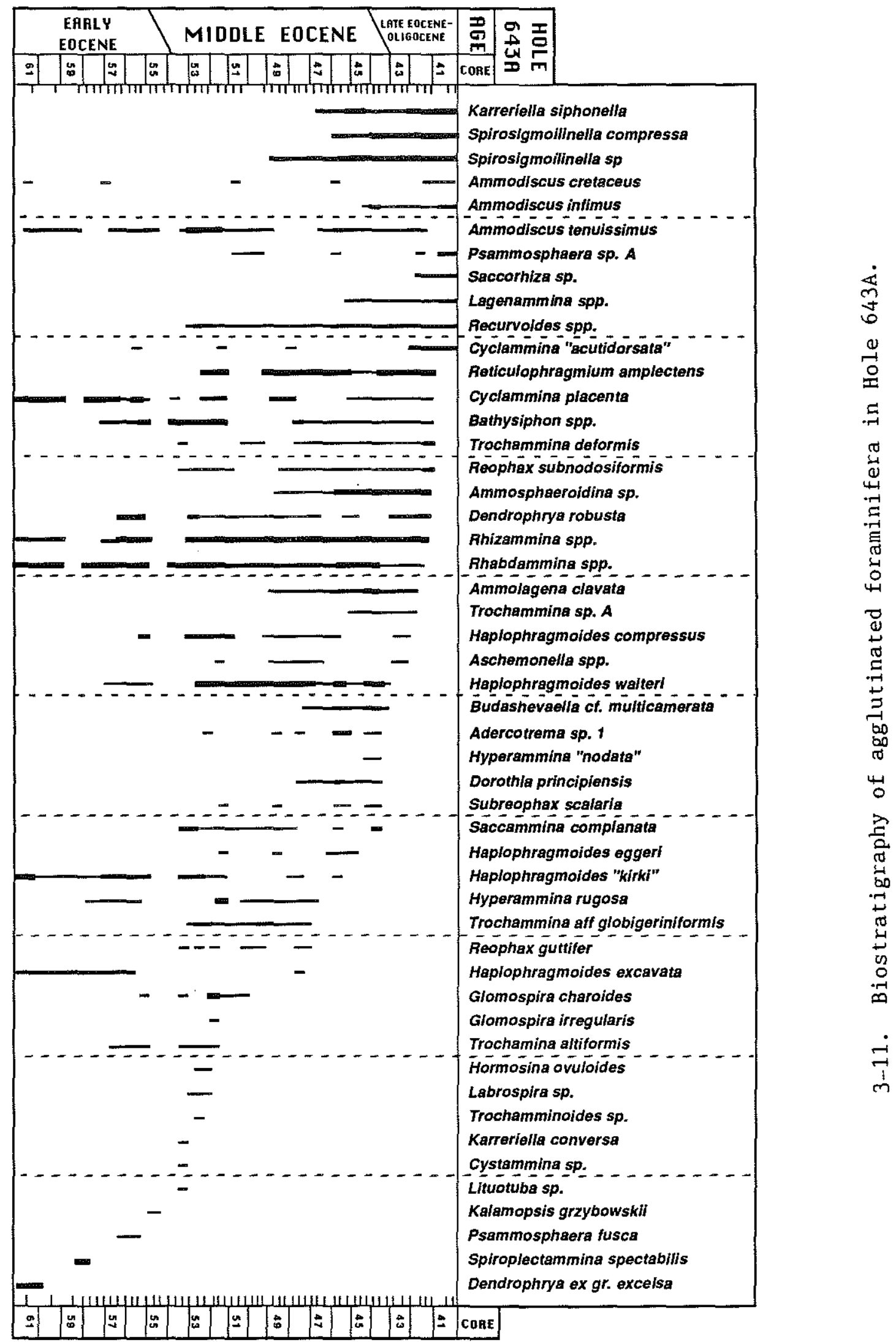




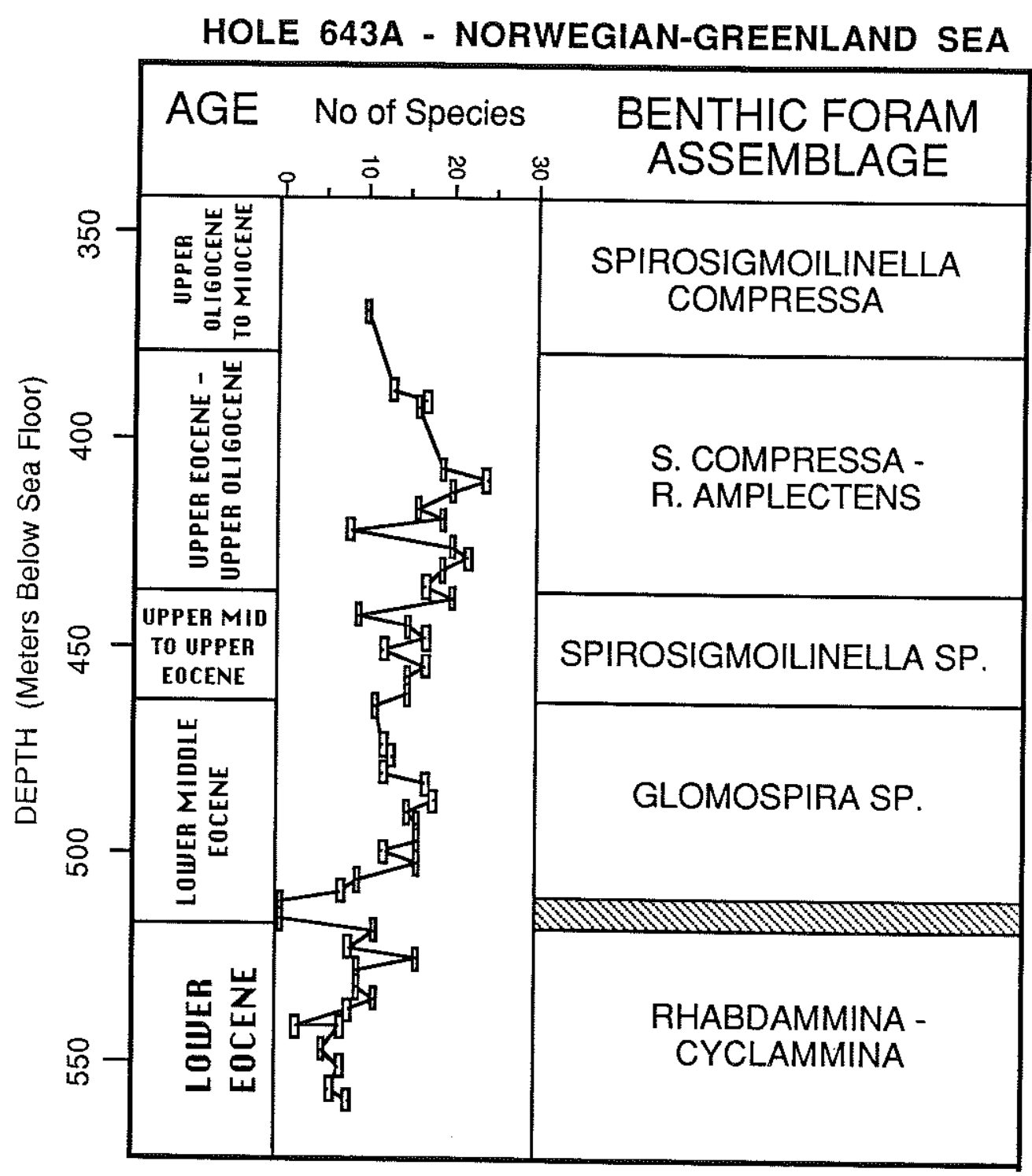

3-12. Age of sediments, diversity of benthic foraminifera and characteristic assemblages defined in ODP Hole 643A. 
upper bathyal paleodepths. Also present in this assemblage are Ammolagena clavata, Ammodiscus tenuissimus and Psammosphaera fusca. An unusual occurrence is an almost monospecific acme of Spiroplectammina spectabilis in Sample 59X-1, 77-81. The age of the Rhabdammina-Cyclammina assemblage is constrained by the basement below and the Eocene Radiolarian Flood in Core 55X. Assuming isochrony of the Eocene Radiolarian Flood with the North Sea, I place Core $55 \mathrm{X}$ in the basal Lutetian.

2. Glomospira Assemblage (Sample $643 \mathrm{~A}-54 \mathrm{X}-5,64-69 \mathrm{~cm}$ to $-50 \mathrm{X}-1,79-84 \mathrm{~cm}$ ). Lower Middle Eocene.

Above the barren interval represented by Samples $55 \mathrm{X}-3,73-78 \mathrm{~cm}$ and $55 \mathrm{X}-1$, 73-78 cm, the benthic foraminiferal assemblage becomes more diversified. The basal samples in this interval (54X-5, 64-69 $\mathrm{cm}$ and $54 \mathrm{X}-3,75-79 \mathrm{~cm}$ ) still contain abundant radiolarians and the benthic assemblage is dominated by astrorhizids. However, the benthic foraminiferal assemblage in the overlying cores contain a diversified, deep-water assemblage. A number of forms make their first appearance in this interval, including Recurvoides spp., Saccammina complanata, Reophax subnodulosus, Glomospira charoides, G. irregularis, Hormosina ovuloides, Buzasina sp., Trochamminoides, Karreriella conversa, and Cystammina $\mathrm{sp}$. The species Haplophragmoides walteri, Trochammina altiformis and Bathysiphon are more abundant in this assemblage compared with the underlying Rhabdammina-Cyclammina assemblage. Most notable is the acme of Glomospira in Samples $53 \mathrm{X}-3,73-78 \mathrm{~cm}$ and $53 \mathrm{X}-1,83-88 \mathrm{~cm}$. The chronostratigraphic and paleoecological significance of the Glomospira facies is discussed in Chapters 4 and 5.

3. Spirosigmoilinella sp. Assemblage (Sample $643 \mathrm{~A}-49 \mathrm{X}-5,79-84 \mathrm{~cm}$ to $-47 \mathrm{X}-1$, 79-84 cm). Upper Middle - Upper Eocene ?.

This interval in Hole $643 \mathrm{~A}$ is characterized by the partial range of Spirosigmoilinella sp. (of Verdenius and Van Hinte, 1983), which has its first occurrence in Sample 49X-5, 79-84 cm. Two stratigraphically important taxa have their first occurrences within this interval. These are Budashevaella cf. multicamerata in Sample 48X-3, 65-69 cm and Dorothia principiensis in Sample 48X-5, 65-69 $\mathrm{cm}$. Near the top of the Spirosigmoilinella sp. 
assemblage, the last occurrences of Hyperammina rugosa (in Sample 47X-3, 7984 ) and Trochammina aff. globigeriniformis (in Sample 47X-1, 79-84) were observed.

The Spirosigmoilinella assemblage is still numerically dominated by tubular

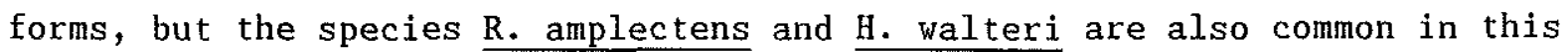
interval. Interestingly, most of the specimens of $\mathrm{R}$. amplectens present in this assemblage are juvenile specimens or belong to the smaller morphotype with fewer chambers and less-well developed alveoles than the typical form. This morphotype is similar to the assumed ancestral species R. intermedia (Mjatliuk) and appears to be morphologically intermediate between $\underline{H}$. walteri and R. amplectens. The common occurrence of the smaller morphotype of $\underline{R}$. amplectens in this interval of Hole $643 \mathrm{~A}$ is usually thought to have stratigraphic significance, since $R$. intermedia was reported by Mjatliuk (1970) to occur in the lower Eocene. However, shipboard palynomorph work yields a conflicting, younger (late oligocene) age for this interval (Shipboard Scientific Party, 1987b).

\section{Spirosigmoilinella compressa - Reticulophragmium amplectens Assemblage} (Sample 643A-46X-5, 65-69 $\mathrm{cm}$ to $-42 \mathrm{X}-1$, 74-77 cm). ?Upper Eocene - ?Lower Miocene.

This interval in Hole $643 \mathrm{~A}$ is defined by the concurrent stratigraphic ranges of the nominate taxa. The co-occurrence of Spirosigmoilinella compressa and R. amplectens in the Norwegian -Greenland Sea was unexpected, since Verdenius and Van Hinte (1983) reported that these species possess disjunct stratigraphic ranges in the Leg 38 sites. S. compressa differs from the larger and thicker Spirosigmoilinella sp., and was first found in Sample $47 \mathrm{X}-3,79-84 \mathrm{~cm}$. The morphotype of $\mathrm{R}$. amplectens occurring in this interval is the larger, typical form with many chambers. The assignment of the base of this zone to the upper Eocene is based upon correlation with the North Sea benthic foraminiferal zonations (Fig. 3-7). The age of the upper portion of this interval was determined by the presence of calcareous nannofossils indicative of Zone NP25 (upper 0ligocene) in Sample 43X, CC (Shipboard Scientific Party, 1987b). Nannofossil samples from Core $42 \mathrm{X}$ did not contain oligocene marker species, and this core was assigned to the lower Miocene.

The $40 \mathrm{~m}$ interval represented by the $\mathrm{S}$. compressa-R. amplectens assemblage is characterized by a gradual decline in diversity culminating near the top of 
the assemblage, which is determined by the LO of R. amplectens. A total of 27 species have their last occurrences in this assemblage, 22 of which occur in the upper $20 \mathrm{~m}$ of the interval. The S. compressa-R. amplectens assemblage contains one important first occurrence - the FO of Ammodiscus infimus in Sample $45 \mathrm{X}-1,79-84 \mathrm{~cm}$. Ammodiscus infimus is a large, coarse variety with unknown affinity to Ammodiscus latus.

In addition to the ubiquitous tubular species, the $\mathrm{S}$. compressa-R. amplectens assemblage is dominated by Karreriella siphonella, Spirosigmoilina sp., S. compressa and Ammosphaeroidina sp. In comparison with the underlying assemblages, A. tenuissimus, Ammosphaeroidina sp., and Budashevaella cf. multicamerata display increased abundance, whereas R. amplectens occurs in lower numbers.

5. Spirosigmoilinella compressa Assemblage (Samples 41X-1, 105-107 and 41X-1, 73-76 cm). Lower Miocene ?.

The Spirosigmoilinella Zone as defined by Verdenius and Van Hinte (1983) corresponds to the total range of the nominate taxon. For the purpose of this study, the S. compressa assemblage in Hole $643 \mathrm{~A}$ is defined by the common occurrence of the nominate taxon above the last occurrence of $\mathrm{R}$. amplectens, and therefore does not correspond to the Spirosigmoilinella Zone. Only two samples examined in this study contains this assemblage, since samples from overlying Core $40 \mathrm{X}$ were cherty and did not break down. Sample 41X-1, 73-76 cm contains 10 species of benthic foraminifera, and is dominated by Psammosphaera sp. A, Saccorhiza sp., S. compressa, K. siphonella, Spirosigmoilinella sp., Lagenammina sp., and A. infimus. The species Ammodiscus cretaceus, Cyclammina acutidorsata and Recurvoides are present in lesser numbers.

\section{LABRADOR SEA -}

Site 647 was drilled at a water depth of $3869 \mathrm{~m}$ in the Southern Labrador Sea $\left(53^{\circ} 19.8^{\prime} \mathrm{N}, 46^{\circ} 15.7^{\prime} \mathrm{W}\right)$ on oceanic crust of Anomaly 24 age. The site is located approximately $90 \mathrm{~km}$ southeast of DSDP Site 112 (Fig. 3-13) on the southeast flank of the Gloria Drift, a depositional feature formed by bottom currents that originate in the Norwegian-Greenland Sea and flow through the Charlie-Gibbs Fracture Zone. Two holes were drilled at Site 647. Hole 647A 


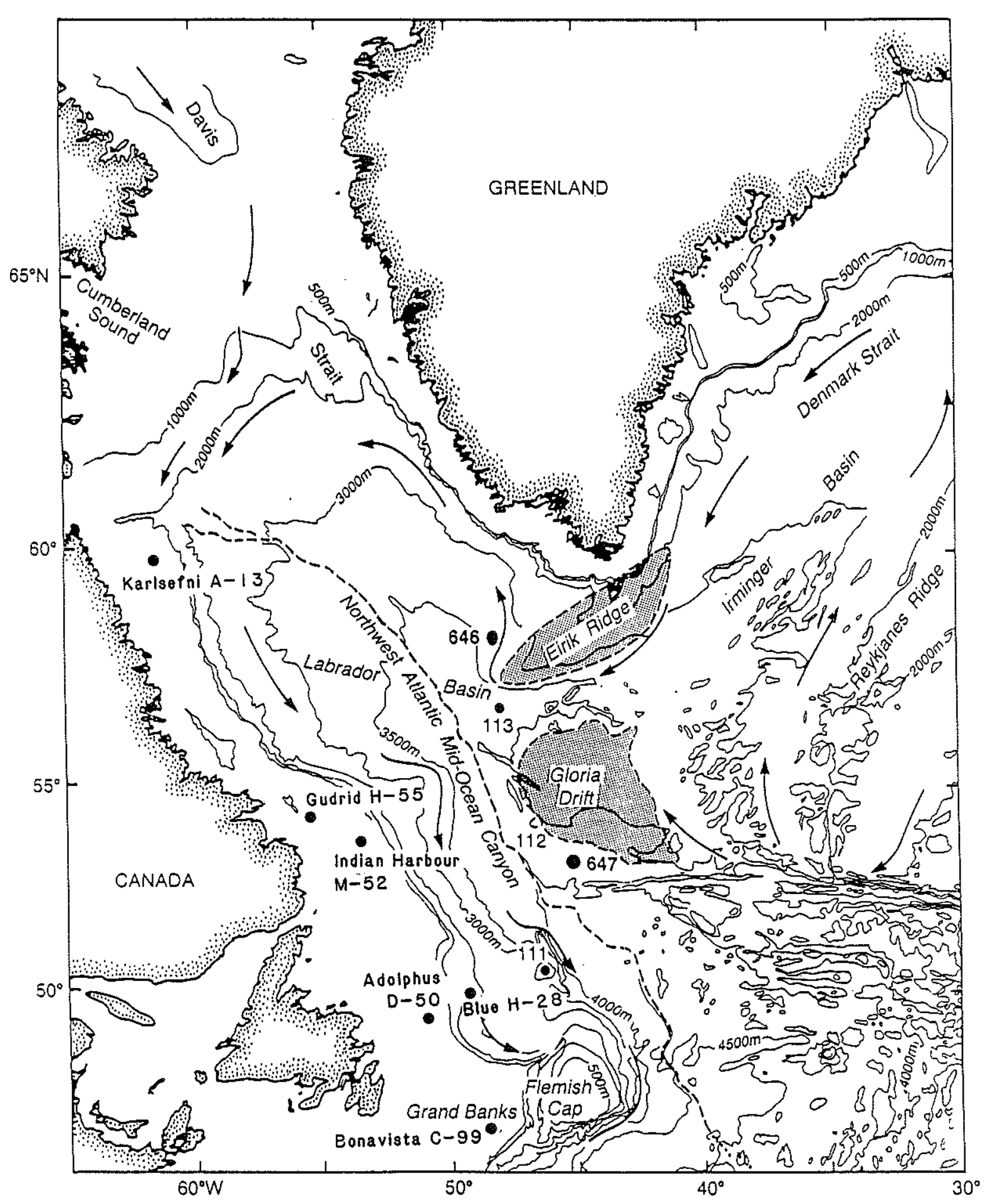

3-13. Location of DSDP and ODP Sites in the Labrador Sea and exploration wells on the Labrador Margin 
penetrated $580 \mathrm{~m}$ of Paleogene sediments which have been subdivided into 4 lithologic units (Fig. 3-14). Hole 647B recovered only Neogene sediments, and was not examined in this study.

The biochronology of Hole 647A is constrained by calcareous nannofossils, planktonic foraminifera, diatoms, radiolarians, and palynomorphs. In addition, the identification of Chron C17 to C19 magnetic reversals allows us to calibrate the age-depth curve to a standard geochronology (Berggren et al. 1985). A list of microfossil datums used to establish the chronology of Hole $647 \mathrm{~A}$ is reproduced in Table 3-4. This chronology has been refined by Firth (in press), and I use his biochronology across the lower/middle Eocene boundary. By interpolation from the sedimentation rate curve, the Eocene/01igocene boundary was placed at 290 mbsf and the middle/upper Eocene boundary at $410 \mathrm{mbsf}$. A hiatus or condensed section separating lower Eocene and middle Eocene sediments is present between 610 and 640 mbsf. This hiatus or condensed interval corresponds approximately to the position of the lowermost intra-Eocene seismic reflector apparent in multichannel seismic records across the Gloria Drift (Fig. 3-14). Core recovery between the intraEocene seismic reflectors was incomplete, and only core-catcher samples from Cores $647 A-55 R$ to $-61 R$ were available for study.

The lower Eocene to lower 0ligocene of Hole 647A can be subdivided into seven assemblages, based on the partial ranges of characteristic benthic taxa. The assemblages were chosen to reflect a subdivision of the sedimentary section at a stage level, and are named after taxa that are cosmopolitan and have correlative value in the North Atlantic. These assemblages are shown in figure 3-14, and are discussed below in order from oldest to youngest. The relative proportions of important taxa in the Paleogene section are shown in figures 3-15 and 3-16. The biostratigraphy of agglutinated taxa is presented in figure 3-17, and the chronology of benthic foraminiferal $\mathrm{FO}^{\prime} \mathrm{s}$ and $\mathrm{LO}^{\prime} \mathrm{s}$ in given in Table 3-5.

\section{Foraminiferal Assemblages:}

1. Dendrophrya ex gr. excelsa - Abyssammina Assemblage (Samples 647A-71R-2, 43-45 cm to $-66 \mathrm{R}-2,24-27 \mathrm{~cm})$. Lower Eocene:

This assemblage is characterized by the presence of the nominate taxa and contains a mixture of agglutinated and calcareous benthics in a Subbotina 
TABLE 3-4.

Sub-bottom depths of biostratigraphic and magnetostratigraphic age picks used to construct the age-depth curve for Hole 647A (after Shipboard Scientific Party, 1987, c).

\begin{tabular}{|c|c|c|}
\hline Name of Datum & AGE & DEPTH \\
\hline LCO Dictyococcites bisectus & $>23.7$ & $135.4-136.1$ \\
\hline Occ Pentadinium imaginatum & $>23.7$ & 145.1 \\
\hline FAD Sphenolithus ciperoensis & $<30.3$ & 147.5 \\
\hline LAD Globigerina angiporoides & $>32.0$ & 190.0 \\
\hline LAD Reticulofenestra umbilica & 34.6 & $214.0-215.5$ \\
\hline Occ Cyclamperium pegetrum & $<33.0$ & 221.9 \\
\hline LO Cestodiscus reticulatus & 34.0 & 221.9 \\
\hline F0 $\overline{\text { Cestodiscus reticulatus }}$ & 36.2 & 239.0 \\
\hline LAD Ericsonia formosa & 35.1 & $250.5-251$ \\
\hline LAD Chiloguembelina & 30.0 & 260.1 \\
\hline Occ Coscinodiscus excavatus & 36.8 & 260.1 \\
\hline Occ Globigerina ampliapertura & $>32.8$ & 262.0 \\
\hline LAD Pseudohastigerina & 34.0 & 269.7 \\
\hline LAD Discoaster barbadiensis & 36.7 & 288.8 \\
\hline L0 Subbotina linaperta & 36.7 & 291.0 \\
\hline LAD Turborotalia cerroazulensis & 36.7 & 298.6 \\
\hline LAD Globigerinatheka & 37.0 & $335.0-337.2$ \\
\hline LAD Nuttallides truempyi & 38.5 & $385.4-395.1$ \\
\hline FAD Chiasmolithus oamaruensis & 39.7 & $443.5-435.0$ \\
\hline LAD Truncorotaloides & 40.6 & $443.5-453.2$ \\
\hline LAD Chiasmolithus solitus & 42.3 & $453.2-454.0$ \\
\hline LAD Acarinina & 40.6 & $463.5-472.5$ \\
\hline FAD Globigerinatheka index & 45.0 & 578.8 \\
\hline L0 Pseudohastigerina wilcoxensis & 44.5 & 588.4 \\
\hline FAD Reticulofenestra umbilica & $<45.5$ & 608 \\
\hline Occ Tribrachiatus orthostylus and & & \\
\hline Discoaster lodoensis & $>55.3$ & 638.5 \\
\hline Fo Homotryblium oceanicum & $<53.6$ & 648.0 \\
\hline occ Morozovelia lensiformis & $>53.4$ & 659.0 \\
\hline FAD Discoaster lodoensis & 55.3 & $675.5-685.0$ \\
\hline F0 ?Dracodinium condylos & 56.0 & 675.5 \\
\hline Occ Tribrachiatus orthostylus & $<56.6$ & 696.6 \\
\hline F0 Dracodinium & $<56.6$ & 696.6 \\
\hline Base Chron C17 & 41.11 & $450.75-453.25$ \\
\hline Top N2 event, Chron C18 & 41.80 & $481.45-482.15$ \\
\hline Base N2 event, Chron C18 & 42.23 & $490.15-490.25$ \\
\hline
\end{tabular}




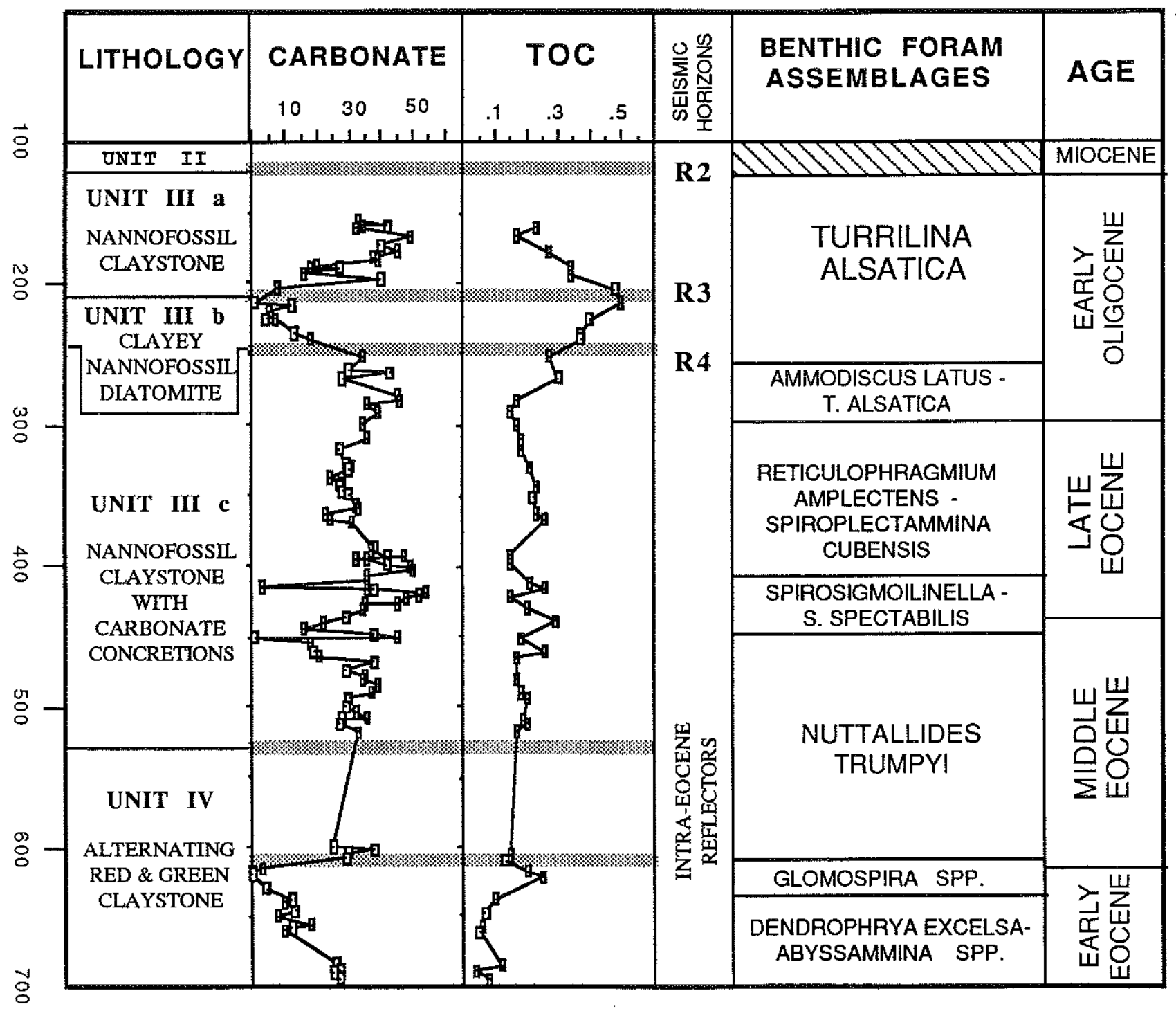

3-14. Comparison of lithostratigraphy, seismic reflectors, percent carbonate and Total Organic Content with benthic foraminiferal biochronology in the Paleogene of Hole 647A. Depth to reflectors and lithologic data are from the Site 647 Chapter (Shipboard Scientific Party, 1987c). 


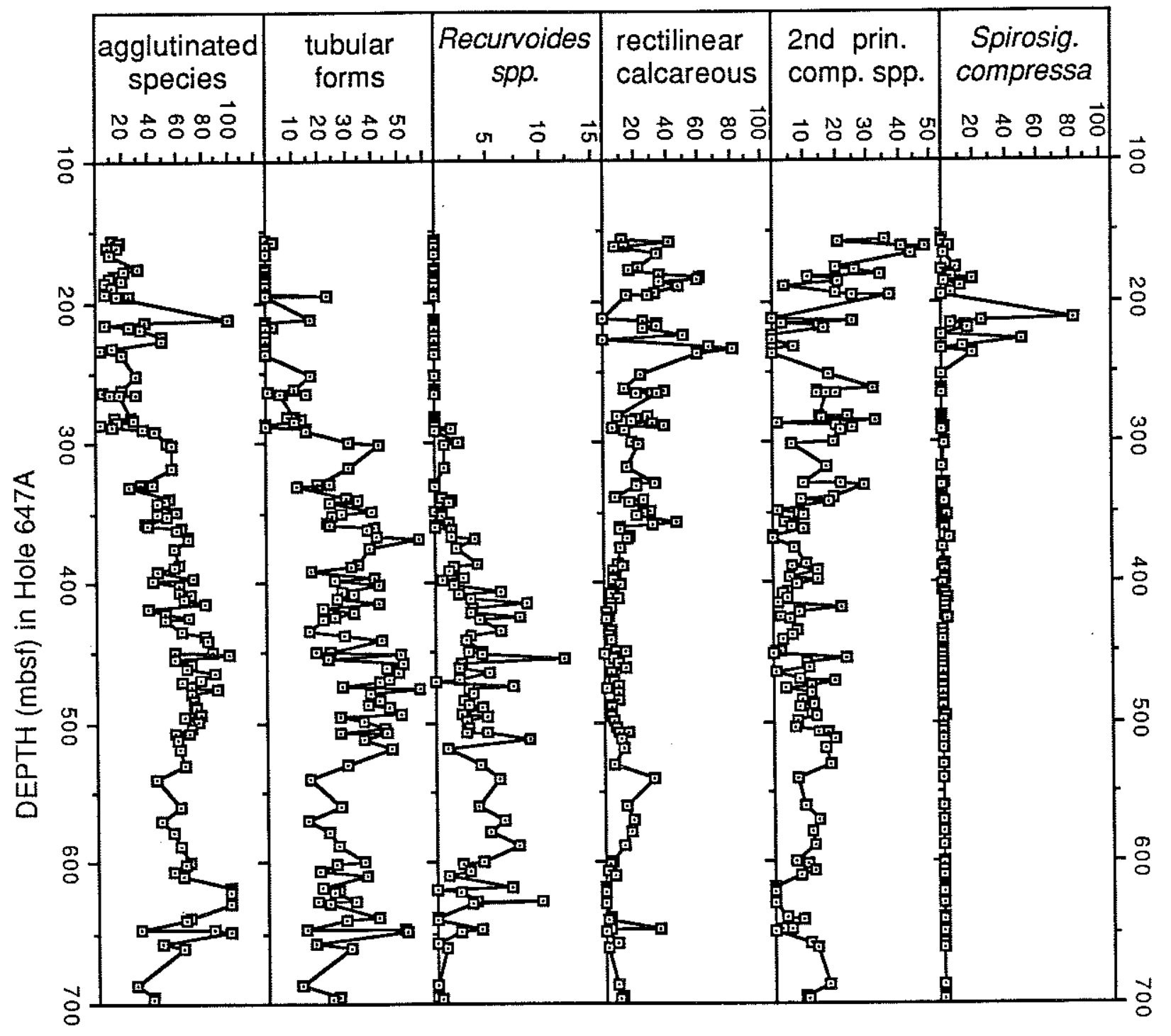

3-15. Relative abundance of common benthic foraminiferal species and species groups in Hole $647 \mathrm{~A}$. 


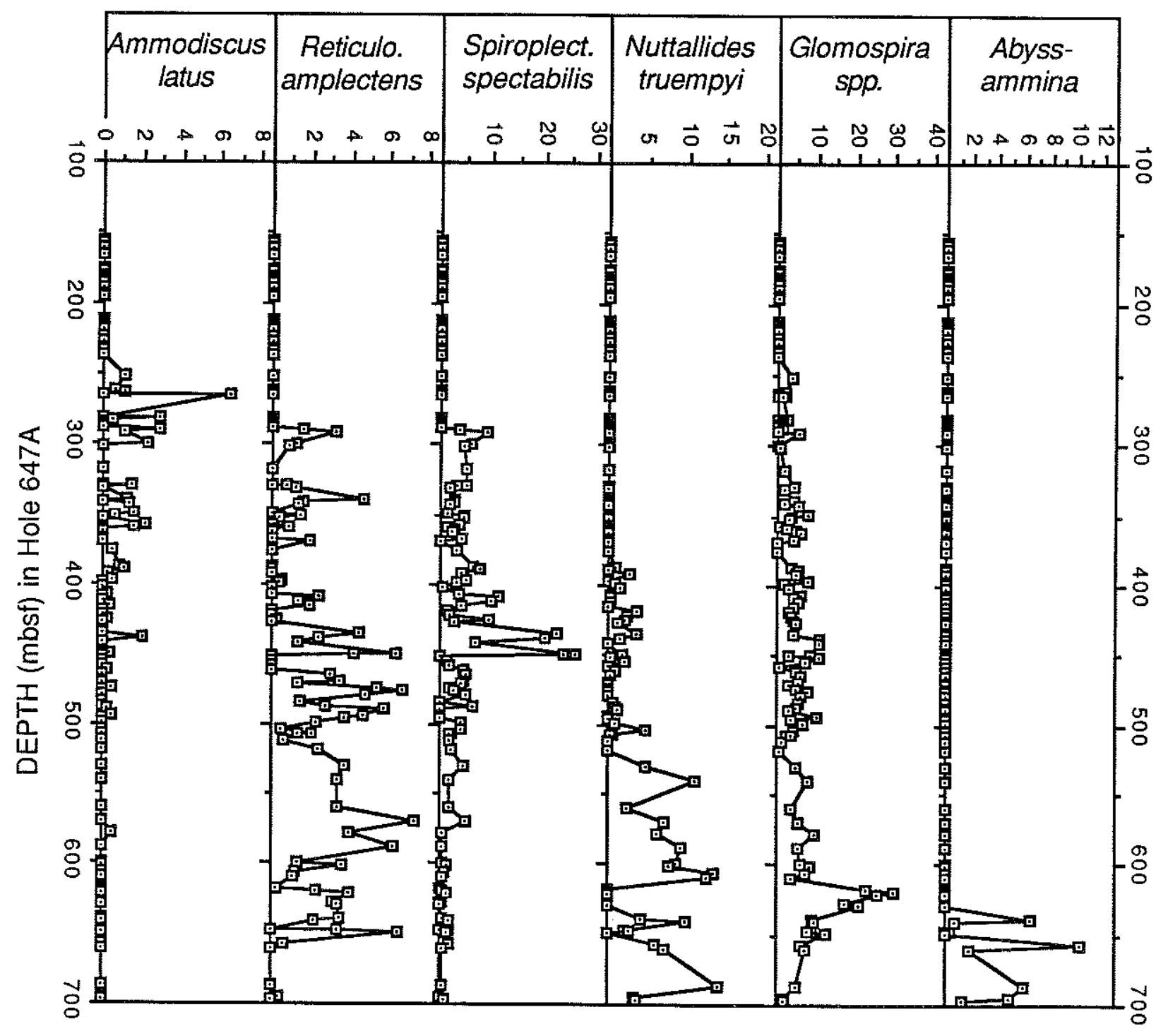

3-16. Relative abundance of stratigraphically important benthic foraminiferal species and in Hole 647B. 


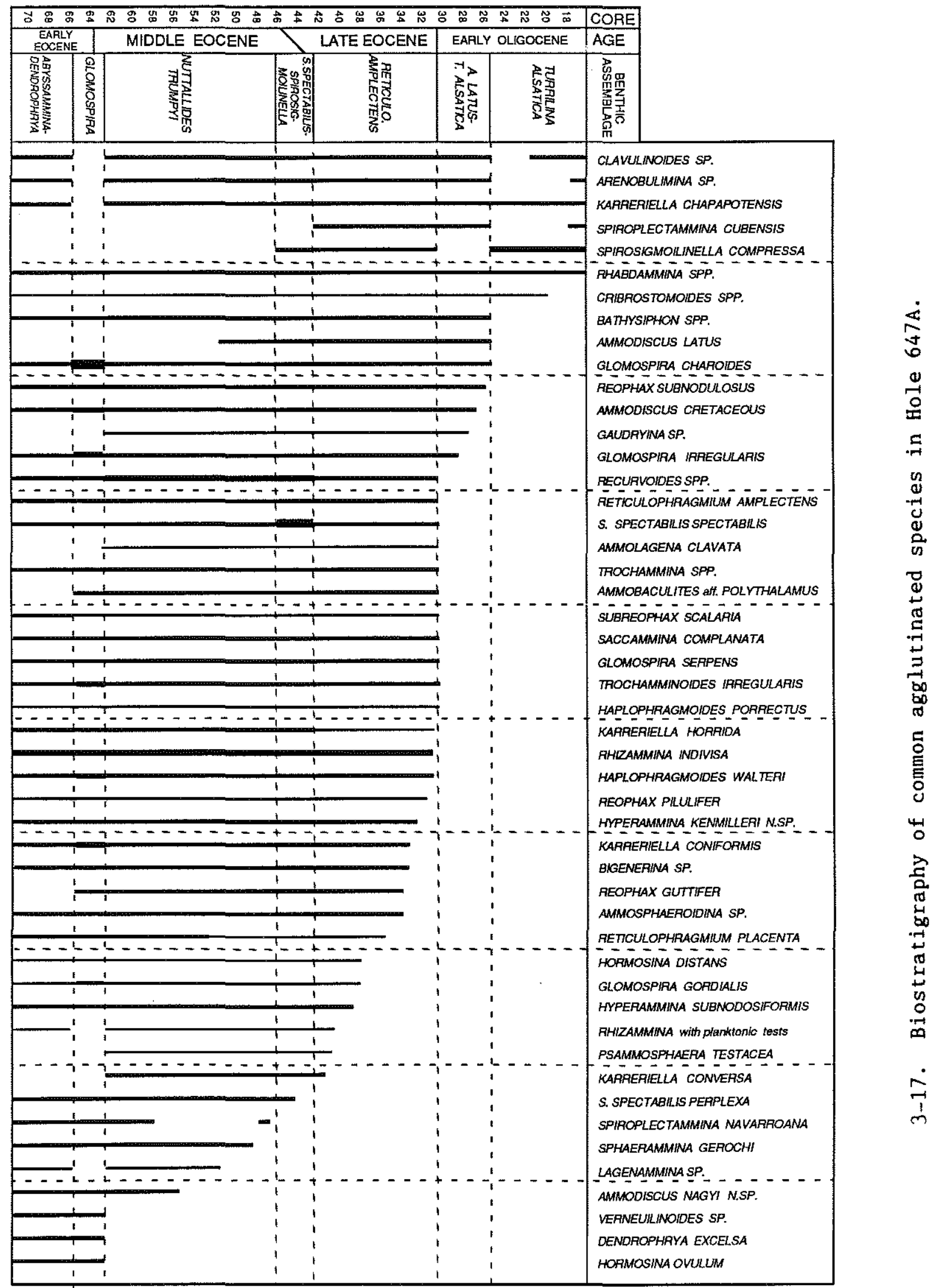


Table 3-5. Chronology of benthic foraminiferal first and last occurrence events in ODP Hole 647A.

\begin{tabular}{|c|c|c|c|}
\hline & Taxon & depth (mbsf) & Age \\
\hline$\overline{\mathrm{LO}}$ & Turrilina alsatica & $155.9 \mathrm{~m}$ & $31 \mathrm{Ma}$ \\
\hline Lo & Bathysiphon sp. & $251.2 \mathrm{~m}$ & $35.5 \mathrm{Ma}$ \\
\hline Lo & Glomospira charoides & $251.1 \mathrm{~m}$ & $35.5 \mathrm{Ma}$ \\
\hline LO & Ammodiscus latus & $251.1 \mathrm{~m}$ & $35.5 \mathrm{Ma}$ \\
\hline Lo & Nuttallides umbonifera & $262.7 \mathrm{~m}$ & $35.8 \mathrm{Ma}$ \\
\hline LO & Ammodiscus cretaceus & $280.5 \mathrm{~m}$ & $36.3 \mathrm{Ma}$ \\
\hline Lo & Osangularia mexicana & $"$ & " \\
\hline LO & Gavelinella micra & $"$ & $"$ \\
\hline L0 & Bolivina huneri & $281.4 \mathrm{~m}$ & $36.4 \mathrm{Ma}$ \\
\hline Lo & Glomospira irregularis & $285.0 \mathrm{~m}$ & $36.5 \mathrm{Ma}$ \\
\hline LO & Recurvoides spp. & $290.3 \mathrm{~m}$ & $36.6 \mathrm{Ma}$ \\
\hline LO & Reticulophragmium amplectens & " & " \\
\hline LO & Spiroplectammina spectabilis & $"$ & $"$ \\
\hline LO & Ammolagena clavata & $"$ & $"$ \\
\hline LO & Trochammina deformis & $"$ & $"$ \\
\hline LO & Ammobaculites aff. poly thalamus & $"$ & $"$ \\
\hline Lo & Subreophax scalaria & $"$ & $"$ \\
\hline LO & Saccammina complanata & $290.8 \mathrm{~m}$ & 36.6 \\
\hline LO & Glomospira serpens & " & $"$ \\
\hline LO & Trochamminoides irregularis & $"$ & $"$ \\
\hline LO & Rhizammina spp. & $300 \cdot 3 m$ & $36.9 \mathrm{Ma}$ \\
\hline LO & Haplophragmoides walteri & $"$ & $"$ \\
\hline LO & Reophax pilulifer & $318.0 \mathrm{~m}$ & $37.4 \mathrm{Ma}$ \\
\hline LO & Gavelinella capitata & " & " \\
\hline LO & Cibicidoides grimsdalei & $328.4 \mathrm{~m}$ & $37.6 \mathrm{Ma}$ \\
\hline Lo & Hyperammina kenmilleri n.sp. & $329.9 \mathrm{~m}$ & $37.7 \mathrm{Ma}$ \\
\hline LO & Bulimina macilenta & $"$ & $"$ \\
\hline LO & Karreriella coniformis & $331.4 \mathrm{~m}$ & $37.7 \mathrm{Ma}$ \\
\hline LO & Bigenerina sp. & $"$ & $"$ \\
\hline LO & Reophax guttifer & $339.2 \mathrm{~m}$ & $38.0 \mathrm{Ma}$ \\
\hline LO & Ammosphaeroidina sp. & $340.7 \mathrm{~m}$ & $38.0 \mathrm{Ma}$ \\
\hline LO & Reticulophragmiun placenta & $350.6 \mathrm{~m}$ & $38.3 \mathrm{Ma}$ \\
\hline LO & Hormosina distans & $360.3 \mathrm{~m}$ & $38.6 \mathrm{Ma}$ \\
\hline LO & Glomospira gordialis & " & $"$ \\
\hline LO & Nuttallides truempyi & $386.0 \mathrm{~m}$ & $39.2 \mathrm{Ma}$ \\
\hline LO & Karreriella conversa & $405.8 \mathrm{~m}$ & $39.8 \mathrm{Ma}$ \\
\hline F0 & Spiroplectammina cubensis & $408.8 \mathrm{~m}$ & $39.9 \mathrm{Ma}$ \\
\hline FO & Spirosigmoilinella compressa & $425.8 \mathrm{~m}$ & $40.4 \mathrm{Ma}$ \\
\hline LO & Spiroplectammina spectabilis perplexa & $434.4 \mathrm{~m}$ & $40.6 \mathrm{Ma}$ \\
\hline LO & Spiroplectammina navarroana & $460.3 \pi$ & $41.3 \mathrm{Ma}$ \\
\hline F0 & Ammodiscus nagyi n.sp. & $498.3 m$ & $42.4 \mathrm{Ma}$ \\
\hline LO & Aragonia spp. & $540.0 \mathrm{~m}$ & $43.5 \mathrm{Ma}$ \\
\hline LO & Cibicidoides subspiratus & $569.1 \mathrm{~m}$ & $44.3 \mathrm{Ma}$ \\
\hline Fo & Ammodiscus latus & $578.8 \mathrm{~m}$ & $44.6 \mathrm{Ma}$ \\
\hline LO & Verneuilinoides polystrophus & $578.8 \mathrm{~m}$ & $44.6 \mathrm{Ma}$ \\
\hline LO & Dendrophrya ex gr. excelsa & $620.7 \mathrm{~m}$ & $48.8-52.6 \mathrm{Ma}$ \\
\hline LO & Hormosina ovulum & $627.2 \mathrm{~m}$ & " \\
\hline LO & Abyssammina spp. & $638.6 \mathrm{~m}$ & $52.6-53.6 \mathrm{Ma}$ \\
\hline LO & Quadrimorphina profunda & $657.5 \mathrm{~m}$ & $54.2 \mathrm{Ma}$ \\
\hline
\end{tabular}


patagonica planktonic ooze typical of Zones P8 to P9 (Berggren and Schnitker, 1983). Calcareous foraminifera are silicified to some degree, probably owing to the proximity of basement. The sediments overlying basement were deposited in 1700-2000 m water depth, based on estimates using the backtracking method of Sclater et al. (1985). The benthic assemblage displays evidence of a lower bathyal setting, for example, the relative proportion of Lenticulina spp. and Bulimina spp. is higher than in any of the overlying assemblages. The Abyssammina - Dendrophrya assemblage corresponds to nannofossil zones NP11 NP13 (J.V. Firth, personal communication 1987).

The nominate taxa are common to abundant in some samples (Fig. 3-16). Abyssammina comprises $10 \%$ of the assemblage in Sample 68R-1, 129-132 cm, and Dendrophrya ex gr. excelsa makes up $37 \%$ of the assemblage in Sample 67-1, 40$43 \mathrm{~cm}$. Abyssammina spp, Quadrimorphina profunda, Bulimina trinitatensis and Bulimina cf semicostata of Tjalsma and Lohmann (1983) are restricted to this assemblage. The latter species is transitional between Bulimina semicostata and Bulimina glomarchallengeri. An interesting agglutinated species tentatively identified as Hormosina ovulum was found in Samples 70R, CC and

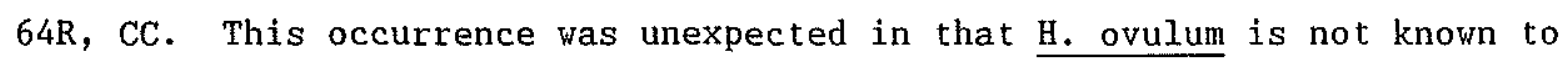
occur above the Paleocene in bathyal assemblages, and there is no other evidence for reworking.

2. Glomospira Assemblage (Samples $65 \mathrm{R}-2,31-34 \mathrm{~cm}$ to $63 \mathrm{R}, \mathrm{CC}$ ). Lower to middle Eocene:

Samples from the $20 \mathrm{~m}$ interval represented by Cores $64 \mathrm{R}$ and $65 \mathrm{R}$ are barren of calcareous microfossils, and the benthic foraminifera are present in a "Glomospira facies". The most common species in this interval are Glomospira irregularis, Glomospira charoides, Ammodiscus cretaceous, Karreriella coniformis, Trochamminoides spp. and Haplophragmoides walteri. Depending upon where the base of the Glomospira Assemblage lies in Zone NP13, the assemblage may be as old as 53.6 to $52.8 \mathrm{Ma}$. A Glomospira-facies also occurs in "lower Eocene" sediments in the Carpathian Mountain Belt, and is usually interpreted as reflecting a pelagic environment at bathyal to abyssal paleodepths (Geroch et al., 1967, 0lszewska, 1984). At Site 647 the presence of a Glomospira facies is likely due to a rise in the lysocline to a level above $2500 \mathrm{~m}$. 
3. Nutallides truempyi Assemblage (Samples 63R-1, 139-142 cm to 47R-4, 74-77 $\mathrm{cm})$, Middle Eocene:

This is the interval in Hole $647 \mathrm{~A}$ between the last occurrence of the carbonate-free claystones containing abundant Glomospira and the first occurrence of Spirosigmoilinella. This assemblage is characterized by the common occurrence of the nominate taxon (Fig. 3-16). The lower portion of the assemblage corresponds to an interval of poor recovery between Samples 54R, CC and 61R, CC. This interval was placed in the middle of Zone NP15 (Zones CP13b - CP13C of Okada and Bukry, 1980) by Firth (in press), which corresponds to an age between 48.7 and $47.0 \mathrm{Ma}$. The N. truempyi Assemblage therefore overlies a condensed section and/or hiatus encompassing the uppermost lower Eocene and the lower middle Eocene. The species Cibicidoides subspiratus (Nuttall) was found in Samples 61R, CC, 60R, CC and 59R, CC. This is a distinctive taxon in the Atlantic owing to its restricted stratigraphic range ( $P 9$ to $P 13$; Van Morkhoven et al., 1986). The last occurrence of Aragonia spp. occurs between Samples 55R, CC and 56R, CC. This event was placed at the top of Zone P14 by Tjalsma and Lohmann (1983), but it apparently occurs earlier in the Labrador Sea. Above Core 55R, recovery was more or less continuous, and Nuttallides truempyi decreases in relative abundance. Core 54R was placed in nannofossil Zone NP16 by Firth (in press), and interpolation from the sedimentation rate curve yields an age of $45.5 \mathrm{Ma}$.

The agglutinated component comprises approximately $80 \%$ of the benthic assemblage between Cores $55 \mathrm{R}$ and 46R. Tubular species are dominant, but Reticulophragmium amplectens and Recurvoides spp. attain their maximum relative abundance in this interval. A number of important stratigraphic events also occur (Fig. 3-17). These are the first occurrence of Ammodiscus latus in Sample 52R-2, $45-48 \mathrm{~cm}$; the last occurrence of Ammodiscus nagyi in Sample $52 \mathrm{R}-5,54-57 \mathrm{~cm}$, and the last occurrence of Spiroplectammina navarroana in Sample 49R-6, $117-120 \mathrm{~cm}$. In the North Sea, the last occurrence of $\mathrm{s}$. navarroana usually occurs lower in the section, in the lower Eocene (Gradstein et al., in press).

4. Spiroplectammina spectabilis - Spirosigmoilinella Assemblage (Samples 46R-

5, 60-63 cm to 43R-5, 97-100 cm), Middle - Upper Eocene:

This interval in Hole $647 \mathrm{~A}$ is defined by the partial range of

Spirosigmoilinella compressa, from its first occurrence to the first 
occurrence of Spiroplectammina cubensis. The assemblage is characterized by the acme of the Spiroplectammina spectabilis plexus (Fig. 3-16). This interval corresponds the uppermost part of middle Eocene nannofossil zone NP17, and the lowermost upper Eocene. The exact position of the middle/upper Eocene boundary, however has not been determined exactly. Nannofossil stratigraphy (Firth, in press) place the boundary within Core 46R, but interpolation from the sedimentation rate curve places the boundary in Core 43R. Our age model yields an age for this assemblage between 40.4 and 39.9 $\mathrm{Ma}$.

Two important stratigraphic events are associated with the $\mathrm{S}$. spectabilis Spirosigmoilinella Assemblage (Fig. 3-17). The last occurrence of the small, compressed variety of Spiroplectammina spectabilis ( . spectabilis perplexa of Kaminski, 1984) occurs in Sample 46R-1, 60-63 cm. The last common occurrence of $\mathrm{S}$. spectabilis spectabilis occurs in Sample 43R-3, 104-107 cm. This event occurs approximately 1 meter above the middle/upper Eocene boundary as determined from the sedimentation rate curve. Above this level, the relative abundance of $\mathrm{S}$. spectabilis in our samples never exceeds $10 \%$.

5. Reticulophragmium amplectens - Spiroplectammina cubensis Assemblage (Sample 43R-3, 104-107 cm to 31R-1, 133-135 cm), Upper Eocene:

Within the accuracy of our microfossil and magnetic chronology, the interval represented by this assemblage encompasses the entire upper Eocene. The assemblage is defined by the concurrent range of $\underline{R \text {. amplectens }}$ and $\underline{S}$. cubensis. The first occurrence of $\mathrm{S}$. cubensis (in Sample 43R-3, 104-107 cm) occurs at about the same level as the LCO of S. spectabilis, so the latter event can also be used to determine the base of the interval. The last occurrence of R. amplectens in Sample 31R-1, 133-135 cm occurs within 1 meter of the Eocene/0ligocene boundary, which was placed at 290 mbsf according to our age-depth model.

Within this interval, there is a gradual transition from an agglutinated assemblage to a predominantly calcareous assemblage in the 0ligocene. A number of typical Eocene taxa such as Nuttallides truempyi, Cibicidoides grimsdalei, and many of the "flysch-type" agglutinated taxa have their last occurrences in this assemblage. This is particularly apparent in Cores 32R and $31 \mathrm{R}$, which contain the last occurrences of 10 agglutinated taxa (Fig. 317). The interval can be further subdivided into a lower and upper portion 
based on the last occurrances of Ammosphaeroidina, Bulimina macilenta, $\mathrm{C}$. grimsdalei, and Karreriella coniformis between Cores $35 \mathrm{R}$ and $37 \mathrm{R}$. The last occurrence of $\mathrm{N}$. truempyi in Sample 41R-1, 58-61 cm, is an important extinction event, and corresponds to an approximate age of $39 \mathrm{Ma}$.

Throughout the interval, the assemblage is still numerically dominated by tubular agglutinated species. In the upper portion of the assemblage, the rectilinear calcareous group (Stilostomella, Dentalina, nodosariids), Pullenia spp, and the "2nd Principal Component" of Tjalsma and Lohmann (Cibicidoides, oridorsalis, Gyroidinoides, and Globocassidulina) become more important.

6. Ammodiscus latus - Turrilina alsatica Assemblage (Samples 31R-1, 133-135 cm to $27 \mathrm{R}-1,78-83 \mathrm{~cm}$.), Basal 0ligocene:

This interval is defined by the concurrent range of the nominate taxa. The first occurrence of Turrilina alsatica coincides with the last occurrence of R. amplectens in Sample 31R-1, 133-135 cm. The last occurrence of Ammodiscus latus was observed in Sample $27-1,78-83 \mathrm{~cm}$, but its true last occurrance may be as much as $14 \mathrm{~m}$ higher, because Core 26R recovered only drilling slurry and was not sampled for benthic foraminifera. This assemblage corresponds to the basal 0ligocene, and represents the time interval between $36.6 \pm 0.05$ and $35.3 \pm 0.2 \mathrm{Ma}$.

The species Ammodiscus latus attains its maximum relative abundance in the basal 0ligocene (Fig. 3-16), and Turrilina alsatica is also a common species in many samples. A "flood" of Nuttallides umbonifera is observed in Sample $30 \mathrm{R}-5,10-13 \mathrm{~cm}(36.5 \pm 0.05 \mathrm{Ma})$, where $\mathrm{it}$ comprises $56 \%$ of the total assemblage. The increased abundance of $\mathrm{N}$. umbonifera has also been observed in the basal 0ligocene of Southern Pacific Site 277 (Corliss, 1979) and Eastern Atlantic Site 119 (Miller, 1983), which suggests that this event may be useful for inter-basinal correlation. Within this interval the agglutinated foraminifera display a noticeable reduction in size, and most of the remaining flysch-type taxa (Glomospira charoides, Bathysiphon sp, Reophax spp, Ammodiscus cretaceous, and Glomospira irregularis) have their last occurrences. Throughout much of the interval, the benthic assemblage is numerically dominated by rectilinear calcareous taxa, the "2nd Principal Component" taxa, and Pullenia spp. This assemblage corresponds to the "Stilostomella assemblage" of Miller et al. (1982) at Site 112. 
7. Turrilina alsatica Assemblage (Sample 25R-4, 107-110 cm to $17 \mathrm{R}-1,107-110$ cm), Lower 0ligocene:

This is the interval between the last occurrence of Ammodiscus latus and the top of the Paleogene section in Hole 647A. The upper limit of the Turrilina alsatica assemblage is truncated by a barren interval and one or more hiatuses above Core 17R. In exploration wells drilled on the Labrador Margin, the last occurrence of T. alsatica is used to identify the Paleogene/Neogene boundary, but a hiatus encompassing much of the upper oligocene is also present in the area (Gradstein, 1987).

Throughout the interval, the abundance and diversity of benthic taxa is low, and washed residues contain mainly siliceous debris. Many samples in Lithologic Unit IIIb contain only rectilinear and unilocular calcareous species, Karreriella, and Spirosigmoilinella. The most characteristic taxa is Spirosigmoilinella compressa, which displays its greatest relative abundance in this relatively depauperate assemblage. However, its absolute abundance in the lower 0ligocene does not differ noticeably from its abundance in the upper Eocene. Uvigerina are common in samples from Core 20R. This occurrence corresponds to a peak in the TOC content of the sediment (Fig. 3-14), indicating high paleoproductivity. Among flysch-type agglutinated taxa, only Cribrostomoides subglobosus and Rhabdammina persist into this assemblage.

\section{NEOGENE BIOSTRATIGRAPHY}

\section{BAFFIN BAY SITE 645 -}

Site 645 lies on the continental slope off southern Baffin Island at a water depth of $2,020 \mathrm{~m}$. Drilling at Site 645 penetrated $1,147.1 \mathrm{~m}$ of sediment, providing a continuous lower Miocene to Recent stratigraphic record. The entire lithologic sequence in Holes 645B, 645D and 645E has a pronounced terrigenous character and was subdivided into 3 lithologic units:

Lithologic unit 1 consists of alternating beds of light tan to gray calcareous gravel-bearing muddy sand and dark gray silty mud with scattered dropstones. This unit occurs from 0 to 168.1 mbsf and $i$ ts age was determined as early Pleistocene to Recent based on dinoflagellates.

Lithologic unit 2 extends from 168.1 to 330.7 mbsf, and consists of noncalcareous silty mud with dropstones. Its age was determined as late Pliocene to early Pleistocene based on dinoflagellates. 
Lithologic Unit 3 extends from 330.7 to $1147.1 \mathrm{mbsf}$ and is lower Miocene to upper Pliocene, based on dinoflagellates and occasional calcareous planktonic microfossils. Subunit 3a consists mainly of poorly sorted olive-gray silty mudstone and muddy sandstone. Scattered pebbles occur to a depth of $605 \mathrm{~m}$. Subunit $3 b$ contains calcareous silty claystones with organic carbon content to ca. $3 \%$ interbedded with muddy sandstones. Subunit $3 \mathrm{c}$ consists of fine to medium grained muddy sandstone and silty mudstones.

\section{Faunal Composition:}

Fifty-five samples from lithologic units 1 and 2 were studied for benthic foraminifera. The upper 220 meters of Hole $645 \mathrm{~B}$ contain benthic foraminiferal assemblages dominated by calcareous species (Fig. 3-18), and were discussed in detail by Kaminski et al. (in press, c). Hole 645D recovered sediments belonging to lithologic units 2 and $3 \mathrm{a}$. Twenty core-catcher samples were examined from this hole, of which only two (Samples 645D-6R, CC and -13R, CC) contain rare specimens of calcareous foraminifera.

Hole 645E penetrated Lithostratigraphic Units 2 - 3 between 301 and 1147 mbsf. A total of 180 samples were examined for foraminifera and associated microfossils. Samples from Unit 2 and the upper portion of lithologic unit 3 are barren. Microfossils are again encountered in subunit $3 \mathrm{~b}$ below approximately 750 mbsf. These consist mainly of fragments of agglutinated foraminifera. Less commonly, calcareous benthic foraminifera, pyritized diatoms and specimens of bolboforma are present. Planktonic foraminifera were only found in two samples. Because of the sparse and fragmentary nature of the assemblages, the microfossil data from this hole are not treated quantitatively.

The presence of Bolboforma metzmacheri in sample $645 \mathrm{E}-36 \mathrm{R}, \mathrm{CC}$ constrains the age of this sample as no younger than nannofossil Zone NN16 (lower Pliocene). This species is known from the North Atlantic (Murray, 1987) and the North Sea (King, 1983). In the North Sea, B. metzmacheri occurs together with the dextral form of Neogloboquadrina atlantica and defines King's upper Miocene Zone NSP14.

The last occurrence of coarse agglutinated species occurs between samples 38R-3,44-47cm and 38R-6,127-129 cm, at approximately $770 \mathrm{mbsf}$. This event occurs in the lower Pliocene in the Beaufort Sea (Young and McNeil, 1984) and 


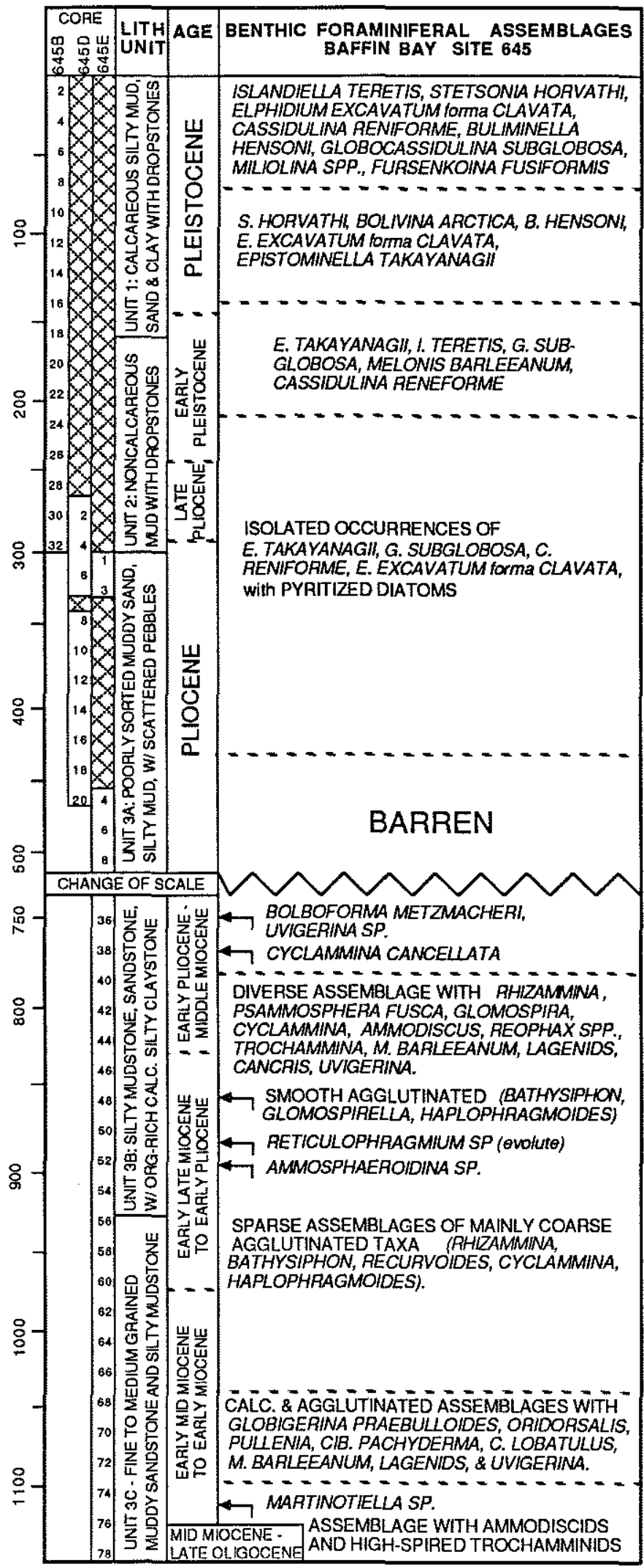

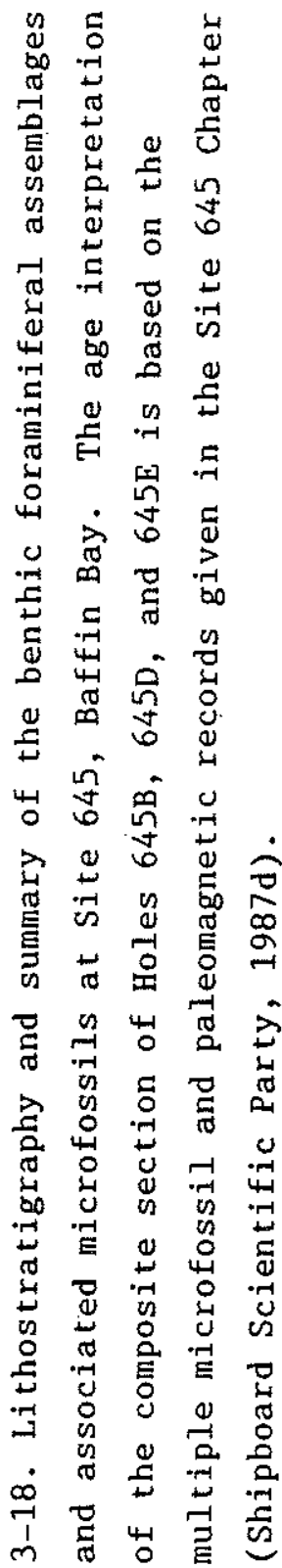


at some DSDP sites in the Norwegian-Greenland Sea (Leg 38 Site reports; Berggren and Schnitker, 1983). Agglutinated foraminifera are locally abundant to the base of Hole 645E. The assemblages consist mainly of coarse species of Rhizammina, Hyperammina, Cyclammina, Reophax, Lagenammina, Ammodiscus, Haplophragmoides, Glomospira, and Trochammina. Less frequently, specimens of Glomospirella, Ammosphaeroidina and Martinotiella are found, but many samples contain little more than unidentifiable fragments. Miocene assemblages of this type have only been reported previously from DSDP Site 348 in the Norwegian-Greenland Sea (Berggren and Schnitker, 1983).

The agglutinated assemblages between approximately 790 and $850 \mathrm{mbsf}$ (fxom Sample $40 \mathrm{R}, \mathrm{CC}$ to $46 \mathrm{R}-3,95-97 \mathrm{~cm}$ ) are dominated by coarse astrorhizids and hormosinids, mainly Rhizammina, Lagenammina and Reophax. Species with finely agglutinated tests become common in sample 49R, CC. Samples between 49R, CC, and 51R-1, 41-43 cm are dominated by finely agglutinated Bathysiphon fragments. Below this interval, the assemblages contain common specimens of Cyclammina cancellata, Recurvoides spp. and Haplophragmoides carinata. Also present is a compressed species of Reticulophragmium similar to a variety described from the Beaufort Sea (Young and McNeil, 1984) that I tentatively identify as R. cf. arctica. Near the base of Hole 645E, a change in the composition of the agglutinated assemblage is observed. The assemblage in sample 78R, CC is dominated by small species of Ammodiscus and Trochammina.

Calcareous benthic foraminifera were also found in samples 38R, CC to $46 \mathrm{R}-$ 3 , 95-97 cm. The dominant calcareous species in this interval is Melonis barleeanum. Unilocular species (Lagena, 0olina \& Fissurina) are common, and accessory forms include Globocassidulina subglobosa and species of Nodosaria, Quinqueloculina and Uvigerina. In the majority of samples, however, preservation of calcareous benthics is poor and only relatively robust specimens are present. Smaller individuals are presumably dissolved. Samples $48 \mathrm{R}-2,84-86 \mathrm{~cm}$ to $60 \mathrm{R}, \mathrm{CC}$ are barren of calcareous foraminifera.

Calcareous foraminifera are again encountered in isolated samples below about 975 mbsf $(60 \mathrm{R}, \mathrm{CC}$ to $77 \mathrm{R}-1,107-109 \mathrm{~cm})$. In this interal B. metzmacheri is absent, and the most common genus is Cibicidoides. The most diverse assemblage was found in sample $67 \mathrm{R}-2,89-91 \mathrm{~cm}$, which contains 0ridorsalis umbonatus, Pullenia bulloides, Cibicidoides pachyderma, C. 1obatulus, Uvigerina sp. (smooth), and four specimens of Globigerina praebulloides. Although the total range of G. praebulloides is from P22 to N18 (Kennett and 
Srinivasan, 1983), this species is restricted to lower to lower middle Miocene sediments in the North Sea (Zone NSP11 of King, 1983) and lower Miocene sediments on the Labrador Margin (Gradstein and Agterberg, 1982).

2. TEXACO BLUE H-28 WELL (Labrador Margin):

The Texaco Blue H-28 well was drilled in $1486 \mathrm{~m}$ of water on the northeastern Grand Banks near Orphan Knoll, and is one of the few commercial wells along the Canadian Atlantic Margin with a deep marine Miocene to Pliocene stratigraphic record. The well is situated near the present axis of the Western Boundary Undercurrent and was a site of rapid sedimentation in the late Neogene. The Cenozoic microfossil record reflects deposition in midbathyal water depths which this well has probably occupied since the late Cretaceous. The Neogene biostratigraphic record displays a four-fold division based on planktonic foraminiferal stratigraphy (Fig. 3-19). The foraminiferal assemblages are discussed from from oldest to youngest:

Middle Miocene sediments with Sphaeroidinella seminulina and Catapsydrax dissimilis occur between 3810 and $3640 \mathrm{~m}$, and immediately overly lower oligocene and older sediments. The middle Miocene benthic assemblage is rich in agglutinated species, including Bathysiphon, Rhizammina, Saccammina, Cystammina, Cyclammina placenta, Cyclammina pusilla, Cyclammina orbicularis, Cribrostomoides subglobosus, Karreriella conversa, and Sigmoilopsis schlumbergeri. This assemblage is remarkably similar to the assemblage from the upper Miocene to lower Pliocene Seismic Unit 3 of Hole 646B. Calcareous foraminifera that testify to the lower - middle bathyal environment are Laticarinina, Melonis pompilioides and Cibicidoides wuellerstorfi.

The upper Miocene (N16-N18) occurs between 3640 and $3160 \mathrm{~m}$. This interval contains the last ocurrences of Sigmoilopsis schlumbergeri, Neogloboquadrina humerosa-atlantica, N. acostaensis, N. continuosa, Globoquadrina dehiscens, and the G. menardii group. A diverse agglutinated assemblage similar to the one mentioned above occurs between 3200 and $3500 \mathrm{~m}$.

The lower/upper Pliocene boundary in this well was originally determined by the last occurrences of Neogloboquadrina atlantica and Globorotalia hirsuta near $2550 \mathrm{~m}$. However, Aksu and Kaminski (in press) report the LAD of $\mathrm{N}$. atlantica at $\sim 2.4 \mathrm{Ma}$ in the Labrador Sea. Therefore, the Lo of this species in exploration wells along the Labrador Margin may be a useful indicator of 
TEXACO BLUE H-28 WELL

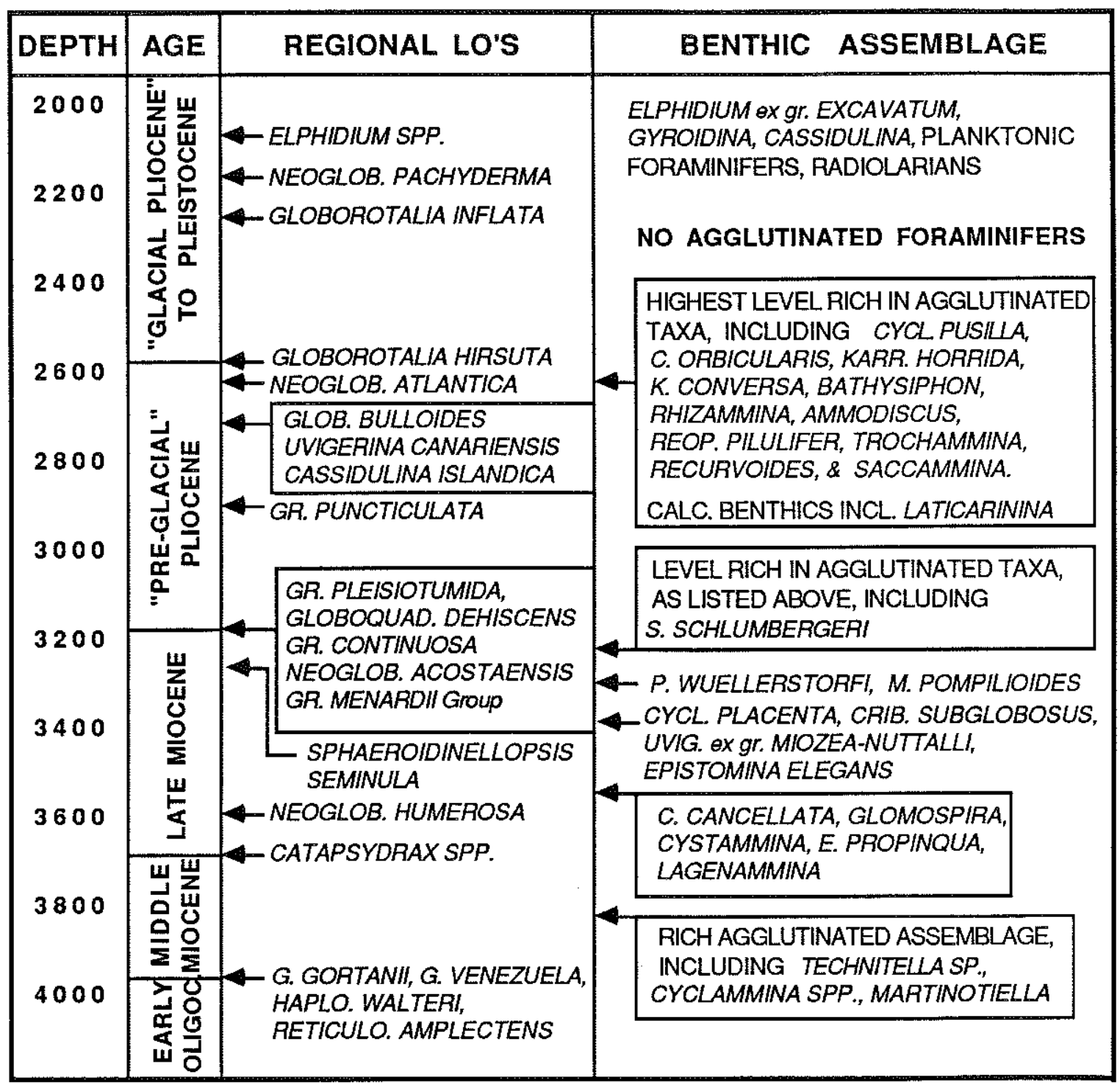

3-19. Biostratigraphic record of the Texaco Blue H-28 well, Labrador Margin. 
the pre-glacial Pliocene. Another useful LO in this well is Gr. puncticulata, which has a LAD at $3.8 \mathrm{Ma}$ in Hole 646B (Aksu and Kaminski, in press). Through much of the Pliocene, the benthic foraminifera are represented by calcareous taxa such as Elphidium, Gyroidina, Cassidulina, Uvigerina, and Laticarinina. However, an assemblage rich in coarse agglutinated species similar to those mentioned above occurs at $2600 \mathrm{~m}$.

ZONATIONS BASED ON AGGLUTINATED FORAMINIFERA:

Agglutinated foraminifera have now been used to define regional zonations for the lower Tertiary in the North Sea, Norwegian-Greenland Sea, Beaufort Sea, on the Labrador Margin, as well as in the Polish Flysch Carpathians (Verdenius and Van Hinte, 1983; Gradstein and Agterberg, 1982; Geroch and Nowak, 1984; Gradstein et al., in press; Mjatliuk, 1970; Miller et al., 1982; King (1983); Young and McNeil, 1984; Kaminski et al., in press, d). A compilation of regional zonations based primarily on agglutinated foraminifera is presented in Figure 3-20. To date, only the zonation of Geroch and Nowak (1984) has been used on a wider scale. This zonation, based on Carpathian material, can be successfully applied in other areas of the Tethys such as the Austrian Alps and the Rif-Betic Flysch (W. Kuhnt, personal communication 1986). This demonstrates the usefulness of agglutinated foraminifera for interregional, or at least intra-tethyan correlation. Correlative extinction events among agglutinated benthic foraminifera have been identified in the North Sea, Labrador Sea and Trinidad (Gradstein, 1983; Kaminski et al., in press, a). However in all the regions mentioned above, the task of correlating these zonations to a standard geochronology has been a problem owing to the paucity of calcareous microfossils and lack of magnetic reversal information. The biochronology of Hole $647 \mathrm{~A}$, therefore, may serve as a key for correlating the benthic foraminiferal stratigraphy of the Labrador Margin to the Norwegian-Greenland Sea and North Sea.

The Paleogene Norwegian-Greenland Sea zonation of Verdenius and Van Hinte (1983) was based upon DSDP Samples collected aboard Leg 38. The Eocene/0ligocene boundary in the Leg 38 sites was recognized using the last occurrences of Spiroplectammina spectabilis and/or Reticulophragmium amplectens. Their use of these taxa as Eocene marker species was based on analogies with the Polish Carpathians (Grzybowski, 1898) and the Eocene of 


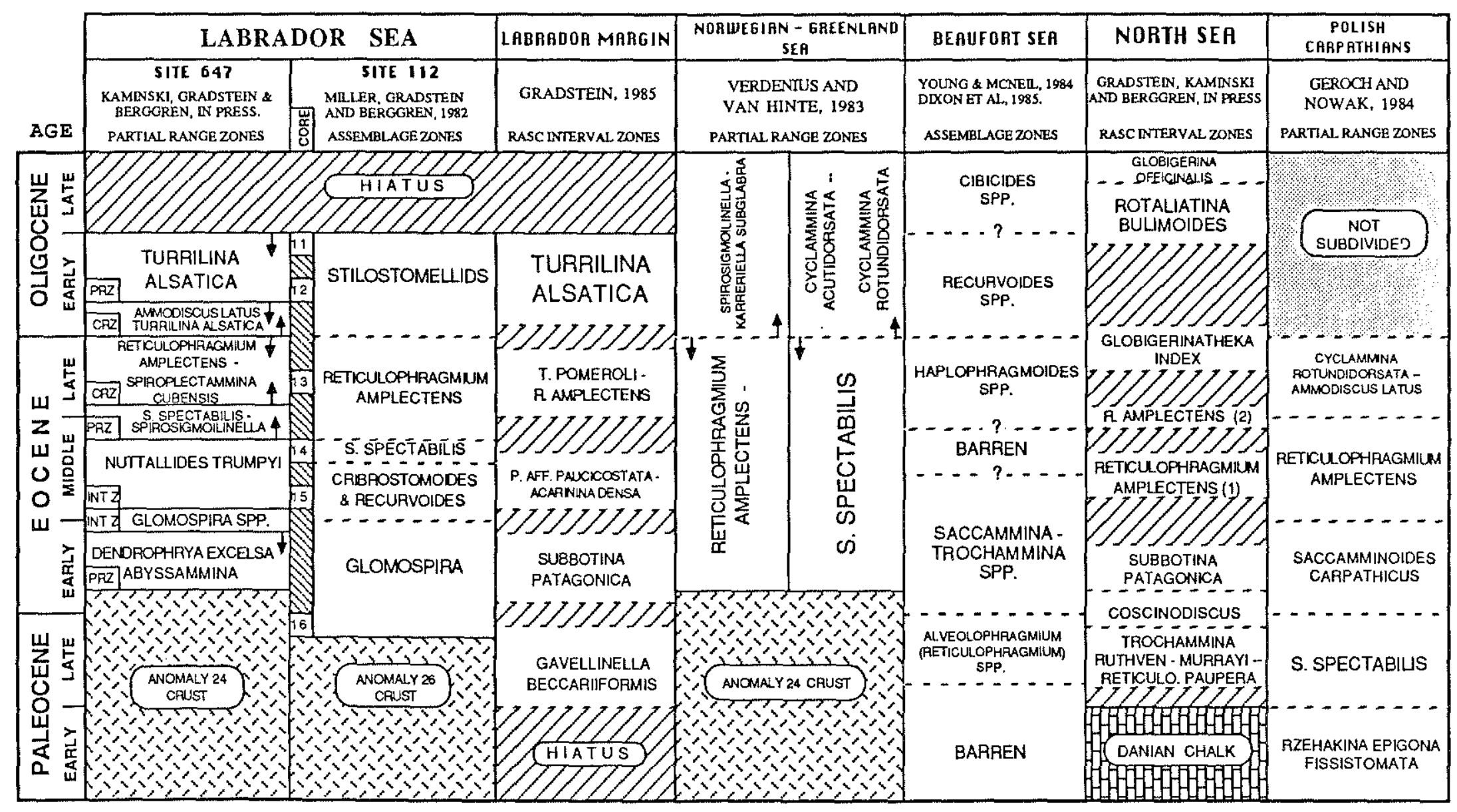

3-20. Comparison of Paleogene zonal classifications in areas containing flysch-type assemblages. Correlation of Sites 112 and 647 is from Kaminski et al., in press, d. Zonal boundaries that have not been tied to a standard geochronology (Berggren et al., 1985) are indicated by dashed lines. The Labrador Margin and North Sea RASC zonations have been scaled against linear time (after Gradstein, 1987) to show the position of stratigraphic breaks. 
Belgium (Kaaschieter, 1961). However in the Leg 38 samples, calibration of ranges of these taxa to a standard planktonic microfossil chronology was tentative. In Hole $647 \mathrm{~A}$, the last occurrence of both taxa was found just 30 $\mathrm{cm}$ below the position of the Eocene/0ligocene boundary predicted by the agedepth model.

The biostratigraphy of agglutinated foraminifera in 29 wells from the Central and Viking Grabens was studied by Gradstein et al. (in press). This zonation based on RASC is very robust and precise in a relative sense, but the chronostratigraphy of benthic foraminiferal datums in the North Sea is still not well established because of the paucity of planktonic foraminifera in most wells. The presence of ash layers and three incursions of planktonic foraminifera provide tie points in the zonation, but it is not possible to recognize or assign standard "P Zones" in the North Sea. This problem can be circumvented, however, by the use of local palynomorph zones.

Both the North Sea zonation and the Labrador Margin zonation are made up of RASC interval "zones" based on clusters of last occurrences of taxa in exploration wells. The RASC biozones are named after characteristic species which most likely have their last occurrences in the interval, but not necessarily at the top of that interval. Therefore, RASC "zones" reflect the average ranges of taxa, and may differ conceptually from traditional zonations based on maximum ranges of taxa in a given interval. When a RASC optimum sequence is scaled in linear time by the identification of microfossil datum events, "missing intervals" of time become apparent. In the Paleogene Labrador Margin and North Sea zonations, the missing intervals correspond to hiatuses caused by basinward shifts in shoreline (Gradstein, 1987). Reviews of the methodology used in constructing and interpreting RASC zonations can be found in Gradstein et al. (1985), D'Iorio (1986), Gradstein (1987) and Williamson (1987).

\section{Correlation of Holes $647 \mathrm{~A}$ and 112}

Site 112 is located approximately $90 \mathrm{~km}$ northwest of Site 647, and until now constituted the only reference section for the abyssal Paleogene in the Labrador Sea. A total of 6 cores containing Paleogene sediments were recovered from this site, and preliminary stratigraphic analysis was carried out by Berggren (1972), Perch-Nielsen (1972) and Bukry (1972). Unfortunately, the Eocene/01igocene boundary and the position of subsurface seismic 
reflectors at this site are represented by coring gaps. The foraminiferal and nannofossil. stratigraphy of Hole 112 was restudied by Miller, Gradstein, Berggren and Aubry (in Miller et al., 1982), who were able to correlate Cores $12 \mathrm{R}$ to $15 \mathrm{R}$ with standard planktonic microfossil zonations (Table $3-5$ ).

Table 3-5. Age of Paleogene cores from Hole 112 (from Miller et al., 1982):

\begin{tabular}{|c|c|c|}
\hline Core & Nannofossil zone & Planktonic zone \\
\hline $12 \mathrm{R}$ & NP22 & not diagnostic \\
\hline $13 \mathrm{R}$ & NP19 & $\mathrm{P} 15-\mathrm{P} 16$ \\
\hline $14 \mathrm{R}$ & NP17 & not older than $\mathrm{P} 14$ \\
\hline $15 R$ & NP14 & P10 \\
\hline $16 \mathrm{R}$ & barren & barren \\
\hline
\end{tabular}

For this study, I examined benthic foraminiferal assemblages from Hole 112 to correlate the position of individual cores from this site with Hole $647 \mathrm{~A}$ (Fig. 3-20).

Core $112-11 R$ contains a calcareous benthic assemblage belonging to the Turrilina alsatica Assemblage in Hole 647A. The diverse nature of the fauna and good preservation present in $112-11 \mathrm{R}-2,103-106 \mathrm{~cm}$ is comparable only to the assemblages above the siliceous sediments of Lithologic Unit IIIb in Hole 647A. The composition of the assemblage compares best with assemblages from Core $17 \mathrm{R}$ of Hole $647 \mathrm{~A}$.

Sample $112-12 \mathrm{R}-1,44-46 \mathrm{~cm}$ contains a planktonic assemblage with Chiloguembelina, Pseudohastigerina, and Bolboforma irregularis. In Hole 647A, the last occurrences of Chiloguembelina and $B$. irregularis were found in Sample 27R-1, 78-85 cm. However, the only flysch-type agglutinated species present in Sample 112-12R-1, 44-46 cm is Rhabdammina $\mathrm{sp}$. The lack of Ammodiscus latus and Glomospira charoides in this sample indicates that it belongs in the Turrilina alsatica Assemblage. The assemblage in this sample probably correlates with the unsampled interval between Cores $25 \mathrm{R}$ and $27 \mathrm{R}$ in Hole 647A.

Two samples from Core 112-13R were examined for benthic foraminifera (Samples 112-13R-3, 118-122 cm and 13R-5, 120-124 cm). Both samples contain 
Ammosphaeroidina and Karreriella coniformis, which suggests that Core 13R correlates with the lower half of our R. amplectens Assemblage. The position of the assemblage with regard to Hole $647 \mathrm{~A}$ can be further constrained by the absence of $\mathrm{N}$. truempyi, and the low abundance of Spiroplectammina spectabilis. This assemblage compares well with assemblages from Cores $36 \mathrm{R}$ to $40 \mathrm{R}$ of Hole 647A.

Cores $112-14 R$ and $-15 R$ correlate with our Nuttallides truempyi Assemblage. In Core 112-14R, I did not find any specimens of Spirosigmoilinella compressa in the two samples examined in this study (Samples 112-14R-2, 100-104 cm and $112-14 \mathrm{R}-3,113-114 \mathrm{~cm}$ ) but its presence is reported by Miller et al., (1982) from a single sample. In the Spirosigmoilinella - S. spectabilis Assemblage of Hole 647A, however, the occurrence of Spirosigmoilinella is continuous (see Appendix). The assemblage from Core 112-14R contains $S$. spectabilis perplexa, Reticulophragmium sp. (evolute), and abundant N. truempyi. In addition, the abundance of S. spectabilis S.1. in our samples from Core 14R does not exceed 6 percent. This suggests a better correlation with our N. truempyi Assemblage. Although Miller et al. (1982) refer the agglutinated component of this core to a "Spiroplectammina spectabilis assemblage", this assemblage does not correlate with our Spirosigmoilinella - S. spectabilis Assemblage (Fig. 320). Core 112-15R belongs in nannofossil Zone NP14 (Miller et al., 1982), and contains poorly preserved calcareous benthics that are overgrown with pyrite in a manner analogous to assemblages from Samples $647 \mathrm{~A}-56 \mathrm{R}, \mathrm{CC}$ and $-58 \mathrm{R}, \mathrm{CC}$. The assemblage in Core 112-15R contains Ammodiscus nagyi, but none of the other species typical of the lower Eocene of Hole 647A (see Fig. 3-17).

The basal core of Hole 112 was cut approximately $10 \mathrm{~m}$ above basement, which at this site was formed near the boundary between the reversed and normal interval of Chron 26. The indurated red claystones overlying basement are barren of calcareous microfossils. On the Labrador Margin, the Paleocene/Eocene boundary is determined by the last occurrences of Stensioina beccarifformis, Rzehakina epigona, and rare Planorotalites chapmani. However, R. epigona persists into the lower Eocene in the abyssal western North Atlantic (Tjalsma and Lohmann, 1983). Other species restricted to the Paleocene on the Labrador Margin are Hormosina ovulum, Hormosina excelsa, Saccammina placenta, Tappanina selmensis, and rare Danian planktonics (Subbotina pseudobulloides, S. triloculinoides, Planorotalites compressus). 
In Sample 112-16R-1, 85-87 cm, I found specimens of Hormosina, but these persist into the lower Eocene of Hole 647A. This sample also contains $R$. epigona, Labrospira pacifica and S. placenta, species which do not occur in Hole 647A. In Trinidad and in the North Sea, Labrospira does not occur above the Paleocene. I therefore favor a Paleocene age assignment for Core 112-16R.

\section{Correlation of Hole 647A with the Labrador Margin -}

The benthic foraminiferal assemblages from Hole $647 \mathrm{~A}$ and the Labrador Margin display differences related to paleobathymetry and depositional setting. The Eocene-0ligocene Labrador Margin sequences were deposited in an outer neritic to upper bathyal clastic environment, and abyssal taxa are absent from the benthic foraminiferal assemblages. Faunal diversity in exploration well samples from the Labrador Margin is noticeably lower than at Site 647 , but a number of important benthic foraminifera occur in both regions, including Turrilina alsatica, Rhabdammina spp., Ammodiscus latus, A. cretaceus, Reticulophragmium amplectens, R. placenta, Haplophragmoides walteri, Ammosphaeroidina sp., Reophax pilulifer, Karreriella conversa, $\underline{\mathrm{K}}$. horrida, Spiroplectammina spectabilis, S. navarroana, Ammobaculites aff. polythalamus, Glomospira charoides, Trochamminoides spp., and Hormosina ovulum. Relatively few species of calcareous foraminifera are present in the Labrador Margin assemblages, and these are represented mainly by neritic to upper bathyal species of Nodosaria, Lenticulina, Plectofrondicularia, Cibicidoides, and uvigerinids. With the exception of T. alsatica, none of the middle Eocene - Oligocene calcareous species typical of the Labrador Margin were found in Hole 647A. In the lower Eocene, a few of the more offshore wells contain deep-water calcareous species, including Nuttallides truempyi.

Figure 3-21 presents Paleogene RASC benthic foraminiferal zones and important benthic taxa in 7 wells aligned from south (Adolphus D-50) to north (Karlsefni A-13) on the Labrador Margin. In these wells, several benthic foraminifera possess the same relative order of last occurrence events. The

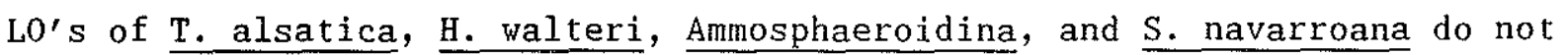
cross over one another. The Lo of Ammodiscus latus, however appears to be variable with respect to T. alsatica. In the Bonavista C-99 and South Labrador N-79 wells A.latus was found above T. alsatica, but this may be an 


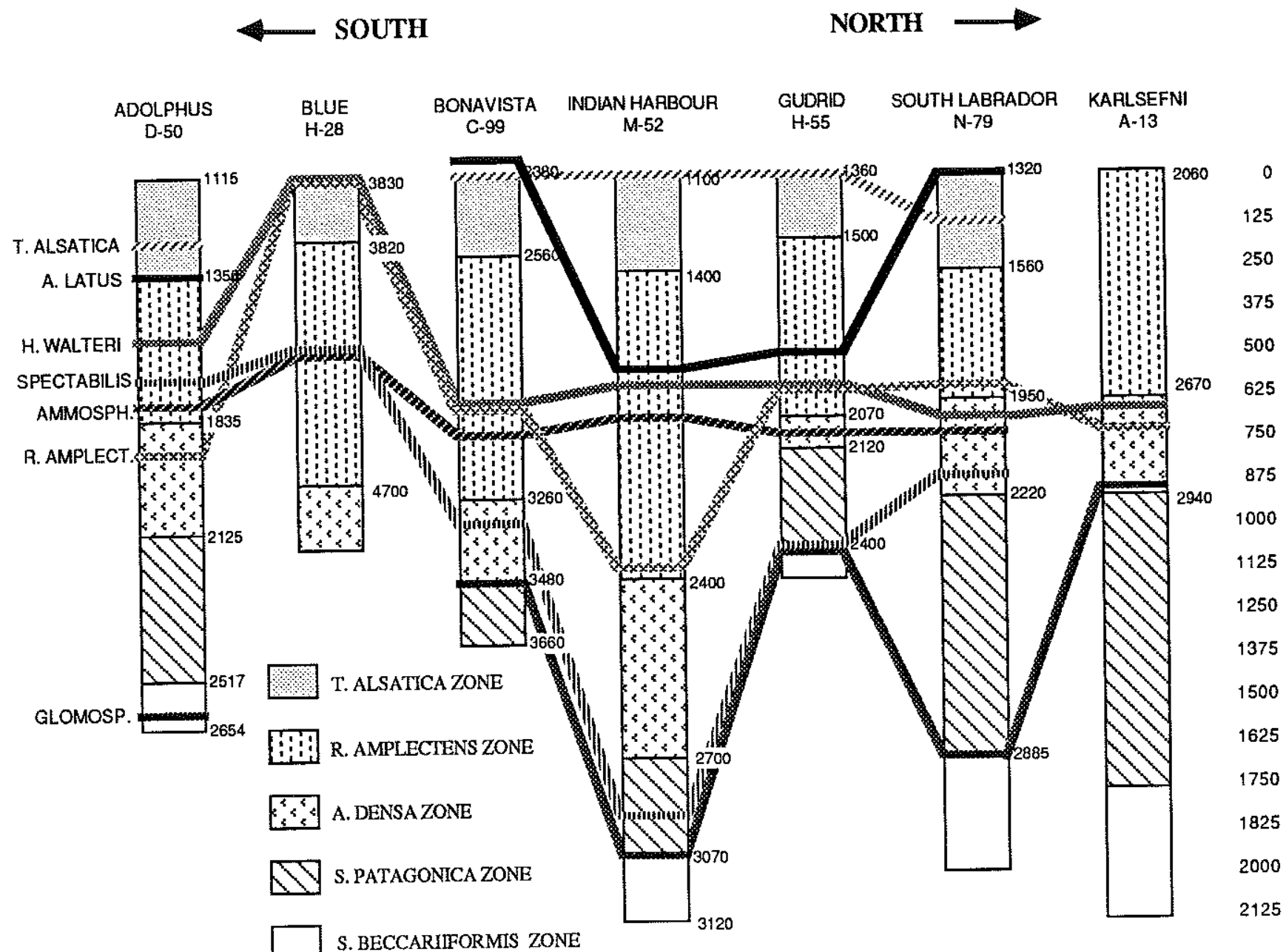

3-21. Important benthic foraminiferal last occurrences in 7 exploration wells on the Labrador Margin. Depth scale on right is thickness of Paleogene sediments (in meters). 
artifact of sampling. T. alsatica is often a rare species on the Labrador Margin. Reticulophragmiumm amplectens displays a high cross-over frequency

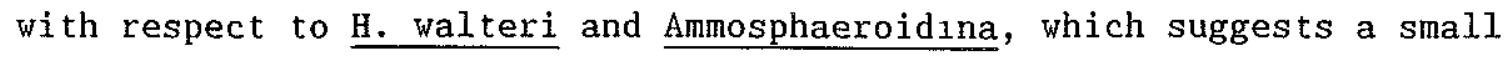
interfossil distance between them. However, this species appears to intergrade with $\underline{R}$. placenta in the younger portion of its stratigraphic range, so determining its true LO is sometimes subjective. The $\mathrm{LO}^{\prime} \mathrm{S}$ of $\mathrm{S}$. spectabilis and Glomospira extend to youngest levels in the southern Adolphus D-50 and Blue H-28 wells, but this may be due to the deeper paleobathymetry of these wells. These species are present at younger levels in deeper assemblages.

The probabilistic optimum sequence of microfossil last occurrences on the Labrador Margin and northern Grand Banks is shown in Eigure 3-22. This is an ordering based on the average position of last occurrences occurring in at least 7 of the 23 wells studied. of the 35 Paleogene last occurrences recorded on the Labrador Margin, 15 were also present in Hole 647A. These last occurrences are listed across the top of figure 3-22, in a manner analogous to a bivariate scatter plot. The probabilistic last occurrence of Turrilina alsatica is used to identify the top of the Paleogene sequence on the Labrador Margin. However, the true upper range limit of this event in Hole $647 \mathrm{~A}$ is most likely truncated by the barren interval and hiatus above Core 17R. Microfossil events that extend to younger stratigraphic levels in Hole 647A than on the Labrador Margin plot below a best-fit line between the points.

The most noticeable difference between the Labrador Margin and deep Labrador Sea last occurrences is the stratigraphic range of Glomospira charoides (number 56 in Fig. 3-22). This is a long ranging taxon that is present in the modern North Atlantic. Its local last occurrence is usually associated with the Paleocene/Eocene boundary on the Labrador Margin and in the southern North Sea, but the taxon extends to the top of the Ammodiscus latus - Turrilina alsatica Assemblage (lower 0ligocene) in Hole 647A. Spiroplectammina spectabilis has its last occurrence earlier on the Labrador Margin than in Hole $647 \mathrm{~A}$, as mentioned above. The planktonic species Pseudohastigerina micra also extends to younger levels in Hole 647A, but this may be a function of poorer preservation of calcareous microfossils or the larger sieve size used to process samples from exploration wells. The 


\section{COMPARISON OF LAST OCCURRENCE EVENTS}

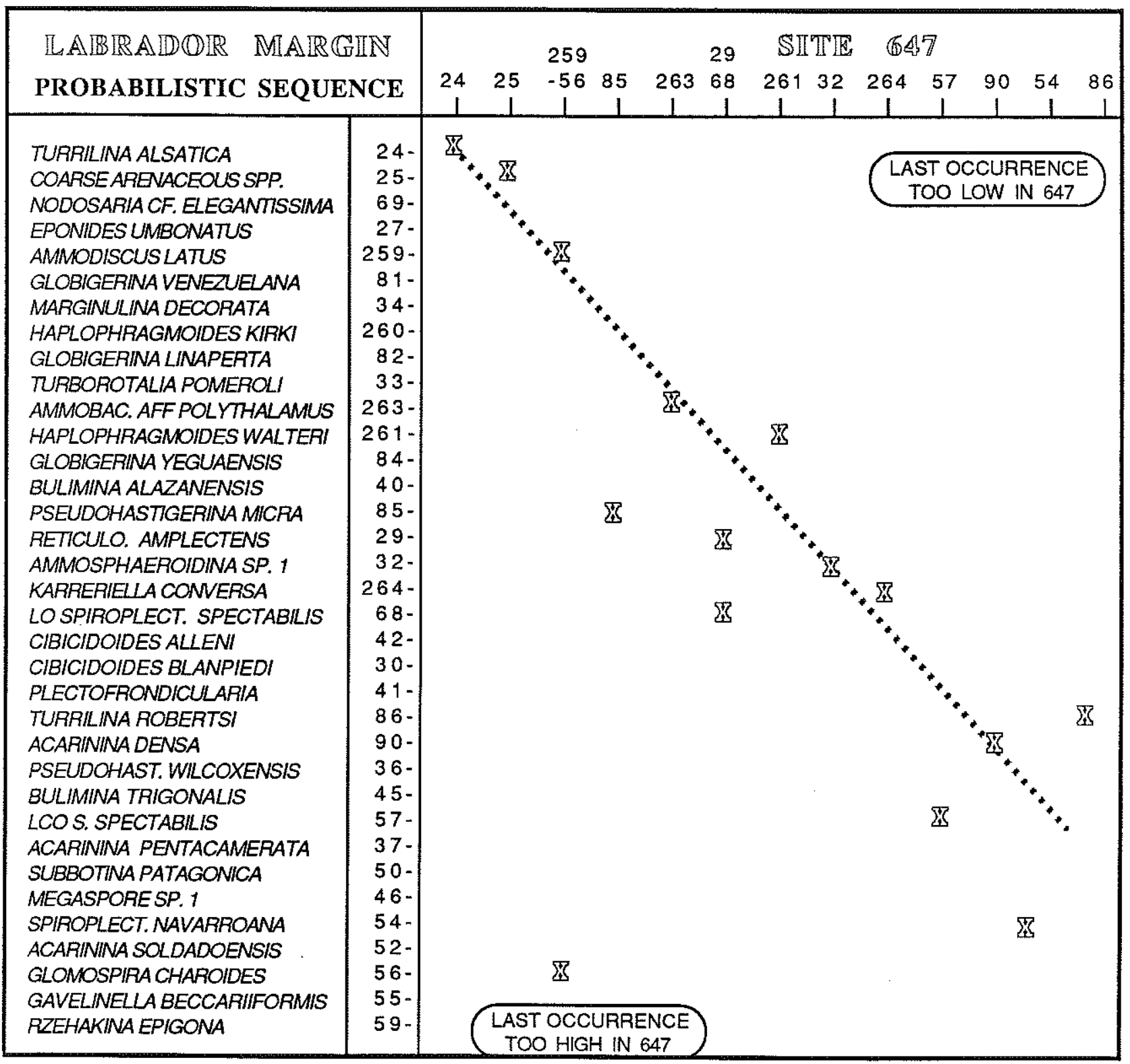

3-22. Comparison of microfossil last occurrences in common between the probabilistic Labrador Margin optimum sequence and Site 647. Numbers across the top of the scatterplot are the dictionary numbers assigned to each taxon. Dashed line is the best-fit line between the points. 
extinction of P. micra, nevertheless occurs about $2 \mathrm{~m} . \mathrm{y}$. earlier in the Labrador Sea than in low-latitude sites, and therefore cannot be used as a reliable planktonic datum event in high latitudes.

of the benthic microfossil last occurrences in figure 3-22, only A. latus, Ammobaculites aff. polythalamus, Ammosphaeroidina sp 1, and Karreriella conversa plot close to a best-fit line. This suggests that these taxa are isobathyal and that their last occurrences can be used for correlation at different paleodepths.

\section{Correlation of Hole 643A with the North Sea Probabilistic Zonation:}

The probabilistic sequence of Gradstein, et al. (in press) was based on the local disappearance levels of 60 agglutinated taxa in 29 wells in the central North Sea. The RASC zonation (using a threshold value $K_{c} \geq 8$ ) identified 25 species of agglutinated foraminifera as possessing regional stratigraphic value. Twelve of these 25 potentially useful species were found in the Paleogene section of Norwegian-Greenland Sea Site 643A. A graphic comparison of the microfossil events in common between Hole $643 \mathrm{~A}$ and the North Sea microfossil optimum sequence is given in figure 3-23.

Although a line can be drawn through the majority of points, there are two notable outliers. The LO's of Karreriella conversa and Spiroplectammina spectabilis occur earlier in Hole 643A than their average position in the North Sea. In Hole 634A, the LO's of both species are in the lower Eocene. On the Voring Plateau, S. spectabilis is found in what Verdenius and Van Hinte termed a "poor association" characterized by low diversity. At Sites 338 and $643 \mathrm{~A}$ this species occurs in nearly monospecific assemblages which may have been deposited in a relatively shallow paleobathymetric setting.

The calibration of the Hole 643A microfossil sequence to a standard chronology is still tentative. The benthic foraminiferal events and lithologic tie-points cannot be assumed to be isochronous between the North Sea and Norwegian-Greenland Sea. Lithologic markers, such as the occurrence of reddish sediments and tuff may likewise be diachronous. The highest occurrence of abundant tuff was observed in Core 643A-51X. This event . correlates with Anomaly 24 in the North Sea, but since volcanic activity continued to younger levels in the Norwegian-Greenland Sea the occurrence of tuff at Site 643A may be diachronous. A late Ypresian age for Core 57X in 


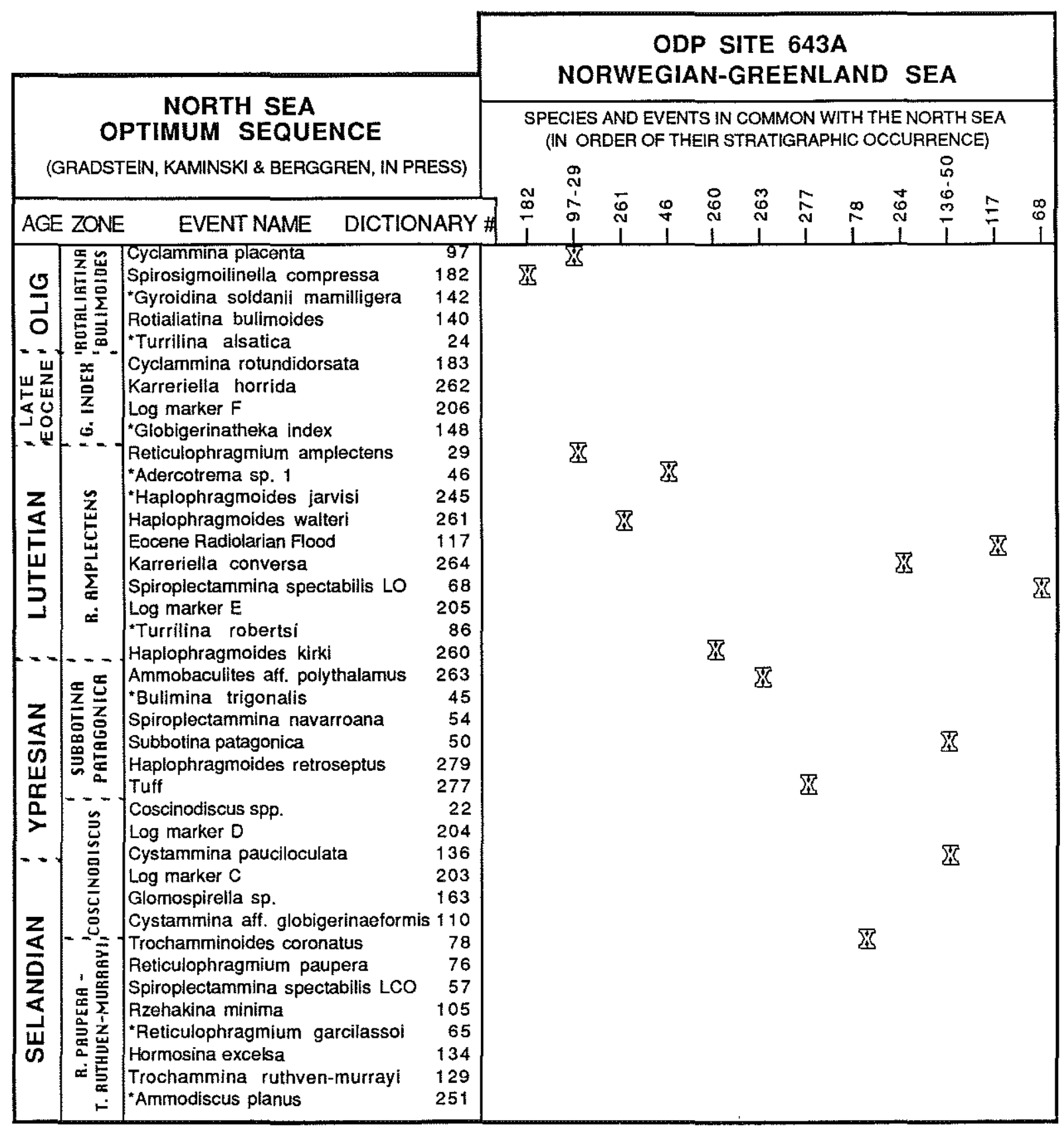

3-23. Comparison of microfossil last occurrences in common between the probabilistic North Sea optimum sequence of Gradstein et al. (in press) and Site 647. Numbers across the top of the scatterplot are the dictionary numbers assigned to each taxon. 
indicated by a dinocyst assemblage containing Wetzeliella hormeomorpha and Homotryblium spp. (Shipboard Scientific Party, 1987b).

A planktonic microfossil event which may have correlative value between the Voring Plateau and North Sea is the "Eocene Radiolarian Flood", which corresponds to the lower Lutetian in the North Sea. In Hole 643A, the top of the interval containing abundant radiolarians occurs in Core 53R. The occurrence of common Glomospira in Core 52R gives supporting evidence for this age assignment.

The sediments in Core $46 \mathrm{X}$ are no older than upper Eocene, based on the F0 of Spirosigmoilinella compressa which is assumed to be isochronous with the North Sea. The most significant turnover in benthic foraminifera occurs in Core $44 \mathrm{X}$, where the LO'S of 7 species were found. Since the LO'S of $\mathrm{H}$. walteri and Adercotrema sp. 1 occur in the upper Eocene in the North Sea, Core 44X may still be of Eocene age. Shipboard nannofossil stratigraphy places Core 43X in upper 0ligocene zone NP25, which suggests a hiatus or condensed section may be present. If this is the case, the LO of $\underline{R}$. amplectens in Core $42 \mathrm{X}$ is anomalously young in comparison to the North Sea biostratigraphy.

\section{STRATIGRAPHIC UTILITY OF AGGLUTINATED FORAMINIFERA:}

\section{A. Paleocene:}

Several species of agglutinated foraminifera appear to be stratigraphically useful and have correlative first or last occurrence levels in different basins in the North Atlantic or Tethys. Taxa with similar stratigraphic ranges have now been observed in Trinidad, Zumaya, the Labrador Margin, North Sea and the Polish Carpathians. The Paleocene/Eocene boundary in most areas is noted by the extinction of a number of agglutinated taxa, but there are fewer distinctive evolutionary events within the Paleocene.

Several species have their LO's near the top of the Paleocene in the areas studied. These are Glomospira diffundens, Hormosina ovulum ovulum, Rzehakina epigona epigona, Rzehakina minima, and Trochammina ruthven-murrayi. The distinctive conical form, Trochammina ruthven-murrayi appears to be a Paleocene index species in all regions except Zumaya, where it was not found. It has a probabilistic last occurrence beneath the Paleocene/Eocene tuff marker in the North Sea (Gradstein et al., in press). In Trinidad this species ranges into Zone $\mathrm{P5}$, and it has now been found in the Paleocene interval of wells along the Labrador Margin. 
The species Hormosina excelsa is restricted to the Paleocene in the North Sea and on the Labrador Margin. However, Morgiel and Olszewska (1982) found this species ranging into the lower Eocene in the Tanger Unit of the Rif Mountains in Morocco. A smaller but morphologically similar form identified as Hormosina cf. excelsa was found in the lower Eocene of Hole 647A. The

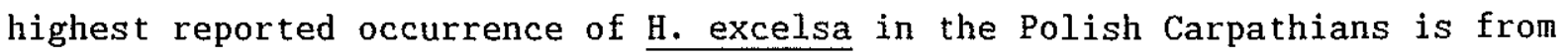
Zone NP12 of the lower Hieroglyphic Beds in the Dukla Unit (01szewska and Smagowicz, 1977). The report of this species from the Eocene of the Norwegian-Greenland Sea (Verdenius and Van Hinte, 1983) is based on a misidentification.

In the probabilistic zonation of the Labrador Shelf (Gradstein and

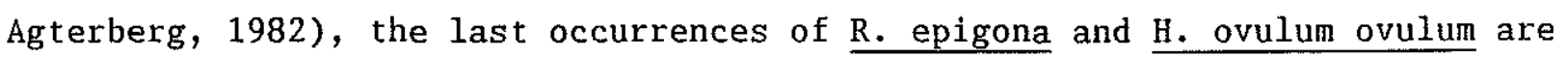
closely associated with the last occurrence of $\mathrm{S}$. beccarifformis, which in Atlantic DSDP Sites occurs near the P5/P6 boundary (Tjalsma and Lohmann, 1983). H. ovulum ovulum is therefore useful for determining the Paleocene/Eocene boundary in bathyal assemblages, but this species ranges into younger levels at abyssal depths. Its last occurrence is in lower Eocene Zone NP12 at Site 647 (Kaminski et al., in press, d). A morphologically related species, Hormosina ovuloides, was found in the lower middle Eocene of Norwegian-Greenland Sea Site 643A.

Another example of coeval (at the resolution provided by planktonic foraminiferal zonations) benthic foraminiferal events is in the equatorial eastern Atlantic. A number of agglutinated species typical of the upper Paleocene in the Lizard Springs Formation of Trinidad, such as Trochammina ruthven-murrayi, Rzehakina epigona and Haplophragmoides jarvisi, possess extinction levels at equivalent stratigraphic positions in the Angola Basin (Serge Gofas, personal communication 1986).

One of the most prominent Paleocene lineages is the evolution of the first primitive Reticulophragmium from Haplophragmoides. Although the genus Reticulophragmium is probably polyphyletic, one particular lineage can be traced in the North Atlantic which may be useful for stratigraphy. The first occurrence of Haplophragmoides walteri (sensu stricto) is noted near the base of the Selandian in Trinidad and Poland. This species may have evolved from a species such as Haplophragmoides cf. glabra (from the Danian of Trinidad) by the addition of more chambers in the last whorl. In Zone $\mathrm{P} 4$, a morphotype of H. walteri began to acquire features which are transitional to 


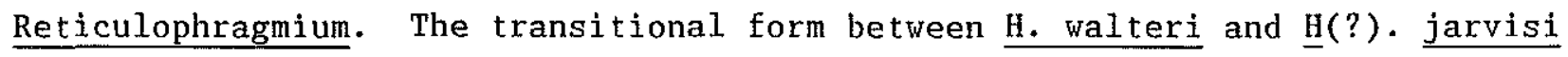
is found in Zone $\mathrm{P} 4$ in Trinidad and Zumaya. The first occurrence of $\underline{\mathrm{H}}(?)$ ). jarvisi is noted in Zone P5 in Trinidad. Near the top of the Paleocene in the Angola Basin, this species developed alveoles near its sutures.

The first primitive Reticulophragmium ( $R$. cf. garcilassoi), appeared in Zone $\mathrm{P} 4$ in Trinidad, but the phylogeny of this species is still uncertain.

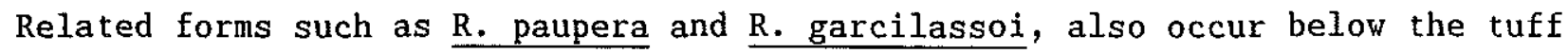
marker in the North Sea.

\section{B. Eocene --}

The species Reticulophragmium amplectens is perhaps the most distinctive Eocene species in North Atlantic and Tethyan flysch-type assemblages, and is used as a stratigraphic marker species in every zonal scheme (Fig. 3-20). Its total range is given as middle to upper Eocene in the Outer Carpathians (Geroch and Nowak, 1984). Its partial range and optimum occurrence characterizes the middle Eocene Cyclammina amplectens Zone of Geroch and Nowak (1984). In the North Sea, Gradstein et al. (in press) define a middle to upper Eocene R. amplectens RASC interval zone based on the partial range of this species. In this region, it is reported to range from the lower Eocene to the Eocene/0ligocene boundary, with possible occurrences in the lower 0ligocene. On the Labrador Margin, Gradstein (1985) defines an upper Eocene Turborotalia pomeroli - R. amplectens RASC interval zone. The total range of this species was given as lower to upper Eocene by Miller et al. (1982).

The relative abundance record of $\mathrm{R}$. amplectens in Hole $647 \mathrm{~A}$ is shown in figure 3-16. The first occurrence of this taxon was found in the upper part

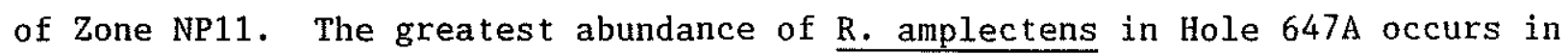
the middle Eocene. In this respect its occurrence displays similarities with the Carpathian assemblages. The last occurrence of this species at $36.6 \mathrm{Ma}$ indicates that it is a reliable indicator of the Eocene/0ligocene boundary in the deep Labrador Sea.

The Karreriella horrida-conversa-coniformis group may also have regional. stratigraphic importance in the Eocene, but more detailed taxonomic work is required on these species. The species Karreriella coniformis has a first occurrence near the base of the Eocene in both Trinidad and Poland. This species is also present at the base of Hole 647A (Zone NN11), but does not occur in the Paleocene in Labrador Margin wells. The last occurrence of $\mathrm{K}$. 
conversa is a useful middle Eocene event in the North Sea and Labrador Sea, but this species ranges to the Eocene/0ligocene boundary in the Carpathians and is found living today in the North Atlantic.

The utility of Spiroplectammina spectabilis as an indicator of the Eocene/Oligocene boundary is probably restricted to abyssal assemblages in the open North Atlantic, but this species also occurs at anomalously shallow paleodepths on the Vøring Plateau. In the North Sea and Labrador Margin, the Eocene sequences display a series of last occurrences of flysch-type taxa which mainly refect the shallowing of the basins as sediment supply exceeded tectonic subsidence. Spiroplectammina spectabilis disappears from the Labrador Margin in the lower Eocene, but persists at Site 647 and the deep Norwegian-Greenland Sea until the Eocene/Oligocene boundary. Interestingly enough, in the North Sea $\mathrm{S}$. spectabilis has a diachronous last occurrence in wells aligned from south to north along the axis of the basin (Gradstein et al., in press).

Upper Eocene assemblages in the North Sea, Poland, and on the Labrador Margin contain the species Ammodiscus latus and Cyclammina rotundidorsata. In the Carpathians, the partial range of the former and the total range of the latter are used to define an upper Eocene zone (Fig. 3-20). Neither of these species, however, is present in the deep Norwegian-Greenland Sea. Cyclammina rotundidorsata was reported by Verdenius and Van Hinte (1983) from the 0ligocene of Site 345 and the Miocene of Site 348 , but the specimen illustrated by them is not typical of the species, and may have been misidentified. Ammodiscus latus (sensu lato) occurs in both bathyal and abyssal assemblages in the Labrador Sea. The abyssal variety is noticeably smaller than the bathyal variety, and because of this Miller et al. (1982) recorded its occurrence at Site 112 as Ammodiscus rugosus Schijfsma, following Krasheninnikov and Pflaumann (1977). However, A. rugosus is an upper Cretaceous species known from the epicontinental deposits of Europe (Schijfsma, 1946) and possibly from Site 367 off Morocco (Krasheninnikov and Pflaumann, 1977). Because of the restricted stratigraphic occurrence of the "rugose" Ammodiscus in Hole 647A, I believe that this species is a deep-water ecophenotype of A. latus. The Fo of A. latus was determined at $44.6 \mathrm{Ma}$ in Hole 647A. This agrees with the findings of Morgiel and 0lszewska (1981), who report its FO in the upper middle Eocene in the Polish Carpathians. 
C. Oligocene --

The 0ligocene of Norwegian-Greenland Sea sites contains Spirosigmoilinella, which was used by Verdenius and Van Hinte (1983) as a zonal indicator. At Site 338 on the Voring Plateau, Spirosigmoilinella is not observed below the last occurrence of $\mathrm{S}$. spectabilis, or below the last occurrence of $\mathrm{R}$. amplectens at Site 345 in the Lofoten Basin. These species were used to determine the Eocene/01igocene boundary in the Leg 38 Norwegian-Greenland Sea Sites (Verdenius and Van Hinte, 1983), and both range to the top of the Eocene at Site 647. The data from Site 643, however, indicate that the ranges of $\mathrm{R}$. amplectens and Spirosigmoilinella sp. overlap. This suggests that the zonation of Verdenius and Van Hinte (1983) may only be applicable to bathymetrically shallower sites, such as Site 338 .

Another event which serves as a correlation horizon in the Labrador Sea is the LO of Ammodiscus latus. In the Polish Carpathians, type area of this species, its stratigraphic range is truncated by the latest Eocene Globigerina Marls. However in Hole 647A, its LO was determined to occur at $35.5 \mathrm{Ma}$. The finding of the Lo of $\underline{A}$. latus above the last occurrence of $\underline{R}$. amplectens in Hole $647 \mathrm{~A}$ agrees with the relative position of these taxa on the Labrador and northern Grand Banks margins (Fig. 3-21).

CONCLUSIONS :

The biostratigraphy of agglutinated foraminifera in the North Atlantic region is based upon examination of core samples from Trinidad, the North Sea, ODP Sites 643A, 645, 646 and 647 and from outcrop sections near Zumaya, Spain. Stratigraphic ranges of 81 agglutinated taxa are reported from the upper Campanian to lower Eocene of Trinidad; 64 taxa are reported in the Danian to Ypresian sediments of Zumaya Spain; 26 agglutinated taxa are reported from the 29 well data base of Gradstein et al. (in press) from the Cenozoic of the North Sea; 50 taxa are given from the lower Eocene to upper 0ligocene of ODP Site 643, and 49 agglutinated taxa are reported from the lower Eocene to lower oligocene of site 647 .

In the Guayaguayare and Lizard Springs Formations of Trinidad, faunal turnovers are observed near the Cretaceous/Tertiary boundary and near the Paleocene/Eocene boundary. The FO's of species such as Glomospira irregularis, Glomospira serpens, Kalamopsis grzybowskii, Hormosina ovulum, 
Recurvoides imperfectus, Labrospira pacifica near the base of the Danian in Trinidad probably reflects increasing paleo-water depths owing to subsidence of the basin. The Paleocene/Eocene faunal turnover observed in Trinidad and Zumaya is characterized by the LO's of calcareous ataxophragmiids and many of the typically deep-water taxa. This turnover is a result of both evolutionary turnover and shoaling paleodepths in both basins.

In the high-latitude slope basins such as the Labrador Margin and North Sea, faunal turnovers are associated with the Paleocene/Eocene and Eocene/0ligocene boundaries. The species Glomospira diffundens, Rzehakina epigona, Trochammina ruthven-murrayi, Matanzia varians and Hormosina ovulum are restricted to the Paleocene in the areas studied. Distinctive taxa with Eocene Fo's are Reticulophragmium amplectens, Karreriella coniformis, Ammodiscus latus and Cyclammina rotundidorsata. The Eocene/0ligocene turnover is ascribed to shoaling paleodepths as sedimentation exceeded subsidence in these basins, a trend which is accentuated by lowered sealevel in the basal oligocene.

The recovery of a continuous section of lower Eocene to lower 0ligocene sediments at Site 647 and the establishment of a multiple planktonic microfossil biochronology allows us to correlate the benthic foraminiferal biostratigraphy to a standard time scale. Seven assemblages of benthic foraminifera were defined in Hole $647 \mathrm{~A}$ based on the stratigraphic ranges of important taxa. This subdivision can also be recognized at DSDP Site 112 , allowing a precise correlation of the two sites. Four of the assemblages (Abyssammina-Dendrophrya, Nuttallides truempyi, Reticulophragmium amplectens, and Turrilina alsatica assemblages) correlate with standard epoch subdivisions (lower, middle, and upper Eocene, and lower 0ligocene). Periods of increased faunal turnover and opportunistic increases in dominance of individual taxa correlate with stage boundaries, and accordingly, the remaining three assemblages (Glomospira, Spirosigmoilinella - S. spectabilis, and Ammodiscus $\underline{\text { latus }}$ - T. alsatica assemblages) are of shorter duration. The lower/middle Eocene boundary is contained within a $20 \mathrm{~m}$ interval of noncalcareous claystones containing a Glomospira facies comprised of only agglutinated taxa. The middle/upper Eocene boundary is characterized by an acme of Spiroplectammina spectabilis and the first occurrence of $\underline{S}$. cubensis and Spirosigmoilinella. The largest cluster of last occurrences occurs near the Eocene/0ligocene boundary, which is delineated by the disappearance of 
about 12 species of flysch-type taxa and an acme of Nuttallides umbonifera. The faunal change from an Eocene agglutinated assemblage to an 0ligocene calcareous assemblage is gradual, having taken place over a period of about 4 m.y. .

Comparison of benthic foraminiferal last occurrences from Site 647 with the Labrador Margin reveals a number of similarities. The last occurrences of Turrilina alsatica, Ammodiscus latus, Haplophragmoides walteri, and Ammosphaeroidina sp., Spiroplectammina navarroana occur in the same relative order on the Labrador Margin and in the deep Labrador Sea, which confirms the utility of these taxa for regional stratigraphy. However, some forms display diachronous last occurrences with depth. Glomospira disappears in the lower Eocene in most Labrador Margin vells, but continues into the lower oligocene at Site 647. The species R. amplectens and $\mathrm{S}$. spectabilis disappeared at the Eocene/0ligocene boundary at Site 647 , but their last occurrences occurred earlier on the Labrador Margin.

The Paleogene sequence of Hole 643A in the Norwegian-Greenland Sea is subdivided into 5 major assemblages based on the stratigraphic occurrence of important taxa. The basal Rhabdammina-Cyclammina assemblage displays low diversity and reflects shallow paleodepths at this site during the intial seafloor spreading phase near the Voring Plateau. The overlying Glomospira assemblage is correlated with the basal Lutetian and may be the temporal equivalent of the Glomospira facies observed in Hole 647A. The Spirosigmoilinella sp. assemblage is correlated with the upper Eocene, based on comparison with the North Sea biostratigraphy. A hiatus or condensed interval is indicated near the base of the $S$. compressa-R. amplectens assemblage, which extends to the upper 0ligocene. The overlying upper Oligocene to Miocene assemblage is characterized by $\mathrm{S}$. compressa.

Comparison of the upper range limits of taxa from Site $643 \mathrm{~A}$ with the North Sea probabilistic zonation of Gradstein et al. reveals 13 biostratigraphic events in common. Many benthic foraminiferal LO's appear to be diachronous between the two regions, with species such as Trochamminoides subcoronatus, Cystammina sp., Reticulophragmium amplectens, and Spirosigmoilinella compressa extending to younger levels in the Norwegian-Greenland Sea. The LO's of Karreriella conversa and Spiroplectammina spectabilis, however, may occur earlier in Hole 643A than their average position in the North Sea. 
A comparison of the biostratigraphy of flysch-type agglutinated foraminifera in the Atlantic basins reveals a number of evolutionary first and last occurrences that serve as important regional stratigraphic marker horizons. The LO's of Glomospira diffundens, Hormosina ovulum, Rzehakina epigona, Rzehakina minima, Trochammina ruthven-murrayi, and calcareous ataxophragmiids occur near the Paleocene/Eocene boundary in bathyal assemblages. The first occurrence of the intermediate forms in the Haplophragmoides cf. glabra $-\underline{H}$. walteri $-\underline{H}$ ?. jarvisi lineage may be usful stratigraphic events in the North Atlantic region. Important marker horizons which probably reflect evolutionary events in the Eocene are the Fo's of Karreriella coniformis, Reticulophragmium amplectens, Ammodiscus latus, Spirosigmoilinella compressa, and Cyclammina rotundidorsata. The Eocene/0ligocene boundary is characterized by a decline in species diversity or local disappearance of flysch-type agglutinated taxa in the areas studied. In abyssal assemblages in the Labrador Sea, the boundary can be recognized by

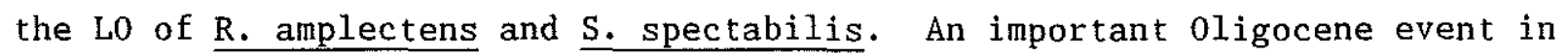
the Labrador Sea is the Lo of Ammodiscus latus. 

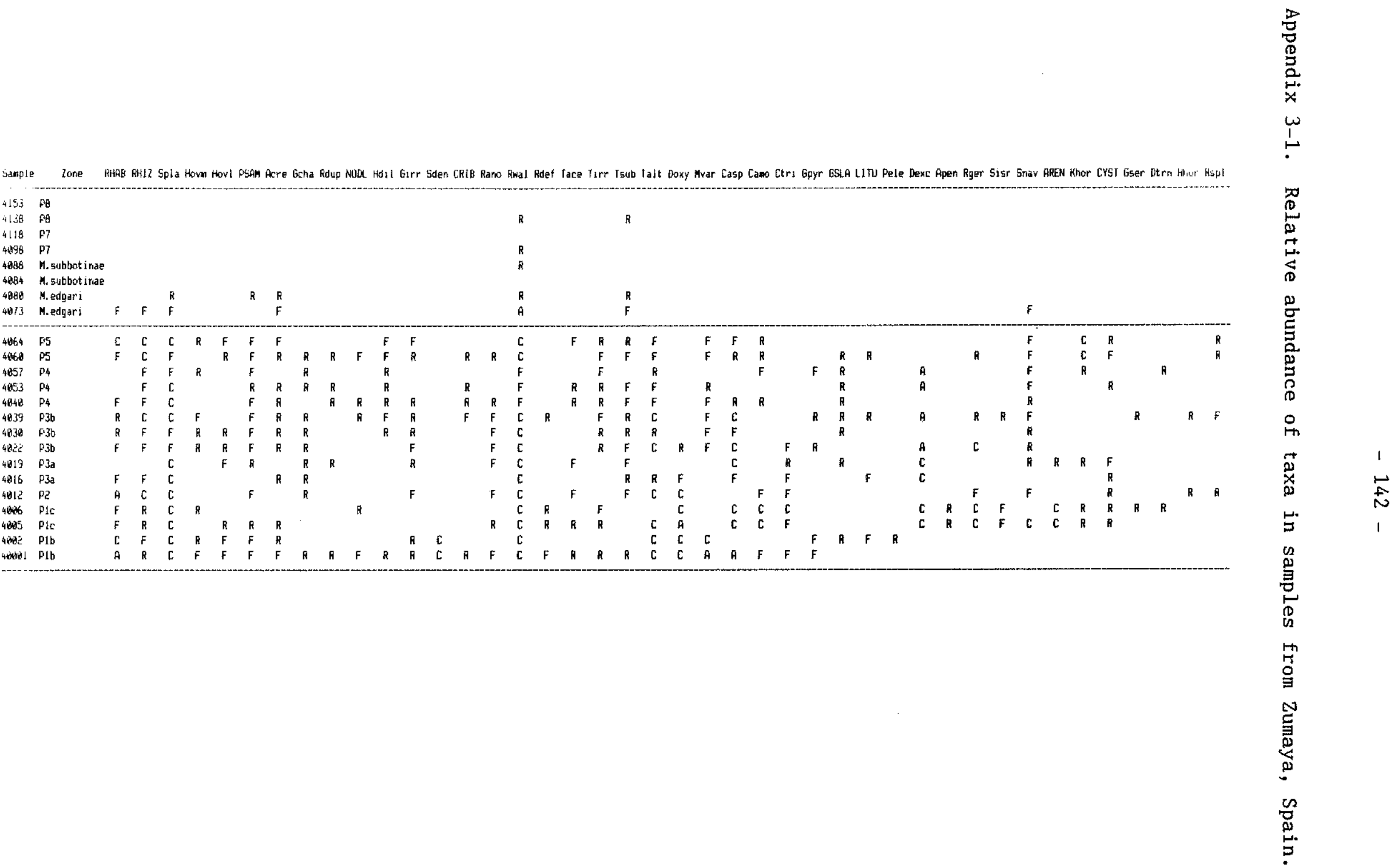


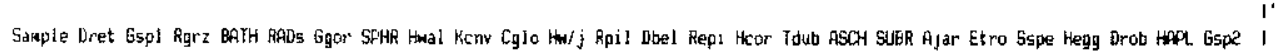

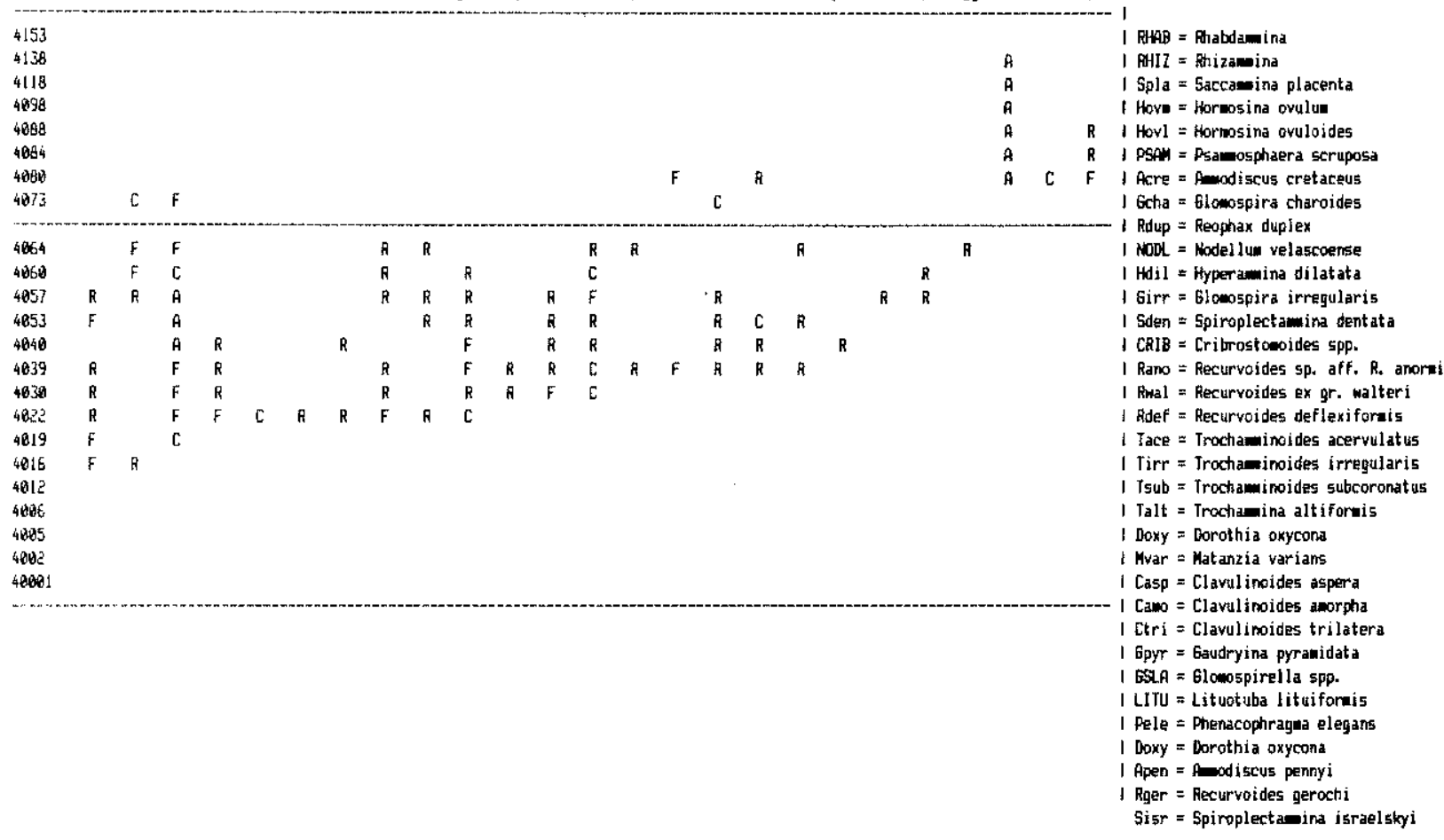

Snav = Spiroplectamina navarroaxa ARNB = Arenobulieina dorbignyi

Khor = Karreriella horrida

CYst $=$ Cystamina sp.

Dtrn $=$ Dorothia trinitatensis

thor = Haplophragmoides horrid

Rspl = Reophax splendidus

Dret $=$ Dorottia a retusa

Gspl = Gaudryina sp. 1

Rgrz = Thizamina grzybonskii

BATH = Bathysiphon spg.

RADS = "Cenosphaera" lenticularis

Ggor $=$ Glomospira gordjalis

SPHR = Sphaeramina gerochi

Mual = Haplophragmoides malteri

Kcnv = Karreriella conversa

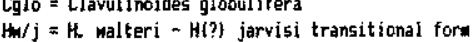

Rpil $=$ Reophax pilulifer
Dbel $=$ Dorothia beloides

Repi = Reophax epigona

Hcor = Haplophraguoides sp. (coarse)

Tdub = Trochaminoides dubi ils

$\mathrm{ASCH}=$ Aschemonel la spp.

SURR = Subreophax scalaria

Ajar $=$ mobaculites jarvisi

Etro $=$ Egyerella trochoides

Sspe $=$ Spiroplectamira spectabilis

Hegan = Haplophragwoides eggeri

Drob $=$ Dendrophrya robusta

$\mathrm{HPPL}=$ Haplophragmi ium sp.

6sp2 = Gaudryina sp. ? 


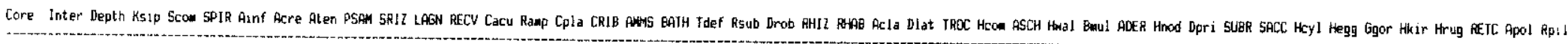
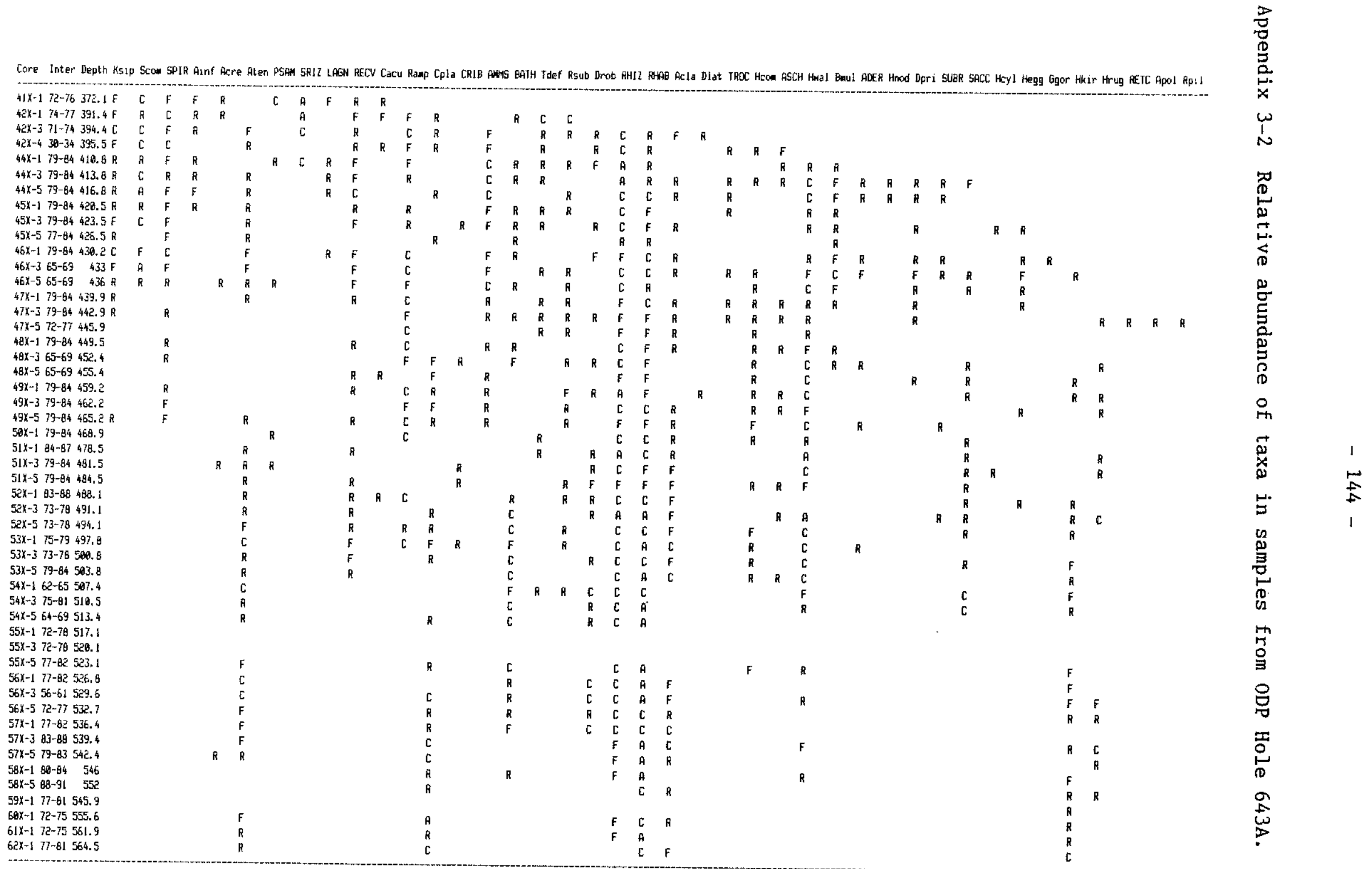
AREREVIATIONS

ksip = Karrerieila siphonell

Core Tglo Rgut Hexc Gcha Girr Tait ypol Hovu BUZA TOID Kcny CYST LITU I Scou = Spirosigwoilinella conpressa

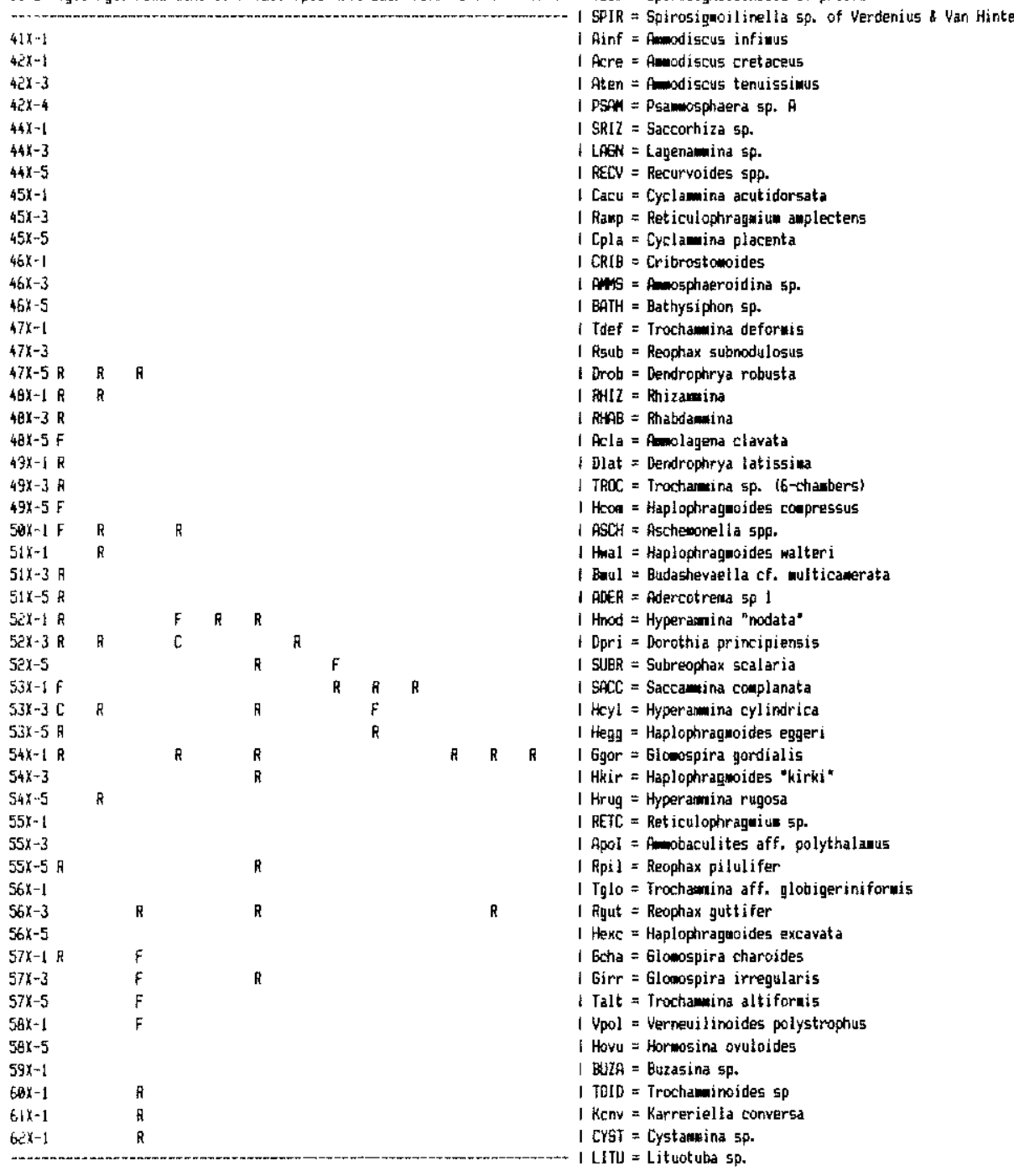




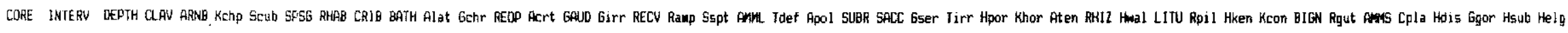

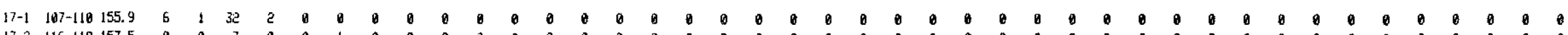

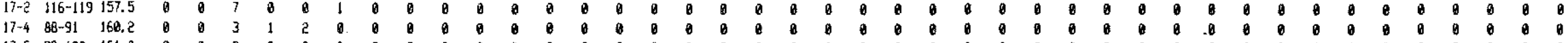
$17-5$ g9-102 161.8 010

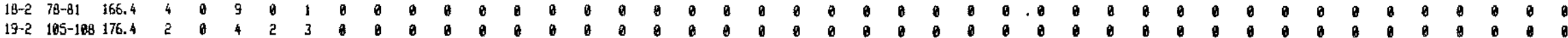

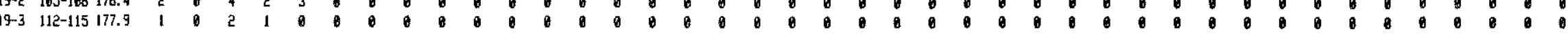

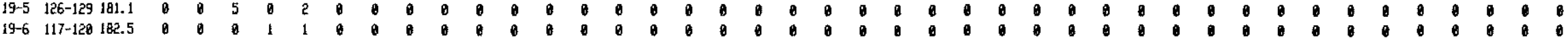

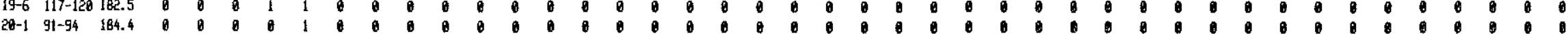

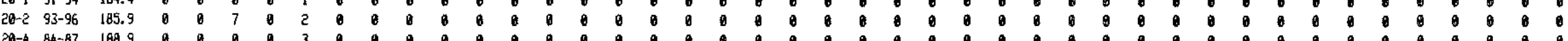

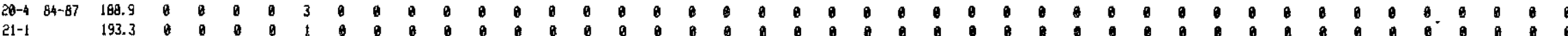

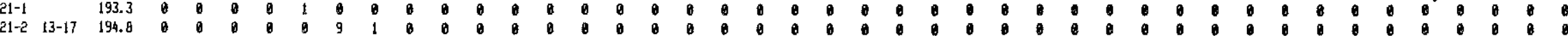

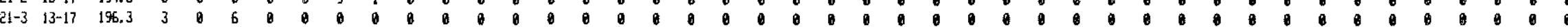

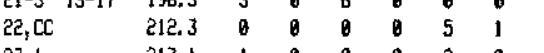

$23-4 \quad 75-78$ 217. $23-5 \quad 23-26 \quad 218.5$

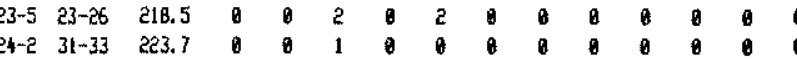
$24-431-33-266.7,0$

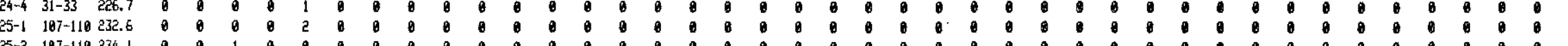

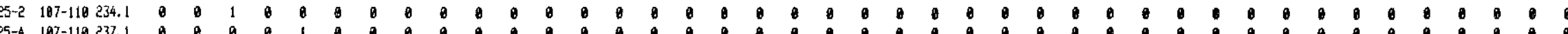

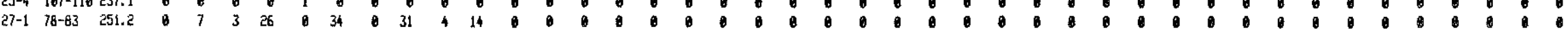

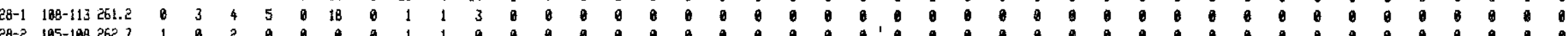
20-3 $302-107254.1$

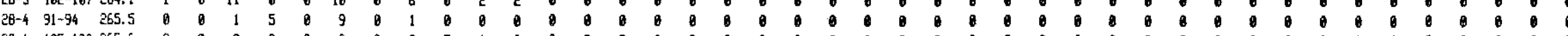

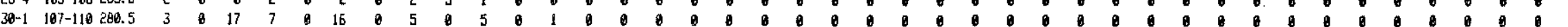

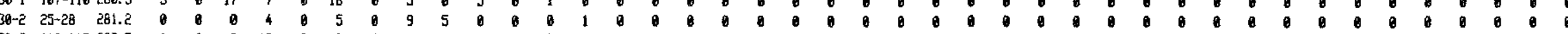

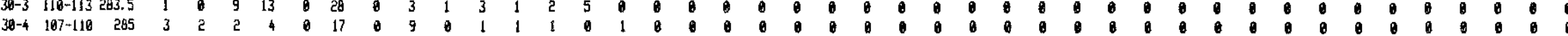

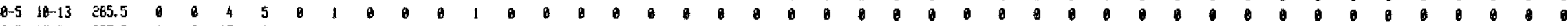

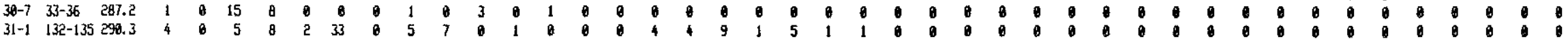

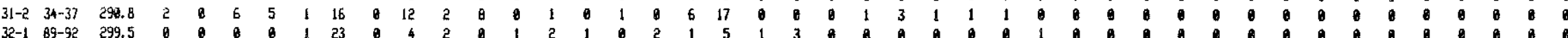

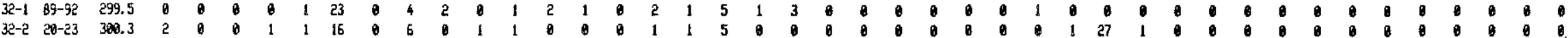

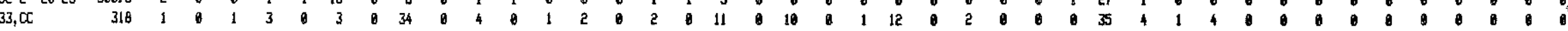

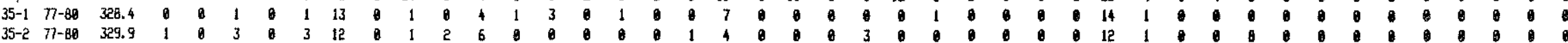

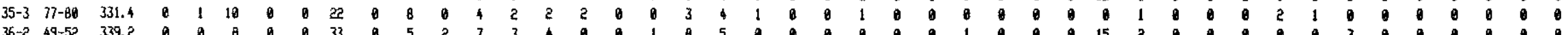

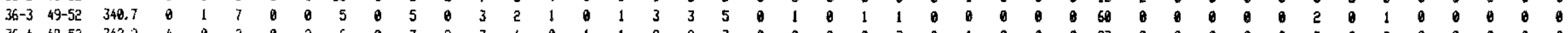

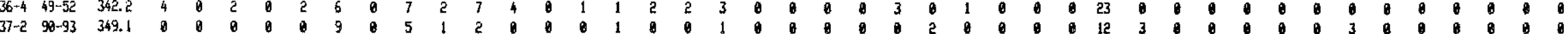

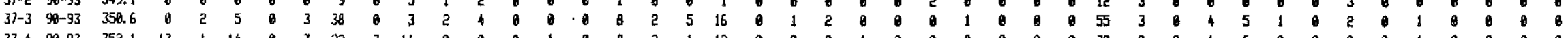

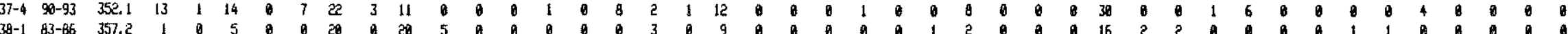

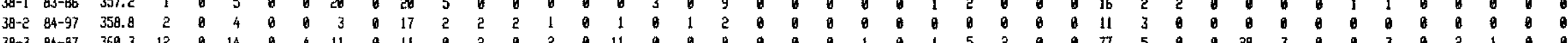




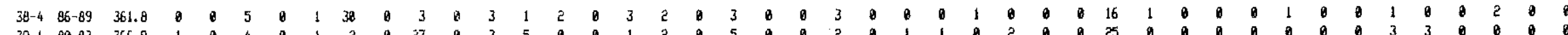
$\begin{array}{llllllllllllllllllllllllllllllllllllllllllllllllllll}39-1 & 80-83 & 366.9 & 1 & 0 & 4 & 0 & 1 & 2 & 0 & 27 & 0 & 3 & 5 & 0 & 0 & 1 & 2 & 0 & 5 & 0 & 0 & 2 & 0 & 1 & 1 & 0 & 2 & 0 & 0 & 25 & 0 & 0 & 0 & 0 & 0 & 0 & 0 & 3 & 3 & 0 & 0 & 0 & 0\end{array}$ $\begin{array}{llllllllllllllllllllllllllllllllllllllllllllllll}39, C C & 375.7 & 0 & 0 & 3 & 0 & 0 & 13 & 5 & 28 & 1 & 0 & 0 & 0 & 0 & 0 & 5 & 0 & 7 & 0 & 1 & 2 & 0 & 6 & 0 & 6 & 0 & 0 & 0 & 36 & 5 & 0 & 0 & 9 & 3 & 0 & 1 & 1 & 0 & 0 & 0 & 0 & 14\end{array}$

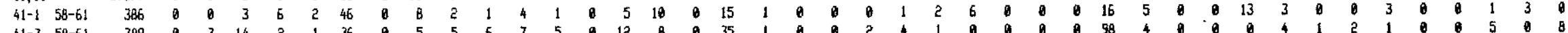

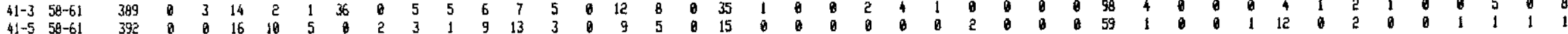

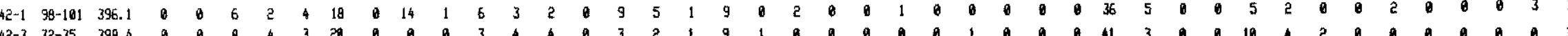

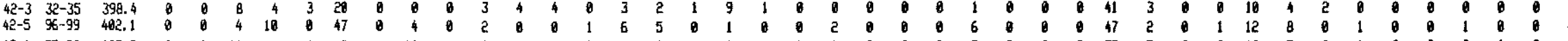

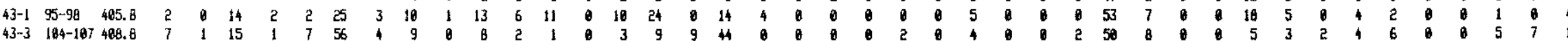

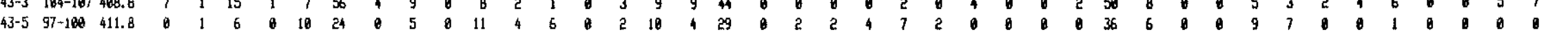

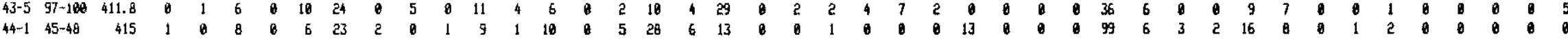

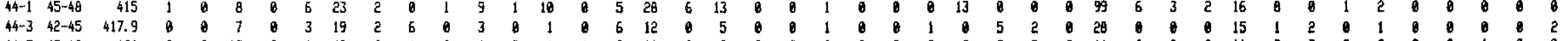

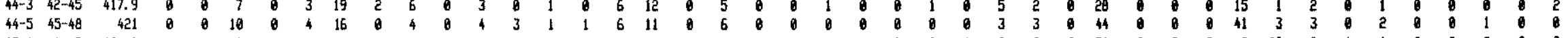

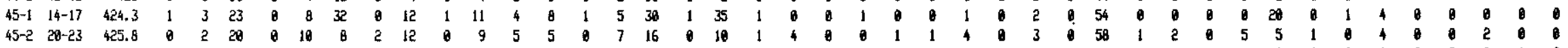

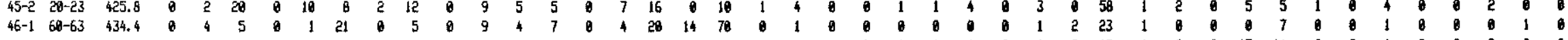
$\begin{array}{llllllllllllllllllllllllllllllllllllllllllllllllllll}46-3 & 60-63 & 437.4 & 0 & 4 & 6 & 0 & 2 & 76 & 2 & 9 & 10 & 39 & 10 & 17 & 0 & 9 & 17 & 12 & 99 & 1 & 0 & 0 & 0 & 0 & 1 & 4 & 0 & 1 & 3 & 43 & 4 & 0 & 0 & 17 & 14 & 0 & 3 & 4 & 0 & 0 & 3 & 0 & 0\end{array}$

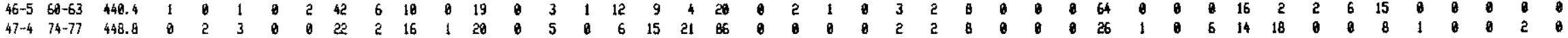

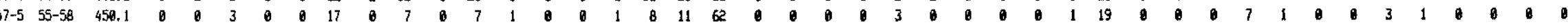

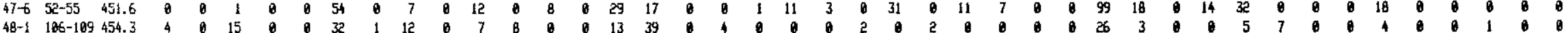

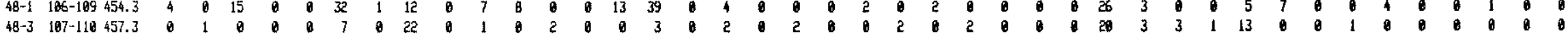

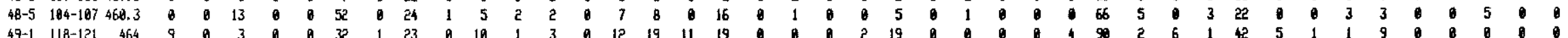

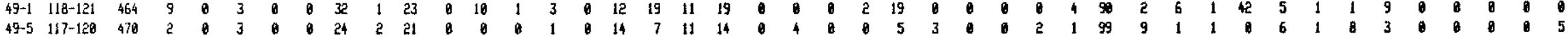

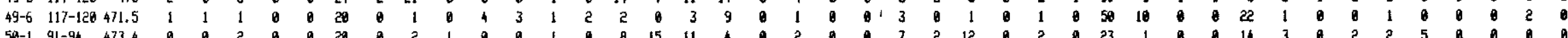

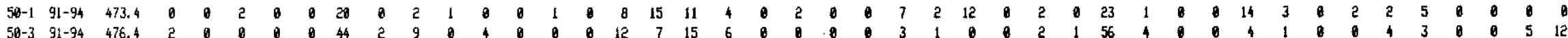

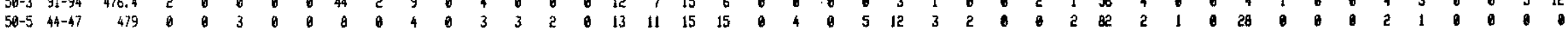

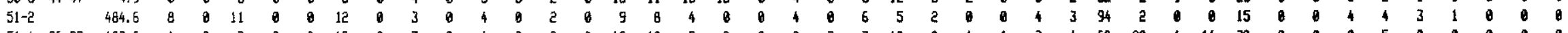

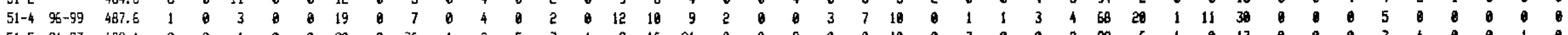

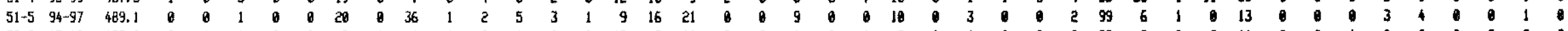

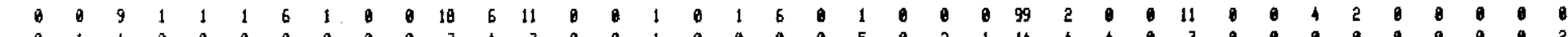

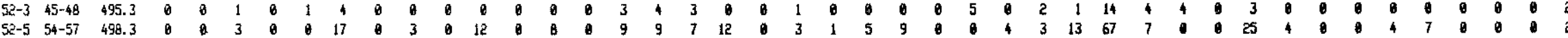

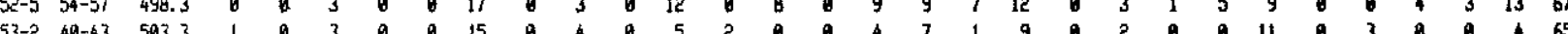

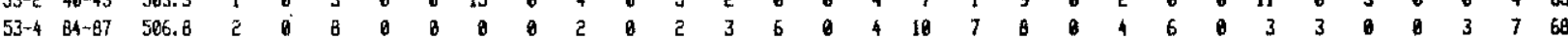

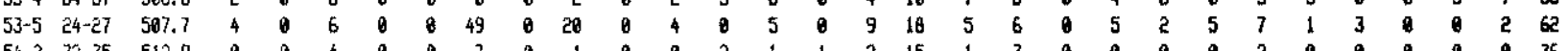

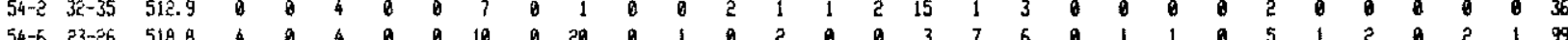

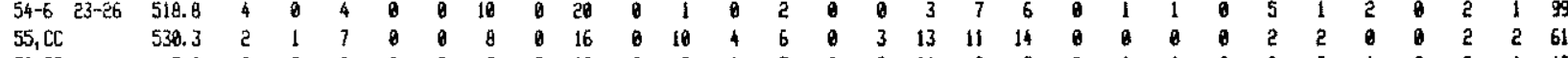
$\begin{array}{rrrllllllllllllllllllllllllllllll}56, C C & 540 & 0 & 0 & 0 & 0 & 0 & 2 & 0 & 12 & 0 & 0 & 1 & 7 & 0 & 6 & 11 & 6 & 3 & 0 & 1 & 1 & 0 & 0 & 0 & 1 & 0 & 0 & 1 & 16 & 1 \\ 58, C C & 559,4 & 8 & 0 & 4 & 0 & 0 & 3 & 0 & 11 & 0 & 1 & 3 & 1 & 0 & 3 & 5 & 4 & 2 & 0 & 0 & 0 & 0 & 0 & 0 & 9 & 0 & 0 & 1 & 18 & 0\end{array}$

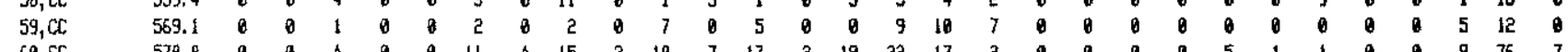
66, CC 578.9 a

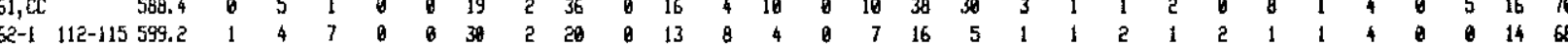
$\begin{array}{ccccccccccccccccccccccccccccccc}62-3 & 60-63 & 691.7 & 7 & 3 & 12 & 0 & 0 & 27 & 0 & 0 & 0 & 12 & 4 & 6 & 0 & 7 & 6 & 9 & 3 & 1 & 0 & 1 & 0 & 0 & 0 & 0 & 0 & 2 & 8 & 36\end{array}$

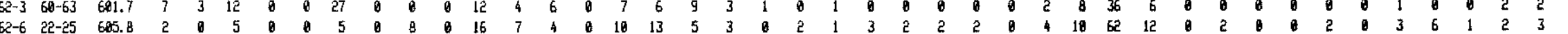

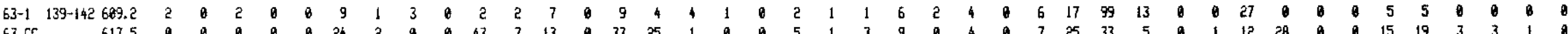

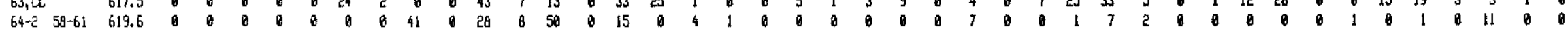


Appendix 3-3 (Continued).

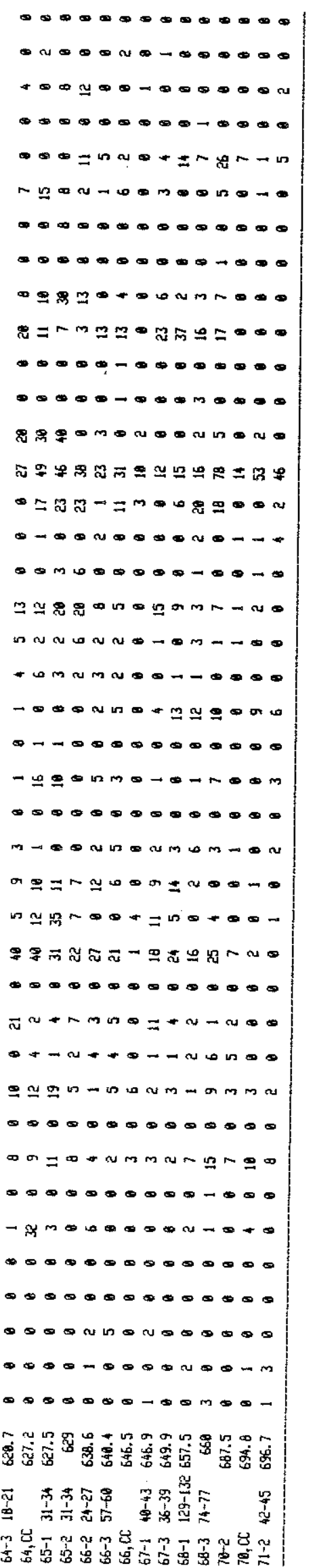




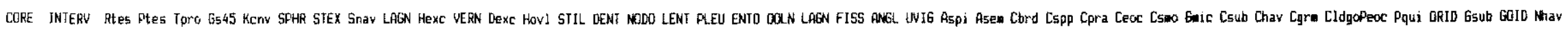

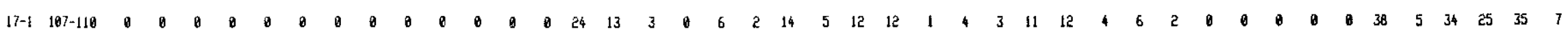

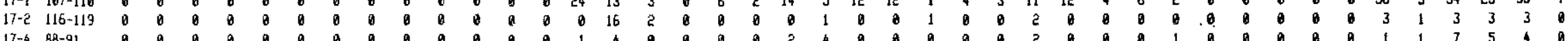

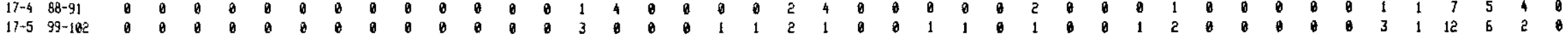

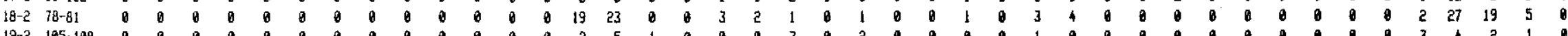

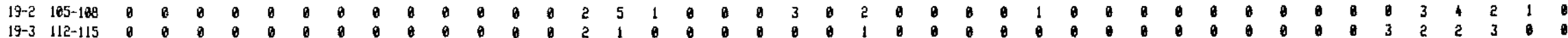

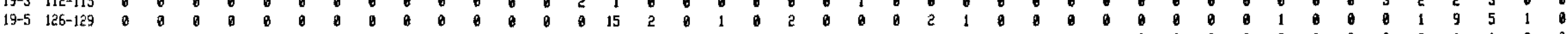

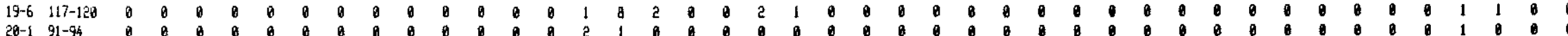

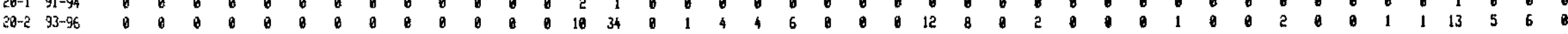
$\begin{array}{ll}-4 & 84-87\end{array}$

$\begin{array}{ll}21-2 & 13-17 \\ 21-3 & 13-17\end{array}$

$22, C C$

23-2 $95-98$

$\begin{array}{rr}23-4 & 75-78 \\ 23-5 & 23-26\end{array}$

$24-2 \quad 31-33$

25-1 107-110 $\begin{array}{llllllll}0 & 0 & 0 & 0 & 0 & 0 & 0 & 0 \\ 0 & 0 & 0 & 0 & 0 & 0 & 0 & 0\end{array}$

$\begin{array}{lllllllll}0 & 0 & 0 & 0 & 0 & 0 & 0 & 0 \\ 0 & 0 & 0 & 0 & 0 & 0 & 0 & 0 \\ 0 & 0 & 0 & 0 & 0 & 0 & 0 & 0 \\ 0 & 0 & 0 & 0 & 0 & 0 & 0 & 0\end{array}$
$\begin{array}{lllllllll}0 & 0 & 0 & 0 & 0 & 0 & 0 & 0 \\ 0 & 0 & 0 & 0 & 0 & 0 & 0 & 0 & 0\end{array}$
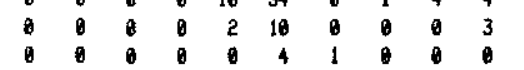

25-2 107-110

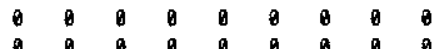

$\begin{array}{lllllllll}0 & 0 & 0 & 0 & 0 & 0 & 0 & 0 \\ 0 & 0 & 0 & 0 & 0 & 0 & 0 & 0 & 0\end{array}$

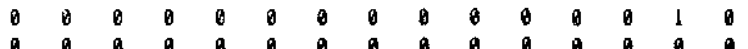

25-4 $107-11$

$2 B-1 \quad 388-113$

$28-2 \quad 105-108$

$\begin{array}{lllllllllll}0 & 0 & 0 & 0 & 0 & 0 & 0 & 0\end{array}$

28-4 91-94

$\begin{array}{cc}28-4 & 185-108 \\ 30-1 & 107-110\end{array}$

$30-2 \quad 25-29$

$\begin{array}{ll}30-3 & 110-113 \\ 30-4 & 107-118\end{array}$

$30-5 \quad 18-13$

$\begin{array}{ll}36-7 & 33-36 \\ 31-1 & 132-135\end{array}$

$\begin{array}{ll}31-2 & 34-37 \\ 32-1 & 89-92\end{array}$

$\begin{array}{rr}32-1 & 89-92 \\ 32-2 & 20-23\end{array}$

33, CC $37-1,37-88$

$\begin{array}{ll}35-1 & 77-88 \\ 35-2 & 77-80\end{array}$

$\begin{array}{cc}35-3 & 77-80 \\ 36-2 & 49-52\end{array}$

$\begin{array}{ll}36-2 & 49-52 \\ 36-3 & 49-52\end{array}$

$\begin{array}{ll}36-4 & 49-52 \\ 37-5 & 90-93\end{array}$

$37-3 \quad 90-93$

$37-4 \quad 90-93$

38-2 84- 87

$\begin{array}{lll}38-3 & 84-87\end{array}$
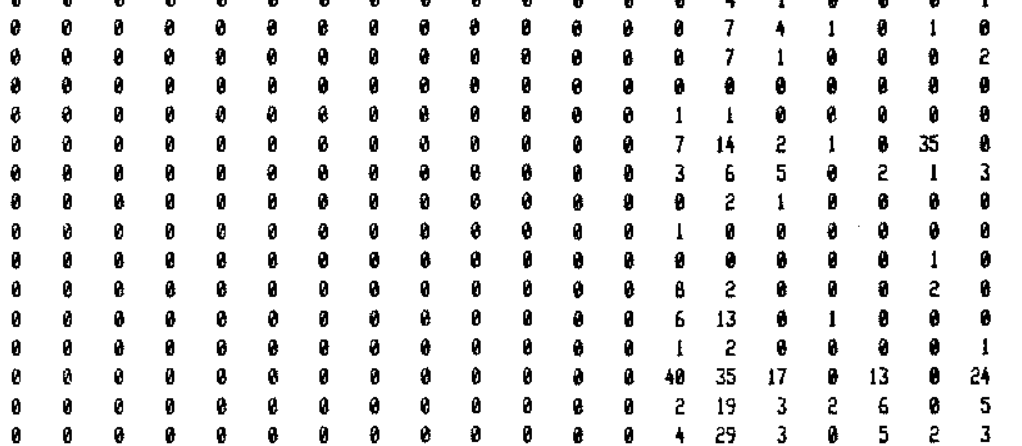

$\begin{array}{lllll}1 & 1 & 0 & 3 & 0 \\ 1 & 1 & 0 & 2 & 0 \\ 0 & 3 & 0 & 2 & 0\end{array}$

$\begin{array}{llllllll}0 & 0 & 0 & 0 & 0 & 0 & 0 & 0 \\ 0 & 0 & 0 & 0 & 0 & 0 & 0 & 0 \\ 0 & 0 & 0 & 0 & 0 & 0 & 0 & 0\end{array}$

$\begin{array}{llllllll}0 & 0 & 0 & 0 & 0 & 0 & 0 & 0 \\ 0 & 0 & 0 & 0 & 0 & 0 & 0 & 0 \\ 0 & 0 & 0 & 0 & 0 & 0 & 0 & 0\end{array}$
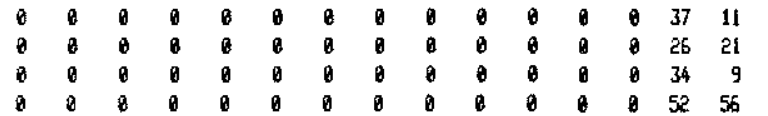

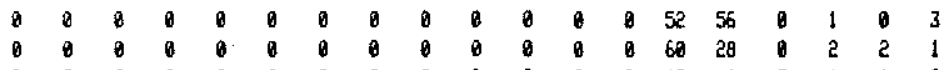

$\begin{array}{lllllllll}2 & 1 & 2 & 0 & 0 & 1 & 0 & 0 \\ 0 & 0 & 0 & 0 & 0 & 0 & 0 & 0 & 0\end{array}$

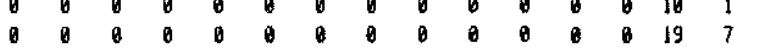

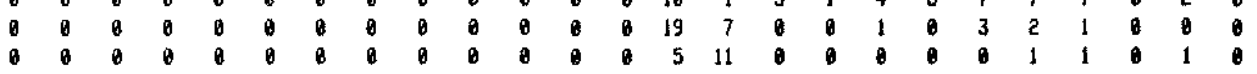

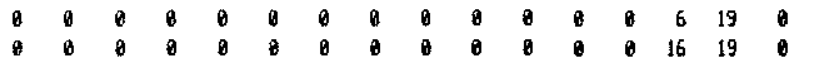

$\begin{array}{llllllllllllllll}0 & 0 & 0 & 0 & 0 & 0 & 0 & 0 & 0 & 0 & 0 & 0 & 0 & 28 & 17 & 0 \\ 0 & 0 & 0 & 0 & 0 & 0 & 0 & 0 & 0 & 0 & 0 & 0 & 0 & 14 & 12 & 0\end{array}$

$\begin{array}{lllllllllllllll}0 & 0 & 0 & 0 & 0 & 0 & 0 & 0 & 0 & 0 & 0 & 0 & 0 & 48 & 10 \\ 0 & 0 & 0 & 0 & 0 & 0 & 0 & 0 & 0 & 0 & 0 & 0 & 0 & 4 & 0\end{array}$

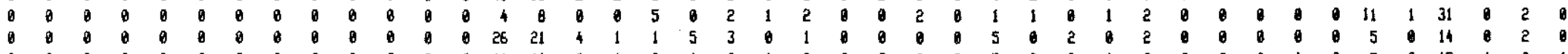

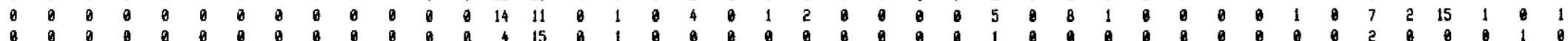

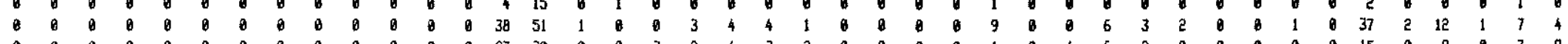

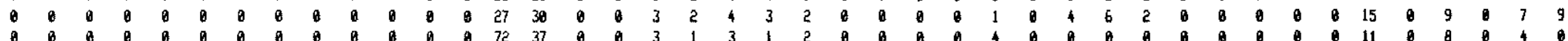

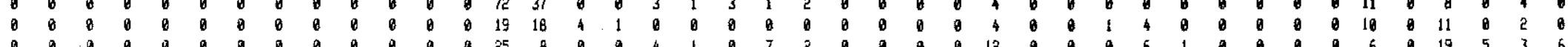


Appendix 3-3 (Continued).

un w 0 $\rightarrow-\infty \pm=$ 只

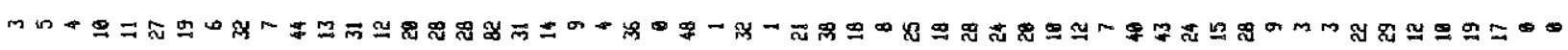

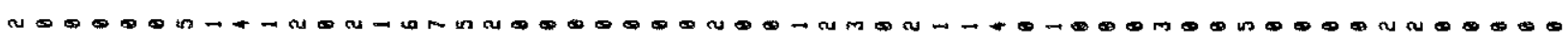

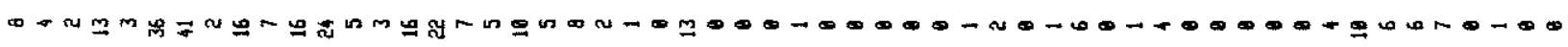

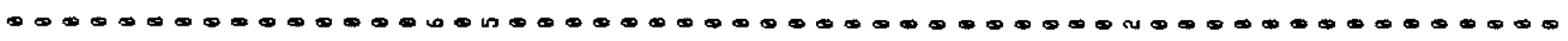
- $00-\infty+0$ N

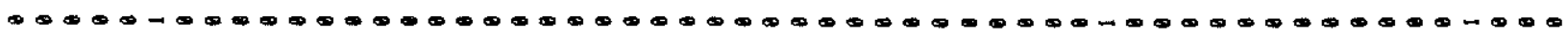

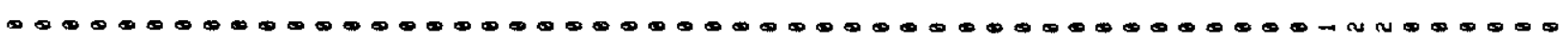

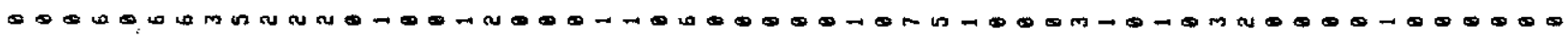

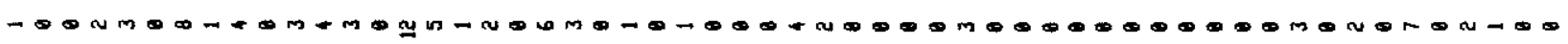

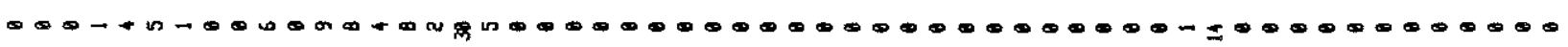
$\neg=0$ n

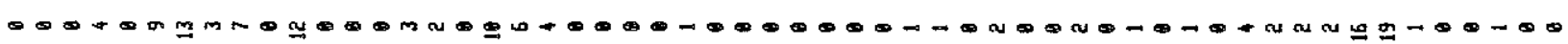

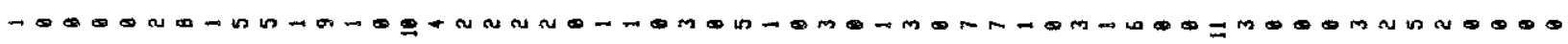

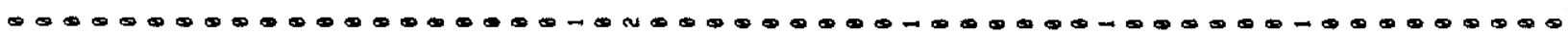
$0000000000000000000000000000000000000000-00000000000000$ $000+\infty \omega-\infty$ n

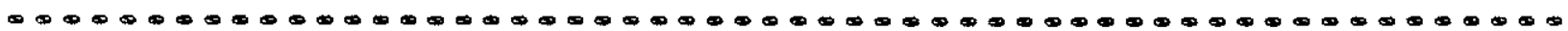
u-Dnm

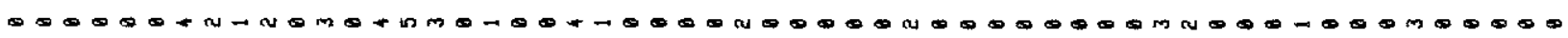

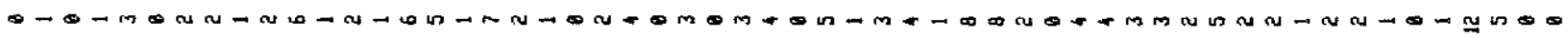

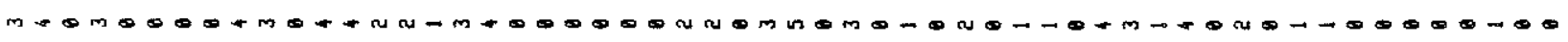

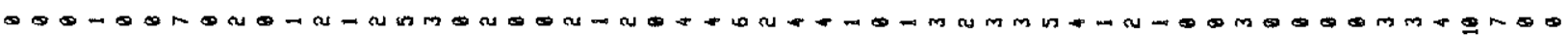

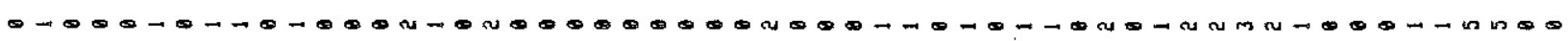
-

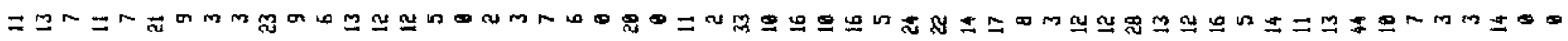
a 00000000000000000000000000000000000000000000000000000000

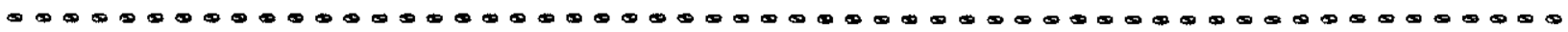
00000000000000000000000000000000000000000000000000000000

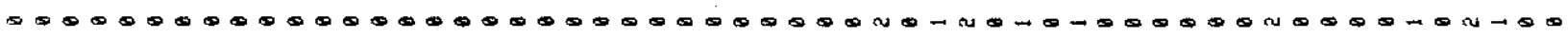
$00000000000000000000000000000-0000-00000-00000000000000000$ $00000000000000000000000000-100000000000000000000000000000$ $000000000000000000000000000-0000-000000000000000000000000$

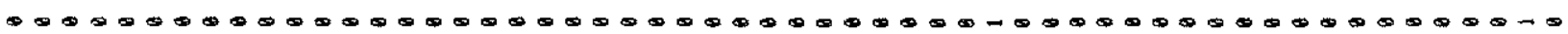

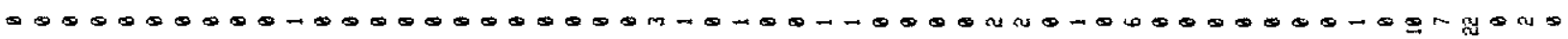
$0000001000000-100000000000000000000000000000000000000000$ $000000-0000000000000000000-100000000-00000000000000000000$

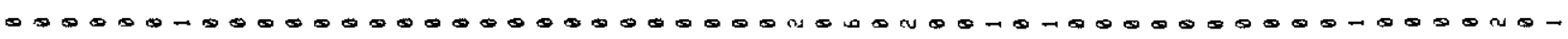

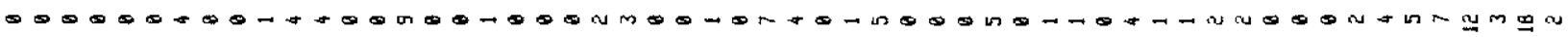

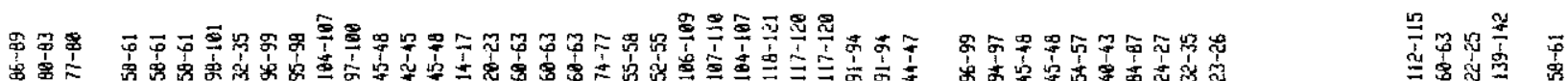

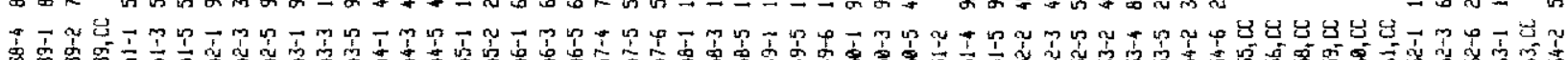


Appendix 3-3 (Continued).

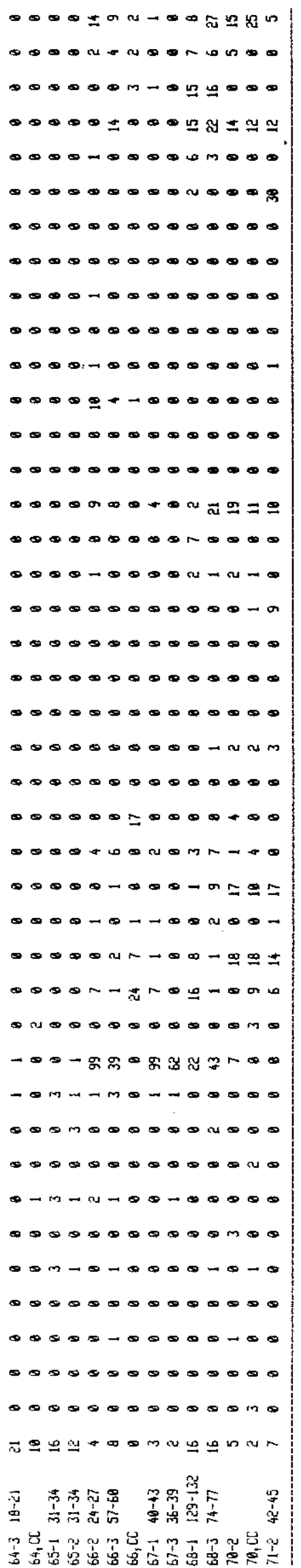




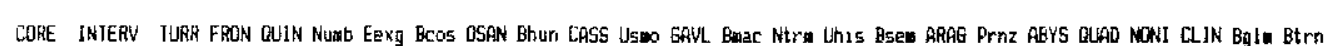

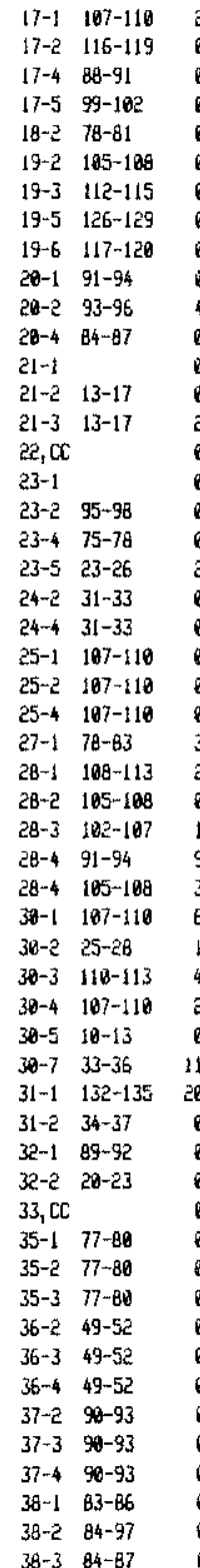

SLW I AEBREVIATIONG OF SPECIES NANES, HOLE 647A:

321 I CLAV = Clavul inoides sp.

43 RANO $=$ Arenot

39 I Kchp ₹ Karreriella chapapotensis (Cole)

43 I Scub = Spiroplectamina cubensis (Cushun and Derauter

125 | SPSG = Spirosigmoilinella compressa Matsunaga

$35 \quad$ I A A A $=$ Rhabdarina spp.

$19 \quad$ I CRIB = Cribrostowoides subglobosus (Brady)

I BaTH = Bathysiphon spp.

18 I Alat $=$ Rmodiscus latus Grzyborski

5 i Gchr = Glowospira charoides (Jones and Parker)

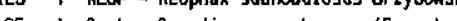

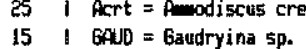

39 | Girr $=61$ omospira irregularis (Grzybowski)

$56 \quad 1$ RECV = Recurvoides 5pp.

6 : Rapp = Reticulophraguium anplectems (Graybowski)

8 I Sspt = Spiroplectamina spectabilis (6rzybowski)

$67 \quad 1$ AwL = Amolagena clavata (Jones \& Parker)

$41 \quad$ I Tdef = Trochannina deforais Grzybouski

12 I Apol = Amobaculites aff. polythalanus Loeblich

I SLUAR = Subreophax scalaria (Grzybowski

2 I SACC = Saccamina couplanata (Franke)

$15 \quad$ Gser $=61$ onospira serpens (Grzybowski)

5 I Hpor = Haplophragmoides porrectus Maslakova

$391 \quad$ | thor = Karreriella horrida Mjatliuk

171 Aten = furodiscus nagyi n. sp.

93 | PHII = Phizanina $5 p p$.

185 I Htwal = Haplophragooides walteri (Grzybowski)

154 I LITU = Lituotuba lituiformis (Brady)

\begin{tabular}{r|l}
77 & Apil $=$ Reophax pilulifer Brady \\
199 & Hken $=$ Hyperamina kerwilleri n.sp. $^{2}$.
\end{tabular}

177 I Kcon = Karreriella coniformis (Grzybowski)

226 | BI6N = Bigenerina sp.

$244 \quad 1$ Rgut = Reophax guttifer Brady

346 I ANW = R-osphaeroidina pseudopauciloculata (Mjatliuk)

224 I Cpla $x$ Cyclamina placenta (Reuss)

240 I his = Hormosina distans (Brady)

187 I Ggor = Glomospira gordsalis (Jones and Parker)

87 I Hsub = Hyperamina ex gr, subnodosiformis Grabowsk

113 I Helg = Hyperamaina elongata Brady

$228 \quad 1$ Ptes $=$ Rhizamina sp. (with planktonic tests)

$140 \quad$ I Ptes $=$ Psamposphaera testacea Flint

133 I Tpro = Trochamininoides proteus (Karrer)

25尺 $\mid$ GS45 = Gaudryina 5 p. 45

174 I Kcnv = Karreriella conversal (Grzybowski)

198 I 5PFiR = Sphaeramina gerochi Hanzlikova

149 I STEX = Siphotextularia sp.

64 I Snav = Spiroplectamina navarroana Cushuan

351 I LA6N = Lagenamina sp.

271 I Hexc = Hormosina cf. excelsa Dylazanka

$234 \quad$ I VERN = Verneuilinoides polystrophus (Reuss)

$126 \quad$ I Dexc $=$ Dendrophrya excelsa Grzybowski 


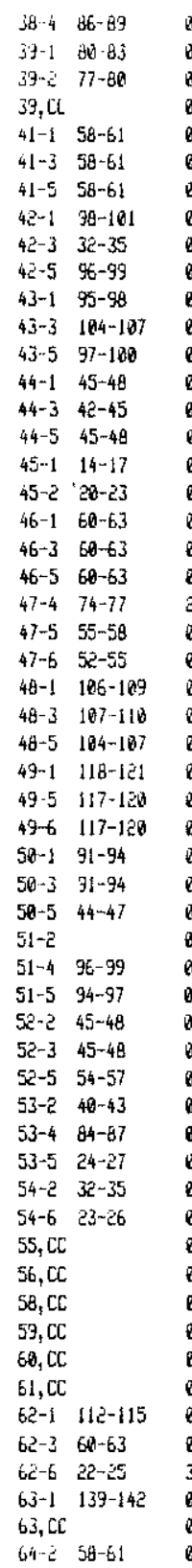
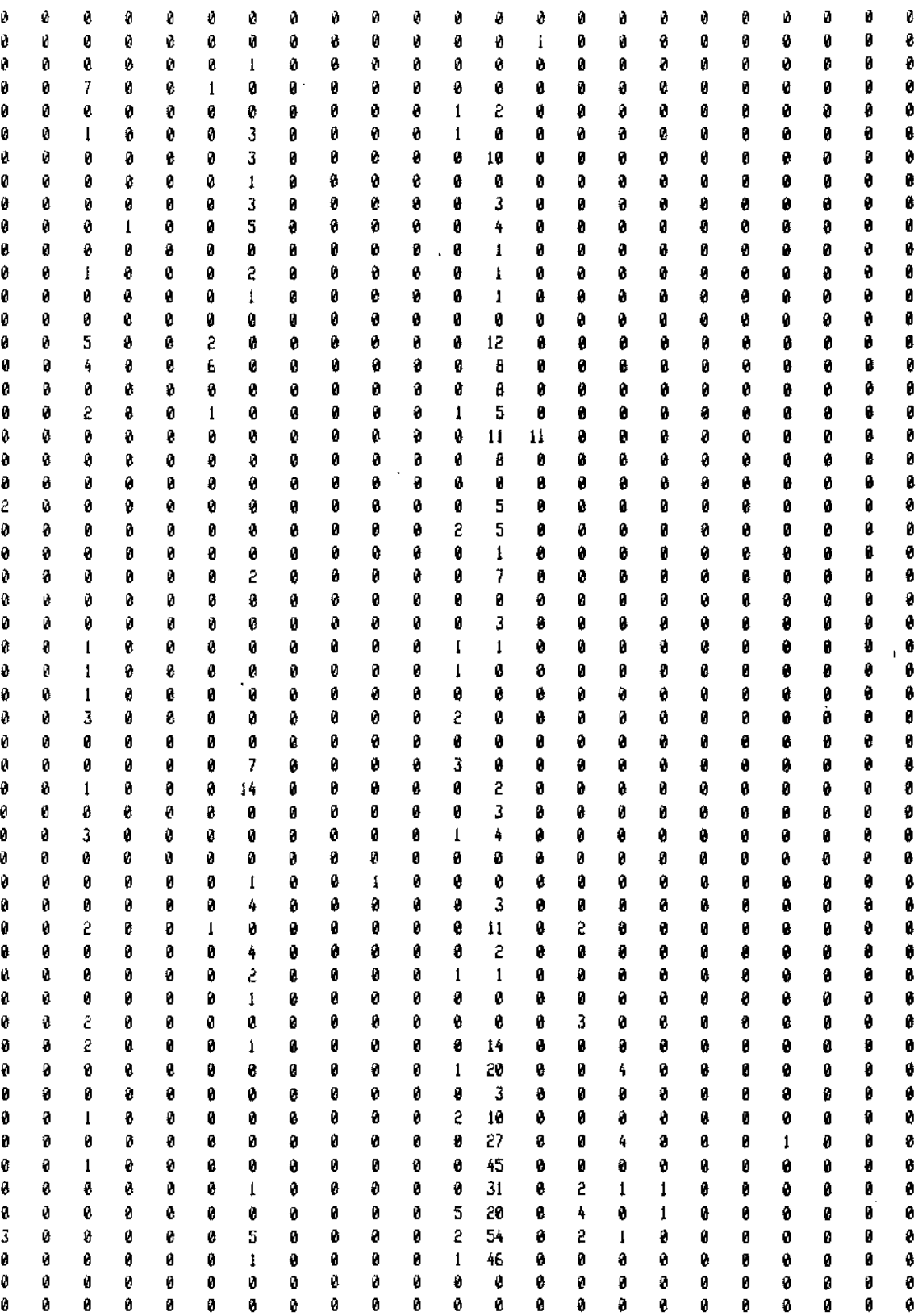

$121 \quad$ I $511 \mathrm{~L}=$ St 1 lost ome lla $5 \mathrm{pp}$

57 DENT = Dertalina spp.

$229 \quad$ I LENT $=$ Lenticulina spo.

248 I PLEU = Pleurostomel la spp.

454 I ENFO = entosolenians

379 I $\quad$ OON = Dolina 5pp.

$\begin{array}{lll}286 & \text { LAGN }=\text { Lagena Spp. } \\ 292 & \text { FISS = Fissurina spp. }\end{array}$

$262 \quad 1 \quad 0 \times 1=$ Anpulogerina

375, UNIG $=$ Uvigerina spp.

$383 \quad$ | Aspi = Anowal inoides spissiformis (Cushman and Stainforth)

291 I Asem = Anomalinoides sewicribratus (Beckwann)

321 | Cbrd * Cibicidoides bradyi (Trauth)

319 I E E $5 p=$ Cibicidoides 5pp. ind

307 I Cpra = Cibicidoides praenurdulus Bergeren and Miller

Caoc $=$ Cíbicidoides eocaenus (Gueabel)

$C_{5 m o}=$ Cibicidoides $5 p$. (smooth)

Gmic = Gavelinella micra (Bermudez)

Csub $=$ Cibicidoides subspiratus (Nuttail

391 Chav = Cibicidoides havanensis (Cushman and Bermudez)

259 Cldgo = Cibicidoides lamontdohertyi Miller and Katz

377 I Peoc = Pullenia eocenica Custman and Seigfus

119 I ORID = Aridorsalia spp.

$359 \quad$ I Gsub $=$ Globocassidul ina subglobosa (Brady)

370 । EOID $=$ Gyroidinoides 5 pp.

318 Thav = Nonion havanense Cushman and Bernudea

220 I TURR = Turrilina alsatica

204 I FRAN = Frondicularia spp.

224 I [UIN = Quinqueloculina 5pp.

312 I Munb = Muttallides unbonifera (Cushean)

I Eexg = Epistoninella exigua (Bradyl

| Bcos = Bul imina 5p. (costate)

366 I DSPN = Dsangularia mericana (Cole)

231 I Bhun = Bol ivina huneri Ho

I Cass = Cassidul ina $5 p p$.

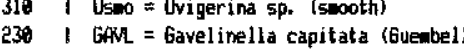

335 I Buac = Bul inina macilenta Cushwan and Parker

367 I Ntra = Nuttallides trumpyi (Nuttall)

167 I this = Uvigerina sp. (hispid)

$299 \quad 1$ Bsem = Bul iwina semicostata

380 I ARPG = Aragonia spp.

$182 \quad 1$ Prnz $=$ Planulina renzi Cushman and Stainforth

$115 \quad$ I ABYS = Abyssamina spp.

137 I QUAD = Quadriworphina profunda Schnitker and Tjalswa

432 I NOWI $=$ Nonion sp.

479 I CLIN = Cl inapertina spp.

365 I Bglm = Bulimina aff. glomarchal lengeri $\mathrm{Tjalsma}$ and Lohmann

254 I Btrn = Bulieina trinitatensis Cushwan and Jarvis

$485 \quad 1$

345 
Appendix 3-3 (Continued).

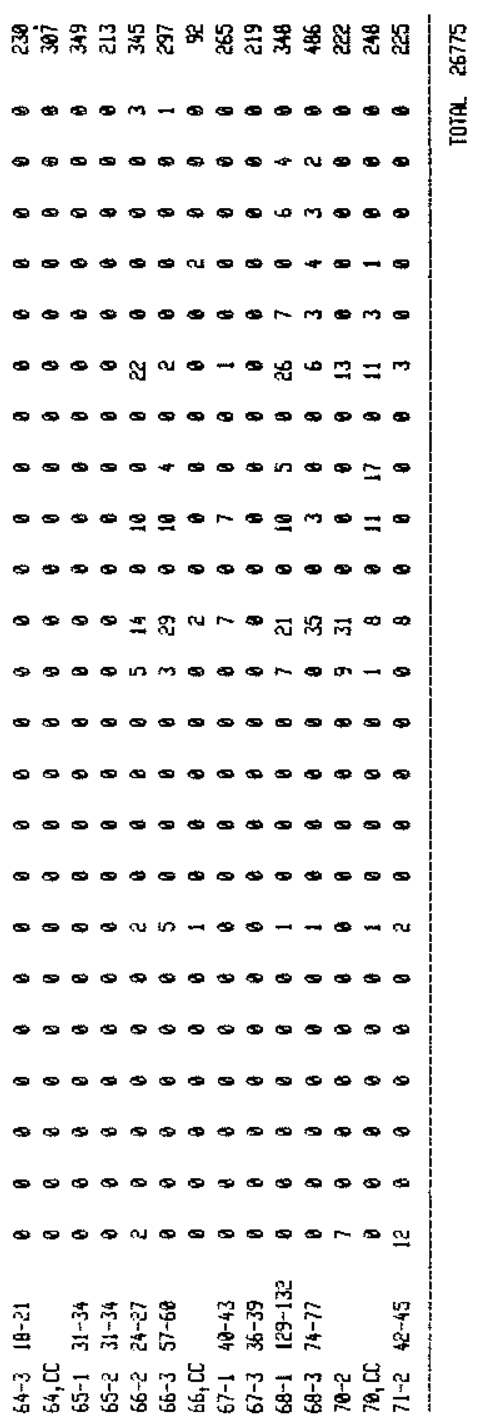




\section{CHAPTER 4}

\section{PALEOBIOGEOGRAPHY OF AGGLUTINATED FORAMINIFERA:}

INTRODUCTION :

The late Cretaceous to Paleogene was a period of transition between a circum-equatorial circulation in the Mesozoic to a more meridional circulation pattern in the Atlantic in the middle to late Cenozoic (Berggren \& Hollister, 1974). In comparison with the present day North Atlantic, the late Cretaceous to Paleocene ocean was characterized by milder climates and a lower temperature contrast between the tropics and high latitudes (Haq, 1981). Equatorial circulation in the Tethyan seaway was directed from east to west, and may have moderated polar influences resulting in the early Paleogene oceans being less stratified than the present day (Johnson, 1984). The paleobiogeography of benthic foraminifera at this time was probably affected by many factors, including global climate and paleocirculation patterns. For example, low-latitude calcareous benthic foraminiferal faunas in the Atlantic reflect Tethyan influence, which affected the composition of Midway faunas (Berggren and Aubert, 1975). In the deep ocean basin, calcareous benthic assemblages can be subdivided into a middle bathyal Stensioina beccariiformis assemblage and a lower bathyal to abyssal Nuttallides truempyi assemblage (Tjalsma and Lohmann, 1983), but superimposed on the bathymetric pattern is a latitudinal differentiation of Nuttallides species.

In addition to paleoclimatic factors, the paleobiogeography of benthic foraminifera in the North Atlantic basins was influenced by regional tectonic effects, such as the relationship between depocenters and continental breakup, and opening and closing of oceanic gateways which at times prevented the migration of species. For example, in the Maastrichtian to Paleocene, the North Sea and Norwegian-Greenland Seas were isolated from the North Atlantic region by the Greenland-Scotland Ridge, which at times formed a barrier to the exchange of surface and deep waters at least until the early Eocene (Eldholm and Thiede, 1980; McKenna, 1983; Miller and Tucholke, 1983; Berggren and Schnitker, 1983). Intermittent shallow marine connections between the North Sea and the northern margin of the Tethys seaway existed across central Europe via the Danish-Polish Trough (Pozaryska, 1981; Ziegler, 1982; McKenna, 1983), but this passageway served as a filter for deeper dwelling species. With the closing of deep-water passageways in the eastern Tethys in the late Eocene 
(Pomerol and Premoli-Silva, 1986), Mediterranean deep-water faunas became isolated from the Indo-Pacific region.

Conpared with planktonic and calcareous benthic foraminifera, relatively little is known about the paleobiogeography of flysch-type agglutinated foraminifera or their response to environmental changes in the Paleogene. The revision of the taxonomy of flysch-type agglutinated species from Trinidad now enables an interregional comparison of agglutinated species from circum-North Atlantic and Tethyan regions (Table 4-1). For comparative purposes, I have examined agglutinated assemblages from the Labrador Sea, North Sea, NorwegianGreenland Sea, West Greenland, Trinidad, Jamaica, Poland, Spain, and Morocco in order to conduct a survey of species based on a standardized taxonomy. Many of the $200+$ species found at the Paleogene localities listed in table 4-1 are cosmopolitan, but some faunal provinciality is evident among deep-water agglutinated assemblages from the North Atlantic and Tethys. Provinciality is manifested by differences in species diversity, the presence of endemic species or disjunct stratigraphic ranges in different areas and in the relative proportions of certain genera or species groups. A comparison of the assemblages of these regions follows below.

\section{SAMPLE LOCALITIES:}

The sample base for the Paleocene consists of exploration well samples from the Guayaguayare Beach Field of Southern Trinidad, the Labrador Margin, the central Viking Graben, and the Zumaya Flysch in Northern Spain (von Hillebrandt, 1965; this study). Spot samples were examined from the Blatt Arba Ayocha section in the external Tangier Unit of the Rif Mountains of eastern Morocco provided by Wolfgang Kuhnt (Tubingen). These samples are from the noncalcareous claystones of Pelitic Series III of Kuhnt (1987), which was deposited in a basin plain environment. Spot samples were also examined from Paleocene flysch sediments in Jamaica, collected by Garry D. Jones (UNOCAL). Microfossil data were compiled from the Schlieren flysch of the Swiss Alps (Winkler, 1984), the Wienerwald flysch in the Austrian Alps (Grun et al., 1964) and the Polish Carpathians (Jurkiewicz, 1967; Jednorowska, 1975; Kaminski et al., in press, a). In the abyssal equatorial Atlantic, data were compiled from DSDP Sites 368 (Krasheninnikov and Pflaumann, 1977) and 543A (Hemleben and Troester, 1984). Spot samples from Sites 543A and 368 were 
Table 4-1. A checklist of Paleogene species from Atlantic and Tethyan localities studied.

ASTRORHIZACEA Brady, 1881

Bathysiphon gerochi Mjatliuk

Bathysiphon microrhaphidus Samuel

Bathysiphon $\mathrm{sp}^{1}$

Dendrophrya ex gr. excelsa Grzybowski

Dendrophrya latissima Grzybowski

Dendrophrya robusta Grzybowski

Lagenammina grzybowskii (Schubert)

Rhabdammina cylindrica Glaessner ${ }^{2}$

Rhabdammina ex gr. discreta Brady

Rhabdammina subdiscreta Grzybowski ${ }^{3}$

Rhizammina grzybowskii Liszka \& Liszkowa

Rhizammina indivisa Brady 4

Psammosphaera fusca Schultze

Psammosphaera scruposa (Berthelin)

Psammosphaera testacea Flint

Saccammina complanata (Franke)

Saccammina placenta (Grzybowski) ${ }^{5}$

Saccammina sphaerica Brady

Saccamminoides carpathicus Geroch

Thurammina sp.

HYPERAMMINACEA Eimer and Fickert, 1899

Hyperammina cylindrica Parr

Hyperammina dilatata Grzybowski

Hyperammina elongata Brady

Hyperammina kenmilleri Kaminski

Hyperammina nodata Grzybowski

Hyperammina rugosa Verdenius \& Van Hinte

Hyperammina ex gr. subnodosiformis Grzybowski

AMMODISCACEA Reuss, 1862

Ammodiscus bornemanni (Reuss)

Ammodiscus cretaceus (Reuss) ${ }^{6}$

Ammodiscus glabratus Cushman \& Jarvis

Ammodiscus incertus (d'Orbigny)

Ammodiscus infimus Bomemann

Ammodiscus latus Grzybowski

Ammodiscus nagyi Kaminski

Ammodiscus pennyi Cushman \& Jarvis

Ammodiscus peruvianus Berry ${ }^{7}$

Ammodiscus planus Loeblich

Ammodiscus tenuissimus Grzybowski

Ammolagena clavata (Jones \& Parker)

Ammovertella sp.

Glomospira charoides (Jones \& Parker)

Glomospira diffundens (Cushman \& Renz)

Glomospira glomerata (Grzybowski)

Glomospira gordialis (Jones \& Parker)

Glomospira irregularis (Grzybowski)

Glomospira serpens (Grzybowski)

Glomospirella grzybowskii (Jurkiewicz)

Tolypammina sp.

RZEHAKINACEA Cushman, 1933

Rzehakina complanata (Grzybowski)

Rzehakina epigona (Rzehak)

Rzehakina fissistomata (Grzybowski)

Rzehakina inclusa (Grzybowski)

Rzehakina minima Cushman \& Renz

Spirosigmoilinella sp. (of Verdenius \& Van Hinte)

Spirosigmoilinella compressa Matsunaga ${ }^{9}$

$\begin{array}{lllllllll} & \mathrm{XX} & & & & & & & \\ \mathrm{XX} & \mathrm{XX} & & & \mathrm{XX} & & \mathrm{XX} & & \\ \mathrm{XX} & \mathrm{XX} & \mathrm{XX} & \mathrm{XX} & \mathrm{XX} & \mathrm{XX} & \mathrm{XX} & \mathrm{XX} & \mathrm{XX} \\ \mathrm{XX} & \mathrm{XX} & \mathrm{XX} & \mathrm{XX} & & \mathrm{XX} & \mathrm{XX} & & \mathrm{XX} \\ \mathrm{XX} & \mathrm{XX} & & & & & \mathrm{XX} & & \mathrm{XX} \\ & \mathrm{XX} & & \mathrm{XX} & \mathrm{XX} & & \mathrm{XX} & \mathrm{XX} & \mathrm{XX} \\ \mathrm{XX} & \mathrm{XX} & \mathrm{XX} & & \mathrm{XX} & \mathrm{XX} & & & \mathrm{XX} \\ & \mathrm{XX} & & & & & & & \\ \mathrm{XX} & \mathrm{XX} & \mathrm{XX} & \mathrm{XX} & \mathrm{XX} & \mathrm{XX} & \mathrm{XX} & \mathrm{XX} & \mathrm{XX} \\ & \mathrm{XX} & & & & & & & \\ \mathrm{XX} & \mathrm{XX} & \mathrm{XX} & \mathrm{XX} & & & \mathrm{XX} & & \\ \mathrm{XX} & \mathrm{XX} & \mathrm{XX} & \mathrm{XX} & \mathrm{XX} & \mathrm{XX} & \mathrm{XX} & \mathrm{XX} & \mathrm{XX} \\ & \mathrm{XX} & & \mathrm{XX} & \mathrm{XX} & & \mathrm{XX} & & \mathrm{XX} \\ \mathrm{XX} & \mathrm{XX} & \mathrm{XX} & & \mathrm{XX} & & \mathrm{XX} & & \mathrm{XX} \\ \mathrm{XX} & & & & & \mathrm{XX} & & & \\ \mathrm{XX} & \mathrm{XX} & \mathrm{XX} & & \mathrm{XX} & \mathrm{XX} & \mathrm{XX} & \mathrm{XX} & \mathrm{XX} \\ \mathrm{XX} & \mathrm{XX} & \mathrm{XX} & \mathrm{XX} & \mathrm{XX} & \mathrm{XX} & \mathrm{XX} & & \\ & \mathrm{XX} & & & & & & & \\ \mathrm{XX} & \mathrm{XX} & & & & & & & \end{array}$

\begin{tabular}{|c|c|c|c|c|c|c|}
\hline \multirow{4}{*}{$\begin{array}{l}X X \\
X X\end{array}$} & $\mathrm{XX}$ & $\mathrm{Xx}$ & $\mathrm{xx}$ & $x x$ & & $x x$ \\
\hline & $x x$ & $\mathrm{XX}$ & & & $\begin{array}{l}X X X \\
X X\end{array}$ & \\
\hline & $x x$ & & & & & $x x$ \\
\hline & $x X$ & & & $\begin{array}{l}X X \\
X X\end{array}$ & $X X$ & $\mathrm{XX}$ \\
\hline
\end{tabular}

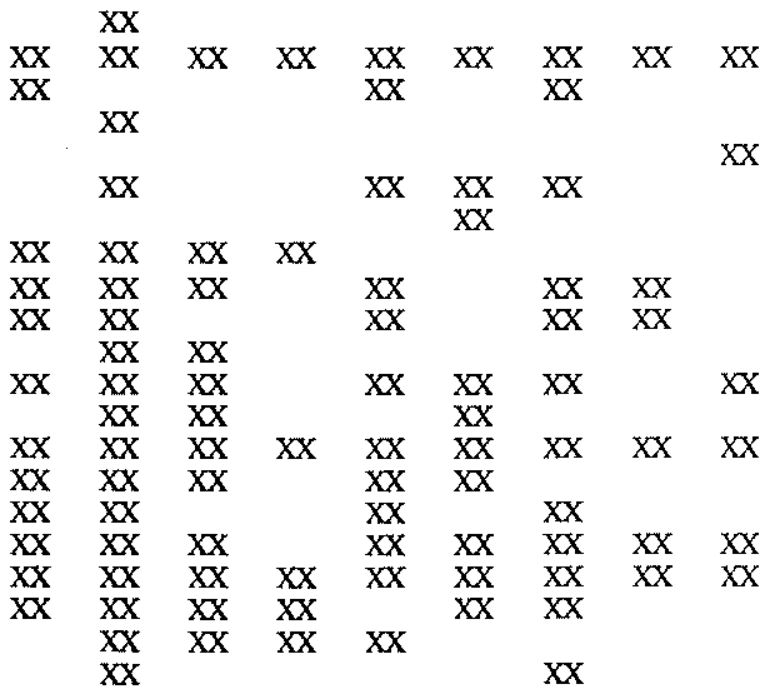

$\begin{array}{lllllllll}\mathrm{XX} & \begin{array}{c}\mathrm{XX} \\ \mathrm{XX}\end{array} & \mathrm{XX} & \mathrm{XX} & \mathrm{XX} & \mathrm{XX} & & \mathrm{XX} & \\ & \mathrm{XX} & & & & & & & \\ \mathrm{XX} & \mathrm{XX} & \mathrm{XX} & & & & \mathrm{XX} & & \\ & & & & & & & & \\ & & & & & \mathrm{XX} & \mathrm{XX} & & \mathrm{XX}\end{array}$ 
Table 4-1 (Continued).

\begin{tabular}{|c|c|c|c|c|c|c|c|c|c|}
\hline SPECIES & $\mathbf{T R}$ & PL & $\mathbf{R F}$ & $\mathbf{Z U}$ & $\mathbf{L A}$ & 647 & NS & WG & NGS \\
\hline \multicolumn{10}{|l|}{ HORMOSINACAE Haeckel, 1894} \\
\hline Aschemonella ex gr. grandis (Grzybowski) & $\mathrm{XX}$ & $\mathrm{XX}$ & $\mathrm{XX}$ & $X X$ & $\mathrm{XX}$ & $\mathrm{XX}$ & $\mathrm{XX}$ & & $\mathrm{XX}$ \\
\hline Aschemonella carpathica Neagu & & $X \mathbf{X}$ & & & & & & & \\
\hline Hormosina excelsa Dylazanka & & $\mathrm{XX}$ & & & $X X$ & $x X$ & $\mathrm{XX}$ & & \\
\hline Hormosina ovuloides (Grzybowski) & $\mathrm{XX}$ & $\mathrm{XX}$ & $\mathrm{XX}$ & $\mathrm{XX}$ & & & & & $\mathrm{XX}$ \\
\hline Hormosina ovulum ovulum (Grzybowski) & $\mathrm{XX}$ & $\mathrm{XX}$ & $\mathrm{XX}$ & $X X$ & $\mathrm{XX}$ & $\mathrm{XX}$ & $\mathrm{XX}$ & & \\
\hline Hormosina ovulum gigantea Geroch & $\mathrm{XX}$ & $\mathrm{XX}$ & & & $X X$ & & & & \\
\hline $\begin{array}{l}\text { Hormosina trinitatensis Cushman \& Renz } \\
\text { Hormosina sp. Gradstein \& Berggren }\end{array}$ & $\mathrm{XX}$ & $\mathrm{XX}$ & & & & & & & \\
\hline & XX & $\mathrm{XX}$ & $\mathrm{XX}$ & $\begin{array}{l}X X \\
X X\end{array}$ & & $X X$ & & $x X$ & \\
\hline Nodellum velascoensis (Cushman) & $\mathbf{X X}$ & $\mathrm{XX}$ & $\mathrm{XX}$ & $\mathrm{XX}$ & $\mathrm{XX}$ & & $\mathrm{XX}$ & & \\
\hline aff. Reophax bacillaris Brady & & & & & $\mathrm{XX}$ & & $\mathrm{XX}$ & & \\
\hline Reophax distans Brady & & & $x x$ & & & $\mathrm{XX}$ & & & \\
\hline Reophax duplex Grzybowski & $\mathrm{XX}$ & $X X$ & $\mathrm{XX}$ & $\mathrm{XX}$ & $X X$ & & $x x$ & & \\
\hline Reophax elongatus Grzybowski & & $\mathrm{XX}$ & $\mathrm{cf}$ & & & & & & \\
\hline Reophax globosus Sliter & $\mathrm{XX}$ & & $\mathrm{XX}$ & & $\mathrm{XX}$ & & & & \\
\hline Reophax guttifer Brady & & $\mathrm{XX}$ & & & & $\mathrm{XX}$ & & & $\mathrm{XX}$ \\
\hline Reophax pilulifer Brady & & $\mathrm{XX}$ & $\mathrm{XX}$ & $\mathrm{XX}$ & $\mathrm{XX}$ & & $\mathrm{XX}$ & $X X$ & $X X$ \\
\hline Reophax splendidus Grzybowski & & $\mathrm{XX}$ & $\mathrm{XX}$ & $X X$ & & & & & \\
\hline Reophax subfusiformis Earland emend Hoglund & $\mathrm{XX}$ & & $\mathrm{XX}$ & & $\mathrm{XX}$ & & $\mathrm{XX}$ & $\mathrm{XX}$ & $\mathrm{XX}$ \\
\hline Reophax subnodulosus Grzybowski & & $\mathrm{XX}$ & & & & $X X$ & & & $X X$ \\
\hline $\begin{array}{l}\text { Reophax sp. } 2 \\
\text { Reophax sp. Gradstein \& Berggren }\end{array}$ & $\mathrm{XX}$ & & & & & & & $\mathrm{XX}$ & \\
\hline Subreophax pseudoscalaria (Samuel) & $\mathbf{X X}$ & $\mathbf{X X}$ & $\mathbf{X X}$ & & & & & & \\
\hline Subreophax scalaria (Grzybowski) & $\mathrm{XX}$ & $\mathrm{XX}$ & $\mathrm{XX}$ & $\mathrm{XX}$ & $\mathrm{XX}$ & $\mathrm{XX}$ & $\mathrm{XX}$ & & $x x$ \\
\hline \multicolumn{10}{|l|}{ LITUOLACEA de Blainville, 1827} \\
\hline Adercotryma sp. 1 & & & & & & & $\mathrm{XX}$ & & $\mathrm{XX}$ \\
\hline Ammobaculites agglutinans (d'Orbigny) & & $\mathrm{XX}$ & & & $\mathrm{XX}$ & & & & \\
\hline Ammobaculites deflexus (Grzybowski) & & $\mathrm{XX}$ & $\mathrm{XX}$ & & $\mathrm{XX}$ & & & & \\
\hline Ammobaculites fontinensis (Terquem) & & $\mathrm{XX}$ & & & & & & & \\
\hline Ammobaculites jarvisi Cushman \& Renz & $\mathrm{XX}$ & $X X$ & & & & & & & \\
\hline Ammobaculites problematicus Neagu & & $\mathrm{XX}$ & & & $X X$ & & & & \\
\hline Ammobaculites wazaczi (Grzybowski) & & $\mathrm{XX}$ & & & & & & & \\
\hline Ammobaculites aff. polythalamus Loeblich & & & & & $\mathrm{XX}$ & $X X$ & $\mathrm{XX}$ & & $x X$ \\
\hline Ammobaculites sp. 1 & $\mathrm{XX}$ & & & & & & $\mathrm{XX}$ & & \\
\hline Ammobaculites sp. 2 & $\mathbf{X X}$ & & $\mathrm{XX}$ & & & & & & \\
\hline Ammobaculites sp. 3 & $X X$ & & & & $\mathrm{XX}$ & & & & \\
\hline Ammomarginulina sp. $\mathrm{G}$ & & $\mathrm{XX}$ & & & $\mathbf{X X}$ & & & & \\
\hline $\begin{array}{l}\text { Ammoscalaria spp. ind. } \\
\text { Budashevaella cf. }\end{array}$ & & & $\mathrm{XX}$ & & & & $\mathrm{XX}$ & & \\
\hline multicameratus (Voloshinova \& Budasheva) & $\mathrm{XX}$ & & & & $\mathrm{XX}$ & & $\mathrm{XX}$ & $\mathrm{XX}$ & $\mathrm{XX}$ \\
\hline Budashevaella trinitatensis (Cushman \& Renz) & $X X$ & & & & $\mathrm{XX}$ & & $\mathrm{XX}$ & & \\
\hline Cribrostomoides scitulus (Brady) & & $\mathrm{XX}$ & $\mathbf{X X}$ & & & & $\mathrm{XX}$ & $X X$ & \\
\hline Cribrostomoides trinitatensis Cushman \& Jarvis & $\mathrm{XX}$ & $\mathrm{XX}$ & $\mathrm{XX}$ & & & & & & \\
\hline $\begin{array}{l}\text { Cribrostomoides sp. } 1 \text { Gradstein \& Berggren } \\
\text { Cribrostomoides spp. ind. }\end{array}$ & & & $\mathrm{XX}$ & $x x$ & $\mathrm{XX}$ & $x X$ & $\mathrm{XX}$ & & $\mathrm{XX}$ \\
\hline Haplophragmoides compressa LeRoy & & & & & & & & & $\mathrm{XX}$ \\
\hline Haplophragmoides eggeri Cushman & & $x \mathbf{x}$ & & $\mathrm{XX}$ & $\mathrm{XX}$ & & $\mathrm{XX}$ & $\mathrm{XX}$ & $\mathrm{XX}$ \\
\hline Haplophragmoides excavatus Cushman & & & & & $\mathrm{XX}$ & & & & $\mathrm{XX}$ \\
\hline Haplophragmoides cf. glabra Cushman \& Waters & $\mathbf{X X}$ & & & & $\mathrm{XX}$ & & $\mathrm{XX}$ & & \\
\hline Haplophragmoides horridus (Grzybowski) & $X X$ & $\mathrm{XX}$ & $\mathrm{XX}$ & $\mathrm{XX}$ & & & & & \\
\hline Haplophragmoides "kirki" Wickenden & & $\mathbf{X X}$ & & & $\mathrm{XX}$ & & $\mathrm{XX}$ & & $\mathrm{XX}$ \\
\hline Haplophragmoides lamella (Grzybowski) & $\mathrm{XX}$ & $\mathrm{XX}$ & & & & & $\mathrm{XX}$ & & \\
\hline Haplophragmoides mjatliukae Maslakova & & $\mathbf{X X}$ & & & & & & & \\
\hline Haplophragmoides porrectus Maslakova & $\mathrm{XX}$ & $\mathrm{XX}$ & & & & $\mathrm{XX}$ & & & \\
\hline Haplophragmoides retroseptus (Grzybowski) & $X X$ & $\mathbf{X X}$ & $\mathbf{X X}$ & & $\mathrm{XX}$ & & & & \\
\hline Haplophragmoides stomatus (Grzybowski) & & $\mathrm{XX}$ & & & & & & & \\
\hline Haplophragmoides subglobulosus (Grzybowski) & & $\mathbf{X X}$ & & & & & & & \\
\hline Haplophragmoides ex gr. suborbicularis (Grzybowski) & $\mathrm{XX}$ & $\mathrm{XX}$ & & & $\mathrm{XX}$ & & $\mathrm{XX}$ & & \\
\hline Haplophragmoides walteri (Grzybowski) & $\mathrm{XX}$ & $\mathrm{xX}$ & $\mathrm{XX}$ & $\mathrm{XX}$ & $\mathrm{XX}$ & $X X$ & $X X$ & $X X$ & $X X$ \\
\hline Haplophragmoides sp. (coarse) & & & & $\mathrm{XX}$ & & & & & \\
\hline
\end{tabular}


Table 4-1 (Continued).

\section{SPECIES}

Haplophragmoides (?) jarvisi (Thalmann)

H. walteri/H(?). jarvisi transitional form

Haplophragmium sp. Gradstein \& Berggren

Labrospira pacifica Krashenninikov

Lituotuba lituiformis (Brady)

Phenacophragma beckmanni Kaminski \& Geroch

Phenacophragma elegans Kaminski

Recurvoides contortus Earland

Recurvoides deflexiformis (Noth)

Recurvoides gerochi Pflaumann

Recurvoides globulosus Jednorowska

Recurvoides imperfectus Hanzlikova

Recurvoides pseudoregularis Mjatliuk

Recurvoides cf. subturbinatus (Grzybowski)

Recurvoides ex gr.walteri (Grzybowski)

Recurvoides varius Mjatliuk

Recurvoides sp, 1.

Recurvoides sp, 2

Recurvoides spp. ind.

Sphaerammina gerochi Hanzlikova

Sphaerammina subgaleata (Vasicek)

Trochamminoides acervulatus (Grzybowski)

Trochamminoides dubius (Grzybowski)

Trochamminoides elegans (Rzehak)

Trochamminoides heteromorphus (Grzybowski)

Trochamminoides intermedius (Grzybowski)

Trochamminoides irregularis White

Trochamminoides mitratus (Grzybowski)

Trochamminoides proteus (Karrer)

Trochamminoides subcoronatus (Grzybowski)

Trochamminoides subtrullisatus (Grzybowski)

Trochamminoides vermetiformis (Grzybowski)

LOFTUSIACEA Brady, 1884

Reticulophragmium amplectens (Grzybowski)

Reticulophragmium garcilassoi sensu stricto (Frizzel)

Reticulophragmium cf, garcilassoi (Frizzel)

Reticulophragmium paupera Chapman

Reticulophragmium sp. (evolute)

Cyclammina sp aff $C$. acutidorsata (Hantken)

Cyclammina placenta (Reuss)

Cyclammina rotundidorsata (Hantken)

SPIROPLECTAMMINACEA Cushman, 1927

Spiroplectammina aff. $S$. dentata (Alth)

Spiroplectammina excolata Cushman

Spiroplectammina isrealskyi Hillebrandt

Spiroplectammina navarroana (Cushman)

Spiroplectammina spectabilis s.l. (Grzybowski)

Spiroplectammina cubensis (Cushman \& Bermudez)

TROCHAMMINACEA Schwager, 1877

Ammosphaeroidina pseudopauciloculata (Mjatliuk)

Conotrochammina whangaia Finlay

Cystammina aff. pauciloculata (Brady)

Praecystammina globigerinaeformis Krashenninikov

Trochammina altiformis Cushman \& Renz

Trochammina bulloidiformis Grzybowski

Trochammina deformis Grzybowski

Trochammina aff globigeriniformis Parker \& Jones

Trochammina quadriloba (Grzybowski)

Trochammina ruthven murrayi Cushman \& Renz

Trochammina subvesicularis Hanzlikova

TR PL RF ZU LA 647 NS WG NGS

$\mathrm{xx}$

$\mathrm{XX}$

$\mathrm{XX} \quad \mathrm{XX}$

$\mathrm{XX} \quad \mathrm{XX}$

$\mathrm{XX} \quad \mathrm{XX}$

$\mathrm{XX}$

$\mathrm{XX} \quad \mathrm{XX}$

$\mathrm{XX} \quad \mathrm{XX}$

$\mathrm{XX}$

$\mathrm{XX} \quad \mathrm{XX}$

$\mathrm{XX}$

$\mathrm{XX} \quad \mathrm{XX}$

$\mathrm{XX}$

$\mathrm{XX}$

$\mathrm{XX}$

$\mathrm{XX}$

$\mathrm{xx}$

$\mathrm{xx}$

$\mathrm{XX}$

$\mathrm{XX}$

$\mathrm{XX}$

$\mathrm{XX} \quad \mathrm{XX}$

$\mathrm{XX} \quad \mathrm{XX}$

$\mathrm{XX} \quad \mathrm{XX}$

$\mathrm{XX}$

$\mathrm{XX}$

$X X$

XX

$X X \quad X X \quad X X \quad X X$

$x x$

$\begin{array}{lllll}X X & X X & X X & X X & X X \\ X X & & X X\end{array}$

$\mathrm{XX}$

$\mathrm{XX} \quad \mathrm{XX} \quad \mathrm{XX}$

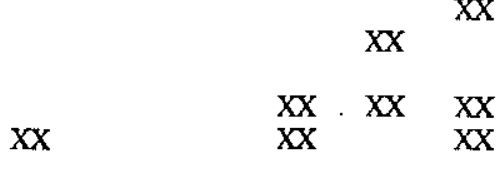

$\mathrm{XX} \quad \mathrm{XX}$

$X X \quad X X$

$\mathrm{XX}$

XX XX

$\mathrm{XX} \quad \mathrm{XX}$

$\mathrm{XX}$

$X X$

$\mathrm{XX} \quad \mathrm{XX}$

X

$\mathrm{XX}$

$\mathrm{XX}$

XX XX

$\mathrm{XX}$

$X X$

$\mathrm{XX}$

$X X$

$\mathrm{XX}$

$\mathrm{XX}$

$X X \quad X X$

$\mathrm{XX} \quad \mathrm{XX}$

$X X$

$\mathrm{XX}$

$\mathrm{X}$

XX

XX XX

$\mathrm{XX} \quad \mathrm{XX} \quad \mathrm{XX}$

$\mathrm{XX}$

XX

$\mathrm{XX}$

XX XX XX

$\mathrm{XX}$

XX

$\begin{array}{ll}X X & X X \\ X X & X X \\ X X & \end{array}$

XX

XX
$X X$

XX

$\mathrm{XX}$ 
Table 4-1 (Continued).

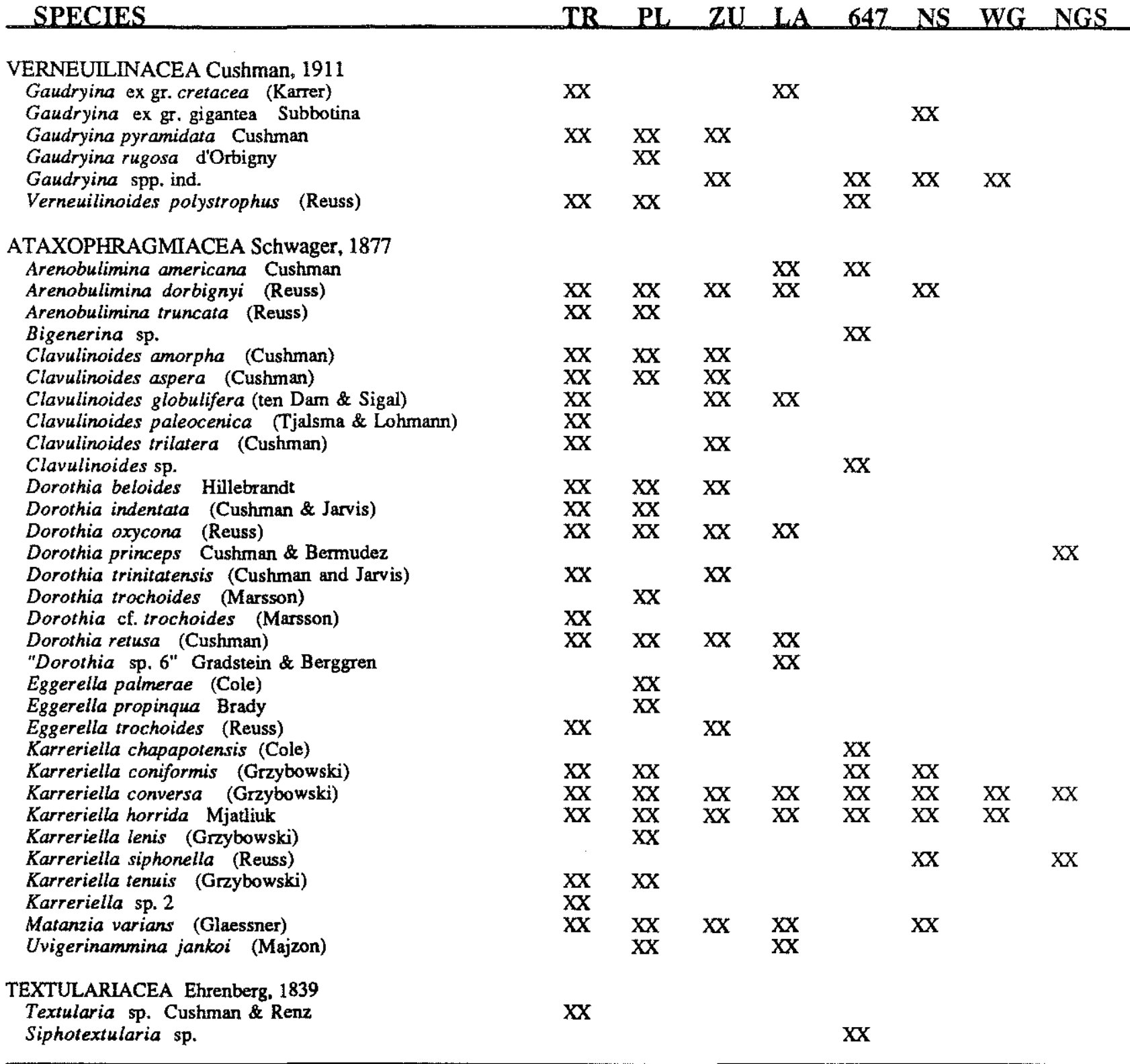

Trinidad data (TR) are from Kaminski $\theta$ al. (in press, a). Data from Zumaya, Spain (ZU) are from this study. Data from Labrador Margin (LA) are from this study. Data from Labrador Sea Sites 112 and 647 are from Kaminski et al. (in press, d). Western Carpathian data (PL) are compiled from modern Polish and Czechoslovakian literature (Geroch, 1960; Jednorowska, 1968, 1975; Hanzlikova, 1972, 1973, 1983; Huss, 1966; Samuel, 1977; Morgiel and Olszewska, 1981; Geroch and Nowak, 1984; Liszkowa and Morgiel, 1984; Olszewska, 1985). West Greenland (WG) and North Sea (NS) data are from Gradstein and Berggren (1981), Gradstein et al. (in press), and Kaminski et al. (in press, d) supplemented by additional observations. Norwegian-Greenland Sea (NGS) species are from Verdenius and Van Hinte (1983) and this study.

Taxonomic notes: ${ }^{1}$ includes Bathysiphon filiformis, $B$. eocenica, and $B$. nodosariiformis. ${ }^{2}$ includes Rhabdammina linearis of Grzybowski and Rhabdamnina abyssorum of Jurkiewicz (1967). ${ }^{3}$ includes Hyperammina subdiscretiformis Mjatliuk. ${ }^{4}$ includes forms with and without small planktonic tests incorporated in the wall, and Protobotellina lofotensis of Verdenius and Van Hinte (1983). ${ }^{5}$ includes Saccammina rhumbleri. ${ }^{6}$ includes Ammodiscus siliceus and A. angustus. ${ }^{7}$ includes Ammodiscus gorayskii. ${ }^{8}$ includes Glomospirella biedai. ${ }^{9}$ includes Rzehakina sp. 1 of Gradstein and Berggren (1981). ${ }^{10}$. includes Textularia plummerae and Spiroplectammina lanceolata. ${ }^{11}$ includes forms also designated as Dorothia crassa in Carpathian literature. ${ }^{12}$ includes forms also described as Karreriella apicularis in Carpathian literature and in Gradstein and Berggren (1981). 
collected to provide additional data on the occurrences of species and estimates of faunal abundance and diversity.

Eocene to 0ligocene flysch-type assemblages are present in Leg 38 and Leg 104 sites in the Norwegian-Greenland Sea (Verdenius and Van Hinte, 1983; this study), the Beaufort Sea (Young and McNiel, 1984; Dixon et al., 1985), Sites 112 and 647 in the southern Labrador Sea (Kaminski et al., in press, d), the Eocene of the Rif-Betic Flysch (Morgiel and 0lszewska, 1980; W. Kuhnt, personal communication), the upper Lizard Springs Formation of Trinidad (Kaminski et al., in press, a), and the Eocene of the Alpine Mountain Belt from Switzerland to Rumania. Assemblage data from Poland were compiled from Jurkiewicz (1967), supplemented by additional observations. Data from the Austria were compiled from Grun et al., (1964), and supplemented by sample material collected from the Buntmergelserie of the Helvetic Zone of the Alps in the Steinbauergraben of Upper Austria (Rogl, 1986). Data from the Schlieren flysch of the Swiss Alps were compiled from Winkler (1984). Assemblages from these localities were examined to determine biostratigraphic and geographic patterns in species diversity, the presence of endemic taxa, and the relative proportions of supra-generic groups.

Neogene agglutinated assemblages were recovered at ODP Site 645 in Baffin Bay, Site 646 in the Labrador Sea, and in the TEXACO Blue-H28 well on the Labrador Margin (Kaminski et al., in press, c). Additional data were compiled from Norwegian-Greenland Sea Sites 338, 344, 345 and 348 from Verdenius and Van Hinte (1983), Berggren and Schnitker (1983) and from Leg 38 site reports (Talwani, Udintsev et al., 1976).

\section{A. PALEOCENE PALEOBIOGEOGRAPHY:}

In the late Maastrichtian and Danian, vertical and latitudinal temperature gradients were low, with surface water temperatures averaging $16^{\circ} \mathrm{C}$ and bottom water $10-12^{\circ} \mathrm{C}$ in the South Atlantic (Shackleton et al. 1984). Paleocene bottom water temperature from paleodepths of $1000-3500 \mathrm{~m}$ in the Atlantic varied by only $2-3^{\circ} \mathrm{C}$ through time and by about $2{ }^{\circ} \mathrm{C}$ from the equator to $50^{\circ} \mathrm{N}$ (Boersma and Primoli-Silva, 1983). The homogeneous water mass resulting from comparatively low thermal gradients in the western North Atlantic has been suggested as a probable cause for the lack of discrete, paleobathymetrically confined benthic foraminiferal assemblages in the Danian (Tjalsma \& Lohmann, 1983). By contrast, in the mid-Paleocene equatorial 
regions and their associated current systems underwent a pronounced warming, and warm water was carried to nearly $40^{\circ} \mathrm{N}$ (Boersma, 1984). Later in the Paleocene and early Eocene, surface water temperatures were higher than at any other time in the Cenozoic, and deep-water temperatures increased by as much as $4^{\circ} \mathrm{C}$ in the South Atlantic (Oberhansli et al., 1984) and $6^{\circ} \mathrm{C}$ in the Pacific (Miller et al., in press). The increase in thermal gradients and increased water column stratification may have led to the restriction in paleobathymetric patterns in deep-water benthic taxa observed by Tjalsma and Lohmann (1983).

In the Paleocene, flysch-type assemblages are widespread in slope basins along the Atlantic margins from Trinidad to the northern Labrador Sea. The distribution of flysch-type foraminiferal assemblages in the North Atlantic and adjacent seas is shown in figure 4-1. These faunas traverse a range of latitudes, and Tethyan and Boreal end member assemblages can be clearly recognized. A meridional diversity gradient is also observed, with 102 species occurring in the Lizard Springs Formation of Trinidad (Kaminski et al. 1987) and around 80 species occurring in Zumaya, Spain. In contrast, Paleocene assemblages from exploration wells in the Labrador and North Seas contain about 60 species. The lowest species diversity is found beneath the oceanic CCD. Paleocene assemblages at Sites 543A and 368 are depauperate, with only about 20 species. Main features of the agglutinated assemblages in each area studied are summarized in Table 4-2.

The availability of calcium carbonate appears to be a major factor controlling the diversity of generic groups with calcareous cement. The calcareous ataxophragmiids (Arenobulimina, Clavulinoides, Dorothia and Gaudryina) are more typical of low latitude assemblages in carbonate environments. These forms are locally abundant in Trinidad and Zumaya, and commonly occur in marly units in the Carpathians. However, the calcareous ataxophragmiids are rare above the Maastrichtian on the Labrador Margin, and in the North Sea their probabilistic last occurrence is near the top of the Danian chalk unit. It is not yet clear whether their paucity in the highlatitude basins reflects differences in temperature. No calcareous ataxophragmiids were found in the abyssal assemblages of Site 543A or in the noncalcareous shales from the Tangier Unit of Morocco.

Provinciality among noncalcareous agglutinated taxa is evident mainly among rzehakinids and loftusiids. The rzehakinids are profusely abundant in 


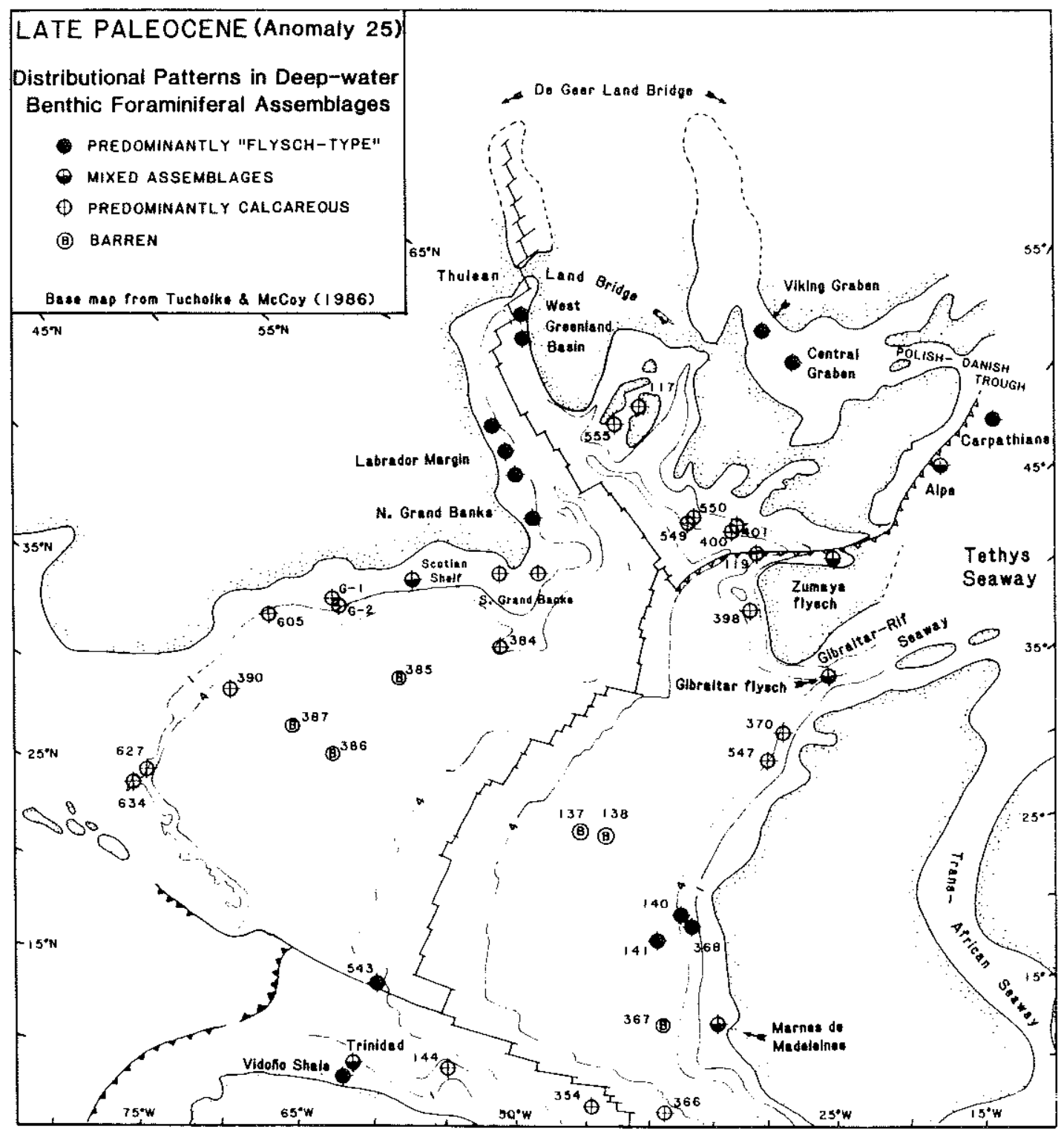

4-1. Distribution of agglutinated, calcareous and mixed benthic foraminiferal assemblages in the North Atlantic in the late Paleocene. Data is compiled from Site reports, personal observations, and personal communication with J.P. Beckmann, W.A. Berggren, S. Gofas, W. Kuhnt, R.M. Leckie, H.P. Luterbacher, K.G. Miller, L.E. Ostermann, C.W. Poag, A. von Hillebrandt, and M.A. Williamson. Plate reconstruction is after Tucholke and McCoy (1986). 
Table 4-2. Main features of Paleocene and lower Eocene assemblages. Numbers in boxes refer to numbers of species represented at each locality.

PALEOCENE FLYSCH.TYPE ASSEMBLAGES

\begin{tabular}{|c|c|c|c|c|c|c|c|}
\hline \multicolumn{2}{|r|}{ TRINIDAD } & \multicolumn{2}{|r|}{ ZUMAYA } & \multicolumn{2}{|r|}{ NORTH SEA } & \multicolumn{2}{|c|}{ LABRADOR MARGIN } \\
\hline 100 & This study & 83 & This study & -40 & This study & $\sim 40$ & This study \\
\hline \multicolumn{2}{|c|}{$\begin{array}{l}\text { Abundant calcareous ataxo- } \\
\text { phragmiids, Rzehakina and } \\
\text { Trochamminids }\end{array}$} & \multicolumn{2}{|c|}{$\begin{array}{l}\text { Characteristic forms: } \\
\text { P. elegans, } \\
\text { H.walteri/H(?). jarvisi }\end{array}$} & \multicolumn{2}{|c|}{$\begin{array}{l}\text { Abundant tubular forms, } \\
\text { lituolids, \& ammodiscids. } \\
\text { Common Spiroplectammina } \\
\text { Few calcareous ataxo- } \\
\text { phragmiids, Rzehakina } \\
\text { Charact. forms: L. pacifica, } \\
\text { A. aff. polythalamus, } \\
\text { R. paupera, Praecystammina } \\
\text { R. aff. garcilassoi, } \\
\text { T. ruthven-murrayi }\end{array}$} & \multicolumn{2}{|c|}{$\begin{array}{l}\text { Abundant tubular forms \& } \\
\text { lituolids. Few ammodiscids } \\
\text { Rzehakina, spiroplect- } \\
\text { amminids and calcaroous } \\
\text { ataxophragmiids } \\
\text { Characteristic forms: } \\
\text { Ammob. aff. polythalamus, } \\
\text { T. ruthven-murrayi }\end{array}$} \\
\hline \multicolumn{2}{|c|}{$\begin{array}{l}\text { RIF MOUNTAINS } \\
\text { (Tangier Unit) }\end{array}$} & \multicolumn{2}{|c|}{$\begin{array}{l}\text { SWITZERLAND } \\
\text { (Schlieren flysch) }\end{array}$} & \multicolumn{2}{|r|}{$\begin{array}{l}\text { AUSTRIA } \\
\text { (Wienerwald flysch) }\end{array}$} & \multicolumn{2}{|c|}{$\begin{array}{c}\text { POLAND } \\
\text { (Central Carpathian Depression) }\end{array}$} \\
\hline 50 & This study & \multirow{2}{*}{\multicolumn{2}{|c|}{ 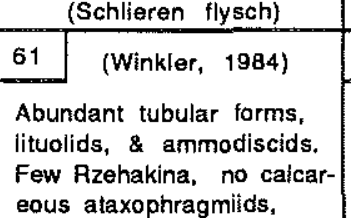 }} & \multicolumn{2}{|r|}{$\frac{\text { (Wienerwald flysch) }}{\text { (Grün et al., 1964) }}$} & \multicolumn{2}{|c|}{\begin{tabular}{l|l} 
(Central Carpathian Depression) \\
95 & $\begin{array}{c}\text { (Jurkiewicz, 1967; } \\
\text { Jednorowska, 1975) }\end{array}$ \\
\cline { 1 - 2 }
\end{tabular}} \\
\hline \multicolumn{2}{|c|}{$\begin{array}{l}\text { Abundant tubuiar forms, } \\
\text { lituolids, \& ammodiscids. } \\
\text { Few calcareous ataxo- } \\
\text { phragmiids, Rzehakina }\end{array}$} & & & \multicolumn{2}{|c|}{$\begin{array}{l}\text { Abundant tubuiar forms, } \\
\text { common Trochamminoides. } \\
\text { Rare Ammodiscids and } \\
\text { Rzehakina. No calcareous } \\
\text { ataxophragmids }\end{array}$} & \multicolumn{2}{|c|}{$\begin{array}{l}\text { Abundant tubular forms, } \\
\text { common Ammodiscus, } \\
\text { hormosinids, fituolids and } \\
\text { Rzehakina. Few calcareous } \\
\text { ataxophragmiids. } \\
\text { No boftusiids }\end{array}$} \\
\hline \multicolumn{2}{|c|}{$\begin{array}{l}\text { Characteristic species: } \\
\text { R. garcilassoi (s.s.) }\end{array}$} & \multicolumn{2}{|c|}{$\begin{array}{l}\text { Characteristic forms: } \\
\text { Fzehakina fissistomata }\end{array}$} & \multicolumn{2}{|c|}{$\begin{array}{l}\text { Characteristic species: } \\
\text { Rzehakina fissistomata }\end{array}$} & \multicolumn{2}{|c|}{$\begin{array}{l}\text { Characteristic species: } \\
\text { Rzehakina fissistomata }\end{array}$} \\
\hline
\end{tabular}

EARLY EOCENE FLYSCH-TYPE ASSEMBLAGES

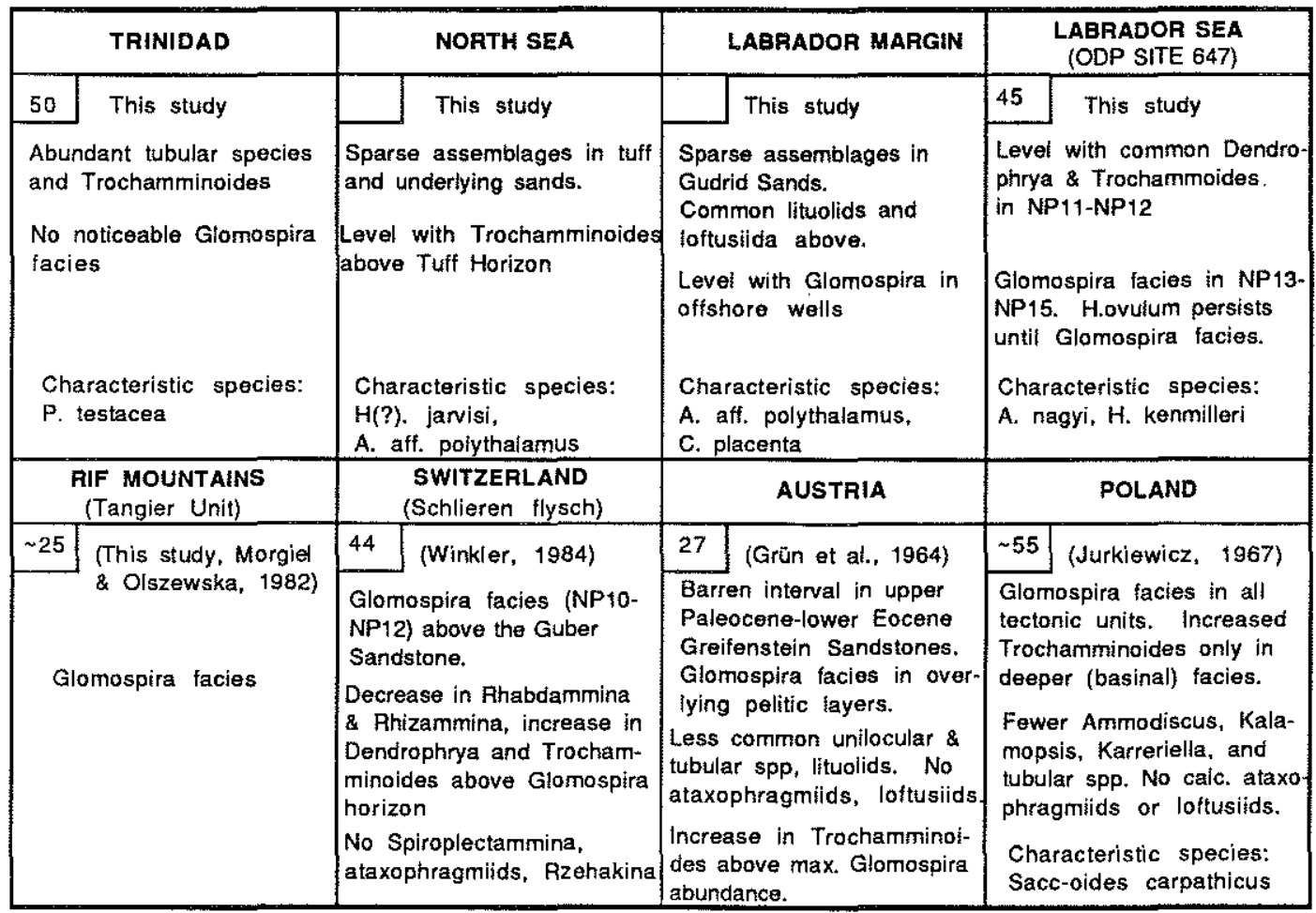


Trinidad, where they are represented by two species (Rzehakina epigona and Rzehakina minima). These species occur only rarely at other Atlantic localities. Paleocene flysch sediments in the Carpathians (Geroch and Nowak, 1984) and Alps (Winkler, 1984) contain R. fissistomata, which may be a geographic (Tethyan) variant of $\mathrm{R}$. epigona. This taxon has been given species or subspecies status by various authors, and has not been unequivocably identified outside the Carpathians. Another Paleocene species that appears to be restricted to Trinidad and Zumaya is Phenacophragma elegans.

The most restricted geographic patterns are exhibited by the primitive cyclamminids. The evolution of alveolar structures apparently occurred rapidly in the Paleocene among several lineages in different areas. Although the taxonomy of the early species of Reticulophragmium is still poorly understood, it appears that the North Sea contained two or more species (Reticulophragmium paupera and $\underline{R}$. cf garcilassoi) which are not found at lowlatitude localities. Deltaic assemblages from the Paleocene Moose Channel Formation of the Mackenzie Delta (Young and McNeil, 1984, Dixon et al., 1985) and from the Selandian of Spitsbergen (J. Nagy, personal communication 1986) contain additional species with alveolar wall structure. In the Atlantic, Reticulophragmium-type features began to appear in the Haplophragmoides walteri lineage in the early Selandian, giving rise to ?Haplophragmoides jarvisi in Zone P5. By the end of the Paleocene, specimens of ?H. jarvisi from exploration wells on the Angola Margin displayed true alveoles, but this species is not found above the Paleocene/Eocene Boundary in low latitudes. The low latitude assemblages contain at least two different species of Reticulophragmium in the Paleocene of Trinidad, Venezuela, and Morocco but their taxonomic affinities are still poorly understood. One of these species, R. garcilassoi (sensu stricto) displays "advanced" morphological features already in the mid-Paleocene in Morocco. For unknown reasons, primitive cyclamminids and $\underline{\mathrm{H}}(?)$. jarvisi do not occur in the Carpathians and are rare on the Labrador Margin.

The Paleocene/Eocene Boundary:

A major turnover in the composition of North Atlantic benthic foraminiferal assemblages occured in Zone P6a. Tjalsma and Lohmann (1983) noted extinctions and depth migrations of calcareous benthics in DSDP sites in the western Atlantic near the Paleocene/Eocene boundary. This turnover was no 
doubt due to a combination of factors, including a lowering of sea level, reduced oceanic primary productivity, and decreased thermal gradients due to warming of deep waters. Carbon isotopic evidence points to increased oxygenation of deep water across the boundary (Shackleton, 1986). The development of more oligotrophic conditions and loss of niche space may have contributed to disappearances of flysch-type taxa in low-latitude assemblages. In Trinidad and Zumaya, about $80 \%$ of Paleocene species disappeared at the end of Zone P5, and early Eocene assemblages were dominated by calcareous benthic taxa. Agglutunated foraminifera disappear entirely from abyssal DSDP sites in the equatorial Atlantic.

The Paleocene/Eocene turnover among agglutinated foraminifera is not as pronounced in the high-latitude basins, but is still easily recognized by the loss of a number of species. In the North Sea, the Paleocene/Eocene transition is represented by a zone of low foraminiferal abundance in the North Sea tuff sequence. In Labrador Margin wells, the lower Ypresian Gudrid Sands produce a similar effect. In these sections, the Paleocene/Eocene boundary is characterized by the loss of the remaining calcareous ataxophragmiids (Clavulinoides, Gaudryina, Matanzia) and the genera Hormosina, Glomospirella, and Rzehakina.

EOCENE PALEOBIOGEOGRAPHY:

The Eocene period witnessed the change from a sluggish, salinity-driven deep circulation pattern to vigorous, thermohaline circulation driven by cooling at high latitudes. After the early Eocene temperature maximum, deep waters underwent a series of stepwise coolings culminating in the ice growth/cooling event of the basal 0ligocene, when deep waters were probably as cool as they are today (Miller et al., 1987). At the same time, changes in global sea level, surface water productivity, the carbonate lysocline, and oceanic circulation patterns affected the sedimentologic record in the North Atlantic to a much greater extent in the Eocene than in preceding times when sediments at abyssal sites consisted predominantly of variegated clays. In the Eocene of the equatorial Atlantic, abyssal agglutinated assemblages were no longer preserved beneath the oceanic CCD. In Hole 543A, the disappearance of agglutinated assemblages coincides with the change from Paleocene variegated claystones to Eocene biosiliceous sediments (Hemleben and Troester, 1985; this study). Eocene radiolarites in the western North Atlantic basin 
are barren of all foraminifera. During the Eocene, bathyal flysch-type assemblages became restricted mainly to high latitudes and areas of the continental margins of the North Atlantic and Tethys which experienced clastic sedimentation. The persistance of bathyal flysch-type assemblages in highlatitude basins may reflect the northward "unzippering effect" of atlantic sea-floor spreading, since rapid subsidence and clastic deposition in sedimentary basins took place during the rifting and early spreading stages. Figure 4-2 shows the distribution of flysch-type assemblages in the Eocene, and main features of these assemblages are summarized in Tables 4-2 and 4-3.

The lowermost Eocene sediments in Austria, Switzerland, Poland, Zumaya and on the Labrador Margin are often represented by sands which are either barren or have sparse agglutinated assemblages. Similarly, North Sea wells contain both sands and ash layers with poor assemblages. Above the ubiquitous sparse interval, certain similarities between lower Eocene agglutinated assemblages are observed throughout the Atlantic and Mediterranean Tethys. Although faunas vary in diversity and species composition from region to region, two basic faunas are observed: one with common Trochamminoides, and a second with abundant Glomospira.

The low-latitude end member of the lower Eocene faunas is represented in the upper Lizard Springs Formation of Trinidad, where the total diversity of agglutinated taxa is about 50 species. These assemblages are characterized by large numbers of the genus Trochamminoides. This genus was presumably well adapted to the more oxygenated deep-water conditions reflected by the widespread development of red clay facies throughout the Atlantic and by the carbon isotope record of Shackelton (1986). The upper Lizard Springs Formation contains several species of this group as well as a number of astrorhizids which build their wall out of small planktonic tests. In the Zumaya section, Trochamminoides is one of the few forms to survive the Paleocene/Eocene boundary event. The lower Eocene red clays in the Magura Flysch of Poland contain assemblages that are numerically dominated by this genus (Morgiel and 0lszewska, 1981). In the North Sea, red sediments with Trochamminoides occur near the top of the ash unit deposited during the Anomaly 23-24 rifting phase in the Norwegian-Greenland Sea, but this genus is not as common in the North Sea as in low latitudes. Trochamminoides does not occur in lower Eocene assemblages on the Labrador Margin. The Trochammininoides assemblage in the North Sea may reflect the early Eocene 


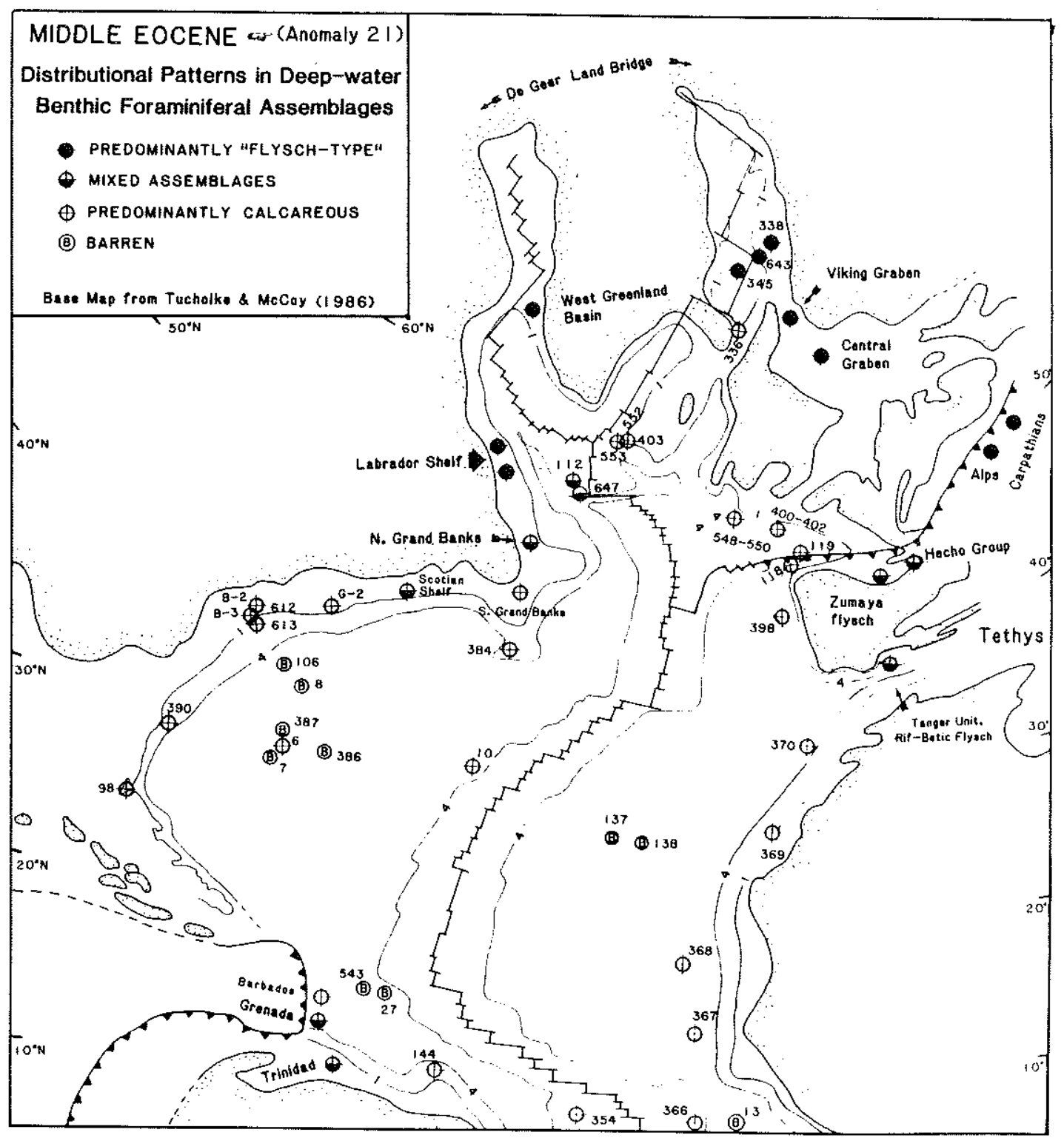

4-2. Paleobiogeography of Eocene benthic foraminiferal biofacies. Data sources are the same used for figure 4-1. 
Table 4-3. Main features of Middle Eocene and 0ligocene assemblages. Numbers in boxes are numbers of species recognized at each locality.

MIDDLE EOCENE FLYSCH-TYPE ASSEMBLAGES

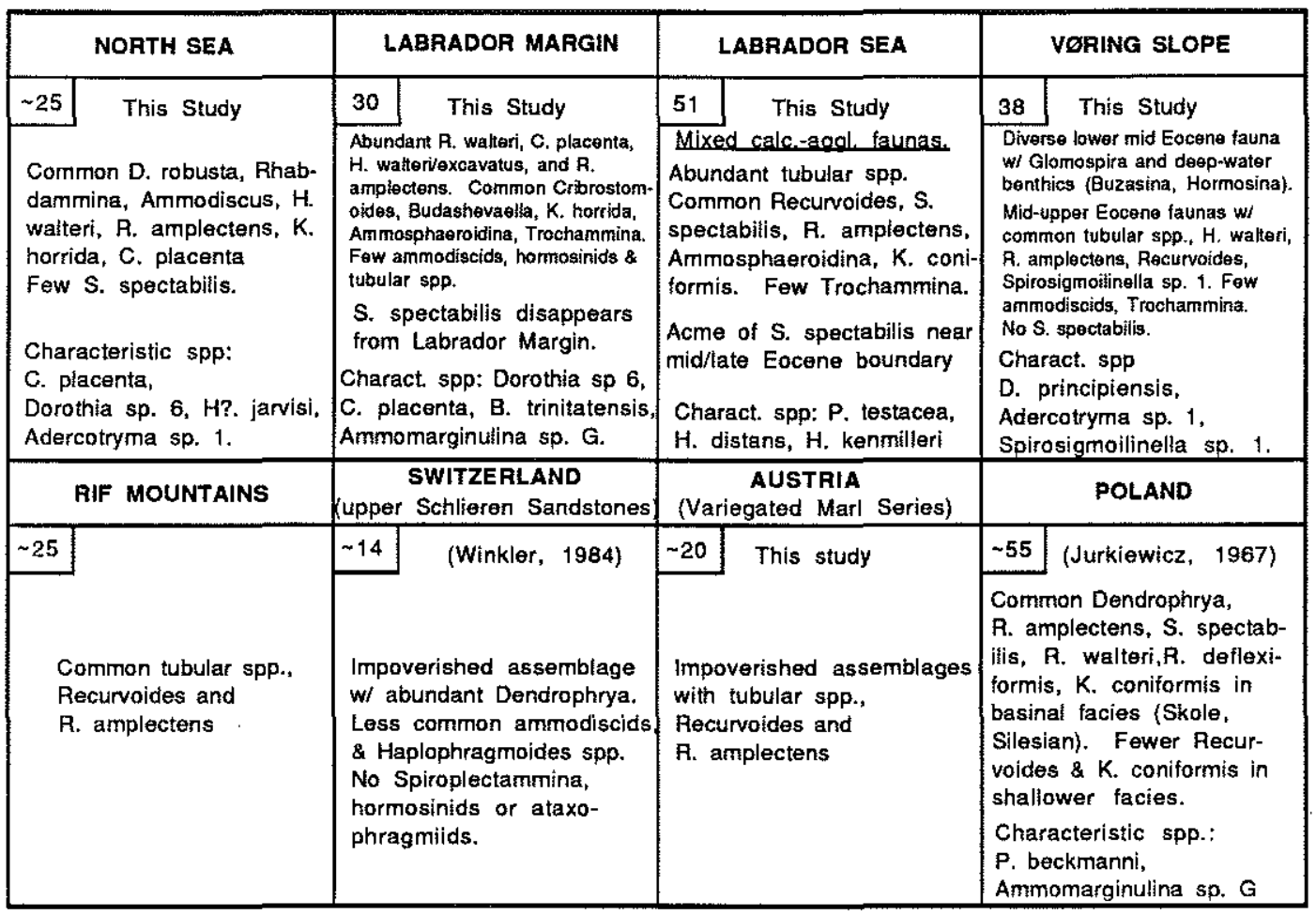

LATE EOCENE - OLIGOCENE FLYSCH-TYPE ASSEMBLAGES

\begin{tabular}{|c|c|c|c|}
\hline NORTH SEA & LABAADOR MARGIN & LABRADOR SEA & POLAND \\
\hline $\begin{array}{l}\text { Late Eocene-early Oligocene } \\
\text { assemblages with common } \\
\text { C. placenta, Rhabdammina, } \\
\text { O. robusta, C. rotundidorsata } \\
\text { A. latus, Spirosigmoilinelia, } \\
\text { H. walteri, R. pilulifer. } \\
\text { LCO flysch-type species } \\
\text { due to mid Oligocene } \\
\text { shallowing and calcareous } \\
\text { sedimentation. }\end{array}$ & $\begin{array}{l}\text { Late Eocene-early Oligocene } \\
\text { assemblages with common } \\
\text { C. placenta, A. latus, } \\
\text { H. walteri/excavatus, } \\
\text { D. robusta, C. rotundidorsata }\end{array}$ & $\begin{array}{l}\text { Eocene assemblages with } \\
\text { S. compressus \& A. latus. } \\
\text { Reduction in size and } \\
\text { LO's of } 32 \text { spp. from late } \\
\text { Eocene to early Oligocene. } \\
\text { LO's of S. spectabilis and } \\
\text { R. amplectens at boundary. } \\
\text { Max. abundance of A. latus } \\
\text { in basal Oligocene. } \\
\text { LCO flysch-type taxa NP22 }\end{array}$ & $\begin{array}{l}\text { Late Eocene assemblages } \\
\text { with common Rhabdammina } \\
\text { A. latus, C. rotundidorsata, } \\
\text { \& R. pitulifer. } \\
\text { S. spectabitis common } \\
\text { in deeper (Silesian) basin. } \\
\text { Flysch-type spp disappear } \\
\text { within Globigerina Marls } \\
\text { (NP19-20), owing to calc. } \\
\text { sedimentation \& shallowing } \\
\text { of the basin. }\end{array}$ \\
\hline JAN MAYEN RIDGE & LOFOTEN BASIN & VERING PLAT & Ve \\
\hline $\begin{array}{l}\text { Low diversity Eocene } \\
\text { assemblages w/ common } \\
\text { iubular spp. and less } \\
\text { common } \mathrm{R} \text {. amplectens, } \mathrm{H} \text {. } \\
\text { excavatus, S. spectabilis, } \\
\text { C. placenta. } \\
\text { Oligocene assemblages } \\
\text { contain only tubular and } \\
\text { unilocular spp. }\end{array}$ & $\begin{array}{l}\text { Eocene assemblage w/ } \\
\text { C. placenta, R. amplectens, } \\
\text { and common tubular spp, } \\
\text { P. fusca \& Recurvoides } \\
\text { Diverse Oligocene assem- } \\
\text { blage w/ Spirosigmoilin- } \\
\text { ella spp., C. acutidorsata, } \\
\text { H. walteri \& K siphonella }\end{array}$ & $\begin{array}{l}\text { Low diversity late Eocene } \\
\text { assemblage w/ S. spectab- } \\
\text { iłis, } \mathrm{R} \text {. amplectens and } \\
\text { calc. benthics (Ceratobul- } \\
\text { imina). } \\
\text { Sparse assemblage in } \\
\text { Oligocene } w / \mathrm{S} \text {. compressa } \\
\text { and Rupelian calcareous } \\
\text { spp. }\end{array}$ & $\begin{array}{l}\text { Late Eocene assemblage w/ Rhizam- } \\
\text { mina, S.compressa, Ammosphaeroi- } \\
\text { dina, H. walteri, Adercotryma sp 1, } \\
\text { Ammodiscus infimus, Karrerielia } \\
\text { siphonella, Budashevaelia. } \\
\text { LO's of } 21 \text { species near } \\
\text { mid-Oligocene hiatus. } \\
\text { Late Oligocene assemblage w/ R. } \\
\text { amplectens/acutidorsata, Recur- } \\
\text { voides, Spirosignoilinella spp., } \\
\text { K. siphonella. } \\
\text { Characteristic spp: } \\
\text { A. infimus, } \\
\text { K. siphoneila }\end{array}$ \\
\hline
\end{tabular}


temperature maximum, or the influx of warm waters from the Atlantic. However, for other species the North Sea served as a refuge. The persistence of ?H. jarvisi in the lower and middle Eocene sediments of the North Sea is evidence that faunal connections with the Atlantic were still restricted.

After early Eocene Zone NP12, bottom waters in the North Atlantic cooled approximately $2^{\circ} \mathrm{C}$, (Boersma et al., 1987) and the CCD in the Labrador Sea shoaled to a level above $2500 \mathrm{~m}$, possibly in response to a change in sea level. Condensed noncalcareous clays in Hole $647 \mathrm{~A}$ contain a Glomospira assemblage. Similar glomospirid assemblages are widespread in the Alpine mountain belt (Grun et al., 1964, Winkler, 1984), Carpathian basins (Jurkiewicz, 1967; Morgiel and 0lszewska, 1981) and in the Tangier Unit of Morocco (Morgiel and 0lszewska, 1982). These assemblages are reported from the lower Eocene, and may be coeval with this event. However, the presence of endemic species such as Saccamminoides carpathicus in the Carpathians, and Ammobaculites aff. polythalamus and Cyclammina placenta in the Labrador and North Seas is evidence of continued provinciality between the Atlantic and Tethys. Marine connections via the Polish-Danish Trough probably did not allow the exchange of deep water between the North Sea and Tethyan basins in Poland.

By middle Eocene time, flysch-type assemblages disappeared from Trinidad and Zumaya, and there is only one report of an isolated occurrence of agglutinated assemblages in western North Atlantic DSDP Holes. In Hole 612, Miller and Katz (1987) found one level with abundant s. spectabilis in the lower Lutetian. DSDP Holes in the eastern Atlantic and bathyal assemblages from Rockall Bank contain only calcareous assemblages. Middle Eocene agglutinated assemblages in the Labrador Sea and in the northern Atlantic basins typically contain 20-50 species of agglutinated forminifera, and a north-south diversity gradient is maintained. Assemblages from Site 647 are most diverse, with about 50 agglutinated species. An intermediate number of species ( 35) occur in the North Sea and in ODP Hole 643A in the NorwegianGreenland Sea, which contains about 38 species. The least diverse assemblages are reported in the Austrian and Swiss Alps, where flysch basins probably experienced shallowing owing to continuing orogeny. Middle Eocene assemblages continue to display higher diversity in Poland, where the basins were not yet affected by orogeny. 
Perhaps the most typical Eocene species in the North Atlantic is Reticulophragmium amplectens. This species is isobathyal and has a cosmopolitan distribution. In the Carpathians, R. amplectens has been found in sediments as old as Zone NP12 (0lszewska and Smagowicz, 1977). In the Atlantic, this species is found in the lower Eocene Tangier Unit of Morocco, in Zone P8 on the Labrador Margin and it occurs as early as Zone NP11 in the deep Labrador Sea. A closely related form which may be synonymous (Cyclammina cf. garcilassoi of Cushman and Renz, 1946) occurs in Zone P8 in Trinidad.

In the North Sea and Labrador Margin, the Eocene sequences display a series of last occurrences of flysch-type taxa which mainly refect the shallowing of the basins as sediment supply exceeded tectonic subsidence. Middle Eocene assemblages in the Labrador Margin wells are typically dominated by lituolids and loftusiids, with lower numbers of astrorhizids, ammodiscids

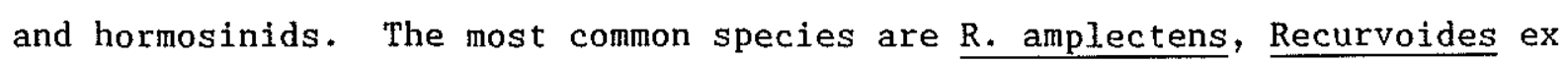
gr. Walteri, and Cyclammina placenta along with subdominant Ammosphaeroidina,

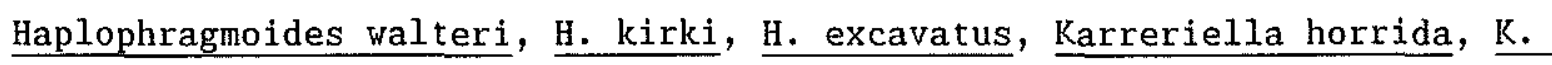
conversa, Ammodiscus latus, Budashevaella cf. multicamerata, Ammobaculites aff. polythalamus and Dorothia sp. 6. The genera Spiroplectammina and Glomospira disappear from the Labrador Margin on average in the lower Eocene, but these persist at Site 647 and in the Norwegian-Greenland Sea until the Eocene/0ligocene boundary. In the North Sea, an interesting pattern is observed in S. spectabilis, which extends into younger strata in northern wells. This species persists into the upper Eocene on the Voring Plateau.

The transition from the middle to late Eocene is associated with a decrease in bottom water temperature of around $\sim 3^{\circ} \mathrm{C}$, and increased oxygenation of intermediate and deep waters (Boersma et al., 1987). Extinctions of warm surface-dwelling as well as cool deeper-dwelling planktonic foraminifera during the late Eocene has been interpreted as an indication of steeper latitudinal and vertical temperature gradients (Corliss et al. 1984; Snyder et al. 1984; Keller, 1985). By the late Eocene, agglutinated assemblages are restricted to Poland, Labrador, and the North Sea - Norwegian Greenland Sea area. All three regions contain the species Ammodiscus latus and Cyclammina rotundidorsata. There is evidence of endemic species particularly in the North Sea and Norwegian-Greenland Sea in the late Eocene. The Norwegian-Greenland Sea assemblages contain Spirosigmoilinella sp. 1 of Verdenius and Van Hinte (1983), Karreriella siphonella, Dorothia 
principiensis, and Adercotryma sp. 1, which are unknown in Labrador and the Carpathians. The only other reported occurrence of a robust Spirosigmoilinella species in the northern hemisphere is in the upper Eocene to Oligocene Kugmallit Formation of the Mackenzie Delta (Dixon et al., 1985).

Spirosigmoilinella compressa is found in the New Jersey Transect Sites as well as in Holes $647 \mathrm{~A}, 643 \mathrm{~A}$ and in the North Sea wells, but this species is not found in the Carpathians. For other species, though, the Carpathian basins served as a refuge. Phenacophragma beckmanni is found in the middle Eocene of the Silesian Unit in Poland, whereas it was not found above the Paleocene in Trinidad. Similarly, Glomospira, S.spectabilis and s. navarroana are common in the region until the latest Eocene, whereas they disappear much earlier from the North Sea and from bathyal assemblages on the Labrador Margin.

\section{OLIGOCENE PALEOBIOGEOGRAPHY:}

A number of paleoceanographic and paleobiogeographic changes occurred near the end of the Eocene which are known collectively as the "Terminal Eocene Event" (Wolfe, 1978; Van Couvering et al., 1981). These changes have been attributed to cool meridional circulation replacing warmer Eocene water masses (Steineck et al., 1984). An increase in benthic foraminiferal oxygen isotope values across the Eocene-0ligocene transition has been interpreted as evidence for increased ice volume and a decrease in bottom water temperature of at least $1-2^{\circ} \mathrm{C}$ (Keigwin and Corliss, 1986). The covariance between planktonic and benthic delta 18-0 records in the lower 0ligocene $(36,31$ and $25 \mathrm{Ma}$ ) led Miller and Fairbanks (1985) to suggest three periods of continental glaciation as a causual mechanism. A change in deep-water mass properties also occurred at this time. In both the Atlantic and Pacific, a major faunal abundance change among abyssal foraminifera is observed in the upper Eocene (Tjalsma and Lohmann, 1983; Miller, 1983; Miller et al., 1985; Wood et al., 1985; Thomas, 1985). Lower 0ligocene benthic carbon isotope records in the western North Atlantic are enriched relative to the Pacific, suggesting a supply of nutrient-depleted deep water in the North Atlantic analogous to modern NADW (Miller and Fairbanks, 1985). The timing of the delta 13-C difference correlates with a period of increased bottom water erosion in the North Atlantic (Miller and Tucholke, 1983). 
Flysch-type assemblages disappeared from the deep Labrador Sea and the Carpathian basins within one or two million years of the Eocene/0ligocene boundary. In Poland, this disappearance was abrupt and takes place within a few meters of the base of the Globigerina marls, which mark the sudden transition from terrigenous sedimentation to calcareous sedimentation in Zone NP19-20 (Van Couvering et al., 1981). About 40 species of agglutinated foraminifera occur directly beneath the marls, whereas only a few rare species of lituolids, Rhabdammina and Ammodiscus are found within the marls. Only isolated occurrences of agglutinated foraminifera are reported from the overlying lower 0ligocene organic-rich siliceous sediments (0lszewska, 1985). These consist mainly of rare specimens of Glomospira, Trochammina, Ammodiscus and Hyperammina in a predominantly calcareous benthic assemblage.

In contrast to the Carpathians, the disappearance of agglutinated species in the continuous hemipelagic section recovered at Site 647 is by no means abrupt, and the last occurrences of individual taxa apparently took place over a period of several million years. At Site 647 , there was a clustering of last occurrences between 36 and $37 \mathrm{Ma}$, but this did not correspond to any obvious change in sedimentation. This suggests that a change in bottom water properties was the likely cause of this faunal turnover, as suggested by Miller et al. (1982). The basal 0ligocene assemblage in Hole 647A contains only 7 flysch-type species, characterized by small-sized specimens of Glomospira and Bathysiphon. The maximum abundance of Ammodiscus latus occurs in this interval. The final disappearance of the remaining flysch-type species is associated with the lithologic change from siliceous hemipelagic clays to diatomites in Zone NP22. Only three species of agglutinated foraminifera (Rhabdammina sp., Spirosigmoilinella compressa, and Cribrostomoides sp.) were encountered in the biosiliceous interval in Hole $647 \mathrm{~A}$.

Flysch-type assemblages persisted on the Labrador Margin and in the central North Sea into the lower 0ligocene, but these assemblages consist of less than ten species. The assemblages in both regions were dominated by lituolids, loftusiids (Cyclammina placenta-cancellata, C. rotundidorsata) and robust tubular species (Dendrophrya robusta and Rhabdammina). In the early 0ligocene in both regions there was a regional trend from slope to shelf environments, accompanied by a transition to calcareous benthic assemblages. 
This trend was accentuated by the "mid"-0ligocene sealevel lowstand which resulted in hiatuses in many sections.

North of the Greenland-Scotland Ridge, more diverse assemblages (about 20 species) were present in the deep Norwegian-Greenland Sea. This area again served as a refuge for some of the "typical Eocene" species such as Ammosphaeroidina, and the R. amplectens lineage. Advanced forms of $\mathrm{R}$. amplectens with numerous lobate chambers and Cyclammina acutidorsata occur as high as Zone NP25 (upper 0ligocene) in Hole 643A. In this Hole, the LCO of agglutinated taxa is associated with the transition to ?upper oligocene lower Miocene siliceous sediments, but in other holes agglutinated assemblages persisted into the Neogene. Similarly, the Mackenzie Delta area harbours a diverse lower 0ligocene assemblage containing $\mathrm{R}$. amplectens (see Dixon et al., 1985, p1. 2, fig. 4) in bathyal facies of the Kugmallit Formation. In this area, the agglutinated facies was replaced by a calcareous fauna with Cibicidoides and Turrilina in the mid-oligocene (Dixon et al., 1985).

\section{NEOGENE PALEOBIOGEOGRAPHY:}

Miocene agglutinated assemblages are known only from the NorwegianGreenland Sea, Baffin Bay, and from two wells in the Labrador Sea (ODP Hole 646B on the Eirik Ridge and the TEXACO Blue H-28 well near Orphan Knol1). The main features of these assemblages are shown in Table 4-4. In all areas, the assemblages are numerically dominated by simple, coarse-walled species (Rhizammina, Rhabdammina, Lagenammina, Saccammina, and Psammosphaera). Only a few stratigraphically distinctive forms are present, the most important of which being the genus Martinotiella, which occurs in all three regions.

In the Norwegian-Greenland Sea, assemblages have been reported from Sites 348 (Berggren and Schnitker, 1983). A lower Miocene assemblage at this site contains a diverse assemblage comprised of Ammodiscus, Bathysiphon, Cribrostomoides, Cyclammina, Haplophragmoides, Reophax, Psammosphaera and Tolypammina. Above this assemblage, however, a depauperate middle to upper Miocene assemblage consists mainly of Spirosigmoilinella, Eggerella and Martinotiella. This type of depauperate Spirosigmoilinella assemblage traverses a wide depth range, since it is also reported in Holes 338 and 643 on the Vøring Plateau and Slope and in Hole 345 in the Lofoten Basin. Middle to upper Miocene assemblages in Holes 338, 345 and 348 consist of only 3 to 5 species. In Holes 338 and 348, the first occurrence of Martinotiella was used 
Table 4-4. Main features of Miocene assemblages.

MAIN FEATURES OF MIOCENE FLYSCH-TYPE ASSEMBLAGES

\begin{tabular}{|c|c|c|}
\hline BAFFIN BAY & LABRADOR SEA & NORWEGIAN-GREENLAND SEA \\
\hline $\begin{array}{l}\text { MIDDLE-UPPER MOCENE } \\
\text { ASSEMBLAGES CONTAINING } \\
\text { COARSE SPECIES OF RHIZAMMINA, } \\
\text { RHABDAMMINA, PSAMMOSPHAERA, } \\
\text { LAGENAMMINA, RECURVOIDES AND } \\
\text { CYCLAMMINA CANCELLATA. }\end{array}$ & $\begin{array}{l}\text { LATE MIOCENE - EARLY PLIOCENE } \\
\text { COARSE ASSEMBLAGES CONSISTING } \\
\text { MAINLY OF TUBULAR SPECIES IN } \\
\text { HOLE 646B, AND TEXACO BLUE H-28 } \\
\text { WELL. ASSOCIATED SPECIES ARE } \\
\text { AMMOSPHAEROIDINA, HAPLOPHRAG- } \\
\text { MOIDES, C. PUSLLLA, K. CONVERSA. }\end{array}$ & $\begin{array}{l}\text { PRE-GLACIAL PLIOCENE ASSEMBLAGE } \\
\text { IN HOLES } 345 \text { MORE DIVERSE THAN } \\
\text { MIOCENE, WITH HAPLOPHRAGMOIDES, } \\
\text { CYCLAMMINA. PREGLACIAL PLIOCENE } \\
\text { ASSEMBLAGES IN HOLE } 344 \text { CONSIST } \\
\text { OF DIVERSE COARSE AGGLUTINATED } \\
\text { SPECIES (HAPLOPHRAGMOIDES, REO- } \\
\text { PHAX, SACCAMMINA, BATHYSIPHON, } \\
\text { CRIBROSTOMOIDES). }\end{array}$ \\
\hline $\begin{array}{l}\text { MIDDLE MIOCENE INTERVAL WITH } \\
\text { SMOOTH AGGLUTINATED SPECIES } \\
\text { (BATHYSIPHON, HAPLOPHRAGMOIDES, } \\
\text { GLOMOSPIRELLA) IN A CLAY-RICH } \\
\text { INTERVAL WITH HIGHER TOC. }\end{array}$ & $\begin{array}{l}\text { TORTONIAN ASSEMBLAGES WITH } \\
\text { SMOOTH SPECIES (BATHYSIPHON, } \\
\text { AMMODISCUS, GLOMOSPIRA) WITH } \\
\text { A NUTIALLIDES UMBONIFERA FAUNA } \\
\text { IN HOLE 646B. }\end{array}$ & $\begin{array}{l}\text { MIOCENE BIOSILICEOUS SEDIMENTS } \\
\text { CONTAIN LOW DIVERSITY ASSEMB- } \\
\text { LAGES WITH SPIROSIGMOILINELLA, } \\
\text { MARTINOTIELLA IN HOLES } 338 \text { \& } \\
345 \text {, AND IN MIDDLE-UPPER MIOCENE } \\
\text { OF HOLE } 348 \text {. }\end{array}$ \\
\hline $\begin{array}{l}\text { LOWER MIOCENE ASSEMBLAGES WTHH } \\
\text { TROCHAMMINA, AMMODISCUS AND } \\
\text { HAPLOPHAAGMOIDES. }\end{array}$ & $\begin{array}{l}\text { MIDDLE MIOCENE ASSEMBLAGES } \\
\text { WITH S. SCHLUMBERGERI IN BLUE } \\
\text { H-28 WELL. }\end{array}$ & $\begin{array}{l}\text { DIVERSE ( } 20 \text { SPP) LOWER MIOCENE } \\
\text { ASSEMBLAGE IN HOLE } 348 \text { WITH } \\
\text { SPIROSIGMOLLINELLA, RECURVOIDES, } \\
\text { BATHYSIPHON, PSAMMOSPHAERA, } \\
\text { HAPLOPHRAGMOIDES, CYCLAMMINA, } \\
\text { BUDASHEVAELLA, REOPHAX. }\end{array}$ \\
\hline $\begin{array}{l}\text { ENDEMIC SPECIES: } \\
\text { CYCLAMMINA PLACENTA-CANCELLATA } \\
\text { RETICULOPHRAGMIUM (EVOLUTE), }\end{array}$ & $\begin{array}{l}\text { ENDEMIC SPECIES: } \\
\text { CYCLAMMINA? PUSILLA, } \\
\text { KARRERIELLA CONVERSA, } \\
\text { ADERCOTRYMA GLOMERATA }\end{array}$ & $\begin{array}{l}\text { ENDEMIC SPECIES: } \\
\text { SPIROSIGMOILINELLA }\end{array}$ \\
\hline
\end{tabular}


by Verdenius and Van Hinte (1983) to determine the base of the middle Miocene. The Miocene to early Pliocene deep water in the Arctic and NorwegianGreenland Sea was apparently corrosive, since carbonate contents at deep sites are less than 1 percent. Agglutinated foraminiferal assemblages are present in pre-glacial Pliocene sediments of Hole 344 on the Knipovich Ridge and Hole 345 in the Lofoten Basin. In Cores 26-33 of Hole 344, the assemblageconsists mainly of Bathysiphon, Haplophragmoides, Reophax, Hormosina and Saccammina, but at some levels Melonis barleeanum and Islandiella teretis occur together with the planktonic species Neogloboquadrina atlantica. The last occurrence of coarse agglutinated taxa was coincident with the onset of ice-rafting in Hole 345. The pre-glacial assemblage at this site is more diverse than the underlying Miocene assemblage and contains calcareous benthics and species of Cyclammina, Haplophragmoides and Martinotiella (Talwani, Udintsev, et al., 1976).

Spillover from the Norwegian-Greenland Sea through Denmark Straits was a likely factor resulting in the presence of agglutinated assemblages at Site 646 on the Eirik Ridge. In Hole 646B, primitive agglutinated species occur as a component of mixed calcareous-agglutinated assemblages. The agglutinated assemblages are late Miocene to early Pliocene in age and are strongly dominated by tubular species, with subdominant unilocular species (Psammosphaera) and Haplophragmoides, and less common Ammosphaeroidina, Cyclamina, Glomospira, Glomospirella, Martinotiella and Recurvoides. Several distinctive forms occurring in these assemblages impart a decidedly modern aspect to these faunas. The species Adercotryma glomerata, Cyclammina(?) pusilla, and Ammomarginulina foliacea, are known to live in the present-day North Atlantic. However, several forms bear marked resemblance to some

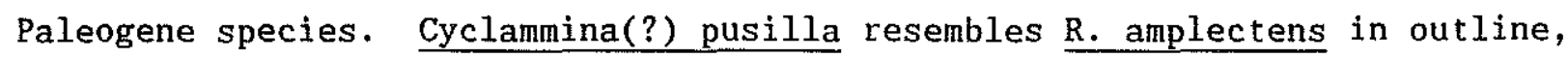
and Haplophragmoides sp. of Kaminski et al. (in press, c) recalls $\underline{\mathrm{H}}$. walteri/excavatus: Also present in this assemblage is a species of Ammodiscus which resembles the upper Eocene - 0ligocene species A. latus. The composition and diversity of upper Miocene to lower Pliocene species (17 total) in Hole $646 \mathrm{~B}$ is similar to the middle - upper Miocene assemblages in the TEXACO Blue H-28 well, although cyclamminids of the C. placanta-cancellata type are more abundant on the Labrador Margin. The generic composition of the foraminiferal assemblage is remarkably similar to the assemblages in the preglacial Pliocene of the Norwegian-Greenland Sea sites. The Miocene 
assemblages in Holes 348 and 345 in the Norwegian-Greenland Sea differ in containing species of Spirosigmoilinella, which was not found in the Miocene of the Labrador Sea wells.

In the Miocene of Baffin Bay Site 645, agglutinated foraminifera are the only forms present in most samples, since the preservation of calcareous species is discontinuous and generally poor. These agglutinated assemblages contain mainly the ubiquitous complement of tubular and unilocular species (Rhizammina, Rhabdammina, Bathysiphon, Psammosphaera, Lagenammina), but differ from Norwegian-Greenland Sea and Labrador Sea assemblages in the species of loftusiids present. In samples from Hole 645E, the most common species of Cyclammina is C. placenta-cancellata, which is morphologically similar to the oligocene species known from bathyal sediments in the North Sea and on the Labrador Margin. Cyclammina(?) pusilla was not observed, nor were any other forms with acute peripheries ("C. acutidorsata" from the Norwegian-Greenland Sea). However, a second species of Cyclammina which is more evolute and laterally compressed was observed in Hole 645E. This species resembles the early Paleogene species $\mathrm{R}$. arctica (Petracca) from the Mackenzie Delta.

\section{SUMMARY:}

In the early Paleogene, flysch-type foraminifera were widely distributed in areas of clastic sedimentation, at high latitudes and beneath the oceanic lysocline. As is true with modern deep-sea organisms (Thompson, 1877), the majority of flysch-type agglutinated foraminiferal species are cosmopolitan. However, lower Paleogene assemblages display some latitudinal differentiation in diversity, species composition and in the proportions of species groups. A general decrease in diversity is observed from low to high latitudes and from the continental slope to the deep ocean basins. Tropical Paleocene faunas contained abundant calcareous ataxophragmiids and rzehakinids. Boreal and Tethyan faunas contained endemic elements in the Paleocene and early Eocene. An early Eocene to early middle Eocene maximum in Glomospira was apparently an oceanwide phenomenon.

The diversity of these microfossils declined with time in most studied sections throughout the Paleogene. The last common occurrence of flysch-type foraminifera in the North Atlantic exhibits a pattern of diachrony with latitude and depth. There were three main periods of faunal turnover among 
agglutinated foraminifera in the Cenozoic. The first turnover, near the Paleocene/Eocene boundary, is characterized by the loss of agglutinated assemblages in the deep ocean basin and the extinction of many species and some genera in bathyal assemblages. However, some species persisted to younger levels in high-latitude basins. The Eocene/0ligocene transition in marked by disappearance of the last deep sea faunas in the Labrador Sea and Poland, and throughout most parts of the Labrador Margin and the North Sea. The early Oligocene witnessed a reduction in diversity on the Labrador Margin and in the Norwegian-Greenland Sea and the disappearance of agglutinated taxa in the Mackenzie Delta. The approximately coeval disappearance of agglutinated assemblages in these areas was caused by a regional trends from slope to shelf environments, accentuated by the "mid"-0ligocene sealevel lowstand.

The early/middle Miocene turnover in the Norwegian-Greenland Sea resulted in a reduction in diversity to around 5 species in the overlying biosiliceous sediments. Pre-glacial Pliocene assemblages display higher diversity until the onset of ice-rafting, when agglutinated species were replaced by calcareous benthic assemblages. In the Neogene, the only DSDP Site in the Atlantic where agglutinated assemblages were preserved is Site 646 in the Labrador Sea. At this site on near the Eirik Ridge, the presence of upper Miocene to lower Pliocene agglutinated assemblages reflects the overflow of dense water from the Norwegian-Greenland Sea over Denmark Straits. Upper Miocene assemblages recovered from Hole 646 contain elements of modern Atlantic faunas. Throughout their respective histories, both Baffin Bay and the Norwegian-Greenland Sea possessed endemic faunal elements. 


\section{CHAPTER 5 - PALEOECOLOGY AND PALEOCEANOGRAPHY}

\section{A. PALEOBATHYMETRY OF AGGLUTINATED FORAMINIFERA} INTRODUCTION :

Since flysch-type foraminifera are significant components of assemblages in economically important sedimentary basins, it is important to assess the paleobathymetric distribution of biofacies in order to improve their usefulness for interpreting regional geohistory. Unfortunately, few studies have been published that relate the abundance and composition of Paleogene flysch-type agglutinated taxa to paleobathymetry. Brouwer (1965) searched for a recent analogue to alpine flysch-type (Rhabdammina) faunas and concluded they are indicative of abyssal depths based on his analogies to recent faunas. Ksiazkiewicz (1975) likewise reviewed the published data on recent deep-sea agglutinated faunas (mainly the works of Brady and Bandy), and assigned bathyal paleodepths to upper Cretaceous and Paleogene assemblages from the Polish Carpathians. The occurrence of agglutinated assemblages in alpine regions and the ocean basins was synthesized by Gradstein and Berggren (1981), who proposed a generalized model for the occurrence of upper Cretaceous to Paleogene flysch-type agglutinated faunas. They related the occurrence of flysch-type assemblages to hydrographic and sediment properties associated with restricted bottom water circulation or the rapid deposition of fine grained clastic sediments (low oxygen low $\mathrm{pH}$, high $\mathrm{CO}_{2}$ low positive or intermittently negative $\mathrm{Eh}$, corrosive bottom water) which lead to reducing substrates and high organic content. Tjalsma and Lohmann (1983) have illustrated depth variations in lower Paleogene calcareous foraminifera, but flysch-type faunas are often found in regions where independent depth control is lacking. This makes the task of assigning paleodepths to agglutinated assemblages all the more difficult.

Although the occurrence of flysch-type agglutinated assemblages is not controlled by bathymetry per se (Gradstein and Berggren, 1981), bathymetric patterns in species composition are apparent from bathyal to abyssal depths. Gradstein and Berggren (1981) recognized two main types of flysch-type assemblages, probably reflecting faunistic trends. A "Type-A" assemblage is comprised primarily of large, coarsely agglutinated taxa which corresponds to the Rhabdammina-fauna of Brouwer (1965). This assemblage is found in slope basins on the continental margins and in DSDP sites with shallow $(2.5-3.5 \mathrm{~km})$ 
paleodepths. A different, "Type-B" assemblage consisting of minute, smoothwalled varieties has been found in deeper $(>4 \mathrm{~km})$ sites such as Sites 196 , 198A, 260, 261, 263 (Krasheninnikov, 1973, 1974) and probably lived beneath the oceanic lysocline. This assemblage is generally restricted to upper Cretaceous zeolitic clays, and is characterized by diverse species of Bathysiphon, Haplophragmoides, small ammodiscids, Hormosina, Recurvoides, Praecystammina, Pseudobolivina and Uvigerinammina. Elements of the upper Cretaceous "Type-B" fauna have been reported from Atlantic DSDP Sites 543A (Hemleben and Troester, 1985), 603 and 641 (Moullade et al., in press). A similar paleobathymetric pattern persists to the present in recent agglutinated foraminifera from the western North Atlantic (Kaminski, 1985; Schroder, 1986), where assemblages along the continental slope and rise consist mainly of large coarse grained astrorhizids and hormosinids, whereas the abyssal plain assemblage consists of small, finely agglutinated lituolids. There is evidence that some representatives of the genera Hormosina, Reophax, Trochammina, Thurammina, Rhizammina, Psammosphaera, Hyperammina, and Ammomarginulina are non-selective in the material used in the construction of the test wall (Schroder, 1986). As a result, their morphology may change dramatically with depth and the grain size of the substrate. On the Newfoundland continental slope and rise, the distribution of some modern agglutinated genera has been correlated with bathymetric patterns in the mean grain size of the sediment, total organic content and the occurrence of water masses (Schafer et al., 1983). Upper to middle slope environments contain a biofacies consisting of Trochammina, Textularia, Hemisphaerammina and Bathysiphon. The tranquil middle slope biofacies is characterized by the tubular genera Rhizammina, Bottellina, and Hyperammina. The abundance of Cyclammina is positively correlated with fine, organic-rich substrates on the middle slope. Lower slope to rise biofacies contain increased proportions of Ammobaculites, Glomospira, Karreriella, Recurvoides, Reophax and Sigmoilopsis. The abundance of Haplophragmoides, Saccammina and Spiroplectammina correlates with coarse substrates on the rise beneath the Western Boundary Undercurrent. The primary purpose of this study is to develop a generalized paleoslope model for the North Atlantic which relates the species composition and relative abundance of agglutinated foraminiferal species to paleobathymetry. This model is based on observations carried out in Trinidad, Zumaya, the Labrador Sea and the Norwegian-Greenland Sea and encompasses the Maastrichtian 
to middle Eocene. Several methodological approaches are utilized to construct this model, including backtracking, paleoslope reconstructions, microfossil facies changes in a deepening-upward sequence and identification of autochthonous vs redeposited assemblages in a basinal setting. Another aspect of this study is to compare the paleobathymetric distribution of assemblages from the North Atlantic with contemporaneous flysch-type agglutinated faunas from the Carpathian basins to determine whether consistent paleobathymetric patterns exist in these regions. Finally, the paleobathymetry of Paleogene agglutinated foraminifera in the North Atlantic is compared with a simple, generalized, mid-Cretaceous paleobathymetric model of Haig (1979) to determine whether this model adequately describes Maastrichtian to Paleogene patterns observed in the North Atlantic basins.

\section{A. TRINIDAD:}

The Lizard Springs formation of Trinidad was deposited on continental crust which has subsequently been deformed and uplifted; therefore paleobathymetric estimates based on thermal subsidence models cannot be used. The approach to studying the paleobathymetry of agglutinated taxa in Trinidad rests upon two assumptions: (1) that the assemblages in the turbidite sediments of the Lizard Springs Formation are made up of a mixture of basinplain assemblages in autochthonous sediments and faunal elements redeposited from shallower paleodepths in turbidite muds, and (2) that end-member assemblages can be identified whose paleobathymetric significance can be determined by means of cross-correlation with calcareous benthic assemblages, whose paleobathymetry has been calibrated in DSDP Sites (Tjalsma and Lohmann, 1983).

Sedimentary structures observed in thin section were used to provide supporting evidence for interpreting sedimentary environments. Thin sections from each core sample in well G-287 were examined to distinguish hemipelagic silts and clays from those of turbiditic origin. Studies of alpine flysch (Hesse, 1975) have revealed differences in bioturbation, grain size, microfossil content, color, bed thickness, and carbonate content between the two facies. Hemipelagic sediments are generally mottled owing to bioturbation, whereas parallel laminae are preserved in turbidites. Turbidite muds are often darker in color due to a greater amount of organic matter present (Piper, 1973; Hesse, 1977; 0'Brian et al. 1980). Despite the 
discontinuous sampling, inferences can be made about the depositional environment of the intervals studied in well G-287. A brief description of the sediments encountered follows, and is summarized in figure 5-1.

A. Sedimentology of TEXAC0 Trinidad Well G-287:

The uppermost interval (3205-3210 ft) consists of a uniform, noncalcareous clay with discontinuous organic-rich laminae. The next lower interval (3232-3248 ft) also contains a uniform clay with organic-rich burrows and streaks, but calcareous particles are present. A single lamina containing silt-sized calcareous grains was found at $3237 \mathrm{ft}$. The interval from 3266 to $3276 \mathrm{ft}$ again contains calcareous mottled clay with organic-rich burrows. Silt laminae containing calcareous particles were encountered at 3270 and $3274 \mathrm{ft}$. The presence of these sedimentary structures implies deposition by traction currents.

Uniform bioturbated noncalcareous clay was found from $3306-3320 \mathrm{ft}$. No sedimentary laminations were observed in this interval, suggesting hemipelagic deposition beneath the local lysocline.

The basal interval from 3348 to $3364 \mathrm{ft}$ contains rather coarse silty shales that are darker in color due to the presence of pyrite and siderite. Calcareous particles are common, and silt laminae were found at $3362 \mathrm{ft}$, suggesting redeposition. Organic-rich burrows were found at 3351, 3362, and $3364 \mathrm{ft}$.

\section{B. Composition of the Sand Fraction:}

The relative proportion of calcareous benthic, agglutinated, planktonic foraminifera, and nonbiogenic constituents (quartz, siderite and pyrite) was estimated for each washed sample (fig. 5-1). Of the five intervals studied, the basal interval displays the largest proportion of nonbiogenic sand and the largest ratio of calcareous/agglutinated foraminifera. Quartz and siderite predominate, and echinoderm fragments are common, supporting the sedimentological evidence suggesting redeposition. The bioturbated noncalcareous interval from 3306-3320 ft contains exclusively agglutinated foraminifera and quartz grains, with only minor authigenic minerals. Laminated sediments higher in the well contain greater proportions of 


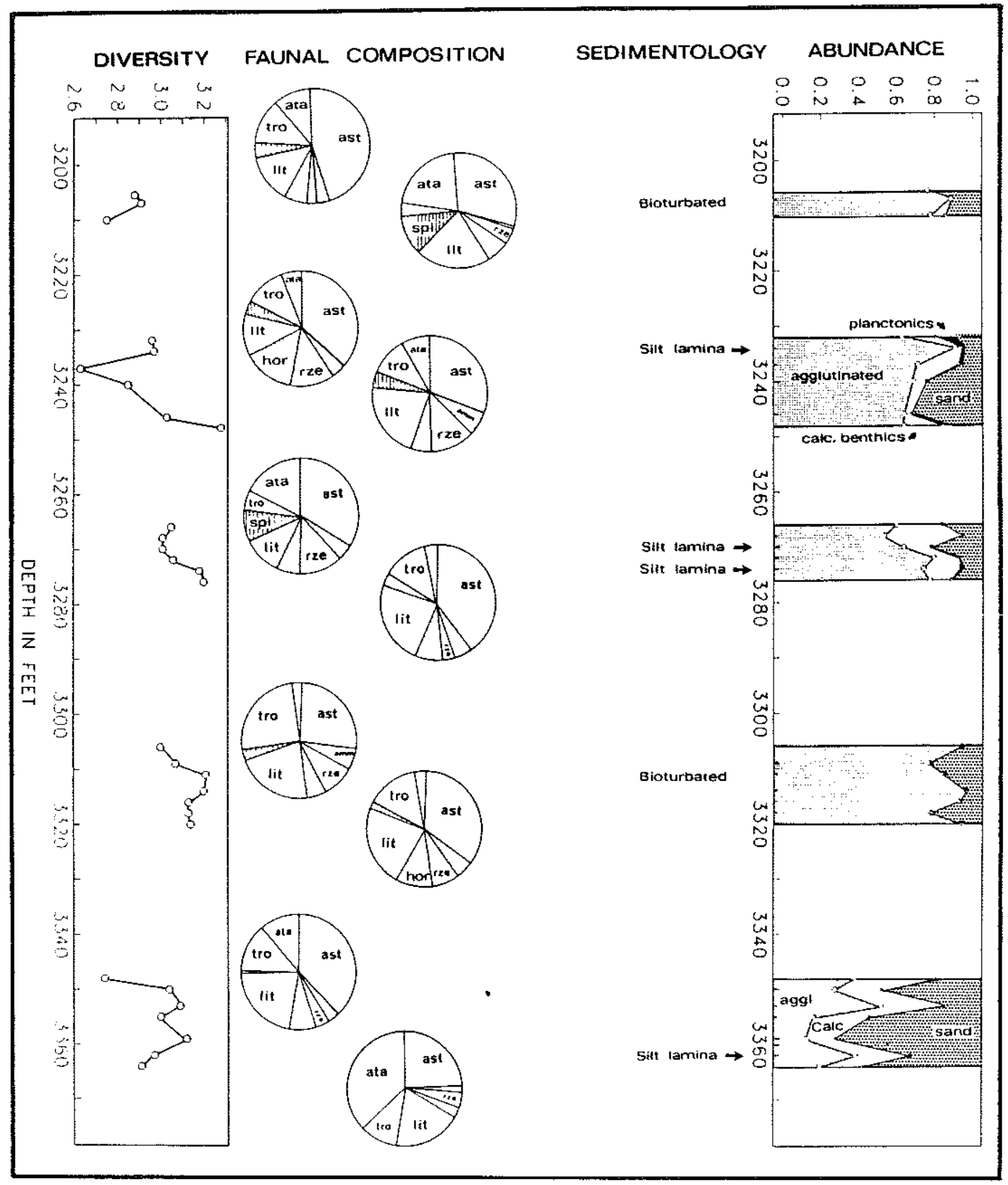

5-1. Shannon-Wiener diversity, faunal composition, sedimentology, and composition of the sand fraction in well G-287. Pie diagrams show faunal composition by superfamily for the top and bottom sample of each interval. ast $=$ astrorhizids, $a m m=$ ammodiscids, $r z e=$ rzehakinids, hor $=$ hormosinids, lit $=$ lituolids, spi= spiroplectamminids, tro= trochamminids, ata= ataxophragmids. 
calcareous benthics, but the amount of nonbiogenic grains does not differ greatly from the noncalcareous interval.

C. Benthic Foraminiferal Assemblages:

The agglutinated foraminiferal component of well G-287 is dominated by astrorhizids. Ataxophragmiids are common in the basal interval, whereas spiroplectamminids, rzehakinids, ammodiscids and hormosinids increase in abundance in the upper section of the well. Figure 5-1 presents the faunal composition by superfamily of Loeblich and Tappan (1984) for the top and bottom sample in each interval. The relative abundance of agglutinated genera in the three intervals in well G-287 is shown in figure 5-2. To provide additional information on the main sources of variation in the data set, the faunal matrix (Kaminski et al., in press, a) was subjected to Q-mode Varimax factor analysis. Three faunal factors were associated with eigenvalues greater than unity, explaining $87 \%$ of the variance. A plot of factor scores showing the composition of each faunal factor is given in figure 5-3.

The first factor, which reflects the "average" fauna, explains $40 \%$ of the variance and consists primarily of Dendrophrya ex gr. excelsa, with Rzehakina epigona, Spiroplectammina spectabilis, Saccammina placenta, and Bathysiphon sp. of lesser importance. Shannon-Wiener faunal diversity is variable in this interval. Faunal factor 2, which describes the principal axis of variation about the "average" explains $28 \%$ of the variance. This factor is made up of forms with finely agglutinated tests such as Ammosphaeroidina pseudopauciloculata, Rhizammina indivisa, Recurvoides gerochi, and Rzehakina epigona, and has highest loadings in the noncalcareous interval from 3306-3318 ft. The third significant faunal factor accounts for $18 \%$ of the variance and is strongly associated with the basal interval. This assemblage exhibits a relatively low diversity of agglutinated taxa, and species awarded highest factor scores are robust coarse forms such as Clavulinoides globulifera, Dorothia retusa, Phenacophragma beckmanni, and Haplophragmoides ex gr. suborbicularis.

The relative abundance of Nuttallides spp. (mostly N. truempyi) is greatest in redeposited intervals between 3232 and $3248 \mathrm{ft}$ (Figure 5-4). Tjalsma and Lohmann (1983) have shown that the Nuttallides fauna was the important abyssal assemblage during the Paleocene. Stensioeina 

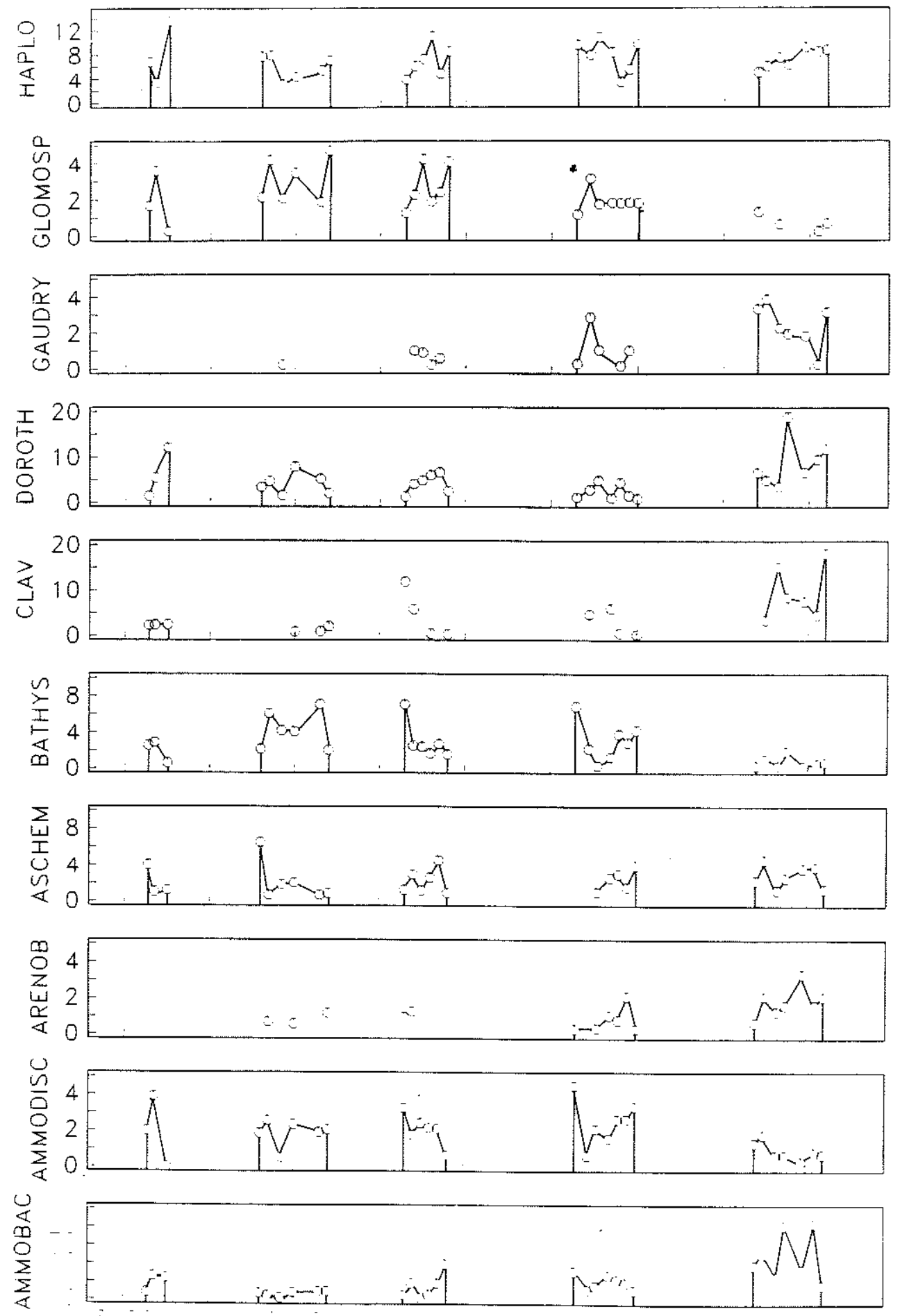

DEPTH IN FEET

5-2a. Relative abundance (in percent) of agglutinated genera in well G-287. Data for Phenacophragma is included in Ammobaculites. Data for Dendrophrya are included in Rhabdammina. 

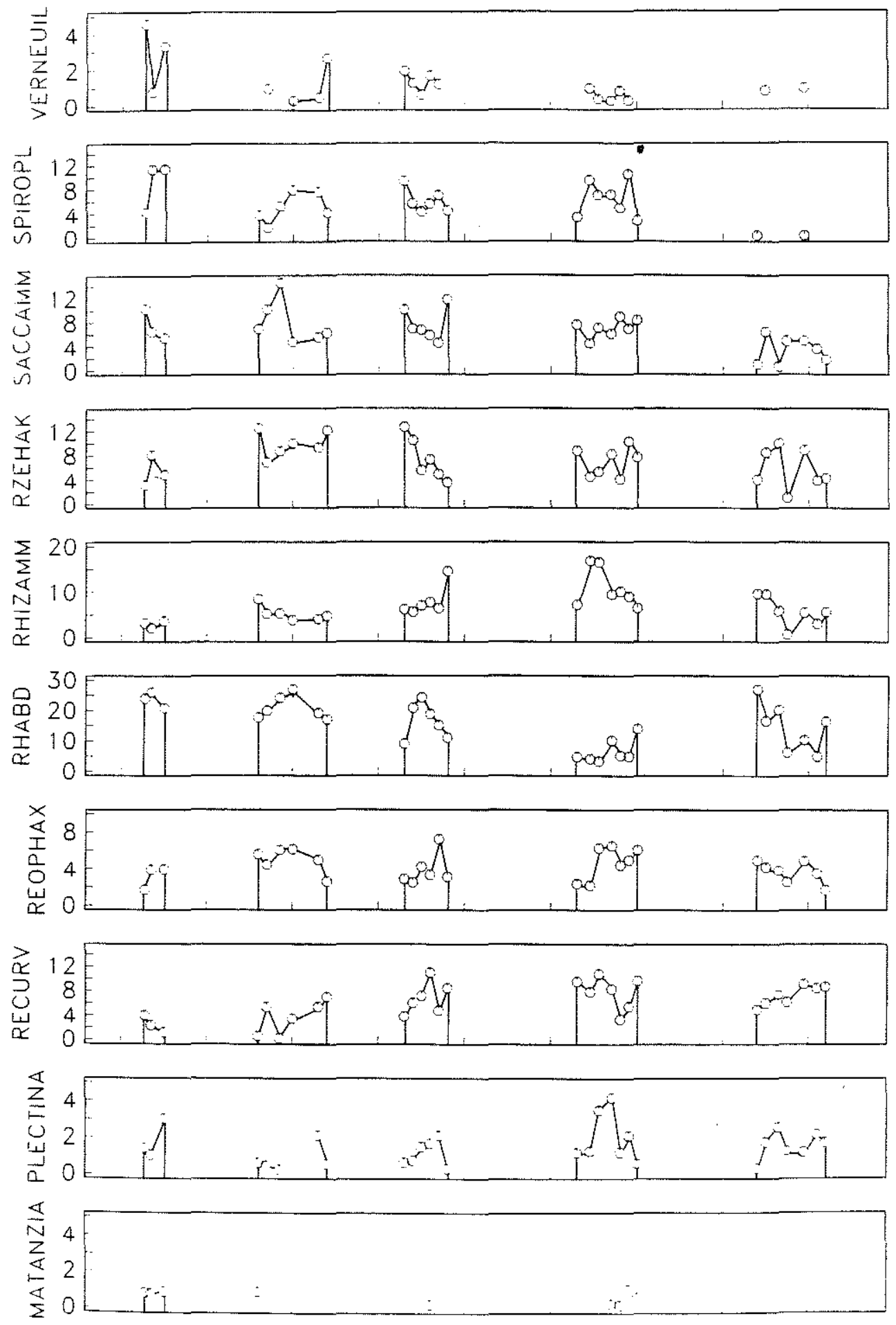

5-2, b. Relative abundance of agglutinated genera in well G-287 (continued). Data for Subreophax are included in Reophax. 
FACTOR 2

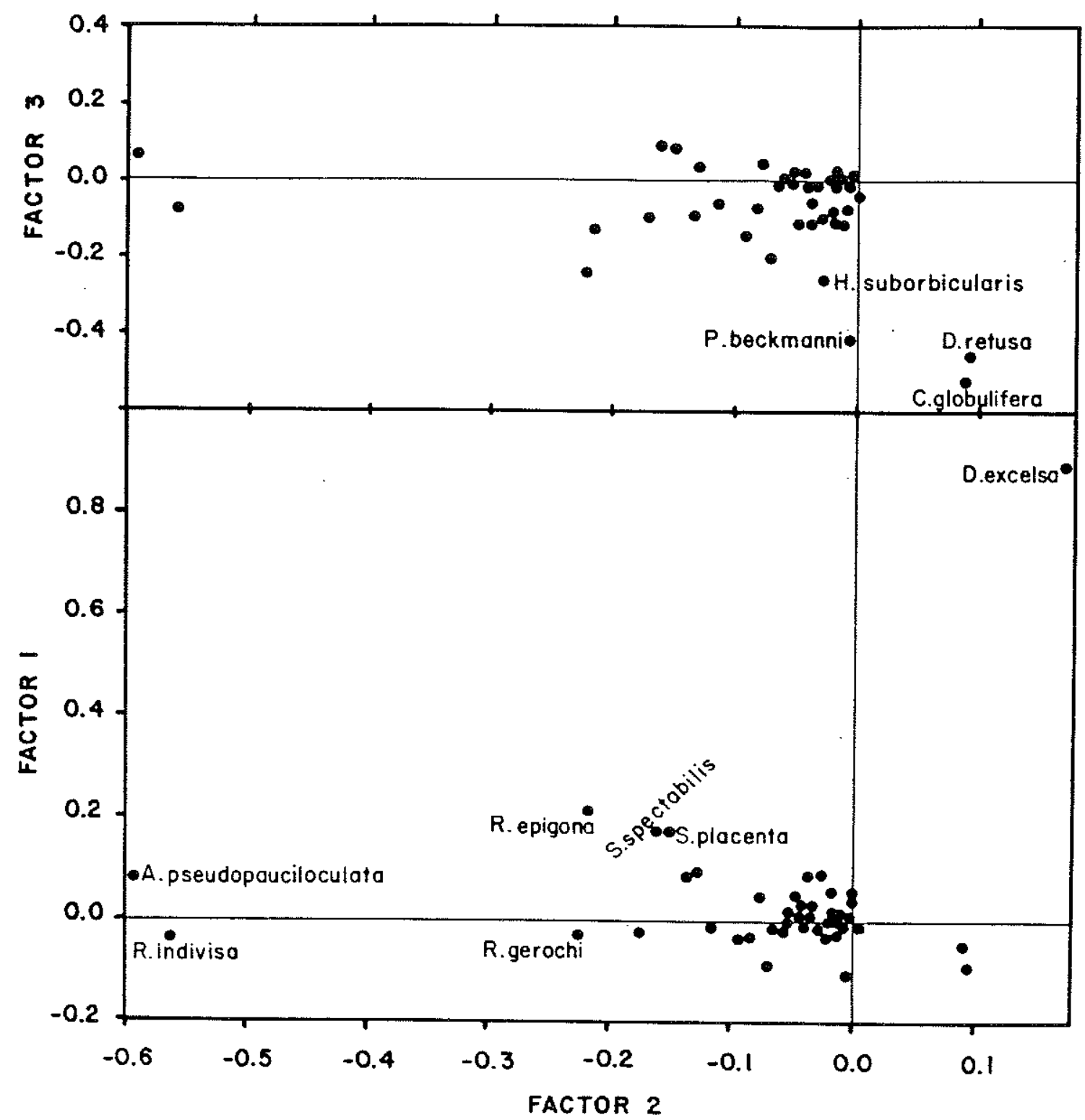

5-3. Distribution of benthic foraminiferal species on first three Q-mode varimax factors. 


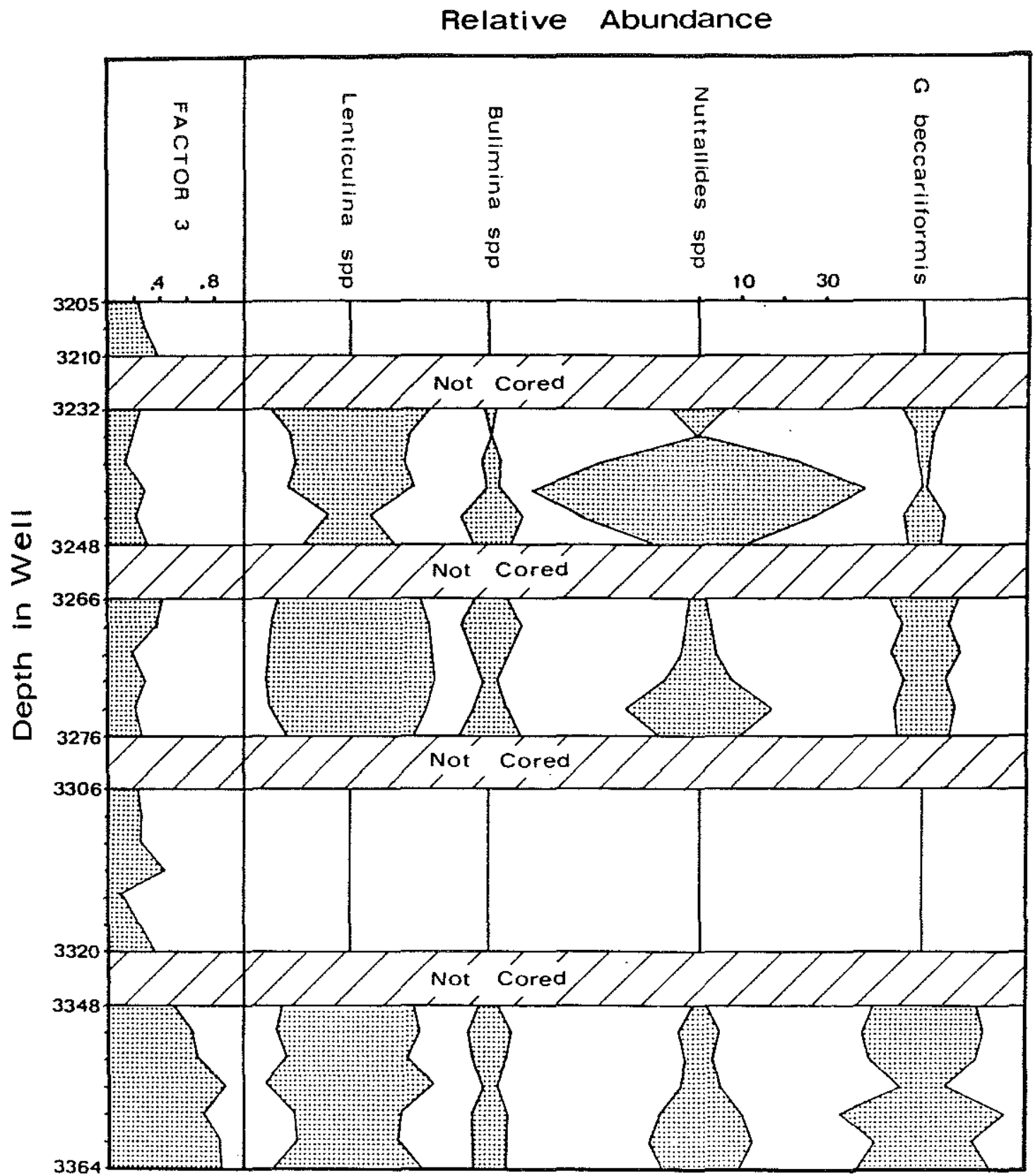

5-4. Relative abundance of important calcareous benthic taxa compared with the importance of faunal factor 3 in well 287. 
beccariiformis, which characterizes a shallower facies in the Paleocene than the Nuttalides fauna, displays greatest relative abundance in the basal interval.

\section{PALEOBATHYMETRY}

Sedimentological and faunal evidence enables the construction of a relative paleobathymetric model for Paleocene agglutinated foraminifera from southeast Trinidad (Fig. 5-5), but assigning well-constrained paleodepths to the assemblages is difficult due to the lack of independent depth control. Tjalsma and Lohmann (1983) assigned a paleodepth of $900 \mathrm{~m}$ to the Lizard Springs Formation but did not specify how they derived this estimate. Since most late Cretaceous species of agglutinated foraminifera range up into the Paleocene, it is possible to compare the generic composition of the Danian Lizard Springs assemblages with existing Cretaceous paleobathymetric schemes.

The bathymetric distribution of late Cretaceous benthic foraminiferal genera in continental margin deposits of southern California was studied by Sliter and Baker (1972), who recognized inner and outer shelf, and upper, middle and lower slope assemblages. Upper slope assemblages in California were found to be dominated by calcareous genera, with Gaudryina, Dorothia, Cribrostomoides, Bathysiphon and Spiroplectammina the most common agglutinated genera. Middle slope assemblages were dominated by agglutinated species and turrilinids, osangulariids, and anomalinids. Agglutinated genera were similar to the upper slope assemblage, with increased importance of Ammodiscus, Hyperammina, Bathysiphon, and Cribrostomoides. Haig (1979) divided midCretaceous agglutinated assemblages into a shallow water Ammobaculites association, an abyssal Recurvoides association, and a bathyal Marssonella association that can be further subdivided with the aid of calcareous taxa.

In the basal interval of well G-287, the composition of the agglutinated assemblage resembles the upper to middle slope assemblages of Sliter and Baker (1972) and the mid slope facies of the "Marssonella association" of Haig. In Cretaceous sediments of the western North Atlantic margin, Nyong and 0lsson (1984) used downdip distance as an independent estimate of paleobathymetry. The greatest abundance of Marssonella and Arenobulimina were found at depths of $200-500 \mathrm{~m}$. 


\begin{tabular}{|l|l|l|l|}
\hline \multicolumn{2}{|c|}{ LIZARD SPRINGS FORMATION - WELL G-287 } & HOLE 543A, Core 5-6 \\
\hline \multicolumn{1}{|c|}{ Upper Bathyal } & \multicolumn{1}{|c|}{ Middle Bathyal } & \multicolumn{1}{|c|}{ Basin Plain } & \multicolumn{1}{c|}{ Abyssal } \\
\hline & & & \\
Dendrophrya excelsa & Dendrophrya excelsa & Ammosphaeroidina & Kalamopsis grzybowskii \\
Clavulinoides globulifera & Rzehakina epigona & Rhizammina indivisa & Haplophragmoides cf walteri \\
Phenacophragma beckmanni & Ammosphaeroidina & Rzehakina epigona & Ammodiscus cretaceous \\
Rzehakina epigona & Rhizammina indivisa & Recurvoides gerochi & Glomospira irregularis \\
Rhizammina indivisa & Spiroplectammina spectabilis & Dendrophrya excelsa & Glomospira charoides \\
Recurvoides gerochi & Saccammina placenta & Spiroplectammina spectabilis & Hormosina ovulum \\
Ammosphaeroidina & Hormosina trinitatensis & Hormosina trinitatensis & Bathysiphon sp. \\
Haplophragmoides retroseptus & Bathysiphon spp. & Saccammina placenta & Hyperammina dilatata \\
Hormosina trinitatensis & Recurvoides gerochi & Saccammina complanata & Paratrochamminoides \\
Conotrochammina whangaia & Haplophragmoides retroseptus & Haplophragmoides retroseptus & \\
Trochammina altiformis & Saccammina complanata & Bathysiphon spp. & \\
Rhabdammina discreta & Aschemonella ex gr. grandis & Trochammina altiformis & \\
Aschemonella ex gr. grandis & Clavulinoides globulifera & Conotrochammina whangaia & \\
Saccammina complanata & Ammobaculites sp. 2 & Ammobaculites sp. 2 & \\
Recurvoides sp. 2 & Glomospira charoides & Aschemonella grandis & \\
& . & & \\
\hline
\end{tabular}

(LISTED IN ORDER OF DECREASING RELATIVE ABUNDANCE) 
The Paleocene bathymetric distribution of several species of calcareous ataxophragmiids are reported by Tjalsma and Lohmann (1983). Clavulinoides globulifera was found to be restricted to sites with backtracking paleodepths above $1800 \mathrm{~m}$, and Gaudryina pyramidata possesses a maximum abundance centered about $2000 \mathrm{~m}$ in Zone P1 time. Two species of Clavulinoides occurring in the outcrop samples possess limited depth ranges. Tjalsma and Lohmann show that Clavulinoides trilatera is restricted to paleodepths between 1000 and $2000 \mathrm{~m}$ in Zone $\mathrm{P} 3 / \mathrm{P} 4$, and $\mathrm{C}$. paleocenica, which occurs only rarely in the samples, was reported to occur most commonly below $2,000 \mathrm{~m}$.

Based on the literature analysis above, the shallowest assemblage in well G-287 is represented by factor assemblage 3. This assemblage is dominated by calcareous ataxophragmiids, occurs in redeposited sediments, and is positively correlated with the relative abundance of Stensioeina beccariiformis (Fig. 54). Sediments in this interval were probably derived from a relatively shallow (more proximal) source area. Factor assemblage 1, from the upper intervals of well G-287, contains fewer calcareous elements and a greater proportion of deeper dwelling Nuttallides truempyi than factor 3 , and probably represents a mixture of autochthonous species and specimens redeposited from a more distal source than the basal interval. Spiroplectamina sp. aff.

S. dentata, which displays maximum abundance in factor assemblage 1, was found by Nyong and 0lsson (1984) to be most common in their lower slope (1500-2500 m) assemblage.

The presumably deepest assemblage in well G-287, represented by factor assemblage 2 , is probably in situ judging from the sedimentological evidence. This assemblage contains more elements of a "Type-B" fauna reported from abyssal DSDP sites, but these are not the dominant forms. The species composition compares well with the lower slope assemblages of Sliter and Baker (1972), which are dominated by the agglutinated genera Glomospira, Hyperammina, Pelosina, Hormosina, Saccammina, Haplophragmoides, and Bathysiphon. Haig defines an abyssal assemblage characterised by Recurvoides, Plectorecurvoides, Uvigerinammina, Hormosina, Dendrophrya and Kalamopsis. At Lizard Springs, Kalamopsis and Hormosina ovulum ovulum are most abundant in factor 2, but the genus Recurvoides was not found to increase in abundance from shallow to deep assemblages. In fact, Recurvoides can be among the most abundant taxa in neritic deposits from high latitudes (see discussion of 
Labrador Margin below). Nyong and Olsson (1984) find abundant Glomospira, Rhizammina, Uvgerinammina, Saccammina, and Trochammina below $2500 \mathrm{~m}$.

A true "Type-B" agglutinated fauna of probable Paleocene or early Eocene age was recovered from noncalcareous pelagic claystones from Cores 5 and 6 of Site 543A (Hemleben \& Troester, 1984). This site is located $600 \mathrm{~km}$ NNE of Trinidad and has a backtracked Paleocene paleodepth of about $5000 \mathrm{~m}$. The fauna displays low diversity and consists mainly of Glomospira charoides, Kalamopsis grzybowskii, and Hormosina ovulum, with less frequent Ammodiscus cretaceus, Glomospira irregularis, G. diffundens, Reophax scalaris, Paratrochamminoides spp., Hyperammina spp., Nodellum velascoensis, Saccammina spp., Praecystammina globigerinaeformis, and Tolypammina sp. All but two of the above species are more abundant in the deeper assemblage from noncalcareous intervals of the Lizard Springs Formation. The sole exceptions are P. globigerinaeformis, and Tolypammina spp., which were not found in the samples.

In summary, the Guayaguayare and Lizard Springs assemblages reflect deposition in a basin plain environment at lower bathyal depths. Generally shallower paleodepths are evident in the lower Maastrichtian and lower Eocene, with the deeper paleodepths recorded in the Danian. Redeposited assemblages present in turbidites are derived from upper bathyal and middle bathyal sources. However, it should be borne in mind that upper depth limits of agglutinated taxa are often elevated in areas of thick clastic sedimentation such as the Mississippi Delta (Pflum and Frerichs, 1976); therefore this estimate represents a lower limit.

\section{LABRADOR MARGIN}

The passive margin setting of the Labrador Margin is structurally less complex than Trinidad and Zumaya where sediments have been uplifted and deformed by Cenozoic tectonic movements. As a result, paleobathymetric patterns exhibited by benthic foraminiferal assemblages in the Labrador Sea reflect the present position of offshore wells. Subsidence in this region was greatest during the late Campanian to late Eocene phase of sea floor spreading in the Labrador Sea (Srivastava, 1978) when a thick wedge of clastic sediment was deposited. The regional geology and stratigraphy of the Labrador Sea area has been discussed by Gradstein and Williams (1976), Umpleby (1979), McWhae et al. (1980), Gradstein and Srivastava (1980) and Gradstein and Berggren (1981). 
Since all well sites on the Labrador Margin are on continental crust, the wells cannot be backtracked using the seafloor subsidence equations. The approach used here to determine paleobathymetric trends in foraminiferal biofacies is similar to that taken by 0lsson and Nyong (1984), who use distance downdip as a measure of increasing paleodepth in Atlantic passive margin settings. The sample base for this study consists of a bathymetric transect of four exploration wells on the Labrador Margin and two DSDP/ODP sites in the Labrador Sea (Table 5-1). The North Lief I-05 well was drilled on a structural high on Hamilton Bank (Fig. 5-6). This well recovered the thinnest Cenozoic section of the Labrador Margin wells studied (Fig. 5-7) and serves as the updip reference site for benthic foraminiferal biofacies. A downslope position on the Labrador Margin is occupied by the Indian Harbour M52 well, which contains a well preserved, deep-water microfauna, especially near the base of the hole. The relative abundance of planktonics and the diversified calcareous and agglutinated benthic assemblages together with the more distal setting of the well site point to a bathyal depositional environment, probably upper to middle bathyal. The Gudrid H-55 and Roberval K-92 wells occupy an intermediate position between the North Leif and Indian Harbour wells. The abyssal end member of Maastrichtian assemblages in the North Atlantic is present in ODP Hole 641A, drilled off the Galicia Margin. This is the geographically closest DSDP/ODP site to the Labrador Margin with well-preserved upper Cretaceous agglutinated assemblages. Paleocene abyssal assemblages were recovered from Core 16R of DSDP Hole 112, whereas ODP Hole $647 \mathrm{~A}$ provides the abyssal reference section for the Eocene.

Maastrichtian to Paleocene flysch-type assemblages on the Labrador Margin are best developed in the Uniform Shale of the Cartwright Formation, a dark green pyritic and micaceous shale unit. The most abundant species in the Cartwright Formation in the North Leif, Gudrid and Indian Harbour wells are listed in figure 5-8 and a full census of species are given in Appendixes 5-1 to 5-4. The Cretacous/Tertiary boundary in these wells was determined by the last occurrences of Maastrichtian planktonics, or in the case of the Gudrid well, by the last common occurrence of reddish-stained calcareous benthic foraminifera. Agglutinated species that are generally restricted to the Maastrichtian portion of the Uniform Shale are Ammobaculites sp. 4, Arenobulimina dorbignyi, Dorothia oxycona, and Uvigerinammina jankoi. The age 


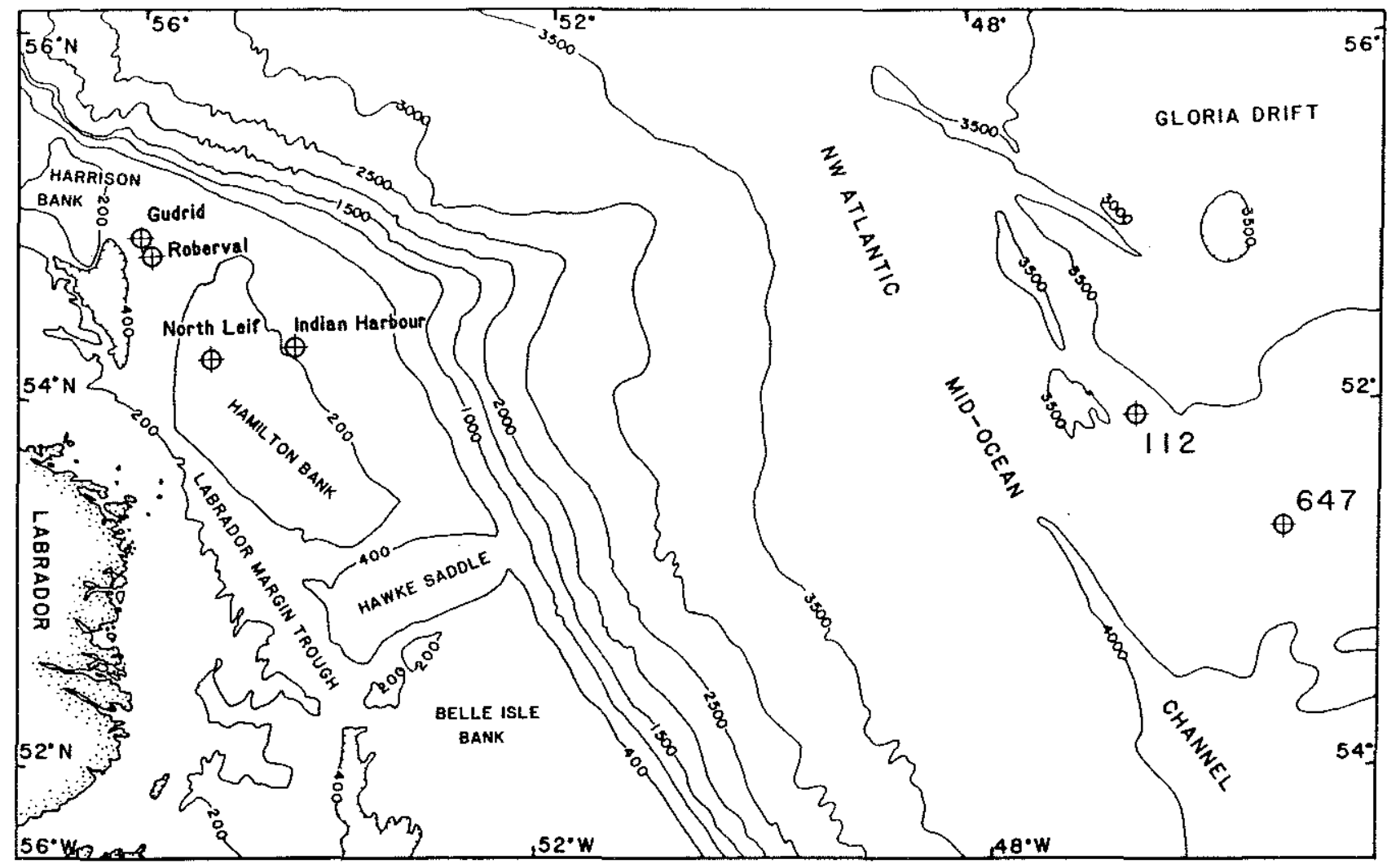

5-6. Location of well sites in the Labrador Sea. Base map redrawn after Srivastava (1986), bathymetry in meters.

TABLE 4-1. Exploration wells and DSDP/ODP Sites in the northern Atlantic examined in this study.

\begin{tabular}{|c|c|c|c|c|c|}
\hline WELL: & LATITUDE & LONGITUDE & $\begin{array}{c}\text { WATER } \\
\text { DEPTH: }\end{array}$ & $\begin{array}{c}\text { INTERVAL } \\
\text { STUDIED }\end{array}$ & AGE: \\
\hline NORTH LEFF & & & & $2465-2700 \mathrm{~m}$ & Maast - Eocene \\
\hline ROBERVAL K-92 & $54^{\circ} 51^{\prime} 35.53^{\prime \prime}$ & $55^{\circ} 44^{\prime} 35.76^{\prime \prime}$ & $268 \mathrm{~m}$ & $2220-3070 \mathrm{~m}$ & Maast - Eocene \\
\hline GUDRID H-55 & $54^{\circ} 54^{\prime} 30.02^{\prime \prime}$ & $55^{\circ} 52^{\prime} 32.2^{\prime \prime}$ & $299 \mathrm{~m}$ & $8070-8730 \mathrm{ft}$ & Maast - Paleoc \\
\hline $\begin{array}{c}\text { INDIAN HARBOUR } \\
\text { M-52 }\end{array}$ & $54^{\circ} 21^{\prime} 51.34^{\prime \prime}$ & $54^{\circ} 23^{\prime} 51.81^{\prime \prime}$ & $198 \mathrm{~m}$ & $10060-10810 \mathrm{ft}$ & Maast - Paleoc \\
\hline DSDP HOLE 112 & $54^{\circ} 01.00^{\prime}$ & $46^{\circ} 36.24^{\prime}$ & $3657 \mathrm{~m}$ & $653 \mathrm{mbst}$ & Paleocene \\
\hline ODP HOLE 647 & $53^{\circ} 19.876^{\prime}$ & $45^{\circ} 15.717^{\prime}$ & $3862 \mathrm{~m}$ & $290-699 \mathrm{mbsi}$ & Eocene \\
\hline ODP HOLE 641A & $42^{\circ} 09.3^{\prime}$ & $12^{\circ} 10.9^{\prime}$ & $4646 \mathrm{~m}$ & $0-54.1 \mathrm{mbsi}$ & Coniac-Maast \\
\hline
\end{tabular}


THE "LABRADOR TRAMSEGT"

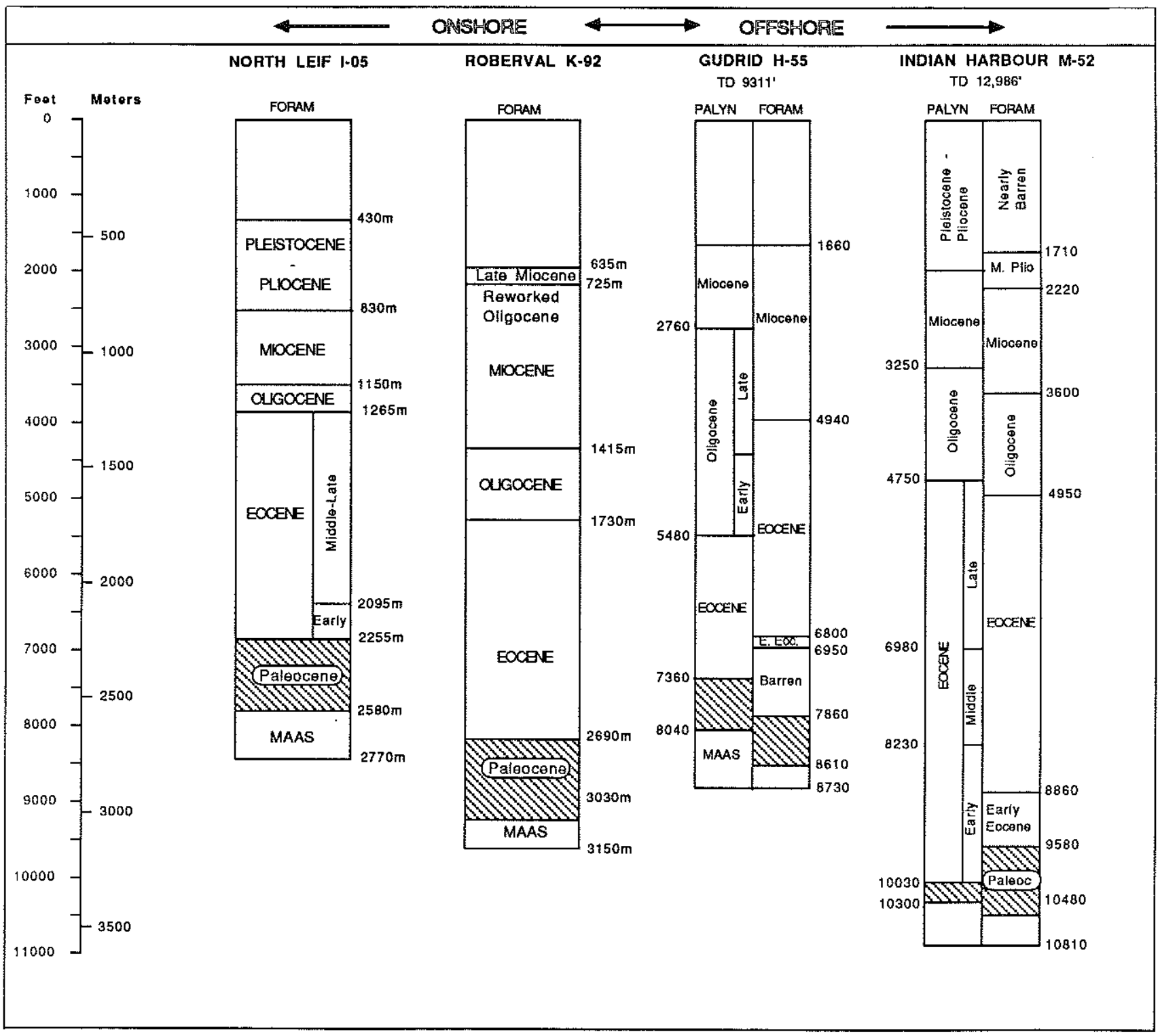

5-7. Cenozoic stratigraphy of four Labrador Margin wells comprising the "Labrador Transect". Stratigraphy of the Indian Harbour and Gudrid wells is after Srivastava (1986). Stratigraphy of North Leif and Roberval wells is based on new observations by Gradstein (personal communication, 1987). 
of sediments in the Gudrid, Roberval and Indian Harbour wells based on foraminifera and palynomorphs was recently summarized by Gradstein (in Srivastava, 1986).

A. Maastrichtian -

The shallowest Maastrichtian assemblage in the transect occurs in the North Lief I-05 well (Fig. 5-8, Appendix 5-1). This assemblage is dominated by large, coarsely agglutinated astrorhizids and lituolids. In contrast with shallow assemblages from Trinidad, the calcareous ataxophragmiids and rzehakinids are rare on the Labrador Margin. Only three of the 12 most common species (Glomospira charoides, Ammodiscus cretaceus and Hormosina ovulum) possess finely agglutinated wall structure. Calcareous benthics are rare in this well and indicate an outer neritic to upper bathyal setting. Agglutinated species which are associated with "Type-B" assemblages, such as Labrospira, Subreophax, Ammosphaeroidina and Uvigerinammina, are represented by few specimens. Planktonic foraminifera are likewise rare and consist mainly of small species of Hedbergella.

The Roberval K-92 well is situated between the North Leif and Gudrid wells. Only one Maastrichtian sample (Appendix 5-2) was examined quantitatively. Although still dominated by coarse tubular forms, this assemblage contains increased proportions of Glomospira and Uvigerinammina in comparison to the North Leif well.

In the Gudrid and Indian Harbour wells, calcareous benthic and planktonic foraminifera are more abundant and more diverse than in the updip wells, and the most abundant agglutinated species is Glomospira charoides. The species Karreriella horrida, Hormosina ovulum, Cribrostomoides sp. (smooth) also display increased relative abundance in both wells relative to the updip wells. Samples from the Gudrid well (Appendix 5-3) also contain increased abundances of species with finely agglutinated tests such as Haplophragmoides glabra, Saccammina placenta and Trochamminoides spp.

The planktonic assemblage in the Indian Harbour well is most diverse and consists of Rugoglobigerina, Globigerinelloides, Heterohelix, and rare Abathomphalus mayaroensis, but still reflects a marginal (as opposed to open ocean) setting. Calcareous benthic foraminifera are more abundant than in other wells which attests to deposition further offshore. The agglutinated 


\begin{tabular}{|c|c|c|c|c|}
\hline \multirow{2}{*}{$\frac{5}{6}$} & \multicolumn{3}{|c|}{ CARTWRIGHT FORMATION - LABRADOR MARGIN } & \multirow{2}{*}{$\begin{array}{c}\text { Abyssal } \\
\text { DSDP HOLE } 112 \\
\text { Core } 16 \\
\end{array}$} \\
\hline & $\begin{array}{l}\text { NORTH LEIF } \\
2465-2505 \mathrm{~m}\end{array}$ & $\begin{array}{l}\text { GUDRID H-55 } \\
8070-8550 \mathrm{ft} .\end{array}$ & $\begin{array}{l}\text { INDIAN HARBOUR M-52 } \\
10060-10450 \mathrm{ft} \text {. }\end{array}$ & \\
\hline $\begin{array}{l}\text { (1) } \\
Z \\
0 \\
0 \\
0 \\
0 \\
0 \\
0\end{array}$ & $\begin{array}{l}\text { Trochammina deformis } \mathrm{S}=41 \\
\text { Recurvoides walteri } \\
\text { Bathysiphon spp. } \\
\text { Rhabdammina spp. } \\
\text { Haplophrag. walteri } \\
\text { Saccammina complanata } \\
\text { Saccammina placenta } \\
\text { Karreriella horrida } \\
\text { Glomospira charoides } \\
\text { Haplo. retroseptus } \\
\text { Ammodiscus planus } \\
\text { Haplophragmoides eggeri }\end{array}$ & $\begin{array}{l}\text { Karreriella horrida } \quad S=53 \\
\text { Recurvoides walten } \\
\text { Ahizammina spp. } \\
\text { Rhabdammina spp. } \\
\text { Trochammina deformis } \\
\text { Saccammina complanata } \\
\text { Haplophragmoides glabra } \\
\text { Bathysiphon spp. } \\
\text { A. aft. polythalamus } \\
\text { Glomospira charoides } \\
\text { Cribrostomoldes (smooth) } \\
\text { Cribrostomoides (coarse) }\end{array}$ & $\begin{array}{l}\text { Rhabdammina spp. } \quad \mathrm{S}=54 \\
\text { Glomospira charoides } \\
\text { Trochammina deformis } \\
\text { Haplophragmoides watleri } \\
\text { Bathysiphon spp } \\
\text { Recurvoides walteri } \\
\text { Rocurvoides gerochi } \\
\text { Rhizammina spp. } \\
\text { Saccammina complanata } \\
\text { Ammosphaeroidina } \\
\text { Karreriella horrida } \\
\text { Ammodiscus cretaceus }\end{array}$ & $\begin{array}{l}\text { Rhizammina spp. } \quad \mathrm{S}=22 \\
\text { Rhabdammina spp. } \\
\text { Glomospira irregularis } \\
\text { Ammodiscus glabratus } \\
\text { Praecystammina spp. } \\
\text { Recurvoides spp. } \\
\text { Haplophragmoides eggeri } \\
\text { Glomospira charoides } \\
\text { Saccammina complanata } \\
\text { Hyperammina spp. } \\
\text { S. spectablls } \\
\text { S. scalaria }\end{array}$ \\
\hline & $\begin{array}{l}\text { NORTH LEIF } 1-05 \\
2580-2700 \mathrm{~m}\end{array}$ & $\begin{array}{l}\text { GUDRID H.55 } \\
8640-8730 \mathrm{ft} .\end{array}$ & $\begin{array}{l}\text { INDIAN HARBOUR M-52 } \\
10510-10810 \mathrm{ft}\end{array}$ & $\begin{array}{c}\text { HOLE } 641 \mathrm{~A} \text {, Cores } 13^{*} \\
\text { (Hormosina gigantea Zone) }\end{array}$ \\
\hline 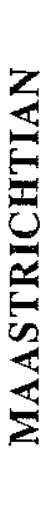 & $\begin{array}{l}\text { Rhabdammina spp. } S=48 \\
\text { Bathysiphon spp. } \\
\text { Rhizammina spp } \\
\text { Glomospira charoides } \\
\text { Recurvoides watteri } \\
\text { Ammodiscus cretaceous } \\
\text { Haplo. suborbicularis } \\
\text { Karreriella horrida } \\
\text { Haplo. retroseptus } \\
\text { Saccammina complanata } \\
\text { Trochammina deformis } \\
\text { Hormosina ovulum }\end{array}$ & $\begin{array}{l}\text { Glomospira charoides } \mathrm{S}=50 \\
\text { Bathysiphon spp. } \\
\text { Karreriella horrida } \\
\text { Ahabdammina spp. } \\
\text { Recurvoides walteri } \\
\text { Ammodiscus cretacous } \\
\text { Haplophragmoides glabra } \\
\text { Hormosina ovulum } \\
\text { Cribrostomoides (smooth) } \\
\text { Rhizammina spp. } \\
\text { Saccammina complanala } \\
\text { Saccammina placenta }\end{array}$ & $\begin{array}{l}\text { Glomaspira charoides } \\
\text { Recurvoides walteri } \\
\text { Rhabdammina spp. } \\
\text { Bathysiphon spp. } \\
\text { Uvigerinammina jankoi } \\
\text { Karreriella horrida } \\
\text { Ammodiscus cretacous } \\
\text { Hormosina ovulum } \\
\text { Glomospira gordialis } \\
\text { Cribrostomoides (smooth) } \\
\text { Ahizammina spp. } \\
\text { Haplophragmoides eggeri }\end{array}$ & $\begin{array}{l}\text { Rhabdammina sp. } \\
\text { Hormosina ovultum } \\
\text { Glomospira charoldes } \\
\text { Paratrochamminoides } \\
\text { Hormosina crassa } \\
\text { Recurvoides spp. } \\
\text { Glomospira irregularis } \\
\text { Karreriella spp. } \\
\text { Haplo. perexplicatus } \\
\text { Labrospira } \\
\text { Haplo. multicamens } \\
\text { Ammodiscus cretaceus }\end{array}$ \\
\hline
\end{tabular}

* Data from this study, supplemented with observations by Moullade et al. (in press). $S=$ Number of species present in assemblage, depths in meters or feet indicate depth in the well.

5-8. Paleobathymetry of agglutinated taxa in the northern Atlantic. Taxa are listed in order of decreasing relative abundance. 
assemblage (Appendix 5-4) displays the highest diversity observed in the Labrador Margin wells ( $\sim 57$ species). The uppermost Maastrichtian assemblage strongly dominated by Glomospira charoides, and the species Uvigerinammina jankoi and Ammosphaeroidina pseudopauciloculata display increased abundance relative to the Gudrid Well. In comparison with the updip wells, this assemblage displays a greater proportion of ammodiscids, hormosinids and lituolids with finely agglutinated wall structure. A paleobathymetric pattern is observed in the smooth, carinate species of Haplophragmoides. Specimens in the Indian Harbour well are small with $\sim 6$ chambers and are assigned to $H$. glabra. However, specimens from the North Leif and Roberval wells are somewhat larger and possess more chambers. These specimens are placed in $\mathrm{H}$. walteri.

Paleobathymetric patterns from shallow to deeper assemblages can be verified by examining changing benthic assemblages with depth in the Indian Harbour Well. The Maastrichtian sediments in this well are only about $100 \mathrm{~m}$ thick, and the well site apparently experienced rapid thermal subsidence after the Anomaly 30 rifting phase in the Labrador Sea. The assemblages in the well display a distinct changes indicating a deepening-upward pattern. Basal assemblages (10720' to 10810') consist mostly of large tubular species. However, above $10720 \mathrm{ft}$ samples contain increased proportions of calcareous benthics as well as Glomospira, Uvigerinammina, Karrieriella horrida, Cribrostomoides sp. (smooth), and Hormosina ovulum. In addition, the genera Trochamminoides, Glomospirella and Labrospira were only found in the upper interval.

Abyssal agglutinated assemblages of Maastrichtian age are wellrepresented in ODP Hole 641A, drilled at a water depth of $4639 \mathrm{~m}$ off the Galicia Margin. These assemblages occur in a $40 \mathrm{~m}$ thick unit of red, noncalcareous clays which were deposited in a fault-bordered basin on thin continental crust. Although situated on continental crust, site 641 had subsided to a depth beneath the oceanic lysocline by the late cretaceous. The benthic assemblages in the upper 3 cores of Hole $641 \mathrm{~A}$ are less diverse ( 21 species) than assemblages from the Labrador Margin wells and are dominated by three forms: Rhizammina spp., Hormosina ovulum, and Glomospira charoides. other less common taxa incude Karreriella lenis/conversa, Hormosina crassa, Glomospira irregularis, Recurvoides spp., and Paratrochamminoides spp. In addition, the species $\underline{H}$. crassa, Haplophragmoides perexplicatus and 
Pseudobolivina cf. P. munda are not recorded on the Labrador Margin, but are known from abyssal DSDP Sites in the equatorial Atlantic (Hemleben and Troester, 1985), in the Indian 0cean (Krasheninnikov, 1974) and Pacific (Krasheninnikov, 1973). One important difference is the stratigraphic position of Uvigerinammina jankoi in Hole 641A. This species is absent from the upper portion of the red clay unit (Cores 1-3), but is abundant in underlying Cores 5-6. Its local extinction in Hole $641 \mathrm{~A}$ was correlated with the top of the lower Campanian by Moullade et al., (in press) based on comparison with the Gubbio Section in Italy. If this chronology for Hole $641 \mathrm{~A}$ is correct, than the LO of U. jankoi is diachronous between the abyssal site and the Labrador Margin. Nevertheless, the finding of this species dominating the ?lower Campanian assemblage in Hole 641A is consistent with its paleobathymetry on the Labrador Margin.

\section{B. Paleocene:}

Paleobathymetric patterns in the Paleocene portion of the Cartwright Formation recovered in the four wells are not as distinct as in the Maastrichtian and their interpretation is complicated by the presence of the prodeltaic Gudrid Sands (McWhae et al., 1980) in the upper Paleocene section in some wells. In both the Gudrid and Indian Harbor wells, a shallowing and coarsening upward trend is detected in the foraminiferal assemblages. There is an uphole decrease in the proportions of Ammodiscus, Glomospira, Saccammina placenta in both wells. However, uphole trends in the abundance of other species appear contradictory. Karreriella horrida, which occurs in deeper facies in the Maastrichtian, decreases in abundance upsection in the Indian Harbour well but increases in the Gudrid well. The abundance of Ammobaculites aff. polythalamus increases upwell in the Gudrid well, but not in the Indian Harbour well. Sonic and gamma ray logs from the Indian Harbour well indicate a change from shales to more sandy sediments above $\sim 10,300 \mathrm{ft}$ (Srivastava 1986, fig. 2). At approximately this level, the benthic foraminiferal assemblage also displays a major turnover, with the last occurrences of $\mathrm{H}$. ovulum, H. excelsa, H. dilatata, R. duplex, Subreophax, G. gordialis, G. irregularis, H. glabra, and T. subcoronatus between 10240 and $10360 \mathrm{ft}$. The overlying assemblage contains more calcareous benthics and $\sim 35$ species of agglutinated foraminifera, including D. robusta, B. cf. multicamerata, $\underline{H}$. 
walteri, T. ruthven-murrayi, and two species of Reticulophragmium. This assemblage appears to be more typical of a clastic (deltaic) environment.

The greatest difference among benthic foraminiferal assemblages is observed between the Labrador Margin wells and DSDP Site 112, which has a backtracked paleodepth of $\sim 1,700 \mathrm{~m}$ for the late Paleocene. The assemblage in Core 112-16R (Appendix 5-5) contains about 22 species dominated by finely agglutinated tubes, Glomospira irregularis, small ammodiscids, Praecystamina, Spiroplectammina spectabilis, and Subreophax. of the four Labrador Margin wells studied, the greatest numbers of these forms were found in the lower Paleocene assemblage of the Indian Harbour well.

Eocene:

The benthic foraminiferal assemblages from Hole $647 \mathrm{~A}$ and the Labrador Margin display differences related to paleobathymetry and the composition of the substrate. The Eocene Labrador Margin sequences were deposited in an outer neritic to upper bathyal clastic (deltaic) environment, while Site 647 experienced pelagic deposition in a ridge-crest setting at lower bathyal to abyssal depths. As a result, coarse grained forms such as Psammosphaera fusca, Dendrophrya robusta and Haplophragmoides (coarse) are absent from this hole. Other taxa, such as Rhizammina, Rhabdammina and Trochammina spp. are noticably smaller and more finely agglutinated. The subsidence history of Site 647 based on backtracking calculations is shown in figure 5-9.

Faunal diversity in exploration well samples from the Labrador Margin is noticeably lower than at Site 647 , and abyssal calcareous benthic foraminiferal taxa are absent from these assemblages. Relatively few species of calcareous foraminifera are present in the Labrador Margin assemblages, and these are represented mainly by neritic to upper bathyal species of Nodosaria, Lenticulina, Plectofrondicularia, Cibicidoides, and uvigerinids. In contrast, the proportion of calcareous benthics in the Eocene of Hole $647 \mathrm{~A}$ ranges from 0 to $\sim 60 \%$ (Kaminski et al., in press, d). With the exception of $\mathrm{T}$. alsatica in the Oligocene, and Nuttallides truempyi in the lower Eocene, none of the calcareous benthic species typical of the Labrador Margin were found in Hole 647A. A number of agglutinated taxa occur in both regions, including Rhabdammina spp., Ammodiscus latus, A. cretaceus, Reticulophragmium amplectens, R. placenta, Haplophragmoides walteri, Ammosphaeroidina sp., 


\section{PALEODEPTH CURVE HOLE 647A}

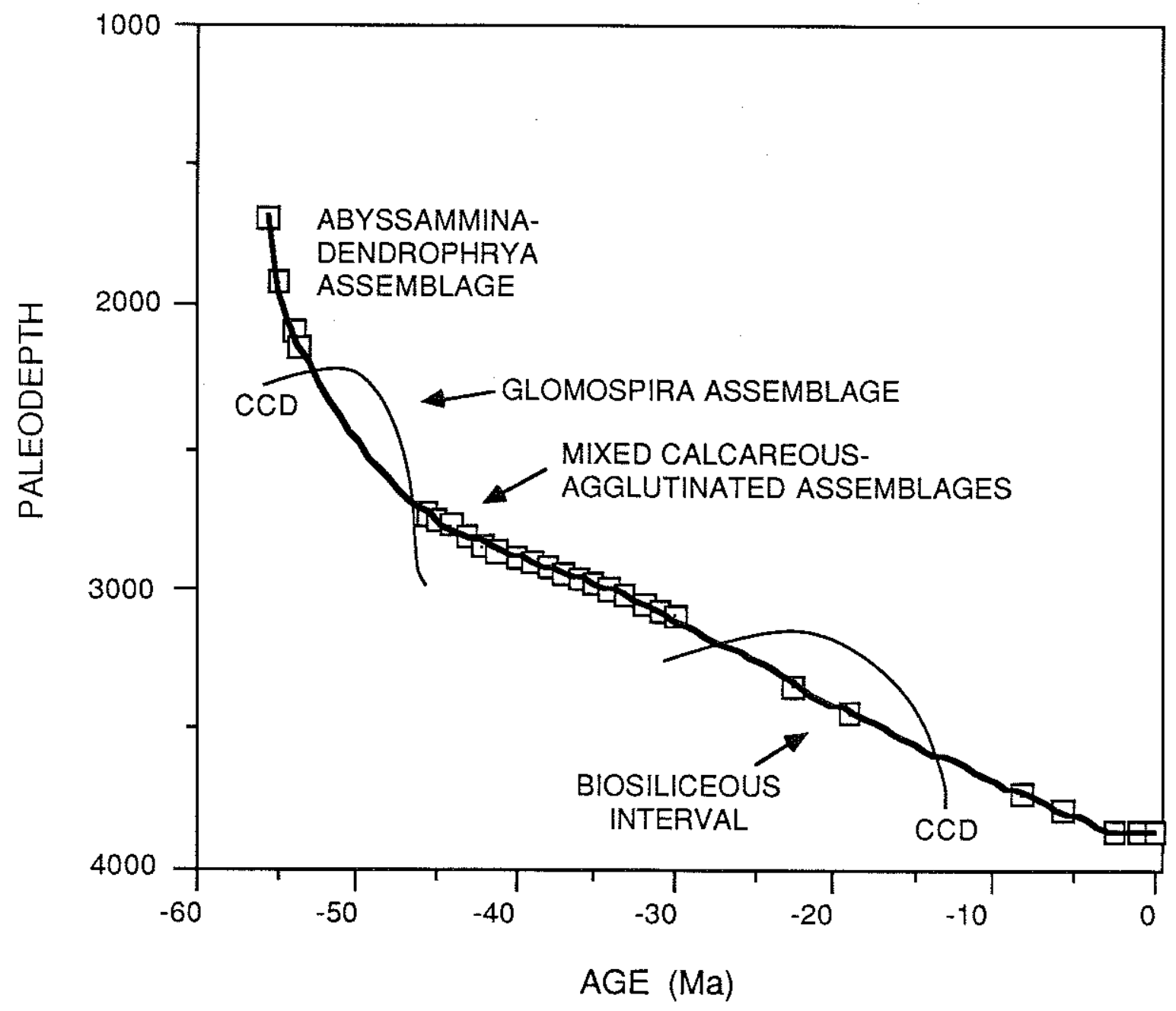

5-9. Paleodepth curve at Site 647 and the history of the lysocline. Thermal subsidence calculations are after Sclater et al., 1985. 
$\underline{\text { Reophax pilulifer, Karreriella conversa, } K \text {. horrida, Spiroplectammina }}$ spectabilis, S. navarroana, Ammobaculites aff. polythalamus, Glomospira charoides, Trochamminoides spp., and Hormosina ovulum. However, the species Ammodiscus planus, Dorothia sp. 6, Ammomarginulina sp. G, and the evolute morphotype of Haplophragmoides (H. excavata) occur only on the margin. Abyssal taxa found only in Hole 647A are Ammodiscus nagyi, Hyperammina kenmilleri, Spiroplectammina cubensis and species which utilize calcareous material in the construction of their tests (Psammosphaera testacea, Arenobulimina, Clavulinoides, and the morphotype of Rhizammina indivisa with planktonic tests).

Important differences between assemblages can be found in the proportions of species and species groups and in disjunct stratigraphic ranges between the Labrador Margin and the abyssal site. A major difference in abundance between the margin and Hole 647A is observed in the relative proportions of tubular species and cyclamminids. In the North Leif well, the middle Eocene assemblage is dominated by $\underline{\mathrm{R} \text {. amplectens }}$ and $\mathrm{C}$. placenta, contains common Budashevaella and only rare tubular forms. In Hole 647, tubular forms are numerically dominant, and the relative abundance of $\underline{R}$. amplectens is usually not greater than $\sim 5 \%$. A noticeable difference is also observed between the timing of extinction events in the Labrador Margin and deep Labrador Sea. The stratigraphic ranges of "deep" taxa determined above, such as Glomospira charoides, Spiroplectammina spectabilis, and Hormosina ovulum are diachronous from bathyal to abyssal depths. Glomospira charoides is a long ranging taxon that is present in the modern North Atlantic. Its local last occurrence is usually associated with the Paleocene/Eocene boundary on the Labrador Margin and in the southern North Sea, but the taxon extends to the top of the Ammodiscus latus - Turrilina alsatica Assemblage (lower 0ligocene) in Hole 647A. Hormosina ovulum and Hormosina excelsa disappear near the Paleocene/Eocene boundary on the margin but are present (albeit in low numbers) in the lower Eocene of Hole 647A. Spiroplectammina spectabilis has its LO in the lower Eocene on the Labrador Margin, but it persists until the Eocene/0ligocene boundary in Hole 647A, as mentioned above. Other species, such as A. latus, Ammobaculites aff. polythalamus, Ammosphaeroidina sp 1, and Karreriella conversa possess more isochronous last occurrences (see Chapter 2). This suggests that these taxa have a more isobathyal distribution. 


\section{NORWEGIAN-GREENLAND SEA}

Quantitative data on Paleogene agglutinated foraminiferal assemblages from the Norwegian-Greenland Sea have been reported by Verdenius and Van Hinte (1983) and in Chapter 3 of this study. The new microfossil data from ODP Site 643, combined with the data of Verdenius and Van Hinte (1983) now enables the construction of a paleobathymetric transect consisting of three sites: Sites 338 and 643 on the Voring Plateau and Site 345 in the Lofoten Basin (Fig 5$10)$.

Site 338 is located on the crest of the Outer Vøring Plateau, and was drilled on a basement high on the seaward side of the Vøring escarpment. Hole 338 penetrated $400 \mathrm{~m}$ of sediment overlying basaltic basement of early Eocene age (Talwani, Udintsev et al., 1976). The basement at this site may actually be transitional between oceanic and continental, since landward of the Voring escarpment, sediments are underlain by continental crust (Eldholm et al., 1987). As a result of the transitional nature of the basement, backtracking calculations (Sclater et al., 1985) at the site yield less reliable results. Early Eocene sedimentation at Site 338 was shallow-water and terrigenous, with predominant lithologies consisting of limey sandstones, glauconitic sandstones, mudstones and basalt breccias. Late Eocene to 0ligocene sedimentation was more pelagic, reflecting the waning influence of local terrigeous sources as the Vøring Plateau subsided (Talwani, Udintsev et al., 1976).

Sites 643 and 345 are situated on oceanic basement, and can be backtracked to estimate paleodepth (Table 5-2). Hole 643A is located near the base of the Vøring Slope and was drilled on ocean crust between magnetic anomalies 23 and 24A. The age/depth estimates used for Hole 634A follow those of the shipboard scientific party (Eldholm, Thiede, Taylor et al., 1987) and those determined in Chapter 3. Hole 345 was drilled at a depth of $3195 \mathrm{~m}$ in the Lofoten Basin, but its precise position in relation to the magnetic anomaly pattern was not determined during Leg 38. By plotting the position of Site 345 on the magnetic anomaly map in Eldholm et al. (1987), a late Eocene (Anonaly 15 correlative) age is inferred for the basement. This estimate is in agreement with the age of sediments overlying basement reported by Verdenius and Van Hinte (1983). Although there may be some error associated with the estimate of the age of the crust used in Table 5-2, paleodepth calculations indicate that the depth of Site 345 in the late Eocene and 


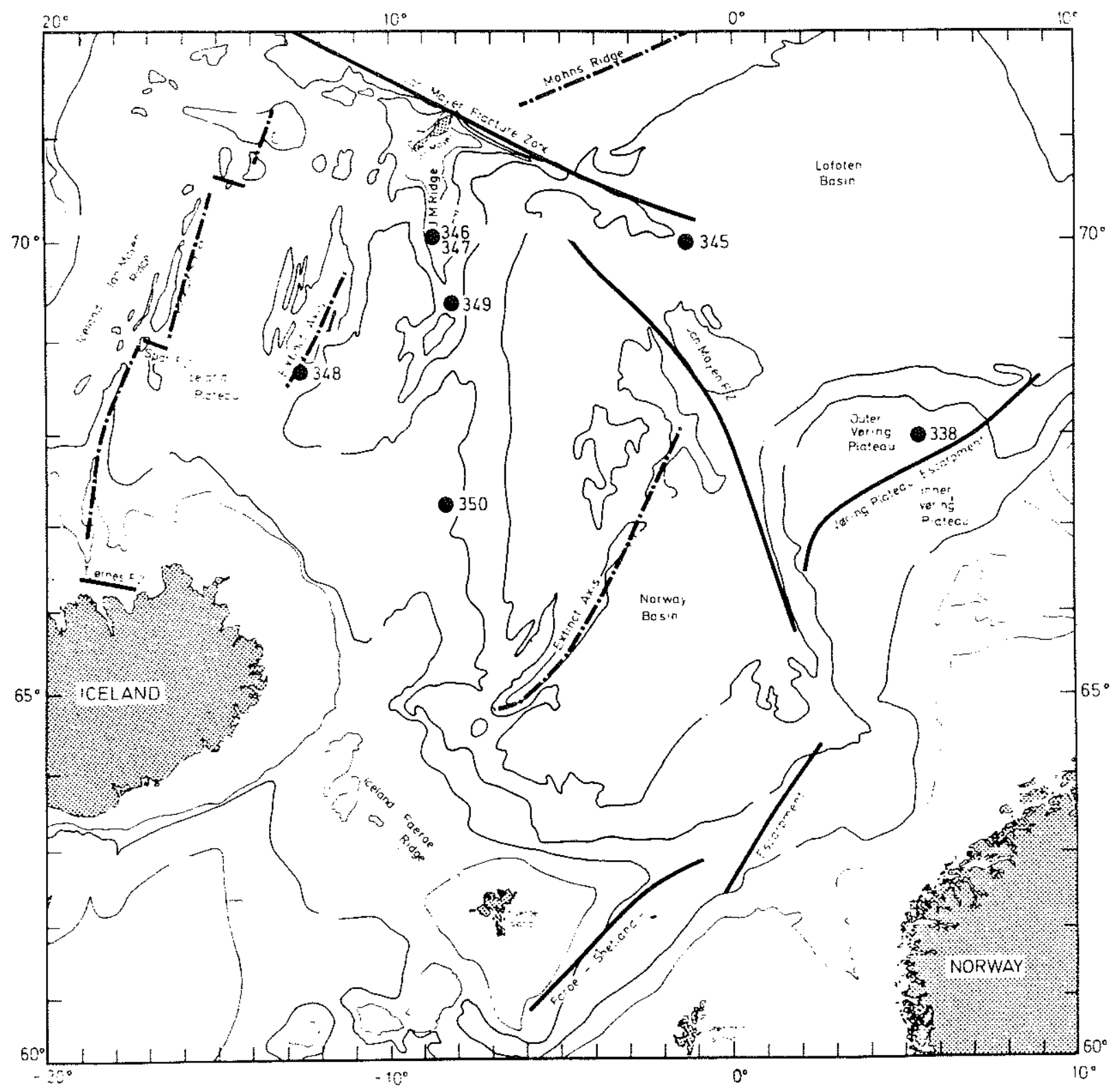

5-10. DSDP and ODP Sites in the Norwegian-Greenland Sea containing Paleogene agglutinated assemblages. Base map is after Gronlie and Talwani (1977), bathymetry in fathoms. 
Table 5-2. Paleodepth of Norwegian-Greenland Sea sites.

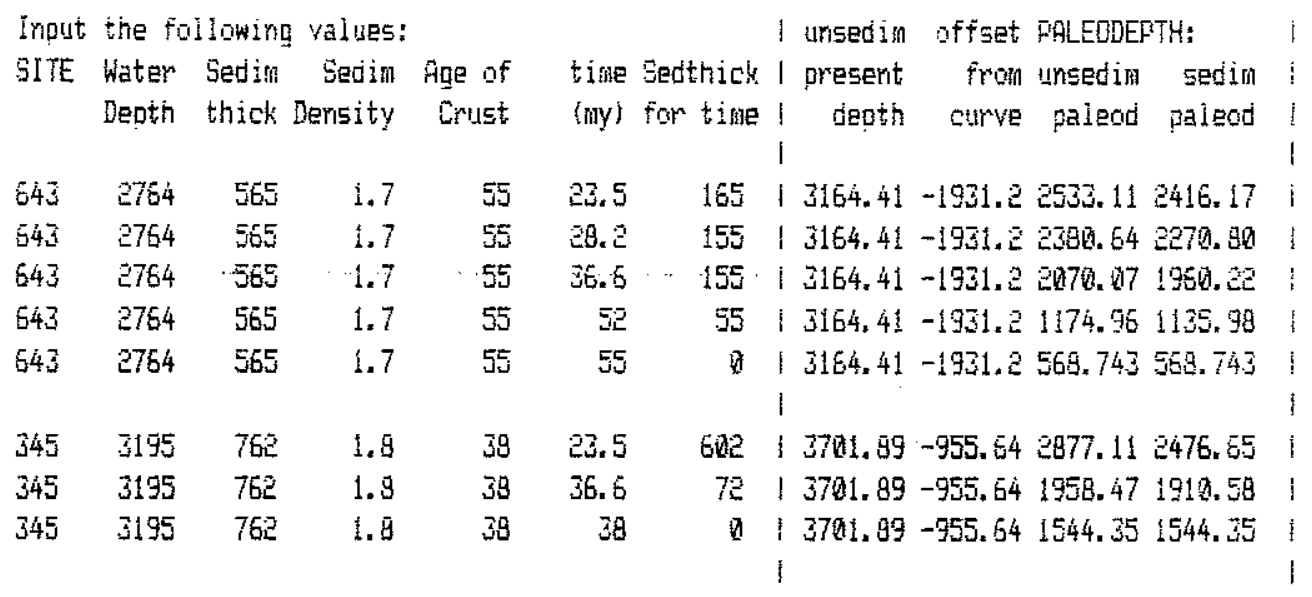


01 igocene did not differ greatly from the depth of Site 643. However, the sediment lithology (turbidites in Hole 345 vs hemipelagic claystones in Hole 643A) suggests that Site 345 was the deeper site.

On the western side of the Lofoten Basin, upper Eocene to Oligocene benthic foraminiferal assemblages are present at DSDP Sites 346, 349, and 350 on the Jan Mayen Ridge. At present, the sites are located at depths of $732 \mathrm{~m}$ to $1289 \mathrm{~m}$. Unfortunately, backtracking paleodepth estimates at these sites are meaningless.

Benthic Foraminiferal Paleobathymetry:

A. Late Eocene:

The major paleobathymetric patterns for the upper Eocene and 0ligocene are summarized in figure 5-11. The shallowest assemblages (Hole 338) display the lowest diversity of agglutinated foraminifera observed in the NorwegianGreenland Sea. Upper Eocene assemblages in this site consist solely of Spiroplectammina spectabilis and Rhabdammina. 0ligocene assemblages contain only S. compressa (Verdenius and Van Hinte, 1983). Although S. spectabilis in usually found at deeper paleodepths in the Eocene (see discussion above on Labrador Margin), in some instances and for unknown reasons, this species appears in large numbers in relatively shallow (bathyal) environments such as in Hole 612 on the New Jersey Margin (Miller and Katz, 1987) or in Hole 338. The finding of a $\mathrm{s}$. spectabilis assemblage in the lower Eocene of Hole 643A (see chapter 3) may be attributable to redeposition from a shallow source.

Hole $643 \mathrm{~A}$ contains a considerably more diverse upper Eocene assemblage ( 30 species) than Hole 338. The most common forms in the $\mathrm{S}$. compressa-R. amplectens assemblage of Hole 643A (Fig. 5-11) are finely agglutinated tubular varieties, Ammospheroidina and Spirosigmoilinella spp. In contrast with Hole $643 \mathrm{~A}$, the most common upper Eocene forms in Hole 345 are coarse species of Hyperammina and Psammosphaera. This is no doubt attributable to the predominance of turbidite sediments near the base of this hole. Verdenius and Van Hinte report 22 species from the upper Eocene of Hole 345. One important difference between the assemblages from Holes 345 and $643 \mathrm{~A}$ is the absence of the species S. compressa, Ammosphaeroidina, Ammodiscus infimus, Dorothia principiensis, and $K$. siphonella in the upper Eocene of Hole 345 . The upper Eocene of DSDP sites 346, 349 and 350 on the Jan Mayen Ridge 


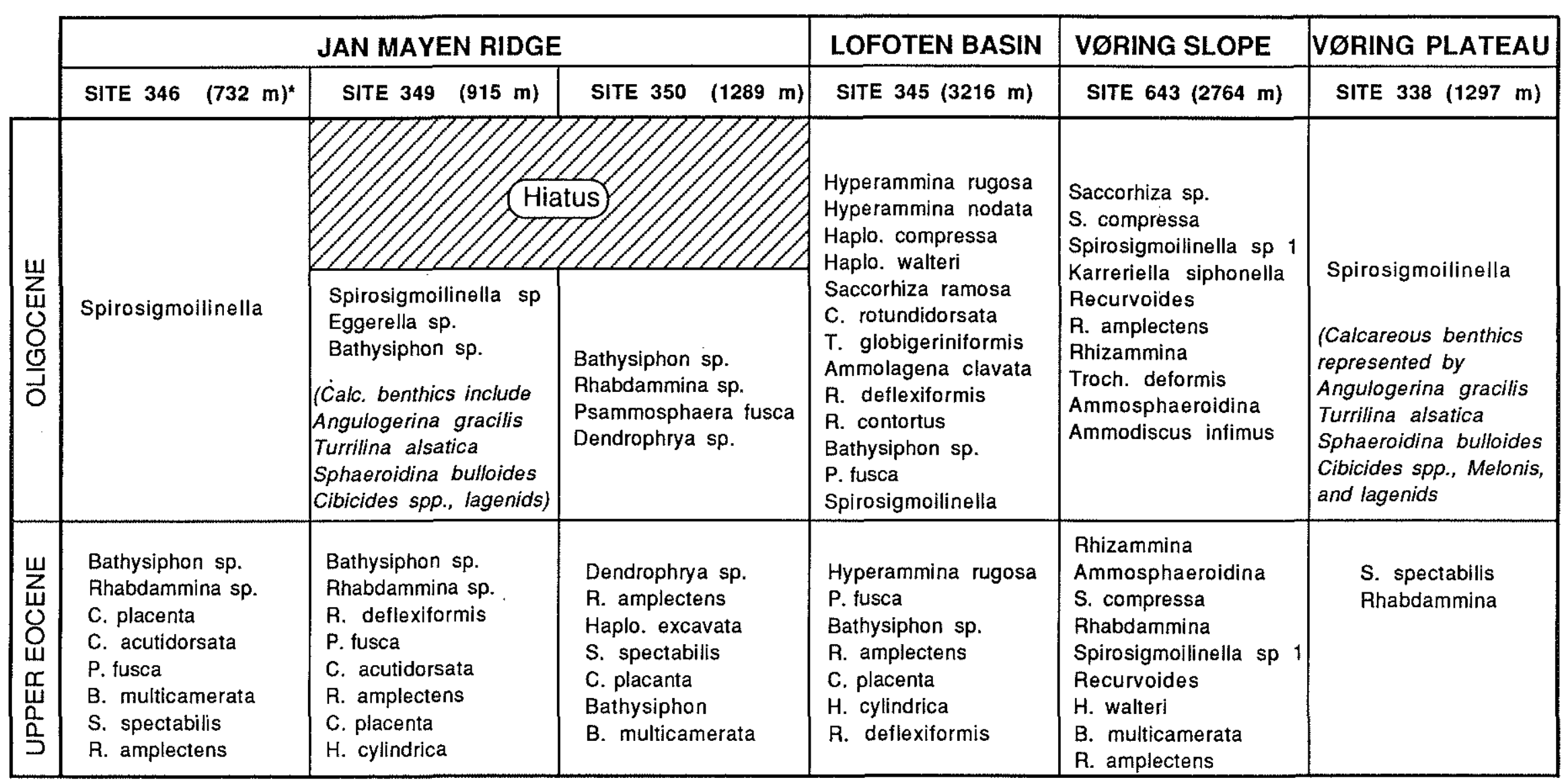

"DEPTHS INDICATE PRESENT WATER DEPTH OF SITE

5-11. Paleobathymetry of agglutinated taxa in the Norwegian-Greenland Sea, compiled from Verdenius and Van Hinte (1983) and this study. Taxa are listed in order of decreasing relative abundance. 
provides examples of shallow (probably upper bathyal) benthic foraminiferal assemblages. Hole 349 contains the shallowest upper Eocene assemblages of the three sites, which consist of a mixture of calcareous benthic and agglutinated species. The predominant sediments at all three sites consist of massive turbidites, which raises the possibility that calcareous components are redeposited. Verdenius and Van Hinte report $\sim 23$ species from Holes 346 and 349, and $\sim 10$ species from Hole 350. Most importantly, these authors report $\underline{\mathrm{S}}$. spectabilis from all three sites. Hole 350 also contains common specimens of H. excavata, which occurs in shallow facies in Spitsbergen ( $\mathrm{J}$. Nagy, personal communication 1986) and on the Labrador Margin.

\section{Oligocene:}

0ligocene paleobathymetric patterns in the Norwegian-Greenland Sea reveal a dramatic difference between shallow and deep sites. At Sites 338, 346 and 349, the only agglutinated species reported by Verdenius and Van Hinte is Spirosigmoilinella compressa. At Site 349, the 0ligocene sediments contain a relatively diverse assemblage of calcareous benthics with Turrilina alsatica, Angulogerina, Sphaeroidina, Melonis, Gyroidina, Pullenia, Eponides, Cibicidoides and lagenids (Talwani, Udintsev, et al., 1976) which displays affinity to the type Rupelian of northwest Europe. In Hole 350, calcareous benthics are absent, and the oligocene assemblage consists of four species of agglutinated foraminifera (Fig. 5-11).

More diversified assemblages ( $25 \mathrm{spp}$ ) are present in Holes 345 and $643 \mathrm{~A}$. Both sites contain only agglutinated foraminifera. Hole $643 \mathrm{~A}$ contains hemipelagic claystones with abundant Saccorhiza and Spirosigmoilinella spp. Hole 345 , which recovered turbidite sediments, contains an assemblage dominated by the coarse tubular species Hyperammina rugosa and lituloids (Haplophragmoides spp.).

\section{DISCUSSION:}

A. Comparison of North Atlantic and Tethyan (Carpathian) Benthic foraminiferal Paleobathymetry:

The tectonic setting of the Outer Flysch Belt of the Carpathians in the Cretaceous and Paleogene has been variously interpreted as a marginal basin which underwent rifting without sea-floor spreading (Unrug, 1982) or that of a series of submarine trenches (Koszarski and Zytko, 1965) which underwent 
subduction in Tertiary time (Pescatore and Slaczka, 1984; Koszarski, 1985). Lithologic and microfaunal facies displayed maximum diversity in the late Senonian to early Paleogene, when thick turbidite sequences were deposited in rapidly subsiding troughs. From north to south these were the Skole-Tarcau, Silesian, Cernogora-Audia, Dukla-Grybow, and Magura Basins (Unrug, 1979, Koszarski, 1985). The Skole and Silesian basins were separated by the Subsilesian submarine high, which experienced mainly pelagic sedimentation.

During the Paleocene, lithofacies in the Carpathian basins became less differentiated as late Cretaceous clastic sedimentation gave way to more pelagic deposition. In the deep Skole, Silesian, Dukla and Magura troughs, noncalcareous pelagic claystones occur among turbidite deposits and contain agglutinated assemblages with few calcareous elements, whereas pelagic claystones and marls from the Subsilesian Unit contain a (predominantly bathyal) Velasco-type fauna containing calcareous and agglutinated taxa. The diversity of agglutinated taxa is highest in the Subsilesian Unit, where Jednorowska (1975) records 94 species. Foraminiferal assemblages from the Subsilesian Unit most closely resemble the assemblages from Trinidad, with about 70 species in common (table $3-1$ ). Therefore, I have focused comparisons on examples from the Subsilesian Unit and adjacent deeper basins.

In southeastern Poland, variegated claystones of the Subsilesian Unit display changes in lithology and microfossil assemblages along a paleobathymetric transect from the axis of the unit to the flysch basins on either side (Koszarski, 1985). Sediments from the slopes of the Subsilesian high are tectonically disturbed, but lateral lithofacies changes can be observed in places. The shallower sediments from the axial region consist mainly of variegated marls with foraminiferal assemblages dominated by planktonic and calcareous benthic taxa. The agglutinated genera are represented mainly by lituolids, ammodiscids, hormosinids and ataxophragmiids (especially Dorothia, Marssonella, Tritaxia and Matanzia).

on the slopes of the Subsilesian high, marly sediments are laterally replaced by reddish-brown noncalcareous pelagic shales which contain a foraminiferal assemblage consisting entirely of agglutinated forms. Further to the south these shales are replaced by thick flysch sediments of the Silesian basin which contain more depauperate agglutinated assemblages. In the deep facies of the Silesian and Magura basins Jednorowska (1975) records 65 species of agglutinated foraminifera. Assemblages from Trinidad compare 
well with those from greenish-grey marly shales of Paleocene age from the southern paleoslope of the Subsilesian Unit exposed in the area of Sanok in southeastern Poland (Koszarski and Liszkowa, 1963). The assemblage is characterized by Rhabdammina spp., Dendrophrya ex gr. excelsa, Ammodiscus spp., Glomospira spp., Hormosina ovulum ovulum, Nodellum velascoensis, Recurvoides spp., Saccammina placenta, Trochamminoides spp., Haplophragmoides walteri, Kalamopsis grzybowskii, Cystammina pauciloculata (=Ammosphaeroidina pseudopauciloculata auct.), Rzehakina epigona, R. fissistomata, Spiroplectammina spectabilis, Karreriella spp., Dorothia trochoides, and Matanzia varians. Planktonic Eoraminifera are absent in these sediments, and rare calcareous benthic taxa are represented mainly by Nuttalides spp., Stensioeina beccariiformis, Osangularia florealis and Aragonia spp. As pointed out by Koszarski and Zytko (1965) these sediments were deposited near the CCD, since nearby they grade into noncalcareous shales.

The most complete quantitative data available on agglutinated assemblages from Southeast Poland are given by Jurkiewicz (1967), and the general similarity between Carpathian and North Atlantic assemblages allows us to distinguish consistent paleobathymetric patterns in species composition. Species that occur in greater abundance in the basin plain facies of the Lizard Springs formation and the Carpathian basins in southeastern Poland (Table 5-3) include Saccammina placenta, Ammodiscus spp., Glomospira spp., Hormosina ovulum, Reophax duplex, Recurvoides deflexiformis, and Trochamminoides spp. The genus Karreriella generally occurs in deeper facies in both Trinidad and Poland. Labrospira pacifica was not recognized at the time of Jurkiewicz's study but occurs in the upper Cretaceous of the Silesian Basin (Geroch and Nowak, 1984). Its occurrence in Table 5-3 is marked by question marks.

By synthesizing microfaunal, sedimentological and ichnofaunal evidence, Ksiazkiewicz (1975) interpreted the paleobathymetry of the subsilesian sediments as outer neritic to upper bathyal, and assigned upper bathyal paleodepths to sediments in the Skole and Silesian Basins. However, Koszarski and Zytko (1963) and 0lszewska (1984) favor a deeper (bathyal to upper abyssal) interpretation based on the assumption of oceanic depths of the CCD in the Carpathian troughs. By comparing the taxonomic composition of the assemblages from SE Poland with DSDP Holes 543A and 641A, abyssal depths can 
Table 5-3.

Agglutinated foraminifera with greater relative abundance in deeper facies of Trinidad and the Polish Carpathians. Carpathian data are compiled from Jurkiewicz (1967). Species listed in column 2 occur in greater abundance in both the Silesian and Skole Basins relative to the paleobathymetrically shallower Subsilesian Unit. Column 3 lists species with greater abundance in the Magura Basin relative to the paleobathymetrically shallower Dukla Unit.

\begin{tabular}{cc}
\hline TRINIDAD & POLISH CARPATHIANS \\
\hline LIZARD SPRINGS & SKOLE-SUBSILESIAN-SILESIAN \\
\hline
\end{tabular}

Bathysiphon sp.

Rhizammina indivisa Saccammina placenta

Dendrophrya ex gr. excelsa

Hyperammina dilatata

Saccammina placenta Saccammina placenta

\begin{tabular}{|c|c|c|}
\hline $\begin{array}{l}\text { Ammodiscus spp } \\
\text { Glomospira spp }\end{array}$ & $\begin{array}{l}\text { Ammodiscus spp } \\
\text { Glomospira spp }\end{array}$ & $\begin{array}{l}\text { Ammodiscus spp } \\
\text { Glomospira spp }\end{array}$ \\
\hline \multicolumn{2}{|l|}{ Rzehakina epigona } & Rzehakina epigona \\
\hline $\begin{array}{l}\text { Hormosina ovuloides } \\
\text { Hormosina ovulum ovulum } \\
\text { Kalamopsis grzybowskii } \\
\text { Nodellum velascoensis } \\
\text { Reophax duplex }\end{array}$ & $\begin{array}{l}\text { Aschemonella spp } \\
\text { Hormosina ovulum ovulum } \\
\text { Reophax duplex }\end{array}$ & $\begin{array}{l}\text { Hormosina ovulum ovulum } \\
\text { Kalamopsis grzybowskii } \\
\text { Nodellum velascoensis } \\
\text { Reophax duplex }\end{array}$ \\
\hline $\begin{array}{l}\text { Haplophragmoides horridus } \\
\text { Haplophragmoides lamella } \\
\text { Haplophragmoides porrectus } \\
\text { H. ex gr. suborbicularis } \\
\text { Labrospira pacifica } \\
\text { Recurvoides deflexiformis } \\
\text { Recurvoides cf. subturbinatus } \\
\\
\text { Trochamminoides irregularis } \\
\text { Trochamminoides subcoronatus }\end{array}$ & $\begin{array}{l}\text { Ammobaculites deflexus } \\
\text { Haplophragmoides horridus } \\
\text { Haplophragmoides lamella } \\
\\
\text { H. ex gr. suborbicularis } \\
\quad \text { ?? } \\
\text { Recurvoides deflexiformis } \\
\text { Recurvoides cf. subturbinatus } \\
\text { Recurvoides walteri } \\
\text { Trochamminoides coronatus } \\
\text { Trochamminoides subcoronatus }\end{array}$ & $\begin{array}{l}\quad \text { ?? } \\
\text { Recurvoides deflexiformis } \\
\text { Recurvoides cf. subturbinatus } \\
\text { Recurvoides walteri } \\
\text { Trochamminoides coronatus } \\
\text { Trochamminoides subcoronatus }\end{array}$ \\
\hline \multicolumn{2}{|c|}{$\begin{array}{l}\text { Ammosphaeroidina pseudopauciloculata } \\
\text { Trochammina altiformis }\end{array}$} & $\begin{array}{l}\text { A. pseudopauciloculata } \\
\text { Trochammina altiformis }\end{array}$ \\
\hline \multicolumn{3}{|l|}{$\begin{array}{l}\text { Spiroplectammina spectabilis } \\
\text { Spiroplectammina navarroana }\end{array}$} \\
\hline $\begin{array}{l}\text { Karreriella tenuis } \\
\text { Karreriella sp. } 2\end{array}$ & $\begin{array}{l}\text { Karreriella tenuis } \\
\text { Karreriella conversa }\end{array}$ & Karreriella coniformis \\
\hline
\end{tabular}


be ruled out because of the lack of diverse, smooth Haplophragmoides spp and other "Type-B" faunal elements in the Carpathian basins. Comparisons with the Lizard Springs Formation constrain the Lower depth limit of the Carpathian basins to lower bathyal depths.

\section{B. Comparison of Paleogene paleobathymetric patterns with existing models:}

Paleobathymetric models of benthic foraminiferal distribution patterns have been established for sediments as old as mid-Cretaceous. For example, Sliter and Baker (1972) compiled a model of the bathymetric distribution of modern species on the Pacific Margin, and used this information to interpret the depositional environment of upper Cretaceous deposits in Southern California. A more generalized model was compiled by Haig (1979), who used both modern and fossil data to interpret global distribution patterns for midCretaceous foraminiferids. Haig divided benthic assemblages into three general paleobathymetric associations. His classification of benthic assemblages into an epicontinetal neritic "Ammobaculites association", a neritic to bathyal "Marssonella association" and an abyssal "Recurvoides association" has been adopted for the alpine basins and these terms have become widely used in the literature (Geroch and Nowak, 1984; Slaczka and Gasinski, 1984; 0lszewska, 1984; Pescatore and Slaczka, 1985). But what exactly are these associations and does this classification adequately describe the faunal patterns observed in the Paleogene North Atlantic and Alpine basins?

Haig based his subdivision of Cretaceous assemblages to a large extent on the work of Sliter and Baker (1972) from the California borderland as well as on a compilation of microfossil data from sedimentary basins in the Carribean, alpine Europe, India and New Guinea. Unfortunately, these localities are mostly in tectonically active regions where deep-water sediments have been obducted and uplifted, and reconstruction of the original bathymetry is not unequivocal. The use of this classification in the Paleogene North Atlantic and Tethyan flysch basins requires a number of assumptions. Firstly, it is necessary to assume that Haig's fossil data was based on samples with good paleobathymetric control. With the lack of an independent means of estimating paleobathymetry there is a possibility of introducing systematic errors into any paleoenvironmental interpretations. Secondly, there is the problem of evolutionary turnover between the Cretaceous and Paleogene. One must also 
Table 5-3.

Agglutinated foraminifera with greater relative abundance in deeper facies of Trinidad and the Polish Carpathians. Carpathian data are compiled from Jurkiewicz (1967). Species listed in column 2 occur in greater abundance in both the Silesian and Skole Basins relative to the paleobathymetrically shallower Subsilesian Unit. Column 3 lists species with greater abundance in the Magura Basin relative to the paleobathymetrically shallower Dukla Unit.

\begin{tabular}{|c|c|}
\hline TRINIDAD & POLISH CARPATHIANS \\
\hline LIZARD SPRINGS & SKOLE-SUBSILESIAN-SILESIAN \\
\hline
\end{tabular}

Bathysiphon sp.

Rhizammina indivisa

Saccammina placenta

Hyperammina dilatata

\begin{tabular}{|c|c|c|}
\hline $\begin{array}{l}\text { Ammodiscus spp } \\
\text { Glomospira spp }\end{array}$ & $\begin{array}{l}\text { Ammodiscus spp } \\
\text { Glomospira spp }\end{array}$ & $\begin{array}{l}\text { Ammodiscus spp } \\
\text { Glomospira spp }\end{array}$ \\
\hline Rzehakina epigona & & Rzehakina epigona \\
\hline $\begin{array}{l}\text { Hormosina ovuloides } \\
\text { Hormosina ovulum ovulum } \\
\text { Kalamopsis grzybowskii } \\
\text { Nodellum velascoensis } \\
\text { Reophax duplex }\end{array}$ & $\begin{array}{l}\text { Aschemonella spp } \\
\text { Hormosina ovulum ovulum } \\
\text { Reophax duplex }\end{array}$ & $\begin{array}{l}\text { Hormosina ovulum ovulum } \\
\text { Kalamopsis grzybowskii } \\
\text { Nodellum velascoensis } \\
\text { Reophax duplex }\end{array}$ \\
\hline $\begin{array}{l}\text { Haplophragmoides horridus } \\
\text { Haplophragmoides lamella } \\
\text { Haplophragmoides porrectus } \\
\text { H. ex gr. suborbicularis } \\
\text { Labrospira pacifica } \\
\text { Recurvoides deflexiformis } \\
\text { Recurvoides cf. subturbinatus } \\
\\
\text { Trochamminoides irregularis } \\
\text { Trochamminoides subcoronatus }\end{array}$ & $\begin{array}{l}\text { Ammobaculites deflexus } \\
\text { Haplophragmoides horridus } \\
\text { Haplophragmoides lamella } \\
\text { H. ex gr. suborbicularis } \\
\quad ? ? \\
\text { Recurvoides deflexiformis } \\
\text { Recurvoides cf. subturbinatus } \\
\text { Recurvoides walteri } \\
\text { Trochamminoides coronatus } \\
\text { Trochamminoides subcoronatus }\end{array}$ & $\begin{array}{l}\quad \text { ?? } \\
\text { Recurvoides deflexiformis } \\
\text { Recurvoides cf. subturbinatus } \\
\text { Recurvoides walteri } \\
\text { Trochamminoides coronatus } \\
\text { Trochamminoides subcoronatus }\end{array}$ \\
\hline Ammosphaeroidina pseudopal & $\begin{array}{l}\text { Tulata } \\
\text { Trochammina altiformis }\end{array}$ & $\begin{array}{l}\text { A. pseudopauciloculata } \\
\text { Trochammina altiformis }\end{array}$ \\
\hline \multicolumn{3}{|l|}{$\begin{array}{l}\text { Spiroplectammina spectabilis } \\
\text { Spiroplectammina navarroana }\end{array}$} \\
\hline $\begin{array}{l}\text { Karreriella tenuis } \\
\text { Karreriella sp. } 2\end{array}$ & $\begin{array}{l}\text { Karreriella tenuis } \\
\text { Karreriella conversa }\end{array}$ & Karreriella coniformis \\
\hline
\end{tabular}

Dendrophrya ex gr. excelsa

Saccammina placenta Saccammina placenta 
be ruled out because of the lack of diverse, smooth Haplophragmoides spp and other "Type-B" faunal elements in the Carpathian basins. Comparisons with the Lizard Springs Formation constrain the Lower depth limit of the Carpathian basins to lower bathyal depths.

\section{B. Comparison of Paleogene paleobathymetric patterns with existing models:}

Paleobathymetric models of benthic foraminiferal distribution patterns have been established for sediments as old as mid-Cretaceous. For example, Sliter and Baker (1972) compiled a model of the bathymetric distribution of modern species on the Pacific Margin, and used this information to interpret the depositional environment of upper Cretaceous deposits in Southern California. A more generalized model was compiled by Haig (1979), who used both modern and fossil data to interpret global distribution patterns for midCretaceous foraminiferids. Haig divided benthic assemblages into three general paleobathymetric associations. His classification of benthic assemblages into an epicontinetal neritic "Ammobaculites association", a neritic to bathyal "Marssonella association" and an abyssal "Recurvoides association" has been adopted for the alpine basins and these terms have become widely used in the literature (Geroch and Nowak, 1984; Slaczka and Gasinski, 1984; 0lszewska, 1984; Pescatore and Slaczka, 1985). But what exactly are these associations and does this classification adequately describe the faunal patterns observed in the Paleogene North Atlantic and Alpine basins?

Haig based his subdivision of Cretaceous assemblages to a large extent on the work of Sliter and Baker (1972) from the California borderland as well as on a compilation of microfossil data from sedimentary basins in the Carribean, alpine Europe, India and New Guinea. Unfortunately, these localities are mostly in tectonically active regions where deep-water sediments have been obducted and uplifted, and reconstruction of the original bathymetry is not unequivocal. The use of this classification in the Paleogene North Atlantic and Tethyan flysch basins requires a number of assumptions. Firstly, it is necessary to assume that Haig's fossil data was based on samples with good paleobathymetric control. With the lack of an independent means of estimating paleobathymetry there is a possibility of introducing systematic errors into any paleoenvironmental interpretations. Secondly, there is the problem of evolutionary turnover between the Cretaceous and Paleogene. One must also 
assume that paleogeographic factors such as provinciality can be ignored in the North Atlantic and European basins.

The Cretaceous Model:

Shelf and Slope Assemblages: Sliter and Baker (1972) compiled the upper depth limits and characteristic occurrences of modern foraminiferal genera along the eastern Pacific margin. Using modern patterns as a key to the past, they constructed a paleobathymetric model of Cretaceous genera by identifying genera or homeomorphs in common with the modern bathymetric succession. Cretaceous assemblages were assumed to indicate water depths analogous to their modern counterparts living in similar clastic environments. They recognized five generalized assemblages indicative of slope and shelf environments (Fig. 5-12). Haig (1979) named the slope assemblages the "Marssonella association" which was further subdivided according to the paleobathymetric model of Sliter and Baker.

Sliter and Baker used their model to interpret the paleobathymetric environment of the upper Cretaceous. Point Loma Formation at La Jolla Bay, California. These flysch sediments were interpreted as being deposited in a setting similar to the modern slope basins off Southern California in water depths of up to $1000 \mathrm{~m}$. The assemblages recorded by Sliter and Baker from La Jolla can be regarded as the type locality of the "Marssonella association" of Haig.

The paleodepth of base of the Point Loma Formation at La Jolla was interpreted by Sliter and Baker as $900-1000 \mathrm{~m}$. This is the deepest part of the sequence, and the benthic assemblage is dominated by Bathysiphon, Cribrostomoides, Dorothia, Gaudryina, Gyroidinoides, Lenticulina, Osangularia, Praebulimina, Pullenia, Reussella, Saracenaria, Reussella, Spiroplectammina, and Stilostomella. This assemblage corresponds to middle bathyal depths as determined from the model. Lower bathyal assemblages were not reported from the Point Loma Formation, but were discussed in the paleobathymetric model. Haig noted that these assemblages are dominated by agglutinated species (mainly Glomospira, Hyperamina, Pelosina, Hormosina, Saccammina, Haplophragmoides and Bathysiphon), and regarded these as transitional to abyssal assemblages.

Abyssal Assemblages: The abyssal realm was not included in the model of 


\begin{tabular}{|c|c|c|c|c|c|}
\hline \multirow{2}{*}{$\begin{array}{l}\text { PALE0- } \\
\text { DEPTH } \\
-200-\end{array}$} & \multirow{2}{*}{\multicolumn{3}{|c|}{$\begin{array}{c}\text { CRETACEOUS PALEOBATHYMETRY } \\
\text { Sliter \& Baker, (1972) } \\
\text { Haig (1979) }\end{array}$}} & \multicolumn{2}{|c|}{$\begin{array}{c}\text { NORTH ATLANTIC PALEOCENE } \\
\text { PALEOBATHYMETRY }\end{array}$} \\
\hline & & & & Low-Latitude & Boreal \\
\hline $\begin{array}{l}\text { UPPER } \\
\text { SLOPE }\end{array}$ & \multirow{3}{*}{ 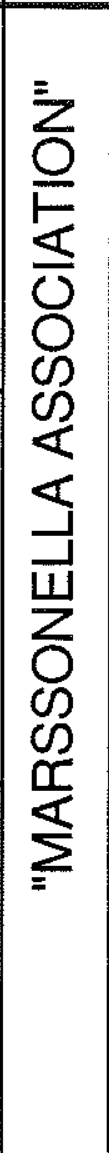 } & $\begin{array}{l}\text { Osangularia } \\
\text { Gavelinella } \\
\text { Gyroidinoides } \\
\text { Hoeglundina } \\
\text { Silicosigmoilina } \\
\text { Bathysiphon } \\
\text { Gaudryina } \\
\text { Cribrostomoides } \\
\text { Praebulimina } \\
\end{array}$ & $\begin{array}{l}\text { Dorothia } \\
\text { Spiroplectammina } \\
\text { Ammodiscus } \\
\text { Trochammina } \\
\text { Colomia } \\
\text { nodosarilds } \\
\text { Tappanina } \\
\text { Pyramidina } \\
\text { Globulina } \\
\end{array}$ & $\begin{array}{l}\text { Clavulinoides } \\
\text { Dorothia } \\
\text { Phenacophragma } \\
\text { coarse Haplophrag. } \\
\text { Ammobaculites } \\
\text { Arenobulimina } \\
\text { Gaudryina } \\
\text { Rhabdammina }\end{array}$ & $\begin{array}{l}\text { cyclamminids } \\
\text { D. robusta } \\
\text { Rhabdammina } \\
\text { coarse Haplophrag. } \\
\text { coarse Trochammina } \\
\text { Recurvoldes walteri } \\
\text { Budashevaella } \\
\text { H. excavata } \\
\text { Ammodiscus planus } \\
\text { Dorothia sp. } 6 \\
\end{array}$ \\
\hline $\begin{array}{l}\text { MIDDLE } \\
\text { SLOPE }\end{array}$ & & $\begin{array}{l}\text { Praebulimina } \\
\text { Dorothia } \\
\text { Osangularia } \\
\text { Hoeglundina } \\
\text { Gaudryina } \\
\text { Chilostomella } \\
\text { Allomorphina } \\
\text { Pullenia } \\
\text { Planulina }\end{array}$ & $\begin{array}{l}\text { Bathysiphon } \\
\text { Silicosigmoilina } \\
\text { Hyperammina } \\
\text { Cribrostomoides } \\
\text { Spiroplectammina } \\
\text { Gavelinella } \\
\text { Ammodiscus } \\
\text { Ammodiscoides } \\
\text { Stilostomella }\end{array}$ & \multirow{2}{*}{$\begin{array}{l}\text { Ammosphaeroidina } \\
\text { Rhizammina } \\
\text { Rzehakina } \\
\text { Rec. gerochi } \\
\text { S. spectabilis } \\
\text { Sacc. placenta } \\
\text { Bathysiphon } \\
\text { Glomospira } \\
\text { Hormosina } \\
\text { Kalamopsis } \\
\text { smooth Haplophrag. } \\
\text { Labrospira } \\
\text { Nodellum } \\
\text { Trochamminoides } \\
\text { Karreriella }\end{array}$} & \multirow{2}{*}{$\begin{array}{l}\text { Glomospira } \\
\text { (G. charoides, } \\
\text { G. irregularis) } \\
\text { Hormosina } \\
\text { (H. ovulum, } \\
\text { H. excelsa) } \\
\text { S. placenta } \\
\text { Ammosphaeroidina } \\
\text { Cribrostomoides } \\
\text { Trochamminoides } \\
\text { S. spectabilis } \\
\text { Reophax duple: } \\
\text { Subreophax } \\
\text { Glomospirella } \\
\text { Labrospira }\end{array}$} \\
\hline $\begin{array}{l}\text { LOWER } \\
\text { SLOPE }\end{array}$ & & $\begin{array}{l}\text { Glomospira } \\
\text { Bathysiphon } \\
\text { Hyperammina } \\
\text { Ammodiscus } \\
\text { Gaudryina } \\
\text { Cribrostomoides } \\
\text { Silicosigmoilina } \\
\text { Osangularia } \\
\text { Pullenia }\end{array}$ & $\begin{array}{l}\text { Praebulimina } \\
\text { Saccammina } \\
\text { Pelosina } \\
\text { Hormosina } \\
\text { Allomorphina } \\
\text { Gavelinella } \\
\text { Haplophragmoides } \\
\text { Spiroplectammina }\end{array}$ & & \\
\hline $\begin{array}{l}\frac{\sigma}{\infty} \\
\stackrel{\infty}{\infty} \\
\frac{\infty}{\alpha}\end{array}$ & 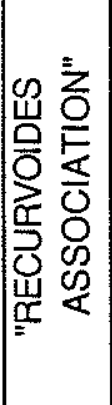 & $\begin{array}{l}\text { RECURVOID } \\
\text { PLECTOREC } \\
\text { THALMANN } \\
\text { UVIGERINAI } \\
\text { HORMOSINA } \\
\text { DENDROPHI } \\
\text { KALAMOPS! }\end{array}$ & $\begin{array}{l}\text { JOIDES } \\
\text { MINA } \\
\text { INA }\end{array}$ & \multicolumn{2}{|c|}{$\begin{array}{l}\text { fine tubular species } \\
\text { HORMOSINA } \\
\text { GLOMOSPIRA } \\
\text { minute AMMODISCUS } \\
\text { S. SPECTABILIS } \\
\text { TROCHAMMINOIDES } \\
\text { KALAMOPSIS } \\
\text { RECURVOIDES } \\
\text { PRAECYSTAMMINA } \\
\text { SUBREOPHAX }\end{array}$} \\
\hline
\end{tabular}

5-12. Comparison of upper Cretaceous and Paleocene paleobathymetric models for agglutinated foraminiferal assemblages. Cretaceous data compiled from Sliter and Baker (1972) and Haig (1979). 
Sliter and Baker, and Haig referred all abyssal assemblages to a "Recurvoides association" characterized by agglutinated foraminifera. Typical genera in this assemblage were listed as Recurvoides, Plectorecurvoides, Thalmannammina, Uvigerinammina, Hormosina, Dendrophrya, and Kalamopsis. Haig noted the similarity of the mid-Cretaceous assemblage with the fauna reported by Bandy and Rodolfo (1964) from depths below 3400m in the Peru-Chile Trench. Haig listed three localities that contain the "Recurvoides association". The first two are from upper Cretaceous red clays in DSDP Sites from the western Pacific and Argo Abyssal Plain recovered on Legs 20 and 27 . The benthic foraminiferal assemblages from these sites were first described by Krasheninnikov (1973, 1974) who regarded them as unique and created about 40 new species. Many of the remaining species at these sites not regarded as new by Krasheninnikov are also known from the Alpine Mountain Belt. Krasheninnikov (1974) noted that although similar genera are present in both regions, upper Cretaceous assemblages from the Carpathians differ from Indian Ocean assemblages in morphology and the types of species present. He remarked that Carpathian specimens are larger and possess coarsely agglutinated tests. This led Krasheninnikov to speculate that true abyssal sediments may be absent on the continents. Despite this fact, Haig included mid-Cretaceous assemblages from Alpine and Carpathian area as the third type locality of the "Recurvoides association", and subsequent authors have followed this usage.

A comparison of Paleogene paleobathymetric patterns with the Cretaceous model (Fig. 5-12) reveals that Haig's threefold paleobathymetric subdivision of agglutinated faunas cannot be applied to Paleogene assemblages without qualification. An important difference is that the "Marssonella association" as defined by Haig cannot be recognized in boreal areas or in sediments younger than Paleocene in the Tethyan region. Assemblages containing meaningful proportions of calcareous ataxophragmiids (Arenobulimina, Clavulinoides, Dorothia, Gaudryina, Matanzia) are present in upper bathyal assemblages in Trinidad, Zumaya and the Subsilesian Unit of the Polish Carpathians, but these genera are rare in the North Sea and Labrador.

If Carpathian localities are excluded from the definition of the "Recurvoides association", this association now corresponds to the "Type-B" fauna, However, there is no strict Paleogene analog of this fauna. The majority of the typical upper Cretaceous "Type-B" species described by Krasheninnikov have their last occurrences in the Maastrichtian and Paleocene. 
Eocene sediments in deep abyssal $(>4 \mathrm{~km})$ sites in the Atlantic are barren of foraminifera. The closest example of an abyssal fauna in the Eocene is found in Hole 647A, but with the exception of the Glomospira facies the site was situated above the oceanic lysocline and therefore the analogy with upper Cretaceous abyssal assemblages is not exact. Moreover, even in bathyal faunas the relative abundance of Recurvoides does not change appreciably from the shallow to deep assemblages. In Trinidad and the Labrador transect, its relative abundance shows no meaningful pattern. A comparison of paleobathymetry of flysch-type agglutinated assemblages allow us to identify other species which display interregional depth-related patterns. Agglutinated taxa which consistently occur in greater abundance in deeper facies in the Paleogene include the genera Bathysiphon, Rhizammina, Ammodiscus, Glomospira, Nodellum, Subreophax, Trochamminoides, Ammosphaeroidina, small, finely agglutinated species of Haplophragmoides, and the species Saccammina placenta, Reophax duplex, Hormosina ovulum, Recurvoides deflexiformis, and R. subturbinatus. In Tethyan areas, Rzehakina and noncalcareous species of Karreriella can be added to the list of deeper taxa. 
SUMMARY:

The lower Lizard Springs Formation of Trinidad contains both in situ and penecontemporaneously redeposited assemblages. Sedimentological and calcareous microfossil evidence enable the construction of a paleobathymetric microfossil facies model for the lower Lizard Springs Formation. Three faunas were delineated by Q-mode factor analysis which explain most of the variance.

The deepest assemblage in the material studied is dominated by small, finely agglutinated species such as Ammosphaeroidina pseudopauciloculata, Rhizammina indivisa, and Recurvoides gerochi, with a lesser contribution by Rzehakina epigona, Spiroplectammina spectabilis and Saccammina placenta. This assemblage occurs in bioturbated, noncalcareous clays and probably represents an in situ fauna in pelagic sediments deposited below a local CCD. An assemblage strongly dominated by Dendrophrya ex gr. excelsa is found in redeposited sediments containing calcareous benthics dominated by Nuttallides truempyi. This fauna was probably redeposited from a deep, distal source. A third faunal assemblage occurs in the basal interval of well G-287. This fauna is dominated by species associated with a calcareous facies, such as Clavulinoides globulifera, Dorothia retusa, Phenacophragma beckmanni, and Haplophragmoides ex. gr. suborbicularis. This assemblage occurs with a calcareous benthic fauna containing an increased abundance of Stensioeina beccariiformis, and is interpreted as being redeposited from a shallower, more proximal source.

The paleobathymetry of agglutinated foraminifera in the northern Atlantic can be reconstructed from a transect of wells on the Labrador Margin and DSDP/ODP sites in the Labrador Sea, Norwegian-Greenland Sea and Galicia Margin. Paleobathymetric patterns in northern assemblages differ from low latitude assemblages by the lack of a shallow "Marssonella association" of calcareous ataxophragmiids. Shallow Maastrichtian and Paleogene assemblages contain abundant coarse tubular species and lituolids with only very rare calcareous ataxophragmiids. Shallow Eocene assemblages on the Labrador Margin contain few tubular species and are dominated by cyclamminids. However, shallow assemblages on the Voring Plateau and Slope contain abundant tubular forms, cyclamminids, and acmes of S. spectabilis. Deeper assemblages contain more abundant Glomospira, Hormosina, Trochamminoides, Ammosphaeroidina, Praecystammina, and finely agglutinated lituolids (Cribrostomoides, Haplophragmoides, Labrospira). Cretaceous deep assemblages contain abundant 
Uvigerinammina, and Paleocene deep assemblages contain more abundant $\underline{\mathrm{S}}$. spectabilis. Hormosina ovulum was common in deep assemblages before the early Eocene.

The paleobathymetric subdivision of Cretaceous agglutinated assemblages of Haig (1979) cannot be used in the Paleogene. The relative abundance of Recurvoides, the nominate taxon of Haig's deep assemblage, does not display meaningful depth-related patterns in the North Atlantic. The "Marssonella association" does not occur at high latitudes, or above the Paleocene in low latitudes. It is therefore neccessary to use other species as paleobathymetric indicators in the Paleocene. A comparison of paleobathymetry of agglutinated assemblages from Trinidad, Poland, Labrador and the Norwegian-Greenland Sea enables the recognition of interregional depth-related patterns. Agglutinated taxa which generally occur in greater abundance in deeper facies include the genera Bathysiphon, Rhizammina, Ammodiscus, Glomospira, Rzehakina, Karreriella, Nodellum, Trochamminoides, Ammosphaeroidina, small, finely agglutinated Haplophragmoides, and the species Saccammina placenta, Reophax duplex, Hormosina ovulum, Recurvoides deflexiformis, and $\mathrm{R}$. subturbinatus. The Carpathian basins do not contain "type-B" elements typical of abyssal DSDP sites, and therefore the basinal facies were probably deposited at shallower (bathyal) paleodepths.

The paleobathymetry of some deep-water species may have been influenced by latitudinal effects. Most noteably, the Eocene distribution of $\underline{S}$. spectabilis displays tropical submergence, since it occurs at relatively shallow paleodepths at high latitudes. This finding is consistent with the observation of Thompson (1877) that the modern abyssal fauna of the ocean resembles the shallow-water faunas of high northern and southern latitudes. 
B. PALEOCEANOGRAPHIC SIGNIFICANCE OF AGGLUTINATED FORAMINIFERAL ASSEMBLAGES.

\section{The Glomospira Facies and the NP14 Sealevel Event -}

In Chapter 2, I noted the occurrence of agglutinated assemblages with abundant Glomospira associated with organic carbon-rich substrates in the Gulf of Mexico. In Chapter 3, I reported assemblages of exclusively agglutinated foraminifera characterized by Glomospira spp. in lower Eocene and lower middle Eocene sediments from the Labrador Sea and Norwegian-Greenland Sea. Similar Glomospira facies have been found in the Austrian Alps (Grun et al., 1964), the Swiss Alps (Winkler, 1984), in the Carpathian basins in Poland (Geroch et al., 1967; Morgiel and 0lszewska, 1981), and in the Tanger Unit of the Moroccan Rif Zone (Morgiel and 0lszewska, 1982). In the Dulka Unit of the Polish Carpathians, the age of the Glomospira facies was constrained by nannofossil-bearing sediments above and below as NP12 to NP14 (01szewska and Smagowicz, 1977). As in the Labrador Sea and Norwegian-Greenland Sea holes, in both Poland and Morocco the Glomospira facies is associated with reddish or variegated (red and green) shales. Morgiel and 0lszewska (1982) noted the remarkable similarity in species composition of this assemblage on both the northern and southern margins of the Mediterranean Tethys. Kaminski et al. (in press, d) were the first to report Eocene Glomospira assemblages outside of Tethyan alpine areas.

In Hole 647, a Glomospira facies was found in a $20 \mathrm{~m}$ interval of noncalcareous claystones and is coincident with an increase in TOC (Fig. 214). The carbonate-free interval is evidence of a rise in the lysocline in the Labrador Sea to a level above $2500 \mathrm{~m}$ (Fig. 5-9). The age of the Glomospira assemblage in Hole 647A is constrained by nannofossils occurring above and below as NP13 to the lower portion of Zone NP15 (CP13b) (Firth, in press). The lithologic change from the carbonate-free interval with Glomospira (below) to calcareous sediments above also corresponds to a midsediment seismic reflector which can be traced regionally in the Labrador Sea (S.R. Srivastava, personal communication, 1987). An assemblage with common Glomospira also occurs at the top of the lower Eocene in the Bonavista C-99 well on the Labrador Margin (Fig. 2-21). In Hole 643A, in the NorwegianGreenland Sea, an acme of Glomospira was found in a $\sim 10 \mathrm{~m}$ interval directly overlying an interval with abundant radiolarians. Although the relative abundance of Glomospira in Hole $643 \mathrm{~A}$ is not as high as in Hole 647A, the 
assemblage is neveretheless distinctive since Glomospira is absent from overlying and underlying assemblages. The temporal coincidence of Glomospira facies in both the Atlantic and Tethys suggests a common ecologic cause.

In the modern Gulf of Mexico, Glomospira assemblages have been reported in areas of low sedimentation rates, such as on submarine highs (Poag, 1981). The Glomospira facies in Hole 647A also represents a period of lowered sedimentation rate ( $\sim 5 \mathrm{~m} / \mathrm{my}$, assuming continuous sedimentation, compared with $37 \mathrm{~m} / \mathrm{my}$ in the middle to late Eocene). A number of important oceanographic events occur near the early/middle Eocene Boundary (Fig. 5-13). The earliest middle Eocene (Zone NP14) was a time of lowered global sealevel (Haq et al., 1987), and much increased paleoproductivity as shown by the presence of biosiliceous sediments in the equatorial Atlantic. Berggren and Hollister (1974) cited volcanism in the Carribean and Norwegian-Greenland Sea as a possible source of nutrients to the North Atlantic. Planktonic and benthic carbon isotope ratios display increased surface to bottom gradients from the early Eocene to the early middle Eocene (Boersma et al., 1987), compared with the late Eocene. These increased carbon gradients suggest higher nutrient contents and paleoproductivity. The highest surface water $\delta 13 \mathrm{C}$ values in the Atlantic were recorded from the lower middle Eocene. In Hole 643A, the Glomospira facies is associated with an interval containing radiolarians, which suggests increased productivity. In Hole 647A, although radiolarians are not present, the findiing of increased TOC contents despite lower sedimentation rates in the Glomospira facies is in aggreement with the scenario of increased nutrients, and (presumably) decreased oxygenation of bottom water. The synecology of the assemblage is consistent with the idea of high productivity. Glomospira and Ammodiscus are assumed to be epifaunal detritus feeders (Haynes, written communication to Jones and Charnock, 1985), and presumably are well-adapted to take advantage of an increased amount of food particles derived from the surface layer of the ocean.

Climatic and paleoceanographic changes were coincident with the eustatic sealevel lowering in the basal Lutetian. In the Atlantic, surface waters cooled approximately $1{ }^{\circ} \mathrm{C}$ and deep water cooled about $2^{\circ} \mathrm{C}$ across the early/middle Eocene boundary (Boersma et al., 1987). At the same time, the proto-Gulf stream flow intensified, possibly due to restriction of the circumglobal current in the Carribean (Tucholke and Mountain, 1986), and an east - 


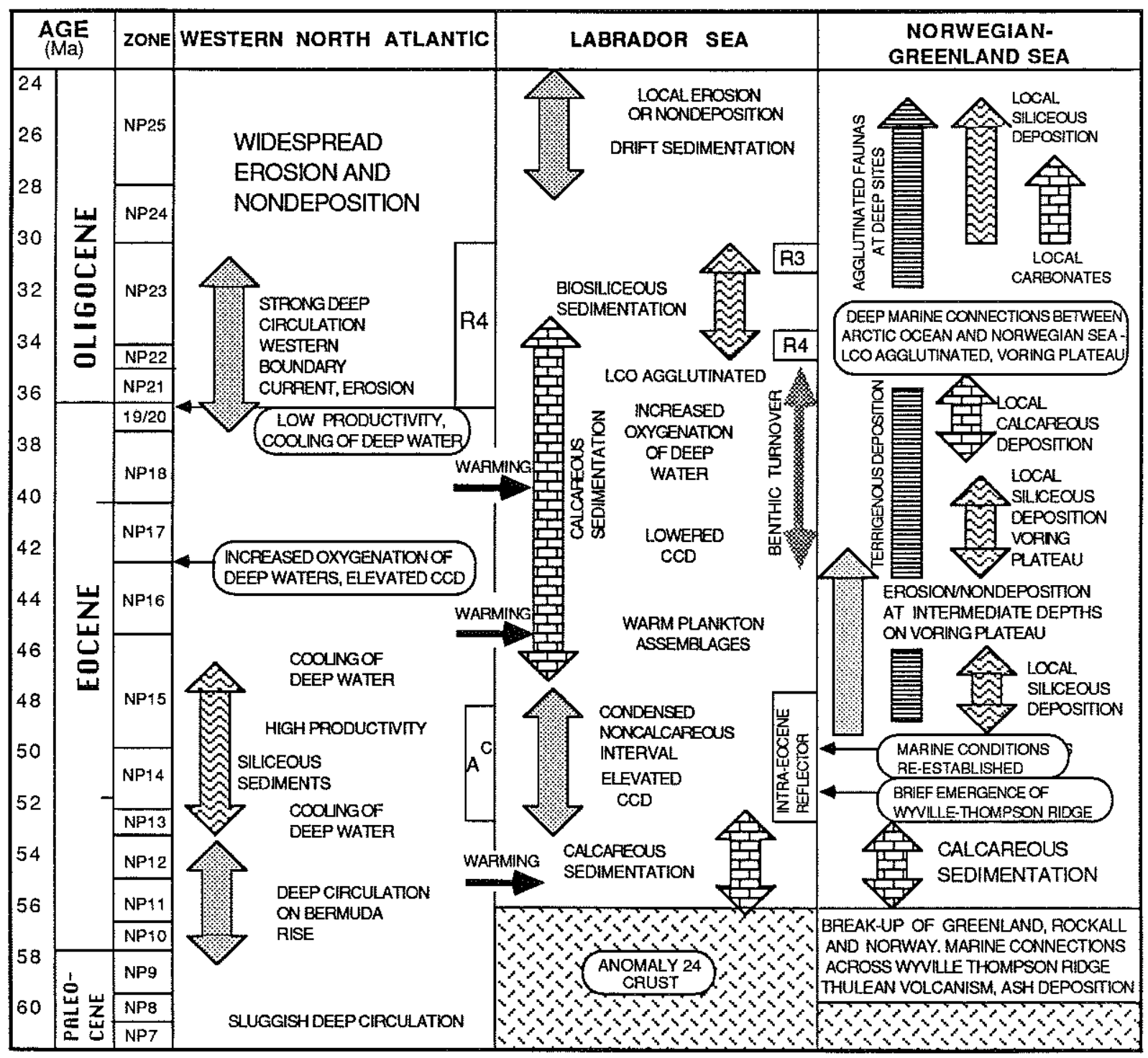

5-13. A synopsis of Paleogene depositional environments, paleoceanography and important faunal events in the high-latitude North Atlantic, compiled from Berggren and 0lsson (1986), Tucholke and Mountain (1986), Boersma et al. (1987) and this study. 
west gradient is established among planktonic foraminiferal faunas (Boersma et al., 1987), indicating intensification of the Atlantic subtropical gyres. The increased circulation and eustatic sealevel drop is a likely cause of numerous hiatuses encompassing the early/middle Eocene boundary at DSDP Sites in the western North Atlantic (Poag, 1987; Miller and Hart, 1987) and at bathyal depths on the Goban Spur (Poag et al., 1985), Rockall Margin (Tucholke and Mountain, 1986), and Labrador Margin - Northern Grand Banks (Gradstein, 1987). Among benthic foraminifera, there appears to be a reduction in numbers of Bulimina and an increase in Nuttallides truempyi across the Ypresian/Lutetian Boundary in the western North Atlantic (Poag and Low, 1987) as well as in the Labrador Sea. Miller et al. (1987) ascribed the sealevel fluctuations in the early and middle Eocene to global tectonic and sea-floor spreading rate changes. In the North Atlantic, sea floor spreading rate changed from $\sim 21$ $\mathrm{mm} / \mathrm{yr}$ to $\sim 9 \mathrm{~mm} / \mathrm{yr}$ between Anomaly 21 and 22 (Srivastava, 1978), and in the Labrador Sea a spreading rate decrease from $7.5 \mathrm{~mm} / \mathrm{yr}$ to $\sim 2 \mathrm{~mm} / \mathrm{yr}$ occurred between Anomaly 20 and 21 (S.R. Srivastava, personal communication, 1987). Carbon isotopic evidence at Walvis Ridge Site 357 (Boersma et al., 1987), points to some nutrient-poor deep-water production in the early middle Eocene. Benthic foraminifera record $\delta C-13$ ratios of $\sim 0.5 \%$ in Zone P10, compared with values of around $-0.1 \%$ in the lower Eocene (Boersma et al., 1987). The source of the deep water, however, is still a matter of debate. During the earliest Lutetian sea-level lowstand, marine connections between the Atlantic and the Norwegian-Greenland Sea were temporarily interrupted allowing the trans-Atlantic migration of terrestrial faunas (McKenna, 1983). Berggren and 0lsson (1986) noted that the opening of surface connections between the Arctic and the Norwegian-Greenland Sea in the early middle Eocene may have been a source of proto-NADW. However, the presence of warm temperate early Eocene floras and faunas in northern high latitudes (Schweitzer, 1980; Wolfe, 1980; Estes and Hutchison, 1980) would argue against outflow from the Norwegian-Greenland Sea being very cold. Annual mean early Eocene temperature in Spitsbergen has been estimated as between 15 and $18^{\circ} \mathrm{C}$ (Schweitzer, 1980 ). Winter temperatures must have been mild, since the fossil flora contains species which do not tolerate frosts (Schweitzer, 1980; M.J. Head, unpublished data).

Berggren and Schnitker (1983) postulated a northward flow of cool water from the South Atlantic, based on a comparison of oxygen isotopic evidence. 
Carbon isotopic evidence from Hole $647 \mathrm{~A}$ lend support to the idea of a southern source of nutrient-depleted deep water. Benthic $\delta \mathrm{C}-13$ ratios at Site $647 \mathrm{~A}$ average about $-0.5 \%$ oo (Arthur et al., in prep). These values are about 1 \%oo lighter than the values recorded at Site 367. Poag (1987) placed the onset of significant thermohaline circulation in the North Atlantic as early as the Paleocene/Eocene boundary, before the opening of the NorwegianGreenland Sea. Recent oxygen isotopic evidence, however, indicates that cooling near Antarctica may have resulted in deep-water production as early as the late Cretaceous (Barrera et al. 1987).

\section{Agglutinated foraminifera and the Eocene/0ligocene Boundary -}

Site 647 is unique because no other DSDP Site in the North Atlantic contains assemblages of flysch-type agglutinated foraminifera in an Eocene0ligocene section. From the middle Eocene to the lower 0ligocene, agglutinated foraminifera in Hole $647 \mathrm{~A}$ display a reduction in abundance, a reduction in size, and a decrease in diversity as the flysch-type taxa underwent a series of extinctions and local pseudoextinctions over a period of $5 \mathrm{~m} . \mathrm{y}$. . There is a cluster of last occurrence events near the Eocene/01igocene boundary, when about 10 species disappeared within a span of $0.5 \mathrm{~m} . \mathrm{y}$. With the exception of two species, the flysch-type taxa disappeared from the deep Labrador Sea by the end of Zone NP21. The disappearance of flysch-type taxa was essentially completed before the onset of major biogenic silica deposition, denoted by the $\mathrm{R} 4$ seismic reflector at 240 mbsf in Hole $647 \mathrm{~A}$.

Unlike at other DSDP sites in the North Atlantic, the Eocene/0ligocene boundary at site 647 is not delineated by a hiatus or any obvious lithologic change. The abundance of biosiliceous components and TOC increased from the upper Eocene to the lower 0ligocene of Hole 647A, therefore there is no evidence of oligotrophic conditions observed in other areas of the North Atlantic (Boersma et al., 1987). The earliest 0ligocene acme of Nuttallides umbonifera at Site 647 apparently correlates with coeval assemblages from the Bay of Biscay (Miller, 1983) and the equatorial Pacific (Corliss, 1979).

The sequence of last occurrences of taxa in Hole $647 \mathrm{~A}$ is shown in figure 3-17. Among agglutinated foraminifera, last occurrences began at an increased rate near the middle/late Eocene boundary. The first group of species to disappear were agglutinated taxa with walls comprised of small planktonic 
foraminiferal tests, such as psammosphaera testacea and a species of Rhizammina. Small elongate forms such as Karreriella conversa, Bigenerina sp., Reophax guttifer, and Karreriella coniformis, and the delicate species such as Hormosina distans, Hyperammina subnodosiformis, and Hyperammina kenmilleri were also among the first forms to disappear in the late Eocene. However, some of these last occurrences were local extinctions, since $\mathrm{K}$.

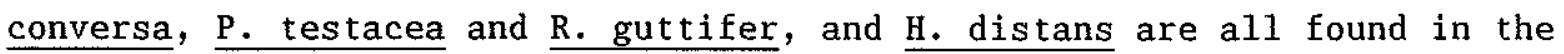
modern North Atlantic. Near the Eocene/0ligocene boundary, the species which disappeared were mainly lituolids and species which presumably shared an epifaunal habitat, such as Glomospira serpens, Trochammina and Saccammina.

About 10 species of "flysch-type" taxa survived the Eocene/0ligocene boundary at Site 647 . These were either robust forms, such as Rhabdammina, Ammodiscus latus and Cribrostomoides, or species with smooth, well-cemented tests, such as Ammodiscus cretaceous, Bathysiphon, or Glomospira charoides. Interestingly, over half the surviving species were ammodiscids or similarly coiled forms (Spirosigmoilinella). Such species are epibenthic detritus feeders, according to Jones and Charnock (1985), but the assemblage in Hole 647A still contains a mix of infaunal species (Reophax subnodulosus) and suspension feeders (Rhabdammina and Bathysiphon). Therefore, there was no obvious change in the synecologic structure of the assemblage, as observed in the Miocene drift sediments at Site 646 (see Chapter 2).

The disappearance of agglutinated taxa near the Eocene/0ligocene boundary in Hole 647A suggests a change in water mass properties as a primary cause. Delicate species disappeared first, indicating that the faunal turnover may be at least partly attributed to preservational factors. This observation is therefore consistent with the "old bottom water model" of Gradstein and Berggren (1981). Although carbon $\delta C-13$ values in Hole 647A show no trend with depth, the Eocene Cibicidoides values are relatively light (mean $=-0.55^{\circ} /$ oo) which suggests the presence of comparatively "old" nutrient-rich bottom water (Zachos et al., in press). Although there is no benthic isotopic data for the 0ligocene of Hole 647A, data from Sites 558 and 563 (Miller and Fairbanks, 1985) indicate the presence of "young" nutrient-poor water in the North Atlantic between 36 and $33 \mathrm{Ma}$. I suspect that increased oxygenation of deep water resulted in increasingly poorer preservation of agglutinated foraminifera observed in Hole 647A. 


\section{Paleoceanographic Significance of Flysch-Type Assemblages}

The disappearance of agglutinated foraminifera in the deep Labrador Sea near the Eocene/0ligocene boundary has been attributed to changes in water mass properties associated with the onset of vigorous thermohaline circulation in the North Atlantic (Miller et al., 1982). Typical bottom water temperatures cooled from about $6-10{ }^{\circ} \mathrm{C}$ in the late Eocene to temperatures similar to modern bottom water in the earliest 0ligocene (Miller et al., 1987). At the same time, the Atlantic carbon isotope values began to diverge from mean ocean water near the Eocene/0ligocene boundary. A comparison of Atlantic benthic carbon isotope records with the Pacific indicates a maximum supply of nutrient-depleted bottom water between 36 and $34 \mathrm{Ma}$ (Miller and Fairbanks, 1985; Miller and Katz, 1987a). The source of the cool, nutrientdepleted deep water in the early Oligocene was reported by Miller and Tucholke (1983) as Greenland-Scotland Ridge 0verflow Water, analogous to the presentday North Atlantic. Therefore, one needs to look to the Norwegian-Greenland Sea for the ultimate cause of the Eocene-0ligocene faunal turnover at Site 647 .

Berggren and Schnitker (1983) and Miller and Tucholke (1983) noted that the opening of a deep channel through the Fram Strait between Greenland and Spitsbergen during Chron 13 probably allowed cold water from the Arctic to enter the Norwegian-Greenland Sea, and from there, to enter the North Atlantic. However, this Arctic water was as dense as the deep water already present in the deep Norwegian-Greenland Sea. At deep sites in the Lofoten Basin and at the base of the Voring Plateau agglutinated foraminiferal assemblages were preserved throughout the 0ligocene, indicating a stable, stratified water column. Shallow sites on the Voring Plateau, however, display a faunal turnover from agglutinated assemblages in the Eocene to predominantly calcareous assemblages in the 0ligocene. Agglutinated foraminifera also disappeared near the Eocene/0ligocene boundary in exploration wells from the Beaufort Sea (Young and McNiel, 1983). Therefore, if Arctic water was the cause of this faunal turnover, the water mass may have been analogous to present-day Polar Water, which is present in the NorwegianGreenland Sea to a depth of $150 \mathrm{~m}$ (Johannessen, 1986). Since there most likely was no connection with the Atlantic through the Denmark Straits until the mid Miocene (Thiede and Eldholm, 1983), Polar Water flowing south along 
the east coast of Greenland would have turned east at the Greenland-Scotland Ridge to recirculate through the Norwegian-Greenland Sea.

An alternative scenario exists which may account for the aisappearance of agglutinated foraminifera in the shallow Norwegian-Greenland Sea. Agglutinated foraminifera also disappear near the Eocene/0ligocene boundary in exploration wells from the Viking Graben (Kaminski and Gradstein, 1987). The outflow of water through the Faeroe-Shetland Channel must be volumetrically balanced by the inflow of Eastern Atlantic surface water, as it is today (Worthington, 1970). Return flow to the Norwegian-Greenland Sea would have existed through the Faeroe-Shetland Channel and through the North Sea via the English Channel. Therefore, Atlantic water may have been present over the Voring Plateau in the early Oligocene, analogous to the present-day Norwegian Current. This Atlantic water would have circulated along the eastern margin of the basin through the Greenland-Spitsbergen Channel and into the Arctic ocean. The first possible evidence for the advection of Atlantic water into the Norwegian-Greenland Sea was the finding of Muller (1976) of an abundant and diverse "mid" Oligocene nannoflora on the Vøring Plateau. Unfortunately, microfossil data near the Eocene/0ligocene boundary is still tenuous. The addition of warm saline water into the Arctic realm may have affected the density structure of the surface layer, thereby effecting faunal changes at neritic to upper bathyal depths. However, the Atlantic vs. Polar Water models of faunal change remain to be tested micropaleontologically using benthic and planktonic microfossils at the Voring Plateau and in the Beaufort Sea.

The disappearance of flysch-type taxa near the Eocene/01igocene boundary in the Labrador Sea and in shallow Voring Plateau Sites at first glance suggests an oceanographic link between the regions. Miller et al. (1982), Berggren and Schnitker (1983) and Tucholke and Mountain (1986) favor the production of northern-source deep water as the cause of the faunal turnover in the deep Labrador Sea. However, northern-source deep water may not have been the universal cause of the disappearance of the flysch-type faunas in the Northern Hemisphere. The paleogeographic distribution of flysch-type assemblages in the North Atlantic suggests that a southern source of deep water may have contributed to the disappearance of the North Atlantic assemblages in the early Paleogene, since the last common occurrence of flysch-type assemblages displays a diachronous pattern with latitude and depth (Fig. 3-1). In the western basin, agglutinated foraminifera first disappear 
from deep, equatorial sites in the upper Maastrichtian, but continue into the Paleocene on the margins and in the eastern basin. Flysch-type assemblages disappear from Site 647 and the Carpathian flysch basins near the Eocene/Oligocene boundary, but persist at bathyal depths on the Labrador Margin and in the central North Sea into the 0ligocene.

The approximately coeval disappearance of flysch-type assemblages in the North Atlantic and Carpathian flysch basins cannot be attributed to northernsource deep water in the latter region. The basal oligocene sealevel lowstand interrupted connections between the North Sea and the northern Tethys through the Polish-Danish trough, allowing the immigration of Asian vertebrate faunas into western Europe (Cavelier et al., 1981). Deep water in the eastern Tethys may have been derived from a southern source, judging from the distribution of hiatuses along the western margin of the Indian 0cean (Kennett, 1977; Davies and Kidd, 1977). Shackleton and Kennett (1975) attributed the Eocene/0ligocene cooling of deep waters and increased deep circulation throughout the southern oceans to sea ice formation near Antarctica. The increasing production of well-oxygenated, northern and southern sources of deep waters at the end of the Eocene, and the basal. 0ligocene sea-level lowering resulted in a deepening of the oceanic lysocline throughout most of the world ocean, including the Tethyan flysch basins (Van Couvering et al., 1981). These events may have led to the extinction of flysch-type assemblages in the North Atlantic and Tethys. However, the shallow Greenland-Scotland Ridge prevented the exchange of deep Arctic and Atlantic water below sill depth in the Norwegian-Greenland Sea, and this area served as a refuge for flysch-type faunas until the late Neogene. This scenario for the disappearance of flysch-type faunas at the Eocene/01igocene boundary still remains to be tested with microfossil paleobiogeographic data.

\section{CONCLUSIONS :}

The lower Eocene to lower middle Eocene Glomospira assemblages in the Labrador and Norwegian-Greenland Seas are apparently coeval with similar assemblages known from the Tethys. By analogy with modern fauna in the Gulf of Mexico, the presence of Glomospira facies in these areas is interpreted as being indicative of organic-rich substrates. Unlike the modern Gulf of Mexico, where Glomospira faunas occur in areas of hydrocarbon seepage, the Eocene Glomospira assemblages owe their presence to a period of increased 
paleoproductivity. This increased productivity is ascribed to paleoceanographic changes caused by the basal Lutetian sea-level lowstand.

The transition from a predominantly agglutinated assemblage in the Eocene to a calcareous assemblage in the 0ligocene is attributed to the increasingly poorer preservation of agglutinated taxa. The temporal coincidence of this faunal turnover in Site 647, the shallow Voring Plateau, the Viking Graben and the Beaufort Sea suggests a common oceanographic link between the regions. At Site 647, the turnover is attributed to the increasing influence of cool, nutrient-poor deep waters associated with the onset of thermohaline circulation. However, the possible oceanographic causes of this faunal change in the high-latitude basins and Carpathian flysch troughs remain to be investigated. 
Appendix 5-1. Benthic foraminiferal data from the North Leif I-05 well.

\begin{tabular}{|c|c|c|c|c|c|c|c|c|c|c|c|c|c|c|c|c|c|c|c|c|}
\hline \multirow{2}{*}{$\frac{\text { SPECIES }}{\text { ASTRORHIZACEA }}$} & \multicolumn{4}{|c|}{ Middle Eccene } & \multicolumn{5}{|c|}{ I Lower Eocene } & \multicolumn{7}{|c|}{ I Paleocene } & \multicolumn{4}{|c|}{ I Maastrichtian } \\
\hline & & & & & 1 & & & & & 1 & & & & & & & 1 & & & \\
\hline Bathysiphon & & 1 & & 1 & 1 & 2 & 3 & & 21 & 1 & 60 & 日 & 2 & 2 & 7 & 40 & 1 & 20 & 52 & 42 \\
\hline Rhabdamtaina & 6 & & 1 & & 1 & 6 & & & 17 & 1 & 23 & 84 & 6 & 11 & 30 & 16 & 1 & 37 & 75 & 109 \\
\hline Phizantmina & & & & & 1 & 1 & 10 & & 1 & 1 & 2 & 4 & & 2 & 8 & 30 & 1 & 28 & 36 & 20 \\
\hline p. fusca & & & & & 1 & & & & & 1 & & 2 & & & & 1 & 1 & & & 4 \\
\hline P. scruposa & & 4 & 3 & 3 & 1 & 5 & & & & 1 & & 1 & & & & & I & & & \\
\hline S. complanata & 2 & 1 & 1 & 3 & 1 & 3 & 2 & & 4 & 1 & 2 & & 4 & & 6 & 35 & 1 & 6 & 9 & 2 \\
\hline 5. placenta & & & & & 1 & & & & 1 & I & & & & 3 & 16 & 12 & 1 & 2 & 3 & $2^{-}$ \\
\hline D. robusta & 2 & 12 & & 1 & 1 & 18 & 13 & 1 & 3 & 1 & 2 & 1 & 1 & & & & 1 & & & \\
\hline HYDERAMMINACEA & & & & & 1 & & & & & i & & & & & & & 1 & & & \\
\hline H. dilatata & & & & & 1 & & & & & । & & & & & & & $i$ & & 5 & 1 \\
\hline AMMODISCACEA & & & & & 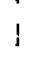 & & & & & 1 & & & & & & & 1 & & & \\
\hline A. cretaceus & & & & & 1 & & & & & 1 & & & 3 & 1 & & 5 & 1 & 4 & 16 & 33 \\
\hline A. glabratus & & & & & 1 & & & & & 1 & & & & & & & i & & & \\
\hline A. latus & & & & & 1 & & & & & 1 & & & & & & & 1 & & & \\
\hline A. peruvianus & & & & 3 & 1 & 1 & 1 & & & 1 & & 3 & 1 & 1 & 1 & & 1 & & & \\
\hline A. planus & & 1 & & 8 & 1 & 3 & 1 & & 3 & 1 & 3 & 6 & 2 & 3 & 1 & 15 & 1 & & 11 & \\
\hline Al. clavata & & & & & 1 & & & & & 1 & & & & & & & 1 & & & 3 \\
\hline G. charoides & & & & & 1 & & & & & 1 & 2 & 1 & & 4 & 5 & 19 & 1 & 14 & 53 & 17 \\
\hline G. gordialis & & & & & 1 & & & & & 1 & & & & & 4 & 4 & 1 & & 5 & 2 \\
\hline G. irregularis & & & & & 1 & & & & & 1 & & 1 & & & & & 1 & 1 & & 5 \\
\hline Glomospirella & & & & & 1 & 1 & & & & 1 & & & & & 2 & 4 & 1 & & 1 & 1 \\
\hline RZEHAKINA & & & & & 1 & & & & & $i$ & & & & & & & $i$ & & 3 & 1 \\
\hline HORMOSINACEA & & & & & 1 & & & & & 1 & & & & & & & 1 & & & \\
\hline Aschemonella & & & & & 1 & 1 & 1 & & 1 & I & 2 & 1 & & & 2 & & 1 & & & \\
\hline H. oviliun & & & & & 1 & & & & & 1 & & & & & & 7 & 1 & 5 & 11 & \\
\hline H. excelsa & & & & & 1 & & & & & 1 & & & & & & & 1 & 5 & 6 & \\
\hline Kalamopsis & & & & & 1 & & & & & 1 & & & & & & & 1 & & & \\
\hline R. duplex & & & & & 1 & & & & & 1 & & & & & 1 & 3 & 1 & 3 & 4 & \\
\hline R. pilulifer & & & & & 1 & & 1 & & & 1 & 2 & 4 & & & 5 & 1 & 1 & 2 & & 4 \\
\hline R. subfusiformis & & & & & 1 & & 1 & & & 1 & 1 & 1 & & & 3 & 3 & 1 & & 3 & 3 \\
\hline R. globasus & & & & & I & & & & & 1 & & & & & & & 1 & & & 1 \\
\hline 8. splendidus & & & & & 1 & & & & & 1 & & & & & & & 1 & 6 & & \\
\hline S. pseudoscalaria & & & & & 1 & & & & & 1 & & & & & & & 1 & & & 2 \\
\hline 5. scalaria & & & & & 1 & & & & & 1 & & & & & & & 1 & & & 1 \\
\hline LITUOLACER & & & & & 1 & & & & & 1 & & & & & & & 1 & & & \\
\hline A. deflexus & & 1 & & & 1 & & & & & 1 & & & & & & 1 & 1 & & & \\
\hline A. aff. polythalamus & & & & & 1 & & & & & 1 & & & & & & 12 & 1 & & & \\
\hline A. 5 p. 3 & & & & & 1 & & & & & 1 & & & & & & & 1 & 1 & 1 & 2 \\
\hline A. $5 p .4$ & & & & & 1 & & & & & 1 & & & & & & & 1 & & & 5 \\
\hline A. agglutinans & & & & & 1 & & & & & 1 & & & & & & & 1 & & & 3 \\
\hline A. jaryisi & & & & & 1 & & & & & 1 & & & & & 1 & & 1 & & & \\
\hline Aamoscalaria & 1 & & & & 1 & & & & & 1 & & & & & & & 1 & & & 2 \\
\hline 8. multicamerata & 40 & 47 & 17 & 4 & 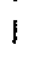 & 11 & 4 & 1 & 2 & $i$ & 17 & 6 & 1 & & 2 & & $i$ & & & \\
\hline 8. trinitatensis & 3 & 1 & 1 & 1 & $i$ & 1 & & & & $i$ & 2 & & & & 3 & 1 & 1 & & & \\
\hline Cribrostomoides & 10 & 2 & 8 & 7 & 1 & 11 & 4 & & 6 & 1 & 4 & 6 & 1 & 3 & 1 & & 1 & & & 4 \\
\hline
\end{tabular}




\section{Appendix 5-1 (Continued).}

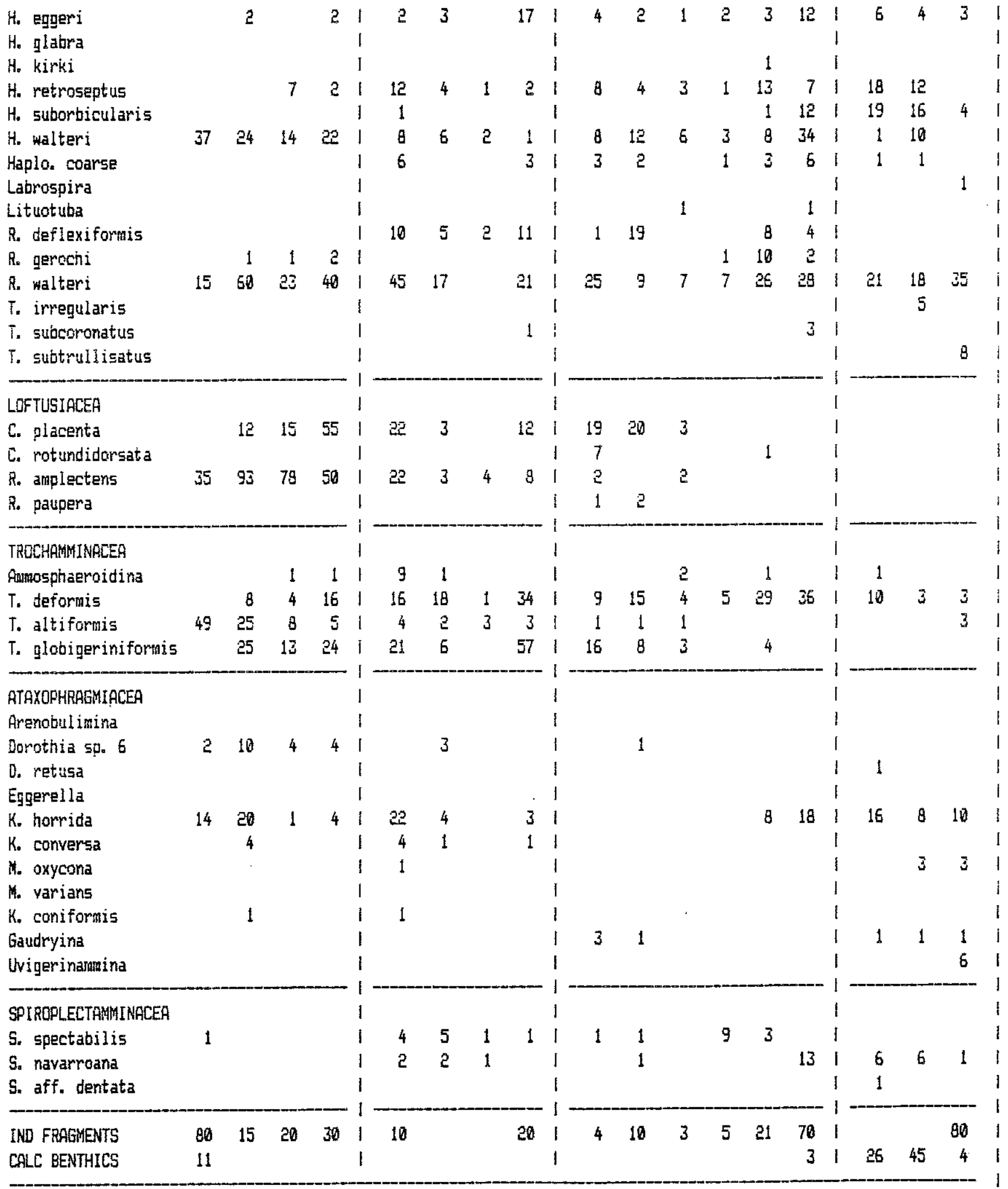


Appendix 5-2. Benthic foraminiferal data from the Roberval $\mathrm{K}-92$ well.

\begin{tabular}{|c|c|c|c|c|c|c|c|c|c|c|c|}
\hline \multirow[b]{2}{*}{ SPECIES } & \multicolumn{2}{|c|}{ Hid Eocene } & \multirow[b]{2}{*}{2340} & \multicolumn{3}{|c|}{ I paleocene } & \multirow[b]{2}{*}{2950} & \multirow{2}{*}{2980} & \multicolumn{3}{|c|}{ I Maast. I } \\
\hline & 2220 & 22984 & & & 950m & 2928 & & & 1 & $387 \overline{8}$ & 1 \\
\hline ASTRORHIZACEA & & & & 1 & & & & & 1 & & \\
\hline Bathysiphon & & & & 1 & 5 & 11 & 14 & 28 & 1 & 54 & \\
\hline Rhabodatmina & 4 & 2 & 1 & 1 & 9 & 23 & 18 & 33 & 1 & 92 & \\
\hline Rhizanmina & & & & 1 & 14 & 4 & 4 & 37 & 1 & 35 & \\
\hline P. fusca & & & & 1 & & 2 & & 4 & 1 & 10 & \\
\hline P. scruposa & & & & 1 & & & & & 1 & & \\
\hline 9. conplanata & 8 & 2 & 8 & 1 & 12 & 6 & 7 & 4 & 1 & 3 & \\
\hline S. placenta & & & & $i$ & 3 & 2 & & 5 & 1 & & \\
\hline D. robusta & & 1 & & 1 & & & & & 1 & & \\
\hline HYPERQNHIWACEA & & & & 1 & & & & & $!$ & & \\
\hline H. dilatată & & & & 1 & & & & & 1 & 3 & \\
\hline AHHODISCACEG & & & & 1 & & & & & 1 & & \\
\hline A. cretaceus & & & & 3 & & 4 & 2 & 7 & $i$ & $2 \bar{y}$ & \\
\hline A. glabratus & & & & 1 & & & & & 1 & & \\
\hline A. peruvianus & & & & 1 & & & & & 1 & & \\
\hline A. planus & & & & 1 & 3 & & & 8 & 1 & & \\
\hline Al. Clavata & & & & 1 & & & & & 1 & 1 & 1 \\
\hline G. charaides & & & & $i$ & 4 & 5 & 4 & 13 & 1 & 46 & \\
\hline G. diffundens & & & & 1 & & & & & 1 & & \\
\hline 6. gordialis & & & & 1 & & & & 7 & 1 & 1 & I \\
\hline G. irreqularis & & & 1 & 1 & & & & 2 & 1 & 2 & 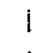 \\
\hline Glonospirella & & & & I & & & & 1 & 1 & & 1 \\
\hline RZEHAKINA & & & & 1 & & 1 & 1 & 4 & 1 & & 1 \\
\hline HORHOSINACEA & & & & 1 & & & & & 1 & & 1 \\
\hline Aschemonelia & & & & 1 & & & & 1 & 1 & & r \\
\hline H. avulua & & & & 1 & 2 & 1 & & 3 & i & 4 & 1 \\
\hline H. excelsa & & & & 1 & 2 & 1 & & 2 & 1 & 2 & 1 \\
\hline Kalamopsis & & & & 1 & & & 2 & 4 & 1 & & 1 \\
\hline Modellum & & & & 1 & & & & & 1 & & 1 \\
\hline R. duplex & & & & 1 & 1 & 2 & 1 & 2 & 1 & 4 & 1 \\
\hline R. pilulifer & 2 & 1 & & 1 & 3 & 3 & 1 & & 1 & 1 & 1 \\
\hline R. subfusi forntis & & & & 1 & 2 & 2 & & 6 & 1 & 4 & 1 \\
\hline R. globosus & & & & 1 & & & & & 1 & & 1 \\
\hline R. splendidus & & & & 1 & & & & & 1 & & 1 \\
\hline S. pseudascalaria & & & & 1 & & & 1 & & 1 & & 1 \\
\hline S. scalaria & & & & 1 & & & & & 1 & & 1 \\
\hline LITUOLACEA & & & & 1 & & & & & 1 & & 1 \\
\hline A. aff. polythalamus & & & & 1 & 16 & 5 & & 9 & 1 & & 1 \\
\hline A. sp. 3 & & & & 1 & & 2 & & 4 & 1 & & 1 \\
\hline A. $s p .4$ & & & & 1 & 4 & 1 & & & 1 & 6 & 1 \\
\hline A. aqglutinans & & & & 1 & 2 & & & 2 & 1 & 1 & 1 \\
\hline A. jarvisi & & & & 1 & & & & & 1 & & 1 \\
\hline Ammomarqinulina & 3 & & & 1 & & & & & 1 & & 1 \\
\hline Aemoscalaria & & & & 1 & & & & & 1 & 4 & 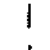 \\
\hline B. witicauerata & 25 & 19 & 13 & 1 & & & & & 1 & & 1 \\
\hline 8. trinitatensis & 6 & 2 & & 1 & & & & & 1 & & \\
\hline
\end{tabular}


Appendix 5-2 (Continued).

\begin{tabular}{|c|c|c|c|c|c|c|c|c|c|c|c|}
\hline Cribrostomoides & 5 & & & 1 & & & & & 1 & & 1 \\
\hline H. eqgeri & & & & 1 & & 2 & & 6 & 1 & 8 & 81 \\
\hline H. glabra & & & & 1 & & & & & 1 & & \\
\hline H. kiriki & 2 & & 1 & 1 & & & & & 1 & & \\
\hline H. retroseptus & & & 6 & 1 & & 15 & 4 & 14 & 1 & 8 & \\
\hline H. suborbicularis & & & & 1 & 7 & 9 & 9 & 18 & 1 & & \\
\hline H. walteri & 7 & 14 & 1 & 1 & 8 & 2 & 11 & 5 & i & 1 & \\
\hline Haplo. coarse & & 3 & 1 & 1 & & & & 1 & 1 & 1 & \\
\hline Labrospira & & & & 1 & & & & & 1 & 2 & \\
\hline Lituotuba & & & & 1 & & & & & 1 & & \\
\hline R. deflexiformis & & & 6 & 1 & 2 & 1 & 2 & & 1 & 16 & \\
\hline R. gerochi & 2 & & & 1 & & & & 1 & 1 & & \\
\hline 8. walteri & $2 \dot{b}$ & 11 & 5 & 1 & 29 & 17 & 19 & 30 & 1 & 37 & \\
\hline T. irregularis & & & & 1 & & & & & 1 & & \\
\hline T. subcoronatus & & & & 1 & & & 1 & & 1 & & \\
\hline T. subtruilisatus & & & & 1 & & & & & 1 & & \\
\hline LOFTUSIACEA & & & & 1 & & & & & 1 & & \\
\hline C. placenta & 15 & 9 & 6 & 1 & & & & & 1 & & \\
\hline C. rotundidorsata & & & & I & & & & & 1 & & \\
\hline R. amolectens & 43 & 31 & 10 & 1 & & & & & 1 & & \\
\hline Retic. acute & & & & 1 & & & & & 1 & & \\
\hline Retic. robust & & & & 1 & & & & & 1 & & \\
\hline Alveoiophragaium & 5 & & & 1 & & & & & 1 & & \\
\hline TROCHAAIHINACEA & & & & 1 & & & & & 1 & & \\
\hline Asnosp̣naeroidina & & & & 1 & & 1 & 2 & & 1 & 1 & \\
\hline T. deformis & 24 & 14 & 9 & 1 & 7 & 5 & 3 & 9 & 1 & 1 & \\
\hline T. aItiformis & & & & 1 & & & & & 1 & & \\
\hline T. globiqeriniformis & 7 & & & 1 & & & & & 1 & 5 & \\
\hline T. Tuthven-aurrayi & & & & 1 & & & & & 1 & & \\
\hline Conotrochamaina & & & & 1 & & & & & 1 & & \\
\hline ATAXOPHRAGITACEA & & & & 1 & & & & & 1 & & 1 \\
\hline Arenobulimina & & & & 1 & & & & & 1 & 2 & 1 \\
\hline Clavulinoides & & & & 1 & & & & & 1 & & I \\
\hline Dorothia sp. 6 & & & & 1 & & & & & 1 & & 1 \\
\hline D. rectusa & & & & 1 & & & & & 1 & & 1 \\
\hline Eggerella & & & & 1 & & & & & 1 & & 1 \\
\hline K. horrida & 5 & 3 & 2 & 1 & 12 & 11 & 9 & 32 & 1 & 18 & 1 \\
\hline K. conversa & & 12 & & 1 & & & & & 1 & & 1 \\
\hline H. oxycona & & & & 1 & & & & & 1 & & 1 \\
\hline M. varians & & & & 1 & & & & & 1 & & 1 \\
\hline K. coniformis & & & & 1 & & & & & 1 & & 1 \\
\hline Gaudryina & & & 1 & 1 & & 1 & & 2 & 1 & 3 & 1 \\
\hline Uvi ఐerinamina & & & & 1 & & & & & 1 & 36 & 1 \\
\hline SPIKOPLECTAMHINACEA & & & & 1 & & & & & 1 & & \\
\hline S. spectabilis & & & & 1 & & & & & I & & 1 \\
\hline S. navarroana & & & & 1 & 8 & 1 & 1 & 8 & 1 & 4 & 1 \\
\hline 5. aff. dentata & & & & 1 & 5 & 2 & & & 1 & & 1 \\
\hline 5. carinata & 5 & 1 & & 1 & & & & & 1 & & 1 \\
\hline . & & & & 1 & 70 & $6 \dot{y}$ & 70 & 110 & 1 & 170 & \\
\hline CALC BENTHICS & 31 & 12 & 6 & 1 & & & & & 1 & & \\
\hline
\end{tabular}


Appendix 5-3. Benthic foraminiferal data from the Gudrid H-55 well.

\begin{tabular}{|c|c|c|c|c|c|c|c|c|c|c|c|c|c|c|c|c|}
\hline \multirow{2}{*}{$\begin{array}{l}\text { SPECIES } \\
\text { ASTRORHIZACEA }\end{array}$} & \multicolumn{11}{|c|}{ Paleocene } & \multicolumn{5}{|c|}{1 Mastrichtian } \\
\hline & & & & & & & & & & & & 1 & & & & \\
\hline Bathysiphon & 13 & 5 & 30 & 11 & 16 & 14 & 13 & 19 & 6 & 8 & 4 & $i$ & 32 & 10 & 111 & 68 \\
\hline Shabdammina & 15 & 4 & 54 & 6 & 20 & 18 & 13 & 19 & 7 & 12 & 3 & I & 23 & 11 & 49 & 56 \\
\hline Rhizangina & 18 & 2 & 4 & 14 & 21 & 18 & 23 & 38 & 22 & 14 & 7 & 1 & 8 & 1 & 13 & 9 \\
\hline P. fusca & 4 & 16 & 2 & 1 & 3 & 3 & 1 & 4 & 2 & & & 1 & 1 & & 1 & 4 \\
\hline P. scruposa & & & & & & & & & & & & $\mathrm{i}$ & & & & \\
\hline S. couplanata & 13 & 12 & $\theta$ & 7 & 22 & 23 & 16 & 15 & 16 & 11 & 5 & 1 & 7 & 2 & 2 & 7 \\
\hline 5. placenta & 2 & 2 & 2 & 3 & 3 & 16 & 4 & 4 & 20 & 6 & 6 & 1 & 10 & 6 & & \\
\hline D. robusta & & & & & & & & & & & & 1 & & & & \\
\hline HYPERRMMIHACEA & & & & & & & & & & & & 1 & & & & \\
\hline H. dilatata & & & & & & & & & & & & 1 & & & & 1 \\
\hline H. elongata & & & & & & & & & & & & 1 & 2 & & 3 & \\
\hline AMHODISCACEA & & & & & & & & & & & & 1 & & & & \\
\hline A. cretaceus & 1 & 2 & 3 & & & 2 & 2 & 3 & 6 & 3 & 2 & $i$ & 3 & 4 & 25 & 17 \\
\hline A. glabratus & & & & & & & & & & & & 1 & & & & 5 \\
\hline A. peruvianus & & & & & & & & & & & & 1 & & & & \\
\hline A. planus & & 1 & 6 & & 1 & 7 & 1 & 2 & 2 & 5 & 5 & 1 & 6 & 2 & & 3 \\
\hline Al. clavata & & & & & & & & & & & & 1 & & & & \\
\hline G. cinaroides & 12 & 9 & 7 & 1 & 6 & 9 & 16 & 5 & 16 & 9 & 12 & 1 & 46 & 48 & 59 & 102 \\
\hline G. diffundens & & & & & & & & & & & & 1 & & & & \\
\hline 6. gordialis & 1 & 1 & 1 & & & & 1 & & & & & 1 & 1 & 2 & 1 & 5 \\
\hline G. irrequiaris & 1 & & & & & & & & & & & 1 & & & 3 & \\
\hline Glowospirella & & & & & & & & & & & & 1 & & & & \\
\hline RZEHAKIKA & & & 5 & & & 1 & 2 & & & & 1 & 1 & & 2 & & \\
\hline HORMOSINACEA & & & & & & & & & & & & 1 & & & & \\
\hline Aschemaneila & & 1 & & 1 & 1 & & 1 & & & & & 1 & & & & \\
\hline i. ovulum & & 3 & 4 & & & 1 & 3 & & & 3 & 2 & 1 & 2 & $1 \ddot{\theta}$ & 19 & 11 \\
\hline H. excelsa & & & & & & & & & & 2 & 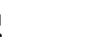 & I & & & & \\
\hline Kalamopsis & & & & & & 1 & & & & & & I & & & & \\
\hline Hodellua & & & & & & & & & & & & 1 & & & & 2 \\
\hline R. dup̣lex & 2 & & & & 6 & 1 & 1 & 3 & & & & 1 & 2 & & & \\
\hline R. pilulifer & 5 & & 4 & 8 & 7 & 1 & 1 & 4 & 3 & 1 & . & 1 & 1 & & & 1 \\
\hline R. subfusi foruis & & & & 2 & 7 & & & & & & & 1 & & 1 & & 1 \\
\hline R. globosus & & & & & & & & & & & & 1 & & & & \\
\hline R. splendidus & & & & & & & & 2 & & 1 & & 1 & & 1 & & \\
\hline 5. pseudoscalaria & & & & & & & & & & & & 1 & & & & \\
\hline S. scalaria & & 1 & & & 3 & & & & & 3 & & 1 & & 1 & & 2 \\
\hline LITUOLACEA & & & & & & & & & & & & 1 & & & & \\
\hline A. aff. polythalamus & 27 & 23 & 22 & 7 & 6 & 4 & 15 & 1 & 9 & 4 & 6 & 1 & 3 & 4 & & \\
\hline A. $s p .3$ & 2 & 1 & 3 & & & 2 & & & & & 3 & 1 & 3 & 2 & & \\
\hline A. sp. 4 & 5 & 3 & 8 & & & & 3 & & & 1 & & 1 & & & & 2 \\
\hline A. agglutinans & & & & 4 & & & & & 2 & 1 & 4 & 1 & & 1 & & \\
\hline A. jarvisi & & & & & & & & & & & & 1 & & & & \\
\hline Ammoscalaria & 6 & & & & & & & & & & & 1 & & & & \\
\hline 8. 酧icamerata & & & & & & & & & & & & 1 & & & & \\
\hline B. trinitatensis & & & & & & & & & & 2 & & 1 & & 1 & & 1 \\
\hline
\end{tabular}


Appendix 5-3 (Continued).

\begin{tabular}{|c|c|c|c|c|c|c|c|c|c|c|c|c|c|c|c|c|}
\hline Cribro. swooth & 7 & 8 & 18 & 5 & 6 & 7 & 3 & 2 & 11 & 5 & 3 & 1 & 11 & 8 & 7 & 8 \\
\hline Cribrostosoides coarse & & 9 & 7 & 11 & 13 & 8 & 12 & 3 & 12 & & & 1 & & & & \\
\hline H. eggeri & 9 & 1 & & & & & & 16 & & & & 1 & 2 & 4 & & \\
\hline H. qlabra & & 19 & 16 & 5 & 16 & 3 & 35 & 1 & 26 & 13 & 8 & 1 & 15 & 20 & 7 & 5 \\
\hline H. kirki & ? & & & & 2 & 1 & 2 & & & 1 & 3 & 1 & 2 & 1 & & 1 \\
\hline H. retroseptus & 1 & & & & & 8 & 6 & 2 & 1 & 4 & & 1 & 10 & & 1 & \\
\hline H. suborbicularis & & & & & & & & & 9 & 1 & 2 & 1 & & & 1 & \\
\hline H. waiteri & 5 & 3 & & & & & & & & & & 1 & & & & \\
\hline H. waIteri/jarvisi & 4 & & & & & & & & & & & & & & & \\
\hline Hapio. coarse & & & 2 & & 4 & & & & & & & 1 & 1 & 1 & $\theta$ & \\
\hline Labrospira & & & & & & & & & & & & $i$ & & & 2 & \\
\hline Lituotuba & & & & & & & & & & & & 1 & & & & \\
\hline R. deflexiformis & 7 & 1 & & 6 & 2 & 1 & 4 & 5 & 2 & & & 1 & & 1 & 5 & 1 \\
\hline R. Qgerochi & 1 & & & 1 & 3 & 11 & 1 & & & 2 & 3 & 1 & & & & 13 \\
\hline R. Walteri & 36 & 30 & 39 & 27 & 37 & 23 & 12 & 38 & 15 & 30 & 29 & 1 & 47 & 32 & 45 & 16 \\
\hline T. irreqularis & & & & 1 & & & & & & & & 1 & & 1 & 6 & 5 \\
\hline T. subcoronatus & & & & & & & & & & & & 1 & 1 & & & \\
\hline$T_{n}$ sugtrullisatus & & & & & & & & & & & & i & & & & \\
\hline LOFTUSIACEA & & & & & & & & & & & & 1 & & & & \\
\hline C. placenta & & & & & & & & & & & & 1 & & & & \\
\hline C. rotundidorsata & & & & & & & & & & & & 1 & & & & \\
\hline R. amplectens & & & & & & & & & & & & 1 & & & & \\
\hline Retic. acute & & & & & & & & & & & & 1 & & & & \\
\hline Retic, robust & & & & 1 & & 2 & & & & & & 1 & & & & \\
\hline TROCHANAINACEA & & & & & & & & & & & & 1 & & & & \\
\hline Ammospideroidina & 2 & 4 & 15 & 1 & 5 & 10 & 8 & 3 & 3 & 5 & 3 & 1 & 7 & 3 & & 2 \\
\hline T. deformis & 11 & 18 & 18 & 7 & 14 & 14 & 15 & 13 & & 18 & 40 & 1 & & 4 & 3 & \\
\hline T. altiformis & & & & & & & & & & & & 1 & & & & \\
\hline T. glooigerini formis & & & 2 & 2 & 1 & 1 & 3 & 4 & 2 & 2 & 1 & 1 & 4 & 5 & 4 & 8 \\
\hline T. Tuthven-nurrayi & & & 1 & & & & & & & & & 1 & & & & \\
\hline Conotrochamaina & & & & & & 1 & & & & & & 1 & & & & \\
\hline ATAXOFHRAGMIACEA & & & & & & & & & & & & 1 & & & & \\
\hline Arenobulinina & & & & & & & & & & & & 1 & & & & \\
\hline Clavulinoides & & & & & & & & & & & & 1 & & & & \\
\hline Dorothia sp. 6 & & & & & & & & & & & & 1 & & & & \\
\hline D. retusa & & & & & & & & & & & & 1 & & & & \\
\hline Eggereila & & & & & & & & & & & & 1 & & & & \\
\hline K. horrida & 39 & 45 & 66 & 33 & 36 & 26 & 22 & 14 & 44 & 25 & 29 & 1 & 38 & 32 & 25 & 57 \\
\hline K. conversa & 4 & 1 & & & & & & & & & & 1 & & & & 1 \\
\hline H. oxycona & & & & 1 & 1 & & & & & & & $i$ & & & & \\
\hline H. varians & & & & & & & 2 & & 1 & & & 1 & & 1 & & \\
\hline$K_{0}$ coniformis & & & & & & & & & & & & 1 & & & & \\
\hline Gaudryina & & & & 1 & 1 & 2 & 1 & & 2 & & & 1 & 2 & & & \\
\hline Uvigerinamaina & & & & & & & & & & & & 1 & 1 & & & 1 \\
\hline SPIROPLECTAMHINACEA & & & & & & & & & & & & 1 & & & & \\
\hline S. spectabilis & 5 & & & & & & & & 1 & 1 & 3 & 1 & & & & \\
\hline S. navarroana & 6 & 3 & 21 & 5 & 5 & 6 & 3 & & 7 & 4 & 3 & 1 & 5 & 1 & 2 & 7 \\
\hline S. aff. dentata & & & & & & 3 & 4 & 1 & 2 & 1 & & 1 & & 1 & & \\
\hline IND FRAGMENTS & 80 & 90 & 70 & & & & & & & 10 & 58 & 1 & & 89 & & 30 \\
\hline CALC BENTHICS & $\theta$ & 0 & $\theta$ & 8 & 0 & 0 & 8 & $\theta$ & 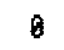 & $\dot{y}$ & 6 & 1 & 45 & 31 & 3 & 3 \\
\hline
\end{tabular}


Appendix 5-4. Benthic foraminiferal data from the Indian Harbour M-52 well.

SPECIES

Paleocene 1096010129101801024010300103601039010450

1 Maastrichtian

ASTRORHIZACEA

Bathysiphon

Rhabdamina

Rhizarsina

P. fusca

P. scruposa

S. cosplanata

5. placenta

D. rabusta

HYPERAHINHACEA

H. dilatata

AMHODISCACEA

A. cretaceus

A. giabratus

A. peruvianus

A. planus

H1. clavata

G. charoides

G. diffundens

b. gordialis

G. irrequiaris

Glonospirella

$$
\begin{aligned}
& \begin{array}{llllllllllllllllll}
5 & 17 & 18 & 62 & 27 & 29 & 33 & 35 & 1 & 59 & 32 & 25 & 22 & 48 & 66 & 65 & 38 & 84
\end{array} \\
& \begin{array}{llllllllllllllllll}
32 & 46 & 6 \dot{0} & 94 & 40 & 48 & 76 & 25 & 1 & 159 & 48 & 87 & 28 & 149 & 46 & 51 & 42 & 56
\end{array} \\
& \begin{array}{llllllllllllllll}
9 & 23 & 52 & 19 & 23 & 35 & 6 & 3 & 10 & 2 & 18 & 13 & 21 & 9 & 11
\end{array}
\end{aligned}
$$

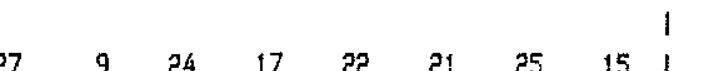

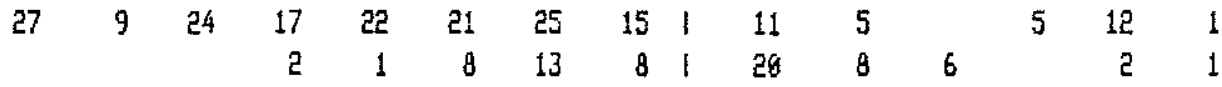

\begin{tabular}{|c|c|c|c|c|c|c|c|c|c|c|c|c|c|c|c|c|c|c|}
\hline RZEHAKIKA & & & & & & & 2 & & 1 & & & & 1 & 2 & & 1 & & 11 \\
\hline HORHOSINACEA & & & & & & & & & 1 & & & & & & & & & $\mathrm{i}$ \\
\hline Aschenonella & & & 1 & & & & & & 1 & & 1 & & & & & & & i \\
\hline H. ovulum & & & & & & 6 & 1 & 14 & 1 & $4 \hat{\theta}$ & 45 & 27 & 16 & 27 & 4 & 6 & 4 & 3 \\
\hline H. excelsa & & & & & 1 & 5 & $1 \overline{8}$ & 7 & 1 & & & & & & & & & i \\
\hline Kalamopsis & & & & & 1 & 2 & 2 & 3 & 1 & & & & & & & & & I \\
\hline Nodellux & & & & & & 1 & & & 1 & & & & & & 1 & & & I \\
\hline R. duplex & & & & & & 4 & & 2 & 1 & 2 & 2 & & & 18 & & 2 & 2 & 11 \\
\hline R. pilulifer & 2 & 己 & & 2 & & & 1 & & 1 & & & & & 2 & 3 & & & $1 \mathrm{i}$ \\
\hline R. subfusiformis & & & & & 1 & & & & 1 & & & & & & & 1 & 1 & 1 \\
\hline R. globosus & & & & & & & & & 1 & & & & & & & & & 1 \\
\hline R. splendidus & & & & & & 3 & 5 & 2 & 1 & & & & & & & & & 1 \\
\hline S. pseudoscalaria & & & & & 2 & 1 & & & 1 & & & & & & & & & । \\
\hline 5. scalaria & & & & & 1 & 6 & 10 & 4 & 1 & & & & 1 & & & 5 & & ! \\
\hline LITUOLACEA & & & & & & & & & 1 & & & & & & & & & 1 \\
\hline A. aff. polythalamus & 3 & & & 4 & ? & 4 & 4 & & 1 & 5 & 5 & 1 & & & & & & I \\
\hline A. $\operatorname{sp} .3$ & & & & & & & & & 1 & & & & & 1 & & & & 1 \\
\hline A. $5 p .4$ & & & & & & & & & 1 & & & & 11 & 27 & 1 & 3 & 3 & 1 \\
\hline A. agqlutinans & & & & & & & 1 & & 1 & & & & 2 & 1 & 4 & 2 & 3 & 1 \\
\hline A. jarvisi & & & & & & & & & 1 & & & & & & & & & 1 \\
\hline Alwoscalaria & & & & & & & & & 1 & & 1 & & & 6 & & & & 1 \\
\hline B. wulticanerata & 13 & 28 & 12 & 2 & 13 & & & & 1 & & & & & & & & & 1 \\
\hline B. trinitatensis & 8 & 3 & 1 & & & 3 & 3 & & 1 & 2 & & & 12 & 14 & & & & $i$ \\
\hline Cribrostosoides & & & & & & & & & 1 & 1 & & 1 & 71 & 87 & 4 & & & 1 \\
\hline
\end{tabular}

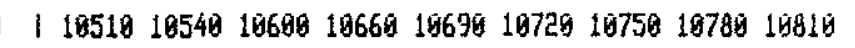

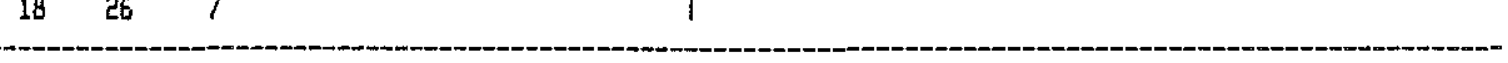


Appendix 5-4 (Continued).

\begin{tabular}{|c|c|c|c|c|c|c|c|c|c|c|c|c|c|c|c|c|c|c|}
\hline H. eggeri & & 2 & & & & 4 & 2 & 11 & 1 & 17 & 7 & & 7 & 26 & 11 & 4 & 7 & 81 \\
\hline H. glabra & & & & & & 9 & 4 & 12 & 1 & 9 & 12 & 6 & 3 & 1 & & & & $\mathrm{i}$ \\
\hline H. kirki & & & & & & & & & 1 & 6 & 1 & & 18 & 1 & & 1 & & $\mathrm{i}$ \\
\hline H. retroseptus & 5 & & 5 & 2 & 13 & 11 & 15 & 10 & 1 & 9 & 2 & & & 2 & & & & 1 \\
\hline $\mathrm{H}_{s}$ suborbicularis & 10 & 5 & & 5 & 4 & 7 & 11 & 6 & 1 & 5 & 5 & & 7 & & 1 & 6 & 2 & 21 \\
\hline H. walteri & 8 & 17 & 65 & 94 & 49 & & & & 1 & & & & & & & & & \\
\hline Haplo. coarse & & & & & 1 & & & & 1 & 1 & & & 4 & 3 & 1 & 1 & & 11 \\
\hline Labrospita & & & & & & & & 1 & 1 & 4 & 2 & & & & & & & 1 \\
\hline Lituotuda & & & & & & & & & 1 & & & & & & & & & $i$ \\
\hline R. deflexiforais & 2 & & & & 2 & 1 & 2 & 12 & 1 & 6 & & & & 3 & 2 & 1 & & 11 \\
\hline R. gerochi & 24 & 25 & 21 & 22 & 23 & 11 & 28 & 21 & 1 & 19 & & & 5 & 13 & & 1 & & $i$ \\
\hline R. walteri & 6 & & & 14 & 4 & 36 & 51 & 67 & 1 & 152 & $9 \overline{1}$ & 104 & 80 & 178 & 39 & 26 & 16 & $23 i$ \\
\hline T. irreqularis & 1 & 1 & 1 & 4 & 3 & & 2 & 5 & 1 & 14 & 5 & & 6 & 2 & & & & . \\
\hline T. subcoronatus & & & & & & 2 & 3 & 2 & 1 & & & 7 & & 2 & & & & 1 \\
\hline T. subtrullisatus & & & & & & & & & 1 & & & & & & & & & \\
\hline LUFTUSIACEA & & & & & & & & & 1 & & & & & & & & & \\
\hline C. placentà & & & & & & & & & 1 & & & & & & & & & \\
\hline C. rotundidorsata & & & & & & & & & 1 & & & & & & & & & \\
\hline R. amplectens & & & & & & & & & 1 & & & & & & & & & \\
\hline Retic. acute & 4 & 10 & 12 & 7 & 3 & & & & & & & & & & & & & \\
\hline Retic. rooust & 27 & & 5 & & & & & & & & & & & & & & & \\
\hline
\end{tabular}

\begin{tabular}{|c|c|c|c|c|c|c|c|c|c|c|c|c|c|c|c|c|c|c|}
\hline TROCHAMWINACEA & & & & & & & & & 1 & & & & & & & & & $\mathrm{i}$ \\
\hline Aasosphaeroidina & 19 & 7 & 29 & 38 & 22 & 26 & 14 & 2 & 1 & 7 & 14 & 3 & 2 & 6 & & 3 & & 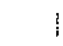 \\
\hline T. deformis & 29 & 13 & 56 & 60 & 36 & 21 & 23 & 23 & $i$ & 21 & 15 & 1 & 17 & 15 & 3 & 4 & 4 & 31 \\
\hline T. aitiformis & & 2 & & & & & & & 1 & & & & & & & & & j \\
\hline T. qlobigeriniformis & 1 & & & & & & & 3 & 1 & 3 & & & 19 & 12 & 4 & 3 & 6 & 4 \\
\hline T. ruthven-murrayi & 2 & 2 & 1 & & 1 & & & & & & & & & & & & & \\
\hline Conotrochaasina & & & & & & & & & 1 & & 2 & & & 1 & & 1 & & 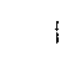 \\
\hline ATAXOPHRAGMIACEA & & & & & & & & & 1 & & & & & & & & & $\mathrm{i}$ \\
\hline Arenobulimina & & & & & & & & & 1 & & & & 3 & 3 & 4 & & 2 & 1 \\
\hline Clavulinoides & & 2 & & & & & & & & & & & & & & & & \\
\hline Dorothia sp. 6 & & & & 1 & & & & & 1 & & & & & & & & & i \\
\hline D. retusa & & & & & & & & & 1 & 1 & & & & & & & & 1 \\
\hline Eggerella & & & & & & & & & 1 & & & & & & & & & i \\
\hline X. horrida & ? & 6 & 3 & 3 & 5 & 42 & 38 & 14 & 1 & 22 & & 12 & 52 & 192 & 4 & 19 & 13 & 61 \\
\hline K. conversa & & & 1 & & & & & & 1 & 1 & 1 & & 1 & & & & & I \\
\hline A. oxycona & & & & & & & & & 1 & & & 2 & & & 1 & & & । \\
\hline M. varians & & & & & & & & & 1 & & & & & & & & & 1 \\
\hline k. coniformis & & & & & & & & & 1 & & & & & & & & & 1 \\
\hline Gaudryina & & & & & & & & & 1 & 1 & & 6 & & & & 1 & & 11 \\
\hline Uvigerinamaina & & & & & & & & & 1 & 3 & 6 & 1 & 140 & 136 & 11 & 10 & 6 & 81 \\
\hline SPIROPLECTAHMINACEA & & & & & & & & & 1 & & & & & & & & & 1 \\
\hline S. spectabilis & & & & 12 & & 12 & 16 & 4 & 1 & & & & & 1 & & & & 11 \\
\hline S. Bavarroana & & & 2 & & 4 & 13 & 7 & 9 & 1 & 2 & 1 & 3 & 1 & 12 & 1 & 3 & & 1 \\
\hline S. aff. dentata & & & & & & & & & 1 & & & 3 & & 1 & & & & . \\
\hline IND FRAGWENTS & & & & & & & & & 1 & & & & & & & & & 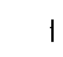 \\
\hline CALC BENTHICS & 48 & 42 & 110 & 62 & 35 & 0 & 3 & $\theta$ & 1 & 118 & 275 & 480 & 23 & 12 & 4 & 11 & 5 & 41 \\
\hline
\end{tabular}




\section{CHAPTER 6.}

GENERAL CONCLUSIONS:

Flysch-type agglutinated foraminifera are found in tectonically active areas of southern Europe, northwest Africa and the Carribean, in offshore wells in northern Atlantic basins, and at some North Atlantic DSDP and ODP sites. In these areas agglutinated foraminiferal facies are particularly well-developed in deep-water facies of late Cretaceous to early Paleogene age.

The revised taxonomic data base ${ }^{1}$ (over 200 species and species groups) used throughout this study has made possible the first regional synopsis of the biostratigraphic and paleobiogeographic distribution of these microfossils in the North Atlantic and western Tethys. A major result of this survey is that most flysch-type taxa are cosmopolitan, but regional differences in species composition, relative abundance and diversity are recognized that can be attributed to differences in latitude and paleodepth between sampled localities. A general decrease in diversity is observed from low to high latitudes and from the continental slope to the deep ocean basins. Tropical Paleocene assemblages contained abundant calcareous ataxophragmiids and rzehakinids. Boreal and Tethyan assemblages contained endemic elements in the Paleocene and early Eocene. An early Eocene to early middle Eocene maximum in Glomospira is apparently an oceanwide phenomenon.

1. Illustrations of species can be found in the following pre-prints, which are available from the author upon request:

Kaminski, M.A., Gradstein, F.M., Berggren, W.A., Geroch, S., and Beckmann, J.P. (in press, a). Flysch-type agglutinated foraminiferal assemblages from Trinidad: Taxonomy, Stratigraphy and Paleobathymetry. Proceedings of the Second International Workshop on Agglutinated Foraminifera, Vienna Austria, June 23-28, 1986.

Kaminski, M.A., Gradstein, F.M., Scott, D.B., and MacKinnon K.D. (in press, c). Neogene benthic foraminiferal stratigraphy and deep water history of Sites 645, 646 and 647, Baffin Bay and Labrador Sea. in: Arthur, M.A., Srivastava, S., et al. Init. Repts. ODP Leg 105.

Kaminski, M.A., Gradstein, F.M., and Berggren, W.A. (in press, d). Paleogene benthic foraminiferal stratigraphy and paleoecology at Site 647 , Southern Labrador Sea. in: Arthur, M.A., Srivastava, S., et al. Init. Repts. ODP Leg 105 . 
Investigation of well samples in different North Atlantic basins indicates that flysch-type agglutinated foraminifera are useful for biostratigraphy, particularly in areas where calcareous microfossils are absent or underrepresented. Biostratigraphic schemes have been developed for flyschtype taxa from Trinidad, Zumaya Spain, the North Sea, Labrador Sea, and Norwegian-Greenland Sea. In Trinidad, Zumaya and the deep Labrador Sea, the stratigraphic ranges of flysch-type taxa were correlated to the GPMS via secondorder correlations using planktonic microfossil zonal schemes. Hole 647A in the Labrador sea is the only section recovered thus far where the chronology of flysch-type taxa can be directly tied to the GMPS by means of first-order correlation with magnetostratigraphy. The finding of disjunct stratigraphic ranges of certain taxa in silled basins is attributed to restricted deep-water connections with the North Atlantic.

A comparison of the biostratigraphy of flysch-type taxa in the basins studied reveals a number of evolutionary first and last occurrences that serve as important regional stratigraphic marker horizons. The LO's of Glomospira diffundens, Hormosina ovulum, Rzehakina epigona, Rzehakina minima, Trochammina ruthven-murrayi, and calcareous ataxophragmiids occur near the Paleocene/Eocene boundary in bathyal assemblages. The first occurrence of the intermediate forms in the Haplophragmoides cf. glabra - $\underline{H}$. walteri $-\underline{H}$ ?. jarvisi lineage may be usful stratigraphic events in the North Atlantic. Important Fo's which probably reflect evolutionary events in the Eocene are Karreriella coniformis, Reticulophragmium amplectens, Ammodiscus latus, Spirosigmoilinella compressa, and Cyclammina rotundidorsata.

The diversity of flysch-type foraminifera in the North Atlantic declined with time throughout the Paleogene, and the last common occurrence of these microfossils exhibits a pattern of diachrony with latitude and depth. The loss of flysch-type assemblages from the abyssal regions may be due to the appearance of younger bottom water in the deep basins. However, their presence in slope basins is related to rapid clastic deposition associated with the early phases of extensional tectonics along the margins of the Labrador and Norwegian-Greenland Sea.

There were four main periods of faunal turnover among agglutinated foraminifera in the Cenozoic. The first turnover, near the Paleocene/Eocene boundary, was characterized by the loss of agglutinated assemblages in the deep ocean basin and the extinction of many species and some genera in bathyal 
assemblages. However, some species persisted to younger levels in highlatitude basins. The lower/middle Eocene transition is marked by additional extinctions and the development of a widespread Glomospira facies. The Eocene/0ligocene transition in marked by disappearance of the last deep-sea faunas in the Labrador Sea and Poland, and throughout most parts of the Labrador Margin and the North Sea. The early 0ligocene witnessed a reduction in diversity on the Labrador Margin and in the Norwegian-Greenland Sea and the disappearance of agglutinated taxa in the Mackenzie Delta. The disappearance of agglutinated assemblages in these areas was caused by regional changes from slope to shelf environments.

The early/middle Miocene turnover in the Norwegian-Greenland Sea resulted in a reduction in diversity to $\sim 5$ species in the overlying biosiliceous sediments. Pre-glacial Pliocene assemblages display higher diversity until the onset of ice-rafting, when agglutinated species are replaced by calcareous benthic assemblages. In the Neogene agglutinated assemblages were preserved under exceptional circumstances in the Labrador Sea. Upper Miocene assemblages recovered from Hole 646 contain elements of modern Atlantic faunas. Throughout their respective histories, both Baffin Bay and the NorwegianGreenland Sea possessed endemic faunal elements.

The paleobathymetry of agglutinated foraminifera in the North Atlantic was studied in Trinidad, Labrador and the Norwegian-Greenland Sea. The presence of redeposited assemblages in the Lizard Springs Formation allows the recognition of shallow and deep assemblages. The shallowest assemblage of the Lizard Springs Formation is dominated by species associated with a calcareous facies, such as Clavulinoides globulifera, Dorothia retusa, Phenacophragma beckmanni, and Haplophragmoides ex. gr. suborbicularis. This assemblage occurs with a calcareous benthic assemblage containing a high abundance of Stensioina beccariiformis. An assemblage redeposited from a deeper source area is dominated by Dendrophrya, and occurs with a calcareous benthic assemblage containing a higher proportion of Nuttallides truempyi. The deepest assemblage of the Lizard Springs Formation is dominated by small, finely agglutinated species such as Ammosphaeroidina pseudopauciloculata, Rhizammina indivisa, and Recurvoides gerochi, with a lesser contribution by Rzehakina epigona, Spiroplectammina spectabilis and Saccammina placenta. In the northern Atlantic, paleobathymetric trends can be reconstructed from a transect of wells on the Labrador Margin and DSDP/ODP sites in the Labrador 
Sea, Norwegian-Greenland Sea and Galicia Margin. Paleobathymetric patterns in northern assemblages differ from low-latitude assemblages by the lack of a shallow "Marssonella association" of calcareous ataxophragmiids. Shallow Maastrichtian and Paleogene assemblages contain abundant coarse tubular species and lituolids with only very rare calcareous ataxophragmiids. Shallow Eocene assemblages on the Labrador Margin contain few tubular species and are dominated by cyclamminids. However, shallow assemblages on the Vøring Plateau and Slope contain abundant tubular forms, cyclamminids, and acmes of $\underline{S}$. spectabilis. Deeper assemblages contain more abundant Glomospira, Hormosina, Trochamminoides, Ammosphaeroidina, Praecystammina, and finely agglutinated lituolids (Cribrostomoides, Haplophragmoides, Labrospira). Cretaceous deep assemblages contain abundant Uvigerinamina, and Paleocene deep assemblages contain more abundant S. spectabilis. Hormosina ovulum was common in deep assemblages before the early Eocene.

The paleobathymetry of species in the North Atlantic compares well with patterns observed in the Carpathian flysch basins, and enables the constructon of an empirical paleobathymetric model for the Paleocene. This model differs from Cretaceous paleobathymetric patterns discussed by Haig (1979) in a number of details. The relative abundance of Recurvoides, the nominate taxon of Haig's deep assemblage, does not display consistent depth-related patterns in the North Atlantic. The "Marssonella association" of Haig can be recognized in the Paleocene at low latitudes, but does not occur at high latitudes or in Eocene or younger assemblages.

The modern analogs of flysch-type agglutinated foraminifera yield information about the autecology of species and the synecology of species associations which provide important constraints for paleoenvironmental analysis. Disequilibrium studies of living agglutinated foraminifera in the Panama Basin and on the Nova Scotian continental rise have documented their microhabitats, identified epifaunal and infaunal forms as well as opportunistic species, and assessed the preservation potential of some modern taxa. This information was used to construct a general model of the response of agglutinated foraminifera to substrate disturbance. Other major conclusions are as follows:

- Tubular forms (Dendrophrya and Rhizammina) are epifaunal and did not recolonize sediment trays. This implys that epifaunal forms are at risk in physically disturbed areas. 
- The genus Reophax has a vagrant infaunal microhabitat and displays the best ability to recolonize sediment trays.

- Nine months is not sufficient time for a the deep-sea benthic foraminiferal community to recover to background abundance levels after a disturbance. This implys that substrate disturbance which occurs on a timescale of about a year is sufficient to produce a "physically-controlled" community consisting of more opportunistic species.

The substrate disturbance model can be used to assess the physical stability of deposional enviroments recorded by fossil assemblages. A study of the synecology of fossil assemblages in ODP Hole $646 \mathrm{~B}$ on the Eirik Ridge is useful for determining the bottom water history of the area. Beneath a regional seismic horizon (reflector "R3"), the presence of smooth-walled agglutinated assemblages point to a tranquil environment. Above horizon "R3", coarse-walled assemblages dominated by large tubular species suggest a disturbed environment. This evidence, along with sedimentologic and isotopic evidence, suggests an intensification of the Western Boundary Undercurrent at the Eirik Ridge at $7.5 \mathrm{Ma}$. The similarity of the agglutinated assemblages and other microfossils in Hole $646 \mathrm{~B}$ to assemblages from the Norwegian-Greenland Sea indicates that Demark Straits overflow was the dominant water mass over the Eirik Ridge in the late Miocene.

A study of the agglutinated foraminiferal fauna at areas of hydrocarbon seepage on the Lousiana slope has identified taxa which tolerate or prefer organic-rich substrates. This finding has potential use for petroleum exploration. In both study areas, the hydrocarbon seep assemblage is characterized by a decrease in the proportion of astrorhizids and a corresponding increase in the relative abundance of trochamminids and textulariids when compared with control samples. At the highly organic-rich substrate in Block 184 where a chemosynthetic macrofaunal community was recovered, infaunal foraminiferal morphotypes are absent and the predominant species are Trochammina glabra and Glomospira charoides. Similar types of assemblages have been reported from organic-rich sediments as old as Jurassic in age. In the course of this study, a Glomospira-dominated assemblage was observed in the upper lower Eocene to lower middle Eocene of ODP Holes 647A and 643A. This "Glomospira facies" is coeval with the well-known Glomospira beds in the Alpine areas, and is the first report of such an assemblage in the Atlantic. The presence of the Glomospira facies in the North Atlantic and western Tethys 
is ascribed to increased nutrients, and (presumably) decreased oxygenation of bottom water resulting from higher paleoproductivity in the surface waters and paleoceanographic changes caused by the basal Lutetian sea-level lowstand. 


\section{REFERENCES}

Aksu, A.E., 1983. Holocene and Pleistocene dissolution cycles in deep-sea cores of Baffin Bay and Davis Strait: paleoceanographic implications. Marine Geology 53, 331-340.

Aksu, A.E., and Kaminski, M.A., (in press). Neogene planktonic foraminiferal biostratigraphy and biochronology in Baffin Bay anf Labrador Sea. in: Arthur, M.A., Srivastava, S., et al. Proc. Init. Repts. (Pt. B) ODP 105.

Aller, R.C., and DeMaster, D.J., 1984. Estimates of particle flux and reworking at the deep-sea floor using 34Th/38U disequilibrium. Earth and Planetary Science Letters 67:308-318.

Arthur, M.A., Zachos, J.C., Kaminski, M.A., and Dean, W.E., (in prep.). Geochemistry of Eocene sediments, Site 647, Labrador Sea. in: Arthur, M.A., Srivastava, S., et al. Proc. Init. Repts. (Pt. B) ODP 105.

Bandy, 0.L., and Rodolfo, K.S., 1964. Distribution of foraminifera and sediments, Peru-Chile Trench area. Deep Sea Res. 11:817-837.

Batten, D.J., 1984. Palynology, climate and the development of late Cretaceous floral provinces in the Northern Hemisphere; a review. in: Brenchley, P.J. (ed) Fossils and Climate. (John Wiley \& Sons), 127-164.

Barrera, E., Huber, B.T., Savin, S.M., and Webb, P.N., 1987. Antarctic marine temperatures: Late Campanian through early Paleocene. Paleoceanography 2:2147.

Beckmann, J.P.,. 1960. Distribution of benthonic foraminifera at the Cretaceous-Tertiary boundary of Trinidad (West Indies). Int. Geol. Congress 21 Session, Norden 5:57-69.

Berggren, W.A., 1972. Cenozoic biostratigraphy and paleobiogeography of the North Atlantic. in: Laughton, A.S., Berggren, W.A., et al., Init. Repts. DSDP, 12: Washington (U.S. Govt. Printing office), 965-1001.

Berggren, W.A., and Hollister, C.D., 1974. Paleogeography, Paleobiogeography and the history of circulation in the Atlantic Ocean. in: Hay, W.W. (ed), Studies in Paleo-oceanography. SEPM Spec. Publ. 20. pp. 126-186.

Berggren, W.A., and Schnitker, D., 1983. Cenozoic marine environments in the North Atlantic and Norwegian-Greenland Sea. in: Bott, M.H., Saxov, S., Talwani, M., and Thiede, J. (eds.) Structure and development of the Greenland-Scotland Ridge. NATO Conference Series IV, 495-548.

Berggren, W.A., Kent, D.V., and Van Couvering, J.A., 1985a. Neogene chronology and chronostratigraphy in: Snelling, N.J. (ed.) The Chronology of the Geological Record. Geological Society of London Memoir no. 10:211-260.

Berggren, W.A, Kent, D.V., and Flynn, J.J., 1985b. Paleogene geochronology and chronostratigraphy, in: Snelling, N.J. (ed.) The Chronology of the Geological Record. Geological Society of London Memoir no. 10:141-195. 
Berggren, W.A., and 0lsson, R.K., 1986. North Atlantic Mesozoic and Cenozoic paleoceanography. in: Vogt, P.R., and Tucholke, B.E., eds. The Geology of North America, Volume $M$, The North Atlantic region. (Geological Society of America), 565-587.

Bernstein, B.B., Hessler, R.R., Smith, R., and Jumars, P.A., 1978. Spatial dispersion of benthic foraminifera in the abyssal North Pacific. Limnology and Oceanography 23:401-416.

Blanc, P.L. and Duplessy, J.C., 1982. The deep water circulation during the Neogene and the impact of the Messinian salinity crisis. Deep Sea Res. $29: 1391-1414$.

Boersma, A., and Premoli-Silva, I., 1986. Terminal Eocene Events: planktonic foraminifera and isotopic evidence. in: Pomerol, C., and Premoli-Silva (eds) Terminal Eocene Events. Amsterdam (Elsevier), 213-224.

Boersma, A., and Premoli-Silva, I., and Shackleton, N.J., (1987) Atlantic Eocene planktonic foraminiferal paleohydrographic indicators and stable isotope paleoceanography. Paleoceanography 2: 287-331.

Bolli, H.M., 1952. Note on the Cretaceous-Tertiary boundary in Trinidad, B.W.I., Jour. Paleontol. 26:699-675.

Bolli, H.M., 1957a. The genera Praeglobotruncana, Rotalipora, Globotruncana, and Abathomphalus in the upper Cretaceous of Trinidad, B.W.I. U.S. Nat. Mus. Bul1 215:51-60.

Bolli, H.M., 1957b. The genera Globigerina and Globorotalia in the Palreocene - lower Eocene Lizard Springs Formation of Trinidad, B.W.I. U.S. Nat. Mus. Bu11. 215:61-82.

Bolli, H.M., 1959. Planktonic foraminifera as index fossils in Trinidad, West Indies and their value for worldwide stratigraphic correlation. Eclogae Geol. Helvetiae 52:627-637.

Bolli, H.M., 1966. Zonation of Cretaceous to Pliocene marine sediments based on planktonic foraminifera. Boletin Inform. Asoc. Venez. de Geologia, Mineria y Petroleo 9:3-32

Bolli, H.M., Saunders, J.B., and Perch-Nielsen, K., (1985) Comparison of zonal schemes for different fossil groups. in: Bolli, H.M., Saunders, J.B., and Perch-Nielsen, K., (eds.) Plankton Stratigraphy. Cambridge University Press. 3-10.

Bremer, M.L., and Lohmann, G.P., 1982. Evidence for primary control of the distribution of certain Atlantic Ocean benthonic foraminifera by degree of carbonate saturation. Deep Sea Res. 29:987-998.

Bronnimann, P., 1952. Trinidad Paleocene and lower Eocene Globigerinidae. Bul1. Amer. Paleontol. 34:1-34.

Brooks, J.M., Kennicutt, M.C., Bidigare, R.R., and Fay, R.A., 1985. Hydrates, 
0il seepage and chemosynthetic ecosystems on the Gulf of Mexico Slope. EoS Trans. AGU 66:106.

Brooks, J.M., Kennicutt, M.C., Bidigare, R.R., Wade, T.L., Powell, E.N., Denoux, G.L., Fay, R.R., Childress, J.J., Fisher, C.R., Rossman, I., and Boland, G., 1987. Hydrates, 0il seepage and chemosynthetic ecosystems on the Gulf of Mexico Slope: An update. EOS Trans. AGU

Bukry, D., 1972. Further comments on coccolith stratigraphy, Leg XII, Deep Sea Drilling Project. in: Laughton, A.S., Berggren, W.A., et al., Init. Repts. DSDP, 12: Washington (U.S. Govt. Printing Office), 1071-1084.

Bukry, D., 1977. Coccolith and Silicoflagellate stratigraphy, South Atlantic 0cean, Deep Sea Drilling Project Leg 39. in: Supko, P.R., Perch-Nielsen, K., et al., Init. Repts. DSDP, 39: Washington (U.S. Govt. Printing office), 825-839.

Bukry, D., 1978. Cenozoic SIlicoflagellate and Coccolith stratigraphy, southeast Atlantic Ocean, Deep Sea Drilling Project Leg 40. in: Bolli, H.M., Ryan, W.B.F., et al., Init. Repts. DSDP, 40: Washington (U.S. Govt. Printing office), 635-649.

Bukry, D., 1981. Synthesis of silicoflagellate stratigraphy for Maestrichtian to Quaternary marine sediment. SEPM Spec. Publ. 32:433-444.

Butt, A., 1981. Depositional environments of the upper Cretaceous rocks in the northern part of the eastern Alps. Cushman Foundation for Foraminiferal Research Special Publication 20:1-121.

Cavelier, C., Chateauneuf, J.J., Pomerol, C., Rabussier, D., Renard, M., and Vergnaud-Grazzini, C., 1981. The geological events at the Eocene/Oligocene boundary. Paleogeo., Paleoclim., Paleoecol., 36:223-248.

Cita, M.B., and Grignani, D., 1982. Nature and origin of late Neogene Mediterranean sapropels. in: Schlanger, S.0., and Cita, M.B., (eds.) Nature and origin of Cretaceous carbon-rich facies. Academic Press. pp. 165-196.

Corliss, B.H., 1979. Response of deep-sea benthonic foraminifera to development of the psychrosphere near the Eocene/Oligocene boundary. Nature $282: 63-65$.

Corliss, B.H., 1985. Microhabitats of benthic foraminifera within deep-sea sediments. Nature 314:435-438.

Corliss, B.H., Aubry, M.P., Berggren, W.A., Fenner, J.M., Keigwin, L.D., and Keller, G., 1984. The Eocene/0ligocene boundary event in the deep sea. Science 226:806-810.

Cushman, J.A., and Jarvis, P.W., 1928. Cretaceous foraminifera from Trinidad. Contr. Cushman Lab. Foram. Res. 4:85-103.

Cushman, J.A., and Jarvis, P.W., 1932. Upper Cretaceous foraminifera from Trinidad. Proc. U.S. Nat. Museum 80:1-48. 
Cushman, J.A., and Renz, H.H., 1946. The foraminiferal fauna of the Lizard Springs Formation of Trinidad, British West Indies. Cushman Lab. Foram. Res. Spec. Publ. 18:1-48.

Cushman, J.A., and Renz, H.H., 1947. Further notes on the Cretaceous foraminifera of Trinidad. Contr. Cushman Lab. Foram. Res. 23:31-51.

Christian, J.T., 1979. A re-examination of the type-locality for the Paleocene Globorotalia pseudomenardii Zone, Pointe-a-Pierre, Trinidad. Trans. 4 th Lat. Amer. Geol. Conf. 2:289-299.

Davies, T.A. and Kidd, R.B., 1977. Sedimentation in the Indian Ocean through time. in: Heirtzler, J.R., et al., (eds), Indian 0cean geology and biostratigraphy. (AGU), 61-85.

D'Iorio, M.A., 1986. Integration of foraminiferal and dinoflagellate data sets in quantitative stratigraphy of the Grand Banks and Labrador Shelf. Bulletin of Canadian Petroleum Geology, 34:277-283.

Dixon, J., Dietrich, J.R., McNeil, D.H., McIntyre, D.J., Snowdon, L.R., and Brooks, P., 1985. Geology, biostratigraphy and organic chemistry of Jurassin to Pleistocene strata, Beaufort-Mackenzie area, Northwest Canada. Course Notes. Can. Soc. Petr. Geol. 41 pp.

Driscoll, M.L., Tucholke, B.E., and McCave, I.N., 1985. Seafloor zonation in sediment texture on the Nova Scotia lower continental rise. Marine Geology $66: 25-42$.

Eldholm, 0., Thiede, J., Taylor, E., et al., 1987. Site 643. in: Eldholm, 0., Thiede, J., Taylor, E., et al., Proc. Init. Repts. (Pt. A), ODP 104, 455615.

Eldholm, 0., Thiede, J., and Taylor, E., 1987. Evolution of the Norwegian continental margin: Background and objectives. in: Eldholm, 0., Thiede, J., Taylor, E., et al., Proc. Init. Repts. (Pt. A), ODP 104, 5-25.

Estes, R., and Hutchinson, J.H., 1980. Eocene lower vertebrates from Ellesmere Island, Canadian Arctic Archipelago. Paleogeogr. Paleoclim. Paleoecol. $30: 325-348$.

Fenner, J., 1985. Late Cretaceous to 0ligocene planktic diatoms. in: Bolli, H.M., Saunders, J.B., and Perch-Nielsen, K., (eds.) Plankton Stratigraphy. Cambridge University Press. 713-762.

Firth, J.V., in press. Eocene and 0ligocene nannofossils from the Labrador Sea, ODP Leg 105. in: Arthur, M.A., Srivastava, S., et al. Init. Repts. ODP Leg 105.

Flint, J.M., 1899. Recent foraminifera, a descriptive catalog of specimens dreged by the U.S. Fish Commission steamer Albatross. U.S. National Museum Annual Report (1897) pp. 249-349.

Geroch, S., Jednorowska, A., Ksiazkiewicz, M., and Liszkowa, J., 1967. 
Stratigraphy based upon microfauna in the western Polish Carpathians. Biuletyn Inst. Geol. 211:186-282.

Geroch, S., and Nowak, W., 1984. Proposal of zonation for the late Tithonian late Eocene, based upon arenaceous foraminifera from the outer Carpathians, Poland. Benthos '83; 2nd International Symposium on Benthic Foraminifera (Pau, April 1983). pp. 225-239.

Gradstein, F.M., 1983. Cenozoic Stratigraphy using agglutinated foraminifera. Proc. First Workshop on Agglutinated Foraminifera, Amsterdam, Sept. 1981. Continental Shelf Institute Special Publication 108:247-250.

Gradstein, F.M., and Williams, G.L., 1976. Biostratigraphy of the Labrador Shelf, Part 1. Geol. Surv. Canada Open File 349, 39 pp.

Gradstein, F.M., and Srivastava, S.P., 1980. Aspects of Cenozoic stratigraphy and paleoceanography of the Labrador Sea and Baffin Bay. Paleogeography, Paleoclimatology and Paleoecology, 30:261-295.

Gradstein, F.M., and Berggren, W.A., 1981. Flysch-type agglutinated foraminiferal stratigraphy and the Maestrichtian to Paleogene history of the Labrador and North Seas. Marine Micropaleontology 6:211-268.

Gradstein, F.M., and Agterberg, F.P., 1982. Models of Cenozoic foraminiferal stratigraphy - northwestern Atlantic margin. in: Cubitt, J.M., and Reymant, R.A., (eds.) Quantitative Stratigraphic Correlation. (J. Wiley \& Sons), 119-170.

Gradstein, F.M., Kaminski, M.A., and Berggren, W.A., (in press). Cenozoic foraminiferal biostratigraphy, Central North Sea. Proceedings of the Second International Workshop on Agglutinated Foraminifera, Vienna Austria, June $23-28,1986$.

Gradstein, F.M., Agterberg, F.P., Brower, J.C., and Schwarzacher, W.S., 1985. Quantitative Stratigraphy. (D. Reidel Publishing Co.), 589pp.

Gradstein, F.M., 1987. Probabilistic biochronology in exploration micropaleontology. Gulf Coast Section/SEPM Foundation 8 th Annual Research Conference, Program and Abstracts.

Grassle, J.F., 1977. Slow recolonization of deep-sea sediment. Nature 265:618619.

Grassle, J.F., 1978. Diversity and population dynamics of benthic organisms. 0ceanus $21: 42-45$.

Grassle, J.F., and Sanders, H.L., 1973. Life histories and the role of disturbance. Deep-Sea Research 20:643-659.

Grun, W., Lauer, G., Niedermayer, G., and Schnabel, W., 1964. Die KreideTertiar grenze im Wienerwaldflysch bie Hochstrass/Niederosterreich. Verhandlungen der Geologischen Bundesanstalt 2:226-283. Wien.

Grzybowski, J., 1898, 0twornice pokladow naftonosnych okolicy Krosna. 
Rozprawy Akademii Umiejetnosci w Krakowie, Wydzial mat-przyr., serya 2, 33:257-305

Haig, D.W., 1979. Global distribution patterns for mid-Cretaceous foraminiferids. Jour. Foram. Res. 9:29-40.

Hanzlikova, E., 1983. Paleogene stratigraphy and foraminifera of the Outer Flysch Belt. Knihovnicka zemniho plynu a nafty 4:43-70.

Haq, B.U., 1981. Paleogene paleogeanography: early Cenozoic oceans revisited. Oceanol. Acta, Acts 26th Int. Geol. Cong, Marine Geol. Colloq. pp. 71-82.

Haq, B.U., Hardenbol, J., and Vail, P.R., 1987. Chronology of fluctuating sea levels since the Triassic (250 millions of years ago to present). Science.

Hart, M.B., and Bigg, P.J., 1983. Arenaceous foraminifera from the late Cretaceous "Anoxic Events" in northwest Europe. Proc. 1st Workshop Arenaceous Foraminifera. IKU Publication 108:89-90.

Heath, G.R., Moore, T.C., and Roberts, G.L., 1974. Minerology of surface sediments from the Panama Basin, Eastern Equatorial Pacific. Journal of Geology 82:145-160.

Hedley, R.H., 1963. Cement and iron in the arenaceous foraminifera. Micropaleontology 9:433-441.

Hemleben, C., and Troester, J., 1984. Campanian-Maestrichtian deep-water foraminifers from Hole 543A, Deep Sea Drilling Project. in: Biju-Duval, B., Moore, J.C., et al. Init. Repts. DSDP, 78A: Washington, D.C., (U.S. Government Printing office), 509-532.

Henderson, G., Schiener, E.J., Risum, J.B., Croxton, C.A., and Anderson, B.B., 1981. The West Greenland Basin. in: Kerr, J.W., Fergusson, A.J., and Machan, L.C. (eds) Geology of the North Atlantic Borderlands. CSPG Memoir 7:399-428.

Hesse, R., 1975. Turbiditic and non-turbididic mudstone of Cretaceous flysch sediments of the east Alps and other basins. Sedimentology $22: 387-416$.

Hillebrandt, A. von, 1965. Foraminiferen-Stratigraphie im Alttertiar von Zumaya (Provinz Guipuzcoa, N.W.-Spanien) und ein Vergleich mit anderen Tethys-Gebieten. Abhand1. Bayer. Akad. Wissenschaften Matemat-Naturwiss. Klasse, Heft 123. $62 \mathrm{pp}$.

Honjo, S., Spencer, D.W., and Farrington, J.W., 1982. Deep advective transport of lithogenic particles in Panama Basin. Science 216:516-

Honjo, S., 1982. Seasonality and interaction of biogenic and 1ithogenic particle flux at the Panama Basin. Science 218:883-884.

Hooper, P.W.P., and Weaver, P.P.E., 1987. Paleoceanographic significance of late Miocene to early Pliocene planktonic foraminifers at Deep Sea Drilling Site 609. in: Ruddiman, W.F., Kidd, R.B., Thomas, E., et al., Init. Repts. DSDP, 94: Washington (U.S. Govt. Printing Office), 925-934. 
Hulburt, S.H., 1971. The nonconcept of species diversity: a critique and alternative parameters. Ecology 52:577-586.

Jednorowska, A., 1975. ZespoXy maXych otwornic w paleocenie Polskich Karpat zachodnich. (Small foraminiferal assemblages in the Paleocene of the Polish Western Carpathians). Studia Geol. Polonica 47:7-103.

Johannessen, 0.M., 1986. Brief overview of the physical oceanography. in: Hurdle, B.G. (ed), The Nordic Seas. New York (Springer-Verlag), 103-128.

Johnson, D.A., 1982. Abyssal teleconnections: Interactive dynamics of the deep ocean circulation. Paleogeogr., Paleoclim., Paleoecol., 38:93-128.

Jones, G.D., (in press). A paleoecological model of late Paleogene "Flyschtype" agglutinated foraminifera using the paleoslope transect approach, Viking Graben, North Sea. in: Proc. 2nd workshop on agglutinated foraminifera, Vienna Austria, June 23 - 28, 1986.

Jones, R.W., and Charnock, M.A., 1985. "Morphogroups" of agglutinating foraminifera. Their life positions and feeding habits and potential applicability in (paleo)ecological studies. Revue de Paleobiologie 4:311320.

Jumars, P.A., 1975. Environmental grain and polychaete species' diversity in a bathyal benthic community. Marine Biology 30:253-266.

Jumars, P.A., 1976. Deep-sea species diversity: Does it have a characteristic scale? Journal of Marine Research 34:217-246.

Jumars, P.A., and Gallagher, E.D., 1982. Deep-sea community structure: Three plays on the benthic proscenium II. Biological environmment of the deep Sea. in: The environment of the deep sea. W.G. Ernst and J.G. Morin (eds) Englewood Cliffs N.J. (Prentice Hall Inc), 217-255.

Jurkiewicz, H., 1967. Foraminifers in the sub-menilitic Paleogene of the Polish Middle Carpathians. Biul. Inst. Geol. 210:5-116.

Kaminski, M.A., 1984. Shape variation in Spiroplectammina spectabilis (Grzybowski). Acta Paleon. Polonica 29:29-49.

Kaminski, M.A., 1985. Evidence for control of abyssal agglutinated foraminiferal community structure by substrate disturbance: Results from the HEBBLE Area. Marine Geology 66:113-131.

Kaminski, M.A., and Gradstein, F.M., 1987. Paleobiogeography of Paleogene flysch-type foraminiferal assemblages in the North Atlantic. Gulf Coast Section/SEPM Foundation 8th Annual Research Conference, Selected papers and illustrated abstracts, pp. 85-89.

Kaminski, M.A., and Schroder, C.J., 1987. Environmental analysis of deep-sea agglutinated foraminifera: Can we distinguish tranquil from disturbed environments? Gulf Coast Section/SEPM Foundation 8 th Annual Research Conference, Selected papers and illustrated abstracts, pp. 90-93. 
Kaminski, M.A., Gradstein, F.M., Berggren, W.A., Geroch, S., and Beckmann, J.P. (in press, a). Flysch-type agglutinated foraminiferal assemblages from Trinidad: Taxonomy, Stratigraphy and Paleobathymetry. Proceedings of the Second International Workshop on Agglutinated Foraminifera, Vienna Austria, June 23-28, 1986.

Kaminski, M.A, Grassle, J.F., and Whitlatch, R.D., (in press, b). Life History and recolonization among agglutinated foraminifera in the Panama Basin. Proceedings of the 2nd Int. Workshop on Agglutinated Foraminifera, Vienna Austria, June 23-28, 1986.

Kaminski, M.A., Gradstein, F.M., Scott, D.B., and MacKinnon K.D. (in press, c). Neogene benthic foraminiferal stratigraphy and deep water history of Sites 645, 646 and 647, Baffin Bay and Labrador Sea. in: Arthur, M.A., Srivastava, S., et al. Init. Repts. ODP Leg 105.

Kaminski, M.A., Gradstein, F.M., and Berggren, W.A. (in press, d). Paleogene benthic foraminiferal stratigraphy and paleoecology at Site 647 , Southern Labrador Sea. in: Arthur, M.A., Srivastava, S., et al. Init. Repts. ODP Leg 105.

Kaasschieter, J.P.H., 1961. Foraminifera of the Eocene of Belgium. Koninkl. Belg. Inst. Natuurwet. Verh. 147. 271pp.

Keigwin, L.D., (in press). Toward a high resolution chronology for latest Miocene paleoceanographic events. Paleoceanography.

Keigwin, L.D., and Corliss, B.H., 1986. Stable isotopes in late middle Eocene to Oligocene foraminifera. Geol. Soc. Am. Bull. 97:335-345

Keigwin, L.D., Aubry, M.P., and Kent, D.V., 1987. North Atlantic late Miocene stable isotope stratigraphy, biostratigraphy, and magnetostratigraphy. in: Ruddiman, W.F., Kidd, R.B., Thomas, E., et al., Init. Repts. DSDP, 94: Washington (U.S. Govt. Printing Office), 935-964.

Keller, G., 1985. Eocene and 0ligocene stratigraphy and erosional unconformities in the Gulf of Mexico and Gulf Coast. Jour. Paleontol. $59: 882-903$.

Kennett, J.P., 1977. Cenozoic evolution of Antarctic glaciation, the Circumantarctic ocean, and their impact on global paleoceanography. Jour. Geophysical Research 82:3843-3860.

Kennett, J.P., and Srinivasan, M.S., 1983. Neogene planktonic foraminifera. Stroudsburg, PA (Hutchinson Ross), $260 \mathrm{pp}$.

Kennicutt, M.C., Brooks, J.M., Bidigare, R.R., Fay, R.R., Wade, T.L., and McDonald, T.J., 1985. Vent-type taxa in a hydrocarbon seep region on the Louisiana slope. Nature 317:351-352.

King, C., 1983. Cainozoic micropaleontological biostratigraphy of the North Sea. Institute of Geological Sciences Report 82/7. 40 pp.

Kitazato, H., 1984. Microhabitats of benthic foraminifera and their 
application to fossil assemblages. in: 0ertli, J.J. (ed.), Benthos '83; 2nd Int. Symposium Benthic Foraminifera (Pau, April 1983) pp. 339-344.

Klose, G.W., Malterre, E., McMillan, N.J., and Zinkan, C.G., 1982. Petroleum exploration offshore southern Baffin Island, Northern Labrador Sea, Canada. in: Embry, A.F., Balkwill, H.R. (eds.) Arctic geology and geophysics. CSPG Memoir 8:233-244.

Knight, R., 1986. A novel method of dark field illumination for a stereomicroscope and its application to a study of the pseudopodia of Reophax moniliformis Siddall (Foraminiferida). Journal Micropaleontology $5: 83-90$.

Koszarski, L., 1985. Geology of the middle Carpathians and the Carpathian foredeep. Guide to Excursion 3. Carpatho-Balkan Geol. Assoc., XIII Congress, Cracow, Poland. 254 pp. Instytut Geol., Warsaw.

Koszarski, L., and Liszkowa, J., 1963. La stratigraphie des depots bigarres du Paleogene dans la partie orientale de la Zone Sous-Silesienne. CarpathoBalkan Geol. Assoc. VI Congress, Repts. pp. 81-84. Warwaw-Cracow, Poland

Koszarski, L., and Zytko, K., 1965. Le probleme de la profondeur de la mer du geosynclinal Karpatique de flysch. Carpatho-Balkan Geol. Assoc. VII Congress, Rept., Part 2, 2:81-86. Sofia.

Krasheninnikov, V.A., 1973. Cretaceous benthonic foraminifera, Leg 20, Deep Sea Drilling Project. in: Heezen, B.C., MacGregor, I.D., et al., Init. Repts. DSDP, 20: Washington (U.S. Govt. Printing office), 205-221.

Krasheninnikov, V.A., 1974. Upper Cretaceous benthonic agglutinated foraminifera, Leg 27, Deep Sea Drilling Project. in: Veevers, J.J., Hertzler, J.R., et al., Init. Repts. DSDP, 27: Washington (U.S. Govt. Printing office), 631-661

Krasheninnikov, V.A., and Pflaumann, U., 1977. Cretaceous agglutinated foraminifera of the Atlantic 0cean off West Africa (Leg 41, Deep Sea Drilling Project). in: Lancelot, Y., Seibold, E., et al., Init. Repts. DSDP, 41: Washington (U.S. Govt. Printing office), 565-580.

Ksiazkiewicz, M., 1975. Bathymetry of the Carpathian flysch basin. Acta Geol. Polonica 25:309-366.

Kugler, H.G., and Bolli, H.M., 1967. Cretaceous biostratigraphy of Trinidad, W.I. Boletin Inform. Asoc. Venez. Geol. Minera y Petrol. 10:207-239.

Kuhnt, W., 1987. Biostratigraphie und Palaeoenvironment der externen Kreideserien des westlichen Rif und Betikum - ein Ansatz zur Rekonstruktion der Kreide-Palaegeographie des Gibraltarbogens. Eberhard-Karls Universitat, Tubingen, Ph.D. Thesis, $271 \mathrm{pp}$.

Lagoe, M.B., 1977. Recent benthic foraminifera from the central Arctic Ocean. Jour. Foraminiferal Res. 7:106-129.

Laird, N.P., 1971. Panama Basin deep water properties and circulation. Journal 
of Marine Research 29:226-234.

LaMolda, M.A., Rodriguez-Lazaro, J., and Wiedmann, J., 1981. Excursions to Coniacian-Maastrichtian of Basque-Cantabric Basin. Univ. of Barcelona Geological Publication No. 14, $53 \mathrm{pp}$.

Laughton, A.S., Berggren, W.A., et al., 1972. Init. Repts. DSDP, 12: Washington (U.S. Govt. Printing office).

Levin, L.A., 1984. Life history and dispersal patterns in a dense infaunal polychaete assemblage: community structure and response to disturbance. Ecology 65:1185-1200.

Levinton, J.S. 1982. Marine Ecology. Englewood Cliffs N.J. (Prentice-Hal1), 526pp.

Loeblich, A.F., and Tappan, H., 1984. Suprageneric classification of the Foraminiferida (Protozoa). Micropaleon. 30:1-70.

Lonsdale, P.F., 1976. Abyssal circulation of the southeastern Pacific and some geological implications. Journal of Geophysical Research 81:1163-1176.

Lonsdale, P.F., 1977. Clustering of suspension-feeding macrobenthos near abyssal hydrothermal vents at oceanic spreading centers. Deep Sea Research $24: 857-863$.

Mjatliuk, E.V., 1970. Foraminifery flishevykh otlozhenii vostochnykh Karpat (Mel-Paleogen). Trudy VNIGRI 282:1-225.

Manum, S., 1976. Dinocysts in Norwegian-Greenland Sea sediments (Deep Sea Drilling Project Leg 38), with observations on palynomorphs and palynodebris in relation to environment. in: Talwani, M., Udintsev, G., et al., Init. Repts. DSDP, 38: Washington (U.S. Govt. Printing Office), 897-919.

Martini, E., and Muller, C., 1976. Eocene to Pleistocene silicoflagellates from the Norwegian-Greenland Sea (DSDP Leg 38). in: Talwani, M., Udintsev, G., et al., Init. Repts. DSDP, 38: Washington (U.S. Govt. Printing office), $857-895$.

McCave, I.N. and Tucholke, B.E., 1986. Deep current-controlled sedimentation in the western North Atlantic, in: Vogt, P.R., and Tucholke, B.E., (eds), The Geology of North America, Vol. M. The Western North Atlantic Region. (Geological Society of America), 451-468.

McKenna, M.C., 1983. Cenozoic paleogeography of North Atlantic land bridges. in: Bott, M.H., Saxov, S., Talwani, M., and Thiede, J. (eds.) Structure and development of the Greenland-Scotland Ridge. NATO Conference Series IV, 351400 .

McWhae, J.R.H., Elie, R., Laughton, K.C., Gunther, P.R., 1980. Stratigraphy and petroeum prospects of the Labrador Shelf. Bull. Canadian Petr. Geol. $28: 450-488$.

Miller, K.G., 1983. Eocene - Oligocene paleoceanography of the deep Bay of 
Biscay: Benthic foraminiferal evidence. Marine Micropaleontology 7:403-440.

Miller, K.G., Gradstein, F.M., and Berggren, W.A., 1982. Late Cretaceous to early Tertiary agglutinated benthic foraminifera in the Labrador Sea. Micropaleon tology 28:1-30.

Miller, K.G. and Tucholke, B.E., 1983. Development of abyssal circulation south of the Greenland-Scotland Ridge. in: Bott, M.H., Saxov, S., Talwani, M., and Thiede, J. (eds.) Structure and development of the GreenlandScotland Ridge. NATO Conference Series IV, 549-590.

Miller, K.G., and Fairbanks, R.G., 1985. Oligocene to Miocene carbon isotope cycles and abyssal circulation changes. in: Sunquist, E., and Broecker, W.S. (eds.), The carbon cycle and atmospheric C02: Natural variations Archean to Present. AGU Geophysical Monograph 32:469-486.

Miller, K.G., and Katz, M.E., 1987a. Oligocene to Miocene benthic foraminiferal and abyssal circulation changes in the North Atlantic. Micropaleon tology 33:97-149.

Miller, K.G., and Katz, M.E., 1987b. Eocene benthic foraminiferal biofacies of the New Jersey Transect. in: Poag, C.W., Watts, A.B., et al., Init. Repts. DSDP, 95: Washington (U.S. Govt. Printing Office), 267-298.

Miller and Hart, M., 1987. Cenozoic planktonic foraminifers and hiatuses on the New Jersey slope and rise. in: Poag, C.W., and Watts, A.B., (eds) Init. Repts. DSDP, 95: Washington (U.S. Govt. Printing Office),

Miller, K.G., Fairbanks, R.G., and Thomas, E., 1987a. Benthic foraminiferal carbon isotope records and the development of abyssal circulation in the eastern North Atlantic. in: Ruddiman, W.F., Kidd, R.B., Thomas, E., et al., Init. Repts. DSDP, 94: Washington (U.S. Govt. Printing office), 981-9 $\overline{96}$.

Miller, K.G., Fairbanks, R.G., and Mountain, G.S., 1987b. Tertiary oxygen isotope synthesis, sea level history, and continental margin erosion. Paleoceanography $2: 1-19$.

Miller, K.G., Janacek, T.R., Katz, M.E., and Keil, D.J., (in press). Abyssal circulation and benthic foraminiferal changes near the Paleocene/Eocene boundary. Paleoceanography.

Moore, T.C., Heath, G.R., and Kowsmann, R.0., 1973. Biogenic sediments of the Panama Basin. Journal of Geology 81:458-472.

Morgiel, J., and 0lszewska, B., 1981. Biostratigraphy of the Polish External Carpathians based on agglutinated foraminifera. Micropaleontology 27:1-30.

Morgiel, J., and 0lszewska, B., 1982. Uniformity of the Tethyan faunas from Cretaceous and Paleogene as shown by foraminifera from Morocco and Polish Flysch Carpathians. Cahiers de Micropaleontologie 3:45-53.

Moullade, M., Kuhnt, W., and Thurow, J., (in press). Agglutinated benthic 
foraminifers from upper Cretaceous variegated clays of the North Atlantic Ocean. in: Boillot, G., Winterer, E.L., Meyer, A.W., et al., Proc. Init. Repts (Pt. B), ODP, 103.

Mount, J.F., Margolis, S.V., Showers, S.V., Ward, P., and Doehne, E., 1986. Carbon and oxygen isotope stratigraphy of the upper Maastrichtian, Zumaya Spain: A record of oceanographic and biological changes at the end of the Cretaceous Period. Palaios 1:87-92.

Muller, C., 1976. Tertiary and Quaternary calcareous nannoplankton in the Norwegian-Greenland Sea, DSDP Leg 38. in: Talwani, M., Udintsev, G., et al., Init. Repts. DSDP, 38: Washington (U.S. Govt. Printing Office), 589-639.

Murray, J.W., 1984. Paleogene and Neogene benthic foraminifers from the Rockall Plateau. in: Roberts, D.G., and Schnitker, D., Init. Repts. DSDP, 81: Washington (U.S. Govt. Printing Office), 503-529.

Murray, J.W., 1987. Benthic foraminifers and Neogene water masses at Deep Sea Drilling Project Leg 94 North Atlantic Sites. in: Ruddiman, W.F., Kidd, R.B., Thomas, E., et al., Init. Repts. DSDP, 94: Washington (U.S. Govt. Printing 0ffice), 965-980.

Murray, J.W., 1987. Bolboforma from North Atlantic sites, Deep Sea Drilling Project Leg 94. in: Ruddiman, W.F., Kidd, R.B., Thomas, E., et al., Init. Repts. DSDP, 94: Washington (U.S. Govt. Printing Office), 813-814.

Nagy, J., Lぬfaldi, M., and Bäckstrom, S.A., (in press). Aspects of foraminiferal distribution and depositional conditions in the Janusfjellet Formation (Bathonian-Hauterivian) in eastern Spitsbergen. Proceedings of the 2nd Int. Workshop on Agglutinated Foraminifera, Vienna Austria, June 23-28, 1986.

Nunns, A.G., Talwani, M., Lorentzen, G.R., Vogt, P.R., Sigurgeirsson, T., Kristjansson, L., Larson, H.C., and Voppel, D., (1983). Magnetic anomalies over Iceland and surrounding seas (Text to accompanying map). in BOTT, M.H.P., et al. (eds) Structure and development of the Greenland-Scotland Ridge. NAT0 Conference Series IV, vol. 8: 661-678.

Nyong, E.E., and 0lsson, R.K., 1984. A paleoslope model of Campanian to lower Maastrichtian foraminifera in the North American Basin and adjacent continental margin. Mar. Micropaleon. 8:437-477.

Oberhansli, H., McKenzie, J., Toumarkine, M., and Weissert, H., 1984. A Paleoclimatic and paleoceanographic record of the Paleogene in the central South Atlantic (Leg 73, Site 522, 523 and 524). in: Hsu, K.J., LaBrecque, J.L., et al. Init. Repts. DSDP, 73: Washington (US Govt. Printing Office), $737-74 \overline{8}$.

0'Brian, N.R., Nakazawa, K., and Tokuhashi, S., 1980. Use of clay fabric to distinguish turbiditic and hemipelagic siltstones and silts. Sedimentology $27: 47-61$.

Okada, H., and Bukry, D., 1980. Supplementary modification and introduction of 
code numbers to the low-latitude coccolith biostratigraphic zonation (Bukry, 1973 ; 1975). Marine Micropaleontology 5, 321-325.

0lszewska, B., 1984. Interpretacja paleoekologiczna otwornic kredy i paleogenu Polskich Karpat Zewnetrznych. Biul. Inst. Geol. 346:7-62.

0lszewska, B., and Smagowicz, M., 1977. Porownanie podzialow biostratygraficznych gornej kredy i paleogenu jednostki dukielskiej na podstawie otwornic planktonicznych i nannoplanktonu wapiennego. Przeglad Geologiczny $7: 359-363$.

Perch-Nielsen, K., 1972. Remarks on late Cretaceous to Pleistocene coccoliths from the North Atlantic. in: Laughton, A.S., Berggren, W.A., et al., Init. Repts. DSDP, 12: Washington (U.S. Govt. Printing Office), 1003-1070.

Pescatore, T., and Slaczka, A., 1986. Evolution models of two flysch basins: the northern Carpathians and the southern Appenines- Reply. Tectonophysics $131: 177-181$.

Pflum, C.E., and Frerichs, W.E., 1976. Gulf of Mexico deep water foraminifers. Cush. Found. Foram. Res. Spec. Publ. 14, 125 pp.

Piper, D.J.W., 1973. The sedimentology of silt turbidites from the Gulf of Alaska. in: Kulm, H.D., Von Huene, R., et al., Init. Repts. DSDP, 18: Washington (U.S. Govt. Printing office), 847-867.

Poag, C.W., 1981. Ecologic Atlas of benthic foraminifera of the Gulf of Mexico. Stroudsburg, PA (Hutchinson Ross Publishing Co.), 174 pp.

Poag, C.W., 1987. The New Jersey Transect: Stratigraphic framework and depositional history of a sediment-rich passive margin. in: Poag, C.W., Watts, A.B., et al. Init. Repts. DSDP, 95: Washington (U.S. Govt. Printing office), 763-817.

Poag, C.W., Reynolds, L.A., Mazzullo, J., and Keigwin, L.D., 1985. Foraminiferal, lithic, and isotopic changes across four major unconformities at DSDP-IPOD Site 548, Goban Spur. in: Graciansky, P.C. de, Poag, C.W., et al. Init. Repts. DSDP, 80: Washington (U.S. Govt. Printing Office), 539-556.

Poag, C.W. and Low, D., 1987. Unconformable sequence boundaries at Deep Sea Drilling Project Site 612, New Jersey Transect: Their characteristics and stratigraphic significance. in: Poag, C.W., Watts, A.B., et al. Init. Repts. DSDP, 95: Washington (U.S. Govt. Printing Office), 453-498.

Pomerol, C., and Premoli-Silva, I., 1986. The Eocene-0ligocene transition: Events and Boundary, in: Pomerol, C., and Premoli-Silva, I. (eds.), Terminal Eocene Events. Devel. Paleontol. Strat. 9:1-24. Elsevier.

Rogl, F., Fuchs, R., Schnabel, W., Seifert, P., and Wagner, L., 1986. Excursion Guide to the 2nd IWAF Excursion in Austria 1986. Second International Workshop on Agglutinated Foraminifera, Abstracts, Program and Excursion Guide. pp. 60-92. H. Peter Press. Strasshof, Austria.

Schafer, C.T., 1983. Foraminiferal colonization of an offshore dump site in 
Chaleur Bay, New Brunswick, Canada. Journal of Foraminiferal Research $12: 317-326$.

Schijfsma, E., 1946. The foraminifera from the Hervian (Campanian) of southern Limburg. [Ph.D. dissert.] Rijksuniversiteit, Leiden.

Schnitker, D., 1974. West Atlantic abyssal circulation during the past 120.000 years. Nature 248:385-387.

Schrader, H., and Fenner, J., 1976. Norwegian Sea Cenozoic diatom biostratigraphy and taxonomy. in: Talwani, M., Udintsev, G., et al., Init. Repts. DSDP, 38: Washington (U.S. Govt. Printing Office), 605-672.

Schroder, C.J., 1986a. Deep-water arenaceous foraminifera in the Northwest Atlantic Ocean. Canadian Tech. Rept. of Hydrography and 0cean Sciences no. 71. $191 \mathrm{pp}$.

Schroder, C.J., 1986b. Changes in benthic foraminifer assemblages across the Holocene/Pleistocene boundary, Sites 619,620,621, 622, and 624, Deep Sea Drilling Project Leg 96. in: Bouma, A.H., Coleman, J.M., and Meyer, A.W., et al., Init. Repts. DSDP 96: Washington (U.S. Govt. Printing Office), 631642 .

Schroder, C.J., (in press). Subsurface preservation of arenaceous foraminifera in the northwest Atlantic 0cean. Proc. 2nd Workshop Agglutinated Foraminifera, Vienna Austria, June 23-28, 1986.

Schweitzer, H.J., 1980. Environment and climate of the early Tertiary of Spitsbergen. Paleogeogr. Paleoclim., Paleoecol. 30:297-312.

Sclater, J.G,. Meinke, L., Bennett, A., and Murphy, C., 1985. The depth of the ocean through the Neogene. in: Kennett, J.P., (ed.) The Miocene 0cean. GSA Memoir 163:1-20.

Scott, D.B., 1987. Quaternary benthic foraminifers from Deep Sea Drilling Project Sites 612 and 613, Leg 95, New Jersey Transect. in: Poag, C.W. , Watts, A.B., et al., Init. Repts. DSDP, 95: Washington (U.S. Govt. Printing office), 313-337.

Scott, D.B., MacKinnon, K.D., and Baki, V., 1987. Arctic Ocean benthonic foraminifera, stable isotope stratigraphy and Quaternary paleoenvironment. INQUA 87 Abstracts and Program.

Severin, K.P., Culver, S.J., and Blanpied, C., 1982. Burrows and trails produced by Quinqueloculina impressa Reuss, a benthic foraminifer, in finegrained sediment. Sedimentology 29:897-901.

Shackleton, N.J., 1986. Paleogene stable isotope events. Paleogeogr., Paleoclim., Paleoecol., 57:91-102.

Shackleton, N.J., and Kennett, J.P., 1975. Paleotemperature history of the Cenozoic and the initiation of Antarctic glaciation: 0xygen and Carbon isotope analyses in DSDP Sites 277, 279, and 281. in: Kennett, J.P., Houtz, 
R.E., et al., Init. Repts. DSDP, 29: Washington (U.S. Govt. Printing Office), 743-755.

Shipboard Scientific Party, 1987. Site 646. in: Srivastava, S.P., Arthur, M.A., Clement, B., et al., Proc. Init. Repts. (Pt. A), ODP 105: 419-647.

Shipboard Scientific Party, 1987. Site 647. in: Srivastava, S.P., Arthur, M.A., Clement, B., et al., Proc. Init. Repts. (Pt. A), ODP 105:675-905.

Shipboard Scientific Party, 1987. Site 645. in: Srivastava, S.P., Arthur, M.A., Clement, B., et al., Proc. Init. Repts. (Pt. A), ODP 105:61-418.

Shipboard Scientific Party, 1987. Site 643. in: Eldholm, 0., Thiede, J., Taylor, ....., et .al., Proc.... Init. Repts...(Pt. A), oDP 104: 454-615.

Slaczka, A., and Gasinski, M.A., 1985. Paleobathymetric model of the upper Senonian flysch sediments of a part of the Silesian Basin (Polish (arpathians). Cret. Res 6:

Sliter, W.V., and Baker, R.A., 1972. Cretaceous bathymetric distribution of benthic foraminifers. Jour. Foram. Res. 2:167-183.

Smith, C.R., 1985. Colonization studies in the deep sea: are results biased by experimental designs? in: GIBBS, P.E. (ed.) Proceedings of the 19 th European Marine Biology Symposium, Plymouth, Devon, U.K., 16-21 September 1984. Cambridge University Press.

Snyder, S.W., Muller, C., and Miller, K.G., 1984. Eocene-0ligocene boundary: Biostratigraphic recognition and gradual paleoceanographic change at DSDP Site 549. Geology 12:112-115

Srivastava, S.P., 1978. Evolution of the Labrador Sea and its bearing on the early evolution of the North Atlantic. Geophys. Jour. Royal Astron. Soc. $52: 313-357$.

Srivastava, S.P., 1986. Geophysical maps and geological sections of the Labrador Sea. Geol. Surv. Canada Paper 85-16, 11 pp.

Stainforth, R.M., Lamb, J.L., Luterbacher, H., Beard, J.H., and Jeffords, R.M., 1975. Cenozoic planktonic foraminiferal zonation and characteristics of index forms. Univ. Kansas Paleontol. Contrib. 62:1-425.

Stam, B., Gradstein, F.M., Lloyd, P., and Gillis, D., 1987. Algorithms for porosity and subsidence history. Computers and Geosciences 13:

Swift, J.H., 1986. The Arctic waters, in: Hurdle, B.G., (ed.), The Nordic Seas. New York (Springer-Verlag), 129-153.

Swift, S.A., 1977. Holocene rates of sediment accumulation in the Panama Basin, Eastern Equatorial Pacific: Pelagic sedimentation and lateral transport. Journal of Geology 85:301-309.

Talwani, M., Udintsev, G., et al., 1976. Initial Reports of the Deep Sea 
Drilling Project, Volume 38, Washington (U.S. Government Printing office), $1256 \mathrm{pp}$.

Thiede, J., and Eldholm, 0., 1983. Speculations about the paleodepth of the Greenland-Scotland Ridge during late Mesozoic and Cenozoic times. in: Bott, M.H., Saxov, S., Talwani, M., and Thiede, J. (eds.) Structure and development of the Greenland-Scotland Ridge. NATO Conference Series IV, 445456.

Thomas, F.C., 1985. Lower Scotian Slope benthic foraminiferal faunas past and present, with taxonomic outline [M.Sc. Thesis]. Dalhousie University, Hali fax. 159pp.

Thomas, E., 1987. Late 0ligocene to Recent benthic foraminifers from Deep Sea Drilling Project Sites 608 and 610, Northeastern Atlantic. in: Ruddiman, W.F., Kidd, R.B., Thomas, E., et al., Init. Repts. DSDP, 94: Washington (U.S. Govt. Printing office), 813-814.

Thompson, C.W., 1877. The Voyage of the "Challenger". The Atlantic, vol. 2. MacMillan \& Co., London. 396 pp.

Tjalsma, R.C., and Lohmann, G.P., 1983. Paleocene - Eocene bathyal and abyssal benthic foraminifera from the Atlantic Ocean. Micropaleontology Spec. Publ. 4. $90 \mathrm{pp}$.

Tucholke, B.E., Hollister, C.D., Biscay, P.E., and Gardner, W.D., 1985. Abyssal current character determined from sediment bedforms on the Nova Scotia continental rise. Marine Geology 66:43-57.

Tucholke, B.E. and Mountain, G.S., 1986. Tertiary paleoceanography of the western North Atlantic 0cean. in: Vogt, P.R., and Tucholke, B.E., (eds), The Geology of North America, Vol. M. The Western North Atlantic Region. (Geological Society of America), 631-650.

Tucholke, B.E., and McCoy, F.W., 1986. Paleogeographic and paleobathymetric evolution of the North Atlantic ocean. in: Vogt, P.R., and Tucholke, B.E., (eds), The Geology of North America, Vol. M. The Western North Atlantic Region. (Geological Society of America), 589-602.

Umpleby, D.C., 1979. Geology of the Labrador Shelf. Geol. Surv. Canada Paper $79-13,36 \mathrm{pp}$.

Unrug, R., 1979. Palynspastic reconstruction of the Carpathian Arc before the Neogene tectonogenesis. Rocz. Pol. Tow. Geol. 49:3-21.

Unrug, R., 1982. Geodynamic evolution of the Carpathians. Rocz. Pol. Tow. Geol. 52:39-66.

Van Andel, T., Heath, G.R., Malfait, B.T., Heinrichs, D.E., and Ewing, J.I., 1971. Tectonics of the Panama Basin, eastern equatorial Pacific. Geological Society of America Bulletin 82:1489-1508.

Van Couvering, J.A., Aubry, M.P., Berggren, W.A., Bujak, J.P., Naeser, C.W., 


\section{BIOGRAPHICAL NOTE}

The author was born on July 17, 1957 in Passaic, N.J. and at tended parochial schools in Wallington and Hawthorne. He graduated from Don Bosco High School (Ramsey, N.J.) in 1975. Growing up in the shadow of the Triassic basalt flows of the Newark Group, he developed an early interest in Geology and at tended classes at the Department of Geology of Rutgers University, where he received a BA in spring, 1979. From fall, 1979 to spring, 1982 he studied at the Stratigraphy and Paleontology Department of the Institute of Geological Sciences, Jagiellonian University (Krakow, Poland) where he received a master's degree in Geology under the supervision of Stanis law Geroch. He entered the WHOI/MIT Joint Program in Oceanography in June, 1982, and worked as a Graduate Research Assistant in William A. Berggren's laboratory, participating in the Deep-water Benthic Foram Project.

During his time as a student at Rutgers, he worked at the Rutgers Geology Museum and as a Labratory Assistant in Richard K. Olsson's lab. While in Krakow, he also translated for the Journal of the Geological Society of Poland (Rocznik PTG), and lectured at the Academy of Mining and Metallurgy. In summer, 1984, he worked as an Assistant Geologist in the Biostratigraphy Group of the UNOCAL Science and Technology Division, under the supervision of Harry Leffingwell and Garry Jones. Between 1985 and 1987, he was a TA for W.A. Berggren's Short Course on Benthic Forams at Brown University.

The author participated on research cruises to the Nova Scotian Continental Rise with the HEBBLE Project, and ODP LEG 105 to the Labrador Sea \& Baffin Bay. He is a member of the Society of Economic Paleontologists and Minerologists, the Cushman Foundation for Foraminiferal Research, and the British Micropaleontological Society. He has accepted a post-doctoral fellowship at the Centre for Marine Geology, Dalhousie University, Halifax Nova Scotia.

\section{PUBLICATIONS :}

Kaminski, M.A., 1982. Spiroplectammininae from the Sub-Silesian Unit of the Polish Carpathians. M.Sc. Thesis, Jagiellonian University.

Kaminski, M.A., 1983. Taxonomic notes on the abyssal agglutinated benthic foraminifera of the HEBBLE Area (lower Nova Scotian Continental Rise). WHOI Tech. Rept. 83-35. 49 pp.

Gradstein, F.M., Berggren, W.A., Kaminski, M.A., and Miller, K.G., 1983. Paleobathymetry of late Cretaceous - Paleogene agglutinated (flysch-type) benthic foraminiferal faunas and a modern analog. AAPG Bull. 67:473.

Van Morkhoven, F.P.C., Edwards, A.S., Berggren, W.A., Aubert, J., Belanger, P.E., Boersma, A., Corliss, B.H., Gradstein, F.M., Kaminski, M.A., Lohmann, G.P., Gamper-Longoria, M., Miller, K.G., Schnitker, D., and Tjalsma, R.C., 1983. Cenozoic cosmopolitan deep-water benthic foraminifera. In-house report to a consortium of oil companies.

Kaminski, M.A., 1984. Shape variation in Spiroplectammina spectabilis (Grzybowski). Acta Paleontol. Polonica 29:29-49.

Kaminski, M.A., 1985. Evidence for control of abyssal agglutinated foraminifera community structure by substrate disturbance: Results from the HEBBLE Area. Marine Geol. 66:113-131.

Srivastava, S., Arthur, M.A., et al. 1986. Drilling beyond the Arctic 
and Wieser, T., 1981. The terminal Eocene event and the Polish connection. Paleogeo., Paleoclim., Paleoecol., 36:321-362.

Van Morkhoven, F.P.C.M, Berggren, W.A., and Edwards, A.S., 1986. Cenozoic cosmopolitan deep-water benthic foraminifera. Bull. Centres Rech. Explor.Prod. Elf-Aquitaine, Mem. 11; Pau, France.

Verdenius, J.G., and Van Hinte, J.E., 1983. Central Norwegian-Greenland Sea: Tertiary arenaceous foraminifera, biostratigraphy and environment. Proceedings of the First Workshop on Arenaceous Foraminifera, 7-9 Sept., 1981. Continental Shelf Institute Publication 108:173-224.

Williamson, M.A., 1987. A quantitative foraminiferal biozonation of the late Jurassic and Early Cretaceous of the East Newfoundland Basin. Micropaleontology 33:37-65.

Winkler, 1984. Rhabdammina fauna: What relation to turbidites? Evidence from the Gurnigel-Schlieren Flysch. in: 0ertli, H.J. (ed.), Benthos '83, 2nd Int. Symp. Benthic Foraminifera, Pau (France), April 11-15, 1983. Elf Aquitaine, ESSO REP and TOTAL CFP, Pau \& Bourdeaux, pp. 611-617.

Wolfe, J.A., 1980. Tertiary climates and floristic relationships at high latitudes in the northern hemisphere. Paleogeogr. Paleoclim. Paleoecol. $30: 313-324$.

Wood, K.C., Miller, K.G., and Lohmann, G.P., 1985. Middle Eocene to Oligocene benthic foraminifera from the 0ceanic Formation, Barbados. Micropaleon. $31: 181-196$.

Worthington, L.V., 1970. The Norwegian Sea as a Mediterranean basin. Deep Sea Res. $17: 77-84$.

Worthington, L.V., 1976. On the North Atlantic circulation: Johns Hopkins Series in Oceanography no. 6. Johns Hopkins University Press, 110 pp.

Worthington, L.V., and Volkmann, G.H., 1965. The volume transport of the Norwegian Sea overflow water in the North Atlantic. Deep Sea Res. 12:667676 .

Young, F.G., and McNeil, D.H., 1983. Cenozoic stratigraphy of the Mackenzie Delta, Northwest Territories. Geol. Surv. Canada Bulletin 336. 63 pp.

Zijderveld, J.D.A., Zachariasse, J.W., Verhallen, P.J., and Hilgen, F.J., 1986. The age of the Miocene-Pliocene boundary. Newsl. Stratigr. 16:169181. 
Circle: ODP Leg 105. Geotimes.

Arthur, M.A., Srivastava, S., et al. 1986. Joides Resolution probes high latitude paleoceanography and tectonics of Baffin Bay - Labrador Sea. Nature

Kaminski, M.A., and Geroch, S., (1987). Two new species of Phenacophragma from the Paleogene of Trinidad and Poland. Micropaleon tology 33:185-188.

Kaminski, M.A., Gradstein, F.M., Berggren, W.A., Geroch, S., and Beckmann, J.P., (in press). Flysch-type agglutinated foraminiferal assemblages from Trinidad: Taxonomy, Stratigraphy and Paleobathymetry. Proceedings of the 2nd Int. Workshop on Agglutinated Foraminifera, Vienna Austria, June, 1986.

Kaminski, M.A., Grassle, J.F., and Whitlatch, R.D., (in press). Life History and recolonization among agglutinated foraminifera in the Panama Basin. Proceedings of the 2nd Int. Workshop on Agglutinated Foraminifera, Vienna Austria, June, 1986.

Gradstein, F.M., Kaminski, M.A., and Berggren, W.A., (in press). Cenozoic foraminiferal biostratigraphy of the Central North Sea. Proceedings of the 2nd Int. Workshop on Agglutinated Foraminifera, Vienna Austria, June, 1986.

Srivastava, S.R., Arthur, M.A., and Shipboard Scientific Party. Proc. Init. Repts. (Pt. A) ODP, 105.

Kaminski, M.A., and Gradstein, F.M., 1987. Paleobiogeography of Paleogene flysch-type foraminiferal assemblages in the North Atantic. Gulf Coast Section/SEPM Foundation 8 th Annual Research Conference, Selected papers and illustrated abstracts, pp. 85-89.

Kaminski, M.A., and Schroder, C.J., 1987. Environmental analysis of deep-sea agglutinated foraminifera: Can we distinguish tranquil from disturbed environments? Gulf Coast Section/SEPM Foundation 8 th Annual Research Conference, Selected papers and illustrated abstracts, pp. 90-93.

Pallant, A., and Kaminski, M.A. (in press). Bolboforma from ODP Leg 105, Labrador Sea and Baffin Bay and the chronostratigraphy of Bolboforma in the North Atlantic. in: Arthur, M.A., Srivastava, S., et al. Init. Repts. ODP Leg 105.

Kaminski, M.A., Gradstein, F.M., Scott, D.B., and McKinnon, K.D. (in press). Neogene benthic foraminiferal stratigraphy and deep water history of Sites 645, 646 and 647, Baffin Bay and Labrador Sea. in: Arthur, M.A., Srivastava, S., et al. Init. Repts. ODP Leg 105.

Kaminski, M.A., Gradstein, F.M., and Berggren, W.A. (in press). Paleogene benthic foraminiferal stratigraphy and paleoecology at Site 647, Southern Labrador Sea. in: Arthur, M.A., Srivastava, S., et a1. Init. Repts. ODP Leg 105.

Aksu, A.E., and Kaminski, M.A., (in press). Neogene planktonic foraminiferal biostratigraphy and biochronology in Baffin Bay and the Labrador Sea. in: Arthur, M.A., Srivastava, S., et al. Init. Repts. ODP Leg 105.

Arthur, M.A., Zachos, J.C., Kaminski., M.A., and Dean, W.E., (in press). Geochemistry of Eocene sediments, Site 647, Labrador Sea. in: Arthur, M.A., Srivastava, S., et al. Init. Repts. ODP Leg 105.

Baldauf, J.G., Clement, B., Aksu, A.E., deVernal, A., Firth, J.V., Hall, F., Head, M.J., Jarrard, R., Kaminski, M.A., Lazarus, D.B., Monjanel, A.-L., Berggren, W.A., Gradstein, F.M., Knuttel, S., Mudie, P., and Russell, M., (in press). Magnetostratigraphic and biostratigraphic synthesis of 0cean Drilling Program Leg 105; Labrador Sea and Baffin Bay. in: Arthur, M.A., Srivastava, S., et al. Init. Repts. ODP Leg 105.

THESIS:

Kaminski, M.A., 1987. Cenozoic deep-water agglutinated foraminifera in the North Atlantic. Ph.D. Thesis, WHOI/MIT Joint Program in Oceanography. 
ABSTRACTS:

Kaminski, M.A., 1982. Agglutinated foraminiferal fauna of an abyssal region dominated by high velocity bottom currents. EOS Trans. AGU 63 (45):991.

Kaminski, M.A., 1984. Response of agglutinated foraminifera to stress. BEM Abstracts.

Kaminski, M.A., Gradstein, F.M., Berggren, W.A., Geroch, S., and Beckmann, J.P., 1986. Flysch-type agglutinated foraminifera from the Lizard Springs and Guayaguayare Formations of Trinidad. 2nd Int. Workshop on Agglutinated Foraminifera, Vienna Austria, Program and Abstracts.

Kaminski, M.A., Stein, R., Gradstein, F.M., and Berggren, W.A., 1986. Flysch-type agglutinated foraminifera from ODP Leg 105, Baffin Bay and Labrador Sea. 2nd Int. Workshop on Agglutinated Foraminifera, Vienna Austria, Program and Abstracts.

Kaminski, M.A., and Grassle, J.F., 1986. Response of abyssal agglutinated foraminifera to physical disturbance. SEPM Annual Midyear Meeting Abstracts. p. 58 .

Scott, D.B., Mackinnon, K.D., and Kaminski, M.A., 1987. Quaternary bottom water paleoceanography from the western North Atlantic. INQUA 187 Programme and Abstracts.

Kaminski, M.A., Gradstein, F.M., and Srivastava, S.R., (submitted). Benthic foraminifera, seismic stratigraphy, and the deep-water history of the Eirik Ridge, Labrador Sea. GAC, MAC, CSPG Joint Annual Meeting, May 23-25, 1988. 